$$
\text { UNIVERSIDADE DE SÃO PAULO }
$$

FACULDADE DE FILOSOFIA, LETRAS E CIÊNCIAS HUMANAS

DEPARTAMENTO DE HISTÓRIA

PROGRAMA DE PÓS-GRADUAÇÃO EM HISTÓRIA SOCIAL

\title{
ENTRE O ESTÚDIO E A RUA: A TRAJETÓRIA DE VINCENZO PASTORE, FOTÓGRAFO DO COTIDIANO \\ DOUTORADO
}

FABIANA MARCELLI S. BELTRAMIM

SÃO PAULO

2015

(Versão Corrigida) 
UNIVERSIDADE DE SÃO PAULO

FACULDADE DE FILOSOFIA, LETRAS E CIÊNCIAS HUMANAS

DEPARTAMENTO DE HISTÓRIA

PROGRAMA DE PÓS-GRADUAÇÃO EM HISTÓRIA SOCIAL

\section{ENTRE O ESTÚDIO E A RUA: \\ A TRAJETÓRIA DE VINCENZO PASTORE, FOTÓGRAFO DO COTIDIANO}

Tese de doutorado em História Social
apresentada ao Programa de História Social da
Faculdade de Filosofia, Letras e Ciências
Humanas da Universidade de São Paulo para
obtenção do título de doutor em História
Social.

Versão Corrigida pós-banca. Original disponível no CAPH da FFLCH

Com aceite da Orientadora: Prof. ${ }^{a}$ Dr. ${ }^{a}$ Maria Odila Silva Dias.

SÃO PAULO

2015 


\section{ENTRE O ESTÚDIO E A RUA: A TRAJETÓRIA DE VINCENZO PASTORE, FOTÓGRAFO DO COTIDIANO}

Tese apresentada ao Programa de PósGraduação em História Social da Universidade de São Paulo.

Aprovada em:

Banca Examinadora

Prof. Dr.

Instituição:

Prof.Dr.

Instituição:

Prof.Dr.

Instituição:

Prof.Dr.

Instituição:

Prof.Dr.

Instituição: 
Para Fabio, Larissa e Vanessa Beltramim, irmãos que são a minha alegria.

Para minha mãe Neoli, por ter me ensinado a ser forte.

Ao meu pai, Lari Beltramim, que festeja no céu! 


\section{AGRADECIMENTOS}

Todo o meu genuíno agradecimento cabe à Maria Lucia Varani Pastore e ao seu marido, José Roberto Varani, netos de Vincenzo Pastore. Agradeço por me concederem o direito de trazer para a casa a coleção de fotos, cartas, diário e recortes de jornais que a família guarda até hoje. Estavam ali, finalmente ao meu alcance, em três grandes caixas, os documentos que eu precisava para dar continuidade à pesquisa.

Pela motivação, pelo ânimo em continuar o trabalho, pelos horizontes interpretativos apontados agradeço à Paulo César Garcez Marins. Suas palavras me fizeram acreditar na pesquisa, me ajudaram a não desistir de Pastore. Seu incentivo me levou aos arquivos de Bari e Potenza, onde consegui me aproximar um pouco mais da trajetória de instabilidade enfrentada por uma leva de fotógrafos, em constante trânsito ao sul da Itália.

À Cristina Wissenbach agradeço pelas sugestões dadas no exame de qualificação. Foi generosa ao chamar a minha atenção para as questões do campo, ajudando-me no meu próprio posicionamento e, mostrando-me que era preciso ajustar a minha interpretação para melhor entender as sociabilidades retratadas por Pastore.

Agradeço à leitura realizada por alguns amigos: Aramis Luiz Silva, Sérgio Damasceno da Silva e, ainda, à minha doce Ana Beatriz de Barros Leal Saraiva. Ao Nelson Coelho e à Vanessa Beltramim, agradeço pela parceria. Estiveram sempre de prontidão e dispostos a me ajudar nesses quatro anos de pesquisa e durante a minha estada na Itália. À Alessandra Ribeiro, sou grata por ter me ajudado a encontrar hospedagem barata em Roma. A minha teia de relações é constituída por esses laços de amor amigo, amor eterno.

Como o volume de tradução do Caderno de Recortes era imenso, Thais Cavalcante traduziu o diário de Elvira, esposa de Pastore. Thais foi, ao longo da pesquisa, também uma parceira, quando eu me sentia insegura com as minhas próprias traduções. Deixo aqui também o meu agradecimento à Maria Hirszman, pesquisadora que, mais uma vez, me ajudou fornecendo fontes, desta vez, sobre o circuito de imagens pictóricas napoletanas, produzidas no século XVIII; Larissa Mies Bombardi, ajudou-me a resolver alguns percalços de última hora; Bruna Oliveira Santiago, Diana Mendes Machado e Jessica Carvalho foram leitoras atentas do capítulo cinco, com observações e sugestões tecidas no embalo da nova amizade construída no grupo de estudos da professora Solange Ferraz de Lima, a quem devo um enorme agradecimento quer pelo carinho de me agregar ao seu grupo de orientandos, quer 
pelas indicações bibliográficas que abriram horizontes de análise na minha formação. A convivência durante um semestre com a professora Maria Helena Toledo Machado e com a minha orientadora Maria Odila Silva Dias, que me acompanha desde o mestrado, compõe essa trama de inspiração intelectual.

Agradeço enormemente a colaboração de funcionários de algumas instituições. Do Arquivo Municipal de São Paulo sou grata à Ricardo Mendes, pesquisador que realizou as entrevistas com descendentes do fotógrafo e me recebeu em algumas tardes para termos aquela conversa informal e sempre esclarecedora. À Marlene da Silva Rebecchi, funcionária deste mesmo arquivo, sou especialmente grata pela atenção em me receber. Da Biblioteca Mario de Andrade agradeço a atitude acolhedora de Joana D”Arc Moreno de Andrade, de Marilza Manoel Dutra Pinto, de Irene Mendonça e do Miguel Pereira Landin. Aos funcionários do Arquivo do Estado de São Paulo agradeço a acolhida e a sempre disposição em trazer muitos exemplares do jornal A Capital, consultados muitas vezes. Do Museu Paulista da USP, agradeço ao Ernandes Evaristo Lopes. Do arquivo Comunalle de Potenza agradeço à Carmela Molinare; Agradeço a todos os funcionários da Biblioteca Provinciale di Potenza e ao Mario Mineo do Museo Nazionale Preistorico Etnografico "Luigi Pigorini”; Ao Sérgio Leonardi, do Archivio Fotogramma Bari, bem como aos professores Alberto Baldi e Lello Mazzacane da Università di Napoli Federico II, com os quais tive a chance de conversar, ler seus estudos sobre a fotografia da Puglia e da Basilicata e ainda conhecer o trabalho que desenvolvem no Centro de Pesquisas Audiovisuais da universidade citada. Da Università Degli Studi Della Basilicata, agradeço de todo coração a todos que me receberam com carinho e atenção.

É preciso agradecer ainda à Andreia Blasquez. Nossos cafés ao final da tarde de muitas quartas-feiras foram momentos de descanso, de interromper a escrita e aproveitar a boa conversa entre amigas. Momentos só superados quando tinha perto de mim minha rede de encantos tecida por Heloisa, Henrique, Joana e Mariana.

Por fim, agradeço ao CNPq pela bolsa concedida, incentivo vital para a realização deste estudo. 
Fabiana Beltramim. Entre o estúdio e a rua: a trajetória de Vincenzo Pastore, fotógrafo do cotidiano. São Paulo, 2015. Tese de Doutorado em História Social. Faculdade de Filosofia, Letras e Ciências Humanas da Universidade de São Paulo.

Resumo: Esta pesquisa segue a trajetória do fotógrafo italiano Vincenzo Pastore, que atuou em São Paulo entre os anos de 1899 e 1918. Se Pastore, por um lado, viveu produzindo retratos comerciais em estúdio, por outro, a sua produção mais emblemática foi a série de fotos realizadas nas ruas e nos arredores da capital paulista. O percurso trilhado por Vincenzo Pastore se entrelaçou nesta análise com o de suas imagens, numa investigação voltada para os processos sociais que constituíram as duas trajetórias: a do fotógrafo e a de suas fotos. Este estudo tentou compreender duas questões principais. A partir de um ponto de vista histórico, documentamos a prática e a vivência de Pastore como um fotógrafo retratista de notável inclinação para o foto-pictorialismo. Observamos o percurso de Pastore no métier do retrato em São Paulo, mas também em Potenza e Bari, cidades italianas onde o fotógrafo atuou. A pesquisa realizada também nos acervos e arquivos na região da Puglia e da Basilicata, proporcionou uma abordagem histórica que delineou os muitos desafios dos retratistas italianos que buscavam incessantemente condições mais favoráveis para sobreviver da produção de retratos ao sul da Itália, forçados, muitas vezes, a vivenciarem a experiência da imigração. Documentamos mais profundamente, o processo de agenciamento sobre as imagens produzidas nas ruas da cidade de São Paulo, entre os anos de 1908 e 1914, mas submetidas a um circuito de apropriação e circulação somente após 1996, depois da doação feita ao Instituto Moreira Salles pelos descendentes do fotógrafo.

Palavras chaves: Fotografia, Trajetória, Imigração, Coleção Fotográfica e Cultura Visual. 
FabianaBeltramin. Between the studio and the street: The trajectory of Vincenzo Pastore, Quotidian Photographer. São Paulo, 2015. Ph.D. thesis in Social History. Faculty of Philosophy, Languages and Literature, and Human Sciences, University of São Paulo.

Abstract: This research follows the trajectory of Italian photographer Vincenzo Pastore, who lived in São Paulo between 1899 and 1918. If Pastore, on the one hand, produced commercial portraits in studio during his life, on the other, his most emblematic production was the series of photographs taken on the streets and surroundings of São Paulo's capital. The path trodden by Vincenzo Pastore entwines with that of his images in this analysis, in a research focused on the social processes that built both paths: that of the photographer and of his pictures. This study tried to understand two main issues. From a historical point of view, we document the practice and the experience of Pastore as a portrait photographer of remarkable penchant for photo-pictorialism. We followed Pastore's path not only in the métier of the portrait in São Paulo, but also in Potenza and Bari, Italian cities where the photographer worked. The research, also carried out on the collections and archives in the region of Puglia and Basilicata, provided a historical approach, which outlined the many challenges of Italian portrait painters, who were constantly searching for more favorable conditions to live by the production of portraits in south of Italy, often forced to undergo the experience of migration. We documented more deeply the agency process on the images produced on the streets of São Paulo, between 1908 and 1914, but that entered an appropriation and circulation circuit only after 1996, when the photographer's descendants donated the photos to the Moreira Salles Institute.

Keywords: Photography, Trajectory, Migration, Photographic Collection and Visual Culture. 
Fabiana Beltramim. Fra lo studio e la strada: La traiettoria di Vincenzo Pastore, fotografo del quotidiano. São Paulo, 2015. Tesi (Dottorato in Storia Sociale). Facoltà di Filosofia, Lettere e Scienze Umane dell'Università di San Paolo.

Abstract: Questa ricerca segue la traiettoria del fotografo italiano Vincenzo Pastore, che ha lavorato a San Paolo fra il 1899 e il 1918. Se, da un lato, Pastore ha vissuto dalla produzione di ritratti commerciali nel suo studio, dall'altro la sua produzione più emblematica è stata la serie di foto scattate per le strade e nei dintorni della capitale paulista. Il percorso compiuto da Vincenzo Pastore in questa analisi è collegato a quello delle sue immagini, in un'indagine diretta ai processi sociali che hanno costituito tutte e due le traiettorie: quella del fotografo e quella delle sue foto. Questo studio ha provato a comprendere due questioni principali. A partire da un punto di vista storico, abbiamo documentato la pratica e la vita di Pastore come un fotografo ritrattista di notevole inclinazione al foto-pittorialismo. Abbiamo osservato il percorso di Pastore nel métier del ritratto a San Paolo, ma anche a Potenza e a Bari, città italiane dove il fotografo ha lavorato. La ricerca, fatta anche nelle raccolte e negli archivi in Puglia e in Basilicata, ha proporzionato un approccio storico che ha delineato le tante sfide dei ritrattisti italiani che cercavano continuamente condizioni più favorevoli per vivere dalla produzione di ritratti nel Sud Italia, costretti tante volte a vivere l'esperienza dell'immigrazione. Abbiamo documentato più profondamente il modo di intermediazione delle immagini prodotte per le strade di San Paolo, fra il 1908 e il 1914, ma sottomesse a un circuito di appropriazione e circolazione solo dopo il 1996, in seguito alla donazione fatta dagli eredi del fotografo all'Instituto Moreira Salles.

Parole chiave: Fotografia, Traiettoria, Immigrazione, Raccolta Fotografica e Cultura Visuale. 


\section{LISTA DE IMAGENS}

Figura 1: Página de abertura do caderno de recortes montado por Elvira Pastore. In: Coleção Dante Pastore.

Figura 2: Primeira página com recortes de jornais. In: Caderno de Recortes. Coleção Dante Pastore.

Figura 3: Reprodução de capa do Álbum de Recordações Vicente e Elvira Pastore. In: Coleção Dante Pastore.

Figura 4: Primeira página que abre o álbum de Recordações Vicente e Elvira Pastore. In: Coleção Dante Pastore.

Figura 5: Primeira página do Passaporte de Vincenzo Pastore. In: Coleção Dante Pastore.

Figura 6: Bilhete de viagem de retorno ao Brasil. In: Coleção Dante Pastore.

Figura 7: Vendeiro ambulante em São Paulo. 1910. Foto: Vincenzo Pastore/Instituto Moreira Salles.

Figura 8: Vendeiro ambulante em São Paulo. 1910. Foto: Vincenzo Pastore/Instituto Moreira Salles.

Figura 9: Fotografia de Pastore em momento de interação com seus filhos no quintal do estúdio e residência da Rua da Assembléia. In: Coleção Costanza Pastore/Mosteiro São Bento.

Figura 10: Pastore no jardim de um de seus ateliês possivelmente na rua da Assembléia, n.12. In: Coleção Dante Pastore.

Figura 11: Fotos do casal Elvira e Pastore. In: Coleção Dante Pastore.

Figura 12: Retrato de meio busto. 1910 (C) Vincenzo Pastore / Museu Paulista/USP.

Figura 13: Retrato mimoso. Foto: Vincenzo Pastore. In: Gerodetti \& Garbin. Álbum de Retratos. Fotografias Brasileiras. 2012.

Figura 14: Retrato mimoso. Foto: Vincenzo Pastore. In: Gerodetti \& Garbin. Álbum de Retratos. Fotografias Brasileiras. 2012.

Figura 15: Retrato mimoso. Foto: Vincenzo Pastore. In: Gerodetti \& Garbin. Álbum de Retratos. Fotografias Brasileiras. 2012.

Figura 16: Retrato mimoso. Foto: Vincenzo Pastore. In: Gerodetti \& Garbin. Álbum de Retratos. Fotografias Brasileiras. 2012.

Figura 17: Reprodução de recorte anunciando o estúdio de Pastore. Caderno de Recortes. In: Coleção Dante Pastore.

Figura 18: Anúncio publicado em outubro de 1900. Jornal O Estado de S.Paulo.

Figura 19: Foto de Vincenzo Pastore retratando as filhas. In: Coleção Dante Pastore. 
Figura 20: Foto de Vincenzo Pastore retratando uma das filhas. Retrato em cianotipia. In: Coleção Dante Pastore

Figura 21: Recorte de jornal que integra o Caderno de Recortes. In: Coleção Dante Pastore.

Figura 22: Foto de cliente realizada em estúdio. Sem data (c) Vincenzo Pastore / Coleção Dante Pastore.

Figura 23: Retrato de cliente feito em estúdio. Foto à carvão em tom terra ou talvez vermelho. S/d. Foto de Vincenzo Pastore. Coleção Dante Pastore.

Figura 24: Retrato de cliente feito em estúdio. Foto à carvão no pigmento em tom azul. S/d. Foto de Vincenzo Pastore. Coleção Dante Pastore.

Figura 25: Recorte de jornal: Fotografias artísticas e inalteráveis à goma e ao pigmento do "Atelieur" Pasteur. In: Caderno de Recortes. Coleção Dante Pastore

Figura 26: Dante Pastore retratado na imagem dentro de um grande sapato. In: Caderno de Recortes. Coleção Dante Pastore

Figura 27: Recorte de anúncio “Arte Fotográfica”. In: Caderno de Recortes. Coleção Dante Pastore

Figura 28: Reprodução de recorte anunciando o estúdio do fotógrafo. In: Caderno de Recortes. Coleção Dante Pastore

Figura 29: Reprodução de recorte anunciando o estúdio do fotógrafo. In: Caderno de Recortes. Coleção Dante Pastore

Figura 30: Reprodução de recorte anunciando o estúdio do fotógrafo. In: Caderno de Recortes. Coleção Dante Pastore

Figura 31: Fotos do casal retratado por Vincenzo Pastore: Adelina Leopardi e José De Mauro. 1900. Coleção Aurélia De Moura Figueiredo. In: Goulart, Paulo Cesar Alves e Mendes, Ricardo. Noticiário Geral da Photographia Paulista 1839-1900.

Figura 32: Fotos do casal retratado por Vincenzo Pastore: Adelina Leopardi e José De Mauro. 1900. Coleção Aurélia De Moura Figueiredo. In: Goulart, Paulo Cesar Alves e Mendes, Ricardo. Noticiário Geral da Photographia Paulista 1839-1900.

Figura 33: Fotos do casal retratado por Vincenzo Pastore: Adelina Leopardi e José De Mauro. 1900. Coleção Aurélia De Moura Figueiredo. In: Goulart, Paulo Cesar Alves e Mendes, Ricardo. Noticiário Geral da Photographia Paulista 1839-1900.

Figura 34: Foto da Rua Direita. 1908. Vincenzo Pastore / Instituto Moreira Salles.

Figura 35: Imagem interna do estúdio de Guilherme Gaensly. 1908. Museu Paulista / USP.

Figura 36: Anúncio do estúdio de Guilherme Gaensly publicado na Revista Industrial de São Paulo, em 1900. Museu Paulista / USP. 
Figura 37: Foto interna do estúdio e da sala de espera do fotógrafo Oreste Cilento. Avenida Rangel Pestana 116. In: In: Gerodetti \& Garbin. Álbum de Retratos. Fotografias Brasileiras. 2012.

Figura 38: Homens retratados em estúdio. Sem data ( Vincenzo Pastore / Museu do Imigrante.

Figura 39: Reprodução de foto do estúdio de Becherini\&Stamoto. 1907. In: Revista A Vida Moderna.

Figura 40: Reprodução de foto interna do estúdio de G. Sarracino. Publicada em Il Brasile e gli italiani. 1906. In: Gerodetti \& Garbin. Álbum de Retratos. Fotografias Brasileiras. 2012.

Figura 41: Foto de Bidão, Joana e Tatá realizada no estúdio da Rua Direita por Vincenzo Pastore. Sem data. In: In: Gerodetti \& Garbin. Álbum de Retratos. Fotografias Brasileiras. 2012.

Figura 42: Fotografia de Pastore retratado em estúdio junto ao homem negro, talvez um ajudante. Sem data (C) Vincenzo Pastore /Instituto Moreira Salles.

Figura 43: Retrato de Leoncio, talvez um ajudante no estúdio de Pastore. In: Caderno de Recortes da Coleção Dante Pastore.

Figura 44: Retrato de Leoncio, talvez um ajudante no estúdio de Pastore. In: Caderno de Recortes da Coleção Dante Pastore.

Figura 45: Retrato de Leoncio, talvez um ajudante no estúdio de Pastore. In: Caderno de Recortes da Coleção Dante Pastore.

Figura 46: Reprodução de foto. Cartão Cabinet. Photographia Central de Michelle Rizzo retratado com Vincenzo Pastore. Sem data. Sem autoria. Coleção Rubens Fernandes Junior. In: Goulart, Paulo Cesar Alves e Mendes, Ricardo. Noticiário Geral da Photographia Paulista 1839-1900.

Figura 47: Fotografia de Vincenzo Pastore. Retrato de Jovita enviado a "querida Aninha". Foto realizada no estúdio localizado na Rua Direita, 24. 1913. Cortesia Museu Paulista/USP.

Figura 48: Reprodução de recorte de jornal "Alla Fotografia Pastore”. In: Caderno de Recortes, p. 18. Coleção Dante Pastore.

Figura 49: Reprodução de recorte de jornal com título "Um presente amado". In: Caderno de Recortes criado por Elvira Leoparde Pastore anunciando o estúdio de Vincenzo Pastore na Rua Direita, 24. Coleção Dante Pastore.

Figura 50: Retrato Mimoso. Fotografia que integrava o álbum de Antonio Jacinto Guimarães, datada no verso 03/11/1903. Foto de Vincenzo Pastore / Museu Paulista/USP.

Figura 51: Retrato Mimoso. Mulher anônima. 1903. Foto de Vincenzo Pastore / Museu Paulista/USP.

Figura 52: Retrato Mimoso. 1906. Foto de Vincenzo Pastore / Museu Paulista/USP.

Figura 53: Retrato de José de Ameida. 1917. Foto de Vincenzo Pastore. In: Garbin \& Gerodetti. Álbuns de Retratos. Fotografias Brasileiras. 2012.

Figura 54: Moacyr retratado em 1937. Sem identificação do fotógrafo. In: Garbin \& Gerodetti. Álbuns de Retratos. Fotografias Brasileiras. 2012. 
Figura 55: Fotografia de Vincenzo Pastore. Retrato Mimoso em formato losangular. Moldura montada em papel cartão. Sem identificação das retratadas. 1910. Cortesia Museu Paulista/USP.

Figura 56: Fotografia de Vincenzo Pastore. Retrato Mimoso em formato losangular. Moldura montada em papel cartão. Sem identificação das retratadas. 1910. Cortesia Museu Paulista/USP.

Figura 57: Fotografia de Vincenzo Pastore. Retrato Mimoso de uma criança. Sem data. Museu do Imigrante.

Figura 58: Reprodução da Revista A Vida Moderna. 25 de dezembro de 1907. Acervo da Biblioteca Mario de Andrade.

Figura 59: Foto de H. Eckmann, Santos. S/d. In: Garbin \& Gerodetti. Álbuns de Retratos. Fotografias Brasileiras. 2012.

Figura 60: Foto realizada por Valério Vieira no estúdio da Estúdio Rua Quinze de Novembro, n. 19. 1905. Cortesia Acervo Museu Paulista/USP.

Figura 61: Foto realizada por Valério Vieira no estúdio da Estúdio Rua Quinze de Novembro, n. 19. 1905. Cortesia Acervo Museu Paulista/USP.

Figura 62: Foto realizada por Valério Vieira. Cartão bebê disponível na Internet.

Figura 63: Foto realizada por Valério Vieira. In: Garbin \& Gerodetti. Álbuns de Retratos. Fotografias Brasileiras. 2012

Figura 64: Foto realizada por Valério Vieira. In: Kossoy. Dicionário Histórico-Fotográfico Brasileiro. São Paulo: IMS, 2002.

Figura 65: Foto José Vollsack. 1900. Cortesia Acervo Museu Paulista/USP

Figura 66: Foto de Vincenzo Pastore. Retrato de Costanza e Francesco Pastore, filhos do fotógrafo. S/d. Coleção Constanza Pastore. Cortesia Mosteiro São Bento.

Figura 67: Foto Vincenzo Pastore. Retrato de menino. Sem data. In: Gerodetti \& Garbin. Álbum de Retratos. 2012.

Figura 68: Foto Vincenzo Pastore. 1910. Cortesia Museu Paulista/USP

Figura 69: Foto de Vincenzo Pastore. Retrato Mimoso. Rua da assembléia, 12. 1908. Cortesia Museu Paulista/USP.

Figura 70: Foto de Vincenzo Pastore. Retrato Dedé e Nh'Ana. Estúdio da Rua da assembléia, 12. S/d. In: Gerodetti \& Garbin. Álbum de Retratos.

Figura 71: Foto de Vincenzo Pastore. Estúdio da Rua da assembléia, 12. S/d. In: Gerodetti \& Garbin. Álbum de Retratos.

Figura 72: Reprodução de recorte anunciando concurso de beleza organizado pelo fotógrafo. Caderno de Recortes montado por Elvira Pastore. Coleção Dante Pastore 
Figura 73: Recorte de notícia sem indicação de revista que anunciava as três primeiras colocadas em concurso organizado pelo fotógrafo Vincenzo Pastore. Reprodução Caderno de Recortes. Coleção Dante Pastore.

Figura 74: Reprodução de recorte do Caderno de Recortes montado por Elvira Pastore. Coleção Dante Pastore.

Figura 75: Reprodução de recorte do Caderno de Recortes montado por Elvira Pastore. Coleção Dante Pastore.

Figura 76: Reproduções de recortes "L"Arte Fotografica". Caderno de Recortes montado por Elvira Pastore. Coleção Dante Pastore.

Figura 77: Reprodução de marcador impresso no cartão suporte das fotografias de Pastore. Símbolo da coroa da Itália e indicação do título concedido a Pastore de Cavalheiro do Reino da Itália. Coleção Dante Pastore.

Figura 78: Reprodução de marcador impresso no cartão suporte das fotografias de Pastore. Selo com a marca do estúdio aberto na Itália "Ai Due Mondo - Fotografia Ítalo Americana". Coleção Dante Pastore.

Figura 79: Foto Vincenzo Pastore. Retrato de meio busto realizado no estúdio da Rua Direita, 24. Apresenta a seguinte dedicatória: “Ao tio Evaristo e à tia Mana pela grande amizade, de Marcos, São Paulo". 1910. Cortesia Museu Paulista/USP.

Figura 80: Reprodução recorte de jornal L'Eco delle Puglie e Il Lucano. 1898. In: Caderno de Recortes. Coleção Dante Pastore.

Figura 81: Retrato de meio busto realizado por Vincenzo Pastore, formato carte-de-visite. Potenza. Sem data. Centro di Ricerca Audiovisuale Università di Napoli Federico II.

Figura 82: Verso da carte- de- visite com retrato de meio busto realizado por Vincenzo Pastore. Potenza. Sem data. Centro di Ricerca Audiovisuale Università di Napoli Federico II.

Figura 83: Foto de Luigi Giocoli. Retrato de mulher com trajes típicos de festa, em Potenza. 1910. Centro di Ricerca Audiovisuale Università di Napoli Federico II.

Figura 84: Verso da foto de Luigi Giocoli. 1910. Centro di Ricerca Audiovisuale Università di Napoli Federico II.

Figura 85: Reprodução Jornal La Tribuna. 22 de dezembro 1895. Num. 51. Archivio di Stato di Potenza.

Figura 86: Reprodução de página com a indicação de nomes, ocupações e endereços que constam no livro de Registros Comerciais de Potenza entre a última década do século XIX e as primeiras do XX. VIII Censimento Generale della Popolazione. Arquivo Comunale de Potenza.

Figura 87: Reprodução de página com a indicação de nomes, ocupações e endereços que constam no livro de Registros Comerciais de Potenza entre a última década do século XIX e as primeiras do XX. VIII Censimento Generale della Popolazione. Arquivo Comunale de Potenza. 
Figura 88: Fotografia de casal. Fotógrafo ambulante anônimo, produzida ao final do século XIX. Potenza. Centro di Ricerca Audiovisuale Università di Napoli Federico II.

Figura 89: Fotografia de casal. Fotógrafo ambulante anônimo, produzida ao final do século XIX. Potenza. Centro di Ricerca Audiovisuale Università di Napoli Federico II.

Figura 90: Fotografia de Carlo Blancagemma realizada em Pisticci. S/d. Centro di Ricerca Audiovisuale Università di Napoli Federico II.

Figura 91: Reprodução de foto anônima que integra a coleção particular familiar estudada por Alberto Baldi. In: Scatti per Sognare. Avigliano nelle fotografie dell' arquivio Andrea Pinto. Napoli: Electa Napoli. 2004.

Figura 92: Fotografia de família realizada por Nicola de Carlo. S/d. In: Bronzini, Giovanni Battista. Lares, Trimestrale di studi demoetno antropologici. Ano LX, n.4. Firenze: Leo S. Olschki. Outubrodezembro de 1994, p. 576.

Figura 93: Foto tomada na frente do estúdio de Pastore, em Bari na Via Sparano, n. 117. Bari, Itália. 12 de abril 1914. In: Caderno de Recordações Elvira e Pastore. Coleção Dante Pastore.

Figura 94: Fotografia feita no piso térreo do sobrado ocupado por Vincenzo Pastore no estúdio aberto em Bari. Itália. Sem data. In: Caderno de Recordações Elvira e Pastore. Coleção Dante Pastore.

Figura 95: Reprodução de verso de cartão postal produzido por Pastore. Bari entre os anos de 1914 e 1915. Coleção Dante Pastore.

Figura 96: Reprodução de detalhe da fachada e da vitrine do estúdio de Vincenzo Pastore. Bari, Itália. 12 de abril 1914. In: Caderno de Recordações Elvira e Pastore. Coleção Dante Pastore.

Figura 97: Auto-retrato de Vincenzo Pastore. Coleção Dante Pastore.

Figura 98: Fotografia da sala de espera do estúdio de Pastore em Bari, Itália. Sem data. Coleção Dante Pastore.

Figura 99: Foto interna do estúdio de Pastore em Bari, Itália. Sem data. Coleção Dante Pastore.

Figura 100: Reprodução de recorte de jornal sobre a participação de Pastore na Exposição Nacional do Rio de Janeiro em 1908. In: Caderno de Recortes. Coleção Dante Pastore.

Figura 101: Reprodução do passaporte de Vincenzo Pastore. Coleção Dante Pastore.

Figura 102: Foto realizada por Melchiorre Falardi. Bari, Itália. In: Leonardi, Sérgio. La Fotografia Dell'ottocento a Bari. Bari: Mario Adda Editore. 1997.

Figura 103: Foto realizada por Melchiorre Falardi. Bari, Itália. In: Leonardi, Sérgio. La Fotografia Dell’ottocento a Bari. Bari: Mario Adda Editore. 1997.

Figura 104: Verso do cartão da foto/figura 111 do fotógrafo Melchiorre Falardi. Sem data. In: Leonardi, Sérgio. La Fotografia Dell'ottocento a Bari. Bari: Mario Adda Editore. 1997.

Figura 105: Retrato realizado em 1880 por Enrico Bambocci. In: Leonardi, Sérgio. La Fotografia Dell'ottocento a Bari. Bari: Mario Adda Editore. 1997. 
Figura 106: Retrato realizado em 1903 por Enrico Bambocci. In: Leonardi, Sérgio. La Fotografia Dell'ottocento a Bari. Bari: Mario Adda Editore. 1997.

Figura 107: Retrato realizado por Giuseppe Tarantini. 1895. In: Leonardi, Sérgio. La Fotografia Dell'ottocento a Bari. Bari: Mario Adda Editore. 1997.

Figura 108: Retrato realizado por Antonelli retratando família em área externa residencial. Bari. Itália. 1900. In: Miraglia, Marina. Bari inizio secolo nelle fotografie degli Antonelli. 1883-1915. Roma: Edizione Quasar. 1985.

Figura 109: Retrato realizado por Antonelli retratando família em área externa residencial. Bari. Itália. 1900. In: Miraglia, Marina. Bari inizio secolo nelle fotografie degli Antonelli. 1883-1915. Roma: Edizione Quasar. 1985.

Figura 110: Foto: Antonelli. Retrato de grupo familiar. Bari. Itália. 1905. In: Miraglia, Marina. Bari inizio secolo nelle fotografie degli Antonelli. 1883-1915. Roma: Edizione Quasar. 1985.

Figura 111: Fotomontagem de Angelo Antonelli. 1906. In: Miraglia, Marina. Bari inizio secolo nelle fotografie degli Antonelli. 1883-1915.

Figura 112: Foto: Liborio Antonelli Matteucci. Retrato de meio busto de Marmete Bambocci pai de Enrico Bambocci. Sem data. In: Giovane, Alfredo. Bari de Fanale a gaz. Bari: Edizione Fratelli Laterza Bari. 1982.

Figura 113: Foto: Angelo Antonelli. In: Leonardi, Sérgio. La Fotografia Dell'ottocento a Bari. Bari: Mario Adda Editore. 1997.

Figura 114: Foto: Angelo Antonelli. In: Leonardi, Sérgio. La Fotografia Dell'ottocento a Bari. Bari: Mario Adda Editore. 1997.

Figura 115: Foto: Angelo Antonelli. In: Leonardi, Sérgio. La Fotografia Dell'ottocento a Bari. Bari: Mario Adda Editore. 1997.

Figura 116: Foto: Angelo Antonelli. In: Leonardi, Sérgio. La Fotografia Dell'ottocento a Bari. Bari: Mario Adda Editore. 1997.

Figura 117: Detalhe de reprodução feita a parti da foto do piso térreo do estúdio de Pastore, em Bari, na Itália. Coleção Dante Pastore.

Figura 118: Reprodução de recorte do artigo "Fotografia ed Arte". In: Caderno de Recortes. Coleção Dante Pastore.

Figura 119: Fotomontagem feita por Pastore retratando sua filha Eleonora. Sem data () Vincenzo Pastore. Coleção Costanza Pastore. Mosteiro São Bento.

Figura 120: Capa da revista A Vida Moderna. Retrato da filha de Pastore Eleonora. 10 de setembro de 1914, n. 238. Biblioteca Mario de Andrade.

Figura 121: Fotomontagem a partir de retratos da filha de Pastore chamada Olga. Coleção Dante Pastore. 
Figura 123: Fotografia de G. Sarracino. Cartão de boas festas publicado na Revista A Vida Moderna em 15 de janeiro de 1908. N. 31.

Figura 124: Fotografia de Valério Vieira. Cartão de Boas Festas. 1903. Cortesia Acervo Museu Paulista/USP.

Figura 125: Reprodução de recorte anunciando calendário oferecido como brinde. Título "I Calendari”. In: Caderno de Recortes. Coleção Dante Pastore.

Figura 126: Retrato de um Ferreiro. Sem data ( V Vincenzo Pastore / Instituto Moreira Salles.

Figura 127: Foto realizada por Albert Gilibert intitulada "Les Charrons". 1904. Biblioteca Nacional de Paris

Figura 128: Foto realizada por L. Figueiredo de Medeiros intitulada "A Forja". 1926. In: Revista Photogramma, n.5. In: Mello. 1998, p. 124-125.

Figura 129: Foto realizada por Vincenzo Pastore. Retrato. Goma bicromatada/Pigmento. 1910. Instituto Moreira Salles.

Figura 130: Foto Vincenzo Pastore. Foto-pintura de uma das filhas de Pastore. Sem data. Coleção Dante Pastore.

Figura 131: Foto Vincenzo Pastore. Fotografia de Anna Candida Bueno, publicada na capa da Revista A Vida Moderna. N.250, no dia 03 de Dezembro, de 1914. Acervo Biblioteca Mario de Andrade.

Figura 132: recorte de comentário que acompanhava a fotografia de Anna Candida Bueno, publicada na capa da Revista A Vida Moderna. N.250, no dia 03 de Dezembro, de 1914. Acervo Biblioteca Mario de Andrade.

Figura 133: Fotografia de Vincenzo Pastore. "Duas mulheres conversando". Proximidades do atual parque D. Pedro II. 1910. IMS.

Figura 134: Fotografia Vincenzo Pastore. "Duas mulheres, uma de costas, descansando em banco de praça”. 1910. Instituto Moreira Salles.

Figura 135: Fotografia Vincenzo Pastore. "Mulheres descansando em banco de praça". 1910. Instituto Moreira Salles.

Figura 136: Fotografia de Vincenzo Pastore. Homem consertando o próprio sapato. Sem indicação de logradouro. 1910. Instituto Moreira Salles.

Figura 137: Fotografia de Vincenzo Pastore. "Retrato de homem idoso recostado em grade metálica da Rua São João" em frente ao Bijou Salão. 1910. Instituto Moreira Salles.

Figura 138: Fotografia de Vincenzo Pastore. "Grupo de pessoas ao redor de realejo, na Praça da República". Foto que retrata a presença de tocadores de realejo trabalhando na capital paulistana. 1910. Instituto Moreira Salles

Figura 139: Fotografia de Vincenzo Pastore. "Vendedor de vassouras em rua do centro da cidade"; a indicação de paralelepípedos indica a possibilidade de se tratar de uma Rua do Triangulo Central. 1910. Instituto Moreira Salles. 
Figura 140: Fotografia de Vincenzo Pastore. "Largo da Sé”. 1912. Instituto Moreira Salles.

Figura 141: Fotografia de Vincenzo Pastore. "Vendedores ambulantes de tecido". 1910. Instituto Moreira Salles.

Figura 142: Fotografia de Vincenzo Pastore. "Grupo de Pessoas na Calçada". 1910. Instituto Moreira Salles.

Figura 143: Fotografia de Vincenzo Pastore. "Retrato de dois homens, um apoiado em poste e outro caminhando". 1910. Instituto Moreira Salles.

Figura 144: Recorte de jornal. Caderno de Recortes. Coleção Dante Pastore.

Figura 145: Fotografia de Vincenzo Pastore. "Grupo de pessoas sobre ponte da Praça da República". 1910. Instituto Moreira Salles.

Figura 146: Fotografia de Vincenzo Pastore. "Ponte sobre lago na Praça da República. 1910. Coleção IMS.

Figura 147: Fotografia de Vincenzo Pastore. "Rochas em meio à mata". 1914. Coleção IMS.

Figura 148: Fotografia Cesare Schiaparelli. "Tavola fuori texto". 1906. In: Zanini. La rivista "La Fotografia Artistica” e il pittorialismo in Italia. 2003.

Figura 149: Fotografia de Vincenzo Pastore. "Rebanho de ovelhas", nas próximidade da Várzea do Carmo. 1914. Instituto Moreira Salles.

Figura 150: Fotografia de Vincenzo Pastore. "Duas mulheres passando por homem idoso, apoiado em grade metálica da Rua São João”. 1910. Instituto Moreira Salles

Figura 151: Reprodução do desenho publicado no Jornal A Capital. 22 de setembro de 1913.

Figura 152: Fotografia de Vincenzo Pastore. "Cavalo da carroça de limpeza pública caído no chão". 1910. Instituto Moreira Salles

Figura 153: Fotografia de Vincenzo Pastore. "Carroça de cervejaria atolada na lama". 1910. Instituto Moreira Salles

Figura 154: Fotografia de Vincenzo Pastore. "Carroça de coleta de lixo". Rua Direita. 1910. IMS.

Figura 155: Fotografia de Vincenzo Pastore. Homem sendo abordado por guarda municipal. Sem data ou referência do logradouro. Coleção Dante Pastore.

Figura 156: Fotografia de Vincenzo Pastore. "Ferroviário lê jornal, cercado por carregadores de malas, em frente à Estação da Luz". 1910. IMS.

Figura 157: Fotografia de Vincenzo Pastore. "Pequenos prestadores de serviço jogando bola de gude, em frente à estação da Luz". 1912. IMS.

Figura 158: Fotografia de Vincenzo Pastore. "Garotos engraxates". 1910. IMS. 
Figura 159: Fotografia de Vincenzo Pastore. "Meninos Engraxates jogando bolinha de gude". 1910. IMS.

Figura 160: Fotografia de Vincenzo Pastore. "Vendedoras de verduras". 1910. Instituto Moreira Salles.

Figura 161: Fotografia de Vincenzo Pastore. "Meninos Engraxates" trabalhando no Largo São Bento. 1910. Instituto Moreira Salles.

Figura 162: Fotografia de Vincenzo Pastore. "Casal trabalhando em plantação de milho". 1910. Instituto Moreira Salles.

Figura 163: Fotografia de Vincenzo Pastore. Retrato de árvore ao centro e casebre. Ao fundo, possivelmente Instituto Bom Pastor, no Ipiranga. S/d. Coleção Dante Pastore

Figura 164: Fotografia de Vincenzo Pastore. Detalhe da fig.163. Coleção Dante Pastore.

Figura 165: Mapa criado por Felipe Scheeffer Bianchetti, indicando as ruas do Triângulo Central e de seus arredores fotografados por Pastore. A marcação inicia-se na Rua Direita em direção à Sé.

Figura 166: Fotografia de Guilherme Gaensly. Figueira Brava. 1901. Cartão Postal impresso. Acervo Apparecido Salatini.

Figura 167: Fotografia de Guilherme Gaensly. Figueira Brava. 1901. Verso de cartão Postal impresso. Acervo Apparecido Salatini.

Figura 168: Fotografia de Vincenzo Pastore. "Casario e lavadeiras às margens do Rio Tamanduateí", região da várzea do Carmo, próximo ao Parque D. Pedro II. 1910. Coleção IMS.

Figura 169: Fotografia de Guilherme Gaensly. Fundos da Ladeira da Tabatinguera. Cartão Postal Impresso, 1900. Acervo Museu Paulista - USP.

Figura 170: Fotografia de Vincenzo Pastore. "Rio Tamanduateí antes da retificação". Fotografia em Papel. 1910. Coleção IMS.

Figura 171: Fotografia de Vincenzo Pastore. "Comércio em frente ao Mercado Municipal", esquina das Ruas 25 de Março e General Carneiro. Instituto Moreira Salles.

Figura 172: Fotografia de Vincenzo Pastore. "Movimento em frente ao Mercado Municipal". 1910. Instituto Moreira Salles.

Figura 173: Fotografia de Vincenzo Pastore. "Homem sentado, comendo, próximo à gaiolas com galinhas". 1910. Instituto Moreira Salles.

Figura 174: Fotografia Aurélio Becherini. Rua da Penha, tendo ao fundo a antiga igrejinha da Penha. Casebres com janela de rótulas à esquerda da foto. 1905-1912. In: Aurélio Becherini (1879-1939). São Paulo: Cosac Naify, 2009.

Figura 175: Fotografia de Vincenzo Pastore. "Mulher com criança no colo". Próximo ao Mercado dos Caipiras, 1910. Instituto Moreira Salles. 
Figura 176: Fotografia de Vincenzo Pastore. "Mulher e dois homens com bebê”. Próximo ao Mercado dos Caipiras, 1910. Instituto Moreira Salles.

Figura 177: Fotografia de Vincenzo Pastore. "Vendedora de galinhas em porta de estabelecimento comercial". 1910. Instituto Moreira Salles.

Figura 178: Fotografia de Vincenzo Pastore. "Grupo de mulheres, vendedoras de verduras e transeunte". 1910. Instituto Moreira Salles.

Figura 179: Fotografia de Vincenzo Pastore. "Vendedora de galinha", em cena de rua adjacente ao Mercado Municipal, 1910. Instituto Moreira Salles.

Figura 180: "Uomo e Donna de Marzano". Reprodução em porcelana. Obras encomendadas pelo "10 Servizio delle Vestiture". Nápoles. Catálogo produzido por Masdea, Maria Cristina. Le Vestiture del Regno di Napoli: Origini e fortune di um genere nuovo. 1991.

Figura 181: "Uomo e Donna de Marzano". Reprodução em porcelana. Obras encomendadas pelo "10 Servizio delle Vestiture". Nápoles. Catálogo produzido por Masdea, Maria Cristina. Le Vestiture del Regno di Napoli: Origini e fortune di um genere nuovo. 1991.

Figura 182: Fotografia Alinari. Vendedoras de frutas, verduras e ervas no mercado Piazza di Campo de Fiori. Roma. 1885-1890. Arquivo Touring Club Italiano. In: Luoghi, volti, gesti e costumi. Collezione fotografica di Alberto Manodori. Editora. Fondazione Pietro Manodori. 2008.

Figura 183: Fotografia Alinari. Barraca de peixe na Praça Monte d'Oro, em Roma. 1880. In: livro Luoghi, volti, gesti e costumi. Collezione fotografica di Alberto Manodori. Editora. Fondazione Manodori. 2008.

Figura 184: Fotografia Alinari. Vendedora de água mineral. Nápoles. Arquivo Touring Club Italiano. 1885-1890. Arquivo Touring Club Italiano. In: Monti, Paolo e Zavattini, Cesare. Foto D'Archivio Italia Tra '800 e '900. Milão: Touring Club Italiano.

Figura 185: Foto Coleção Brogi. Arquivo Alinari. Firenze. 1870-1880. In: Luigi, Magni e Settimelli, Wladimiro. Roma e il Lazio Archivi Alinari, 1989.

Figura 186: Fotógrafo não identificado. Potenza. 1906. Editore Vincenzo Garramone. In: Luccioni, Luigi. La Basilicata ...com'era. Aspetti territoriale urbani ed umani della Basilicata in um album di immagini d'epoca. (1896-1945). Roma: Edizione Atena. 1988.

Figura 187: Fotografia de Mario De Maria. Roma. Campo di Fiori. 1882- 1887. In: Del Balbarò, Michele Falzone e Tempesta, Claudia. Marius Pictor Fotografo. L'album fotografico di Mario De Maria. 1882-1887. Editora IFotolibri/Longanesi\&C. 1979.

Figura 188: Foto anônima. Imagem estereoscópica 1900. Roma. In: Luoghi, Volti, gesti e costumi. Collezione fotografica di Alberto Manodori. Editora. Fondazione Pietro Manodori. 2008.

Figura 189: Foto G. Sommer. Foro Civile. Pompei. 1870. In: Luoghi, Volti, gesti e costumi. Collezione fotografica di Alberto Manodori. Editora. Fondazione Pietro Manodori. 2008. 
Figura 190: Fotografia anônima. "Venditrici di frittelle", "vendedora de doce". Veneza. 1870. In: Luoghi, Volti, gesti e costumi. Collezione fotografica di Alberto Manodori. Editora. Fondazione Pietro Manodori. 2008.

Figura 191: Foto de C. Naya realizada em Veneza retratando "venditrice di zucca arrostita". "Vendedora de abóbora grelhada". 1900. In: Luoghi, Volti, gesti e costumi. Collezione fotografica di Alberto Manodori. Editora. Fondazione Pietro Manodori. 2008.

Figura 192: Fotografia de Giorgio Sommer. "Mangiatori di maccheroni", 1886. In: catálogo Volti e Figure. Il ritratto nella storia della fotografia. Editora Apax libri. Aión. 2009

Figura 193: Fotografia de Carlo Brogi. "Napoli - Maccheronaio napoletano", 1880. In: catálogo Volti e Figure. Il ritratto nella storia della fotografia. Editora Apax libri. Aión. 2009. Ambas as fotos reprodução da página 75 .

Figura 194: Fotografia anônima. "Bruscolinaro" sob os arcos da Piazza Vittorio. 1891. In: La Fotografia a Roma Dalla Origini al 1915. Roma. Editora Colombo. 1983.

Figura 195: Fotografia de Gaetano Senni. Vendedor de panelas. Mercado Campo Di Fiori. Roma. 24 de março de 1896. In: La Fotografia a Roma Dalla Origini al 1915. Roma. Editora Colombo. 1983.

Figura 196: Fotografia de Conrado Giuseppe e Fornari Felippo Vendedores ambulantes. 1890-1899. Arquivo Comunale de Roma/Museu de Roma.

Figura 197: Fotografia Alinari. Vendedores de peixe em Rua de Nápoles. 1873. In: Catalogo Generalle Delle Publicate daí Fratelli Alinari.

Figura 198: Fotografia de Enrico Bambocci. Bari. 1900. In: Leonardi, Sérgio. La Fotografia Dell'Ottocento a Bari. Bari: Mario Adda Editore. 1997:67.

Figura 199: Fotografia de Enrico Bambocci. Vendedor em rua de Bari. 1900 / Archivio A. Giovine. In: Giovine, Alfredo. Bari la zita me. Bari: Edizione Fratelli Laterza .1981.

Figura 200: Fotografia de Lopez Vendedores na Avenida Corso Cavour em Bari. Foto intitulada Venditori di Ricci. S/d. Archivio A. Giovine. In: Giovine, Alfredo. Bari la zita me. Bari: Edizione Fratelli Laterza.1981.

Figura 201: Fotografia anônima. Vendeiros na cidade de Bari. Archivio A. Giovine. In: Giovine, Alfredo. Bari la zita me. Bari: Edizione Fratelli Laterza. 1981

Figura 202: Fotografia dos irmãos Alinari. Carroça de Vinho. Palermo. 1900. In: Luoghi, Volti, gesti e costumi. Collezione fotografica di Alberto Manodori. Editora. Fondazione Pietro Manodori. 2008.

Figura 203: Fotos G. Sommer. 1870. In: Fanelli, Giovanni. L'Italia virata all'oro attraverso le fotografie di Giorgio Sommer. 2007, p. 121.

Figura 204: Fotografia de Carlo Brogi. "Nápoles. Carroça carregada de caixas de macarrão", 1880. In: catálogo (org) Pagnotta, Linda. Volti e Figure. Il ritratto nella storia della fotografia. Editora Apax Libri. Aión. 2009. 
Figura 205: Fotografia anônima. 1890. In: Storia Fotografica di Roma. 1900 a 1918. Dalla Belle Époque alla Grande Guerra. Editora Intra Moenia. 2003.

Figura 206: Fotografia de Mario De Maria. In: Del Balbarò, Michele Falzone e Tempesta, Claudia. Marius Pictor Fotografo. L'album fotografico di Mario De Maria. 1882-1887. Editora IFotolibri/Longanesi\&C. 1979, p.51.

Figura 207: Fotografia de Ettore Roesler Franz. Barcos ao sul do rio Tevere. In: livro Itinerari nella Roma pittoresca di Ettore Roesler Franz. Palombi Editora. 2012.

Figura 208: Fotografia de Mario De Maria. In: Del Balbarò, Michele Falzone e Tempesta, Claudia. Marius Pictor Fotografo. L'album fotografico di Mario De Maria. 1882-1887. Editora IFotolibri/Longanesi\&C. 1979, p.51.

Figura 209: Fotografia de Vincenzo Pastore. "Barcos no rio Tamanduateí", 1910. Instituto Moreira Salles.

Figura 210: Fotografia Coleção Brogi. Arquivo Alinari. Firenze. In: Roma e il Lazio Negli Archivio Alinari. 1989.

Figura 211: Fotografia de Giuseppe Primoli. 1890. Ponte Milvio. Fondazione Primoli. In: Brizzi, Bruno. Il Tevere. Um secolo di Immagini. Editora Colombo. 1989.

Figura 212: Fotografia de Giuseppe Primoli. Venditrice ambulante a Ponte Sant'Angelo. Sem data. Fondazione Primoli. In: Brizzi, Bruno. Il Tevere. Um secolo di Immagini. Editora Colombo. 1989.

Figura 213: Fotografia anônima. Vendedora de ovos. Potenza. Cartão postal de 1902. In: Luccioni, Luigi. Saluti Da Potenza. Potenza: La Buona Stampa. 1983.

Figura 214: Fotografia anônima. Cartão Postal. Potenza. 1900. Biblioteca Nacional de Potenza.

Figura 215: Fotografia de C. Naya. "Mulheres no poço do Campo San Zanipolo". Coleção de Alberto Manodori. 1870. In: Luoghi, Volti, gesti e costumi. Collezione fotografica di Alberto Manodori. Editora. Fondazione Pietro Manodori. 2008.

Figura 216: Fotografia de Eugenio Buono. In: Italia inédita di un secolo fa. Napoli, Venezia, Palermo, i borghi di Caiazzo e di Cerreto Sannita nelle lastre ritrovate di Eugenio Buono. Napoli: Edizioni Intra Moenia. 2008.

Figura 217: Fotografia Alinari. Mulher vendedora de louças. 1880. Coleção fotográfica de Alberto Manodori. (1866-1935). In: Luoghi, volti, gesti e costumi. Collezione fotografica di Alberto Manodori. Editora. Fondazione Pietro Manodori. 2008

Figura 218: Fotografia Alinari. Vendedora de Pastarelle em Nápoles. 1873. Coleção Alinari, Firenze. In: Catalogo Generalle Delle Fotografie Publicate dai Fratelli Alinari. 1873.

Figura 219: Fotografia de Eugenio Buono. Vendeira sentada sob grande cesto. Nápoles. Sem data. In: Italia inédita di un secolo fa. Napoli, Venezia, Palermo, i borghi di Caiazzo e di Cerreto Sannita nelle lastre ritrovate di Eugenio Buono. Napoli: Edizioni Intra Moenia. 2008. 
Figura 220: Fotografia de Eugenio Buono. Vendedores ambulantes. Nápoles. In: Italia inédita di un secolo fa. Napoli, Venezia, Palermo, i borghi di Caiazzo e di Cerreto Sannita nelle lastre ritrovate di Eugenio Buono. Napoli: Edizioni Intra Moenia. 2008.

Figura 221: Fotografia de Vincenzo Pastore. "Mulher de costas conversa com homem”. 1910. Instituto Moreira Salles.

Figura 222: Fotografia de Vincenzo Pastore. "Comércio de frutas no mercado dos caipiras". 1910. Instituto Moreira Salles.

Figura 223: Fotógrafo anônimo. Vendedor ambulante de peixe. Veneza. 1900. Coleção fotográfica de Alberto Manodori. (1866-1935). In: Luoghi, volti, gesti e costumi. Collezione fotografica di Alberto Manodori. Editora. Fondazione Pietro Manodori. 2008.

Figura 224: Fotografia Eugenio Buono. Vendeiro em Veneza. Sem data. In: Italia inédita di un secolo fa. Napoli, Venezia, Palermo, i borghi di Caiazzo e di Cerreto Sannita nelle lastre ritrovate di Eugenio Buono. Napoli: Edizioni Intra Moenia. 2008.

Figura 225: Fotografia Eugenio Buono. In: Italia inédita di un secolo fa. Napoli, Venezia, Palermo, $i$ borghi di Caiazzo e di Cerreto Sannita nelle lastre ritrovate di Eugenio Buono. Napoli: Edizioni Intra Moenia. 2008.

Figura 226: Pintura em aquarela de Eugenio Buono. In: Italia inédita di un secolo fa. Napoli, Venezia, Palermo, i borghi di Caiazzo e di Cerreto Sannita nelle lastre ritrovate di Eugenio Buono. Napoli: Edizioni Intra Moenia. 2008.

Figura 227: Fotografia Eugenio Buono. Mulheres moradoras da comuna de Cerreto Sannita, região da Campania, província de Benevento. Itália. In: Italia inédita di un secolo fa. Napoli, Venezia, Palermo, i borghi di Caiazzo e di Cerreto Sannita nelle lastre ritrovate di Eugenio Buono. Napoli: Edizioni Intra Moenia. 2008.

Figura 228: Fotografia Eugenio Buono. Mulheres moradoras da comuna de Cerreto Sannita, região da Campania, província de Benevento. Itália. In: Italia inédita di un secolo fa. Napoli, Venezia, Palermo, i borghi di Caiazzo e di Cerreto Sannita nelle lastre ritrovate di Eugenio Buono. Napoli: Edizioni Intra Moenia. 2008.

Figura 229: Fotografia Eugenio Buono. Mulheres moradoras da comuna de Cerreto Sannita, região da Campania, província de Benevento. Itália. In: Italia inédita di un secolo fa. Napoli, Venezia, Palermo, i borghi di Caiazzo e di Cerreto Sannita nelle lastre ritrovate di Eugenio Buono. Napoli: Edizioni Intra Moenia. 2008.

Figura 230: Fotografia Mario De Maria. Mulheres retratadas na comuna de Terracina. 1882- 1887. In: Del Balbarò, Michele Falzone e Tempesta, Claudia. Marius Pictor Fotografo. L'album fotografico di Mario De Maria. 1882-1887. Editora IFotolibri/Longanesi\&C. 1979.

Figura 231: Fotografia Francesco Paolo Michetti. Imagens realizadas na comuna de Orsogna. 1895 a 1900. In: Miraglia, Marina. Francesco Paolo Michetti Fotografo. Torino: Einaudi Letteratura 43. 1975.

Figura 232: Fotografia Francesco Paolo Michetti. Imagens realizadas na comuna de Orsogna. 1895 a 1900. In: Miraglia, Marina. Francesco Paolo Michetti Fotografo. Torino: Einaudi Letteratura 43. 1975. 
Figura 233: Fotografia Francesco Paolo Michetti. Imagens realizadas na comuna de Orsogna. 1895 a 1900. In: Miraglia, Marina. Francesco Paolo Michetti Fotografo. Torino: Einaudi Letteratura 43. 1975.

Figura 234: Francesco Paolo de Michetti. Mulher levando água. Comuna de Orsogna. 1895 a 1900. In: Miraglia, Marina. Francesco Paolo Michetti Fotografo. Torino: Einaudi Letteratura 43. 1975

Figura 235: Fotógrafo não identificado. Comuna Olevano Romano, Lazio, província de Roma. S/d. In: Brizzi, Bruno. Lazio Scomparso. Edizioni Quasar. 1977.

Figura 236: Fotógrafo não identificado. Marino, Donne al Lavatoio. In: Brizzi, Bruno. Lazio Scomparso. Edizioni Quasar. 1977, p. 35.

Figura 237: Fotografia Alinari. Mulheres lavadeiras na Via Tuscolana. Fontanile nella Campagna. Coleção Alinari. Firenze.

Figura 238: Fotografia Brogi. Tipos e costumes de Roma e Província. Coleção Brogi - Archivio Allinari. In: Settimelli, Wladimiro. Roma e il Lazio Negli archivi Alinari.1989, p. 112.

Figura 239: Fotografia Eugenio Buono. Mulheres lavadeiras na comuna de Caiazzo. 1900. In: Sorbo, Luca e Scateni, Luciano. Italia inédita di in secolo fa. Edizioni Intra Moenia. 2008, p. 44.

Figura 240: Pintura a óleo de Mario De Maria. Donne al Monte di Pietà. Pintura a óleo. 1886-1920. In: Del Balbarò, Michele Falzone e Tempesta, Claudia. Marius Pictor Fotografo. L'album fotografico di Mario De Maria. 1882-1887. Editora IFotolibri/Longanesi\&C. 1979, p.10.

Figura 241: Fotografia de Mario De Maria. Imagem que integra a série de fotos para a realização da pintura Donne al Monte di Pietà. 1886. In: Del Balbarò, Michele Falzone e Tempesta, Claudia. Marius Pictor Fotografo. L'album fotografico di Mario De Maria. 1882-1887. Editora IFotolibri/Longanesi\&C. 1979, p.11 e 33.

Figura 242: Fotografia de Mario De Maria. Imagem que integra a série de fotos para a realização da pintura Donne al Monte di Pietà. 1886. In: Del Balbarò, Michele Falzone e Tempesta, Claudia. Marius Pictor Fotografo. L'album fotografico di Mario De Maria. 1882-1887. Editora IFotolibri/Longanesi\&C. 1979, p.11 e 33.

Figura 243: Desenho de Mario De Maria para a realização da pintura Donne al Monte di Pietà. 18861920. In: Del Balbarò, Michele Falzone e Tempesta, Claudia. Marius Pictor Fotografo. L'album fotografico di Mario De Maria. 1882-1887. Editora IFotolibri/Longanesi\&C. 1979, p.11 e 13.

Figura 244: Fotografia de Mario De Maria para a realização da pintura Donne al Monte di Pietà, empregando a técnica da grade quadriculada. 1886-1920. In: Del Balbarò, Michele Falzone e Tempesta, Claudia. Marius Pictor Fotografo. L'album fotografico di Mario De Maria. 1882-1887. Editora I Fotolibri/Longanesi\&C. 1979, p.11 e 13.

Figura 245: Fotografia de Vincenzo Pastore. "Idoso sentado em degrau de escada". 1910. Instituto Moreira Salles.

Figura 246: Fotografia de Eugenio Buono. Idoso sentando em guia de calçamento em Nápoles. In: Italia inédita di un secolo fa. Napoli, Venezia, Palermo, i borghi di Caiazzo e di Cerreto Sannita nelle lastre ritrovate di Eugenio Buono. Napoli: Edizioni Intra Moenia. 2008. 
Figura 247: Detalhe da reprodução de recorte de jornal sobre a participação de Pastore na Exposição Nacional do Rio de Janeiro em 1908. In: Caderno de Recortes. Coleção Dante Pastore.

Figura 248: Reprodução de recorte de jornal. Artigo "Il Nostro Carnet". In: Caderno de Recortes. Coleção Dante Pastore.

Figura 249: Fotografia Marc Ferrez. Mercado na Beira do Cais. Rio de Janeiro. 1875. Instituto Moreira Salles.

Figura 250: Fotografia de Vincenzo Pastore. "Retrato de mulher com criança no colo". 1905. Instituto Moreira Salles.

Figura 251: Fotografia de Vincenzo Pastore. "Retrato de mulher diante da cruz, com criança chorando ao lado". 1905. Instituto Moreira Salles.

Figura 252: Fotografia Vincenzo Pastore. "Retrato de índio com arco e flechas". 1905. Instituto Moreira Salles.

Figura 253: Fotografia Vincenzo Pastore. "Retrato de três índios com cocar e arco e flechas". 1905. Instituto Moreira Salles.

Figura 254: Reprodução de ficha técnica da imagem VP006, página 01. Acervo do Instituto Moreira Salles.

Figura 255: Reprodução de acompanhamento ficha técnica da imagem VP0006 com descrição indicação das características de deteriorização. Acervo do Instituto Moreira Salles.

Figura 256: Reprodução da parte superior e inferior de ficha técnica informatizada com descrições e códigos de catalogação. Instituto Moreira Salles.

Figura 257: Reprodução de páginas da Revista Veja São Paulo. Janeiro/fevereiro de 1997. Biblioteca Mario de Andrade.

Figura 258: Reprodução Jornal Folha de S.Paulo, dia 29 de fevereiro de 1997. Caderno Acontece. Arquivo do Estado de São Paulo.

Figura 259: Reprodução Jornal O Estado de S.Paulo. 29 de janeiro de 1997. Caderno 2. Arquivo do Estado de São Paulo.

Figura 260: Reprodução Jornal O Estado de S.Paulo, dia 29 de fevereiro de 1997. Fragmento de capa do jornal. Arquivo o Estado de São Paulo.

Figura 261: Foto da exposição realizada em janeiro de 1997. Acervo do Instituto Moreira Salles.

Figura 262: Foto da exposição realizada em janeiro de 1997. Visitante observa imagens originais em uma das vitrines da mostra. Acervo do Instituto Moreira Salles.

Figura 263: Fotografia Vincenzo Pastore. Foto panorâmica com vista do Vale do Anhangabaú, realizada em quatro diferentes tomadas. (Viaduto do Chá). 1910. Instituto Moreira Salles 
Figura 264: Desenho de Hélio de Almeida e Fotografias de Vincenzo Pastore em painel apresentado na exposição realizada em janeiro de 1997. Espaço da Galeria Higienópolis. Foto concedida pelo IMS.

Figura 265: Fotografia Vincenzo Pastore. Vista do "Vale do Saracura". Aproximadamente 1900. Instituto Moreira Salles

Figura 266: Fotografia Vincenzo Pastore. "Procissão na Rua Direita". 1910. Ao lado direito, mostruário de fotos fixado na parede externa do atelier de Pastore. Instituto Moreira Salles

Figura 267: Fotografia Vincenzo Pastore. "Homem idoso em pequena carruagem". 1910. Instituto Moreira Salles

Figura 268: Reprodução fotografia de fólios do catálogo da exposição de Vincenzo Pastore no Espaço Higienópolis. 1997. Foto Panorâmica tirada a partir do Largo São Bento.

Figura 269: Fotografia Vincenzo Pastore. "Largo da Sé”. 1910. Instituto Moreira Salles.

Figura 270: Reprodução da capa do livro / Portfólio “Na Rua, Vincenzo Pastore”. São Paulo: Instituto Moreira Salles. 2009.

Figura 271: Fotografia Vincenzo Pastore. "Barcos no rio Tamanduateí". 1910. Instituto Moreira Salles.

Figura 272: Fotografia Vincenzo Pastore. "Barcos no rio Tamanduateí". 1910. Instituto Moreira Salles.

Figura 273: Fotografia Vincenzo Pastore. "Figueira junto ao rio Tamanduateí". 1910. Instituto Moreira Salles.

Figura 274: Fotografia Vincenzo Pastore. "Grupo de pessoas ao redor de realejo, na Praça da República". 1910. Instituto Moreira Salles

Figura 275: Fotografia Vincenzo Pastore. "Grupo de pessoas ao redor de realejo, na Praça da República”. 1910. Instituto Moreira Salles

Figura 276: Fotografia Vincenzo Pastore. "Encontro de mulheres, próximo ao mercado dos caipiras". 1910. Instituto Moreira Salles

Figura 277: Fotografia Vincenzo Pastore. "Mulheres conversando em área descampada". 1910. Instituto Moreira Salles

Figura 278: Fotografia Vincenzo Pastore. "Casario da Rua da Esperança". 1910. Instituto Moreira Salles

Figura 279: Fotografia Vincenzo Pastore. "Casario em demolição na Rua da Esperança". 1910. Instituto Moreira Salles

Figura 280: Detalhe da imagem 278

Figura 281: Detalhe da imagem 279 
Figura 282: Reprodução capa e contra-capa do livro Telles. Libertas entre Sobrados. Mulheres negras e trabalho doméstico em São Paulo (1880-1920). São Paulo: ed. Alameda. 2013.

Figura 283: Fotografia Vincenzo Pastore. "Dois homens conversando na calçada". 1910. Instituto Moreira Salles.

Figura 284: Reprodução do documento de nomeação de Vincenzo Pastore como Cavalheiro da Ordem da Coroa da Itália. Cadernos de Recortes. Coleção Dante Pastore, p. 3.

Figura 285: Reprodução do documento assinado pelo prefeito de Bari. Maio de 1916. Caderno de Recortes. Coleção Dante Pastore, p. 86.

Figura 286: Reprodução de carta com agradecimento real, pelo envio de fotos realizadas por Vincenzo Pastore retratando índios Bororos no Brasil. Reprodução Caderno de Recortes. Coleção Dante Pastore, p. 8.

Figura 287: Reprodução de carta real agradecendo o envio de fotos de "grupos de negros" retratados por Vincenzo Pastore no Brasil. Caderno de Recortes. Coleção Dante Pastore, p. 7.

Figura 288: Reprodução de carta real parabenizando o fotógrafo Vincenzo Pastore pela realziação de concurso de beleza em Bari, região da Puglia. Caderno de recortes Coleção Dante Pastore, p. 85. 


\section{SUMÁRIO}

\section{Introdução}

A coleção: um breve panorama da "Fortaleza de lembranças e permanências" construídas por

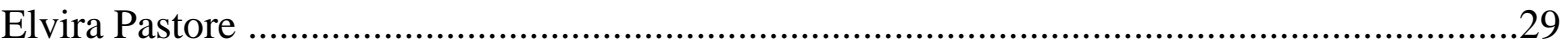

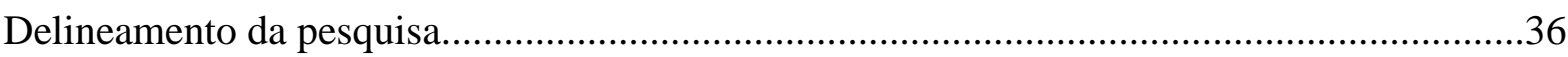

Os capítulos: espaços da construção narrativa - interpretativa sobre Pastore..........................42

\section{Capítulo 1: 0 circuito social do retrato}

1.1 Da Rua Assembleia à Rua Direita: O atelier como espaço de trabalho, convivência

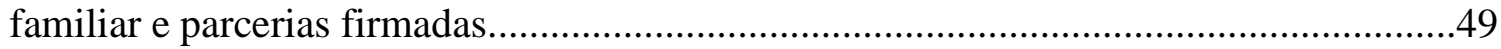

1.2 Viver do retrato na capital paulista: desafios e práticas fotográficas...............................58

1.3 A troca de endereços de estúdios na São Paulo de início de século....................................68

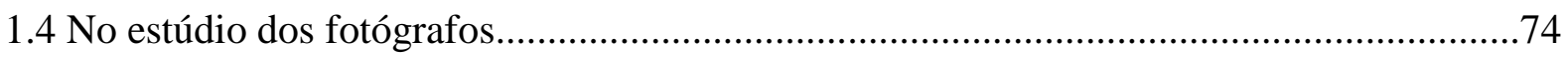

1.5 Intrigantes aspectos entrevistos no estúdio de Pastore.................................................84

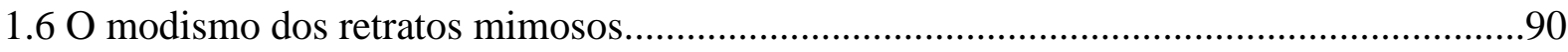

\section{Capítulo 2: Vestígios de práticas fotográficas errantes}

2.1 "La Fotografia Pastore" na antiga Lucania: fragmentos e arranjos recriados por Elvira.

2.2 Basilicata: terra de Elvira

2.3 A "formidável memória visual” da Basilicata: vestígios de fotógrafos em trânsito no "profondo sud" italiano

2.4 Entre o estúdio e a estrada: o difícil contexto vivenciado por Pastore na antiga

Lucania.

2.5 Pastore em seu "templo de arte": um interessante circuito de exposições

2.6 Vincenzo Pastore, "Cavalheiro da ordem da Coroa da Itália": uma trajetória de silêncios em sua província natal.

2.7 Na "Galeria de Imagens": Pastore entre o pictoralismo e as fotos montagens, desejos de transcendência do fotógrafo 


\section{Capítulo 3: Da galeria de imagens à foto guardada}

3.1 Vincenzo Pastore, Fotógrafo do Cotidiano. 186

3.2. Poses negociadas: o fotógrafo e seus retratados, agências em construção. 189

3.3 O olhar fotográfico de Pastore: sutilezas insinuadas em sua narrativa visual.

3.4 Entre panos, quinquilharias e muitas vassouras: Brechas de resistências na São Paulo que recebia Pastore.

3.5 Traços da especificidade da série fotográfica: atitudes e invenções assumidas por Pastore.

3.6 O cotidiano de trabalho dominando o recorte da narrativa.

$3.7 \mathrm{O}$ fotógrafo nos arredores de vegetação rasteira: cenas pitorescas da Várzea do Carmo ao Ipiranga.

$3.8 \mathrm{O}$ fotógrafo nas proximidades dos mercados: zonas de contato e interações na sinuosa

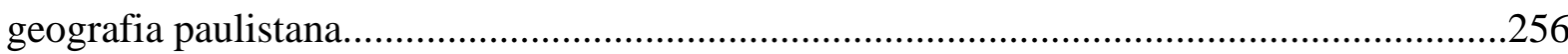

3.9 A imagem nos caminhos de sua longa duração. .265

\section{Capítulo 4: Pastore e a tradição da fotografia de rua italiana.}

4.1 "Uma fotografia que se pode abraçar": o encontro com fontes inesperadas. .273

4.2 O mosaico visual do Grand Tour: rastros de um intenso trânsito de imagens

4.3 A pulsão das ruas atraindo os fotógrafos por toda a península itálica

4.4 Figuras femininas na interface da Fotografia com a Pintura.

4.5 Quando os novos sentidos superam o referente e rompem a tradição

4.6 Quando a referência não explica tudo: camadas de complexidade do ato fotográfico de

Pastore.

4.7 Fotos e cartas: redes de contato possíveis de se indiciar.

4.8 Fotografias que se desdobram em uma coleção doada e reinventada. As motivações para o capítulo seguinte.

\section{Capítulo 5: Memória do ato fotográfico}

5.1 Cadeia de historicidade das fotos 
5.3 Biografia da doação

5.4 Organicidade da coleção doada.

5.5 A coleção VP

5.6 Rastros de um acontecimento: a divulgação 364

5.6.1 Pastore recriado na Revista Veja São Paulo: memórias em disputa. 365

5.6.2 Pastore recriado no jornal Folha de S.Paulo: Apego a signos conhecidos.

5.6.3 Pastore recriado no jornal $O$ Estado de S. Paulo: agenciamentos compartilhados

5.7 A exibição: "São Paulo de Vincenzo Pastore”, fotos que finalmente se faziam para a História.

5.8 Pastore em catálogo e Portfolio: vestígios de uma circulação em novos suportes de memória do ato fotográfico

5.9 A série fotográfica: entre diálogos com a história social e perspectivas familiares em busca de Pastore. .409

Considerações Finais .423

Anexos 429

Arquivos Consultados 434

Bibliografia. 436 


\section{Introdução}

\section{A coleção: um breve panorama da "fortaleza de lembranças e permanências" construídas por Elvira Pastore}

Seguir a trajetória de Vincenzo Pastore e o percurso trilhado por suas fotos compõem a trama deste estudo. Propõe-se uma inversão de interpretação: além de acompanhar a sua produção mais emblemática, as fotos tomadas nas ruas da capital paulista, incorporamos ao campo dos estudos históricos, a instabilidade enfrentada por Pastore no métier do retrato. A despeito do fotógrafo ter sobrevivido e criado seus dez filhos realizando retratos comerciais, essa atuação foi quase sempre apresentada de modo secundário.

A ausência inicial de fontes levava ao desespero. Não há interpretação histórica possível quando rareiam os documentos. Mas, na trajetória do pesquisador da história social, há também magia. Maria Lúcia Varani Pastore e seu marido José Roberto Varani, netos do fotógrafo, permitiram acesso aos documentos preservados pelos laços fraternos e familiares que envolvem Pastore. Foram meses e meses tecendo aproximações com os descendentes. Meses de espera. Depois de ouvir de Maria Lúcia "venha me encontrar, eu tenho algumas coisas" surgiu, verdadeiramente, a chance de uma pesquisa. É preciso ser verdadeira com o leitor. As problematizações mais acertadas, o viés interpretativo mais adequado, surgiram na feitura de cada capítulo, no enfretamento de cada dado novo que despontava. Porque Pastore é assim, movediço, dinâmico, camaleão. É feito da instabilidade frente às vicissitudes de um destino marcado por um ir e vir constante, marcado pelo desafio de sobreviver por meio da fotografia.

A riqueza das fontes documentais cedidas pela neta do fotógrafo é resultado de um gesto antecedente: Elvira, esposa de Pastore, avó de Maria Lúcia, criou uma biografia material que guarda vestígios da atuação do marido em sua experiência profissional, pessoal, ou no âmbito familiar. Após a morte de Pastore, em 1918, na angústia de tentar vencer a "passagem inexorável do tempo", ${ }^{1}$ num gesto que mostrava a tentativa de preservar aquilo que amava e sentia falta, Elvira criou uma coleção. Reuniu, organizou, selecionou e colou fragmentos que pudessem preservar a memória de Pastore. Ocupou, assim, o lugar da primeira guardiã de documentos que mostram nuances, no folhear de muitas páginas, dos

\footnotetext{
${ }^{1}$ Para os estudos de formação de coleções particulares cf. estudo de Blom, 2003, p.115.
} 
caminhos trilhados por esse fotógrafo quer em São Paulo, quer em Potenza ou Bari, províncias italianas, onde Pastore também atuou.

Lidamos, portanto, com essa documentação que indicia tanto o prestígio alcançado por Pastore nos locais onde abriu seus ateliês, quanto possibilita melhor documentar a própria inserção social da fotografia nesses diferentes contextos sociais. Mas, há ainda outro corpus documental que colaborou para a observação da atuação de Pastore, em contrapartida, nas ruas da capital paulista, como retratista das sociabilidades vistas no centro antigo da cidade e nos seus arredores. Tais fotos formam atualmente a coleção integrada ao acervo do Instituto Moreira Salles, intitulada coleção VP, à qual foi possível ter amplo acesso. Essa coleção foi doada em 1996. Mas, a outra, criada por Elvira, os descendentes ainda não abrem mão. Ambas, contudo, foram essenciais para se compreender a trajetória desse retratista, profundamente ligado a dois continentes, ambos lhe conferindo préstigio.

Este não é um estudo sobre coleção, mas é pertinente explicar ao leitor os meandros da documentação montada por Elvira, sob a guarda familiar. Essa coleção, entendida como um "suporte de significados", porque sempre investida de valor, premissa da perspectiva defendida por Blom (2003, p.192), formou o corpus documental essencial desta tese, que se debruçou sobre textos e fotos e, ainda, cartas e documentos oficiais enviados da Itália, desvelando a vida instável daqueles envolvidos com a prática fotográfica.

Um caderno compõe o diário pessoal de Elvira; em outro, se tem os arranjos de recortes de jornais publicados no Brasil e na Itália que noticiam inaugurações e o prestígio dos estúdios do fotógrafo abertos primeiro em Potenza, região da Basilicata; depois, na capital paulista; e, em seguida, em Bari, província da região da Puglia. Há ainda o "Álbum de recordações Vicente e Elvira Pastore", que apresenta uma montagem revelando cartas trocadas entre os familiares, documentos pessoais como passaportes, boletins escolares dos filhos do casal e, até bilhetes de viagens. São muitas fotos num álbum que é de família, mas de onde despontam cenas internas e externas do estúdio de Pastore, além de retratos de possíveis clientes. Após a morte de Elvira, seu filho Dante Pastore, pai de Maria Lúcia, tornou-se o guardião da coleção que recebe seu nome, em homenagem prestada pela filha que zela pelo material herdado. As chances de se documentar mais profundamente também a trajetória profissional de Pastore, na tentativa de viver como retratista, surgiu devido ao encontro com fontes que apontavam para a construção de novos rumos, mais empolgantes: ver Pastore entre o estúdio e a rua. 
A página de abertura do caderno de recortes (fig.1) mostra o quanto, na feitura de sua composição, inscrevem-se aspectos do retrato fotográfico. A delicadeza do desenho feito à mão, em letras azuis, mostra Elvira retomando o estilo art nouveau, em formas que "deixam entrever a mão feminina que (...) quis salpicar pétalas de rosas, inventando uma maneira singular de fabricar molduras", menciona Abreu (1994), em relação à participação decisiva da mulher na elaboração de álbuns de família, remontando à prática de Elvira.
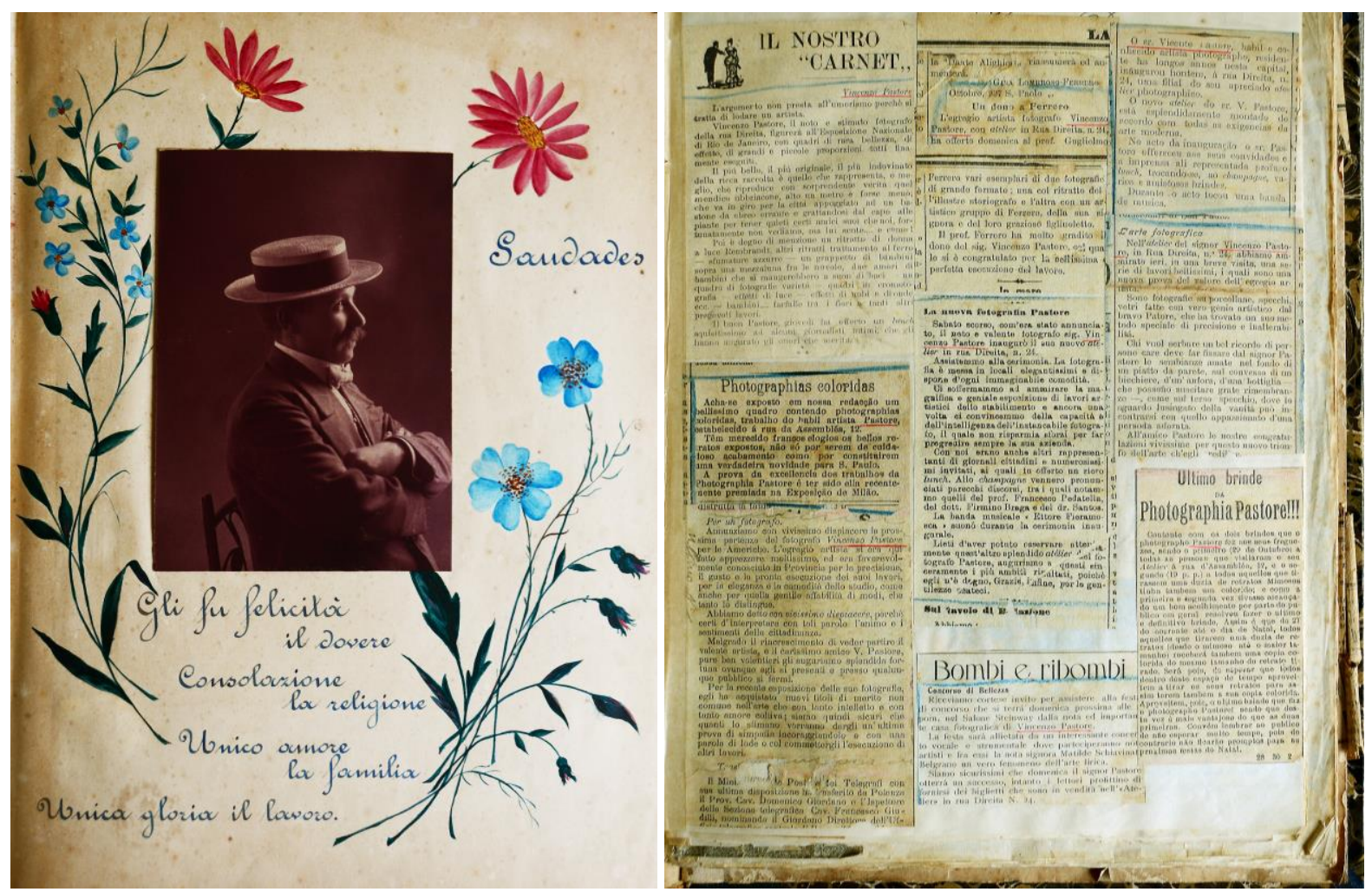

Figuras 1 e 2 :Reprodução de páginas iniciais do Caderno de Recortes montando por Elvira Pastore esposa de Vincenzo Pastore. Coleção Dante Pastore.

O auto-retrato de Pastore posicionado no centro da primeira página do Caderno de Recortes indicava a quem o caderno era dedicado. Essa montagem de Elvira lembra Blom (2003, p.179), quando o autor tratou dos sentidos imbricados na formação de uma coleção. Estamos diante de uma materialidade que dá corpo a uma "poderosa presença onde existe a ausência". A "Saudade" inscreve o sentido da perda. Se, os objetos de uma coleção, têm a função de conter o passado como testemunha muda da história, como afirmou Blom, Elvira escolheu o seu modo de narrar para informar o máximo das qualidades do marido já falecido. 
$\mathrm{Na}$ aparente falta de sentido ou coesão entre as notícias recortadas e coladas em cada página, que somam cem no total, Elvira dava algum sentido cronológico ao reorganizar a trajetória de Pastore. Ao arquivar inúmeros vestígios escritos (fig.2), a guardiã dessa memória fabricada se lançou numa prática de triagem e seleção, entendida por Artières (1998), como um verdadeiro gesto de "arrumar" e "manipular a existência".

Nesse processo de "arquivamento do eu”, que se funda na relação ambígua entre o indivíduo e aquilo que Pearce (1993, p.15) chama de "material things", não se deu uma construção de si mesma, mas sim a tentativa de elaborar, simultaneamente, uma quase biografia de Pastore, a partir da ordenação de uma documentação que relatava aspectos da prática fotográfica vivenciada por ele.

Nessa remontagem artificial, o nome dos jornais foi, na maioria das vezes, recortado. Apenas o conteúdo de notas que se referiam à Pastore ou a alguma matéria sobre ele, interessava a Elvira preservar. Sobre o ato de colecionar, Blom confirma a importância de tais montagens, que assumem os verdadeiros sentidos de uma coleção:

Ao mesmo tempo, esses objetos adquirem uma vida nova, como parte de um organismo, como parte da imagem duplicada do colecionador, entidades que fazem suas próprias exigências, que criam suas próprias regras e transpiram seu próprio poder. Como relíquias, são mortos e, apesar disso, muito vivos na mente do crente, do colecionador, do devoto. Sendo assim, formam uma ponte entre nosso mundo limitado e outro, infinitamente mais rico, da história, da arte, do carisma, do sagrado - um mundo de suprema autenticidade e, portanto, uma utopia profundamente romântica. Por intermédio deles, o colecionador pode continuar a viver depois que sua própria vida termina; e a coleção torna-se um baluarte contra a mortalidade. (Blom, 2003, p.177)

Em seu ato de evocação, Elvira também montou o "Álbum de Recordações Vicente e Elvira Pastore" (fig.3). Escolheu uma encadernação de capa dura de couro escuro, pesada, reunindo inúmeras fotografias coladas em folhas de papel cartão, fixadas à capa por dois parafusos. Na primeira página, colou a foto onde se via ao lado do marido (fig.4). Nas linhas enquadradas acima da foto, a "Viúva Pastore" inscreveu a sequência de nomes e datas de nascimentos dos filhos nascidos a partir dessa união, assim enunciada: "Vicente Pastore e Elvira Leopardi Pastore casaram-se em 1898, permaneceram juntos até 1918, quando ele faleceu. Tiveram os seguintes filhos sobreviventes...”. 

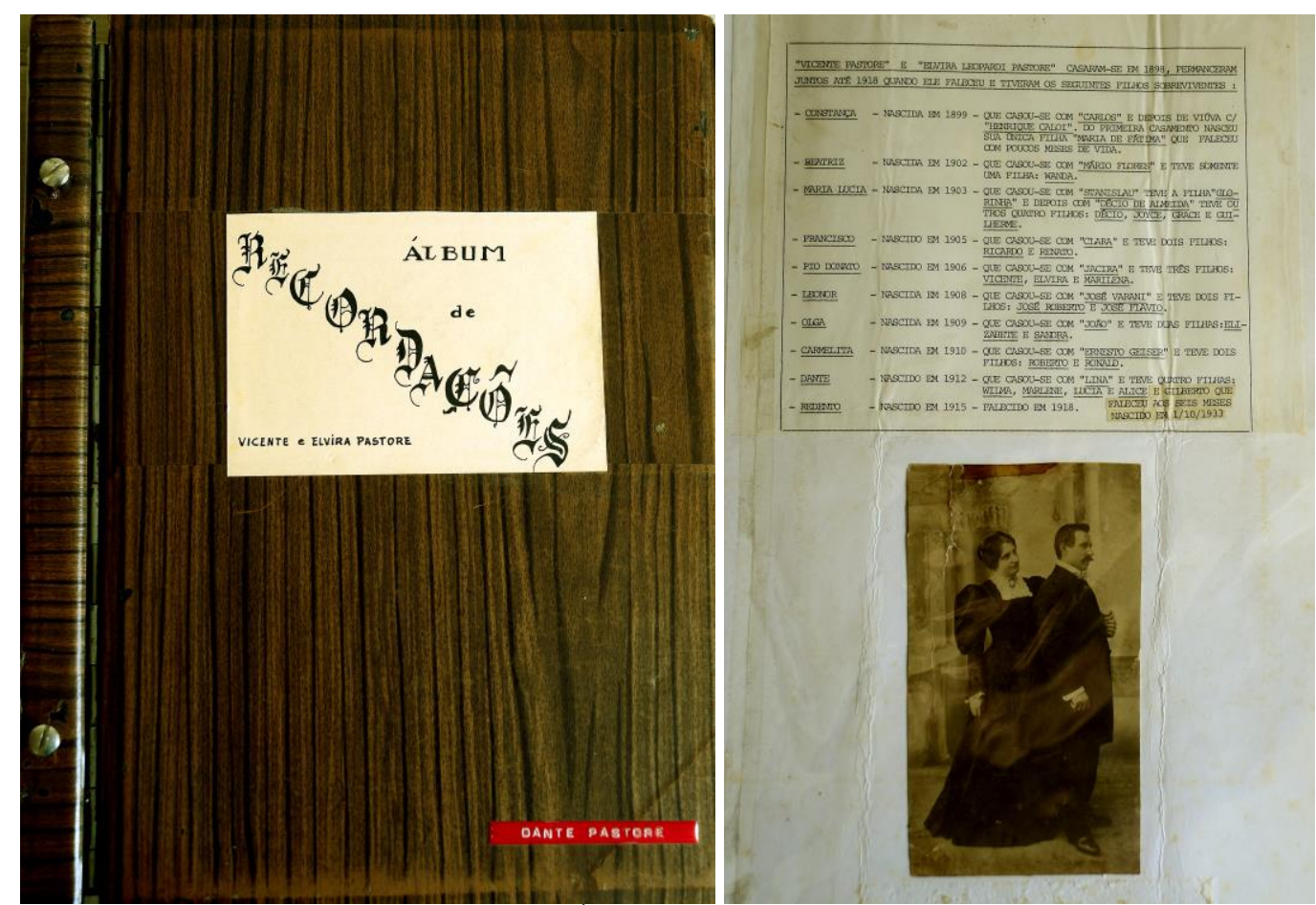

Figuras 3 e 4: Reprodução de capa do Álbum de Recordações Vicente e Elvira Pastore e também da primeira página que abre o álbum. Trata-se de outra encadernação, contendo muitos retratos e fotos da família feitas por Pastore, cartas enviadas aos filhos que estudavam na Itália, cópias de passaportes, etc... Essa documentação está sob a guarda de Maria Lúcia e José Roberto Varani, um casal de primos e netos de Pastore. Coleção Dante Pastore.

Encontra-se nesse artefato muitos retratos dos membros da família, registros de momentos de viagens ou de outros desfrutados no jardim do ateliê na Rua da Assembleia, mas, também, surpreendentemente, fotos do estúdio aberto na Itália, vestígios que indiciavam uma etapa importante na vida de Pastore como fotógrafo retratista. O seu passaporte (fig.5) foi colado próximo ao "Biglieto Di $1^{a}$ Classe $n^{\circ} 580^{\prime}$ (fig.6), documentando a partida de Gênova, no dia 9 de dezembro de 1915, com destino a Santos, ao retornar para o Brasil pela terceira vez. O insucesso da empreitada em Bari pontuou uma vida marcada por idas e vindas no percurso Brasil-Itália, com recursos ainda suficientes para todos da família ocuparem um posto de maior conforto no navio.

Para conferir prestígio ao marido, Elvira guardou também a carta oficial enviada de Roma, no dia 6 de maio de 1916, com brasão italiano do Ministério da Agricultura, Indústria e Comércio impresso, nomeando Pastore como "cavaliere dell'Ordine della Corona d'Italia". A certidão de óbito do marido registrada no Cartório de Paz e Registro Civil da Bela Vista, compõe, por fim, a materialidade constituída por Elvira. O filho caçula, demonstrando como a coleção é um objeto em aberto, passível de constante reconstrução, inscreveu, logo no início da encadernação, a preocupação em compor a "Árvore Genealógica da Família Pastore", 
destacando o topo como lugar dos patriarcas. O culto dos antepassados está, para Blom, "na raiz de toda a compreensão religiosa do mundo" (2003, p.179). ${ }^{2}$
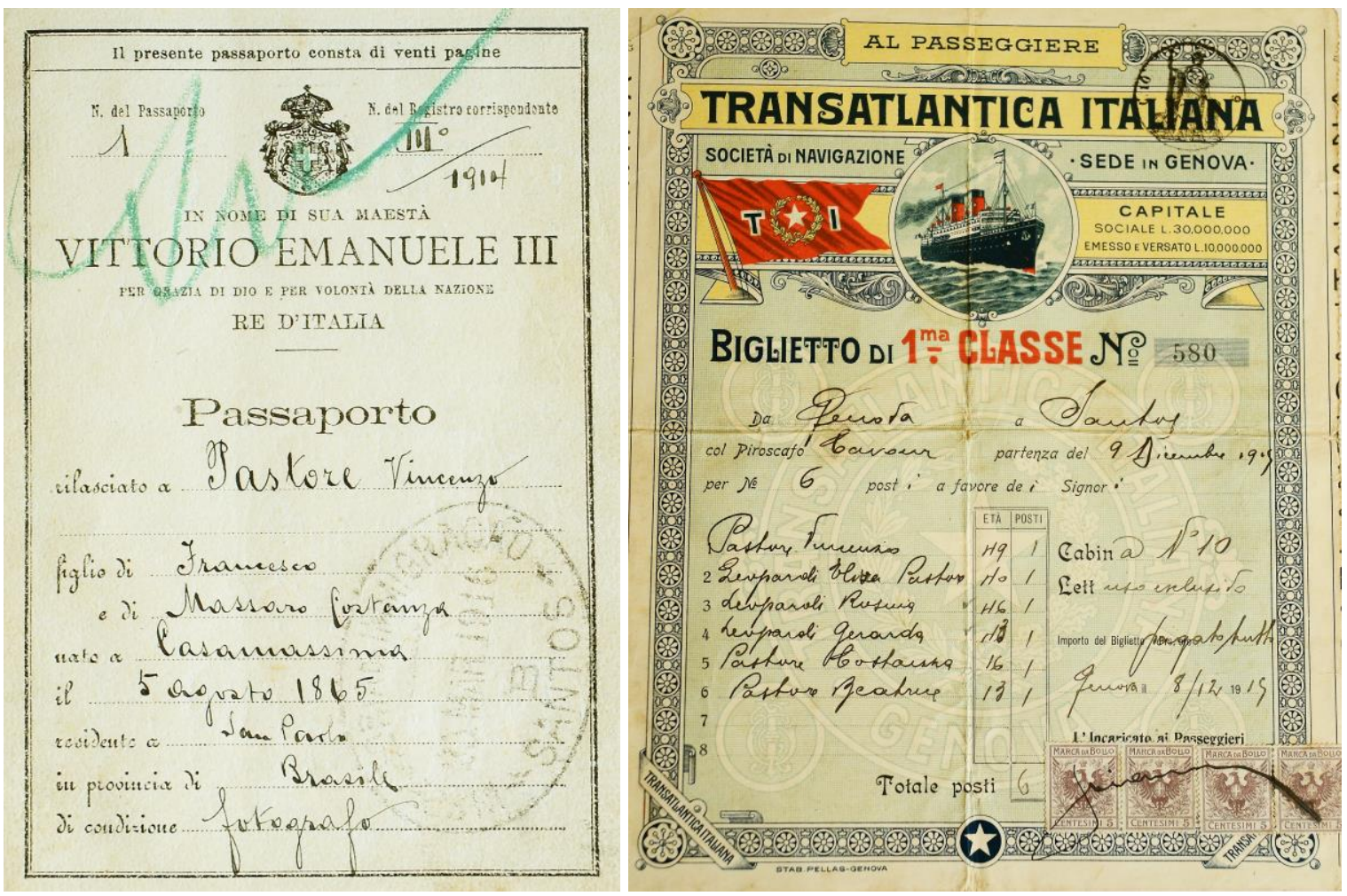

Figuras 5 e 6: Primeira página do Passaporte de Vincenzo Pastore e bilhete de viagem de retorno ao Brasil após o fechamento do estúdio aberto em Bari, na Itália. Coleção Dante Pastore.

Desejos foram projetados nessa coleção, que se tornou a documentação vital para este estudo. Ao se observar este corpus documental, nota-se ativada a função autobiográfica da própria família, que vai além da trajetória do fotógrafo. $\mathrm{O}$ diário "Memórias de Elvira L. Pastore", produzido na intimidade de sentimentos de uma mulher que iniciava a viuvez, tratase de uma escrita criada a partir de cartas enviadas aos filhos, um manuscrito em italiano bastante legível. A narrativa construída inscrevia na capa do Caderno de Recortes certos ideais: o amor à família, a devoção à fé católica e ao trabalho, eram dadas como virtudes, encerrando lembranças e saudades.

Philippe Artières (1998), ao tratar das funções sociais que arquivos de vida cumprem, afirmou que nada é deixado ao acaso. Além da identidade reconhecida, alude a outras intenções: arquivos são mantidos "para recordar e tirar lição do passado para preparar o futuro”. Talvez isso explique os motivos pelos quais Elvira não tenha escrito sobre a parceria

\footnotetext{
${ }^{2}$ Árvore genealógica feita por José Roberto Varani, filho de Eleonora, uma das filhas de Pastore.
} 
que mantinha com o marido, trabalhando no laboratório, prensando fotografias nos cartões suportes ornamentados e escolhidos pelos clientes. Apenas os relatos dos filhos mais velhos relembram as horas de trabalho de Elvira e Pastore juntos, lado a lado, entrando na madrugada, para cumprirem prazos de entrega. ${ }^{3}$

Elvira, ao escrever o seu diário, esteve às voltas com essa "prática social corriqueira", sondada por Artières (2003, p.179) como quase um dever onipresente de arquivar vidas. O diário escrito, entretanto, revela aspectos mais íntimos da personalidade de Pastore, onde Elvira assumiu o lugar de porta-voz da família, remetendo à natureza perceptiva delineada por Armando Silva (2008, p.19): “Além do ponto de vista familiar, há outra qualidade grupal: alguém narra as histórias, a família, seu narrador coletivo; contudo, outro as contam, em geral, a mãe, a avó, a filha mais velha, a irmã ou a tia, e isso as torna uma história de mulheres". ${ }^{4}$

No entanto, é preciso saber o quanto nessa "seara de encantos" se lançam ao ar o perfume do feitiço disfarçado de autêntico, defende Gomes (1997, p.126): "Documentos pessoais em nada diferem de todos os demais documentos históricos. Dito de outra forma, o feitiço pode estar em toda parte, havendo apenas alguns lugares mais perigosos que outros".

As fotografias produzidas por Pastore apresentadas nos dois primeiros capítulos da tese foram divididas entre os descendentes após a morte de Elvira. Aquelas de posse da filha mais velha do fotógrafo, Costanza Pastore, acabaram deixadas em testamento ao Mosteiro São Bento, que reúne um conjunto considerável de imagens avulsas da família e de clientes retratados em estúdio. O caderno de recortes, o diário de Elvira e o Álbum de Recordações ficaram sob a incumbência do filho caçula, Dante Pastore, desde 1944. Nessa coleção, encontram-se muitas imagens soltas e avulsas, outras fixadas em pesadas molduras e, algumas coladas em cartões suporte rígido ou montadas em álbuns quase desfeitos.

A prática de reunir artefatos segue "regras próprias", entendidas como um ato de colecionismo assim explicado por Carvalho e Lima (2005, p.86): “Atende a necessidades de estabilização emocional, integração e triagens sociais, bem como a construção de formas de prestígio e distinção individual servindo ainda como suporte de laços de afetividade ou como apaziguador das mudanças sociais ou de natureza cíclica da vida”. Expectativas pessoais e

\footnotetext{
${ }^{3}$ Entrevista de Dante Pastore falando do trabalho exaustivo para se cumprir os prazos de entrega dos retratos. Depois de colocarem os filhos para dormir, ficam até uma da madrugada; não iam dormir enquanto não terminassem "o que tivessem de serviço". Ver entrevista realizada por Ricardo Mendes no IMS, Rio de Janeiro.

${ }^{4}$ Armando Silva apresenta neste estudo uma análise de álbuns de várias famílias colombianas.
} 
retorno psicológico, para as autoras, são obtidos pela "prática de coletar, reunir e gerenciar um conjunto de objetos eleitos" (2000, p.16).

A preservação da coleção é prova não somente dos gestos afetivos empreendidos pelos descendentes de Pastore, como também do reconhecimento do valor dos documentos que guardam por quase cem anos, transmitidos como herança entre as gerações. Posse que "torna valioso todo objeto colecionado" e, leva a reconhecer a atitude de preservar, e, reforça a menção a Philipp Blom (2003, p.192): "atire a primeira pedra aquele ou aquela que não se comove com a história contida num pequeno objeto que sobreviveu ao longo dos séculos".

\section{Delineamento da pesquisa}

Em 1894, Pastore desembarcou no porto de Santos. Ficou apenas por um ano em São Paulo. Segundo seu neto, Flávio Varani, o avô "Veio ao Brasil antes de se casar. Voltou com o dinheiro ganho para começar nova vida na Itália e depois se deu conta que poderia viver melhor por aí começando de novo". ${ }^{5}$ Em 1899, retornou ao Brasil pela segunda vez, permanecendo no país até 1918, quando faleceu. Justapondo essa experiência entre Brasil e Itália, Pastore, em 1914, abriu um estúdio em Bari, chamado Ai Due Mondi - Fotografia Italo-Americana, que era a expressão de seu ir e vir constante, motivado pelo desejo de retornar a terra de origem, sentimento comum entre aqueles que vivenciam a experiência da imigração. Em 1915, toda a família Pastore retornou mais uma vez a São Paulo. Possivelmente, em meados de 1910, teria feito incursões pelas ruas, sobretudo, pelos arredores da cidade retratando aqueles que viviam de forma autônoma nas redes de abastecimento da capital.

O recorte da pesquisa, entre 1894 a 1918, trata das experiências desse fotógrafo a partir de uma periodização criada para ajudar na observação de sua trajetória profissional. Sua prática fotográfica se deu primordialmente como fotógrafo retratista, empenhado em afirmar as diferenças entre "fotografias comerciais" e a "verdadeira arte". Seu ato fotográfico"

\footnotetext{
${ }^{5}$ Entrevista com Flávio Varani realizada em dezembro de 2012. Pastore, ao retornar ao Brasil, em 1899, trazia com ele a esposa, Elvira, que trabalhava com o marido no laboratório. Sua dedicação, talento e total domínio dessa etapa da produção das imagens serão depois analisadas.

${ }^{6}$ Ver Dubois. O ato fotográfico e outros ensaios. Campinas, SP: Papirus. 1993, pp. 59-60. Da “impressão luminosa", tem-se o traço do real, que é a própria essencialidade da fotografia e a sua definição mais "minimalista", que constitui a sua "condição indicial", defende Philippe Dubois. Contudo, a imagem deve ser pensada em todo o seu modo constitutivo. Fotografia será sempre dotada de um sentido icônico, de uma "gênese automática", como explicou André Bazin. Deve ser compreendida desde sua "tomada", até sua
} 
múltiplo impõe o desafio de entendê-lo em rede, em relação aos seus clientes no estúdio, em relação aos fotógrafos concorrentes nas cidades em que atuou, em relação à sua esposa Elvira, que o ajudava no laboratório, e em relação às referências do movimento pictorialista italiano, porque Pastore se apresentava como um fotógrafo preocupado com as questões da fotografia como arte.

Este estudo bem se enquadra nas pesquisas voltadas para trajetórias de sujeitos sociais que constituíram suas experiências sociais numa teia de interação. Que pode ser interação íntima familiar, interação entre seus pares, entre seus concorrentes, ou interação com o universo da arte, fazendo uso de aparatos técnicos necessários ao seu ofício, assumindo o papel de um ser social integrado a um sistema de relações sociais, econômicas e, culturais. Casar, emigrar, sustentar a si próprio e aos seus dez filhos, sonhando em retornar à pátria, foram atos que atravessaram a trajetória de Pastore. Compreender as redes de interação criadas pelo fotógrafo, visto como um ser social em interação com o mundo que via, retratava e reconhecia pelas ruas da cidade, estrutura a problematização criada.

Recorremos a um campo teórico para se trabalhar na perspectiva reflexiva da trajetória: "Sem descurar das especificidades do indivíduo analisado, é preciso sempre situar o agente em seu grupo e no contexto social em que se encontra inserido". Quando Lilian Schwarcz (2013, p.56) fez essa afirmação, traçou o enfoque reflexivo colocando o indivíduo em relação ao grupo em seus diversos campos sociais, alinhando-se a um campo teórico precedente. Entre o estúdio e a rua, Pastore trilhou uma trajetória observada seguindo pressupostos de Pierre Bourdieu, para quem uma trajetória de vida só será verdadeiramente inteligível à luz daquilo que lhe é imanente: o seu campo de relações. Esse horizonte teórico apresentado ajuda a compreender o sujeito social na mediação travada com seus pares. Bourdieu (1998) articulou em sua análise o ponto nodal para os estudos de trajetórias: a reconstrução do contexto que o indivíduo age. Ao intérprete, cabe a tarefa de dar atenção aos movimentos de um indivíduo, mas também à inconstância da vida e das relações. Bourdieu designou a "superfície social" como categoria de análise para os estudos voltados para a trajetória de vidas, ajustando o foco para o individual atrelado com o campo que o cerca, observando um conjunto de relações objetivas, onde as ações do indivíduo se dão de forma sempre ambígua,

"difusão/recepção", como afirma Dubois, que defende o dispositivo teórico de "o fotográfico", uma própria categorização do pensamento, que problematiza as relações entre os "signos, o tempo, o espaço, o real, o sujeito, o ser e o fazer". A fotografia, assim, transborda-se dos limites de seus suportes, atinge a vida, a política, as relações humanas, em toda sua complexidade. 
marcadas por autonomia e impasses; aspectos esses que melhor tornam singular o indivíduo sempre capaz de encontrar brechas para enfrentar certos condicionantes sociais.

Não podemos compreender uma trajetória sem que tenhamos previamente construído os estados sucessivos do campo no qual ela se desenrolou e, logo, o conjunto das relações objetivas que uniram o agente considerado - pelo menos em certo número de estados pertinentes - ao conjunto dos outros agentes envolvidos no mesmo campo e confrontados com o mesmo espaço dos possíveis. (Bourdieu, 1998, p. 190)

Essa abordagem tenta rever alguns pressupostos que afirmaram "o que há de marcante na obra de Pastore, não são seus retratos".7 Sua prática no estúdio não foi nesse estudo preterida a sua atução nas ruas. Constatamos que Pastore em seu estúdio atendeu crianças e adultos, inserindo-se num mercado de intensa concorrência, demonstrando que, além de um domínio técnico evidente, ${ }^{8}$ precisou ter uma capacidade inventiva e forte aptidão comercial, ao criar os "retratos mimosos", o formato Elena, e ao organizar concursos e premiar as melhores fotos infantis. Além de criar novos formatos para o retrato, dominou com rigor procedimentos como o uso da goma-bicromatada, fotos miniaturas e platinotipias, técnicas de foto-pintura a óleo que iriam se popularizar após os anos 1920, e que eram experimentadas por Pastore, desde 1900. Foi um verdadeiro homem de negócios da fotografia. Sondar sua prática em torno do retrato na capital paulista, e os desafios enfrentados quando tentou sobreviver de seu ofício em seu próprio País, ajudou a reconstituir aspectos da história social da fotografia aproximando Brasil e Itália, revelando aspectos da própria trama que enredava aqueles que tentavam viver da produção de retratos em contingências quase sempre desfavoráveis.

Em sua trajetória, se vê um fotógrafo dividido entre dois mundos. Balaustradas, panos de fundo, tapetes, cortinas, chapéus, bengalas, redingotes, móveis luxuosos e outros ornamentos compunham o cenário de seu ateliê. Era uma cultura material apropriada por diversos grupos sociais que cada vez mais se familiarizavam com esse ambiente de encenação, da qual sabiam participar e encontravam meios de se representar socialmente por meio da fotografia. Mas,

\footnotetext{
7 AVANCINI. Em Flagrante. Leitura de Fotografias de Rua do Cotidiano da Cidade de São Paulo Nas Duas Primeiras Décadas do Século XX. Dissertação de Mestrado em Ciências da Comunicação na área de Jornalismo apresentada à Escola de Comunicação e Artes da Universidade de São Paulo, ECA- USP. 1999, p. 80.

${ }^{8}$ Com os avanços técnicos que facilitavam o domínio da técnica fotográfica, popularizada a partir dos carte-devisite, muitos profissionais aventuraram-se pela fotografia, não sendo exímios especialistas, o que para Gisele Freund passou a comprometer grande parte dos registros realizados. Essa fase de massificação da fotografia teria promovido, segundo Freund, uma "decadência artística do retrato". Ver Freund. Fotografia e Sociedade, Gustavo Gilli, 1976, p. 80-83.
} 
Pastore foi além. Revelou-se também como um fotógrafo que não se recusou em observar e retratar homens e mulheres egressos da escravidão ou oriundos da imigração, trabalhando nos arredores dos mercados e ruas da cidade, ágeis na improvisação submetida a uma conjuntura onde o trabalho era marcado pela fluidez e mobilidade, um trabalho feito de pequenos expedientes, instável e temporário, mas fundamental para ganhar a vida. Contingências com as quais o fotógrafo se identificava, porque era ele também um imigrante, submetido a instabilidade de seu ofício, lançando-o a deslocamentos constantes entre Brasil e Itália. Tratamos da infixidez típica da experiência da imigração que também marcava o fotógrafo.

Pastore retratou meninos que improvisavam a sobrevivência como engraxates, expondo as sociabilidades e as convivências entre muitas mulheres quituteiras, ou aquelas outras rodeadas de panos estendidos na Várzea do Carmo, às margens do rio Tamanduateí. Trata-se, portanto de uma documentação preciosa para a história social da cidade, da imigração, enunciando um fotógrafo que sobrevivia do retrato comercial de estúdio, no qual ganhava dinheiro, mas também interessado pelo espaço urbano que preservava traços ainda coloniais, apesar de todos os esforços modernizantes.

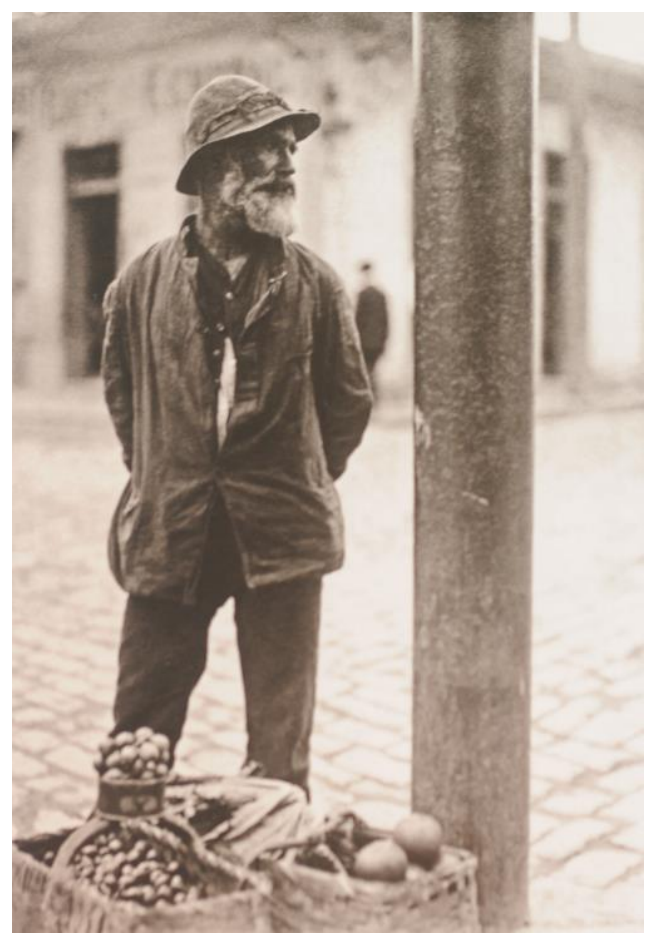

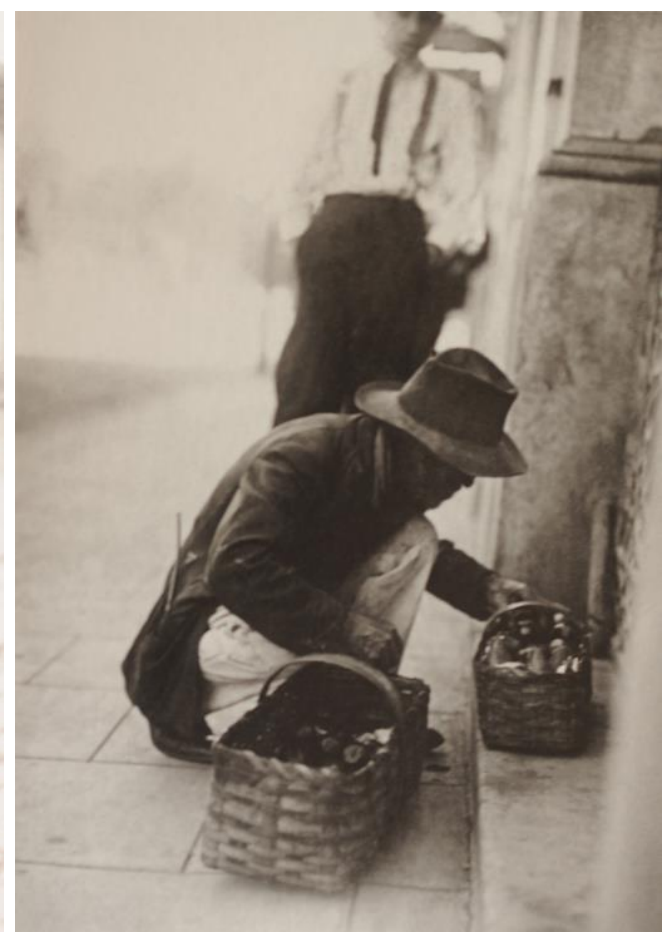

Figuras 7 e 8:

Fotografias em papel Vendeiros ambulantes em São Paulo próximo da década de 1910 (c) Vincenzo Pastore/Instituto Moreira Salles.

Por meio de sua fotografia, tem-se um importante registro da economia de subsistência paulistana, bem como a própria elaboração da representação da importante força de trabalho composta pela presença de muitas mulheres, mas também de homens negros, tão obscurecidos 
nas tramas da história, mostrando o quanto as discussões sobre o social, são perpassadas pelas questões raciais e de gênero. A abordagem pela história social permite, assim, a sondagem desse cotidiano nos arredores dos principais mercados da cidade, entrevisto por meio dessa documentação visual, articulada com o todo social, tentando-se garantir a "relação dialética permanente entre documento e problemática histórica", como bem indicou Ulpiano Bezerra de Meneses (2003).

Homens brancos e negros foram retratados (Fig.7 e 8). Talvez comprassem suas frutas, verduras, nozes e raízes nos mercados populares a preço concorrentes e depois, descumprindo as determinações da Câmara Municipal, que restringia a venda ambulante à região limite da várzea, seguissem rumo às ladeiras que levavam ao topo da colina, onde obtinham uma pequena margem de lucro. Talvez transitassem nos arredores e áreas próximas da entrada dos mercados tentando escapar das cobranças e normas fiscais impostas àqueles que estavam autorizados a vender em seus espaços internos. É certo que atraíram o fotógrafo que fazia questão de se aproximar, carregando sua câmera portátil, propondo conversas ao menos para negociar a pose e a desatenção sugerida em muitas das fotos.

Há um campo teórico pertinente para a sondagem de tais sociabilidades. A sutil interpretação de Elena Perez Pajáro no trato das populações que se deslocavam do campo para a cidade, chamadas de "moventes", "invisíveis" e "exuberantes", foi, sem dúvida, inspiração na construção dessa interpretação. Ao tratar dos “inúmeros negros que ganhavam a vida pelas ruas de São Paulo, juntando-se paulatinamente, aos brancos que procuravam uma colocação, abandonando as fazendas e as pequenas cidades”, Pajáro (2006, p.16) empresta o viés interpretativo-conceitual para sondar essa tradição caminhante de "grupos impulsionados pela falta de perspectivas nos locais de origem".

O estudo de Maria Odila da Silva Dias (1995, p.90) é uma importante referência teórica para as análises da série de Pastore. Dias documentou a sociabilidade das mulheres brancas empobrecidas, mulheres de "maridos ausentes", rejeitadas pela sociedade, que andavam pela rua, cobertas com manto de baeta, para assim disfarçar a pobreza e sobreviver de pequenos excedentes. A relação entre a casa e a rua, frente ao crescente empobrecimento da população e ao enriquecimento das elites ligadas ao setor cafeeiro, foi sendo lentamente desvelada pela autora, numa trama analítico-interpretativa dos "elos que uniam entre si, nas fímbrias das classes dominantes, mulheres livres empobrecidas, escravas e forras". Das subjetividades femininas, Dias rastreou o comércio ambulante, onde conviviam escravizados na atividade de 
ganho, ao lado de uma vastidão de outros agentes sociais, forros e brancos pobres, roceiros, caipiras, todos no centro de uma economia popular, assumindo papéis de autonomia inegáveis, diante do desafio de sobreviver nas décadas que cruzavam o século XIX.

Esse viés interpretativo da história social tentou reconstruir as formas de organização da sobrevivência de experiências sociais marcadas por práticas constantemente improvisadas, mas ágeis em forjar modos de resistência. A crescente urbanização expunha a precária organização da produção e comercialização de gêneros de primeira necessidade, colocando as mulheres à frente do sustento da família. Formava-se um excedente de mão-de-obra que passava a sobreviver do expediente dado nas ruas. Era esse o meio de ganhar o próprio sustento e, ainda, garantir, o de seus senhores e senhoras já bastante empobrecidos, donos de poucos escravos, verificou Dias (1995, p.23). A autora documentou modos de sobrevivência levados ao novo século como aprendizado de experiências mais antigas. Tem-se, assim, uma interpretação que valorizou e documentou sociabilidades e a importância dos papéis informais assumidos no "processo concreto da vida quotidiana".

Contamos também, com os estudos de Ecléia Bosi (1994) e Teresinha Bernardo (1998) porque remontaram experiências de agentes socais que viveram em São Paulo, nas décadas iniciais do século XX. As autoras revelam relatos históricos que nos aproximam das experiências de parte dos moradores da capital retratados por Pastore.

A visualidade se coloca cada vez mais como um "campo de operação de grande valor estratégico para o conhecimento histórico da sociedade, na sua organização, funcionamento e transformação", como afirmou Menezes (2005), abordagem histórica que problematiza o contexto de produção do material visual relacionado às práticas que envolvem a trama de sua constituição. Segundo Ivan Gaskell (1992), que, assim como Menezes, pontuou a necessidade de estudos voltados para o contexto de produção, de consumo e de circulação das imagens, as reflexões sobre o fotográfico não podem deixar escapar o lugar em que as imagens ocuparam no passado; procedimentos inadequados podem ser evitados ao não se perder de vista a complexidade que envolve a especificidade das práticas visuais e das convenções iconográficas.

Deste modo, ampliam-se os horizontes de análise da série incluindo o repertório visual italiano que Pastore bem conhecia e que tanto se aproximava das fotos produzidas nas ruas da capital paulista. A sua produção emblemática leva a pensar a fotografia de rua produzida na 
Itália, para depois melhor entender como as fotos foram mobilizadas em 1997, quando apresentadas na exposição organizada pelo IMS.

\section{Os capítulos da tese: espaços da construção narrativa - interpretativa sobre Pastore}

No primeiro capítulo analisamos o trabalho de Pastore realizado no estúdio no Brasil, a partir de uma perspectiva que delineou traços de uma rede de experiências compartilhadas na produção de retratos, envolvendo muitos fotógrafos contemporâneos de Pastore, numa convivência que não deixava sombra à concorrência travada entre eles.

A experiência de Pastore se entrelaçava com o todo vivido no métier do retrato, envolvendo múltiplos agentes, situações e expectativas. Essa abordagem tentou compreender aquilo que Mauad (2004) delimitou como "circuito social da fotografia", no início do século XX. A análise dos anúncios e almanaques publicados, somados à documentação da coleção Dante Pastore, contribui para a investigação das estratégias empreendidas nesse mercado onde ser fotografado tornava-se parte de um evento social amplo, cada vez mais corriqueiro, aberto finalmente aos novos grupos sociais que emergiam, acarretando enorme competitividade entre os estúdios. Para enfrentá-la, Pastore investiu e diferentes circuitos para expor suas fotos e anunciar seu estúdio, valendo-se de vitrines de estabelecimentos comerciais, organizando concursos infantis, além das capas de revistas ilustradas. Constata-se, por meio dessas fontes, as estratégias de venda de muitos fotógrafos noticiando seus estúdios, atendendo a domicílio, criando variados formatos como o retrato mimoso, mignon, photographia sello e cartão bebê; foram essas, estratégias para sobreviver fazendo fotografia em fin de sicle.

O corpus documental visual refere-se às fotografias de Pastore também localizadas no acervo do Museu Paulista/USP, Memorial do Imigrante, e a outras publicadas no livro de

Garbin \& Gerodetti, Álbuns de Retratos. Fotografias Brasileiras, bem como as fotos guardadas pelos descendentes do fotógrafo.

Tratar da experiência individual do fotógrafo alarga os horizontes para as práticas fotográficas mais antigas constituídas em sua terra de origem, visceralmente entrelaçadas em sua trajetória. Desse modo, o segundo capítulo, volta-se para a atuação de Pastore em Potenza, capital da Basilicata, onde manteve estúdio aberto no ano de 1898. Foi também sondada sua tentativa de viver do retrato no estúdio aberto em Bari, sua província natal pugliese, no ano de 1914. Depois de quinze anos ininterruptos vivendo no Brasil, Pastore 
investiu toda sua economia no estúdio barese, delineando como retornar à terra de origem, mantinha-se no escopo de muitos agentes sociais que vivenciavam a experiência da imigração.

Foi documentado como muitos fotógrafos potentinos eram obrigados a se deslocarem entre as diversas comunas que integravam a região. Fotógrafos com estúdios fixos, ambulantes e ainda os considerados semi-ambulantes, acumulando as duas atuações, participaram da cultura do retrato na qual Pastore tentou se inserir antes de se lançar na experiência da grande imigração, buscando condições mais favoráveis.

Os desafios enfrentados na capital potentina se assemelharam àqueles do estúdio Fotografiia Italo-Americana - Ai Due Mondi, em Bari, contexto no qual muitos retratistas abriam filiais de seus estúdios em diferentes comunas, estratégia para sobreviverem do retrato. A Primeira Guerra Mundial colocou fim ao sonho de Pastore, obrigando-o a deixar seu país. Não se imaginava que a construção interpretativa do segundo capítulo seria uma importante contribuição para a historiografia da fotografia pugliese, onde a trajetória do fotógrafo no circuito local não é citada. Apenas na capital potentina, há um breve registro sobre a atuação de Pastore no ano de 1898. A sua experiência barese no ano de 1914 continua obscura na história da fotografia da Puglia.

O Caderno de Recortes da coleção Dante Pastore traz inúmeras fontes que indiciam o quanto a inauguração do estúdio barese foi comemorado pela imprensa local. Tais fontes revelam ainda mais. Pastore era reconhecido pelas técnicas e procedimentos fotográficos adotados como um fotógrafo artista. Muitos foram os relatos escritos que demonstraram o esforço de Pastore em dominar certos procedimentos visando ser reconhecido como um "mago da fotografia". O fotógrafo ao publicar seu artigo escrito em italiano, intitulado "Fotografia e Arte", apresentava-se para sua clientela como um profissional que acompanhava a cultura fotográfica de seu tempo, sustentada por meio da produção de muitos textos que davam as diretrizes definidoras dos fotógrafos artistas, ou seja, daqueles que se aproximavam do pictorialismo. Apesar de não haver nenhuma ligação de Pastore em associações ou fotoclube documentada, ainda assim são pertinentes os vestígios que delineiam o quanto esse retratista se apresentava como um profissional engajado no debate que marcava as tensões da fotografia de virada de século.

No capítulo três desdobram-se questionamentos para a série produzida nas ruas paulistanas, desvelando o quanto Pastore, ao deixar seu estúdio, experimentou registros mais 
documentais, desafiando as práticas mais antigas de representação, desprezando as convenções formais preestabelecidas na produção de retratos oitocentistas. Pastore ao voltarse para o cotidiano de trabalho na cidade, experimentou a instantaneidade na fotografia, recusando a convenção da pose, lançando os corpos retratados para a experiência do movimento, da fragmentação. Os novos aparatos foto-mecânicos incentivavam a criação de novas linguagens.

Lidamos com a hipótese de que Pastore, também nas ruas da cidade praticou o viés pictorialista, visto na sua produção de retratos feitos no estúdio, inspirado pelas referências que trazia da Itália. Tentamos demonstrar como nesse país os fotógrafos profissionais não deixaram de participar das inovadoras técnicas de experimentação, tanto nas produções realizadas em estúdio, quanto nas ruas. A concorrência os impelia a se apresentarem atualizados com as novas tendências que marcavam as discussões sobre o fotográfico.

Pastore como um flaneur, um andarinho pela cidade, realizou registros que sugerem fotos flagrantes, tomadas em contra-luz, dando força aos tons claros e escuros, em leves silhuetas, recorrendo muitas vezes ao efeito flou, defendido por ele em seu artigo, e por muitos outros textos assinados por importantes teóricos da fotografia pictorialista no quadro italiano. Observar textos e artigos publicados em revistas especializadas, como "La fotografia Artistica", publicada entre 1904 e 1917, confirma essa premissa, numa abordagem metodológica que aproximou fotos e textos para demonstrar como a produção de Pastore tomava lugar na economia visual de sua época, afinal era preciso mostrar-se atualizado com as novidades de seu metier.

Na compreensão de Stephen Bann a economia visual é o conceito que explica toda a produção, reprodução e circulação de imagens realizadas num determinado período histórico. Observar uma rede de imagens de um local e de um tempo específico é, como defende Bann, uma pertinente abordagem para melhor se compreender uma dada iconografia, a qual consequentemente resulta das ações de muitos fotógrafos, que também escreviam. Foram analiasados vários textos que legitimavam certas produções visuais, bem como delimitou-se uma demanda que sustentava um determinado quadro de difusão de imagens:

Por economia visual, eu entendo a consideração da totalidade dos meios de reprodução iconográfica disponíveis em uma época dada: não somente dos dispositivos específicos a cada técnica, de seu custo e sua eficácia, mas 
também dos diversos modos contemporâneos de publicação e de difusão. (Bann. 2011. Tradução nossa) ${ }^{9}$

No terceiro capítulo, além de nos aproximarmos de Pastore por meio da economia visual de seu tempo, estratégia metodológica para melhor compreender a sua prática e seus esforços em se autopromover como um fotógrafo conhecedor de preceitos pictorialistas, aborda-se ainda como a série é uma rica documentação sobre a vida social paulistana, em suas mais profundas contradições, em meio ao processo de industrialização incipiente: essa coleção que integra o acervo do IMS ajuda a documentar as relações dos agentes sociais envolvidos nas práticas de serviços essenciais ao abastecimento da cidade, mostrando uma faceta particular do processo de urbanização e de modernização brasileira, com sua força de trabalho urbana não associada diretamente ao processo de expansão industrial, forçando muitos a buscarem “uma renda própria para sobreviver", explica Pinto (1994, p.114). As fotografias associadas às fontes complementares como relatos publicados em jornais, leis e atos municipais, ajudaram a sondar como, nas décadas iniciais do século XX, aqueles que viviam das atividades informais, produziam suas próprias condições de existência, numa cidade caracterizada pela convivência entre o rural e o urbano.

Fontes complementares aproximam as vivências retratadas por Pastore. Artigos, crônicas e reportagens publicadas no jornal A Capital, O Estado de S.Paulo e Diário Popular, foram também selecionados. Esse conjunto de fontes impressas exige uma análise a contrapelo porque, afinal, eram muitas vezes discursos comprometidos com políticas de dominação vigente. Tratam-se de fontes ideologicamente enviesadas como pontuou Dias (2003, p.61), o que exige uma interpretação histórica atenta às nuances e às brechas que possibilitem uma compreensão da história social.

No Arquivo Histórico Municipal de São Paulo foram analisadas leis municipais, relatórios anuais, promulgação de atos municipais e, balanços relacionados à arrecadação de impostos de serviços ambulantes, bem como caixas localizadas na seção de Papéis Avulsos e de Polícia e Higiene, onde foram encontradas inclusive, cartas-queixas enviadas à prefeitura e muitos pedidos de residentes da capital solicitando licença para a obtenção de concessão para atuar no comércio de rua da cidade. Pressupõe-se que, dessa forma, foi possível ter mais proximidade com as sociabilidades retratadas pelo fotógrafo.

\footnotetext{
9 Bann, Stephen. Photographie et reproduction gravée: I'economie visuelle au XIXeme siècle. In: Études Photographiques, n.09, maio/2011. Texto disponível em https://etudesphotographiques.revues.org/241
} 
A consulta aos arquivos e acervos em Potenza e em Bari, inicialmente feita para documentar a trajetória de Pastore como retratista ao sul da Itália, abriu caminhos para uma proposta reflexiva que deu corpo ao capítulo quatro. Pensar as convenções visuais, ou melhor, as "redes de imagens" constituídas na Itália, ampliaram os horizontes de compreensão das fotos produzidas nas ruas da capital paulista. Seguem os aportes teóricos sugeridos por Meneses (2005):

É necessário circunscrever o que vem sendo chamado de iconosfera, isto é, o conjunto de imagens - guia de um grupo social ou de uma sociedade num dado momento e com a qual ela interage. Não se pode tomar a iconosfera, obviamente, apenas como o elenco de imagens disponíveis; trata-se, sim, de identificar as imagens de referência, recorrentes, catalisadoras, identitárias, ou aquelas que em linguagem não técnica, são conhecidas como emblemáticas ou icônicas e integram aquelas redes de imagens. (Menezes, 2005, p. 34)

Os fotógrafos amadores e profissionais, conterrâneos de Pastore, voltaram-se, de modo surpreendente, no quadro contextual italiano, às práticas de comércio de abastecimento feito nas ruas de várias províncias e comunas, configurando um vasto repertório posto em intensa circulação. O foco da análise elegeu uma visualidade estruturada na imagem dos tipos sociais, repertório que tanto seduziu Pastore, que chegou a exibir na Itália, na mostra organizada em seu próprio ateliê, chamado pela imprensa barese como uma "galeria de imagens", fotos produzidas nas ruas da capital paulista, demonstrando a intenção de tentar fazer sucesso por meio do material produzido no Brasil. Documentamos a existência de um circuito de produção de imagens de rua vendidas no contexto italiano como souvenirs, dentro do circuito de turismo ainda pertinente nas últimas décadas do século XIX, tendo encontrado meios de se atualizar no início de século XX. Tratamos, desse modo, de como a produção de Pastore em São Paulo delineia a força do padrão visual de cenas de costumes na Itália, reafirmadas no Brasil nos anos de 1910.

Pensar as fotos em movimento, ou seja, em suas trajetórias específicas, é o foco do capítulo cinco. A série fotográfica foi apresentada ao público somente em 1997, momento em que abandonava o seu status de foto guardada por quase noventa anos numa caixa de papelão. Dali, raramente saíram, passando pelas mãos apenas de pessoas intimamente ligadas à família. Após doação feita pelo neto do fotógrafo, Flávio Varani, em 1996, as fotos foram mobilizadas e assumiram o seu lugar social como coleção institucionalizada pelo Instituto Moreira Salles. Sua historicidade, portanto, é fortemente marcada pelos desdobramentos subsequêntes à doação. 
Contamos com aportes teóricos que apontam a importância de se reconstituir aquilo que Arjun Appadurai nomeou como "biografias das imagens". Observar o "percurso", a "estrada trilhada" pelos objetos, quando agenciados socialmente, para se concentrar nos termos propostos pelo autor, torna-se fundamental para melhor compreender as práticas sociais envolvidas nos ambientes em que tais imagens transitaram:

(...) temos de seguir as coisas em si mesmas, pois seus significados estão inscritos em suas formas, seus usos, suas trajetórias. Somente pela análise dessas trajetórias podemos interpretar as transações, e os cálculos humanos que dão vida às coisas. Assim, embora de um ponto de vista teórico, atores humanos codifiquem as coisas por meio de significações, de um ponto de vista metodológico, são as coisas em movimento que elucidam seu contexto humano e social. (Appadurai, 2008, p. 17).

Pensar "toda a trajetória, desde a produção, passando pela troca/distribuição, até o consumo" como propõe Appadurai (2008, p.27), é a proposta final da análise que contempla a série fotográfica que apresenta vendeiros, quituteiras e tantas outras cenas de um cotidiano repleto de práticas autônomas de sobrevivência. Observar o trânsito de tais imagens e como diferentes agentes sociais fizeram uso desse material visual, foi essencial para demonstrar como as fotos foram mobilizadas para criar Pastore como fotógrafo da cidade, apesar de sua prática ter estado essencialmente vinculada ao cotidiano de trabalho no estúdio. Suas imagens realizadas nas ruas foram revividas e reativadas como memória da cidade. A fotografia foi, em larga medida, também usada como suporte para tais invenções, tendo uma vocação, dado ao seu potencial icônico, de promover certas apreensões.

A perspectiva do agenciamento, também proposta por Ulpiano Toledo Bezerra de Menezes (2012, p.256), foi importante para esse viés interpretativo que tenta compreender como tais imagens foram ressignificadas. "As imagens têm potencial de produzir efeitos, gerar transformações, dispor de agência. Mais que isso, são integrantes da interação social”, afirma o autor. Dialetizar os processos de acomodação da série, submetida a montagens e remontagens posteriores, foi essencial para melhor compreender como as imagens de rua feitas por Pastore foram lançadas no circuito das exposições, observadas pelos olhares nostálgicos dos visitantes, vistas com entusiasmo pelos historiadores sociais que se esforçavam em documentar as experiências sociais retratados pelo fotógrafo. Fotos que, em sua divulgação espontânea circularam na mídia, sendo depois comercializadas em catálogo e livro. Nesse processo de apropriação/consumo, as fotos foram mobilizadas em novos 
circuitos, ressemantizando-se, como defende Meneses (2003), fazendo-se para a história, numa situação cultural específica, de forte demanda por representações da cidade.

Respeitar a historicidade do próprio objeto e de toda complexidade que envolvia a vida daqueles que tentavam viver da fotografia nos primeiros anos do século $\mathrm{XX}$, permitiu que se abrissem os caminhos para esta investigação. 


\section{Capítulo 1}

\section{O circuito social do retrato}

\subsection{Da Rua Assembleia à Rua Direita: O atelier como espaço de trabalho, convivência familiar e parcerias firmadas}

Vincenzo Pastore de Francesco desembarcou no porto de Santos a tempo de ver a segunda filha nascer em São Paulo. ${ }^{10} \mathrm{Na}$ Rua da Assembleia, número 12, em 1899, o fotógrafo instalou seu estúdio no mesmo espaço que abrigou a residência e a família constituída com Elvira Teresa Angela Leopardi. Juntos, um ano após o casamento, atravessaram o Atlântico. Ele deixava para trás a comuna de Casamassima, região da Puglia ao sul da Itália, onde nasceu em 1865; Elvira nascida, em 1876, na província de Potenza, despediu-se da região da Basilicata, antiga Lucania.

Pastore integrou o grupo de fotógrafos retratistas que buscava as cidades em expansão para viver do retrato. Sua filha mais velha, Costanza, nascida na capital paulista no dia 7 de novembro de 1899, trazia guardado nas lembranças do tempo de menina o burburinho de que o pai esteve sempre de "pé levantado para deixar a Itália". Pastore pensava em fazer a vida nos Estados Unidos, como a maioria dos imigrantes da Itália meridional. ${ }^{11}$ A voz de sua mãe Elvira contava: "eu deveria estar falando inglês com vocês". ${ }^{12}$

Mas a São Paulo à principio renegada, tornou-se o espaço de uma longa sobrevivência. A sua experiência de imigração se estendeu entre os anos de 1899 até 1918. Costanza lembra apenas os endereços dos estúdios localizados inicialmente na Rua da Assembleia e, depois, na Rua Direita, 24-A, essa última cheia de prestígio, submetida aos melhoramentos e à elegância de seus transeuntes desde a segunda metade do século XIX. ${ }^{13}$

\footnotetext{
${ }^{10}$ Não há noticias sobre os motivos do falecimento da primeira filha de Elvira e Pastore. O casal teve no Brasil dez filhos no total: Costanza, 1899; Beatriz, 1902; Maria Lucia, 1903; Francisco, 1905; Pio Donato, 1906; Leonor, 1908; Olga, 1909; Carmelita, 1910; Dante, 1912; Redento, 1915. Todos com o sobrenome apenas do pai.

${ }^{11}$ Segundo Alvim, o trabalhador do sul da Itália era fascinado pela idéia de emigrar para os Estados Unidos, país que recebeu 13, 5 vezes a mais o contingente imigrante italiano quando comparado ao Brasil. Ver Alvim. Brava Gente. Os italianos em São Paulo. 1870-1920. 1986, p. 60.

12 Entrevista com Costanza Pastore realizada pelo pesquisador Ricardo Mendes, em 1994. Gravação e transcrição parcial encontram-se arquivadas na Divisão de Pesquisa do Centro Cultural São Paulo.

${ }^{13}$ Segundo Kossoy, Pastore, em 1901, abriu novo estúdio na Rua Dr. Rodrigo Silva, 12; somente em 1908, se transferiu para Rua Barão de Itapetininga, para, em 1912, anunciar seus serviços na Rua Direita. Cf. Kossoy, Boris. Dicionário Histórico-Fotográfico Brasileiro. Fotógrafos e Ofício da Fotografia no Brasil (1833-1910). São Paulo: Instituto Moreira Salles, 2002, p. 253. Em 1897, a capital já apresentava um enorme contingente de italianos na cidade, "superavam numericamente os brasileiros na proporção de dois para um, foi um fenômeno decisivo do período". MORSE. 1970, p. 240. A técnica de tal ofício foi aprendida com a família que o adotou.
} 
No cotidiano da família Pastore expressava-se uma integração familiar composta pela presença de agregados. De sua infância, a filha de Pastore lembrou o convívio com as tias Adelina e Lúcia, irmãs de sua mãe Elvira. Tia Rosinha Ruvo chegou a ajudar Elvira no laboratório do primeiro estúdio, já que era a irmã, segundo Costanza, com mais instrução. Nas teias do universo familiar e feminino, o estúdio de Pastore, reproduziu de certo modo traços da experiência da imigração mais abrangente: laços solidários se espraiavam no trabalho e nas tarefas compartilhadas entre seus integrantes empenhados na sobrevivência do núcleo familiar, aventurando-se em uma imigração caracterizada como espontânea, diferenciada da arregimentação de mão-de-obra para a grande lavoura cafeeira, não associada tampouco a indústria. ${ }^{14}$

Tratamos aqui de uma experiência de desterro de sujeitos históricos que exerceram atividades relacionadas a serviços. Artesãos, padeiros, sapateiros, marceneiros, alfaiates, costureiras, mascates, ambulantes ou pequenos negociantes buscavam maior oportunidade de autonomia e improvisação oferecidas nas áreas de atração citadinas. Áreas que atraíam os artistas: gente que trabalhava no teatro e com arquitetura, com madeira, tinta ou impressão, e ainda, litógrafos, gravadores, decoradores, escultores ou pintores, também de casas, seges ou tabuletas. Os artistas eram também os fotógrafos. ${ }^{15}$

Emociona ouvir a voz de Costanza gravada em entrevista: "se eu me concentro posso me ver passeando no jardim e na casa da rua da Assembleia". ${ }^{16}$ Segundo a descrição, a casa térrea, com ateliê na frente, não era muito grande, faltavam recursos. Os irmãos caçoavam entrando na casa pelas janelas baixas, de onde muitos moradores paulistanos costumavam acompanhar o movimento das ruas. No jardim ao fundo da casa cresciam as flores cuidadas por Pastore. Era proibido tirar uma que fosse, "esperamos o ano inteiro por elas", dizia o fotógrafo, chamado de "papai" em todo o relato da filha, dona de uma voz fragilizada pela idade e pelo gesto de lembrar.

\footnotetext{
${ }^{14}$ Trata-se de uma arregimentação subsidiada, fruto de um grande sistema racionalizado como estratégia de organizar a divisão de trabalho internacional formando uma massa de trabalhadores que iriam compor os quadros de força de trabalho excedente. Os baixos salários do campo, associados às precárias condições de trabalho nas areas de cultivo e ao excedente de mão-de-obra tornava a cidade uma opção cada vez mais interessante para esse contingente que muitas vezes iria depois atingir as cidades em expansão.

${ }^{15}$ Segundo Grangeiro os considerados como artistas superavam o número de advogados, funcionários públicos, militares e religiosos. Cf. Grangeiro, 2000, p. 30.

${ }^{16}$ Entrevista dada a Ricardo Mendes. Gravação presente no acervo do Centro Cultural São Paulo. Além das fitas cassetes existem ainda transcrições de parte da gravação realizada.
} 


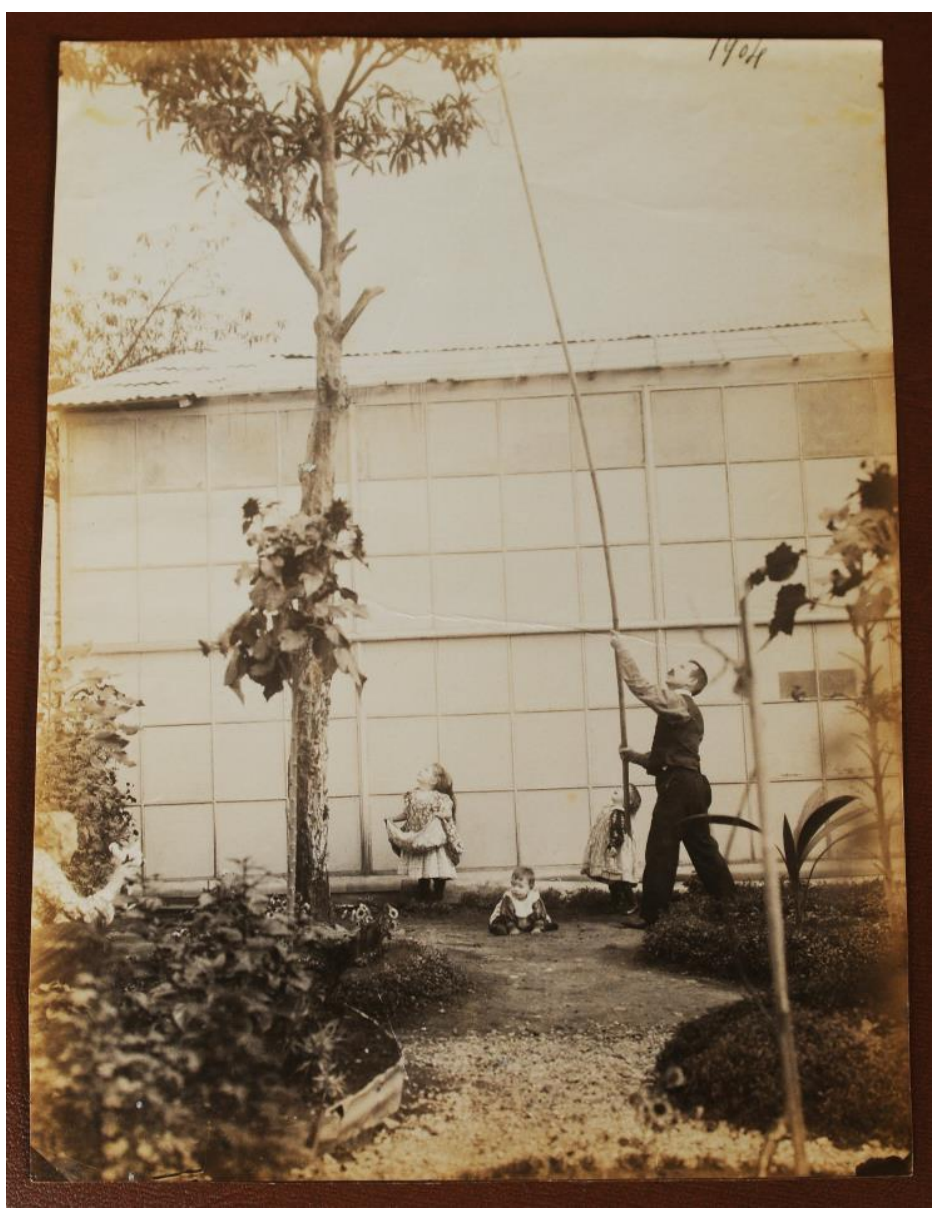

\section{Figura 9:}

Fotografia de Pastore em momento de interação com seus filhos no quintal do estúdio e residência da Rua da Assembleia. Não há identificação de quem teria realizado o registro. A esposa de Pastore, Elvira, aparece no conto esquerdo da foto, observando algumas rosas. $\mathrm{Na}$ parte superior da imagem aparece a data de 1904 inscrita, momento em que Pastore ainda atuava na Rua da Assembleia, n.12. Costanza Pastore manteve essa imagem no álbum da família. Coleção Costanza Pastore/Mosteiro São Bento.

A foto realizada em 1904 guarda o instante em que Pastore dividia o tempo com seus filhos no jardim composto pelo imaginário do tempo da infância (fig.9). O domínio da técnica fotográfica facilitava a produção de imagens que reforçavam o vínculo e a integração da família. Mas o próprio gesto de conservá-las e contemplá-las emprestam à fotografia de família, "o teor de ritual de culto doméstico, em que a família pode ser estudada como sujeito e como objeto", menciona Miriam Moreira Leite (1993, p. 87) ${ }^{17}$

Apesar de não tratarmos de um estudo de álbum de família estamos diante de imagens que trazem uma dimensão da vida íntima e privada de Pastore, e dos muitos sentidos que a fotografia assumiu para seus descendentes, afinal Costanza, a filha mais velha, assim como Dante, um dos filhos mais novos, reuniram e guardaram fotos da família; fotos que desvelam

\footnotetext{
${ }^{17}$ A autora analisa os álbuns de família produzidos na maior parte das vezes pelas camadas médias e altas, mas presentes também, nos núcleos familiares mais empobrecidos. Para estes a fotografia era obtida em menor número, mas mantendo-se o mesmo hábito e expectativas em torno do retrato: promover a aproximação efetiva bem como "constituir um distintivo social". Ver Leite. 1993, p.75.
} 
subjetividades que envolviam o fotógrafo, que tranquilamente, pelas manhãs, costumava fumar e depois beber sua meia xícara de café. ${ }^{18}$

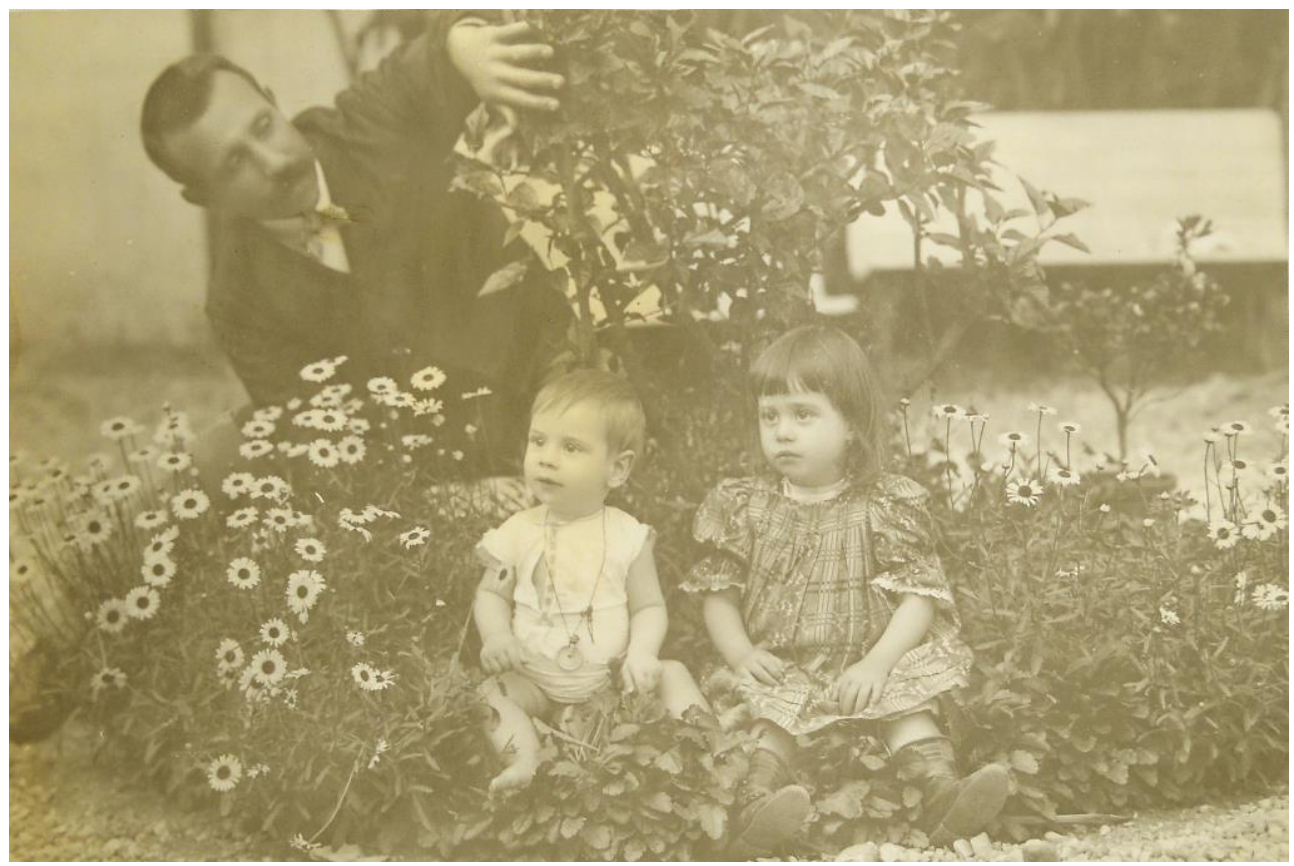

\author{
Figura 10: \\ Fotógrafo não \\ identificado. \\ Pastore no jardim \\ de um dos seus \\ ateliês \\ possivelmente na \\ rua da \\ Assembleia, n.12. \\ Coleção Dante \\ Pastore.
}

Mas nas coleções dos dois descendentes não se vê retratos feitos no interior da residência. Para a família o estúdio e o jardim foram os espaços onde a vida se fazia para o retrato. Do jardim invocamos a seguinte cena (fig.11). Por meio dela começamos a desvelar uma verdadeira parceria firmada entre Pastore e Elvira. É dessa parceria que se pode escrever essa história, afinal Elvira guardou fotos, escreveu um diário, reuniu no caderno de recortes muitas notícias e anúncios publicados sobre o marido. No dia-a-dia familiar lá estava Elvira atuando no laboratório, espaço que se estendia associado à prática do estúdio.

A rotina de suas vidas esteve marcada pelo trabalho diário feito no estúdio, intercalado pelas horas desdobradas no laboratório, o "quarto escuro", como declara Dante, filho do casal. Suas memórias retomam uma intimidade familiar enredada nesses espaços ocupados por Pastore e Elvira, numa parceria que garantia a sobrevivência de todos.

\footnotetext{
${ }^{18}$ Coleção Dante Pastore. Ver Diário de Elvira escrito em 1918.
} 


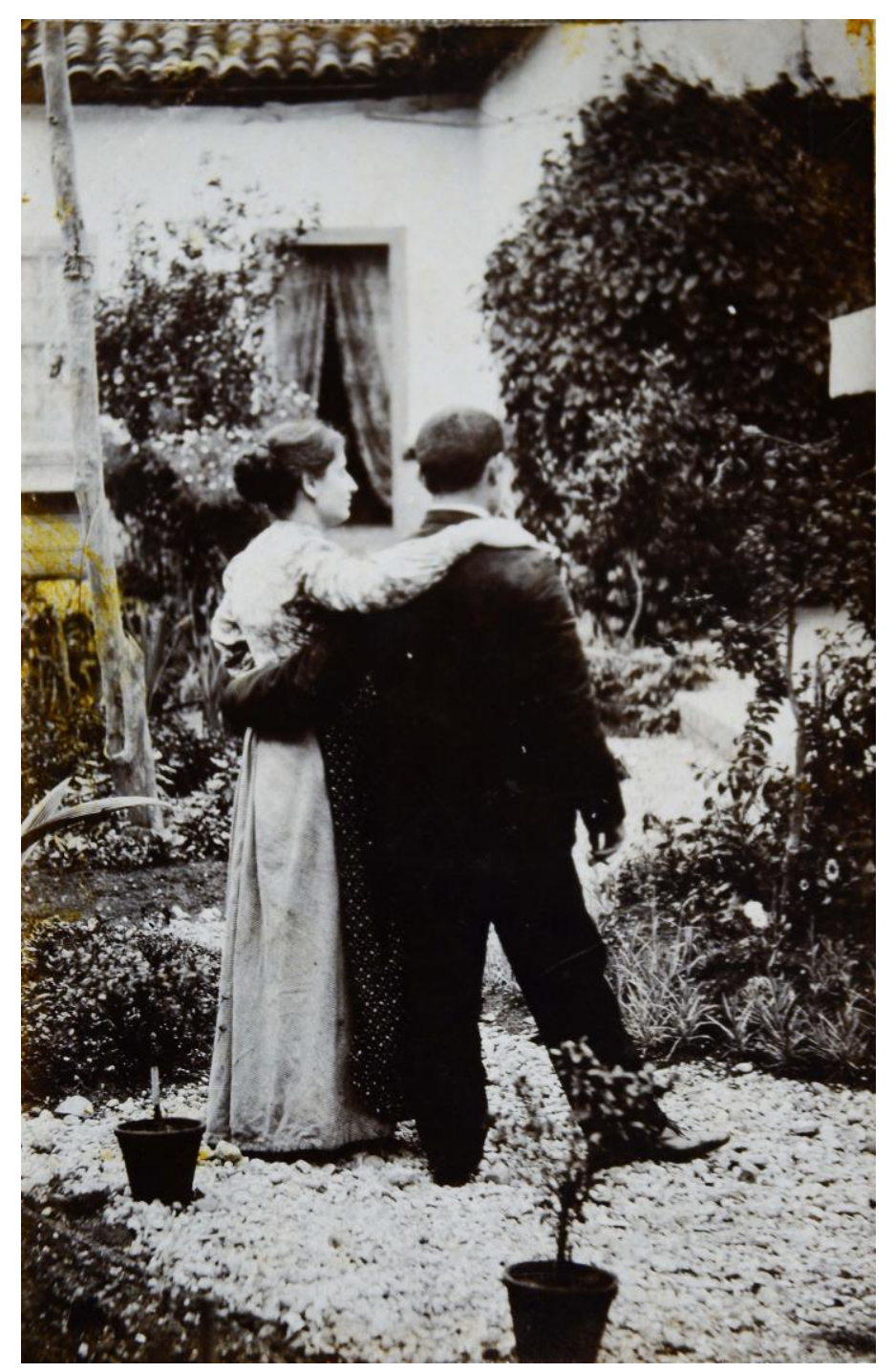

\section{Figura 11:}

Fotos do casal possivelmente no estúdio da Rua da Assembleia. S/d. Sem indicação de autoria. Coleção Dante Pastore.

Entre a casa e o "quarto escuro", Elvira dividia seu tempo e afazeres, na dupla jornada de trabalho assumida. Minuciosamente ela cumpria o papel social como mãe e esposa, cuidando do lar, filhos e marido, acumulando outras funções na dinâmica da casa. Abre-se assim um feixe de relações que levam a uma interpretação para os laços de parceria firmados entre casais. Assumi-se aqui aportes teóricos recentes apontados por Simioni (2007).

Dante, filho do casal, relembra como Elvira e Pastore trabalhavam até a uma da manhã depois de colocarem os filhos para dormirem. ${ }^{19}$ A parceria conjugal se estendeu entre o estúdio e o laboratório, na lida diário de cumprir os prazos de entrega, configurando uma experiência de trabalho realizado em dupla até as primeiras horas do dia, frente à contingência de se criar os dez filhos.

\footnotetext{
${ }^{19}$ Entrevista com Dante Pastore realizada pelo pesquisador Ricardo Mendes no dia 10 de janeiro de 1997. Documentação presente no acervo do IMS no Rio de Janeiro.
} 
Pensar a autoria como uma categoria fixa deixaria escapar os meandros dessa parceria firmada e de todos os esforços movidos por Elvira. Sua filha Costanza, assim como o irmão, guardava na memória a atuação da mãe:

Entravam no laboratório apenas os mais velhos. Não era muito grande. A mãe dizia que queria ajudar o pai, então aprendeu o quarto escuro. Ela trabalhava sozinha no laboratório. Quando perguntavam se ela tinha medo de ficar sozinha no quarto escuro ela respondia: eu nunca estive só, o anjo da guarda esteve sempre comigo. Ficou um ano aprendendo. ${ }^{20}$

Elvira, como se vê, ocupou uma posição para além do lugar social da esposa. Tratá-la como colaboradora implicaria lhe conferir uma posição secundária, quando na verdade se indicia fortemente uma divisão sexual do trabalho realizado no ateliê fotográfico. Não secundarizar o papel assumido pela mulher na parceria com o homem, da esposa com o marido, é uma perspectiva assumida pelos estudos de gênero voltados para parcerias artísticas que redimensionam a posição das mulheres, a partir de pressupostos que valorizam a experiência de todos (Simioni, 2007). O homem, o fotógrafo, dominava o espaço de maior contato físico, o estúdio, espaço que determinava o contato entre a casa e a rua; a mulher, Elvira, ocupava o espaço mais recluso, com sua presença mais restrita a um cômodo no interior da residência: o quarto escuro, uma espécie de bastidor deslocado do estúdio.

A presença de Elvira ajudava a preservar o acesso de muitas clientes a um espaço predominantemente masculino. Posar para um retrato no estúdio fotográfico exigia ainda certo pudor, obviamente mais verificável nos oitocentos, período que concebia tal prática como "atividade mundana", decorrente, segundo Krauss (2013, p.25) da intimidade e proximidade física da situação fotográfica.

O cuidado de Pastore em separar o dia para moças e para rapazes realizarem as fotos de formatura sintetiza bem comportamentos em continuidade nos primeiros anos de 1900. A presença de Elvira ajudava a tornar mais confortável a presença de outras mulheres no local.

A escassez de trabalho levara Elvira muitas vezes a se queixar. ${ }^{21}$ Para sobreviver e sustentar a família Pastore precisou baixar o preço de sua produção. Era preciso atrair uma clientela que não queria pagar pelos suportes mais caros como as fotominiaturas para medalhões e pingentes, ou imagens em esmaltes para broches, e ainda autocromos e

\footnotetext{
${ }^{20}$ Entrevista realizada pele pesquisador Ricardo Mendes, em 1997, com Costanza Pastore. Gravação presente no acervo do Centro Cultural São Paulo. Além das fitas cassetes existem ainda transcrições da gravação realizada.

${ }^{21}$ Coleção Dante Pastore. Cf. Diário de Elvira escrito em 1918.
} 
platinotipias, técnicas dominadas por Pastore. Segundo Costanza, o pensamento do pai lentamente se inclinaria em realizar "o que rendia mais".

Na Rua da Assembleia Pastore fotografou Manoel Correia Dias (fig.12). A escolha recaiu para um retrato de meio busto, uma exibição mais individualizada do retratado, comum na produção da carte-de-visite oitocentista, bastante popularizada. Mantinha-se a tradição do uso do terno escuro, indumentária masculina típica. A procura se deu aqui certamente por um registro mais barato, prensado numa simples moldura em papel cartão.

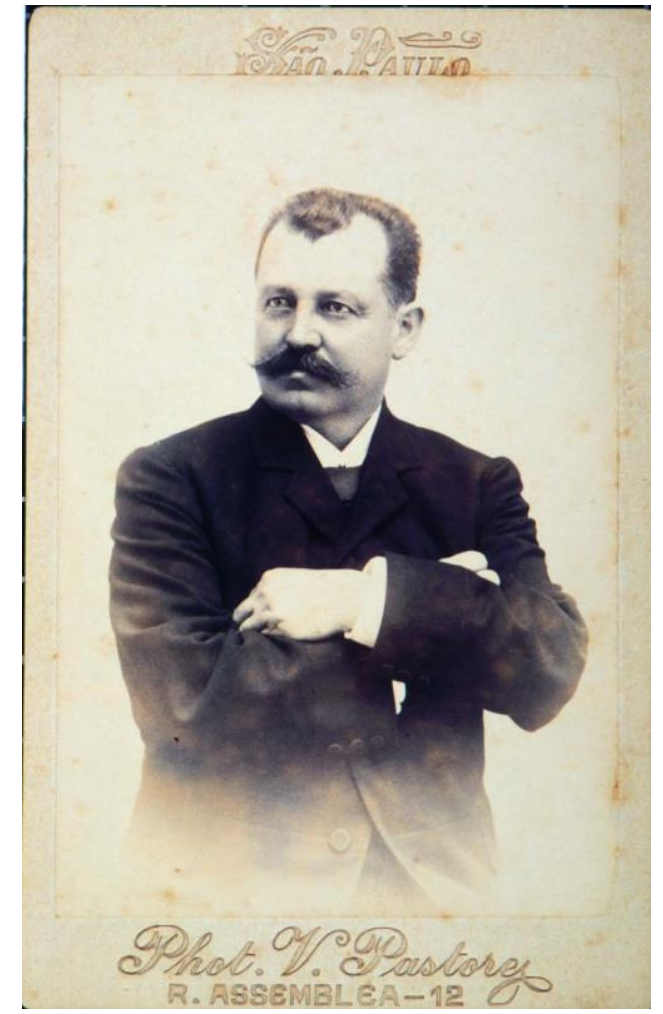

\section{Figura 12:}

Retrato de meio busto. 1910 (c) Vincenzo Pastore / Cortesia Museu Paulista/USP.

Mas foi com a invenção dos retratos mimosos que Pastore obteve maior lucro. As fotografias em formato losangular, prensadas em papel cartão com desenhos art nouveau impressos foram anunciadas como um produto "em moda em São Paulo". Segundo sua filha Costanza, Pastore teria feito muito dinheiro com o retrato mimoso, trabalhando até mesmo aos domingos para dar conta da demanda que se avolumava. Bastante religioso e devoto fervoroso de Nossa Senhora do Carmo o fotógrafo teria solicitado autorização à Igreja para trabalhar até mesmo no dia reservado ao descanso. ${ }^{22}$

22 Coleção Dante Pastore. In: Caderno de Recortes. Não consta o nome do jornal anunciado, tendo sido guardado apenas o recorte do anúncio publicado em jornal. 
A crescente demanda pelos retratos mimosos confluiu com um gosto e uma crença: caberia ao retrato fotográfico o mérito de reproduzir a imagem "tal e qual" se via na realidade. A "precisão espetacular do registro", como salienta Pavan (2008, p.233), conquistava um público atraído pela "arte baixa”, de rápida execução, de custo cada vez mais barateado e de confiança inegável; uma fotografia que presta tributo a carte-de-visite, massificada e democratizada após a invenção de Disdéri, que inaugura a fase de decadência da fotografia promovida pela sua versão industrial, repetitiva e monótona (Benjamin,1994).
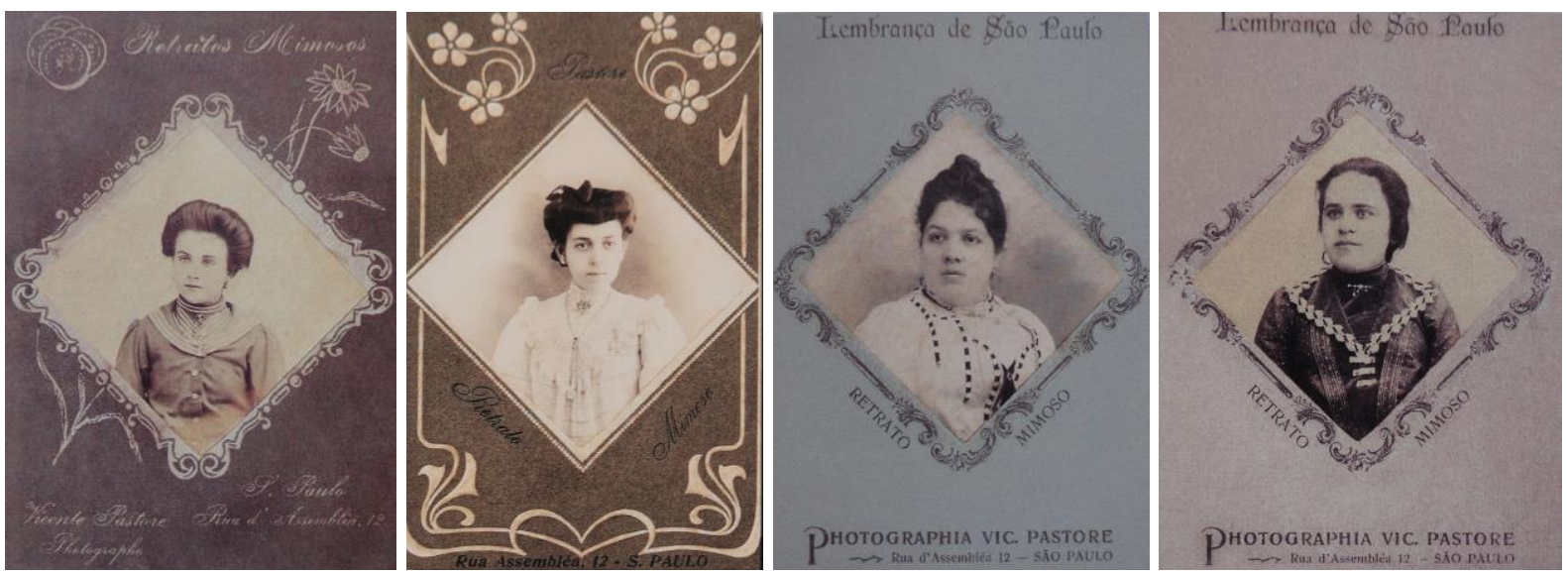

Figuras 13, 14, 15 e 16:

Retratos mimosos realizados por Pastore possivelmente entre os anos de 1899 a 1904. Reprodução feita a partir do livro Gerodetti \& Garbin. Álbum de Retratos. Fotografias Brasileiras. 2012.

$\mathrm{Na}$ encenação do estúdio, as quatro mulheres consumidoras dos retratos mimosos, tentavam assegurar o status social garantido no domínio documental do suporte material que adquiriam, tendo ali materializada a idéia que tinham sobre si mesmas. A melhor aparência era alcançada seguindo as intenções de cada retratada, assegurada pela técnica do fotógrafo, que precisava também conhecer as artimanhas dos negócios. Os retratos podiam ser pagos à vista ou a prestação, satisfazendo assim, os desejos de personalização que acompanhava o retrato desde o século XIX, cada vez mais disponível para grupos sociais menos abastados.

Todas usavam cabelos presos, com roupas cuidadosamente escolhidas. Obedeciam às orientações de não olharem diretamente para o fotógrafo, posando ligeiramente de semi-perfil, ansiosas pela melhor representação de si, em meio a retratos comercializados também como uma "Lembrança de São Paulo". Pastore articulava diferentes significações associadas aos sentimentos de pertencimento a um lugar. A divulgação do novo formato, o retrato mimoso, foi uma estratégia do fotógrafo para conseguir popularizar essa produção de custo mais 
reduzido, anunciada algumas vezes como brinde, para atrair maior clientela, demarcando atributos que lhe conferiam domínio de outras técnicas na feitura do retrato:

O senhor Vincenzo Pastore se dedica especialmente ao retrato artístico em miniatura para medalhões e pingentes. Com isso, domingo, o senhor Pastore presenteará com uma fotografia tipo "mimoso" em aquarela e em todas as cores a quem visitar domingo pela manhã o seu estabelecimento na Rua da Assembleia. ${ }^{23}$

A inauguração do novo estúdio na Rua Direita, bem localizada e destinada aos mais afortunados, indicia como Pastore começara a ganhar dinheiro com seus retratos mimosos. Mudou-se para um estúdio maior, com instalação elegante, modernos equipamentos. O anúncio publicado em jornal para a comunidade italiano rastreia o desejo de atrair uma clientela conterrânea: "Hoje será inaugurado o novo estabelecimento do sr. Pastore na rua Direita 24. A instalação elegante e os equipamentos modernos colocam a fotografia Pastore entre as melhores de São Paulo". ${ }^{24}$

Pastore protagonizava o papel de anfitrião servindo champagne aos convidados presentes na inauguração. Contratou banda de música. Queria levantar os olhares para o seu sobrado, atraindo os transeuntes que passavam e, logo notariam, o burburinho causado pela banda "Ettore Fieramosca". Temos aqui pormenores virtuosos porque permitem reviver e imaginar os esforços empreendidos pelo fotógrafo que tentava fazer da inauguração um evento comemorado, tentando se diferenciar, conquistando espaços para divulgar seu novo estúdio.

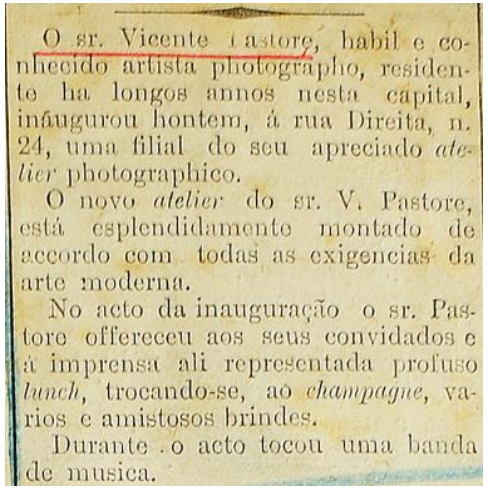

\section{Figura 17:}

Reprodução de recorte anunciando o estúdio de Pastore. Caderno de Recortes montado por Elvira Pastore. O nome do fotógrafo aparece sublinhado, pratica recorrente empregada pelos descendentes do fotógrafo. Coleção Dante Pastore.

Pastore, um apaixonado por música e tocador de bandolim, como relatou a filha Costanza, passou a viver e manter seu negócio realizando constantes viagens para a Itália.

\footnotetext{
${ }^{23}$ Coleção Dante Pastore. Caderno de Recortes. Tradução nossa.

${ }^{24}$ Coleção Dante Pastore. In: Caderno de Recortes.
} 
Trazia na bagagem papéis fotográficos comprados em Milão, ou equipamentos e materiais químicos necessários no laboratório.

O novo estúdio ocupou o segundo andar do sobrado. Havia uma entrada separada para o apartamento onde a família residia no primeiro andar. Eram ali três dormitórios grandes. Nesse mesmo andar funcionava o laboratório. No térreo do sobrado funcionava a loja $\mathrm{Au} B o n$ Marché. A legislação do período era clara ao determinar o fechamento das portas dos estabelecimentos comerciais aos domingos. Apenas aqueles que apresentassem entrada comum à residência de seus donos, como o estúdio de Pastore, poderiam funcionar. Se, este cumpriu pelo menos parcialmente a lei municipal, trabalhou aos domingos sem a ajuda de qualquer ajudante já que no ato municipal n. 443, de 9 de janeiro de 1912, em regulamentação da lei sobre a obrigatoriedade dos horários de funcionamento e fechamento de estabelecimentos comerciais, determinava-se a proibição de qualquer serviço em que se ocupem empregados no dia semanal reservado ao descanso. ${ }^{25}$

\subsection{Viver do retrato na capital paulista: desafios e práticas fotográficas}

Nos dias 22 e 23 de outubro de 1900, vê-se como Pastore enfrentava a concorrência no circuito do retrato: oferecia aos seus clientes "seis photopraphias/ novo formato Elena, em elegantíssimos cartõezinhos ornados, só $4 \$ 500$ e por poucos dias". ${ }^{26}$ Disponibilizar variados produtos era condição para não ver o fïm do negócio empreendido. Segundo Grangeiro, desde as últimas décadas do século XIX,

percebe-se que conseguiam permanecer por mais tempo na cidade os fotógrafos que possuíam melhor estrutura, variedades de produtos conseguidos com diversas técnicas e acabamentos, aqueles que mantinham venda de álbuns de retratos, acessórios, coleções de postais e de personagens ilustres (...) os fotógrafos que executavam apenas cartões de visita ou vistas fotográficas tinham seus dias contados. (Grangeiro, 2000, p. 77).

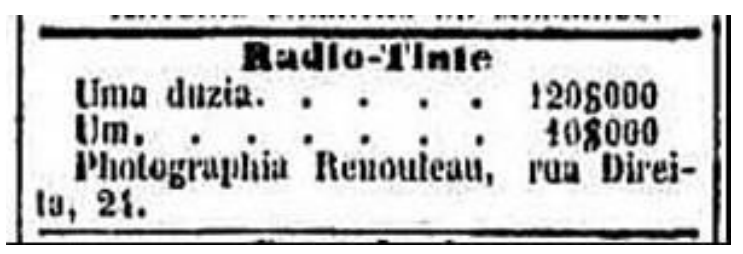

Figura 18:

Anúncio. Jornal O Estado de S. Paulo. 1900.

\footnotetext{
${ }^{25}$ Arquivo Municipal de São Paulo. Ato Municipal 1912. Lei n. 450 instituída desde 1900.

${ }^{26}$ Jornal O Estado de S.Paulo. Outubro de 1900. As características do formato Elena não são conhecidas.
} 
Quem seria o fotógrafo que atuara no estúdio depois ocupado por Pastore na Rua Direita? O anúncio ao lado (fig.18) revela o quanto este retratista não identificado desejava se associar aos domínios sofisticados do processo de radio-tinte, ressaltava o domínio da técnica de fotopintura, imitando a pintura à óleo.

Ao longo do mês de outubro de 1900, o jornal O Estado de S.Paulo publicou esse anúncio que oferecia serviços, preços e diferentes processos. A dúzia anunciada imprimia "uma das novidades da fotografia" segundo Benjamin (2000, p.168): a preocupação com a "quantidade, o número e a medida na própria matéria da imagem". A "existência serial" revelava-se como um fenômeno da própria modernidade, como também pontuou Rouillé:

O tempo da exposição, a duração de revelação, a distância, a profundidade de campo, a sensibilidade das emulsões, formam um conjunto de parâmetros que tecem uma verdadeira trama digital imanente aos clichês. Mas, ao permitir a repetição das tomadas de um mesmo objeto e a reprodução de um mesmo clichê, a fotografia marcou no domínio das imagens também o advento da série: uma passagem decisiva do único para o múltiplo, dos valores artísticos tradicionais para os valores industriais modernos. (Rouillé, 2009, p. 37)

No processo de publicização dos serviços fotográficos era preciso enfatizar o novo, o criativo, o avanço tecnológico da reprodutibilidade. Intervenções com retoque das imagens à lápis, com carmim, grafite, esfuminho, e todo o processo de coloração com anília, óleo e aquarela, ${ }^{27}$ ofereciam, na época, traços de diferenciação de um fotógrafo. Garantir a superioridade da fotografia sobre a pintura, segundo Lima (2008, p.73), explica os anúncios da photographia renouleau, uma estratégia de divulgação para vendas de início de século: "trabalhos em retratos colloridos pelo systema Radio-Tinte, ainda desconhecido nessa capital, garantindo a inalterável fixidade das cores cuja frescura e relevo excedem a mais perfeita aquarella e tem todo o brilho da pintura a óleo".

Pastore, frente a expansão do mercado fotográfico, mostrava-se a par de processos avançados e modernos, anunciando a especialidade que dominava:

Estúdio fotográfico / Vincenzo Pastore

Executa-se com a máxima perfeição e cuidado todo trabalho desse tipo. Especialista em trabalhos de ampliação: gelatina-brometo de prata, até o natural: "platinotipia", semiesmaltados, fotominiaturas para broches,

\footnotetext{
27 Ver Balady. Sonia Umburanas. Valério Vieira: um dos pioneiros da experimentação fotográfica no Brasil. Dissertação de mestrado do Programa de Pós-graduação Interunidades em Estética e História da Arte - USP. 2012, p. 67.
} 
alfinetes. Executa-se bem os retratos em fotocromo sendo este um trabalho de especialidade exclusiva do estúdio de Pastore em São Paulo. ${ }^{28}$

A expansão dessa atividade comercial garantia a sobrevivência dos fotógrafos, desafiados a dominar diferentes materiais envolvidos no processo foto-químico e fotomecânico:

\begin{abstract}
Embora tenha sido largamente empregada como instrumento de documentação, a principal atividade desenvolvida pelos fotógrafos em todo o mundo foi o retrato; esse era efetivamente o seu ganha-pão. A expansão da fotografia foi decorrente de uma clientela que se ampliava ininterruptamente, desejosa de representação. Este modelo se repetiu na América Latina e ocorreu igualmente no Brasil: os verbetes bem o confirmam. (Kossoy, 2002, p.24)
\end{abstract}

O anúncio sobre L'arte fotográfica de Pastore mostra um fotógrafo atento ao gosto e ao modismo de seu tempo:

(...) Quem quer manter boas lembranças de seus entes queridos deve procurar pelo senhor Pastore para ter fixada sua aparência na parte inferior de um prato de parede, no casco convexo de um copo, em uma ânfora, em uma garrafa - o que pode suscitar memórias - como o espelho claro, onde o olhar da vaidade lisonjeada pode encontrar-se com um amante de uma pessoa amada. $(. . .)^{29}$

Além das fotominiaturas, das platinotipias ${ }^{30}$ e das fotografias em aquarela anunciadas, Pastore desenvolveu também um processo de pigmentação especial, saturando cores fortes; processo divulgado como uma "verdadeira novidade" obtida pelo "hábil artista".

A forte pigmentação avermelhada (fig.19) foi escolhida para o retrato de suas filhas, imagem que integra a coleção Dante Pastore. A presença da cor, obtida desde o final do século XIX com a fotopintura, foi um fenômeno de captação artificial, "mas a mais real de todas enquanto simbologia", difundido pela autocromia entre "os fotógrafos amadores de maior refinamento ou para uso restrito de fotógrafos profissionais" (Mendes, 2007, p.23).

\footnotetext{
${ }^{28}$ Coleção Dante Pastore. Caderno de Recortes.

${ }^{29}$ Coleção Dante Pastore. Caderno de Recortes, p. 11. Tradução nossa. Trata-se de processo foto-mecânico, com o uso de tinta para a reprodução da imagem. A foto captada do negativo sensibilizado era transferida para uma matriz, depois transferido para o suporte escolhido, dando origem à reprodução.

${ }^{30}$ A platinotipia é uma técnica para realização de cópias de imagens obtidas à base de sais de ferro fotossensível e platina precipitada para a formação da imagem final, depois impressas em papel, com menor chance de deteriorização.
} 

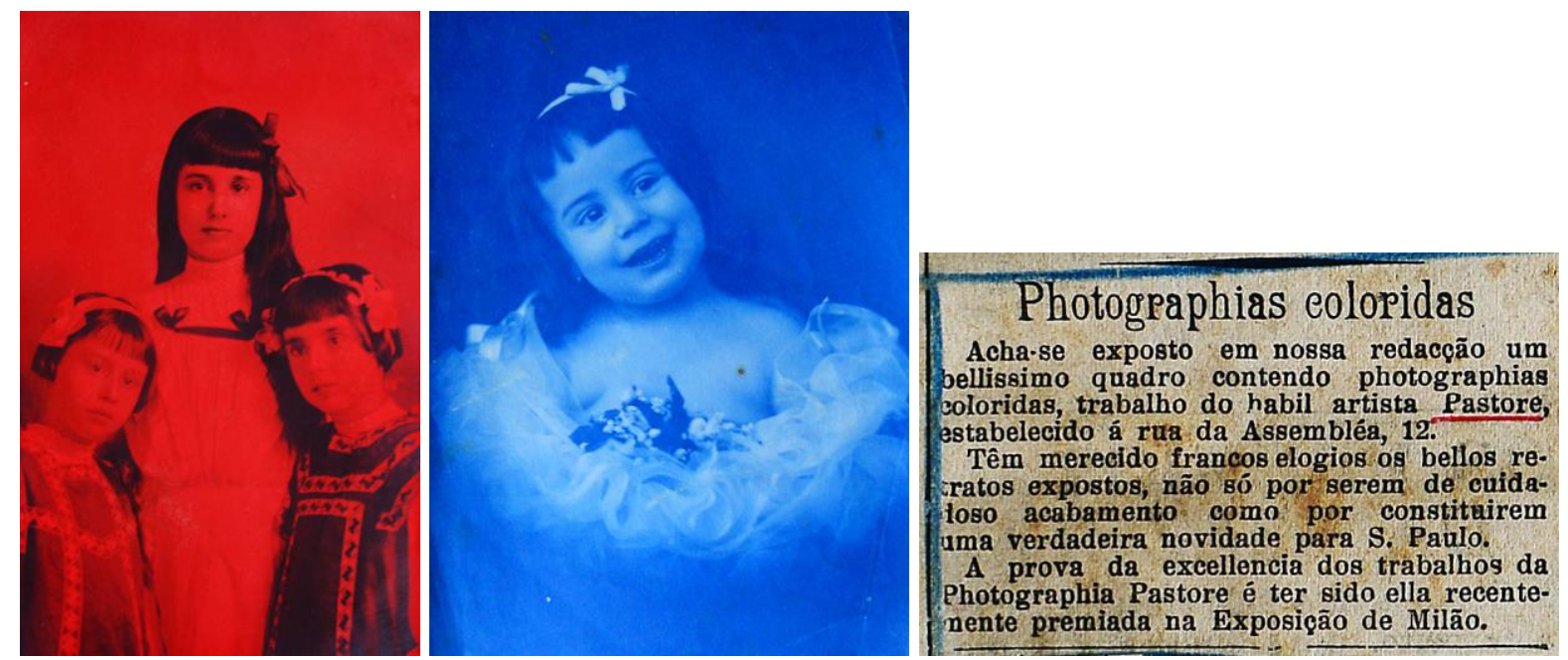

Figuras 19, 20 e 21: à esquerda reprodução de foto em que Pastore retratou as filhas, ao centro a filha Costanza, à esquerda Maria Lúcia, à direita, Beatriz. Imagem central retrato em cianotípia. Sem data. () Vincenzo Pastore / Coleção Dante Pastore. À direita, reprodução de recorte de jornal. Caderno de Recortes. Coleção Dante Pastore

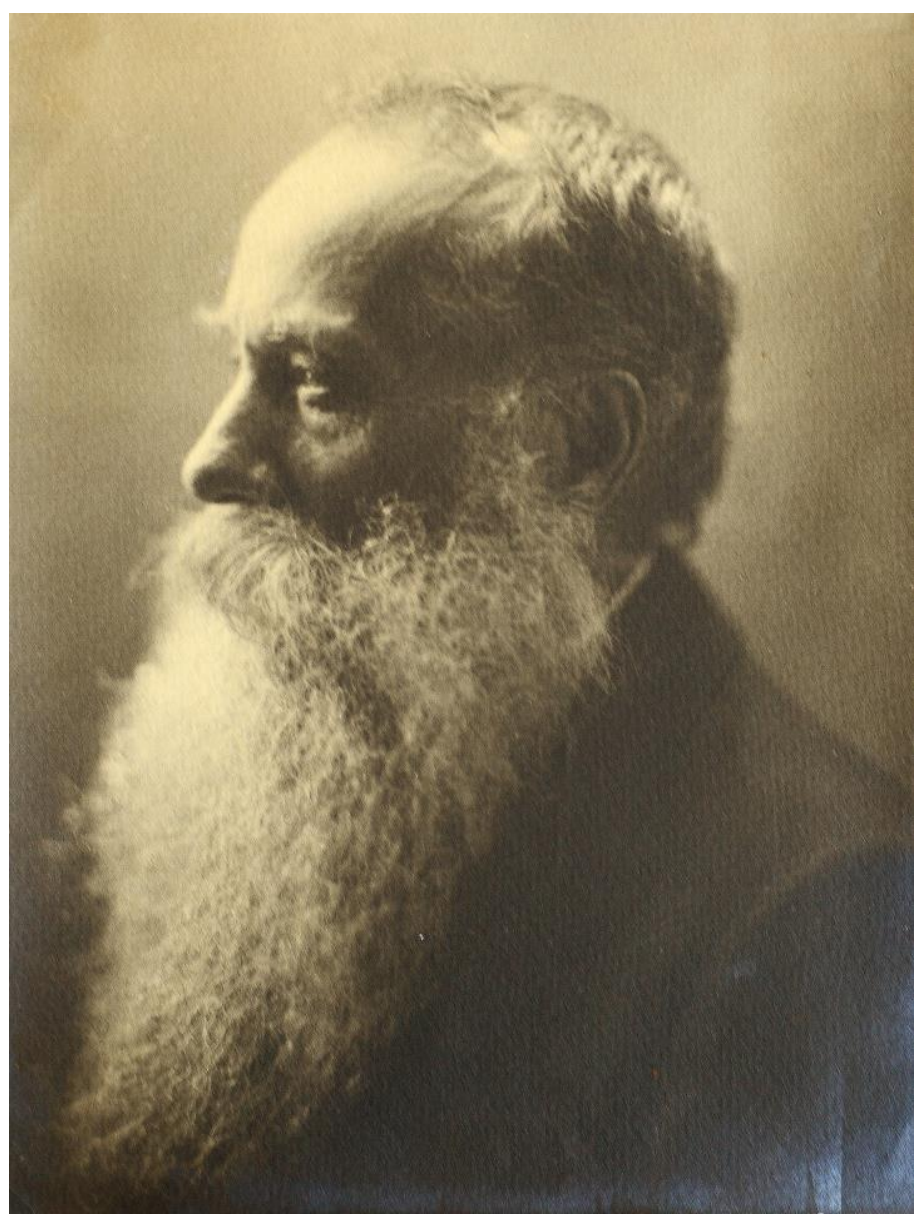

\section{Figura 22:}

Fotografia em papel, $22,5 \mathrm{~cm}$ x $28,5 \mathrm{~cm}$. Foto de cliente com espelhamento na borda inferior à direita. Sem data (C) Vincenzo Pastore / Coleção Dante Pastore.

Trata-se este de um processo mais simples, dominado por Pastore com o possível uso de um filtro vermelho, ou foto positivada em papel fotográfico com pigmento colorido. $\mathrm{O}$ cianótipo (fig.20), que sempre resulta numa reprodução em tom azul, foi outro processo 
fotográfico dominado por Pastore. Esse processo executado sobre o papel fotográfico em contato com o negativo, expostos ao sol, conta com resíduos químicos a partir de sais de ferro, reproduzido em papel salgado e albumina, mais propensos ao amarelecimento.

$\mathrm{Na}$ arte do retrato, Pastore vai se mostrando um fotógrafo zeloso em todas as etapas de seu trabalho. É evidente o cuidado na captação de uma luz quase efêmera (fig.22); o empenho em revelar bem, em escolher um papel fotográfico que chama atenção pela textura, pelas pequenas ranhuras, com as fibras do papel quase invisíveis dá a ver minúcias escolhidas por Pastore. A nobreza dos suportes ajudava a singularizar as ambições de fotógrafos inseridos em práticas mais artísticas da fotografia (Roullé, 2009). O alcance de detalhes em todos os tons, claro e escuro, faz dessa fotografia (fig.22), um emblema da qualidade do fotógrafo. Foto que apresenta uma dupla camada de gelatina e prata, já apresentando os efeitos da luz e do tempo, com espelhamento em toda borda inferior subindo para as laterais da reprodução, sobretudo à direita. Sais de prata sempre provocam tais resultados devido a oxidação. Frente à ausência total dos negativos nas coleções, a reprodução em papel constitui a materialidade sobrevivente.

Outras duas imagens prensadas em cartão suporte (fig. 23 e 24) revelam aspectos que explicam o fato de Pastore ter sido considerado "è proprio il mago della fotografia". ${ }^{31}$ Temos a produção das chamadas "fotos inalteráveis", sem uso de prata, tratando-se apenas de pigmento, gelatina e papel. Imagens conhecidas como carvão-print mostram como esse procedimento reforça as áreas escuras, sem perder detalhes, misturados aos efeitos brumados. $\mathrm{Na}$ imagem à direita, vê-se o carvão no pigmento em tom azul; o tom em terra ou talvez vermelho, é o pigmento da imagem à esquerda; ambas compondo traços de uma poética fotográfica em Pastore.

\footnotetext{
${ }^{31}$ Coleção Dante Pastore. Caderno de Recortes.
} 


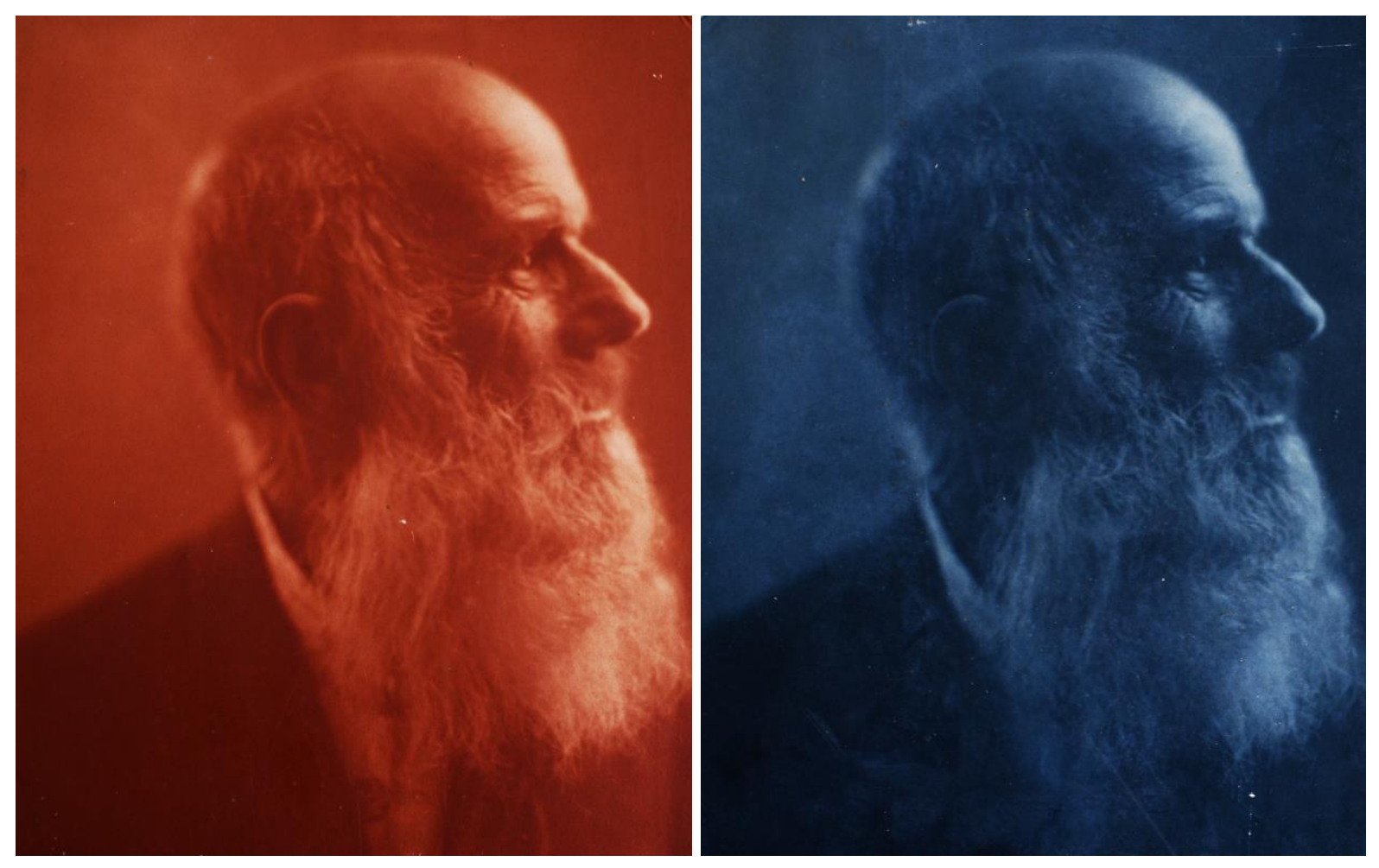

Figuras 23 e 24: Fotografias em papel, 22 x $28 \mathrm{~cm}$. Possível foto de clientes guardada na coleção familiar. s/d (C) Vincenzo Pastore. Coleção Dante Pastore.

Não sabemos ao certo se o retrato desse senhor, encontrado em uma das caixas de fotografias guardadas por Maria Lúcia Pastore Varani, hoje a guardiã da coleção herdada do pai, Dante Pastore, refere-se à imagem citada na seguinte nota (fig.25). Eloqüentes elogios aos "efeitos belíssimos obtidos" na "magnífica execução" conferem um lugar social para Pastore, o lugar em que a fotografia, inscreve-se como sucedâneo da arte.

Dominar a técnica do processo inalterável dava maior prestígio aos fotógrafos. Pastore, contudo, não enganava com banhos de viragens e falsos anúncios. Tais fotos mostram como de fato Pastore alcançava o requinte do processo à carvão, não precisando recorrer a subterfúgios que apenas parcialmente podiam preservar as imagens. O uso da goma bicromatada, o verdadeiro fetiche entre os fotógrafos pictorialistas segundo Rouillé (2009), começa a indiciar a inclinação de Pastore para práticas mais sofisticadas do retrato, pertinentes a um campo de intenso debate em torno da fotografia, práticas interpeladas mais adiante. 


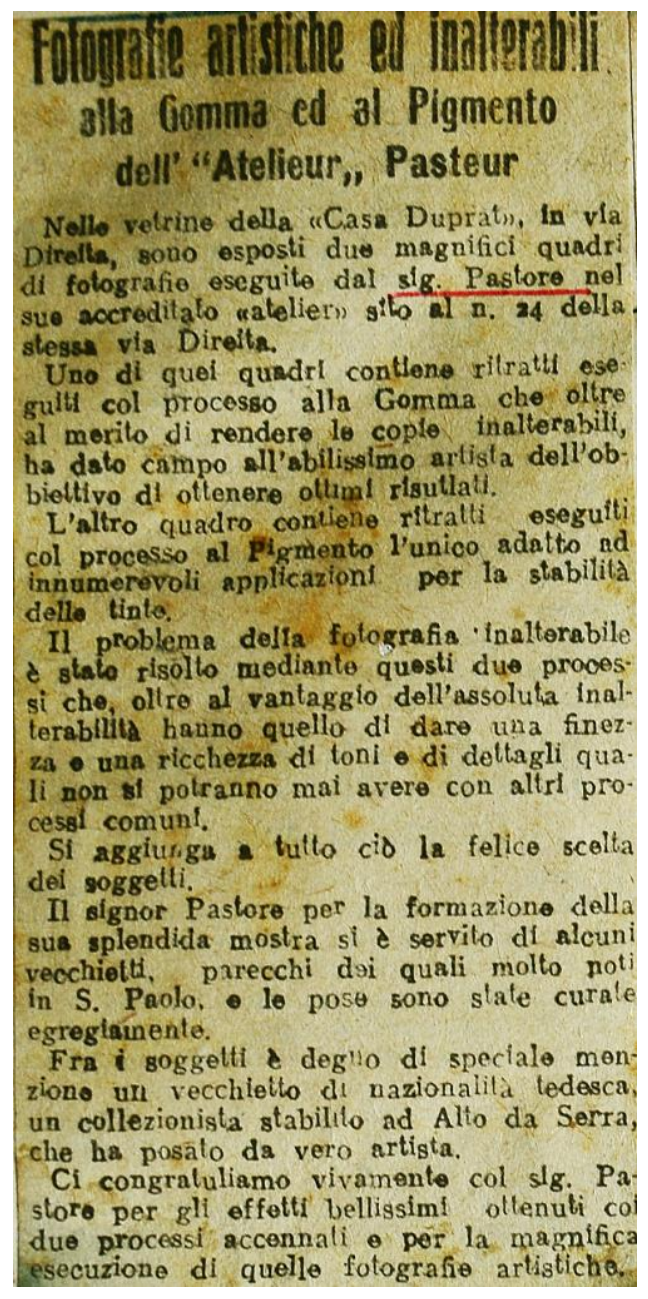

Figura 25: Reprodução Caderno de Recortes. Coleção Dante Pastore.
Fotografias artísticas e inalteráveis

à goma e ao pigmento

do "Atelieur" Pasteur.

Nas vitrines da "Casa Duprat", na rua Direita, estão expostos dois magníficos quadros de fotografias feitas pelo Sr. Pastore em seu renomado "atelier" situado no $\mathrm{n}^{\circ} 24$ da mesma rua Direita.

Um desses quadros contém retratos feitos com o processo à goma-bicromatada, que além de ter a vantagem de tornar as cópias inalteráveis, deu espaço para que o habilíssimo artista da objetiva pudesse obter ótimos resultados. $\mathrm{O}$ outro quadro contém retrato feito com o processo ao pigmento, o único adequado a inumeráveis aplicações em razão da estabilidade das tintas. O problema da fotografia inalterável foi resolvido mediante esses dois processos que, além da vantagem da absoluta inalterabilidade, têm também o mérito de dar uma fineza e uma riqueza de tons e de detalhes que são impossíveis de se obter com outros processos comuns. Junte-se a isso a feliz escolha dos sujeitos. O Sr. Pastore, para a formação de sua esplêndida mostra, serviu-se de alguns velhinhos, muitos dos quais bastante conhecidos em São Paulo, e as poses foram criadas magistralmente. Entre os sujeitos, é digno de menção especial um velhinho de nacionalidade alemã, um colecionador domiciliado em Alto da Serra, que posou como um verdadeiro artista. Parabenizamos vivamente o Sr. Pastore pelos efeitos belíssimos obtidos com os dois processos citados e pela magnífica execução daquelas fotografias artísticas. (Tradução Nossa)

Pastore investia suas imagens em múltiplos circuitos de divulgação. Exposições eram realizadas em seu ateliê, mas também em variados circuitos de recepção. $\mathrm{O}$ uso de vitrine de lojas bem localizadas e conhecidas no Triângulo Central, ou ainda exibidas em mostruário de redação de jornal mostra estratégias de publicização empreendidas frente à concorrência entre os ateliês.

Valendo-se da vitrine da Casa Duprat, ou da Casa Camargo, localizadas na Rua Direita, Pastore expunha ao público as diferentes técnicas que dominava. O seguinte anúncio destaca a produção de fotocromos, "a última palavra na fotografia tida como arte", dado ao surpreendente efeito de luz. O anúncio reiterava a recente viagem feita à Europa, de onde Pastore trouxe "muitos novos recursos e material necessário" para a execução do "belíssimo trabalho em fotocromotografia e semi-esmalte". A experiência e a assiduidade do estúdio completavam as informações postas em circulação. 

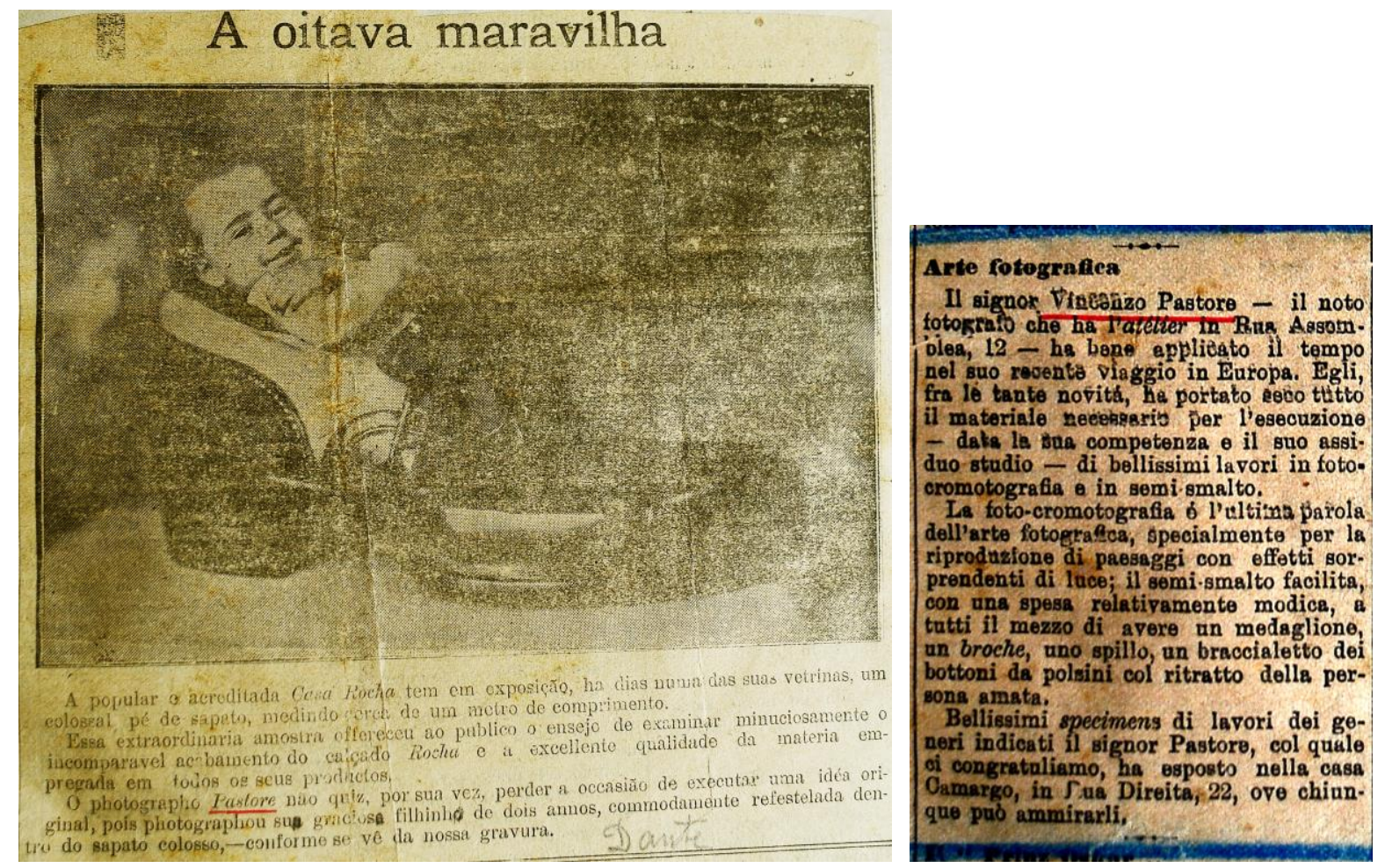

Figuras 26 e 27: Na foto à esquerda vê-se o filho Dante retratado na imagem dentro de um grande sapato. Como 1912 é a data de seu nascimento, e o artigo cita a idade de 2 anos do menino, sabemos que essa imagem foi publicada em 1914. Ambos os recortes são reproduções de recortes de jornais no Caderno de Recortes criado por Elvira Pastore/ Coleção Dante Pastore.

De modo bastante irreverente Pastore fez também uso da vitrine da "popular e acreditada Casa Rocha" (fig.26). Executou ali "uma ideia original”: colocou o seu filho Dante, com dois anos de idade, "commodamente refestelado" dentro de um "colossal pé de sapato medindo cerca de um metro de cumprimento", que ele havia mandado confeccionar na casa citada. Estratégia que tentava provocar em algum cliente o desejo de possuir a mesma imagem, ${ }^{32}$ mas também da própria loja que "offereceu ao publico o ensejo de examinar minuciosamente o incomparável acabamento do calçado Rocha e a excellente qualidade da matéria empregada em todos os seus productos".33

Pastore contava com um ambiente de inovações embaladas pelos modismos da Belle Époque. Jornais e revistas estrangeiras mais atualizados e objetos de arte eram encontrados na Casa Garraux, que também exibiu o trabalho de Pastore. Lojas de departamentos, restaurantes, casas de artigos elétricos, ateliês, foram importantes espaços de circulação de

\footnotetext{
32 Foi o neto de Pastore, José Roberto Varani, filho da caçula de Pastore, Eleonora, que relatou a encomenda do sapato feita à Casa Rocha. Ver entrevista realizada pelo pesquisador Ricardo Mendes em outubro de 1994 . Divisão de Pesquisa Centro Cultural São Paulo.

${ }^{33}$ Coleção Dante Pastore. Caderno de Recortes.
} 
imagens, auxiliando os artistas, segundo Balady (2012), a divulgar seus trabalhos por custos mais baixos.

$\therefore$ FOTO 3 RAFIA - II fotogiafo Vincanzo Pasture, che tinto bu:n nomu gode net nostro mondo aitisuco, lia conseguato allo Stato maggiore 11 giandissimo el elegate quadru-album de!"utlicialilà della öo." brigsta, 16'. batqagilune di falleria della gruardia naziothate.

Lo splendido lavoro dell'artista, di un modello fotalmente nuovo, il esposto alla liasa Garraux, dore riscosse la pubblica ammarazione.

Noi, segualand, questa nuova villoria artistica del sg. Pastore, grli ficcliano yive congratuiaztoni.

Figura 28: Reprodução Caderno de Recortes. Coleção Dante Pastore.

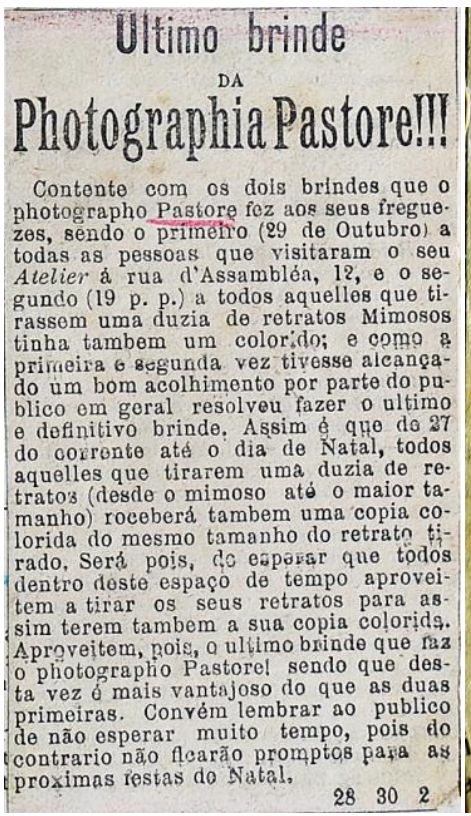

\section{Photographia}

Tivemos occasião de visitar o conhecido estabelecimento photographico de eximio artista, sr. commendador Vicente Pastore, sito á RUA DIREITA nesta capital. As galerias de retratos, que examinamos attentamente, attestam a capacidade do commendador Pastore, que, attendendo a crise, reduziu o preço dos seus trabalhos. Recommendamos ás pessoas do interior, que estejam de passagem nesta capital, visitarem esse estabeleA simento.

\section{Figura 29 e 30 :}

Reprodução de recorte anunciando o estúdio do fotógrafo. Caderno de Recortes montado por Elvira Pastore. Coleção Dante Pastore

No recorte, vê-se o anúncio “Ultimo brinde da Photographia Pastore!!!”. Era notável o esforço do fotógrafo em divulgar os seus retratos mimosos, oferecendo uma foto colorida. Anunciar o estúdio em jornais que circulavam no interior do Estado paulista foi outra tentativa de Pastore para atrair possíveis clientes, leitores do Jornal Independente, que estivessem em viagem pela capital.

Na trajetória de Pastore como retratista não encontramos apenas um fotógrafo astuto, criativo ao inventar novos formatos, conseguindo se anunciar com frequiência em jornais e revistas de grande circulação, do interior ou da capital, valendo-se de variadas vitrines para expor seu trabalho. Laços de solidariedade e ajuda mútua constituem o metier do retrato. 
Pastore ensinava outros a fotografar, relembrou Costanza, justificando como a vida do pai foi dedicada à fotografia. Ao transferir-se para Rua Direita, deixou um de seus fotógrafos aprendiz, José Victor de Mauro, casado com a cunhada de Pastore, Adelina Leopardi, dando continuidade ao trabalho feito na Rua da Assembleia.
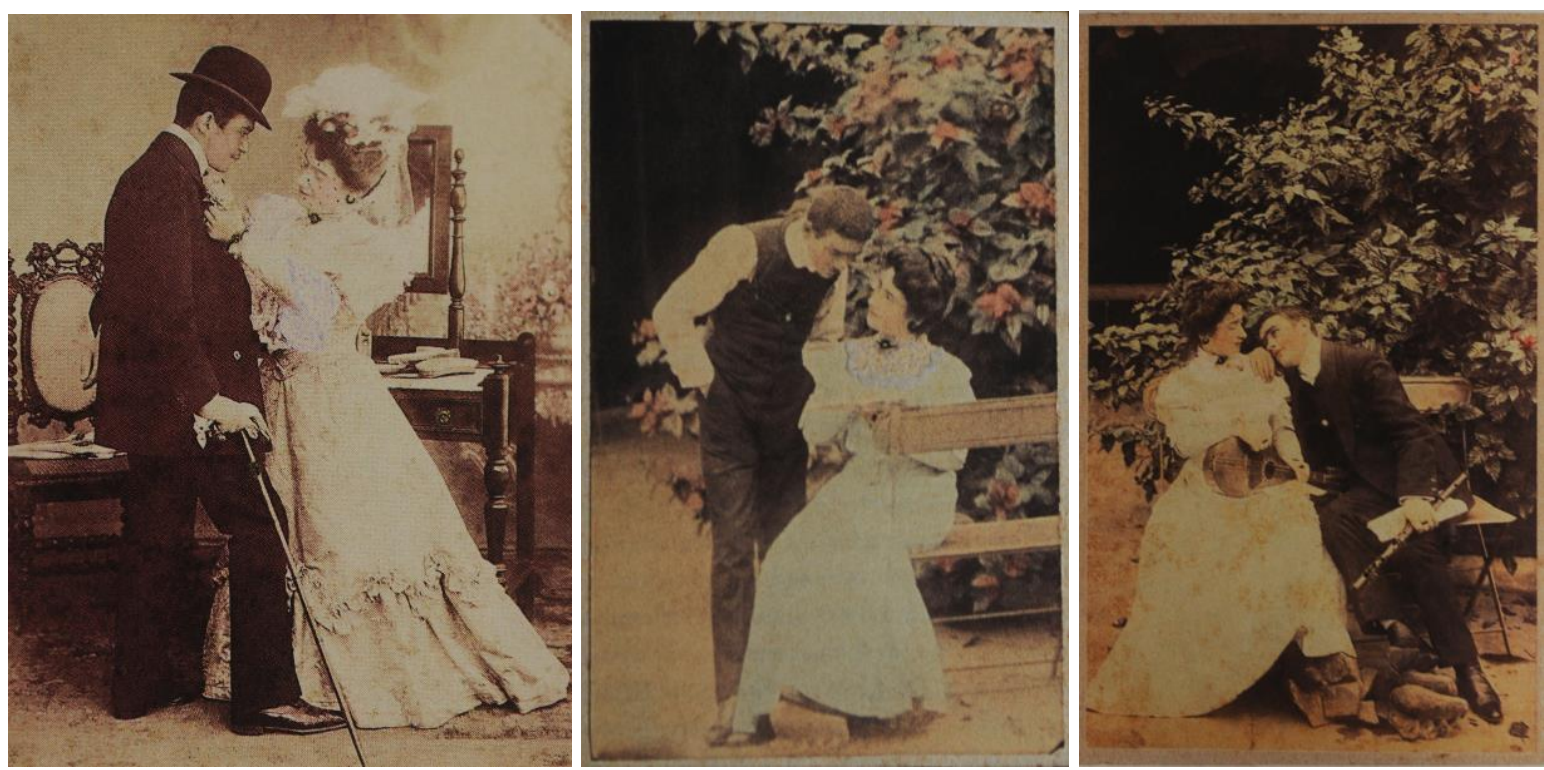

Figuras 31, 32 e 33: Adelina Leopardi e José De Mauro. Fotos realizadas no estúdio da Rua da Assembleia. Cópias em papel, pequeno formato, aquareladas. (C) Vincenzo Pastore. Coleção Aurélia De Moura Figueriedo.

Ao ensinar o ofício ao pretendente da cunhada, talvez Pastore quisesse ajudar a garantir o futuro de Adelina, acima retratada, vinda muito jovem ao Brasil. Ao lado da irmã Elvira, Adelina muitas vezes ajudou a prensar fotografias em cartões. Talvez tenha seguido também ajudando o próprio marido. A partir de 1910 o estabelecimento mudava de nome: Photographia de Mauro. Talvez neste momento tenha se desligado por completo do estúdio da Rua Direita, onde Pastore concentrou suas atividades desde 1909, deixando na Rua da Assembleia a estrutura que havia montado nos últimos dez anos. ${ }^{34}$

As imagens do casal retratado por Pastore em 1900, ora no estúdio, ora no jardim mostram o domínio sobre a técnica com acabamento aquarelado. Tons rosados e avermelhados nas bochechas do casal repetiam-se como cor nas flores dispostas ao fundo. $\mathrm{O}$ uso pictórico no suporte fotográfico se dava numa gama de domínios técnicos contando com retoques mais simples, até aos de riqueza extrema. A técnica da foto aquarela foi aqui

\footnotetext{
34 Muitas das informações sobre o fotógrafo José Victor de Mauro foram obtidas na entrevista realizada em 1994, por Ricardo Mendes, com Aurélia Maria de Mauro Figueiredo, filha de Avelina Leopardi Di Moura e do fotógrafo citado, nascida em São Paulo no dia 12 de setembro de 1918. Foi ela quem relembrou as histórias da mãe que contava ter ajudado Elvira no laboratório.
} 
empregada de modo mais singelo, numa composição de cenas que descortinam o cuidado de Pastore na feitura de cada retrato.

\subsection{A troca de endereços de estúdios na São Paulo de início de século}

O oficio ensinado por Pastore ao cunhado Mauro seguiu como aprendizagem e meio de sobrevivência da família por outras gerações. Em 1910 e 1911 o Almanaque Laemmert anunciou o estúdio de Mauro na Rua da Assembleia 12. Depois Mauro passou a ser anunciado na Avenida São João e depois Libero Badaró. Photographia de Mauro durou por muitos anos. O filho do casal, Francisco de Mauro trabalhou com o pai e foi, segundo a irmã, um grande fotógrafo.

Observar os almanaques do período mostra o quanto os fotógrafos mudavam de endereços, ora em busca de aluguéis mais acessíveis ora vislumbrando ocupar sobrados de áreas mais valorizadas. Ver o espaço é ver o horizonte de inter-relações permeadas por expectativas e desejos. Através do Almanaque Laemmert vê-se como a concorrência e a crescente disputa caracterizavam cada vez mais o mercado do retrato. São Paulo, em 1862, contava com a presença de apenas 4 estabelecimentos fotográficos: O fotógrafo Nuno Perestrello da Câmara, com estúdio aberto no Largo da Cadeia, rompeu a sociedade com o português Gaspar Antonio da Silva, que se tornou seu maior concorrente, passando a atuar na rua da Cruz Preta, chefiando a Carneiro \& Gaspar, uma filial da oficina fotográfica carioca, a famosa Carneiro\&Smith. Na Rua Direita encontrava-se o estúdio do Sr. Muller. O dono do estabelecimento fotográfico paulistano mais antigo pertencia a Inácio, na Rua das Freiras. Em 1863, chegava a cidade para viver da fotografia o Sr. Rubini. (Grangeiro, 2000, p.73). Três anos depois, com o fim da sociedade entre Carneiro e Smith, Gaspar tornou-se dono da Photographia Academica Carneiro \& Gaspar, a mais luxuosa da cidade, que depois se tornaria, ao ser vendida para Militão Augusto de Azevedo, Photographia Americana.

Pastore, em 1899, tinha a frente outro mercado. A cidade, em crescente processo de urbanização, passou a apresentar, na década seguinte, um número cada vez maior de fotógrafos disputando a mesma clientela. Acompanhar a presença de Pastore na cidade ajuda a visualizar o próprio fenômeno da expansão da fotografia. Essa importante atividade comercial já passava a apresentar 34 estúdios em São Paulo. 88\% destes estabelecimentos 
estavam nas mãos de fotógrafos estrangeiros. Os italianos somavam a metade desse contingente. ${ }^{35}$

Um novo circuito fotográfico muito mais dinâmico desenhava-se na urbe paulistana. Espanta a proximidade de alguns desses estabelecimentos, dividindo algumas vezes a mesma calçada, dando vistas da acirrada disputa pela clientela:

G. Sarracino, Rua 15 de Novembro,20.

Guilherme Gaensly, Rua 15 de Novembro, 28.

Valério Vieira, Rua 15 de Novemvro, 19.

Tobias \& Irmão, Largo da Sé, 5-B.

Pedro Ivancko, Largo da Liberdade, 27.

Affonso Giannini, rua Immigrantes, 48.

C. Scardini \& Irmão, rua S. Bento, 26.

M. L. Freire, rua S. Bento, 82.

E. P. Quaas, rua Barra Funda, 119.

Vicente Russo \& Irmão, rua Barão Itapetininga, 55.

José Minervino, rua Bom Retiro, 25.

Fratelli Maglino, Avenida Rangel Pestana 116.

Patoilo \& Richinte, Avenida Rangel Pestana, 117.

Henrique Clareto, Avenida Intendencia, 200.

Ricardo Molhenhauer, rua Aurora, 28.

Bernardo Kohring, rua S. Caetano, 95.

Miguel Rizzo, Rua Direita, 10-C.

C. Camerino de Castro, rua S. Bento, 2-C.

José Wolsack, Rua Direita, 2.

Vicente Tartore, Rua Direita, 24.

Becherini \& Stamati, rua Marechal Deodoro, 34.

Rodolpho Mau, rua S. Caetano, 103. ${ }^{36}$

O Almanak Lammert anunciou o estabelecimento fotográfico de Pastore na Rua Direita, em 1909, tendo, contudo, errado o sobrenome do fotógrafo. Um ano depois na publicação de 1910, mais uma vez se vê: "Vicente Tartore, Rua Direita, 24”. Outros fotógrafos concorrentes também tiveram nomes impressos equivocadamente. Affonso Licarelli, por exemplo, tratavase, na verdade, de Affonso Picarelli:

José Minervino, rua dos Immigrantes, 53.

Julino Nickelsen, rua Barão Jaguará, 20.

Affonso Licarelli, rua da Glória, 188.

Carlo Orsetti, rua da Consolação, 15.

\footnotetext{
35 Segundo Kossoy entre 1850 e 1859 já existiam no Brasil cerca de 90 fotógrafos em atividade, sendo 30\% nacionais. Na década de 1860 eram um pouco mais de 200, passando a somarem 40\% de fotógrafos estrangeiros, agora em menor proporção. Com ressalva às regiões sul e São Paulo apresentaram sempre a presença acentuada de estrangeiros. Os $90 \%$ de fotógrafos na cidade citada vinham de fora do país. $27 \%$ deles eram de origem italiana na última década do século XIX. Na década de 1900, em São Paulo se fixaram $14 \%$ dos fotógrafos de todo o Brasil. Ver Dicionário Histórico-Fotográfico Brasileiro. Fotógrafos e Ofício da Fotografia no Brasil (1833-1910). São Paulo: Instituto Moreira Salles, 2002, p.27-28.

${ }^{36}$ Almanak Lammert. 1909, p. S-59.
} 
O estúdio adquirido por Pastore na Rua Direita 24, provavelmente em 1909, como anunciou o Almanak Lammeert, havia sido ocupado anteriormente por Guilherme Neuhaus, em 1897. Neuhaus, todavia, já em 1901, anunciava-se na Ladeira Porto Geral. Quem teria ocupado o espaço nesse intervalo de tempo?

No lado impar da Rua Barão de Itapetininga, noticiava-se, em 1911-1912, a presença de “Alfredo Russo, photographia”. Seria o mesmo anunciado em 1909, com sociedade familiar entre "Vicente Russo \& Irmão, rua Barão Itapetininga, 55"? Em 1913, Vicente Russo, aluno de Bernardo Mandelbaun, dono da Photographia Amandier e também professor de fotografia, como menciona Kossoy, (2002), foi anunciado na rua Xavier de Toledo, número 46. Em 1916, Alfredo Russo continuava a anunciar a Photographia Artistica na rua Barão de Itapetininga, 55, mostrando que ele havia ficado no endereço antigo.

A partir de 1910 não há mais referências quanto ao estúdio de Pastore no almanaque citado, que anunciou, na Rua dos Immigrantes, número 131, a localização de M. Pitorcio. Quase em frente ao seu estúdio, o fotógrafo Zeferino Rinalto, era anunciado, no mesmo período, no número 124. Na conceituada Rua Quinze de Novembro, dois estabelecimentos fotográficos se localizavam frente a frente: do estabelecimento do fotógrafo Varello, no número 19 , se avistava o movimento da empresa de Sarracino \& $C^{a}$, no número 20 , do outro lado da rua.

Bernardo Kohring, n.103, na Rua S. Caetano, tinha Rodolpho Mau, como concorrente direito. Este chegou até mesmo a ser anunciado em 1909 nessa mesma numeração. O fotógrafo José Lacerda, ficava mais distante das disputadas ruas comerciais do Triângulo, com o seu estabelecimento localizado no número 56, da rua Victoria. Entre a sua vizinhança, encontrava-se uma parteira. ${ }^{37}$ Affonso Giannini, conterrâneo de Pastore, em 1906, passou a se anunciar na rua dos Immigrantes, primeiro no número 48, depois no 29 , ali se anunciado até 1913. Antes disso, em 1901, manteve estúdio aberto na rua Barra Funda, 90.

Benedito Braz Fernandes era noticiado pela primeira vez na rua Santo Antonio, 218; Carlo Orsetti, fixou ateliê na rua da Consolação, 15, em 1910, estando em 1913, no número 205 da mesma rua, enfrentado a concorrência C. Scardigno, que passava a ocupar o número 15; Fratelli Maglino, antes na Avenida Rangel Pestana, 116, estava, em 1913, no número 130; Ricardo Molhenhauer, antes na rua Aurora, 28, em 1913, tinha se transferido para o número

\footnotetext{
${ }^{37}$ Museu Paulista. Almanak Lammert. 1909, p. S-59.
} 
34. Os estúdios, como se vê, eram freqüentemente anunciados em novos endereços, que abrigariam ainda os retratistas recém chegados na capital paulista:

F. Gargi. Rua Conselheiro Nebias, 33.

Na rua Liberdade, 68-A, Carmine Palma

Fratelli Ziccardi, praça Alexandre Herculano, 37.

Gino Ardenghi, rua S. Caetano, 77.

Manoel \& Andrade, Avenida Celso Garcia, 213.

Photographia Alema, rua dos Immigrantes, 131.

Rosato Augusto, rua do Oriente, $105 .{ }^{38}$

G. Ricchiuti anunciado em 1913, na Avenida Rangel Pestana, 144, seria o mesmo anunciado com sociedade de Patoilo \& Ricchinte, Avenida Rangel Pestana, 117? Kossoy apontou essa possibilidade, indiciada também no Almanak Lammert, de 1909. Segundo este autor, Ricchiuti, “foi proprietário de um dos mais tradicionais estabelecimentos fotográficos do bairro do Brás". Tendo retratado freqüentemente os membros da colônia italiana, com “cuidado especial com a iluminação e os cenários de fundo”. (Kossoy. 2002, p.273)

Em 1913, o fotógrafo tido como "bem sucedido" que fazia imagens "de uma nitidez e de uma fidelidade incríveis", Otto Rudolf Quaas, como afirma Kossoy (2002, p.264), passou a anunciar seu atelier na Rua das Palmeiras, 59, estando também em constante mudança de endereços, saindo de bairros mais distantes, até chegar na região de prestígio do Triangulo: saiu da Rua do Gazometro, 20, em 1895; Largo Sete de Setembro, 11, em 1896, para a conceituada Rua de São Bento, primeiro no número 30, depois no número 46, tendo fícado neste endereço entre 1896 a 1901; em 1908, transferiu-se para a Rua Barra Funda, 140, conforme anúncio do Almanak Lammert. Qual seria o vínculo com o fotógrafo anunciado, em 1909 como E. P. Quaas, Rua Barra Funda, 119, tendo, em 1917, realizado uma seqüência de capa na revista A Cigarra?

Em 1915 novos anúncios delineiam a rota que atraia tantos profissionais da fotografia: Frenzel \& Schmidt na rua Aurora, 34; L. Visconti, rua da Consolação, 15; photographia Tucci, na rua da Glória, 9. Em 1916, Guilherme Gaensly, deixava a Rua 15 de Novembro, 28 e passava a ser anunciado na rua Boa Vista, 39, indiciando mais uma vez o cenário de mobilidade dos fotógrafos pela cidade em busca de espaços mais notáveis e próximos das regiões mais centrais.

O fotografo Michelle Rizzo, que anunciava seu estúdio também na Rua Direita, "Photographia Central", inaugurada em 1892, destacava-se como a "primeira fotografia

${ }^{38}$ Museu Paulista. Almanak Lammert. 1913, p. 4542. 
italiana no Brasil”; em 1907, Rizzo atuava na Rua Direita 55. Depois, em 1909, o fotógrafo já se anunciava na Rua Direita 10C, onde manteve seu estúdio até 1912 (kossoy, 2002, p.276). Rizzo com freqüência aparece nos anúncios publicados em jornais e revistas na época. Talvez por disponibilizar de mais recursos.

A instabilidade dos endereços, das associações, rastreia as chances de mobilidade e lucro entre os fotógrafos, em constantes deslocamentos em busca de maior clientela. Muitos tiveram os seus primeiros ateliês montados nos caminhos que levavam aos bairros mais distantes, como Oreste Cilento, com estúdio na Rangel Pestana, 116, em caminhos que levavam ao Brás. O acesso à imagem entre as diferentes camadas da população revela um processo efetivo de democratização da fotografia. Fabris $(2007$, p.57) chama atenção para as "marcas da diferenciação social evidenciadas por uma concepção de qualidade que não era apenas técnica ou artística”. O prestígio do fotógrafo amalgamava-se com a melhor localização.

Tornar a fotografia cada vez mais acessível, prática de todos os fotógrafos em seus anúncios, oferecendo preços melhores e promoções, não encobre, contudo, os esforços de diferenciação social pela localização dos estúdios, aspecto que podia legitimar o trabalho de um fotógrafo.

A localização do estúdio de Pastore era sem dúvida bastante privilegiada. A Rua Direita “principia no Largo da Sé, atravessa as de José Bonifácio, Quintino Bocayuva e S. Bento, e finaliza na Libero Badaró, em frente ao Viaduto do Chá, (centro da cidade)". ${ }^{39}$ Considerada como "rua de la Paix", ${ }^{40}$ a rua Direita ficava próxima das principais vias comerciais centrais, sendo um dos principais lugares de compras e passeio, um "ponto de reunião chic da cidade", 41 "onde se agitava a vida comercial e onde se acotovella uma numerosa população entre cosmopolita e laboriosa". 42

Na Rua Direita e a XV de Novembro, as de maior destaque no Triângulo Central, G. Sarracino, com estúdio no número 20, tinha a frente Valério Vieira, instalado no número 19; adiante, na calçada ímpar, localizava-se a famosa casa de produtos fotográficos Stolze \& Stuck, ocupando a numeração 29 , de onde se observava o número 28, onde atuava Guilherme Gaensly.

\footnotetext{
${ }^{39}$ Almanak Lammert. 1913, p. 4542.

${ }^{40}$ Revista A Cigarra. 25 de fevereiro de 1915.

${ }^{41}$ Revista A Cigarra. 1915. Editorial intitulado Ponto de reunião chic.

${ }^{42}$ Almanak Melillo. 1904, pp. 70-71.
} 


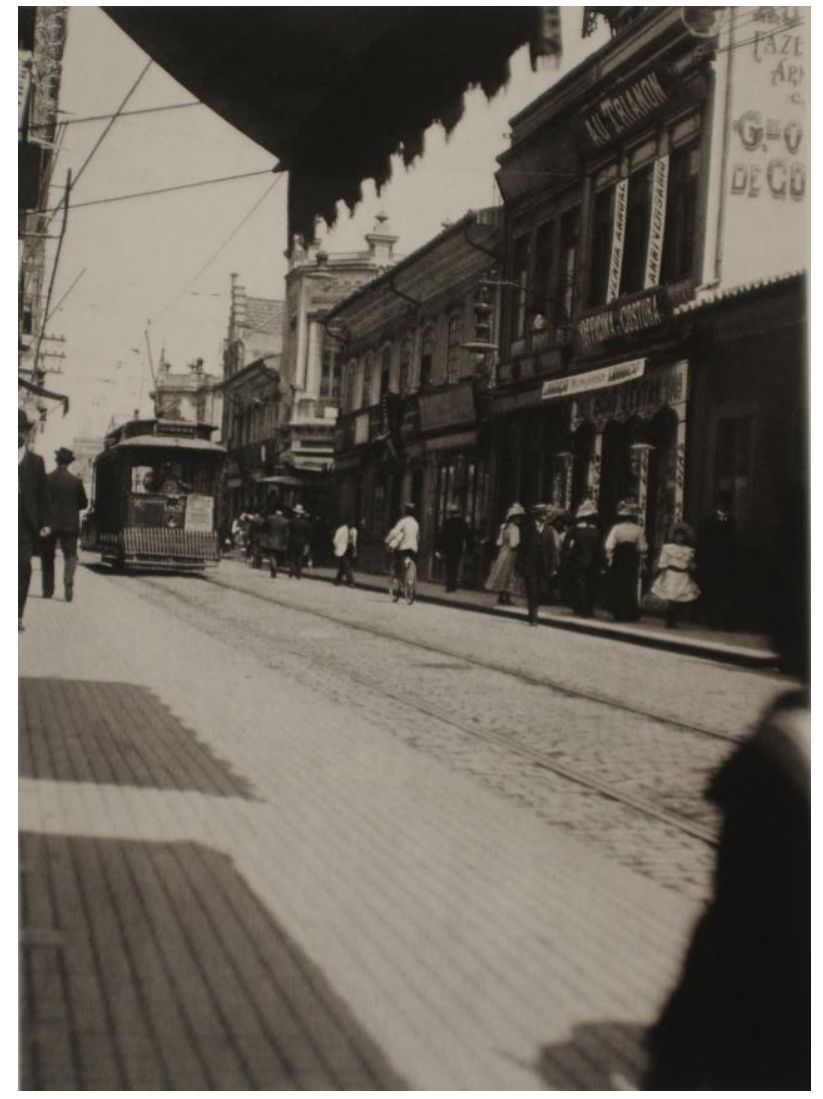

Figura 34: Rua Direita. 1908 CVincenzo Pastore / Instituto Moreira Salles.

Pastore não deixou de retratar a Rua Direita (fig. 34) destacando os mesmos aspectos ressaltados na descrição feita no Almanaque Melillo.

As ruas, principalmente nos arrebaldes novos, são em geral bem alinhadas e largas. O calçamento das ruas centraes, de parallelepipedos bem talhados e assentes, sobre um leito de cascalho e cimento é o que se pode desejar de melhor, não só pela belleza como pela solidez. ${ }^{43}$

A rua que abrigaria o estúdio de Pastore endereçava casas comissárias, comércio de novidades, indo da quinquilharia à moda, que se concentravam nas principais ruas do Triângulo, espaço de uma suposta animação. ${ }^{44} \mathrm{O}$ cosmopolitismo e os outros ideais exaltados nestes endereços estavam respaldados pelas constantes transformações urbanas, pelo rápido crescimento demográfico e pelos novos hábitos sociais. Aos fotógrafos, nacionais e estrangeiros, um campo de possibilidades emergia na urbe cada vez mais populosa, elegante e barulhenta. Cafés, confeitarias, hotéis, lojas de artigos femininos, farmácias, padarias, choperias e restaurantes, estes incomuns no século XIX, eram os novos pontos de atração do

\footnotetext{
${ }^{43}$ Almanak Melillo. 1904, p. 70-71.

${ }^{44}$ Ver o estudo de Deaecto, Marisa Midori. Comércio e vida urbana na cidade de São Paulo (1889-1930). São Paulo: editora Senac. 2002, p.65. Ver também Pinto, Alfredo Moreira. A Cidade de São Paulo em 1900. Coleção Paulística. V. 14, 2a edição. 1979.
} 
centro (Monteleone, 2008, p.87-96), onde muitos seguiam em busca de um espaço para montarem seus estúdios fotográficos, onde tantos outros encenariam uma nova condição social exaltada no retrato.

\subsection{No estúdio dos fotógrafos}

Muitos fotógrafos buscavam ocupar o último pavimento de sobrados, típicos da arquitetura do período, para suprimir a necessidade de tetos ou aberturas laterais envidraçados, essenciais para a entrada de luz natural. Precisavam também dispor de diversos equipamentos investindo em bibelôs, cortinas, mobílias, num ambiente decorado com os ícones do refinamento burguês.

$\mathrm{O}$ ateliê era retroalimentado pelas normas de refinamento da casa, morada da ostentação burguesa, entrevista por meio de uma cultura material definidora de "noções de dignidade, opulência e bom gosto", como indicam Carvalho e Lima (2005). Tudo nesse espaço de interação social estava disponibilizado e à escolha do cliente, interessado pela "boa figura" inventada nos contornos da representação.

A “parafernália artificial” sugerida nas orientações do manual de John Towler, como aponta Mendes (2008), contava com o uso de pássaros empalhados, animais, vasos. Pastore também seguiu padrões antigos de representação, demonstrando o sucesso de códigos antes idealizados. No estúdio de Pastore não faltou o esnobe pavão. Sua filha Costanza relembrou o estúdio da Rua Direita. Os olhos atentos de uma criança eram lentamente revisitados, descortinando uma imensidão de relações preservadas como lembrança:

O estúdio era grande. Tinha toalete feminino e masculino. Tinha um pavão daqueles muito ricos e muito orgulhosos. E uma estatua muito bonita para fotografar as crianças. Ateliê com duas paredes de dois lados de vidro. A luz vinha da esquerda. Tinha o Ateliê e depois tinha um sótão para guardar fotos, peças sem concertos. Entravam no laboratório apenas os mais velhos. Não era muito grande. A mãe dizia que queria ajudar o pai, então aprendeu o quarto escuro. Ela trabalhava sozinha no laboratório. Quando perguntavam se ela tinha medo de ficar sozinha no quarto escura ela respondia: eu nunca estive só, o anjo da guarda esteve sempre comigo. Ficou um ano aprendendo. Ela ficava também com os filhos pequenos. Então papai contratou um retocador italiano para ajudar. Ele ficava o dia inteirinho.Mas não lembra o nome. Com ele papai desabafava a saudade com os italianos. Tinha um lugar no estúdio para guardar os negativos muito bem trabalhados, isso queria dizer muito bem lavados. A torneira ficava aberta para o negativo durar até 
100 anos mamãe dizia. Negativos guardados para poder reproduzir. Peças que eram importadas e ninguém sabia concertar ficavam no sótão. ${ }^{45}$

A mobília do estúdio era toda importada. Costanza contou sobre os muitos fundos, uns oito, enrolados numa máquina. Com o uso de uma manivela fazia-se o ambiente, o fundo descia inteiro. Ao se ouvir a descrição de Costanza chama a atenção o cuidado de Ricardo Mendes em arrancar tais detalhes da entrevistada; sabia ao certo o valor de tais informações para o pesquisador da história da fotografia e para aqueles que tentam entender o circuito social do retrato.

Mas o relato ainda guarda minúcias relembradas com prazer e empenho: "Não me fala, me deixa testar a memória”, afirmava Costanza; Revivia em seu relato o momento em que o pai perguntava aos clientes qual era o ambiente que desejavam ser fotografados, vontades "naturalmente" atendidas. A moça romântica queria ser fotografada num "caramanchão" num jardim, completava Costanza.

Na própria Rua Direita, Pastore enfrentava a acirrada concorrência de fotógrafos estabelecidos há décadas. O fotógrafo Vollsack, com bastante prestígio na imprensa, atuava em São Paulo desde 1880. Não era apenas a boa localização, como vizinho de Pastore no sobrado de numeração 2, que o diferenciava. "Pode-se affirmar que na Europa não se consegue ainda trabalho melhor", afirmava nota publicada na A Província de São Paulo, em 1883. Ou ainda no Diario Mercantil em 1888: "além dos sorvetes, outra coisa tem São Paulo em que leva as lampas à capital do Império: é o estabelecimento fotográfico do Sr. Vollsack, sucessor da firma Henchel \&Cia". Vollsack, esforçava-se em manter seu prestígio: "mandou expressamente pintar em Monfalcone, na Itália, pelo célebre pintor M. Moro, vários fundos para o seu magnífico atelier, e de lá traz também objetos lindíssimos, alguns dos quais completamente novos e desconhecidos entre nós". ${ }^{46}$

\footnotetext{
45 Apesar de Costanza estar em casa apenas nas férias neste período, já que Pastore mandava os filhos mais velhos estudarem na Itália, ela nos deu detalhes antes desconhecidos dos estúdios de propriedade de Pastore. Ver entrevista dada a Ricardo Mendes. Gravação presente no acervo do Centro Cultural São Paulo. Além das fitas cassetes existem ainda transcrições de parte da gravação realizada.

${ }^{46}$ O estúdio de Vollsack foi destruído no incêndio, em 1888, iniciado na Casa do Torrador. Meses depois foi anunciada a reabertura do estúdio após completa reforma. Ver Diário Popular. 13 de novembro de 1888. In: GOULART e MENDES, 2007, p. 174.
} 


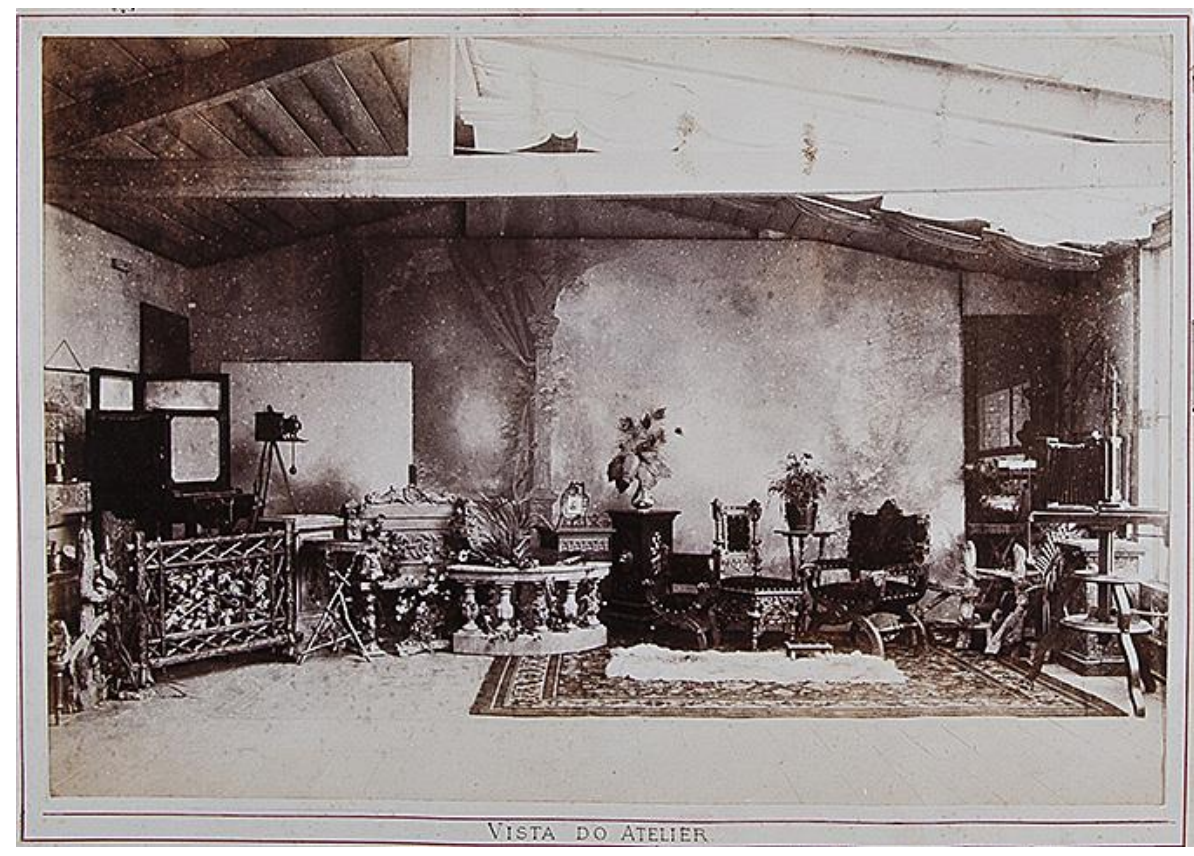

\section{Figura 35:}

Imagem interna do estúdio de Guilherme Gaensly publicado na Revista Industrial e Lindeman, em 1908.

Cortesia Museu Paulista / USP.

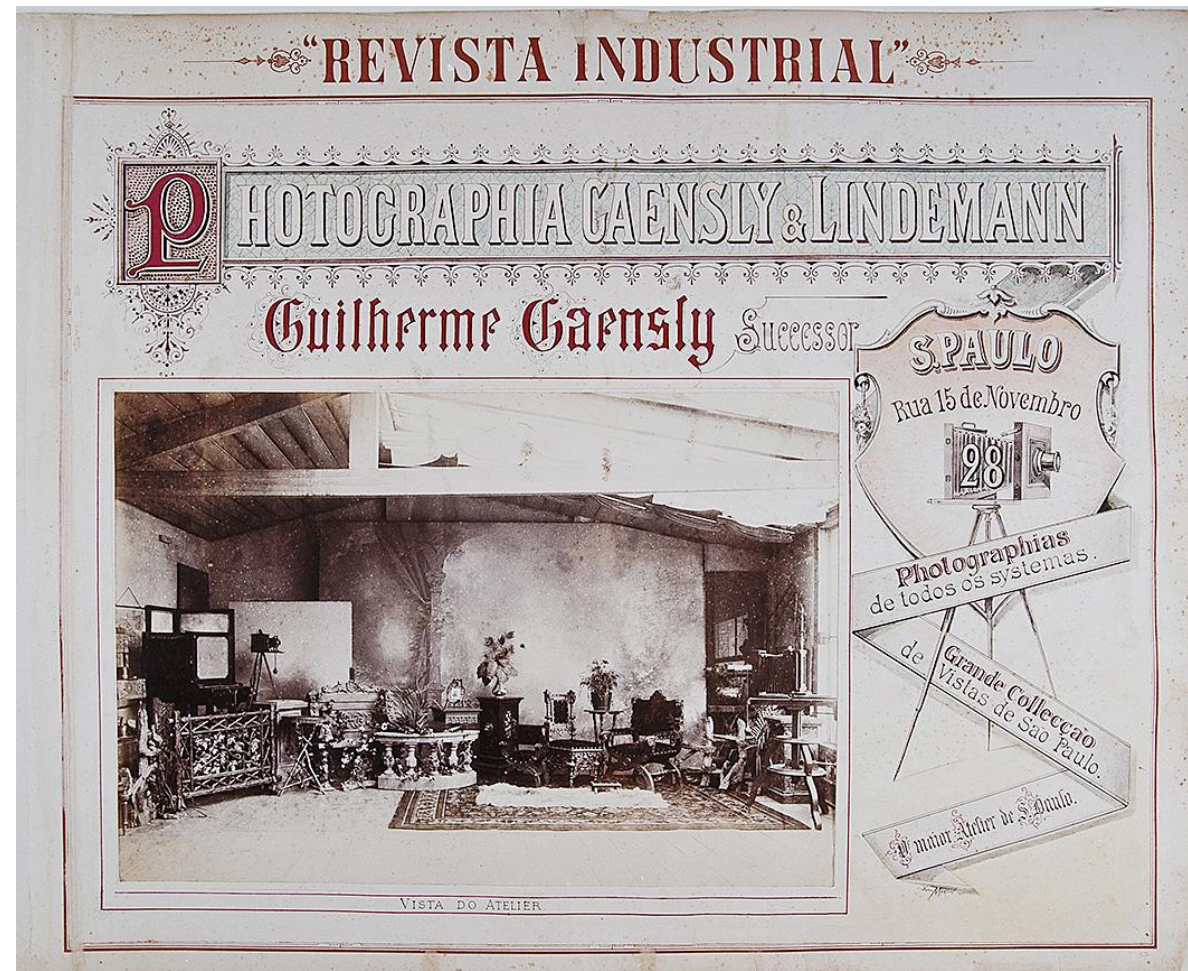

\section{Figura 36:}

Anuncio do estúdio de Guilherme Gaensly publicado na Revista Industrial de São Paulo, em 1900. Cortesia Museu Paulista / USP.

Observar o anúncio do estúdio de Guilherme Gaensly é paradigmático (fig. 36). O dono do "maior atelier de São Paulo", tinha a incumbência de divulgar e dar visibilidade ao empreendimento que mantinha em sociedade com o fotógrafo Lindemann. $\mathrm{O}$ desejo dos clientes era atraído pelo requinte oferecido com uma variedade de objetos, coluna e vasos, um 
amplo fundo, tudo em organizado arranjo de composição para divulgar o bom gosto do atelier. $\mathrm{O}$ teto de vidro cintilava a promessa de boa luz. $\mathrm{O}$ tapete generoso insinuava conforto.

O prestígio ficava por conta de três aspectos de distinção indicados: a localização do estúdio na "Rua 15 de novembro", a realização de "photographias de todos os systemas", a venda de "collecção de vistas de São Paulo". Na retórica da persuasão se contava com a técnica de impressão associando imagem - texto- ilustração num mesmo suporte, sintetizando todo um repertório visual impresso: as cores múltiplas, o branco, marrom, vermelho, o preto, podem indiciar maior investimento no anúncio; o vermelho sobre papel apenas na primeira letra se destacava num fundo colorido emoldurado em quadrado; a fotografia com linhas de moldura separava-se das ilustrações. O desenho da câmera, à direita, marca estilística e formal dos fotógrafos, ainda hoje em uso, trazia em seu corpo o número do estabelecimento. Gaensly contava com esse anúncio que pode ser categorizado seguindo os estudos de Cardoso (2009) como um "impresso efêmero". Tinha apenas um dia, uma semana, com sorte uma quinzena e quiçá um mês, caso o fotógrafo pudesse pagar por tantos dias de anúncios, para lançar a flecha do desejo de consumo, contando com um suporte onde confluem texto e desenho amalgamados com a fotografia.

A fotografia do estúdio de Oreste Cilento (fig. 37), aberto por volta de 1900, mostra também toda a estrutura montada para a realização de retratos. A sala de espera revela, contudo, outra faceta dos estúdios. O cliente ali experimentava a ansiedade de ver uma imagem tão boa quanto aquelas apresentadas nos mostruários exibidos nas vitrines. ${ }^{47}$ Expectativa que rondava a experiência do sujeito colocado em cena.

O estúdio revela-se também como lugar de convencimento. Os clientes que buscavam o retrato ficariam seduzidos primeiro pelos mostruários que eram fixados em vitrines, ou em frente dos estúdios ou ainda nas paredes laterais externas disponíveis nos prédios, como fez Pastore. Neles, imagens em diferentes poses e formatos eram apresentadas. Estratégias que demonstravam o enraizamento de uma mentalidade empresarial. $\mathrm{O}$ cliente podia ali verificar a habilidade, a precisão, a técnica do fotógrafo, enquanto ícones da atmosfera vivida. 


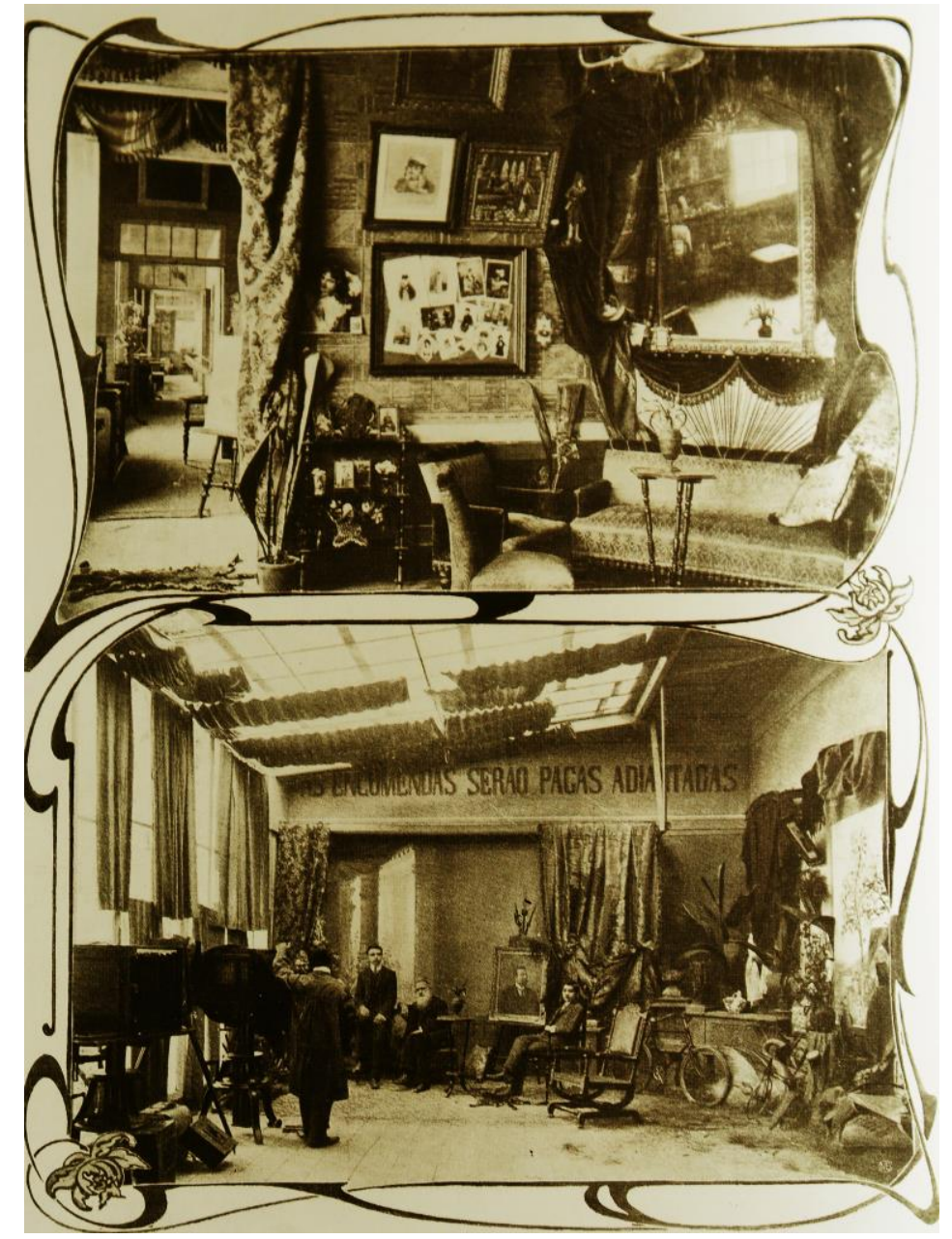

\section{Figura 37:}

Reprodução de foto interna do estúdio e da sala de espero do fotógrafo Oreste Cilento. Avenida Rangel Pestana 116.

Em muitos dos ateliês álbuns eram apresentados aos clientes que procuravam o estabelecimento fotográfico. Era esse o instante inicial do retratado como "protagonista da cena" (Grangeiro. 2000, p.144). As escolhas começavam sendo feitas diante dos mostruários de fotos. Quando levados para o interior do estúdio, podiam conferir os atributos materiais disponíveis para a realização do ideal construído na intimidade de seus desejos. Apesar do estúdio de Oreste Cilento localizar-se distante da região prestigiada do centro da cidade era este "um dos estabelecimentos tradicionais dentre os fotógrafos de origem italiana do princípio do século XX" ${ }^{48}$

A sala de espera dá vista do longo corredor que conduzia ao estúdio. Mobiliário confortável ficava disposto nesse espaço que por certo propunha interações. Paredes e teto envidraçados, valiam-se de vidros opacos e transparentes (Grangeiro. 2000, p.102). O estúdio

\footnotetext{
48 Cilento em 1901 anunciava seu estúdio na Travessa do Braz, 19. A partir de 1906 já estava atuando na Avenida Rangel Pestana, 116. Cf. Kossoy, 2002, p.109.
} 
de Cilento, como se vê, foi construído num andar onde poderia se beneficiar de luz solar o ano todo, assim como fez Pastore, que também conseguia aproveitar a derradeira luz ao fim do dia, apressando-se para não perder os últimos instantes de luz natural, como fez no dia 2 de janeiro de 1918. O retrato de uma senhora reproduzidos no tamanho $24 \times 30 \mathrm{~cm}$, manteve o fotógrafo até às 17 horas em seu estúdio, relatou Elvira, deixando em seu diário fragmentos do cotidiano de trabalho do marido. ${ }^{49}$

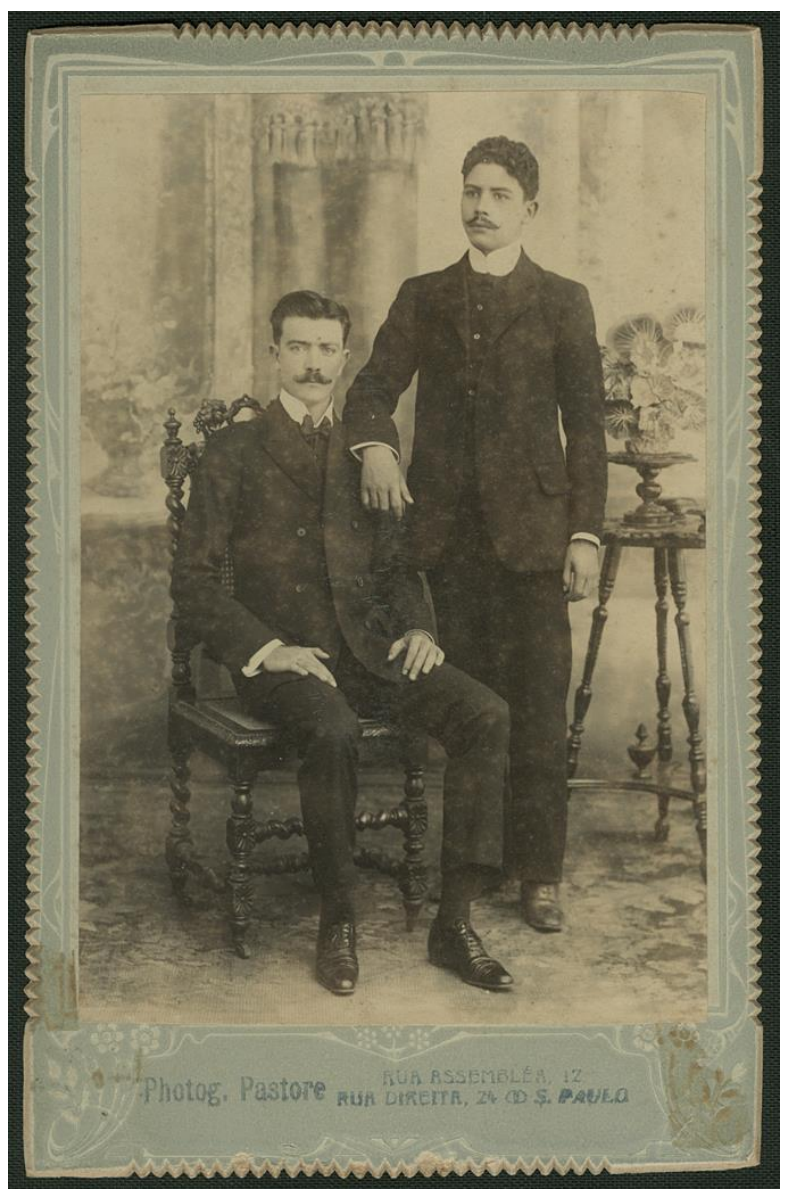

Figura 38:

Homens retratados em estúdio. Sem data ( $)$ Vincenzo Pastore / Museu do Imigrante.

A imagem interna do estúdio de Pastore mostra o investimento em mobílias (fig. 38). Cadeira de madeira e a mesa lateral bastante rebuscadas, pano de fundo com detalhes florais, cortinas, o uso de tapetes e vasos com flores sobre a mesa denotam aspectos da encenação negociada. Inscrevem-se nesse espaço códigos de representação empregados em todo o processo de expansão da fotografia.

A atenção para as mãos de ambos os fotografados, a ausência do riso e o ligeiro cuidado em colocar o homem de pé levemente de perfil, dão vistas de como Pastore seguia um estilo clássico do retrato, atento às normas estabelecidas nos manuais fotográficos produzidos em

\footnotetext{
${ }^{49}$ Coleção Dante Pastore. Relato encontrado no Diário de Elvira escrito em 1918. Tradução nossa.
} 
meados do século XIX. A contenção, o rigor e a austeridade da pose, ícones dos tempos oitocentistas, expressam a força dos códigos, a rigidez da norma, da pose e do gosto típicos do retrato (Beltramim, 2013).

Nota-se o cuidado de Pastore ao fotografar os dois homens de corpo inteiro. Escolha que trazia sempre informações sobre o retratado sendo, no entanto, a mais difícil de ser realizada. Se por um lado promoviam variações de composição, por outro havia o risco de deixar fora de foco rosto, pés ou mãos. ${ }^{50}$ Depois do sucesso da carte-de-visite, assistiu-se ao declínio do retrato de corpo-inteiro, pose como código inspirado nos retratos da pintura à óleo, segundo Carvalho e Lima (2005, p.275). Já havia caído também em desuso o hábito da corrente de relógio de bolso, da sobrecasaca e cartola preta vistos nos retratos masculinos ao longo do século XIX. O homem em pé foi orientado a manter um olhar distanciado, desviando-o da direção do fotógrafo. $\mathrm{O}$ cotovelo apoiado no amigo ou parente talvez tenha sido indicado para evitar uma pose demasiada ereta.

O resultado final do clichê estava investido de um poder, afinal como expressa François Soulages (2012, p.72) "a identidade nasce da ilusão afirmada" por meio de apanágios das elites disponibilizados pelo fotógrafo e cobiçados pelos clientes, interessados por toda a parafernália oferecida: Tapetes, mesas laterais, cadeiras de madeira ou estofadas, panos de fundo reproduzindo a natureza, variados bibelôs, pedras artificiais, estatuetas de bronze e estátuas de mármore, vasos de alabastros, jardineiras, douradas ou de bronze, jarras e outros enfeites de mesa eram objetos apresentados como vitais à cultura do retrato.

Becherini, e seu sócio Stamato, fotógrafos contemporâneos de Pastore, ao anunciarem, em 1907, o ateliê localizado na Rua Marechal Deodoro, 34, fizeram questão de ressaltar o fato de estarem "estabelecidos com um bem montado e confortável atelier".51 Atributos que diferenciavam os fotógrafos.

Ao lado direito da foto desse estúdio (fig.39), vemos uma janela com a cortina fechada. Uma maior intensidade de luz poderia atrapalhar as intenções na composição do retrato, prejudicando seu resultado final. Towler, em 1864, já enfatizava ao orientar as etapas de

\footnotetext{
${ }^{50}$ Cf. Mendes, 2008, p. 103. O autor analisa três manuais publicados e reeditados durante o século XIX pelos seguintes autores: Henry H. Snelling, em 1849; John Towler, em 1864 e Edward M. Estabrooke, em 1872. O primeiro tratando sobre processo de daguerreotipia, o segundo, considerado como "um livro para homens práticos", tratando sobre o processo de colódio úmido, quando se obteve o avanço para o processo negativopositivo, dando à fotografia a possibilidade de reprodutibilidade; e o terceiro destinado a orientação da tecnologia do ferrotipo, criada em 1854: um sistema de positivo direto que resultou, na verdade, na criação de uma nova superfície para a emulsão de colódio. Ver p. 118.

${ }^{51}$ Revista A Vida Moderna. 25 de dezembro de 1907, p.28.
} 
constituição das imagens: "Tão logo a figura ou grupo esteja fixo na posição agradável, cômoda e artística, a próxima etapa importante se apresenta, iluminar esta figura ou grupo de modo a obter uma imagem clara e distinta no despolido da câmera". ${ }^{52}$ A direção do fotógrafo se dava no movimento decisivo de se abrir e fechar cortinas, controlando assim a entrada e saída de luz no estúdio.
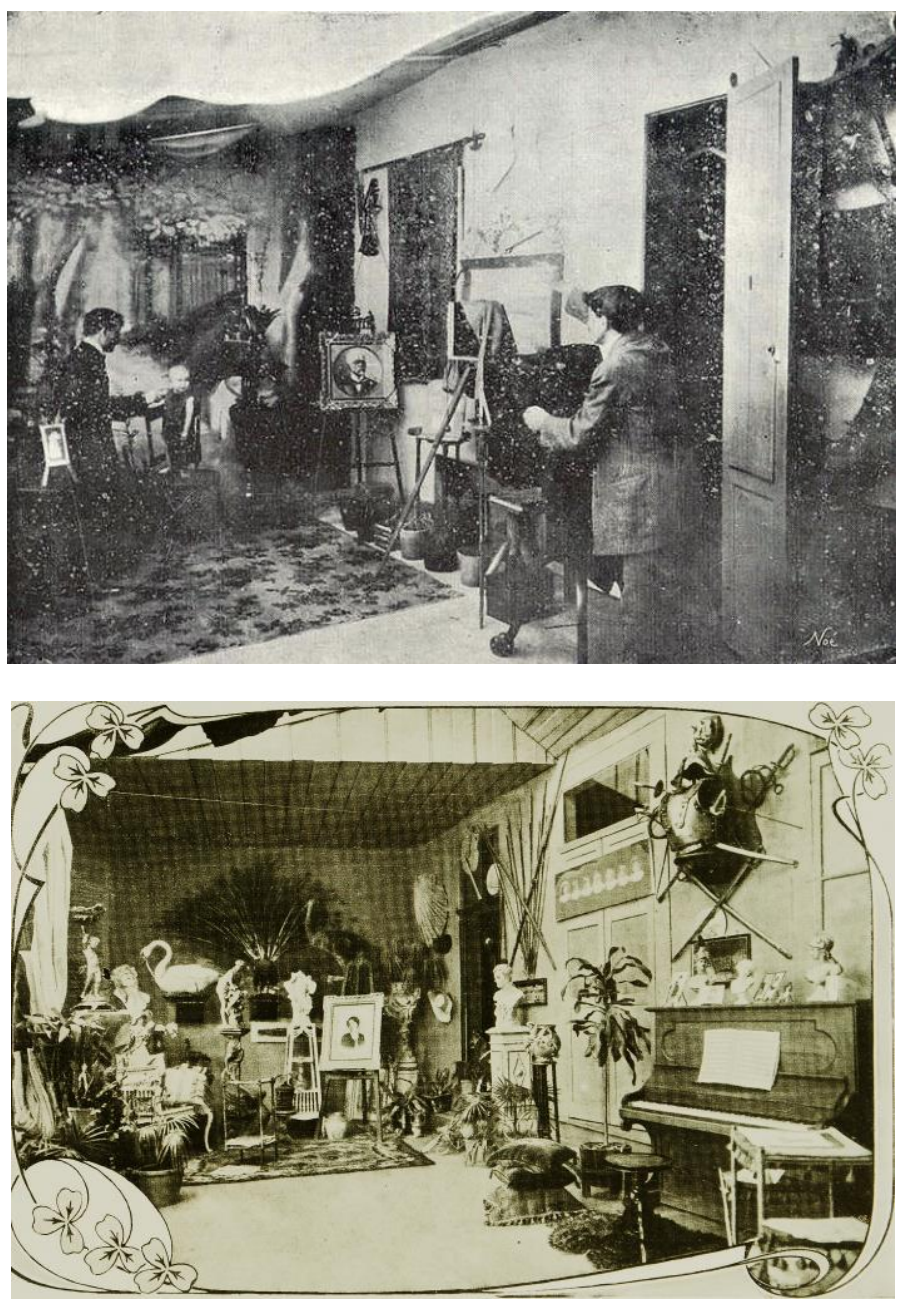

\section{Figura 39:}

Reprodução de foto do estúdio de Becherini\&Stamoto. 1907. Revista A Vida Moderna. O momento escolhido para se retratar o interior do ateliê não foi aleatório. Visavam-se uma especifica clientela quando para a foto de divulgação do estúdio colocaram uma criança em pé em cima de uma cadeira.

\section{Figura 40:}

Reprodução de foto interna do estúdio de G. Sarracino. In: Il Brasile e gli italiani. 1906.

O piano podia também integrar o conjunto de aparatos materiais escolhidos pelo retratado. Na foto do interior do estúdio de Giovanni Sarracino, (fig.40), lá estava ele, rodeado de almofadas, plantas, pequenas esculturas, porta-retratos talvez emoldurando fotografias de pessoas ilustres. Sarracino não economizou nos exageros: cisnes e aves eram oferecidos como opção para a realização dos retratos. Esculturas e estatuetas ajudavam a formar um conjunto de objetos disponíveis para satisfazer desejos, mostrando o controle do homem sobre o mundo dos objetos. A indústria os produzia; o estúdio fomentava a encenação de uma posse material

\footnotetext{
52 Towler Apud Mendes, 2008, p.115.
} 
vislumbrada: "for the consumer this meant not only an abundance of objects available, but a variety of styles and ornamentation that gave to the midle class a new vocabulary of expression based on the language of the upper classes" (Orvell, 1989, p.50).

No estúdio se inventava ou imitava uma realidade fundada na fantasia e na ilusão, como defende Miles Orvell (1989, p.77): "photography is properly understood as an artificial realism in with the images offers the viewer a representation of reality a typification, a conscious simulacrum - though a simulacrum that elicited a willing suspension of disbelief". Nada parecia estranho a essa audiência urbana, como argumenta Orvell. As construções formais e estéticas elaboradas pelos fotógrafos são antes filtradas pela cultura, imagens tecidas por um imaginário que extrapolava as fronteiras do real e da ambientação teatralizada no estúdio, espaço produtor de um "realismo artificial", de um imaginário das quinquilharias, ainda visto nas décadas iniciais do século XX (Orvell, 1989, p.91).

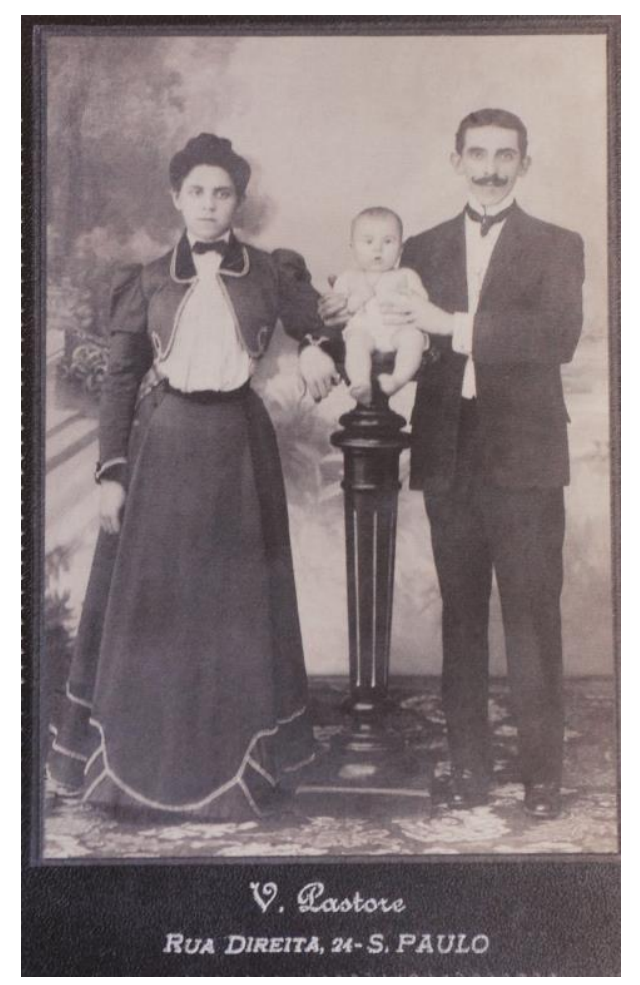

\section{Figuras 41:}

Foto de Bidão, Joana e Tatá realizada no estúdio da Rua Direita. Sem data $\odot$ Vincenzo Pastore.

"O uso dessa parafernália não era aleatório", defende Schapochnik para quem estava em jogo a produção de mensagens em meio a uma contingência ilusória: "A posse de objetos induzia à associação de idéias, e, assim, o livro indicaria o pendor bacharelesco, ilustração ou erudição; o cachorro, a fidelidade; o colar de pérolas, a riqueza; o requinte do mobiliário, a ascensão social; jardins ou flores, a delicadeza, e assim por diante” (1998, p.464). As projeções mentais, emocionais e as expectativas individuais materializavam-se no estúdio do 
fotógrafo, diluindo as fronteiras em relação às experiências vivenciadas do lado de fora, projeções e desejos que os suportes carregavam.

A produção de retratos de início do novo século revela traços de uma cultura que conseguiu promover, por muitas décadas, elementos de representação, se ilusórios por um lado, aceitáveis como autênticos por outro, na tentativa de afirmação individual dos retratados:

Em todos os níveis da sociedade, os indivíduos buscaram uma elevação de status através da compra de bens cuja aparência contava mais do que sua substância. O resultado foi um mundo fictício no qual a coisa falsificada foi orgulhosamente promovida pelo fabricante e facilmente aceita pelo consumidor, como um substituto válido para a autenticidade. (Orvell, 1989, p. 49. Tradução nossa)

Pastore também recorreu ao uso de colunas e pedestais para equilibrar sua composição (fig.41). Balaustrada, colunas e cortinas, típicas nos retratos oitocentistas, apontados nos manuais fotográficos como "equipamentos básicos de um estúdio" segundo Mendes (2008) eram ainda recursos usados nas primeiras décadas do século $\mathrm{XX}$, apesar do desenvolvimento técnico alcançado. Seguiam ainda estranhamente colocadas sob tapetes (Benjamin, 1994), revelando como certos ícones vulgarizados atravessavam as imagens, produzidas em diferentes periodos, fotos que há muito haviam deixado de ser um apanágio de poucos.

Não se vê nessa imagem, a típica composição da mãe levando a criança ao colo. Foi segurada pelo pai, mais confortável na pose quando comparado à mãe, um pouco desajeitada ao tentar apoiar o braço e uma das mãos. Pastore ativou em seu estúdio modelos visuais clássicos produzindo carte-de-visite levadas ao bolso, ou colocadas em álbuns de família. ${ }^{53}$

\footnotetext{
${ }^{53}$ A carte de visite caracteriza uma tomada simultânea normalmente de 8 a 12 clichês numa mesma chapa, (uma média de 6 por $9 \mathrm{~cm}$ ) fixados depois de reproduzidas de forma plana ou destacada (em relevo) em papelcartão ligeiramente maiores, facilitando sua manipulação. O papel-cartão podia variar de qualidade e desenho, eram importados, de formato retangular, gramaturas distintas, podendo o cliente optar entre bordas coloridas, com frisos, com relógios cucos ou molduras desenhadas e eram, assim denominados: imperial, fantasia, vitória e bijou. As imagens eram fixadas, num mesmo negativo, ou seja, placas de vidro sensíveis usadas como negativo por todos os fotógrafos da época. Nessa placa de vidro preparava-se o colódion úmido de forma homogenia, mergulhado num banho de nitrato de prata, formando-se assim o iodo de prata, material sensível à luz, colocado ainda úmido na câmara para a exposição da foto, que deveria ser rapidamente revelada. Esta técnica foi desenvolvida em 1851 por Desdèri, com redução de custos de produção e sua conseqüente popularização. Cf. Grangeiro, 2000. p. 118.
} 


\subsection{Intrigantes aspectos entrevistos no estúdio de Pastore}

Ao contar orgulhosa sobre os móveis distribuídos no ateliê do pai "uns mais bonitos do que o outro", Costanza relembrou a presença de ajudantes no ateliê. Talvez Pastore tenha retratado um deles, responsável por arrastar cadeiras, mesas e muitos objetos de um canto ao outro (fig.42). Teríamos aqui um fotógrafo audacioso tentando explicitar e refutar a perversa idéia de que "o 13 de maio extinguiu a raça”, premissa da qual Elciene Azevedo (2009) veementemente se opõe em seus estudos. Pastore insistia em lembrar e fotografar em seu estúdio a gente desprezada pela elite paulistana, mas que seguia ora atuando em atividades essenciais ao funcionamento e abastecimento da cidade, fato que caracterizava essa parcela da população como os "principais agentes sociais da urbanização", como afirmou Liana Trindade, (2004, p.101), ora atuando no estúdio do fotógrafo, talvez como possíveis ajudantes, de pés descalços, suscitando uma relação ambígua, que sutilmente evocava outros tempos. $^{54}$

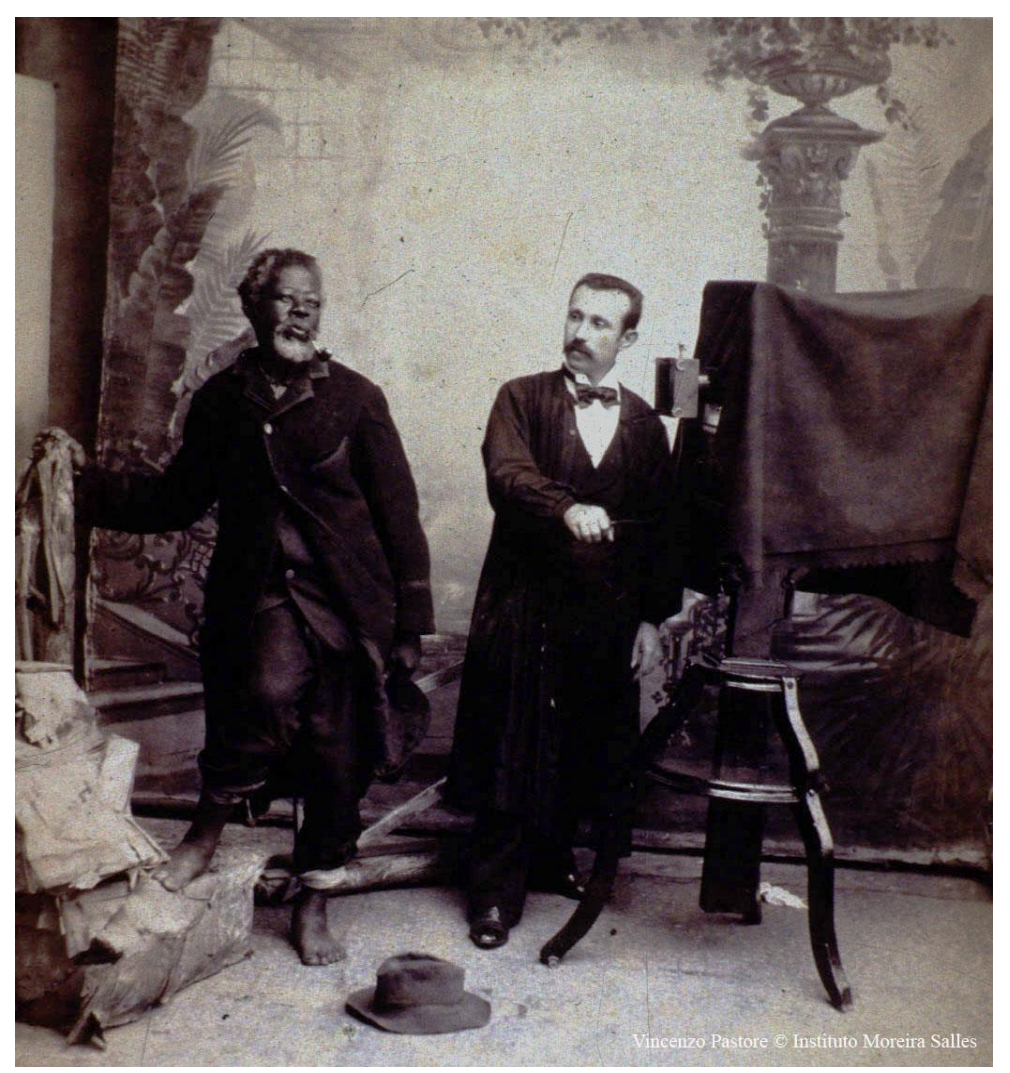

\section{Figura 42:}

Fotografia em papel de Pastore em estúdio com homem negro, talvez um ajudante. Sem data (C) Vincenzo Pastore /IMS.

\footnotetext{
${ }^{54} \mathrm{~A}$ autora investiga a atuação de parte da população negra nos setores administrativos, no comercio fundamental ao consumo interno como atividades fundamentais da emergia da urbanização, tentando demonstrar como a população negra não recaiu totalmente na marginalização, apesar de apontar o quanto ela era comum na vida de muitos deles.
} 
Goulart e Mendes (2007) chamam a atenção para o "signo da informalidade" no anúncio de Carlos Hoenen que solicitava "um moço para desenvolver trabalhos fotográficos". Acreditamos ser preciso destacar e documentar o estúdio em início de século como espaço de sobrevivência possível não apenas para peritos em retocar e pintar fotografias, ou conhecedores de técnicas de laboratório e impressão de imagens. Talvez se indicie aqui a presença de homens que trabalhavam dia-a-dia ao lado do fotógrafo, fazendo o serviço mais pesado, envolvidos no metier do retrato.

É o próprio ato fotográfico que Pastore tentava representar ao colocar-se ao lado da câmera característica dos anos de 1890, com pano preto sobre todo o corpo e obturador de cortina sobre a objetiva. O fotógrafo segura o disparador de borracha e se faz também sujeito da encenação. Fotógrafo e o possível ajudante posicionaram-se em frente de um painel de fundo mal centralizado, num evidente desequilíbrio de composição. Quem é o sujeito da foto? Parece ser essa a busca reflexiva de Pastore. Seria essa a sua provocação? Tem-se uma fotografia não extática, questionadora da experiência da visualidade construída, expondo gestos em interação, além de assumir um valor de documento, reafirmando a presença do negro na cidade. Teria sido este um dos retratos de Pastore feito por sua esposa Elvira? Afinal está foi uma prática corrente relembrada por Costanza, filha do casal.

Outros três registros encontrados no caderno de recortes organizado por Elvira também surpreendem ao revelar outro possível ajudante de Pastore, menos anônimo desta vez (fig.43, 44 e 45). Leôncio turista, orador e fotógrafo foi citado como o "typo paulista", em fotos publicadas numa revista que dedicava a página 6, a "sciencia e arte". O mesmo tapete e o semelhante aramado de madeira, vistos em outros retratos na coleção da família, como verificamos, mostram imagens possivelmente realizadas no ateliê de Pastore.

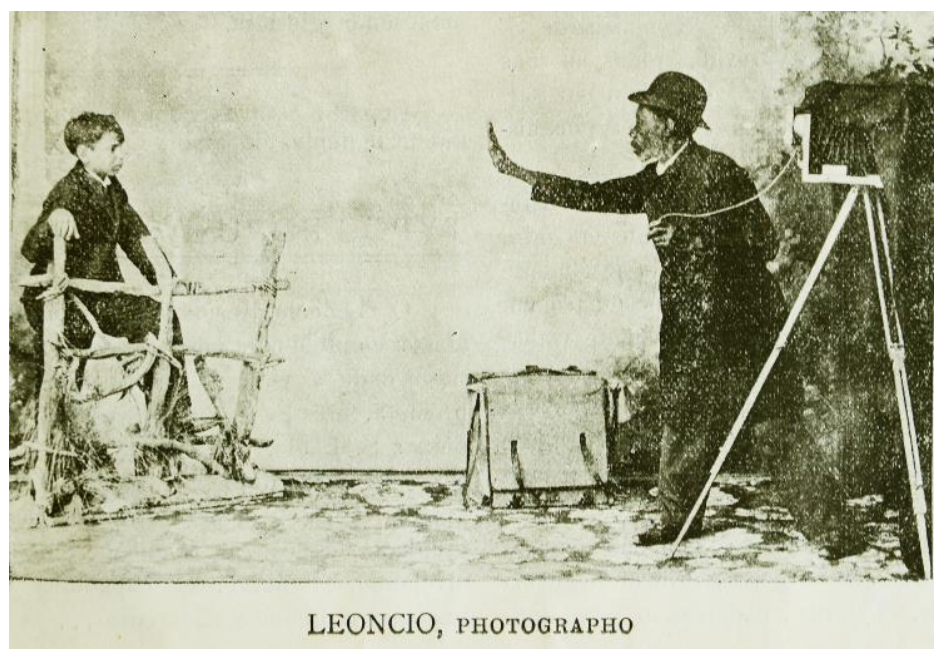

\section{Figura 43}

Leoncio pode ser um ajudante no estúdio de Pastore. Reprodução de fotos que integram o Caderno de Recortes da Coleção Dante Pastore. 

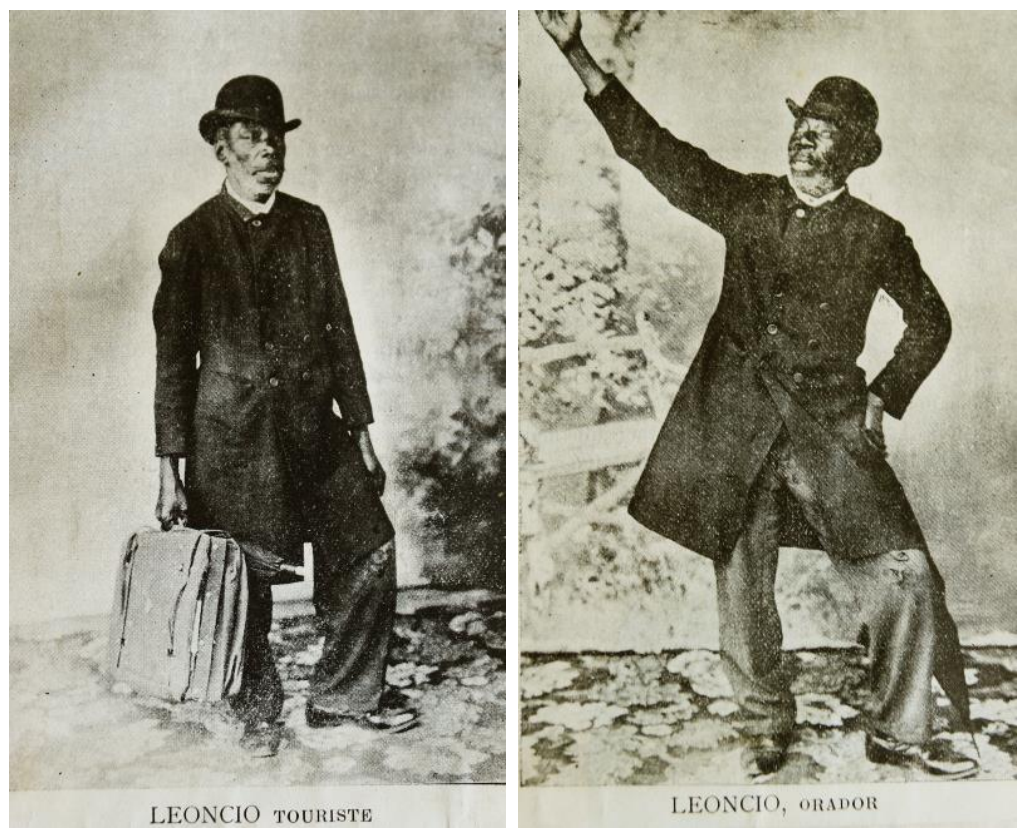

\section{Figuras 44 e 45:}

Leoncio pode ser um ajudante no estúdio de Pastore. Reprodução de fotos que integram o Caderno de Recortes da Coleção Dante Pastore.

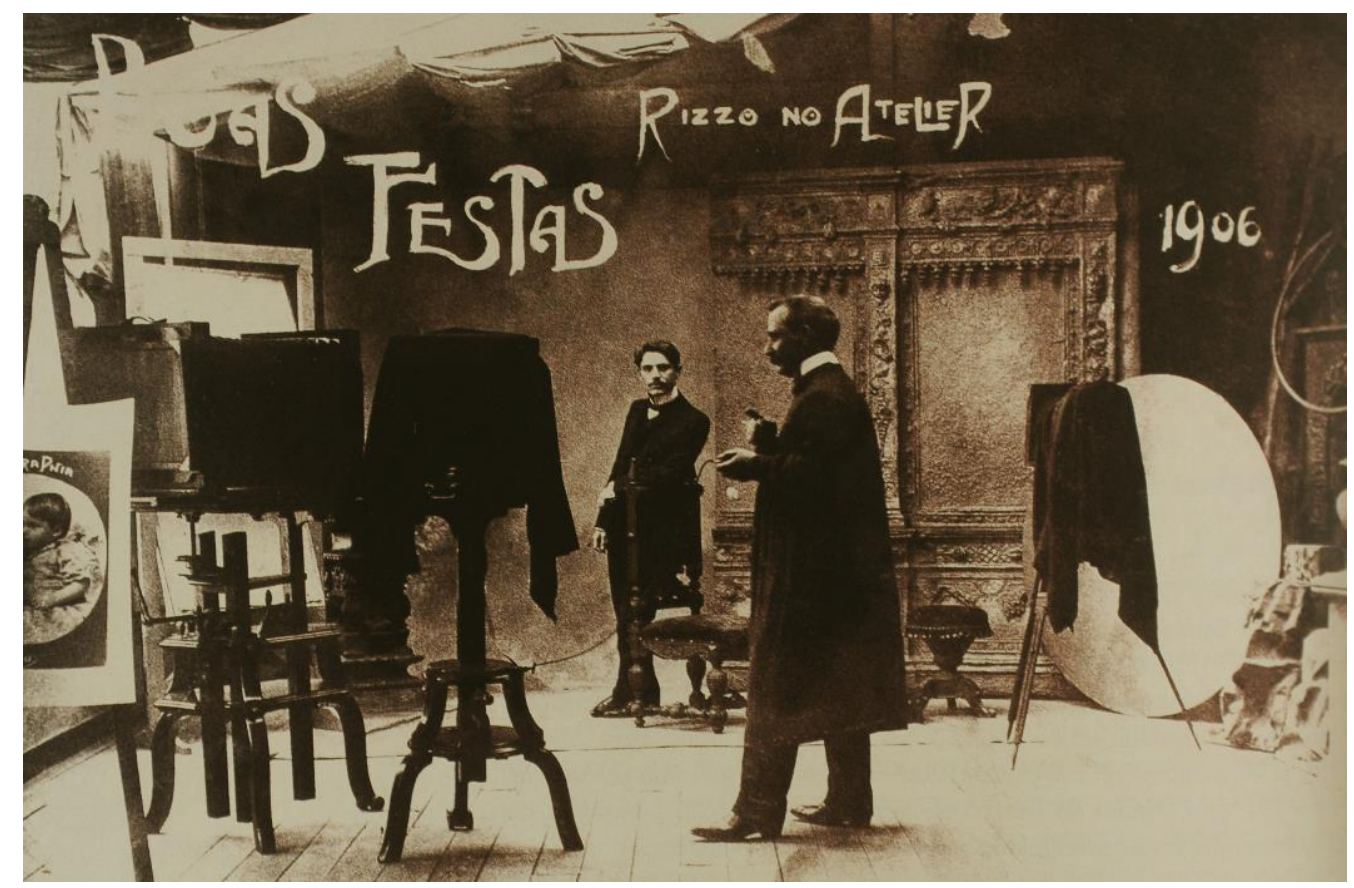

Figura 46:

Reprodução de foto. Cartão Cabinet. Photographia Central de Michelle Rizzo. Sem data. Sem autoria. Coleção Rubens Fernandes Junior.

Os ateliês fotográficos eram também um lugar de interação entre fotógrafos. O cartão de boas festas, possivelmente oferecido como brinde, comemorava a chegada do ano de 1906, onde pudemos ver Pastore interagindo com o fotógrafo calabrês Michelle Rizzo, que já atuava em São Paulo, no ano de 1892 (fig.46). O seu estúdio figurava entre as "Case italiane raccomandate". 55

55 Jornal Fanfulla. 26 de setembro de 1893. In: GOULART e MENDES, 2007, p.189. Tradução: Casas italianas recomendadas. 
Pastore tomou o centro da imagem, levando à mão esquerda o disparador da câmera de grande formato. Retratado de perfil representava mais uma vez o próprio ato de fotografar. Temos aqui a foto como índice das ações dos homens da fotografia, atestando a existência de uma convivência entre os fotógrafos imigrantes residentes em São Paulo. A foto assume, nesse sentido, a sua função primária, porque buscamos a relação com o objeto referencial sondando contatos entre Pastore e Rizzo. Este também exibia imagens em vitrines de estabelecimentos comerciais. Na Casa Bernardino de Abreu, os "bacharelandos do anno findo" fotografados "num trabalho muito nítido e de agradável apparencia feito na Photographia Central do sr. M. Rizzo", tiveram sua foto exibida em setembro de 1893 (Goulart e Mendes, 2007, p.189). Teria ele orientado Pastore a exibir suas fotos em estabelecimentos comerciais nem sempre ligados ao mercado de fotografias?

O estúdio de Rizzo, "primeira fotografia italiana no Brasil”, como ele passou a chamar em 1898, localizava-se na Rua Direita, n.55. Pastore se estabeleceu nessa rua a partir de 1909. A filha de Pastore relembrou da amizade do pai com o fotógrafo Rizzo e da proximidade dos dois estúdios. Aproximação que retrata dois imigrantes da Itália meridional, região de sujeitos sociais que quase sempre, na experiência da imigração, escolhiam as cidades para refazer a vida, dadas as maiores possibilidades de reconstrução das redes de amizade e relações pessoais, retomando contornos do vivido nos antigos burgos populosos do sul de sua península (Alvim. 1986). Fotógrafos que manifestavam interesse pelas maiores cidades, estiveram motivados pela maior demanda por retratos.

O interesse compartilhado pela fotografia e os laços de afeto construídos na experiência da imigração ajudavam a estabelecer laços de solidariedade. Quando Pastore encontrava-se doente no hospital em seus últimos dias de vida, Rizzo esteve ao seu lado para ouvir do amigo:

Ouça colega quando eu tiver morrido, se você souber que meus filhos não seguem o caminho que eu lhes ensinei, pegue-os pelo pescoço e lembre-os que o pai não era assim... eu te peço colega, me prometa! Rizzo chorava, não conseguia responder àquelas palavras. Quem poderia não se comover. ${ }^{56}$

A assinatura de Michele Rizzo foi deixada no livro do obituário do velório de Pastore. Quando Rizzo cedeu seu funcionário Carlos Tornatti para ajudar Elvira no estúdio após a

\footnotetext{
${ }^{56}$ Coleção Dante Pastore. Diário de Elvira escrito em 1918, p. 3177. Tradução Thais Cavalcante.
} 
perda do marido, mostrou sua colaboração com a família do amigo conterrâneo que ainda tentaria sobreviver do retrato. ${ }^{57}$

Nessas redes de sociabilidade construídas pelo fotógrafo encontramos também rivalidades. Se o convívio compensava de um lado, a concorrência pesava no outro. Costanza em entrevista relembrou tensões nas fímbrias das relações entre os fotógrafos.

Papai era sempre convidado a fotografar os novos governadores, presidentes, esse pessoal graúdo, o embaixador, por exemplo, um grande pianista, um artista. O Rizzo era sempre ciumento porque papai era chamado em primeiro lugar, ele não se oferecia, porque gostava do amigo, mas depois, mais tarde, pessoas contavam. Não podiam ser muito amigos, porque eram dois rivais, não é? ${ }^{58}$

O relato de Costanza, deixou vestígios das aproximações do pai com a prática do fotojornalismo que começava a se desenhar de modo ainda bastante inicial. O célebre tenor Enrico Caruso teve seu retrato estampado na capa da Revista A Cigarra, retratado pelo "habil profissional sr. Comendador Vicente Pastore"; 59 O retrato do cônsul italiano no Brasil Pietro Baroli, foi enviado às redações dos jornais; em troca, Pastore esperava ser anunciado, frente a diminuição de espaços disponíveis na seção de classificados, como delineou o estudo de Lima (2008).

O fotógrafo, bem relacionado era rápido em atender a nova clientela que conseguia conquistar.

O conhecido fotógrafo Sr. Vicente Pastore, com seu zelo habitual foi esta manhã para a casa de Dom Duarte Leopoldo, o novo bispo de S. Paulo e obteve permissão para a primeira fotografia do bispo na capital. Fez tudo tão rapidamente que às $12 \mathrm{hs}$ nos trouxe em nossos escritórios a primeira grande fotografia de Monsenhor. Somos gratos ao bom artista pela preferência. ${ }^{60}$

São muitos os vestígios que indiciam o quanto Pastore trabalhava em seu estúdio, mas se inclinava para outras práticas, empregadas por muitos fotógrafos que produziam fotos e depois as enviavam aos jornais, fotos feitas com o intuito de serem publicadas. Na prática de Pastore, vê-se aquilo que era freqüente na atuação de muitos fotógrafos, acostumados a enviar seus registros às redações:

\footnotetext{
${ }^{57}$ Acervo Centro Cultural São Paulo.Tornotti aparece em papéis de carta timbrados como gerente. Manuscritos microfilmados.

58 Divisão de pesquisa Centro Cultural São Paulo. Entrevista com Costanza Pastore. Gravações são acompanhadas de transcrição.

${ }^{59}$ Revista A Cigarra. 28 de setembro de 1917. N.76. Anno IV. Biblioteca Mario de Andrade.

${ }^{60}$ Coleção Dante Pastore. Caderno de recortes. Tradução nossa.
} 
Recebemos do sr. V. Pastore, proprietário do conhecido estabelecimento photographico da rua da Assembleia, 12, uma magnífica fotografia representando os drs. Bernardino de Campos e Jorge Tibiriça à saída do edifico do Congresso, depois da posse deste último no cargo de presidente do Estado. ${ }^{61}$

Há ainda este registro (fig.47) que revela cenas mais obscurecidas do estúdio. Retratos colados em passe-partout ou montados em caixinhas revelam todo um processo de acabamento realizado em outro cômodo do sobrado, mostrando que a prática de trabalho se realizava também fora do espaço de realização da encenação. Máquinas de cortar chapas e prensas podiam dividir o mesmo local destinado ao arquivo das fotos e negativos, guardados para futuras reproduções. Pastore algumas vezes anunciava a guarda de negativos. Seu estúdio era composto por diversos ambientes.

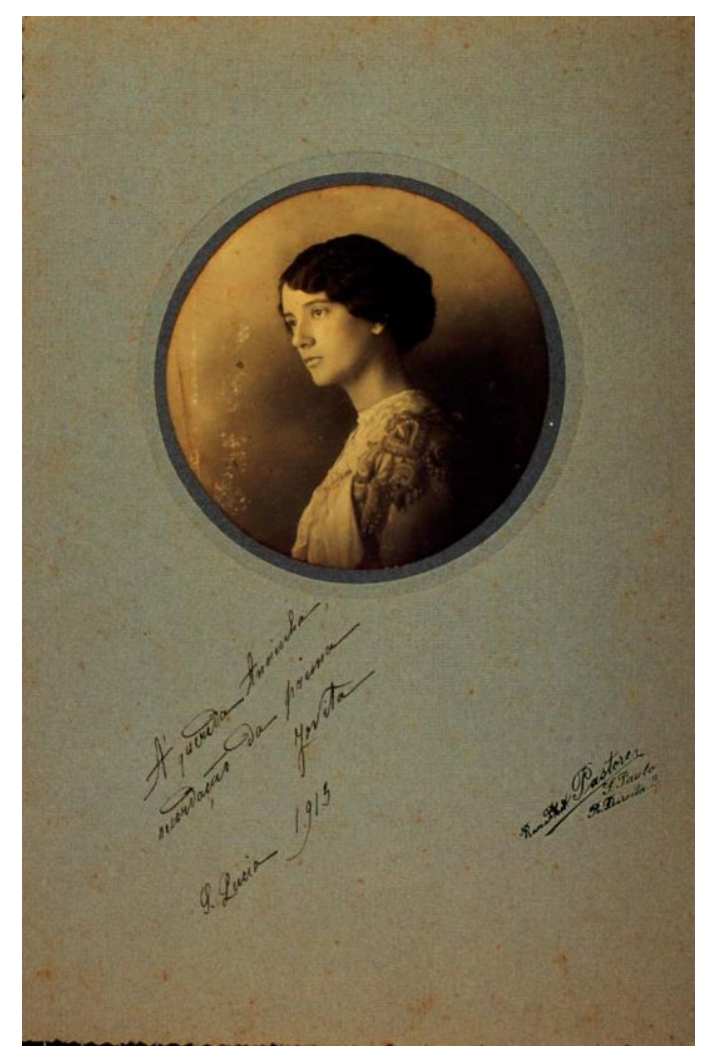

\section{Figuras 47:}

Retrato de Jovita enviado a "querida Aninha". Foto realizada no estúdio localizado na Rua Direita, 24. 1913 (C) Vincenzo Pastore / Cortesia Museu Paulista/USP.

Nessa montagem da foto a cliente optou por um acabamento de maior requinte. O papel cartão de maior espessura traz seu retrato que ganhava contornos sombreados, num interessante jogo de luz criado pelo fotógrafo. Jovita Arruda procurou o estúdio de Pastore na Rua Direita. Sua fotografia, em formato oval, com $10 \mathrm{~cm}$ sem moldura, foi prensada em papel cartão de grande formato medindo $27,5 \mathrm{~cm}$ x $18 \mathrm{~cm}$, o que lhe conferia maior sofisticação. A

${ }^{61}$ Cf. Coleção Dante Pastore. In: Caderno de Recortes. 
circularidade do retrato expressa relações afetivas não restritas ao retratado e ao destinatário, presenteado com a imagem. $\mathrm{O}$ gesto de recordar envolvia terceiros: $\mathrm{O}$ retrato de Jovita foi enviado “à querida Aninha”. O cartão foi assinado, contudo, pela prima T. Lucia, em 1913.

Mas foi com a invenção do retrato mimoso que Vincenzo Pastore tentava assegurar o seu "ganha- pão", sem medir esforços para tal fim. Distribuía "amáveis convites", cerveja e champanhe para aqueles que pudessem anunciar seu estúdio.

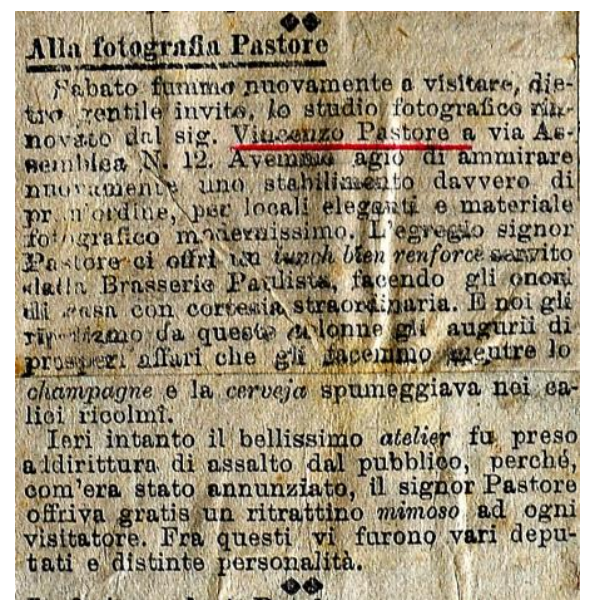

Tivemos tempo livre para novamente admirar o material fotográfico do estabelecimento muito elegante e moderno. $\mathrm{O}$ ilustre Sr. Pastore nos ofereceu um lunch bem reforçado servido na Brasserie Paulista, fazendo as honras da casa com cortesia extraordinário. E nós desejamos um negócio próspero enquanto o champanhe e a Cerveja borbulhavam nos copos cheios. Ontem, entretanto, o estúdio foi tomada pelo público, porque, como foi anunciado o senhor Pastore ofereceu um retratinho mimoso livre em cada visita. Entre eles havia vários deputados e personalidades distintas. (Tradução Nossa.)

Figura 48: Reprodução do caderno de recortes, p. 10.

Coleção Dante Pastore.

\subsection{O modismo dos retratos mimosos}

"Dá de presente aos seus clientes seis photographias (...) em elegantíssimos cartõesinhos ornados, só 4\$500 e por poucos dias", ${ }^{62}$ anunciava Pastore em 1900. Diante de um intenso mercado de circulação de imagens, o fotógrafo criou o retrato mimoso anunciado pela "insignificante soma de $4 \$ 000$ réis", ${ }^{63}$ aparentemente pouco caro para um trabalhador da indústria têxtil que, segundo Lima (2008), ganhava 75\$000 de salário mensal. No entanto, metade desse valor, em 1905, fica comprometido com o aluguel mensal de 35\$000, preço que se pagava por uma casa na Rua da Mooca, como menciona Oliveira (2005, p.57). Os gastos com alimentação, vestuário e outras necessidades cotidianas, deviam exigir contenção ainda maior para ter disponível uma reserva para retratos. Poupança, economia e sacrifício eram

\footnotetext{
62 Jornal O Estado de S. Paulo. Outubro de 1900.

${ }^{63}$ Coleção Dante Pastore. Cadernos de Recortes, p. 17.
} 
exigências para muitos adquirirem a reprodução de suas imagens. ${ }^{64} \mathrm{Um}$ operário especializado trabalharia um dia para pagar a dúzia de retratos em fins do século XIX.

A popularização da carte de visite como já se sabe promoveu "a massificação do retrato". ${ }^{65}$ Em meados do século XIX o custo foi sensivelmente barateado, o tempo de exposição reduzido, ficando entre dois e vinte segundos para retratos pequenos. ${ }^{66}$ Apesar de todo avanço técnico muitos dos consumidores de imagens não conseguiam formar um álbum completo que relatasse a "dinâmica da casa, os pretendentes das filhas, os negócios do pai, as amizades da mãe", ${ }^{67}$ hábito dos grupos mais abastados, acostumados a deixar suas fotos expostas na sala de visitas em álbuns que eram tidos como demonstração de bom gosto, atestando a capacidade de expressão criativa e progresso pessoal dos proprietários. ${ }^{68}$

A comparação de alguns dados mostra como a fotografia não era um produto barato. Para aqueles que podiam contar com certa economia era possível entrar, já na década de 1870 , no estúdio de Militão de Azevedo Marques e adquirir a dúzia de fotografias para presentear parentes e amigos. Segundo Grangeiro "a generalização da posse do retrato é inegável”. Não estava, de modo algum, circunscrita a determinados grupos sociais: "o desejo de posse de um retrato está além da condição social e seu uso está determinado pelos condicionantes impostos pela vida". Desse modo, homens e mulheres pobres, a partir de suas economias, podiam pagar um retrato da família, dos filhos, ou simplesmente posar individualmente perpetuando um rito social antes exclusivo das elites.

Ao analisar preços e consumidores Solange Lima (2008, p.77) traz as seguintes referencias para os carte-de-visite: em 1866, a dúzia de retratos na Photographia Paulistana saia por $8 \$ 000$; Em 1876, na Photographia Americana, pagava-se $5 \$ 000$ a dúzia, "o equivalente a duas camisas para homem ou cinco passagens para a Penha"; Por volta da

\footnotetext{
${ }^{64}$ Os valores de salários e aluguel foram citados em Oliveira, Maria Luiza Ferreira de. Entre a casa e o armazém. Relações sociais e experiência da urbanização. São Paulo, 1850-1900. São Paulo: Alameda. 2005, pp. 35-36.

65 Grangeiro. 2000, p. 51.

66 Para Fabris, o processo de colodio úmido criado como técnica para desenvolvimento mais rápido na realização das imagens era ainda bastante complicado. Todo o processo não poderia durar mais de quinze minutos, contando do antecipado preparo da placa que deveria ser revelada na câmera escura logo após a tomada da fotografia. Ver Fabris, Annateresa (org.) Fotografia. Usos e Funções no século XIX. 2008, p. 16.

${ }^{67}$ Grangeiro. 2000, p. 124. Se fosse ainda difícil pagar pelos serviços de um fotógrafo de estúdio já era possível levar para casa a foto instantânea tirada no Parque da Luz, como vemos a seguir. A máquina-caixote dos fotógrafos lambe-lambes registrava o dia de passeio em praças e jardins embelezados, refletindo uma condição de trabalho marcada pela instabilidade. Oficinas fixas garantiam ao fotógrafo uma maior chance de estabilidade financeira. Ver Grangeiro. 2000, p. 79.

${ }^{68}$ Carvalho, Vânia Carneiro de. As representações da natureza na pintura e na fotografia brasileiras do século XIX. In: Fotografia. Usos e funções no século XIX. São Paulo Edusp, 2008.
} 
década 1880, segundo Oliveira, o aluguel de um quarto na Rua Nova do Hospício, na beira do Rio Tamanduateí, onde as casas térreas, de taipa, quase sempre precisando de reparos e sob o constante risco de inundação, custava de $10 \$ 000$ a 15\$000. Para muitas famílias pobres, moradoras na região da Várzea do Carmo, era preciso economizar a metade do aluguel mensal para pagar a dúzia de retratos. Para muitos, portanto, não era barato adquiri-los.

A propaganda do estúdio de G. Kern\&Co, localizado na rua Direita, 38, oferecia, em 1915, além de atendimento dia e noite, "preços módicos": a dúzia de "retratinhos mignon", custava $\mathrm{R} \$ 2 \$ 000$, prontos em 24 horas. ${ }^{69}$ A comparação com produtos básicos e populares da alimentação ajuda a perceber uma redução com o custo dos retratos nas décadas iniciais do século XX. O custo do tocinho estava tarifado, no ano de 1913, em $1 \$ 500$ o quilo. Um litro de azeite podia ser adquirido por $4 \$ 000 .^{70}$ Levar então a dúzia de retratos não teria um valor muito distante da compra de dois quilos de tocinho aproximadamente, ou de um litro de azeite. A dúzia de retratos poderia ser uma opção frente ao preço do bilhete no Cine Belém indicado por Penteado (2003). Adultos pagavam às segundas preços reduzidos de 1\$200; crianças, $\$ 500$.

Os retratos mimosos circulavam na capital desde 1903. O fotógrafo oferecia um produto de custo menor, visando uma clientela menos abastada, interessada pelas imagens definidas pelo fotógrafo como fotos "comerciais". Eram inclusive anunciadas como um presente amado “que todos já conhecem e estão em moda em São Paulo", como se vê no seguinte anúncio.

A fotografia em formato losangular era prensada em cartões suportes. Alguns traziam desenhos diferenciados. No início da produção, tais suportes eram mais simples, ganhando posteriormente uma configuração que expressaria o gosto pelas formas art nouveau que agradaria cada vez mais uma clientela heterogênea. Os rebuscados cabelos ornamentais usados pelas mulheres reproduziam a moda de virada do século. Mas os retratos mimosos eram também procurados por homens. Em 1906, a escolha do retratado por Pastore (fig.52) foi por um suporte de papel cartão escuro. José de Almeida (fig.53), em 1917, optou por cartão suporte em tom claro, sem nenhum rebuscamento; são esses registros que indicam como Pastore produzia seus retratos mimosos em toda sua permanência na capital paulista.

\footnotetext{
69 Revista A Cigarra. 25 de fevereiro de 1915. Segundo Kossoy, em seu importante livro documentando a trajetória de muitos fotógrafos nos anos de 1833 a 1910, Dicionário Histórico - Fotográfico, fotógrafos e oficio da fotografia no Brasil, vê-se que atuava na corte carioca, em 1866 o fotógrafo Carlos Kern \& C.que teria se anunciado no Jornal do Commercio no dia 11 de junho de 1866, p. 4. Não faz, contudo, referência ao G. Korn anunciado na revista $A$ Cigarra em 1915.

${ }^{70}$ Arquivo do Estado de São Paulo. Jornal A Capital. 07 de junho de 1913.
} 


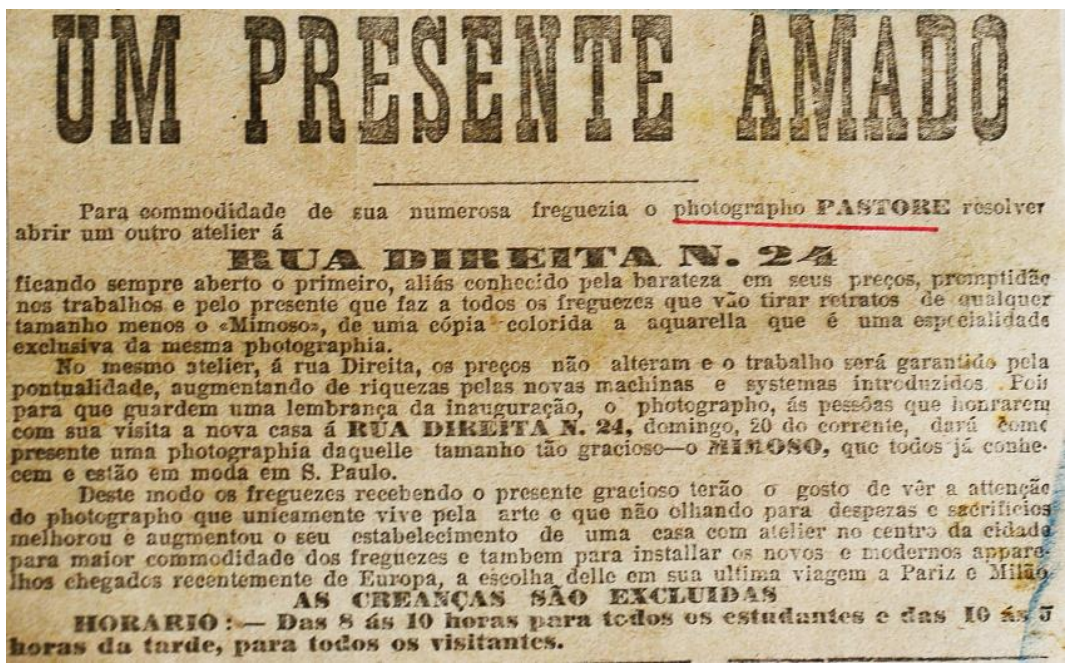

\section{Figura 49:}

Reprodução de recorte do Caderno de Recortes criado por Elvira Leoparde Pastore anunciando o estúdio de Vincenzo Pastore na Rua Direita, 24. O Retrato Mimoso era oferecido como brinde. Coleção Dante Pastore.
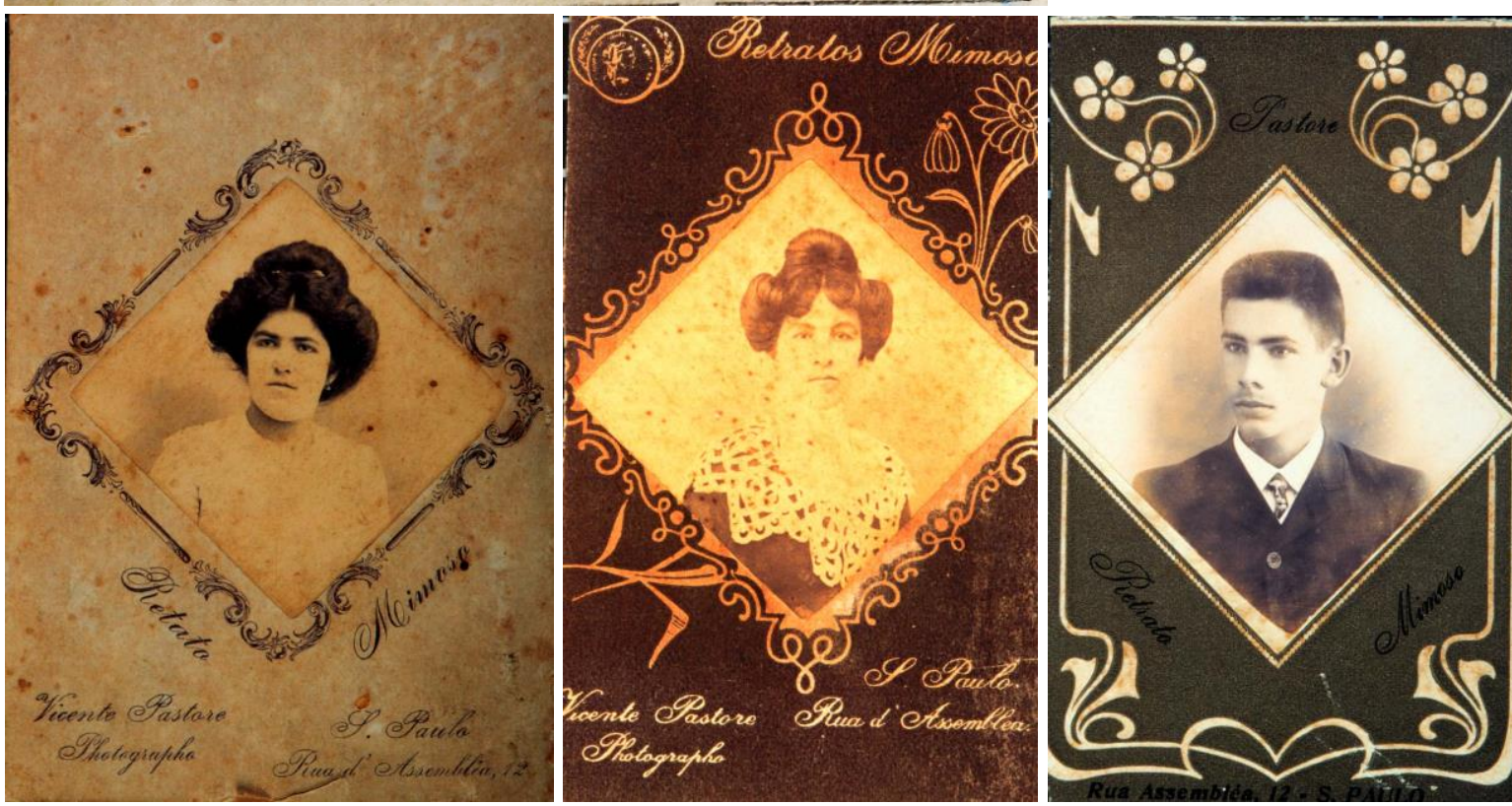

Figuras 50, 51 e 52: À esquerda moldura em Papel cartão. Datada no verso 03/11/1903. Assinada: Mariquinhas. Fotografia que integrava o álbum de Antonio Jacinto Guimarães, doado pela sobrinha Cláudia Guimarães. Ao centro mulher anônima. 1903. Fotografia que integrava o álbum de Aureliana Rocha Marcondes de Moura, tia de Carlos Eugenio Marcondes de Moura que, mantinha-se como "guardião" do álbum desde 1984. Foto à direita, 1906 ( ) Vincenzo Pastore / Cortesia Acervo do Museu Paulista/USP.

A recorrência de um padrão da vestimenta bastante formal se evidencia. Podemos ver nas duas imagens o uso de paletós, camisas e gravata. O retratado em 1917 (fig.53) usava camisa branca, com colarinho padre alto, paletó escuro. O garoto retratado em 1906 (fig.52) usava camisa com colarinho clássico, gravata fina estampada, paletó escuro tendo, abotoamento alto, gola clássica, e lapela em ponta, posando em meio perfil. Prevalecia ainda o uso dos trajes masculinos escuros. 
O retrato mimoso que integrou o álbum da família Almeida, desvela o registro de diferentes gerações em pose diante do fotógrafo. Pastore, retratou o pai, em 1917, guardando as feições que um dia estariam espelhadas no filho, retratado anos depois, em 1937 (fig.54).
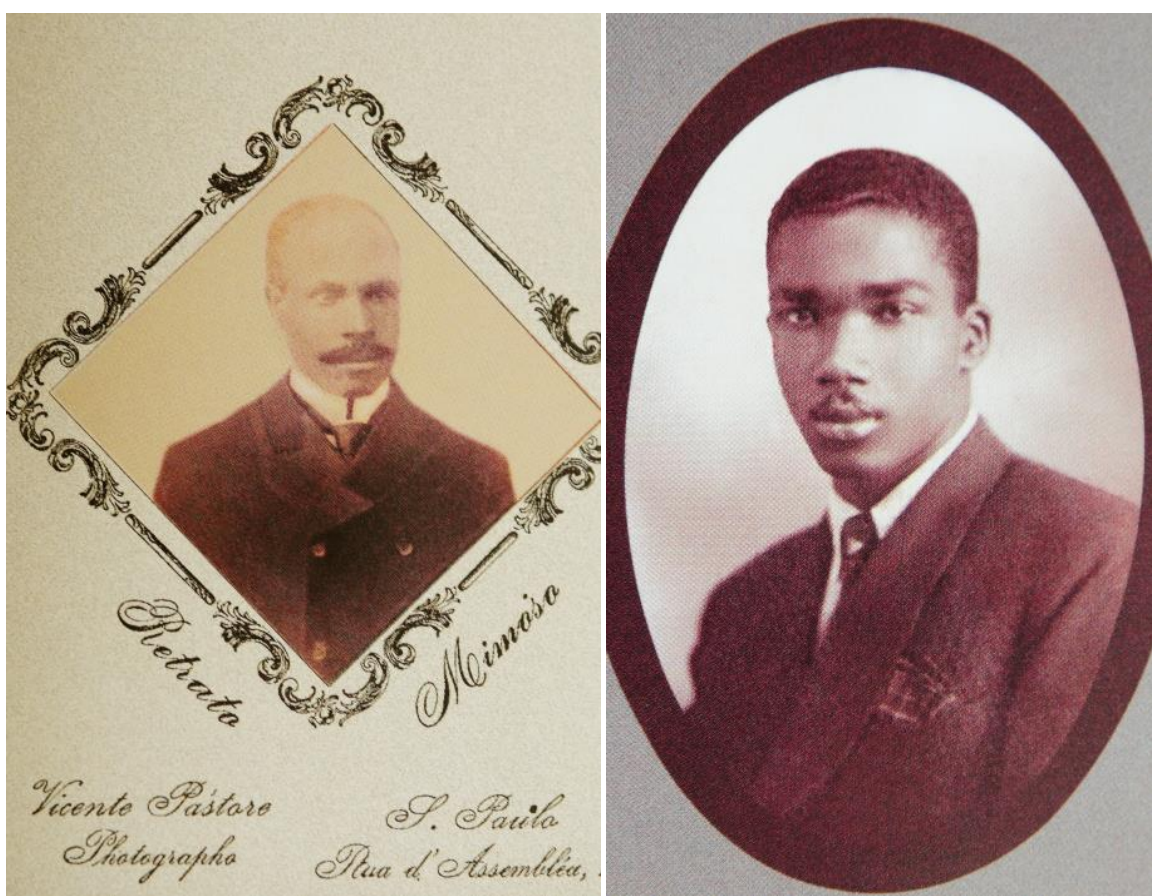

\section{Figuras 53 e 54:}

Foto à esquerda Retrato de José de Ameida. 1917 (C) Vincenzo Pastore; à direita Moacyr retratado em 1937. Sem identificação do fotógrafo. In: Garbin \& Gerodetti. Álbuns de Retratos. Fotografias Brasileiras. 2012.
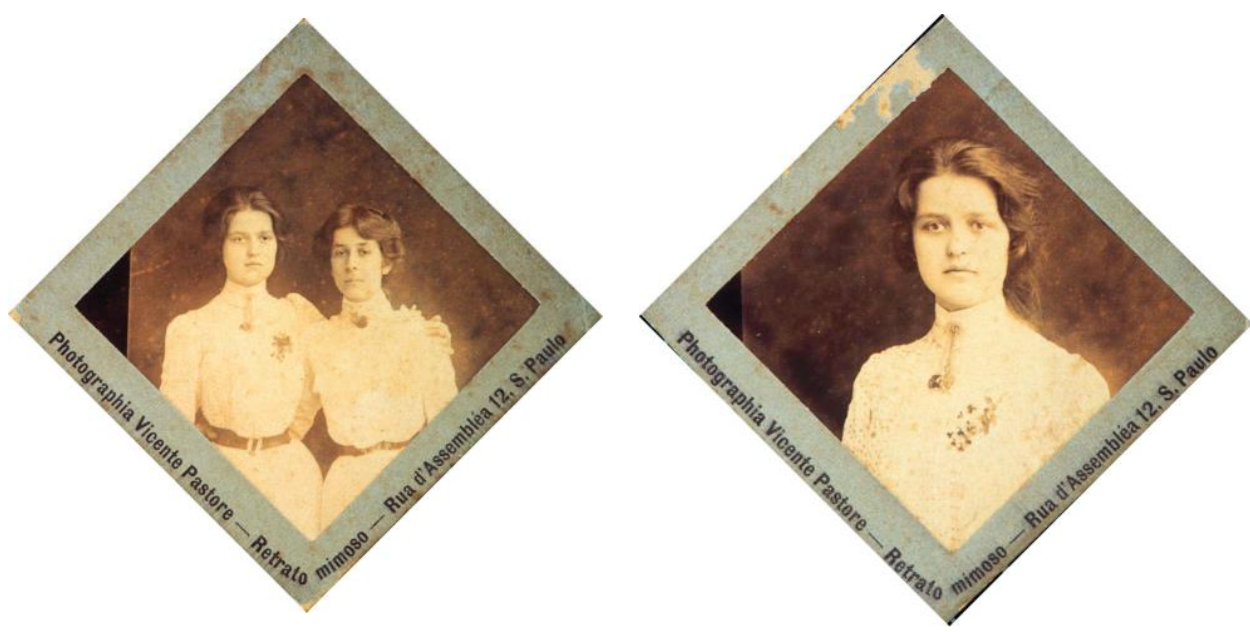

Figuras 55 e 56 :

Retratos Mimosos em formato losangular. Moldura montada em papel cartão. Sem identificação das retratadas. 1910 ○ Vincenzo Pastore. Cortesia Museu Paulista/USP.

No álbum doado ao Museu Paulista em 23 de novembro de $1995,{ }^{71}$ encontram-se duas fotografias de Pastore, em papel albuminado, que talvez demonstrem uma primeira montagem dos retratos mimosos criados pelo fotógrafo experimentando o corte na forma losangular. $\mathrm{O}$

\footnotetext{
${ }^{71}$ Essas imagens integram o álbum de Leônidas e Rosa Amélia Lopes de Oliveira, doado ao Museu Paulista pela neta da família, Miguy Vicente de Azevedo.
} 
suporte onde as fotos foram prensadas apresenta laterais reduzidas, sem ornamentos em art noveau. São registros que denotam a exigência e o cuidado com a aparência nas visitas feitas aos estúdios dos fotógrafos, num evento compartilhado entre familiares, ou reforçando laços entre amigos (fig.55).

O termo representação pode ser empregado porque as fotos evocam a sua função informativa, documental. Denotam como o momento era aproveitado também para a realização do retrato individual. Chama atenção a semelhança da roupa de ambas. Elas escolheram vestidos brancos, obedientes aos padrões da moda, que recomendava o uso da seda, da gabardine, da musselina, do linon, "não perdendo os forros de fidalguia absoluta, o mimoso tafetá"; ${ }^{72}$ nota-se de seus vestidos detalhes em rendas, bordados finos e a vaga marcação da cintura.

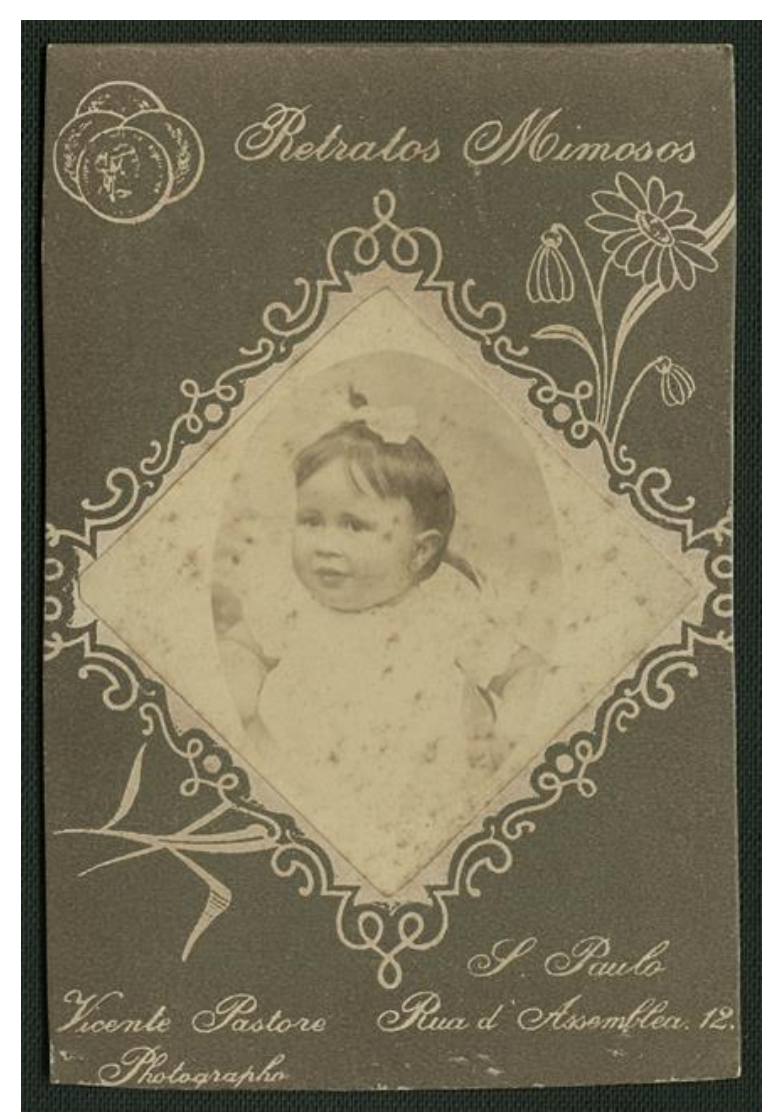

\section{Figura 57:}

Retrato Mimoso de uma criança. Sem data (C) Vincenzo Pastore / Museu do Imigrante.

O anseio pelo novo explica o sucesso dos retratos mimosos. A novidade não vinha, contudo, proposta no retrato em si. A moldura propunha o novo e atendia o desejo de uma clientela com clara empatia aos invólucros ornamentais. Das artes gráficas surgia todo um repertório art nouveau apropriados nos suportes visuais fotográficos, que experimentavam a

\footnotetext{
${ }^{72}$ Revista A Cigarra. 14 de março de 1917. Biblioteca Mario de Andrade.
} 
opção de tratamento gráfico empreendidos em revistas de variedades e atualidades, em cartões postais, depois migrando para álbuns da cidade, que recorriam a molduras, vinhetas, cantos, florões e nervuras como atributos decorativos. A chave aqui é o moderno em construção, como bem delineiam Vania Carvalho e Solange Lima:

Esses atributos ornamentais garantem a necessária familiaridade com os temas tratados ao facilitar a apreensão visual por integrarem um repertório imagético que abarca desde a ornamentação arquitetônica de fachadas, portões e gradis de ferro, papéis de parede e pintura decorativa parietal, até aquela praticada no campo das artes gráficas. ${ }^{73}$

Neste sentido, encontramos Pastore buscando novos elementos de composição investidos no produto oferecido aos clientes, dialogando com a visualidade de seu tempo. Os retratos mimosos atendiam também a uma demanda por registros de crianças. Nesse comemorava-se a vida da pequena que, bem ao centro da imagem, de vestido branco e laço no cabelo, teve a chance de eternizar-se na luta pela memória (fig.57). Fotos avulsas em suportes ornamentados comercializadas por Pastore poderiam compor álbuns, ou serem dadas de presente, deflagrando a importância da criança na família burguesa, e o papel do retrato na vida doméstica. A criação dos filhos e filhas tornava-se central nas décadas iniciais do século $\mathrm{XX}$, onde começava a se delinear um novo ideal de infância. ${ }^{74}$

O espaço da figuração de tais registros estava anteriormente ligado à representação da maternidade tão somente. Crianças eram retratadas ao lado dos pais, no colo das mães e avós, ou ganhando a proteção dos irmãos mais velhos, relata Muaze (2008). Com o desenvolvimento de novas tecnologias as crianças ganharam representações mais individualizadas, tornando-se cada vez mais importantes na representação familiar. Segundo Muaze, os retratos da primeira infância apontam que,

com o passar do tempo, as crianças foram sendo retratadas cada vez mais novas. Até que, nas décadas de 1880 e 1890, tornou-se bastante comum aparecerem individualmente, ainda bebês, com cerca de quatro meses. Tal representação infantil individualizada era impensada nos anos de 1860,

${ }^{73}$ Carvalho e Lima. Vistas Urbanas, doces lembranças. O "antigo" e o "moderno" nos álbuns fotográficos comparativos. In: Pires, Francisco Murari (org.) Antigos e Modernos, diálogos sobre a (escrita da) história. São Paulo: Alameda Ed. 2009, p. 411. Ver também Cardoso, Rafael. O design brasileiro antes do design. Aspectos da história gráfica, 1870-1960. São Paulo: CosacNaify. 2011.

74 O cuidado com a criação tornava-se um elemento novo na cultura definida como ocidental. Eram preocupações ligadas às questões demográficas, a formação de um contingente populacional produtivo, que atuaria nas fábricas, que seria consumidora dos produtos consumidos em larga escala. Crianças que passavam a preocupar médicos, pedagogos, juristas, políticos e governantes. Ver Arend, Silvia Fávero. Trabalho, Escola e Lazer. In: In: Nova História das Mulheres no Brasil. São Paulo: Contexto, 2012, p. 68. 
época em que a idade mínima encontrada foi superior a um ano. Abaixo dessa faixa etária, os bebes eram registrados no colo de suas mães e avós.

(Muaze. 2008, p. 158)

A especificidade de sentidos se dá também pela cultura material, descortiando a feitura de muitas imagens que promoviam redes de sociabilidades, empolgavam as conversas na sala de visitas, com muitas mães ansiosas em mostrar uma as outras a nova fotografia adquirida dos filhos pequenos.

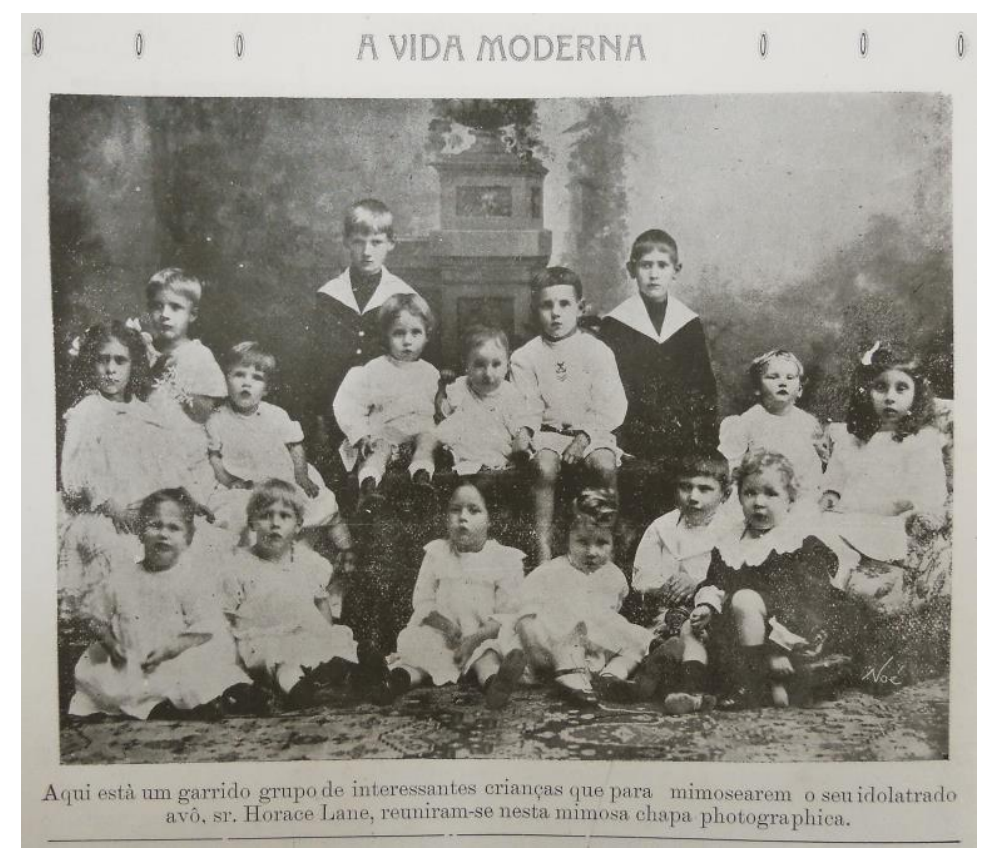

\section{Figura 58:}

Reprodução da Revista A Vida Moderna. 25 de dezembro de 1907. Acervo da Biblioteca Mario de Andrade.

A invenção de Pastore lançou tais imagens em novas experiências comunicáveis, disseminadas pelo uso de uma nova adjetivação. A foto era um objeto "para mimosear" e reafirmar relações afetivas (fig.58). A legenda deste outro retrato (fig.59) sugere uma apropriação da criação de Pastore. O fotógrafo de Santos, H. Eckmann, "retratista de talento", ${ }^{75}$ recorreu à mesma estratégia de Pastore nomeando seus retratos também de mimosos. Expressão de como o novo código verbal foi criado a partir do visual colocado em circulação, depois apreendido e difundido socialmente com claras ambições comerciais.

\footnotetext{
75 O fotografo Eckmann, nascido em Hamburgo, chegou ao Brasil na década de 1880. Atuou primeiro no Rio de Janeiro, dirigindo-se depois para a cidade de Santos, onde realizou cartões postais com vistas da cidade, chegando a ser premiado na Exposição Nacional de 1908. Ver Kossoy. Dicionário Histórico-Fotográfico Brasileiro. São Paulo: IMS, 2002, p.126.
} 


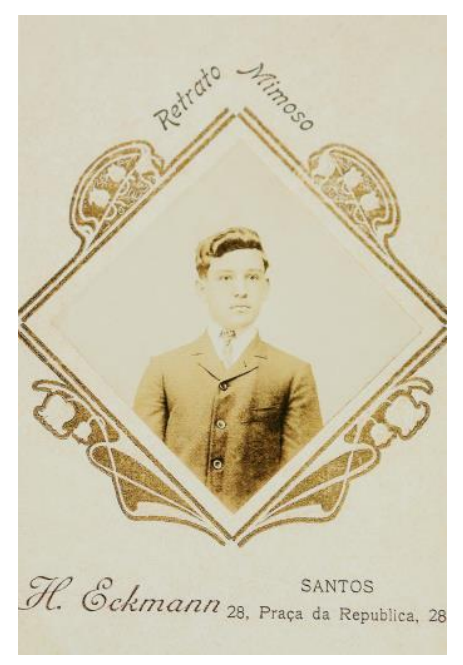

\section{Figura 59:}

Foto s/d @ H. Eckmann, Santos. In: Garbin \& Gerodetti. Álbuns de Retratos. Fotografias Brasileiras. 2012.
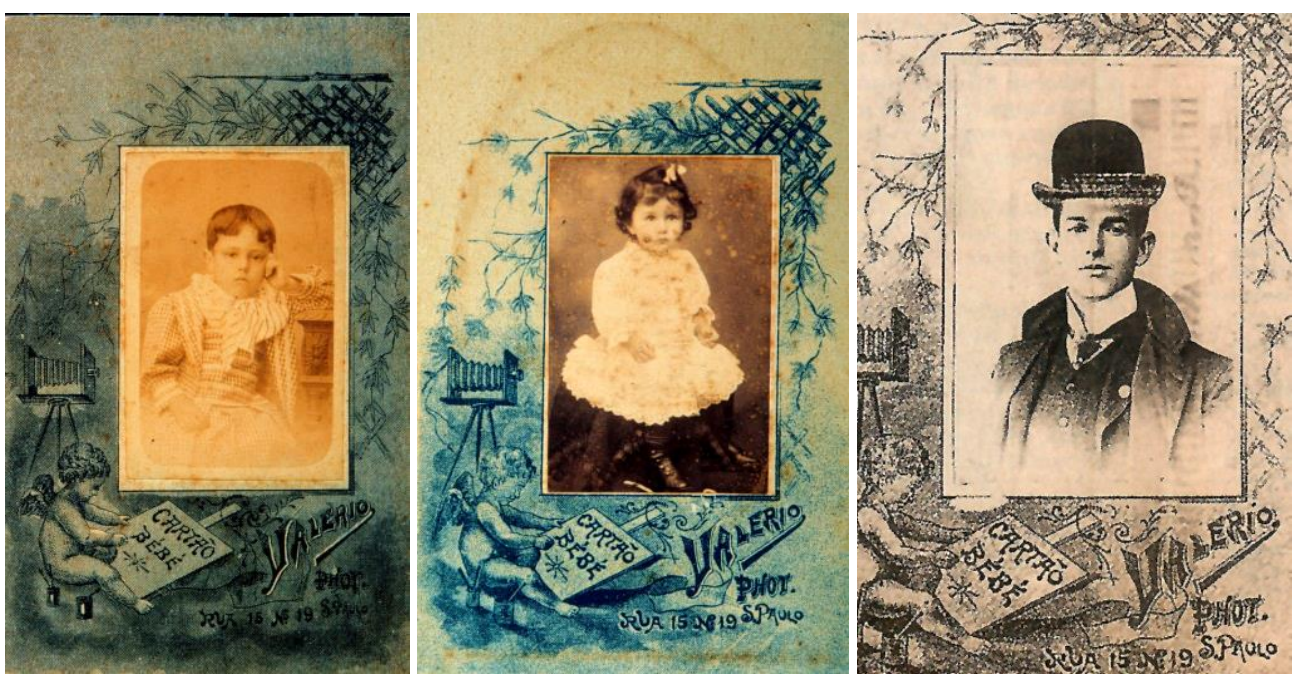

\section{Figuras 60,61 e}

62: à esquerda $\mathrm{e}$ ao centro Estúdio Rua Quinze de Novembro, n. 19. 1905 () Valério Vieira Ambas Cortesia Acervo Museu Paulista/USP. À Direita, cartão bebê disponível na Internet.
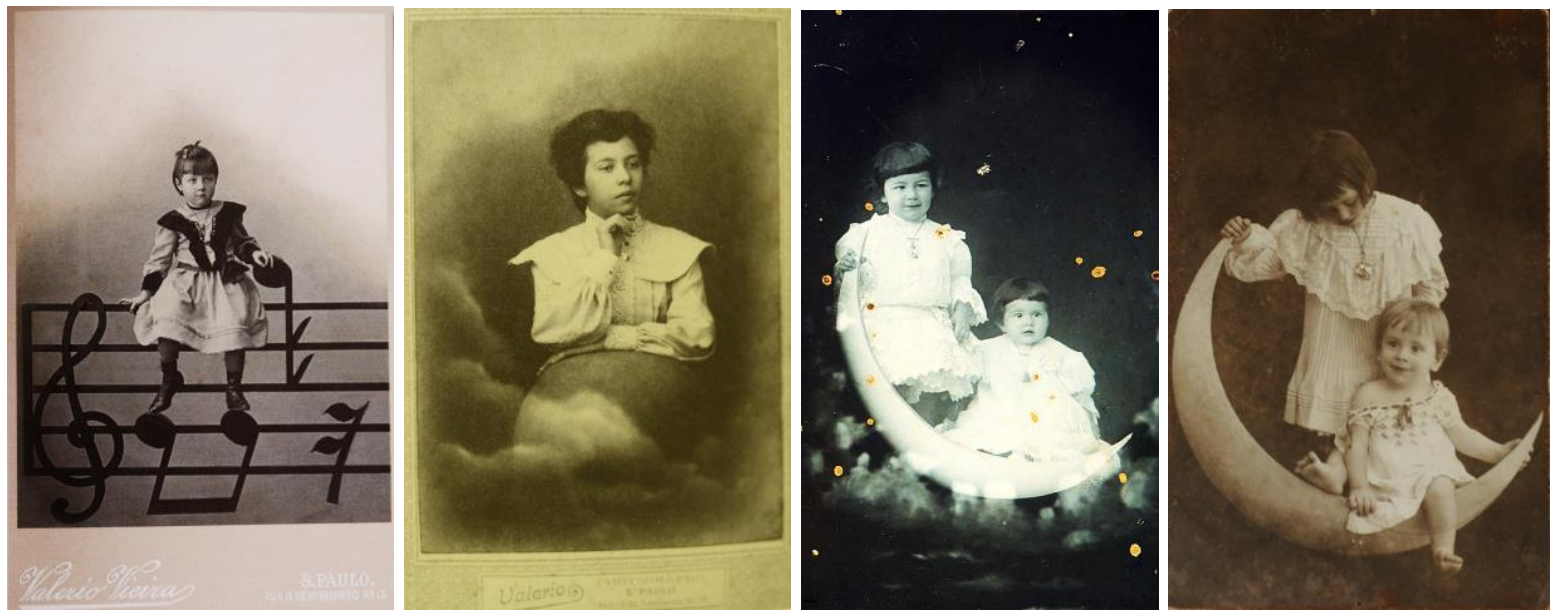

Figuras 63, 64, 65 e 66: As duas primeiras fotos são do fotógrafo Valério Vieira. A fig 63 In: Garbin \& Gerodetti. Álbuns de Retratos. Fotografias Brasileiras. 2012; a fig. 64 In: Kossoy. Dicionário HistóricoFotográfico Brasileiro. São Paulo: IMS, 2002. A terceira foto José Vollsack. 1900. Cortesia Acervo Museu Paulista/USP. A última foto à direita retrato de Costanza e Francesco Pastore, filhos do fotógrafo. S/d (CVincenzo Pastore / Coleção Costanza Pastore / Cortesia Mosteiro São Bento. 
Outro fotógrafo atento à nova linguagem promovida pelo retrato foi Valério Vieira, dono de um estúdio freqüentado pela elite paulistana. Foi ele o inventor de uma variação de carte-de-visite, o chamado cartão bebê. ${ }^{76}$ A cultura do retrato mais uma vez recebia a contribuição do dinamismo da língua, sempre viva, criadora de sentidos socialmente compartilhados em termos lingüísticos, mas como se vê, indeléveis à cultura material.

Valério Vieira, figura popular entre os paulistanos, segundo Kossoy, esteve sempre interessado na inseparável relação entre realidade e ficção, eminentes no retrato. $\mathrm{O}$ cliente podia escolher se queria ver a criança retratada nos populares cartões bebê, ou nas fotomontagens, expressões da criatividade do fotógrafo. ${ }^{77}$ Podiam ora se acomodar em notas musicais ou fazer da lua apoio para o braço, apoio para sentarem, composição também escolhida pelo fotógrafo austríaco José Vollsack, assim como pelo italiano Vincenzo Pastore. $^{78}$

\footnotetext{
${ }^{76}$ Este fotógrafo nascido no Rio de Janeiro, em Agra dos Reis, em 1862, foi aluno ouvinte da Academia Imperial de Belas Artes. Trabalhou com um dos fotógrafos mais conceituados da região, inventor do flash, antes chamado de "Relâmpago Guimarães" apresentado na Exposição de Paris, em 1900, demonstrando assim a falsa concepção de um centro (europeu e norte americano) produtor de inovações, e uma periferia consumidora e passiva. Insley Pacheco foi um dos grandes fotógrafos da corte carioca, dono de um estúdio que oferecia variadas técnicas como daguerreótipos, fotos sobre papel, vidro e marfim, além de retratos a óleo e fotopintura. Valério Vieira, segundo Balady, "dominava diferentes variantes do processo fotográfico como platinotipia, fotopastel, bromocromia, técnicas a carvão, fotomontagens, entre outras variantes". Alem disso equipamentos modernos com tecnologia avançada, sendo, inclusive, inventor de acessórios, como o "degradador Valério". Ver Balady. Sonia Umburanas. Valério Vieira: um dos pioneiros da experimentação fotográfica no Brasil. Dissertação de mestrado do Programa de Pós-graduação Interunidades em Estética e História da Arte - USP. 2012, p. 40-49.

${ }^{77}$ Muitas opções foram anunciadas pelo fotógrafo Valério Vieira: cartões art Nouveau, Phototypia, Aquarellas, Pastel, Pleo, Carvão, Miniaturas (em cartão, porcelana e marfim), alto relevo, geminatura, uma técnica de gravação de retratos sobre cristal de espelho. ${ }^{77}$ Tamanha variedade deve ajudar a explicar o sucesso de Valério que afirmou ter ganho muito dinheiro, sem nenhum arrependimento em tê-lo gastado. Ver Balady. Sonia Umburanas. Valério Vieira: um dos pioneiros da experimentação fotográfica no Brasil. Dissertação de mestrado do Programa de Pós-graduação Interunidades em Estética e História da Arte - USP. 2012. Segundo a autora Valério recebeu importantes títulos: condecorado como comendador pela cobertura da visita do rei Carlos de Portugal ao Brasil; recebeu o título de Cavagliere della Corona do rei da Itália por uma propaganda em prol da imigração na Exposição Turim. Sua primeira foto panorâmica foi apresentada em 1905, na Exposição do salão Progredior.

78 José Vollsack, fotógrafo de origem austríaca também colocou meninas na lua, experimentando a fotomontagem prensada em cartão cabinet. Atuou em são Paulo entre os anos de 1880 a 1912. Foi, com certeza, outro fotógrafo de sucesso tendo sido gerente e sucessor da filial paulistana da famosa Photographia Allemã, com sede no Rio de Janeiro. O ativo e o passivo da empresa, após 1887, passaram a pertencer à Vollsack, após a morte do fotógrafo Henschell, dono do estabelecimento. Ver Kossoy. Dicionário HistóricoFotográfico Brasileiro. São Paulo: IMS, 2002, p. 325. A viúva de Henschel transferiu a escritura pública para Vollsack. Logo depois o fotógrafo já se anunciava como "photographo da Casa Henschel, por espaço de sete annos e photographo gerente da casa que hoje passa a ser sua". (Correio Paulistano. 12 de fevereiro de 1887, p.3).
} 
Imagens lúdicas e fantasiosas atendiam ao gosto da clientela da época, rastreando práticas comuns de interferências dos fotógrafos na constituição final das imagens. Portanto não é novo o interesse em manipular e participar de forma ativa na invenção do processo fotográfico constituído. Costanza, filha de Pastore delicadamente comentou: "repare como ele era artístico mandou fazer a lua, mas esqueceu das estrelas, ai que pena". ${ }^{79}$

A mesma encenação realizada nos diferentes estúdios indicia uma mesma sensibilidade socialmente compartilhada no circuito do retrato, ideia central para os estudos da cultura visual, que não pode ser entendida como uma concepção abstrata, mas como uma prática envolvendo um amplo campo de intenções e interações sociais mediadas por imagens, submetidas a uma demanda e às novas expectativas sociais e torno do retrato, materialidade que envolve modos de ser, de pensar, consciente ou não. Os fotógrafos, envolvidos nessa trama visual, estavam atentos a este mercado consumidor que individualizava a representação dos membros da família, sedimentando ali seus fetiches.
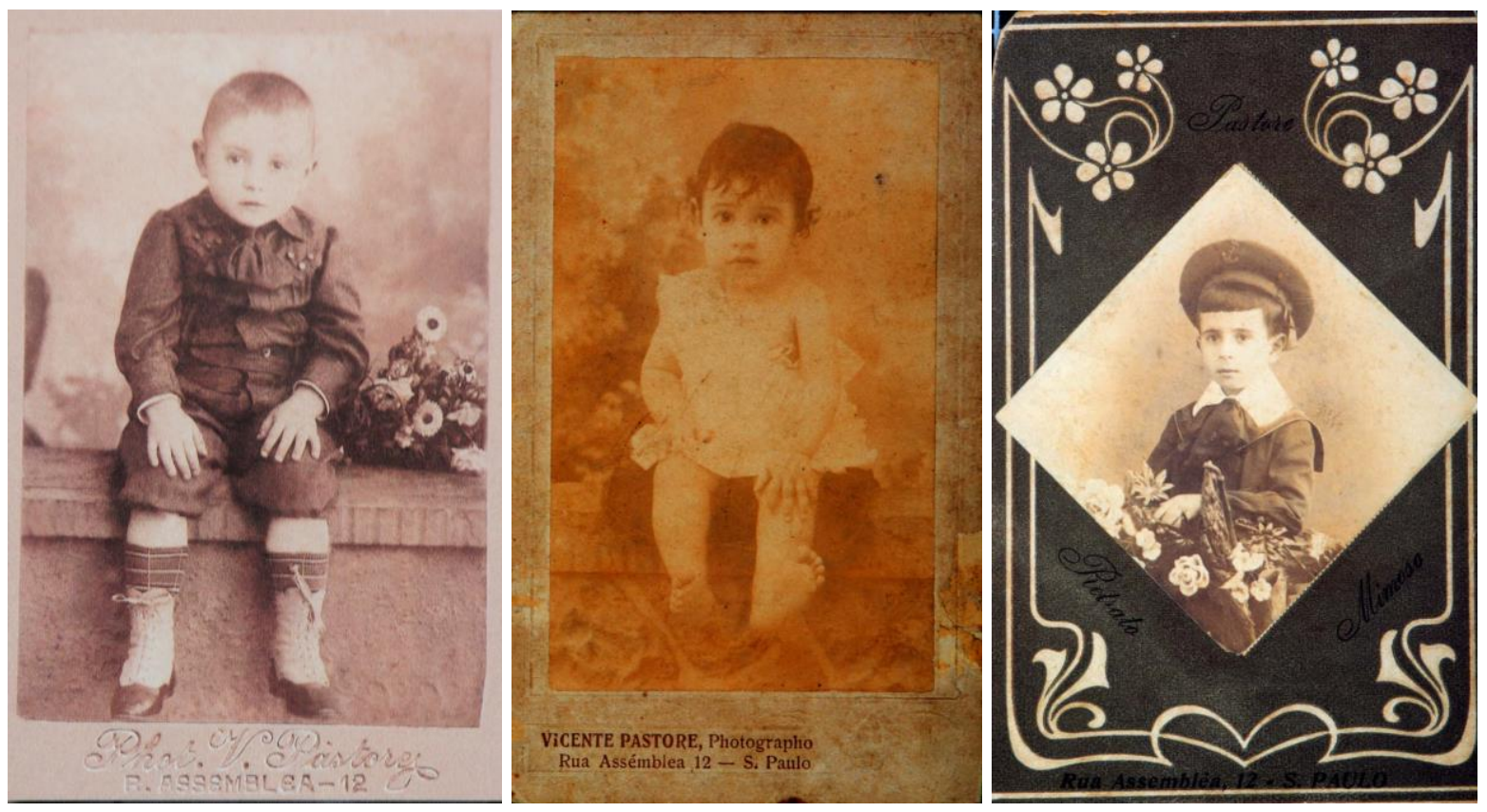

Figuras 67, 68 e 69: À esquerda, retrato de menino. Sem data () Vincenzo Pastore. In: Gerodetti \& Garbin. Álbum de Retratos. 2012. Ao centro, 1910 (C) Vincenzo Pastore / Cortesia Museu Paulista/USP. Foto à direita Retrato Mimoso. Rua da assembléia, 12. 1908 (C) Vincenzo Pastore / Cortesia Museu Paulista/USP.

Pastore foi habilidoso na difícil arte de fotografar crianças. Conseguia manter a atenção de muitas delas, acomodadas em almofadas (fig. 68). Nota-se o uso de painel de fundo

\footnotetext{
${ }^{79}$ Entrevista feita pelo pesquisador Ricardo Mendes com Costanza Pastore, em 1994. Gravações e transcrição parcial com alguns descendentes de Pastore encontram-se na Divisão de Pesquisa do Centro Cultural São Paulo.
} 
esfumaçado e colunas de pedras usadas nas duas primeiras imagens. Flores murchas expressam o arranjo da foto à direita (fig.69) ${ }^{80}$

O uso de folhagens secas e flores são fortes elementos de composição das cenas criadas por Pastore. A escolha dos passe-partouts garantia delicadeza à imagem, harmonizando-se com arranjo colocado à frente (fig.69). Tais suportes, importados na maioria, trariam o "requinte de orladuras, tamanhos e cores, trazendo muitas vezes impressa as referências do fotógrafo" (Schapochnik, 1998, p.465). O estilo art nouveau apropriava-se de um repertório do campo com forte tradição do paisagismo, com forte valorização do bucólico, representado não por um desejo de estar lá, mas como uma convenção estética, ou simplesmente, como moda no período, contaminada por um gosto que trazia a natureza para o estúdio.
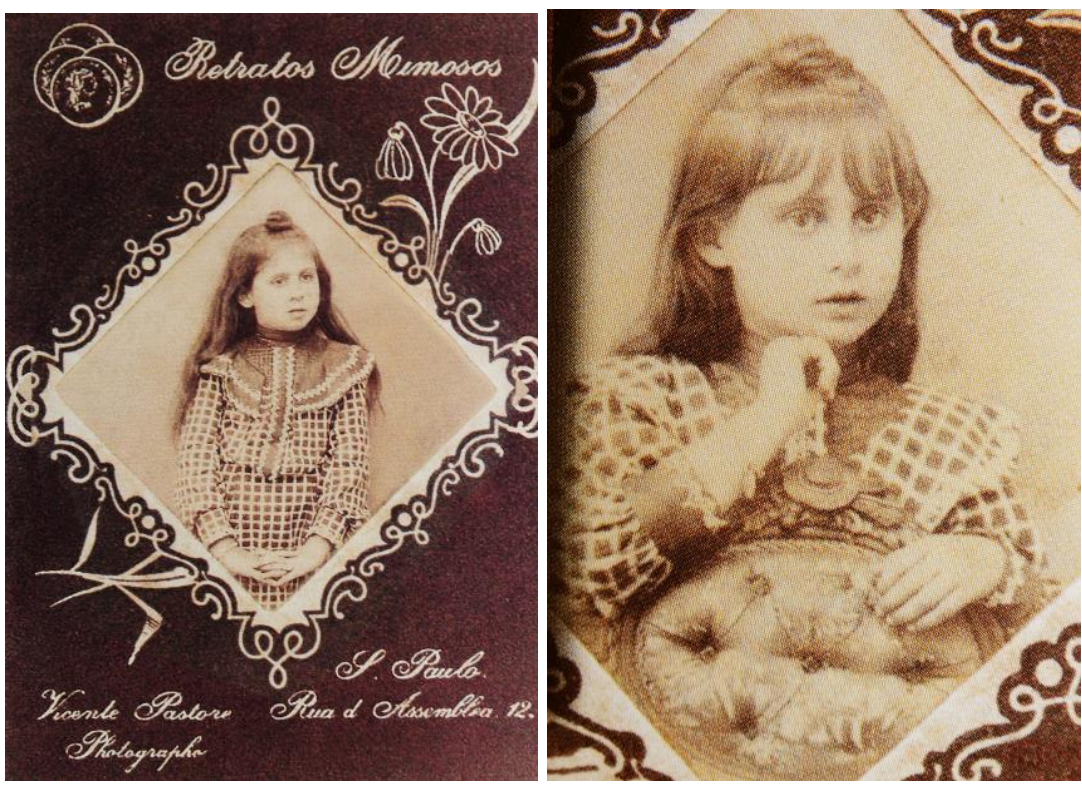

CONCURSD DE BELLEZA

No proxinio domingo, ás 2 horas la tardo, realisa-so no Salão Steinway 2 reunião do jury que deve conferir bs premios (medalhas de ouro, prata - bronze) $\theta$ as menções honrosas ás meninas que concorrem ao concurs de belleza organisado pelo photographo sr. Vicente Pastore.

Durante a reunião,cujos bilhetes : sacontram na photographia Pastore rue Direita n. 24 , haverá um con serto em que tomarão parte distin certo em que

Tomam parte no concurso 140 me ina.s.

Figuras 70, 71 e 72: Retratos de Dedé e Nh'Ana realizados no estúdio da Rua da Assembleia, 12. Ao centro detalhe do carte-de-visiste. Ambas sem data (C) Vincenzo Pastore. In: Gerodetti \& Garbin. Álbum de Retratos. Á direita, reprodução de recorte anunciando concurso de beleza organizado pelo fotógrafo. Caderno de Recortes montado por Elvira Pastore. Coleção Dante Pastore.

Pastore retratou Dedé e Nh'Ana (fig.70 e 71). Uma delas ficou em pé, com mãos entrelaçadas. A outra foi posicionada atrás da cadeira estofada. A variedade de poses mostra um fotógrafo preocupado em oferecer mais opções aos clientes. Diferentes dúzias, em diversas poses para presentear o maior número possível de amigos e familiares. Frente a esse mercado consumidor se tornava urgente empreender novas estratégias e artimanhas para sobreviver. A invenção de Pastore mostra como os estúdios não se mantinham apenas do

\footnotetext{
${ }^{80}$ A expressão um "arranjo feliz" foi utilizada por John Towler no manual The Silver Sunbeam, em 1864, quando caracterizava o cuidado do fotógrafo com o contraste de luz e sombra. As flores murchas fizeram relembrar a expressão de Towler. Ver Mendes, 2008, p. 111.
} 
prestígio do fotógrafo. Era preciso entender das artes do negócio, como afirma Grangeiro (2000).

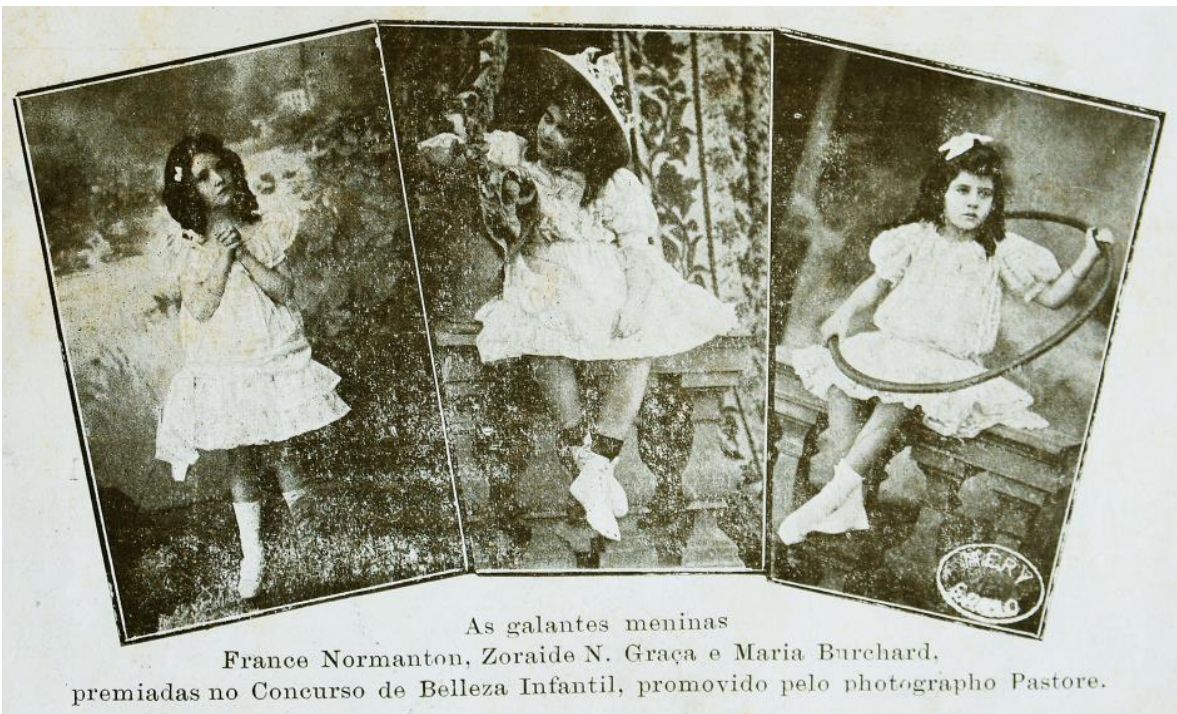

\section{Figura 73:}

A notícia deste recorte de uma revista anunciava as três primeiras colocadas em concurso organizado pelo fotógrafo Vincenzo Pastore. Reprodução Caderno de Recortes / Coleção Dante Pastore.

La commissione nomináva rel conferimento dei premi era cosi coppostis: sig.r a Berta Worms, valentissima pittrice; sig.ra Brandina Ratto, maestro Agostino Cantù del Conservatorio drammatico musicale, signor Gaetano Pierri fotugrafo, sig. Jonas do Barros artista-pitture, sig. Alfonso Picarelli-fotografo, sig. Carls viurdelli pianista, Umberto Olivatti fut grafo, sig. Gelaso Pimenta dell'(Estado de S. Paulow ed Ex rico Bellasalma :]el FANFTI.I.A

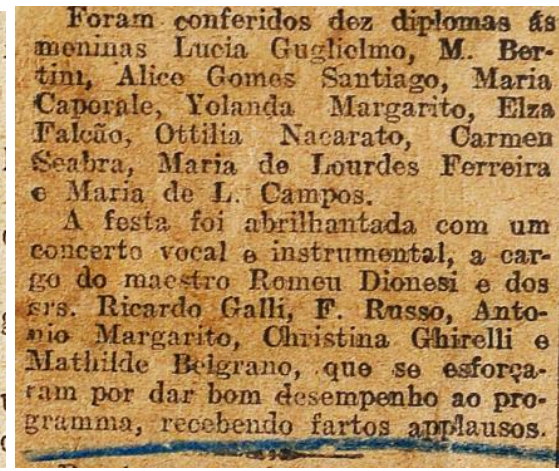

Figuras 74 e 75: Reproduções de recortes do Caderno de Recortes montado por Elvira Pastore. Coleção Dante Pastore.

O fotógrafo organizou o concurso de beleza infantil, um festival com "grande brilhantismo", oferecendo uma "elegante" festa no salão Steinway, "repleto de famílias, cavalheiros, notando-se a presença de muitas crianças". Entre os convidados via-se o cônsul da Itália. ${ }^{81}$ Concorriam no concurso as 140 meninas fotografadas em seu ateliê. Foram premiadas com medalhas as primeiras colocadas; diplomas foram entregues as demais. Os jornais italianos, publicados na capital, anunciaram o evento, destacando a presença do "abrilhantado concerto vocal e instrumental" e da "conhecida senhora Matilde Schiavinat

\footnotetext{
${ }^{81}$ Ver Coleção Dante Pastore. Caderno de Recortes, p. 13.
} 
Belgrano, um verdadeiro fenômeno da arte lírica". ${ }^{22}$ Pastore, como se vê, promovia um evento, divulgando assim seu ateliê, num agenciamento que merece ser ressaltado.

$\mathrm{Na}$ comissão julgadora contava com a presença de fotógrafos conterrâneos (fig.74). Gaetano Pierri, Alfonso Picarelli e Umberto Olivatti, formavam o grupo dos fotógrafos. Profissionais de veículos de grande circulação no período integraram a comissão julgadora formada por Pastore. Gelasio Pimenta representava o Estado de S. Paulo ao lado de Enrico Bellasalma, jornalista da Fanfulla. Seria o senhor Jonas de Barros, a artista pintor que ajudava Pastore a retocar suas imagens no laboratório?

Essas fontes explicam o resultado de algumas mediações mobilizadas por Pastore: foi organizado um álbum contendo fotografias das meninas que participaram do concurso de beleza infantil, realizado em 1908; este material foi depois oferecido à "Sua Alteza Real e aos seus filhos". Em nome do rei da Itália, o ministro da Casa Real, em abril de 1909, agradecia a oferta. Para os representantes do reino a atitude de Pastore "expressa o amor que mantém vivo a pátria distante". ${ }^{83}$ A prática fotográfica de Pastore mostra como na sua experiência de desterro lhe parecia pertinente manter vínculos com a pátria italiana.

Ao se observar o contexto de produção de suas imagens, vê-se a existência de um mercado acirrado, exigindo aptidão comercial e criatividade para conquistar a clientela. ${ }^{84} \mathrm{~A}$ barateza dos preços, a pontualidade e a prontidão na entrega dos trabalhos foram aspectos ressaltados no anúncio em que Pastore oferecia um retrato mimoso como brinde, aqueles que "honrarem com sua visita a nova casa a Rua Direita N.24". Em seu novo atelier aberto com “despezas e sacrifícios", Pastore anunciava os novos e modernos aparelhos escolhidos durante suas viagens à Paris e a Milão. ${ }^{85}$ Viagens que ele anunciava aos clientes paulistanos para comprovar as suas conexões com a Europa:

\footnotetext{
${ }^{82}$ Ver Coleção Dante Pastore.Caderno de Recortes, p. 11.

${ }^{83}$ Cf. Anexo. Coleção Dante Pastore. Caderno de Recortes.

84 Diante da competição comercial entre os fotógrafos, alguns que desejavam impressionar a clientela, chegaram a dar falsas referências nas propagandas de seus serviços. O verso dos cartões, que sempre traziam informações semelhantes, podia iludir a clientela. O nome e endereço do estabelecimento iriam sempre conferir. No entanto, as referencias de matrizes ou filiais, os vínculos com outras oficinas, possíveis prêmios recebidos, nem sempre eram facilmente verificáveis.

${ }^{85} \mathrm{Em}$ entrevista a filha de Pastore, Costanza, afirmou que o pai usava um papel produzido na Itália, de três a quatro cores chamadas eternas, mas "não pegou em São Paulo porque eram muito caro as gelatinas eternas". Cores eternas. Pastore, segundo ela, chegou a fazer algumas viagens até Milão para buscar o papel. Acervo na Divisão de Pesquisa do Centro Cultural.
} 


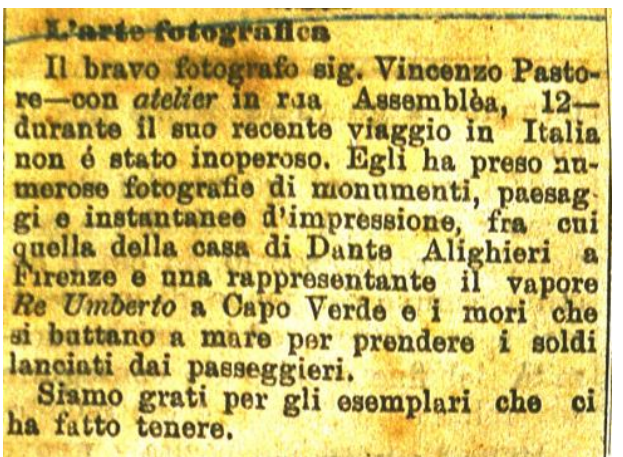

Sxorte fotogkanca

Il bravo fotografo sig. Vincenzo Pasto durante il suo recente viaggio in Italio non é stato inoperoso. Egli ha preso $\mathrm{na}$ merose fotografie di wonumenti, paesag gi o instantanee dimpressione, fra cu guells della cass di Danto Alighieri a (1) vapore di battano a mare per prendere $i$ sold langinti dai passeggieri.

ha fatto tenere.

Figura 76: Caderno de Recortes, p. 23.

Coleção Dante Pastore.
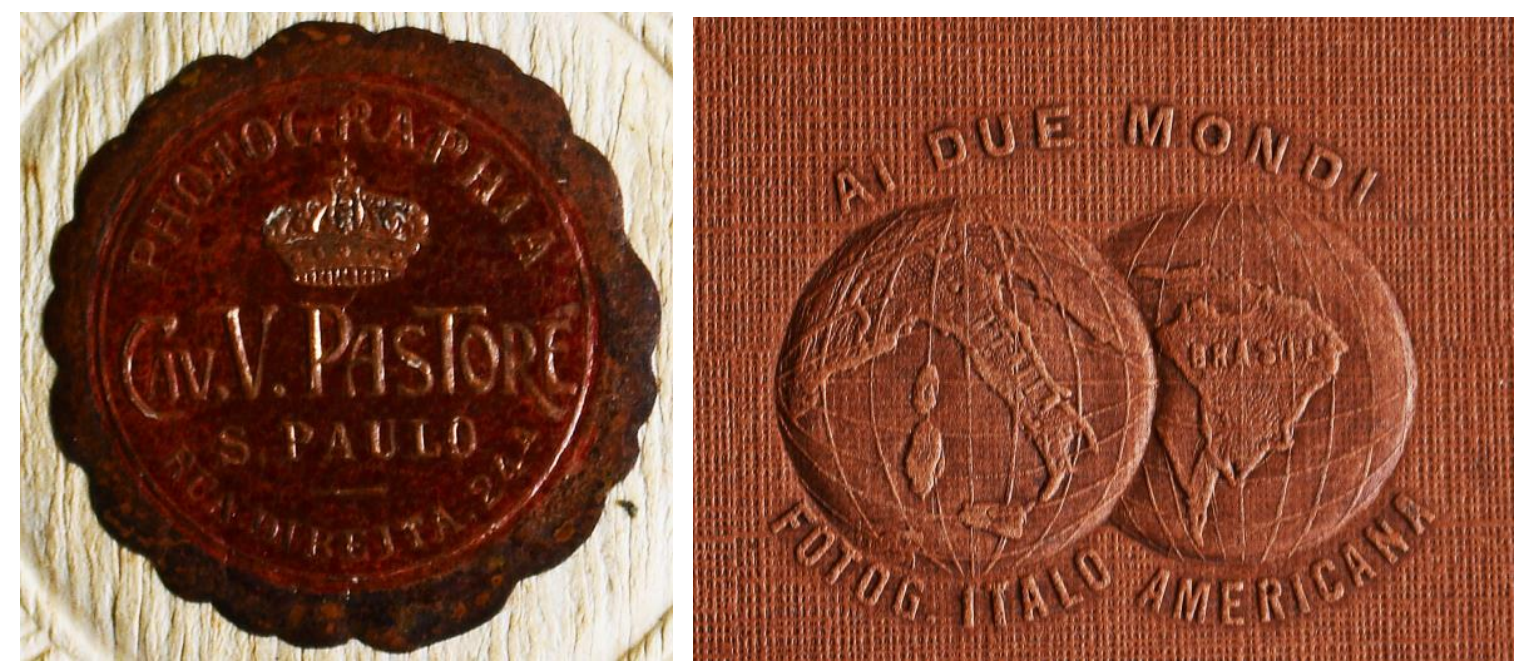

Figuras 77 e 78: Reprodução de marcadores impressos no cartão suporte das fotografias de Pastore. À esquerda o símbolo da coroa da Itália e indicação do título concedido a Pastore de Cavalheiro do Reino da Itália: à direita selo com a marca do estúdio aberto na Itália “Ai Due Mondo - Fotografia Ítalo Americana”. Coleção Dante Pastore.

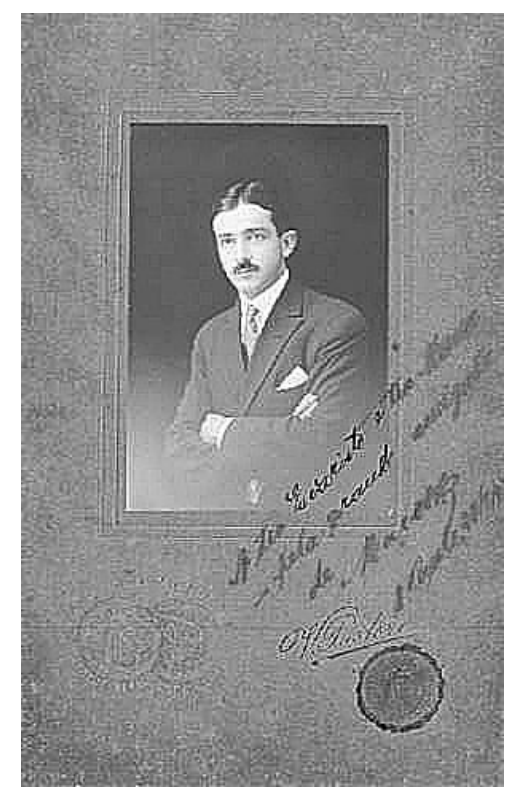

\section{Figura 79:}

Retrato de meio busto em papel cartão com moldura $14,8 \mathrm{~cm} \times 23,3 \mathrm{~cm}$, realizado no estúdio da Rua Direita, 24. Na dedicatória assinada se lê "Ao tio Evaristo e à tia Mana pela grande amizade, de Marcos, São Paulo”. 1910 (C) Vincenzo Pastore / Cortesia Museu Paulista/USP. 
Reafirmar contatos com países estrangeiros era estratégia pertinente à tentativa de se imprimir distinção e prestígio. Encontramos Pastore reforçando com insistência a sua estreita ligação com a Itália: sobre papel cartão (fig.79) Pastore destacava ora o título de cavalheiro do reino, sob a insígnia Photographia Cav. V. Pastore (fig.77), ora o ateliê Ai Due Mondi Fotografia Ítalo-americana (fig.78). Na comercialização de seus retratos, o fotógrafo inscrevia em alto relevo os contornos de um mapa que ele tentou aproximar. A dedicatória escrita (fig.79) foi assinada "Ao tio Evaristo e à tia Mana pela grande amizade, de Marcos, São Paulo, 22/05/1910", cidade em que o fotógrafo nunca havia verdadeiramente pensado em se radicar.

Em sua experiência de imigração, Pastore mantinha vivo o desejo de retorno à Itália. Quando Costanza afetuosamente afirmou que "papai era um artista e ganhou muito dinheiro quando inventou o Retrato Mimoso", ${ }^{86}$ refere-se a um dinheiro acumulado em São Paulo com destino certo: Bari, no ano de 1914, receberia o estúdio do fotógrafo ${ }^{87}$ Ao sondarmos esses caminhos percorridos por Pastore não imaginávamos poder rastrear a instabilidade nos destinos compartilhados por muitos fotógrafos ao sul da Itália; instabilidade que se coloca no horizonte dessa análise como uma contingência deste específico métier, no qual muitos profissionais enfrentaram um destino que nem sempre jogava à favor.

Trilhamos agora um caminho para demonstrar como Pastore foi um típico fotógrafo do sul da Itália, precisando emigrar de uma província a outra em seu próprio país de origem: Atravessou diferentes regiões meridionais, lançou-se na grande imigração, que pouco encerrou os desafios tidos à frente. Observar a prática fotográfica de muitos fotógrafos conterrâneos de Pastore ajudou a compreender tanto a sua própria experiência e trajetória individual, quanto seus atos em torno do retrato, antes de sua chegada à capital paulista. Foi na província potentina que realizou o seu primeiro ato de migração interna. A seguir ajustamos o nosso foco para trajetórias marcadas por idas e vindas aproximando Potenza, São Paulo e Bari, cidades que se inscreveram nos destinos do fotógrafo.

\footnotetext{
${ }^{86}$ Depoimento de Costanza Pastore concedido à Atílio Avancini, em São Paulo, no dia 9 novembro 1999. Ver artigo Apreciador da Gente Brasileira - o Fotógrafo-cronista Vincenzo Pastore.

87 O serviço de informações sobre imigração, oferecido pelo Banco de Nápoles, traz o nome de Vincenzo Pastore na listagem daqueles que movimentaram dinheiro na Itália no ano de 1907, indiciando ainda mais as ligações que o fotografo sempre manteve com a Itália. Fonte internet file://C:/Users/VISTA/Desktop/Servizio\%20Emigrati\%20frameset files/aem spaulo.htm
} 


\section{Capítulo 2}

\section{Vestígios de práticas fotográficas errantes}

\section{1 "La Fotografia Pastore" na antiga Lucania: fragmentos e arranjos recriados por}

\section{Elvira}

Na semana entre os dias primeiro e oito de dezembro de 1898, o jornal L'Eco delle Puglie, que circulava nas províncias de Bari, Potenza, Foggia e Lecce noticiou "La fotografia Pastore in Potenza (Basilicata)". Na montagem realizada no caderno de recortes a "Viúva Pastore", inscrevem-se traços dessa trajetória. Elvira justapôs ainda outro anúncio sob o título "La fotografia Pastore”. Os descendentes, repetidas vezes sublinharam em vermelho o nome que homenageavam (fig.80). Descobrimos nas pesquisas em arquivos e acervos potentinos, que esse último recorte havia sido impresso no jornal Il Lucano, de 14 de outubro de $1898 .^{88}$

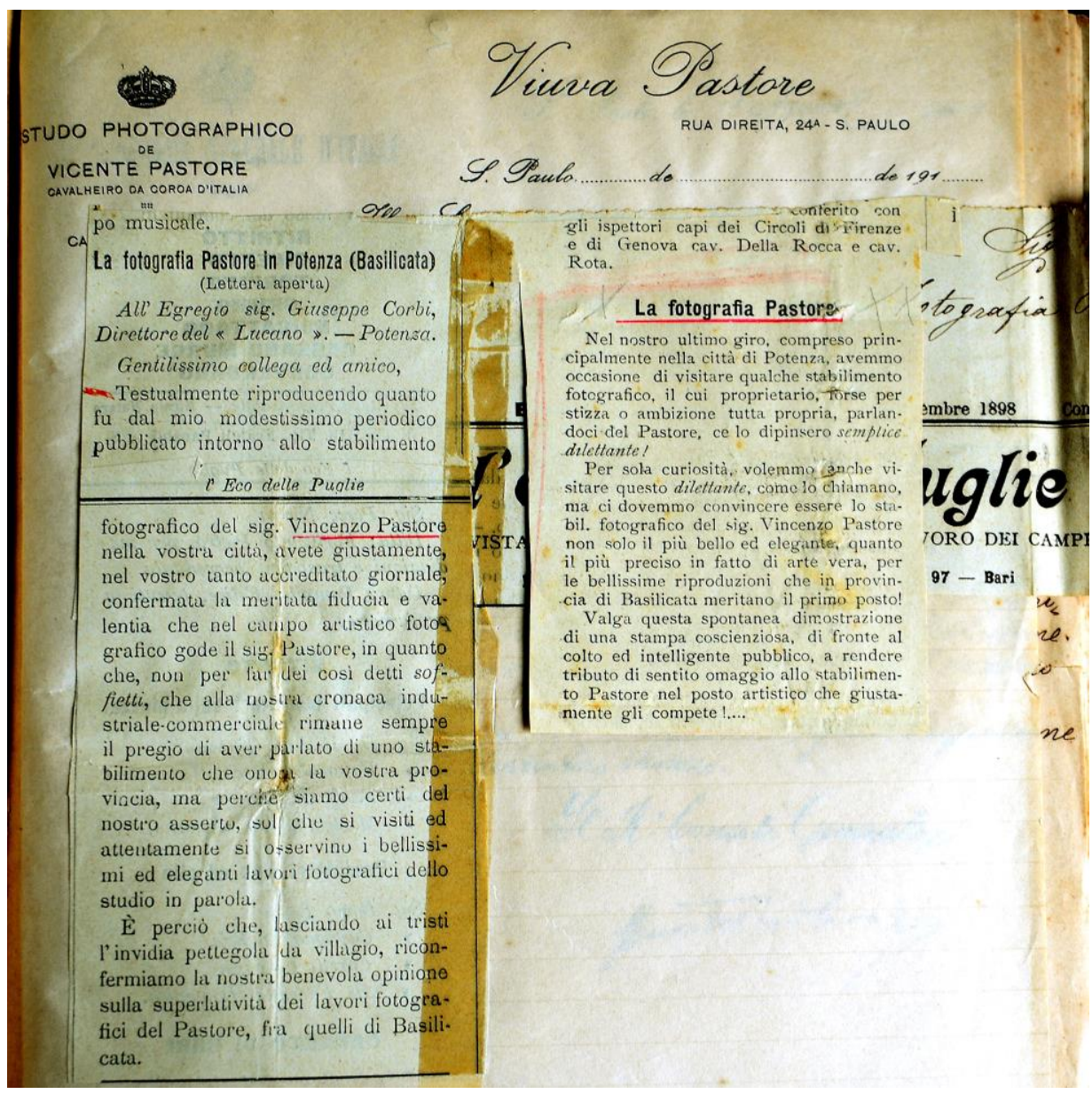

Figura 80:

Reprodução de recortes colados no Caderno de Recortes criado por Elvira Pastore. À esquerda jornal L'Eco delle Puglie; à direita jornal Il Lucano. 1898. Coleção Dante Pastore.

\footnotetext{
${ }^{88}$ Ver jornal II Lucano. Outubro de 1898. www.internetculturale.it Tradução nossa.
} 
Compreender a tentativa de Pastore de sobreviver como retratista em seu país compõe a trama deste capítulo. Primeiro documentaremos o quanto os profissionais que se dedicavam a este ofício, na Basilicata, precisavam se deslocar entre as províncias e as pequenas comunas ao sul da Itália, com uma frequiência surpreendente, para viver da produção de retratos. Desvelamos os imanentes obstáculos e a enorme concorrência enfrentada por Pastore nessa região, no ano de 1898, antes de sua chegada a São Paulo. Depois, sondamos este fotógrafo em sua província natal no ano de 1914, afinal o desejo de retornar à terra de origem ajuda a caracterizar o ato de emigrar e a própria experiência da imigração, em contingências que traziam uma promessa frustrada: a de se vivenciar uma permanência apenas temporária na terra de acolhida. ${ }^{89}$

O estúdio de Pastore, inaugurado na província capital da região da Basilicata, além de ser descrito como o mais belo e elegante, era tido como aquele que realizava "a mais verdadeira arte com suas belas reproduções fotográficas”. Sem ressalvas, anunciavam o fotógrafo como merecedor do primeiro lugar em toda região. Na dimensão do superlativo acionado o trabalho de Pastore foi julgado eloquentemente. Talvez por isso Elvira, ao montar o caderno de recortes após a perda do marido, na construção de uma narrativa cronológica, colou já na primeira página esses dois fragmentos (fig.80), recortes que rastreiam o percurso desse retratista, antes de sua chegada à São Paulo, em 1899.

A carte-de-visite reproduzida em frente e verso foi a única imagem encontrada da produção de Pastore na antiga Lucania (fig. 81 e 82). Trata-se de um retrato de meio busto, frontal, com luz bastante equilibrada. $\mathrm{O}$ esfumaçamento criou um efeito oval à imagem. $\mathrm{O}$ estilo padrão conferido a esta proposta representacional nos priva de maiores detalhes sobre o estúdio. Deste modo, é inevitável uma lacuna sobre a presença de possíveis mobílias e artefatos eventuamente sido usados na feitura dos retratos produzidos no ateliê potentino. A ausência de dedicatória repete o fenômeno quase freqüente de como circulavam os retratos nessa região.

89 Cf. LANNA, Ana Lúcia Duarte. Aquém e além-mar. Imigrantes e Cidades. 2012; E também SAYAD, Abdelmalek. A Imigração. 1998. 

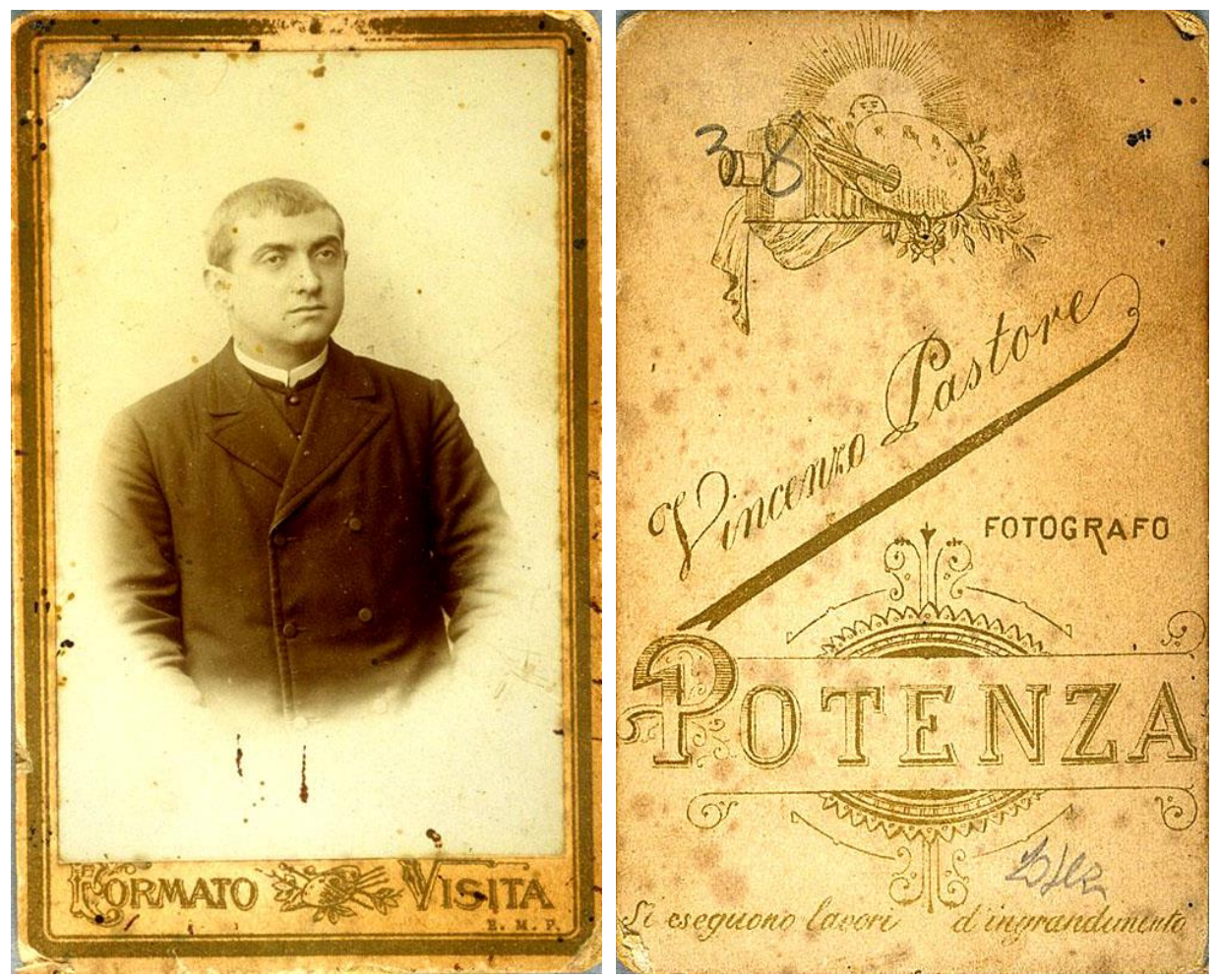

\section{Figuras 81 e 82:}

Retrato de meio busto, formato carte-de-visite, realizada em Potenza, província da Basilicata. Foto frente e verso. Sem data (C) Vincenzo Pastore /Concedida pelo Centro di Ricerca Audiovisuale Università di Napoli Federico II.

As letras, em caixa alta, na parte inferior do cartão suporte indicam além do formato oferecido aos clientes todo um repertório visual art noveau reproduzido em todo produto final. Pássaros, folhas e pequenas flores dão volume às formas gráficas usadas como empréstimo de textos impressos em livros ilustrados. As vinhetas migravam para outros contextos e se tornaram elementos decorativos de diferentes impressos ao longo do século XIX. Também preencheram o verso da carte-de-visite produzida por Pastore, usadas como molduras não só para destacar o nome da cidade, apresentado em fonte maior, como também para delimitar o espaço que faz referência ao nome do fotógrafo, centralizado em diagonal; abaixo, anunciava-se, em fonte menor, o trabalho de reprodução de fotos realizadas em outro atelier. O desenho de uma máquina fotográfica na parte superior do verso do cartão se confundiu com a paleta do pintor. Essa sobreposição sugeria um domínio requintado do retrato com o uso de elementos gráficos reforçando a estreita relação do pintor-fotógrafo, do fotógrafo artista. Tema esse, segundo Mendes (2010), recorrente na produção de cartões e anúncios fotográficos..$^{90}$

\footnotetext{
90 Para uso de vinhetas e elementos decorativos de diversos suportes Cf. Mendes, Ricardo. Pequeno Livro das Vinhetas. Fotografia no Brasil. 1860-1920. 2010. Cf. http://www.fotoplus.com/vinhetas/pag/vinhetas.htm.
} 
Mas esse retrato não inscreve apenas a prática de se valer de tais repertórios visuais gráficos apropriados pela produção fotográfica do período. Uma experiência de deslocamento em torno da fotografia começa a se desenhar na trajetória desse fotógrafo, submetida a sua prática de estar sempre em trânsito: da Cassamasima, comuna da província de Bari, na região da Puglia onde nasceu, Pastore se deslocou para São Paulo, em 1895; três anos depois já se encontrava novamente na Itália. Nesse primeiro movimento de retorno ao seu país o fotógrafo se dirigiu para Potenza, capital da região da Basilicata. Tal deslocamento interno começou a delinear uma problemática pertinente: muitos fotógrafos retratistas ao sul da península migravam intensamente pelas diferentes províncias e regiões meridionais, como fez Pastore, saindo da Puglia para Basilicata. Em 1899, estaria, contudo, de volta ao Brasil. Quinze anos depois partiria novamente, dessa vez para tentar se fixar em Bari.

Pela trajetória individual de Pastore tentaremos a seguir entender o campo da fotografia potentina e barese, que em reverso amplificou a compreensão da experiência de nosso fotógrafo na capital paulista. Sua prática fotográfica em São Paulo remete à sua experiência anterior, vivenciada ao sul da Itália, onde precisou dominar técnicas sofisticadas do retrato para melhor enfrentar a crescente concorrência que o forçou a imigrar.

\subsection{Basilicata: terra de Elvira}

Não conseguimos documentar se Pastore, ao retornar para a Itália, depois de ter permanecido em São Paulo no ano de 1895, tentou abrir um estúdio primeiro em Bari, se deslocando posteriormente para a região da Basilicata. Quando tenta-se compreender por que teria ele escolhido a pouco promissora província potentina, que ao final da última década do século XIX era considerada como uma zona opaca, como uma região remota, mal integrada com as grandes redes de comunicação ao sul da Itália, vê-se como inicialmente apenas razões particulares, de parentesco ou afetivas, explicariam seu ato de imigração interna.

O fato de Elvira ter nascido e vivido na capital da antiga Lucania se coloca como a mais plausível explicação para a ida de Pastore para a região da Basilicata, deixando para trás a sua província barese, que apresentava dimensões urbanas mais significativas. Após a unificação desse país, Bari havia se tornado a capital da província da Puglia assistindo a um intenso crescimento demográfico e urbano, com notável expansão das classes médias, consequiência do aumento das funções burocráticas e terciárias desenvolvidas na cidade. Pastore, na 
trajetória de deslocamentos de fotógrafos das províncias do sul não optou por Nápoles, o grande local de irradiação cultural de toda Itália meridional, dividindo com Salermo o posto de grande centro de atração para os fotógrafos retratistas. Trata-se de cidades que também se destacavam na comercialização de produtos fotográficos. ${ }^{91}$

O trajeto de Bari à Estação Central de Potenza ainda hoje é realizada com exaustão. Quatro horas e meia foram necessárias para se cumprir tal trajeto. Na metade do percurso, na comuna de Foggia, troca-se de trem que apresenta apenas dois carros, nada confortáveis. A linha ferroviária Foggia-Potenza foi inaugurada em 1897, diminuindo o isolamento da região da Basilicata, ligando a capital potentina com as demais províncias do sul da Itália (Buccaro, 1997). Tratamos da linha férrea utilizada por Pastore no percurso Bari-Foggia-Potenza, ainda hoje ativado.

Para sair de Bari rumo a Potenza, ao final dos oitocentos, levava-se uma média de onze horas de viagem. Imagina-se o desgaste de tal travessia. Realizá-la foi a chance de se ter a exata noção deste ato de migração interna trilhado por Pastore.

Foi no dia seis de setembro de 1897 que Pastore casou-se com Elvira. A certidão de casamento traz Potenza como o "lugar de celebração do matrimônio". 92 Um ano depois seu estúdio já se destacava na região da antiga Lucania, composta por duas províncias: Matera, com trinta e três comunas e Potenza, capital da Basilicata, constituindo-se um total de cem comunas. Se por um lado Potenza não era na época considerada como uma cidade em expansão, por outro a extensão territorial e a proximidade entre as várias comunas poderiam ter dado esperança a Pastore, prometendo uma ampla clientela.

A província potentina é uma cidade popularmente conhecida pelas riquezas arqueológicas sobrepostas. Segundo Alfredo Buccaro (1997), trata-se de uma cidade primitiva, sedimentada e constantemente reconstruída após inúmeros terremotos, dado a instabilidade geo-física da região. Antes da unificação do país a capital da Basilicata era considerada a quarta província do antigo reino de Nápoles.

No relato de muitos viajantes, Potenza em meados de 1860 era tida como um lugar a ser evitado. O "Diario di un viaggiatore tedesco in Basilicata" com o título "La terra incognita", escrito pelo médico alemão Karl W. Scharns descrevia Potenza como "colocada no meio de um estenso vale, como uma cidade montanhosa, isolada e submetida a ventos frios e fortes".

\footnotetext{
91 Sobre o desenvolvimento da fotografia ao sul da Itália ver Leone, Nicole. La scoperta da fotografia nella stampa napoletana. 1839. In: Segni Di Luce. V. 1.1993, pp. 181-192.

92 Coleção Dante Pastore.
} 
A cidade cravada entre montanhas hoje conta para o deslocamento da população com imensas escadas rolantes que vencem as dificuldades de uma região acidentada, a qual em 1883 foi assim descrita pelo arqueólogo Francois Lenormant: "para um viajante que chega de Nápoles, Potenza é um buraco na província, atrasada, vulgar e morta” (Perretti, 2008, p.22.). São essas visões pejorativas decepcionadas pela ausência de monumentos e grandes edificações, atributos do fetiche do Grand Tour.

A capital potentina entra no século XX com um pouco mais de 16 mil habitantes. Até 1881, 85\% da sua população era tida como analfabeta. As precárias condições sanitárias ajudavam a explicar a difusão das epidemias de cólera. Apenas a partir de 1912 foi de fato conduzido por alguns anos um projeto de melhoramentos para a província. Iniciaram-se obras de pavimentação de algumas ruas e becos da cidade, levando mais de vinte anos para ampliar a rede de esgostos, restrita à nova estrutura urbana que se desenvolvia ao entorno da sua principal rua, a Via Pretoria, o coração do centro histórico da capital potentina que exige atualmente cerca de menos de 30 minutos para ser percorrida em toda sua estensão.

Perretti (2008) reitera Buccaro (1997) quando se queixa da ausência de uma única monografia sobre a região. Pouco se documentou sobre a vida cotidiana desse antigo "paese" que se tornou "città", afirma Perretti, pesquisador da história meridional da Itália. O que se tem de conhecimento produzido condensam-se em descrições "genéricas, superficiais, lacunares" (2008, p.11).

A província potentina que acolhia Pastore na virada de século era tida como a região mais pobre de todo reino. Sua população teve poucas chances de escapar da situação de expulsão que lançaria um grande contingente para a experiência de imigração. Agricultura pobre, pouco mecanizada, além da concorrência das grandes propriedades produtoras empurravam as famílias com menores posses e propriedades para a experiência do deslocamento além-mar. Alvim (1986) reitera Ana Lanna (2012): entender os fatores de expulsão da população da Itália ilumina as ações de um vasto contingente saído primeiro da região norte da Itália, sobretudo da cidade de Veneto, depois motivando os camponeses e pobres do sul, grupos que não hesitavam em fugir da perene miséria e evidente ausência de perspectivas.

Abandonar a região da Basilicata vinha também como resposta a alta carga de impostos locais, outro fator de expulsão da população local. Pequenos proprietários viviam de uma agricultura de pouca renda, numa região marcada pelo isolamento, com poucos médicos, 
muitas epidemias e estruturalmente muito precária. Razões da grave situação de despovoamento de inúmeras províncias ao sul do país.

Apesar da trajetória de Pastore não se encaixar no perfil chamado por Ana Lanna (2012) de migração masculina e solitária, elemento este que foi para a pesquisadora fundamental na manutenção dos vínculos firmados na experiência vivenciada na terra de acolhida, é pertinente notar os dados que rastrearam a saída de parte da população meridional italiana:

A maioria daqueles emigrantes originários do sul da Itália era constituída por homens jovens e que viajavam sozinhos, fossem ou não casados. Dados mostram que, para o período de 1876 a 1905 , de 70 a $85 \%$ dos emigrantes calabreses eram homens, jovens, com mais de 14 anos. (Lanna, 2012, p. 881)

Pastore viria para o Brasil num período no qual o sul da Itália começava a se destacar pelo deslocamento Atlântico. Isto posto, vemos Pastore integrando as levas de calabreses chegados à terra de acolhida:

Os imigrantes oriundos da Itália predominaram na corrente imigratória para
o estado de São Paulo no período entre 1886 e 1902 . Desta data até 1920, as
condições de atração exercidas pelos EUA diminuem consideravelmente o
fluxo migratório para o Brasil. A partir de 1905 , já são majoritários
migrantes oriundos de Portugal e Espanha. Entre 1870 e 1902, a média anual
de entrada era de 43.116 italianos; entre 1902 e 1920 , este número cai para
14.328. Outro dado importante refere-se à origem destes italianos. De 1886
até 1902 predominavam vênetos e lombardos (30,9\%). Após esta data
aqueles originários das províncias do sul eram a maioria. Alvim demonstra
que o período que abarca os anos $1895 / 1896$ a 1902 caracteriza-se por
expressivo aumento da chegada das populações meridionais. (Lanna, 2012,
p. 880 )

Migrações internas entre as próprias comunas e províncias de diferentes regiões italianas, mas também para a Europa central, segundo Alvim (1986), marcaram a experiência de sazonalidade oriunda de uma economia de transumância compartilhada entre os povos das regiões setentrionais da Itália. Ana Lanna observa mais pontualmente as migrações da região originária de Pastore, explicando a forte e a antiga tradição de deslocamentos sazonais de trabalhadores habitantes do sul rumo ao norte do país:

Eventos naturais, como o terremoto ocorrido na região da Calábria em1905 são poderosos estímulos ao incremento do movimento migratório. Entretanto, múltiplas são as causas desta emigração indo desde a estrutura da propriedade da terra e condições de pobreza até os movimentos de cunho mais político que envolvem a unificação italiana. Todos estes fatores atuam sobre uma cultura que tinha a viagem e a peregrinação como dados presentes e ativos. O deslocamento não é, portanto, novidade para estas regiões, mas as dimensões em que ele ocorre a partir de finais do século XIX e o sentido 
de longa duração a ele associado marcam novas escalas e questões. As regiões da Calábria, Basilicata e a parte mais pauperizada da Campânia têm forte imigração transoceânica já a partir de 1870, mas acentuada no início do século XX. Os anos de 1905 a 1907 são os de maiores índices de emigração. (Lanna, 2012, p.876)

A região onde Pastore abriu seu estúdio depois de casar-se com Elvira integra, segundo Ana Lanna (2012), os grupos da Calábria entendida pela autora como a região composta pela região da Campânia, Basilicata e Calábria. Desse modo, Pastore na capital paulista tomou lugar entre os grupos reconhecidos e auto-identificados por "calabreses". Da Basilicata partiram 52.888 compatriotas. Atravessarem as águas do Atlântico, buscando abrigo e trabalho no Brasil, dado apresentado por Alvim (1986, p.62). A Calábria perdeu entre 1900 e 1914 um terço da sua população masculina, entre 15 e 40 anos. Cerca de $8 \%$ do total da população desta região veio para a América. Basilicata, região italiana com maior emigração, assistiu a sua população diminuir em 5\%. Migravam trabalhadores agrícolas sem posse de terra e ainda pequenos proprietários. Os desterrados do sul, de acordo com Alvim (1986), a partir de 1902, superavam numericamente a imigração para o Brasil, mantendo quase sempre a esperança de um dia voltar.

Veremos a seguir como de fato a procedência está atrelada à experiência de chegada e às tentativas de reconstrução de sociabilidades firmadas no ato de imigração, como defendem Alvim e Ana Lanna. A disposição de Pastore de viver do retrato na capital paulista deve ser vista à luz de sua trajetória precedente. Hábitos, experiências herdadas e tradições articulam lugar de origem e lugar de acolhimento. De Potenza, Pastore trouxe o aprendizado de tentar viver do retrato.

Uma contingência de forte concorrência nas províncias do sul da Itália impelia os fotógrafos retratistas a práticas que pudessem destacar seus ateliês. Passavam muitas vezes a vender em seus estúdios equipamentos fotográficos; dedicavam-se à técnicas de maior sofisticação e requinte da fotografia, explica D'Autilia (2012). Talvez essa contingência explique o amplo domínio de Pastore que realizava fotos em aquarelas e cianotipia, mas também dominava outras técnicas mais aprimoradas de foto-pinturas, valendo-se da técnica à óleo, da foto à carvão-print conhecidas como "fotos inalteráveis", oferecendo ainda fotos miniaturas para medalhões e pingentes, fotos em porcelana, em esmaltes para broches, e ainda autocromos, platinotipias e fotos em tamanho natural. A não especialização era decorrente da 
necessidade de sobreviver de seu ofício. Necessidades enfrentadas desde sua experiência na terra de origem.

\subsection{A “formidável memória visual” da Basilicata: vestígios de fotógrafos em trânsito no "profondo sud" italiano}

O estudo da fotografia Lucana surpreendente pela efetiva atuação de muitos fotógrafos retratistas, envolvidos numa prática onde tudo se assemelha ao provisório, ao incerto, à disposição para enfrentar um metier marcado por experiências errantes e instáveis. As vicissitudes enfrentadas por estes profissionais nos aproximam do percurso de Pastore na Lucania de 1898, desvelando o contexto social da fotografia na qual tentou se inserir.

Os primeiros estúdios fotográficos começaram a surgir nas antigas províncias do sul de modo mais generalizado somente entre as décadas de 1850 e 1860, ou seja, nos anos que precederam o fim dos reinos da Sicília e Nápoles. O percurso da fotografia da Basilicata está, portanto, ligada ao processo de unificação italiana que fomentou o avanço da fotografia em toda a região. Intuíam oferecer visualmente a dimensão da península em processo de unificação, concluída em 1870. A queda do reino dos Bourbons e o avanço da técnica do colódio úmido foram fatores que contribuíram para a disseminação da fotografia entre as províncias meridionais fortemente associadas à prática científica. A fotografia foi tida como ferramenta vital aos métodos de observação e descrição, empregados nos estudos de diversas áreas do conhecimento. Para Ernesto Salinardi a fotografia era um apanágio para arquitetos, viajantes, paisagistas e, principalmente, para os primeiros engenheiros que tomavam a fotografia dada a sua aparente objetividade, explorada também como "novo meio de comunicação". 93

Lello Mazzacane, ao tratar da clientela da Lucania como menos exigente, definiu "três orientações que prevaleceram ao se restituir a imagem da região": a Basilicata retratada por conta de suas catástrofes, como os trabalhos realizados pela expedição para estudos do terremoto de 1857, configurando-se como um filão recorrente da fotografia lucana, uma

\footnotetext{
93 Salinardi, 2008. O autor cita o terremoto de 16 dezembro, de 1857, que devastou uma grande área da província de Potenza e parte da porção sudeste de Salermo como o primeiro evento onde se destaca o uso da fotografia como método de observação de estudos realizados por engenheiros, como o estudo realizado pelo irlandês Robert Mallet que estudava a região da Basilicata. Os relatórios de tais estudos e da vasta documentação fotográfica que os acompanha encontram-se hoje no acervo da Royal Society de Londres, com 341 ilustrações entre gravuras, desenhos, diagramas e 156 fotografias, das quais, 120 são imagens de estereoscópico e monoscópica 36.
} 
iconografia que reforçava o estereótipo de uma região tida como desolada e abandonada; o segundo "topos" fotográfico foi caracterizado como "o subdesenvolvimento da Basilicata" que começava a se alterar a partir de 1910, intensificando-se na década de 1950, ora, através de campanhas parlamentares interessadas pela "a miséria na Itália e os meios para combatêla", ora através de imagens produzidas numa "tradição de estudos geográficos". Para finalizar Mazzacane refere-se à "Basilicata exótico-etnográfica", lugar de confinamento e exclusão, percepção enraizada, estigmatizando a região como o lugar de lamento fúnebre e magia, de rituais de colheita do "profondo sud", ou seja, o profundo sul como lugar fora do mundo. ${ }^{94}$

Mas essa é uma subdivisão proposta por Mazzacane para a fotografia lucana dentro de um cenário mais abrangente. Uma “orientação" voltada para o processo de construção da nação tendo a fotografia como um instrumento para inventariar, catalogar, classificar o novo contexto nacional e territorial, revelando uma visualidade preocupada em formar a imagem da pátria unificada. Tratava-se, portanto de uma fotografia entendida como parte de uma retórica nacional didática e celebrativa, para fomentar não apenas uma identidade nacional em construção, mas a própria prática do turismo, impulsionada também pela configuração de uma visualidade do novo país unificado. ${ }^{95}$ A construção de tantos estereótipos visuais se dá a partir de uma produção visual pouco expressiva para Luigi Tomassini (2010, p.160). Este pesquisador chega a defender a não existência de uma iniciativa fotográfica significativa em toda Lucania, ao longo da primeira metade do século XX. ${ }^{96}$

Se a região da Basilicata pouco atraia os fotógrafos - editores renomados em todo o país, responsáveis pela produção e publicação de conhecidos catálogos fotográficos editados para reverenciar o patrimônio artístico e histórico nacional, com clara valorização de aspectos paisagísticos italianos, outros profissionais tentavam na pouco valorizada Lucania, viver do retrato. Falamos de profissionais que deixavam muitas vezes cidades de maior expansão e desenvolvimento e se dirigiam rumo a Potenza, apesar da capital da região ser considerada como terra distante, separada, ou como lugar esquecido da Itália, num imaginário que

\footnotetext{
${ }^{94}$ A Basilicata retratada como esotica-etnografica, teria segundo o autor, influenciada as visões construídas também pelo cinema após os anos cinqüenta do século XX. Cf. Mazzacane, 2010, pp. 35-56. Tradução nossa.

${ }^{95}$ Sobre o uso da fotografia como um campo de análise das construções de discursos sobre a unificação italiana ver G. Bollati. Note su fotografia e storia. In: Storia d'Italia. Le immagine fotográfica:1845-1945. Torino: Einaudi, 1979, pp. 3-55. Tradução nossa.

96 Segundo Tomasini, apenas em 1937, surgiu um real interesse de se oferecer uma imagem fotográfica da região em nível nacional, com a publicação do volume dedicado a Puglia, Lucania, Calabria, volume que integrava a série "Attraverso l'Italia". A Lucania, de acordo com o autor, foi ainda a região menos ilustrada, entre as regiões meridionais da publicação do Touring Club. Ver Tomassini. 2010, p. 181. Tradução nossa.
} 
reforçava, ainda na primeira metade do século XX, ora o estigma da alteridade, ora o caráter periférico, marginal e atrasado da Basilicata.

Temos nuances dos primeiros indícios que ajudam a explicar essa etapa de experiência vivenciada por Pastore. O desenvolvimento da fotografia de retrato das famílias lucanas está diretamente associado à ascenção da pequena burguesia meridional que começava a reivindicar o seu papel de prestígio político, social e econômico. Um conjunto de daguerreótipos e ambrótipos testemunham, como menciona Salinardi (2008), o quanto esta clientela à principio se dirigia à Nápoles para obter a representação imagética do novo papel social que ocupavam após a unificação. Para o autor a atividade fotográfica exercida nos estúdios chegou à Basilicata com certo atraso. Essa premissa indica como a fotografia surgiu na Itália de modo não homogêneo, dissociada na maior parte das regiões de seu caráter de autoria. Por muitas décadas não foi entendida como produto material da cultura. Seu desenvolvimento teve início apenas a partir da década de 1880. Os primeiros estúdios fotográficos que surgiam estavam circunscritos, na maioria das vezes, a "alta borghesia", que inclusive, segundo o pesquisador Alberto Baldi (2010), quando existente, procurava "ateliês fotográficos reais" que se destacavam pelas suas ligações com a corte.

Mas a redução dos custos de produção devido às novas técnicas mudaria este quadro. Crescia progressivamente a demanda por fotografias, traço que ajuda a explicar o trânsito de fotógrafos ao sul do país. Esse é o fenômeno histórico no qual se inscreve o deslocamento interno de Pastore.

O primeiro fotógrafo a abrir seu estúdio em Potenza vinha de Nápoles, primeira cidade a dar início à prática daguerreotipista, nos anos de $1840 .{ }^{97}$ Vincenzo Giambrocono foi pioneiro na produção de retratos na capital lucana. Atuou, segundo Salinardi (2008), de modo contínuo e freqüente entre os anos de 1860 a 1880, na rua Vico Savoja, ora denominando seu ateliê como "Fotografia Americana", ora como "Fotografia Lucana”. Em Nápoles preservava a sociedade do estúdio localizado na Vico Lungo-Celso, 50. O estúdio da capital potentina, cruzava a importante Rua Pretoria, até hoje tida como a principal rua comercial da cidade.

Sua prática principal se dava em estúdio, mas atendia também a domicílio. Além dessa disponibilidade oferecida a sua clientela, sabe-se da técnica aprimorada de seus retratos, aspecto de distinção também atribuído à Pastore. A habilidade de Giambrocono, fotógrafo miniaturista, que produzia imagens para medalhões e fotos com bastante retoque e

${ }^{97}$ Fotógrafos daguerreotipistas e colotipistas estrangeiros como Alexander John Ellis, se dirigiram a Nápoli, Pompei e depois Salermo, entre os anos de 1840 a 1841. Ver Salinardi, 2008, p. 1042. Tradução Nossa. 
esfumaçamento, vinha de uma possível prática como pintor, segundo Salinardi (2008) que cita, para a década de 1890, a existência "de um certo Vincenzo Pastore cuja habilidade e capacidade estavam descritas na página do jornal 'Il Lucano' de 14 de outubro de 1898", notícia que abre a montagem do caderno de recortes feito por Elvira Pastore.

O cenário de um contexto pouco promissor à Pastore começa a ser nuançado quando se observa mais profundamente a produção historiográfica sobre a fotografia lucana. Foi apenas a partir da primeira década do século XX que se iniciaria o verdadeiro troca a troca de cartede-visite, oferecidos como presentes em diferentes formatos:

O famoso 'Formato visita', confortável e fácil de manusear; o 'Formato Margherita', versão patriótica - em homenagem à rainha da Itália - do Formato Victoria de origem anglo-saxônica e o 'Formato Gabinete', termo italiano para indicar o Formato Salon ou Cabinet, comuns na Inglaterra e nos Estados Unidos. (Salinardi, 2008, p. 1044. Tradução nossa.)

Pastore em 1898, já comercializava o retrato de meio busto no Formato Visita. Se, Giambrocono atuou em Potenza duas décadas antes da chegada de Pastore na região, Luigi Giocoli foi seu contemporâneo. Trata-se de outra trajetória que ajuda a compreender o deslocamento de fotógrafos na Itália meridional. Giocoli deixou Nápoles no final da última década dos oitocentos. Diferentemente de Pastore, teve uma atuação longa na Basilicata. O estúdio aberto em Potenza, no largo Castellucci, hoje Piazzetta Martiri Lucani, funcionou até início dos anos de $1930 .^{98}$ No verso das fotos prensadas em cartões suporte destacava ora a "Fotografia Artistica", ora "Premiada Fotografia Luigi Giocoli" ou ainda, "Fotografia Giocoli”. Apesar de atender a uma vasta clientela anunciava como sua especialidade retratos de crianças.

\footnotetext{
${ }^{98}$ Marino Giocoli, filho do fotógrafo deu sequencia a atividade do pai após 1930; assim como no Brasil vê-se na Itália trajetória de sucessivas gerações que se dedicaram a fotografia de retrato. Salinardi aponta essa década como o momento em que Potenza viveu um intenso interesse pela fotografia, tanto para profissionais e amadores, como uma explosão de demanda por retratos. O estúdio de Giocoli tornou-se um importante ponto de encontro e formação de fotógrafos até 1940, quando toda a família se transfere novamente para Nápoles.
} 


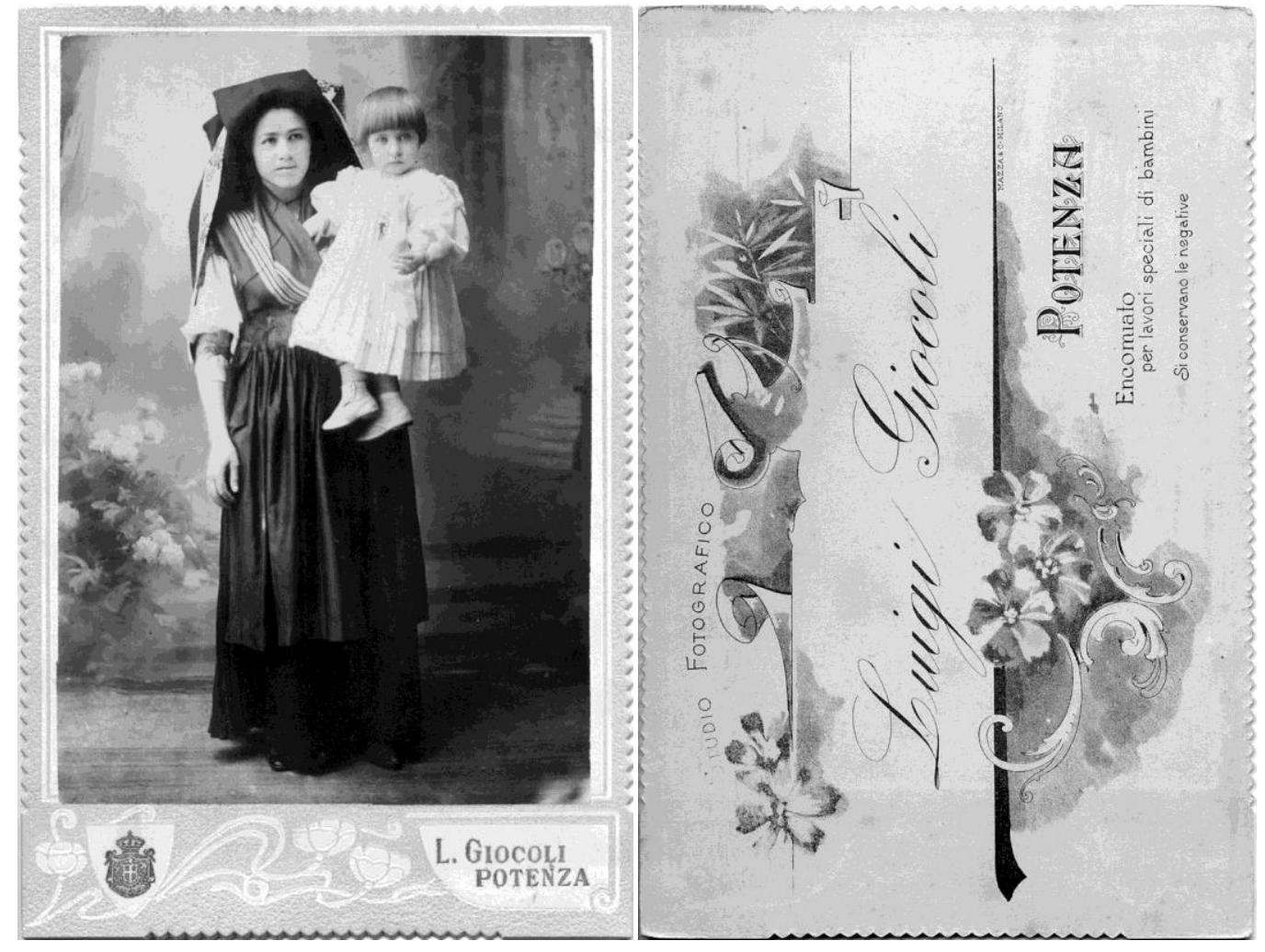

\begin{tabular}{l} 
Figuras 83 e \\
\hline 84: \\
Retrato de \\
mulher com \\
trajes típicos de \\
festa, levando \\
seu filho ao \\
colo, realizado \\
em Potenza. \\
Foto frente e \\
verso. 1910 @ \\
Luigi Giocoli / \\
Concedida pelo \\
Centro di \\
Ricerca \\
Audiovisuale \\
Università di \\
Napoli \\
Federico II.
\end{tabular}

Nos anos de 1915, nomes de outros fotógrafos já assinalavam uma maior concorrência à Luigi Giocoli. Francesco Faranda atuava nesse ano na Rua Meridionale, número 15. Encontramos registrado na junta comercial do município de Potenza a inscrição do estabelecimento de Faranda no Vico Rosica, número 17. Infelizmente, como tal registro não estava datado podemos apenas verificar como esse fotógrafo atuou em diferentes endereços na capital potentina. ${ }^{99}$

Outro importante fotógrafo retratista conhecido como G. V. Sapienza, mantinha seu estúdio no Largo Liceo, atual Piazza R. Pignatari ao longa da avenida Cesare Battisti. A prática fotográfica de Sapienza sugere uma experiência fotográfica decisiva no contexto fotográfico lucano. Apesar de manter um estúdio fixo em Potenza, muitas de suas fotografias, segundo Salinardi (2008), foram encontradas em álbuns de famílias que viviam nas comunas fora da capital potentina. Temos assim um importante indício a rastrear uma prática de deslocamento de fotógrafos nas diversas comunas da Basilicata apesar de manterem seus estúdios fixos na capital. Foi essa uma estratégia freqüente para aumentar a clientela,

99 Arquivo Comunale de Potenza. Pasta 18. Seção I, página 03. VIII Censimento Generale della Popolazione. Circolare: 199-113-C. 
atendendo a uma demanda que esperava o anúncio da visita de um fotógrafo de passagem pela comuna. ${ }^{100}$

O estudo de Angela Verrastro (2005, p.72) mostra como foi preciso esperar a primeira década do século XX para ver estúdios fotográficos voltados para uma clientela "com modesta disponibilidade econômica", tendo acesso a um número limitado de fotos. A maior parte das famílias camponesas que se dirigiam ao estúdio do fotógrafo na capital podiam pagava apenas por dois ou três retratos, obtidos em circunstâncias bastante particulares: registrar o elo do matrimônio, enviar um retrato a um afeto distante, registrar o nascimento de um filho.

Sobreviver do retrato significava ter disposição para conquistar todo tipo de cliente, que raramente queria se retratar por prazer ou apenas para exibir-se. Fotografar "il contadino", significava atender a uma necessidade primordial de atestação e necessidade, com total ausência daquilo que Mazzacane (2010) chama de "caráter lúdico". A produção de retratos, na província em que Pastore atuou em 1898, estava atrelada ao costume de uma fotografia familiar, preocupada em documentar nascimentos, matrimônios, comemorações festivas, assim como noticiar aos parentes as condições de saúde, de trabalho e de morte. Uma fotografia que ocupava uma importante função nas relações sociais internas das comunas porque garantia um fluxo recíproco de informações; atestar a existência do indivíduo e do grupo para fora da Lucania é outra vertente de estudo sobre a fotografia potentina, porque eram fotos muitas vezes enviadas aqueles que haviam emigrado para terras distantes de acolhida. Mazzacane se refere à fotografia da "Lucania oltre oceano", Lucania de além-mar, dando a dimensão desse circuito promovido pela produção de retratos, num intenso trânsito de imagens produzidas de dentro para fora, mas também na reciprocidade daqueles que partiram e queriam atestar a melhora da vida com a experiência vivenciada pela imigração. Foram exibidas inúmeras fotos e certificados de bem-estar, artefatos que circularam como testemunhas de um conforto sonhado na pátria e finalmente alcançado, afirmou Mazzacane (2010).

100 O estudo de G. Bertuzzi sobre a fotografia da comuna de Piacenza, entre os anos de 1857 a 1900, indiciou uma prática de intenso deslocamento dos fotógrafos pela a Itália. Apesar de pouco se conhecer a prática fotográfica nas cidades menores da península, indica-se como nos anos de 1860, muitos retratistas saiam das grandes cidades rumo à pequena comuna piacentene, tentando se afirmar artística e financeiramente. Em 1900, G. Bertuzzi aponta uma "decadência artística" no campo do retrato. Cf.G. Bertuzzi. 1982, p.8. 
No entanto, como nos mostra Verrastro (2005), este foi um circuito alimentado pela produção realizada nos estúdios apenas a partir de 1900. Antes disso, era a prática retratista ambulante e semi-ambulante que fomentava de modo mais ativo este circuito de imagens potentinas rastreado por Mazzacane. Com a evolução dos procedimentos fotográficos, resultando na prática da fotografia amadora, os fotógrafos que haviam se estabelecido na capital potentina, passaram a enfrentar uma acirrada concorrência. $\mathrm{O}$ gosto da clientela exigia apenas preços reduzidos.

Observar a fotografia da Basilicata mais pontualmente equivale a constatar uma prática que foi se tornando cada vez mais complexa. Indiciar aquilo que tratamos como um deslocamento interno de Pastore em seu próprio país acabou nos remetendo para uma prática que se impunha como vital para a sobrevivência dos fotógrafos ao sul da Itália, que percorriam diferentes províncias, vizinhas ou distantes. Precisavam muitas vezes, manter sucursais de seus estúdios em diferentes comunas para conseguir sobreviver da fotografia. Diversos estudos definem a fotografia lucana a partir de diferentes práticas retratísticas: havia fotógrafos que abriam seus pequenos estúdios; havia ainda aqueles voltados para a prática ambulante, homens que levavam seu "studio per strada"; havia os semi-ambulantes confluindo em seu cotidiano ambas as práticas, explicou o pesquisador Baldi (2010).

Seus estudos demonstraram como a história da fotografia da Basilicata foi também escrita pela "formidável memória visual", constituída a partir de uma visão interna porque realizada por fotógrafos muitas vezes da própria comuna, afinal uma infinidade deles participava do mesmo contexto sócio-cultural que documentavam, acumulando outras funções além de fotógrafos retratistas. Carpinteiros, encanadores, artesãos, cabeleireiros podiam dedicar algumas horas do dia a prática da fotografia amadora (Baldi, 1996, p.148), gente que não conseguia sobreviver apenas fazendo retratos.

As fotos adquiridas em números quase sempre reduzidos eram por vezes realizadas a partir de relações marcadas pela proximidade cotidiana, por figuras que viviam na própria comuna e que aprendiam as regras básicas da fotografia, recorrendo aos jornais locais. 


\subsection{Entre o estúdio e a estrada: o difícil contexto vivenciado por Pastore na antiga}

\section{Lucania}

Aldo Gilardi (1993, p.111-123) refere-se de modo contundente à existência de uma categoria de fotógrafos denominada como semi-ambulante, associada à prática estritamente ambulante, que apesar de submetida ao quase total esquecimento, raramente observada na história da fotografia social italiana, se multiplicava em toda Itália, entre as décadas de 1850 e 1860, prolongando-se por toda a segunda metade dos oitocentos. Segundo Gilardi, fotógrafos caminhantes percorreram frequentemente as pequenas comunas. Bateram em diferentes portas oferecendo seus serviços para famílias que, na maioria das vezes, podiam pagar apenas por uma única reprodução fotográfica. Reproduções que sobreviveram guardadas por diferentes gerações.

\section{CORRIERE FOTOGRAFICO}

Espos'zione della hastara sensibile

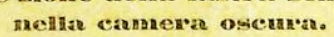

Se, cortese lettore, vuoi ottenere un buon negativo, ti è d'uopo attendere con tutta la cura di non far vedere luce alla tua lastra sensibile. Comprata Cal vegoziante la scatola delle lastre sensibili, ti rachiuderai nel tuo camerino perfettamente oscuro, quindi aprirai la scatola delle tue lastre e 13 porrai, la laccia seusibile in fuori, nel quadro o telaio, come tu chiamar lo voglia, ma che, con termine fotografico, dicesi : chassis dai Francesi, frame da. gli Inglesi e rahme dai Tedeschi. Se la tua macchina e istantanea, non avrai a fare altro che introdurre nella camera oscura, l'un dopo l'altro, gli chassis che contiene, e quindi, ponendoti dinanzi all'oggetto che vuoi riprodurre, scaricare l'otturatore, e quindi cambiare clussis e ricominciare fino a che non hai terminate lo tue lastre. Abbi cura di aver sempre il sole dietro le spalle. Se poi la tua macchina fotografica è a posa, collocala avanti gli oggetti che vuoi riprodurre. Se tali oggretti sono illuminati dal sole, procura che lo siano in senso obliquo, affine di ottenere contrasti fra luci e ombre, e sopratutto prucura che i raggi solari non rasentino gli orli del tuo obbiettivo. Metti sul tuo vetro, spulito a fuoco, l'immagine da riprodursi, e ció facendo avanzare o retrocedere, col mezzo della parte mobile della camera oscura, detto vetro, fino a che l'immagine vi si dipinga sopra ben nitida e distinta, sia al centro, sia all'estremita. L'imma. gine non ti apparira diritta, ma, come suol dirsi, gine ne fito. Per osservare nettamente detta immagine, coprirai il capo e la camera oscura con ma tela nera, onde impedire il passaggio della luce asterna ehe impedirebbe di vedere l'immagine.

Quando ti parri che la tua immagine sia perfetQuante mobile con la vite tamente cióntivo, e togli il retro a cio into suo posto lo chassis che spulito, hai dimenticato cosa alcuna, e, sicuro di questo, innalza la persiana che copre la tua lastra sensiinnalza la persiana che dellotturatore, e rinbile. Tcg i allora il coperchi sicuro che la posa e chindilo poi subito come sarai sicuro che la posa stata sufficiente. La lace inviata dag riprolursi e trasmessa dall oblientivo, veria percuotere ed impressionare lo steato seni ilo della tua lastra. II tempo di posa da darsi si dere giudicare dalla intensita e qualiti della huco nella quale operi, dalla sensibilita delezca d'upertura delghezaa del foco e dalla grandezza d apertura del lobbiettivo. Chiadi quindi di nuovo la persiant tuo chassis, e riponi la macchina al suo posto. Ti rachíuderai quindi nel tuo laboratorio illuminato da luce rosso-rubino, e svilupperai in ta

lastra. Di cio parieremo uel prossimo numero.

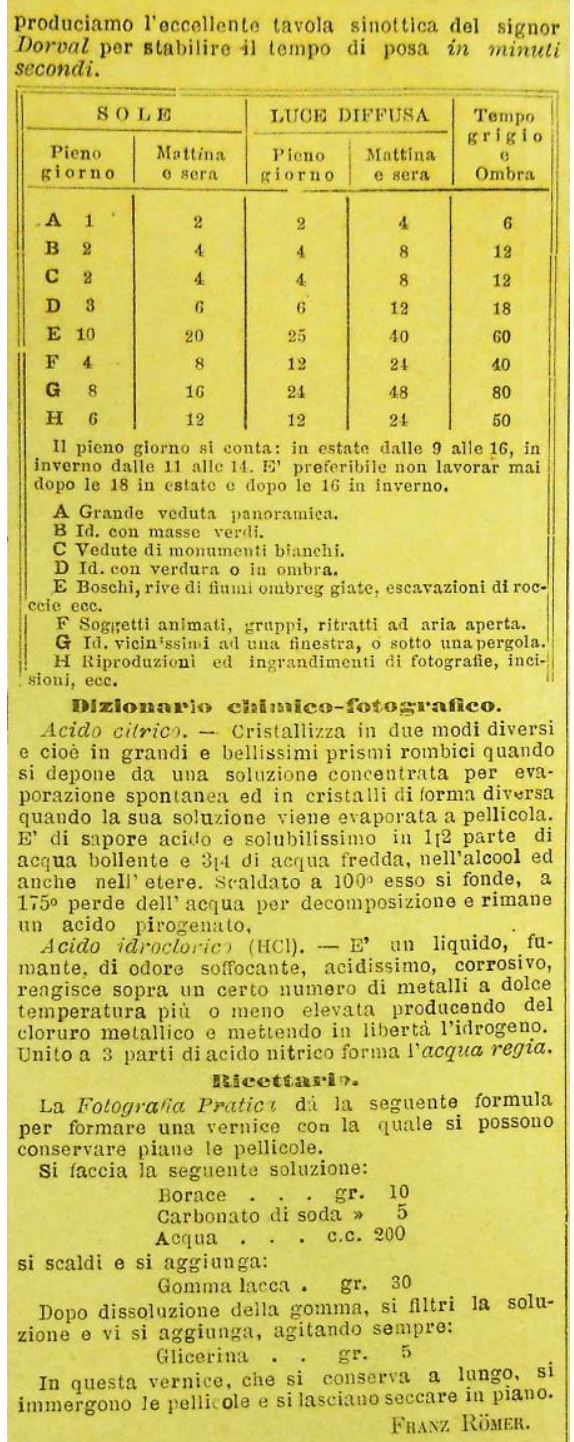

\section{Figura 85}

Reprodução Jornal $L a$ Tribuna. 22 de dezembro 1895. Num. 51. Archivio di Stato di Potenza. 
No Archivio di Stato di Potenza encontramos o jornal La Tribuna-Supplemente illustrato della domenica, com uma sessão fixa chamada Corriere Fotografico, publicando conselhos e técnicas que se disseminavam como saberes, envolvendo a prática fotográfica de modo abrangente (fig.85). No dia 24 de novembro de 1895, afirmaram que "a maior parte das pessoas com matemática certeza podem deleitar-se da fotografia amadora". ${ }^{101}$ Se antes ela era considerada como uma "arte misteriosa", praticada por "magos", ao fim do século XIX, na província potentina, "todos se pretendiam fotógrafos". Nessa sessão, encontram-se "conselhos úteis" e as "melhores receitas" sobre o uso do fotômetro, ou como se compreender " a instantaneidade na fotografia" a partir do uso do processo de colódio (gelatina-bromuro), e ainda orientações mais simples como posicionamentos adequados para se alcançar efeitos de luz, contrastes ou definição de foco, indicações precisas para se fotografar com luz de sol ou difusa, etc.

Os fotógrafos profissionais, frente a essa contingência, precisavam ser capazes de ampliar a sala de pose, ter uma estrutura ágil, vital diante das vicissitudes decorrentes de uma clientela aristocrática ou "alto borghese", ausente ou pouco significativa no centro lucano. Os fotógrafos precisavam buscar nova clientela por entre as diversas comunas da Basilicata, concorrendo com aqueles que aprendiam a fotografar pelos jornais.

Mazzacane (2010) pontuou o quadro da situação da fotografia lucana afirmando que em escala nacional a contribuição de fotógrafos ambulantes foi muitas vezes episódica e fragmentada, mas na Lucania tal prática se deu de forma mais consistente e dinâmica do que em outras regiões italianas. Se, se deixassem permanecer inertes em seus estúdios fixos os fotógrafos poderiam ver a sua clientela minguar.

Nicola Grego, nascido em Potenza em 1899, teve uma vida profissional longa assumindo ainda muito jovem, como afirma Salinardi, a tarefa de fotógrafo itinerante. No Arquivo Comunale de Potenza encontramos o registro feito na junta comercial onde Grego registrou sua prática ambulante (fig.86), fonte que nos ajuda a aferir sobre a atuação de fotógrafos entre o estúdio e a prática per strada, ${ }^{102}$ ainda nas décadas iniciais dos novecentos. Quando tais fontes foram se apresentando ainda não se supunha que a prática de fotógrafos retratistas em estúdio estivesse de modo vital associada à prática ambulante.

\footnotetext{
${ }^{101}$ Archivio di Stato di Potenza. Jornal La Tribuna. Caderno Supplemento Illustrato della domenica. Num. 47. 24 de novembro de 1895, p. 372. Tradução Nossa.

102 Reprodução Pasta 18 dos registros feitos na Junta Comercial do Município de Potenza. Seção III, página 06. VIII Censimento Generale della Popolazione. Arquivo Comunale de Potenza.
} 


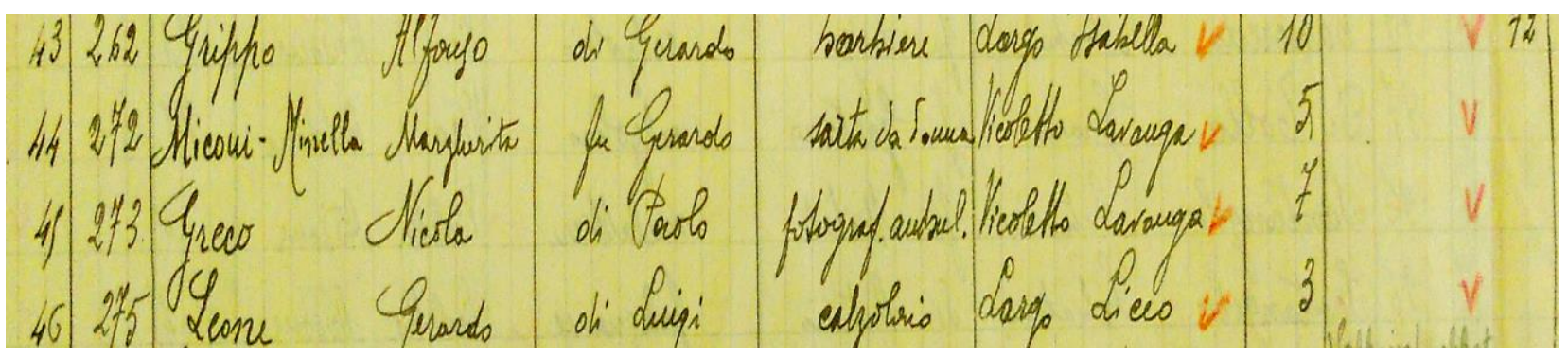

Figura 86: Reprodução de parte de página com a indicação de nomes, ocupações e endereços que constam no livro de Registros Comerciais de Potenza entre a última década do século XIX e as primeiras do XX. VIII Censimento Generale della Popolazione. Arquivo Comunale de Potenza.

O local de habitação indicado como a Rua Vico Lavanga, 7, era, como nos informa Salinardi (2008, p.10) simultaneamente local de funcionamento do estúdio fixo de Nicola Greco, fotógrafo que também percorreu por mais de 30 anos toda a Basilicata. A prática ambulante não estava, como se vê, dissociada da manutenção de ateliês permanentes mantidos nos mesmos espaços de moradia de muitos fotógrafos.

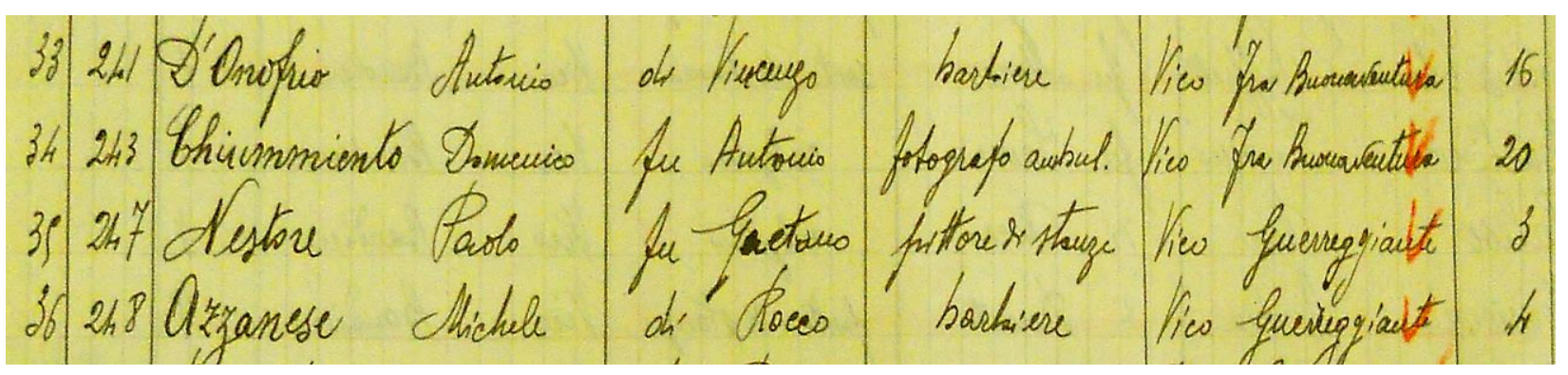

Figura 87: Reprodução de parte de página com a indicação de nomes, ocupações e endereços que constam no livro de Registros Comerciais de Potenza entre a última década do século XIX e as primeiras do XX. VIII Censimento Generale della Popolazione. Arquivo Comunale de Potenza.

Greco chegou a anunciar estúdios em outros endereços como nas ruas Ianfolla 37 e Angilla Velha. A licença para atuar como fotógrafo itinerante na comuna de Senise, ajudou a rastrear os passos desse retratista fora da capital potentina, nos anos de 1922, mostrando como essa prática avançava pelas décadas inicias do novo século.

A presença de mais um fotógrafo ambulante chamado Domenico Chiummiento, o qual inscreveu-se no registro de número 243, com a indicação de um estúdio aberto em Potenza na Rua Vico BuonaVentura, número 20 (fig.87) chamou-nos atenção. ${ }^{103}$ Sondamos como a improvização técnica dos fotógrafos ambulantes e a sempre maior elegância e profissionalismo dos ateliês residenciais não eram, quando pensamos na Basilicata, práticas excludentes. A pesquisadora da fotografia italiana Gabriele D”Autilia (2012) também afirmou

\footnotetext{
103 Reprodução Pasta 18 dos registros feitos na Junta Comercial do Município de Potenza. Seção V, página 10. VIII Censimento Generale della Popolazione. Arquivo Comunale de Potenza.
} 
como o ateliê seguia ao lado da prática ambulante que se multiplicou por todo o país a partir de 1850 e 1860, apesar desse período ser também marcado pela difusão de ateliês nas pequenas comunas; a prática itinerante esteve em ascensão até o final do século XX. Apenas em meados de 1990 passava a declinar.

Não falamos da prática itinerante como sendo de concorrência direta à Pastore, mas que por certo algum impacto lhe causava já que sua restrita clientela citadina, possivelmente pouco se renovava. O pesquisador Alberto Baldi que se dedica ao estudo da fotografia da Basilicata desde a década de 1980 arrisca afirmar que se tratavam possivelmente de mais de cem retratistas itinerantes por toda a Basilicata. ${ }^{104} \mathrm{~A}$ fotografia lucana inscreve-se desse modo numa prática de constantes movimentos que envolviam muitos fotógrafos, que por vezes, aproveitavam a primavera e o verão para saírem de seus estúdios e se lançarem à estrada, cientes da falta de um fotógrafo local, como explica Baldi:

Estando na vila da cidade, num alargamento da passagem, no adro da igreja matriz ou da prefeitura, às vezes se faz anunciar por um mensageiro, por um menino que, por algumas moedas, aceita percorrer as ruas da cidade comunicando em voz alta, e com o auxílio de um sino que o fotógrafo colocara em sua mão, a presença deste último. Essencial e, portanto, ainda mais simbolicamente significativa, é a encenação, reduzida ao uso, se tudo correr bem, de um par de panos de fundo para o cenário e, às vezes, um tapete, uma esteira a ser estendida sobre chão para esconder a calçada de pedras sugerindo a ideia de um piso residencial. (Baldi, 2010, pp. 57-71. Tradução nossa.)

Salenardi, por sua vez, fez referência aos fotógrafos que eram aguardados pela população das diferentes aldeias e vilas, antecipadamente avisada sobre o domingo, como dia de se fazer o retrato. Os moradores das comunas vizinhas muitas vezes iam de encontro ao fotógrafo que apesar de desprovido da parafernália típica dos estúdios, buscavam constantemente a melhor luz, enfrentando condições quase sempre adversas:

Nas menores cidades, nas pequenas vilas das montanhas, nas aldeias remotas, a chegada do fotógrafo aos domingos é programada e divulgada com antecedência para dar tempo às famílias de conseguirem os figurinos necessários para que sejam bem retratados também os camponeses, que vêm do campo para vender ou trocar os seus produtos na cidade, aproveitando a ocasião para serem fotografados ou para realizar a fotografia dos filhos. $\mathrm{O}$ ambulante, também conhecido como fotógrafo andarilho ou de estrada, obviamente não tinha todos os acessórios que estavam disponíveis nos estúdios das cidades, como cenários, colunas, balaústres ou poltronas: os fundos são, portanto, substituídos por lençóis brancos que escondem paredes

104 Conversa com o professor e pesquisador Alberto Baldi, realizada em junho de 2014, na Universidade de Napoli Federico II. 
rachadas e servem como contraste para ressaltar melhor imagem; as poltronas são velhas cadeiras trazidas de casa; o vestuário muitas vezes revela a condição econômica daqueles que são fotografados, como quando as crianças estão com os pés descalços ou com sapatos que são demasiado grandes para sua idade. A foto feita pelo fotógrafo ambulante, portanto, se por um lado mascara, distorce indulgentemente a realidade, por outro lado continua a ser um documento inalterável da condição social do povo. (Salinardi, 2008, p. 1051. Tradução nossa.)

$\mathrm{Na}$ teia de tais relações vemos uma população que não ficava confinada à espera do fotógrafo. Ao se noticiar a presença de um retratista na comuna vizinha, dava-se início aos preparativos de um deslocamento que podia envolver toda a família. Se existiam aqueles que se esforçavam em "se fazer em dignas figuras" se valendo, como delineia Baldi (1999, p.130) de sapatos grandes demais, recusando-se a se retratarem descalços, havia, contudo, famílias com uma renda melhor que se dirigiam ao menos uma vez aos pequenos estúdios fixos. Se Pastore contava com essa clientela logo deve ter descoberto que ela podia pagar por poucos retratos. Baldi (2004), contundente, afirmou como não se pode deixar de apontar o quanto essas populações se moviam com certa desenvoltura entre as comunas locais, gente com pouco dinheiro.

A fotografia potentina realizada durante as andanças de muitos fotógrafos retratistas não escapava da típica função social do retrato visto mundo a fora, documentando aquilo que Verrastro (2010), chamou de "rotinas sociais segundo um tempo biológico": o batismo, a primeira comunhão, a crisma, o casamento, o funeral. Mesmo que a cerimônia de casamento tivesse ocorrido meses atrás, era preciso aproveitar a presença do fotógrafo andarilho e documentar a união recém firmada. O vestido de casamento e também o terno eram outra vez vestidos, enfeitando novamente os noivos que recompunham a indumentária para o retrato, numa encenação onde estava "tudo confirmado e reconfirmado, sobreposto, a partir de uma retratistica prescritiva que se impunha ao fotógrafo". 105

Revivia-se o momento do dia do casamento numa encenação rígida e contida; encenação resultante da estreita relação entre fotógrafo e retratados, quando ambos ativavam códigos construídos conjuntamente.

Era comum que fotógrafos ambulantes e semi-ambulantes desenrolassem seus panos de fundo pictóricos em alguma esquina de praça, espaço onde também ocorria uma "sorta di

${ }^{105}$ Cf. A. Schwarz. La commedia del Ritratto. Bari: Laterza. 1986, p.15. APUD. Verrastro, 2010, p, 72. Tradução Nossa. 
teatrino". ${ }^{106}$ Nessa "espécie de teatro", pouco se dissimulava o chão de pedras que ocupava o primeiro plano de inúmeras imagens produzidas nesse contexto (fig.88 e 89). Os clientes na maioria não deixavam nenhum vestígio inscrito no verso dos cartões. Preocupavam-se em vestiar roupa de festa ou próprias para comemorações especiais. Havia sempre uma cadeira improvisada num cenário que reproduzia a cada gesto a artificialidade da encenação do estúdio. A melhor pose podia ser feita diante de tecidos ora rendado, ora marcado por dobras. O pouco pano era improvisado como fundo de ateliê, servindo para a foto individual, foto de casal ou de grupo familiar.

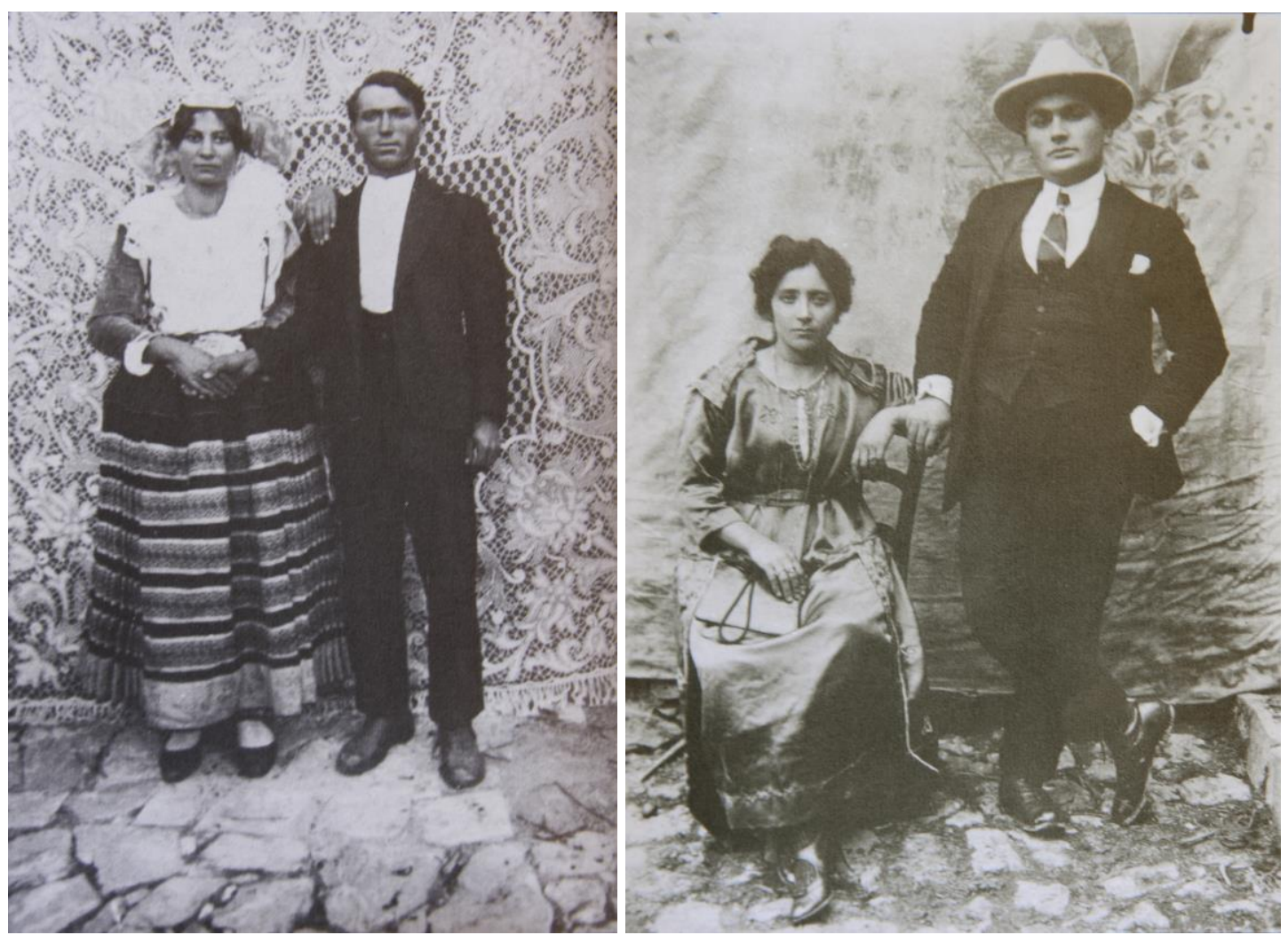

Figuras 88 e 89: Fotografias de fotógrafos ambulantes anônimos, produzidas ao final do século XIX. Potenza. Centro di Ricerca Audiovisuale Università di Napoli Federico II.

O rigor da pose que transitava como convenção ao longo da segunda metade do século XIX, ainda recorrente nas primeiras décadas do século XX, apresenta uma alteração nos registros fotográficos produzidos na Basilicata. Se, nas fotos realizadas dentro dos estúdios e ateliês fotográficos as cadeiras e as poltronas se colocavam como lugares privilegiados dos homens na pose de casal, as imagens tomadas em ambiente externo invertem certos preceitos normativos. As mulheres ganham os assentos nos retratos tirados em número sempre limitado

106 Baldi, Alberto. 1999, p. 129. Tradução nossa: "uma espécie de teatro". 
de cópias. Eram outras as normas de hierarquização da pose: os homens, segundo Baldi (2004, p.39) ocupavam sempre o lado direito da foto, "o lado forte e, sobretudo, masculino" do retrato (fig.88 e 89).

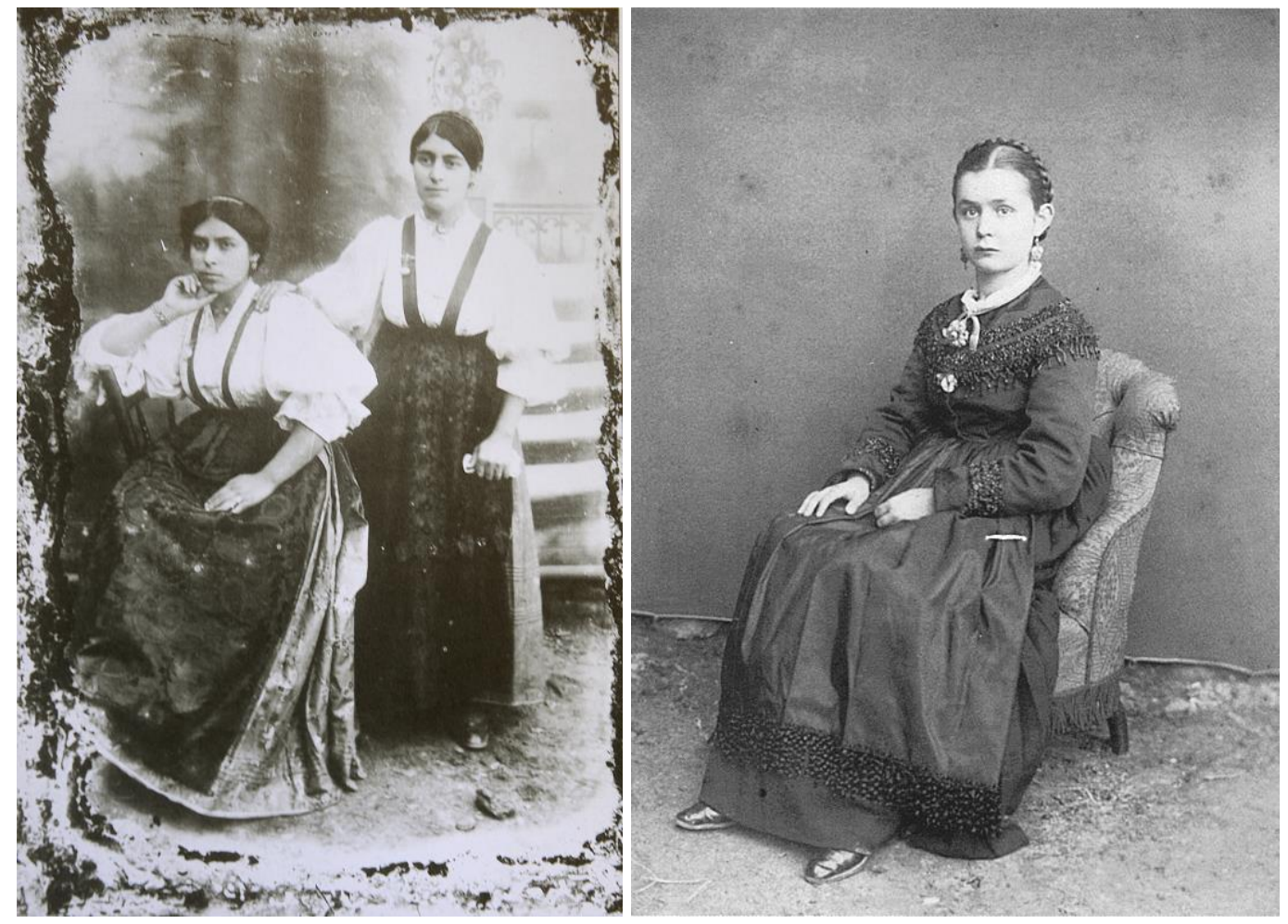

Figuras 90 e 91: Foto à esquerda realizada em Pisticci. S/d (c) Carlo Blancagemma / Centro di Ricerca Audiovisuale Università di Napoli Federico II. Foto à direita: reprodução de foto anônima que integra a coleção particular familiar de Giambattista Pinto, estudada por Alberto Baldi. In: Scatti per Sognare. Avigliano nelle fotografie dell' arquivio Andrea Pinto. Napoli: Electa Napoli. 2004. ${ }^{107}$

Os laços de afeto ou parentesco unem as duas mulheres como faz parecer este retrato, laços reafirmados no gesto da mão levada ao ombro (fig.90). Os degraus do pano de fundo mal estendido não alcançaram o chão de terra, que toma a parte esquerda inferior do retrato. $\mathrm{O}$

\footnotetext{
${ }^{107}$ A fotografia de Angela integra a montagem de um álbum fotográfico familiar originalmente formado por Giambattista Pinto. Segundo Baldi, Giambattista Pinto era um meticuloso e apaixonado colecionador de muitos materiais que faziam referência a história local de Avigliano, comuna da Basilicata, tendo realizado um trabalho de recuperação de imagens da região, preservando fotos colecionadas por seu pai desde 1922, além da compra de outras coleções familiares. Entre os anos de 1960 a 1994, com sua prática autodidata e sua vocação enciclopédica, contribuiu para a publicação de um livro intitulado Avigliano di Lucania escrito por Antonio Lucio Tripaldi, além de outras publicações. Seu esforço individual que ajuda a valorizar a história da região contou posteriormente com a ajuda do filho Andrea, que ajudou a sistematizar o arquivo do pai, reunindo hoje um total de 2.300 fotografias, realizadas entre 1870 a 1970; material identificado e catalogado em vinte álbuns, classificados por temas. Em seu estudo, Baldi contou com cento e cinqüenta imagens identificadas como fotos de família. Depoimentos orais colhidos por Giambattista em entrevistas com as pessoas mais velhas das diferentes famílias ajudavam a recompor as circunstancias da realização de muitas imagens, formando um conjunto de informações relativas a sua produção. Ver Baldi, Alberto. Scatti per sognare: Avigliano nelle Fotografie dell'archivio Pinto. Napoli: Electa Napoli. 2004. Tradução nossa.
} 
pano de fundo escuro usado na foto ao lado (fig.91), possivelmente fixado em algum muro, foi opção para melhor destacar a moça, retratada individualmente, de corpo inteiro, com ligeira inclinação à esquerda. A poltrona estofada com franjas nas laterais, comum nos retratos realizados no interior dos estúdios, acomodava Angela Rosa Maria Claps, retratada em ambiente externo. Na construção da melhor imagem de si não abrio mão de certos aparatos recorrentes. Signos da casa moderna transitavam nas imagens que indiciam a passagem dos fotógrafos ambulantes.

Pouco se disfarçava a simplicidade do ambiente externo. Segundo Alberto Baldi, os fotógrafos que atravessam as diversas comunas lucanas, se concentravam em outros elementos da imagem, os quais julgavam mais importantes, a saber, rostos, penteados, roupas, ornamentos e enfeites, sendo o mais relevante, aquilo que o autor chama de "la convencionalità della posa", inscrita dentro de um jogo controlado por aspectos formais, carregados de sentidos socialmente reiterados, no qual os retratistas reconhecem e se movem, compartilhando seus códigos. A artificialidade da encenação expressava na verdade uma consciência imbricada à feitura do próprio retrato: "uma sua consistência, uma sua densidade que, de fato a modela, a trasforma em pré-requisito essencial em torno do qual acontece essa circulação incessante, este denso movimento de idas e vindas de fotos de uma família para outra, de um país para outro, de um continente para outro" (Baldi, 2004, p.20).

Não se trata de observar a verossimilhança ou existência de um mesmo real verificável, mas sim o evidente uso dos mesmos códigos expressivos compartilhados na construção de fotografias que tentavam se distanciar da cotidianidade, fazendo esquecer a vida dura ou simplesmente monótona que muitos retratados vivenciavam. A produção de retratos da Itália meridional guarda, para o pesquisador Alberto Baldi, uma especificidade que a diferencia daquelas imagens produzidas sob motivação do desejo narcísico de representação, de atestação e promoção de um status social. Posar para o retrato significava subtrair tempo de trabalho e gastar muito dinheiro. A produção de retratos dos grupos tidos como "classes subalternas meridionais", apesar de altamente ritualizada, num complexo de expressões codificadas, se realizava na verdade por necessidade, assumindo uma importante função social de atestar tão somente a própria existência, a presença enunciada por meio de um processo de comunicação visível, vital no seio de áreas afetadas por um analfabetismo endêmico. A foto, para Baldi, se colocava para as províncias ao sul, como um substituto da palavra escrita: 
Com o retrato de um homem ou de uma mulher, de um casal de noivos com os "compadres", dos pais juntamente com seus filhos, de uma mãe sozinha com o caçula, de um grupo de amigos se autenticam assim, se impõem e reforçam certos valores e normas determinadas, vínculos e relacionamentos humanos, mas também se reconstrõem, se sacralizam e se eternizam, sobre um plano meta-histórico, laços de parentesco e de afeições que as distâncias, o tempo e a morte dissolveram. (Baldi, 1999, p. 149. Tradução nossa.)

Nesta "particular forma de comunicação visual confiada à fotografia", Angela escolheu o típico vestuário das mulheres solteiras, conhecido na região como "vagnarde". Atestava-se pelo caráter denotativo da imagem uma condição civil que talvez almejasse modificar. Apenas às solteiras era possível este retrato frontal; às demais, frequentemente dirigiam com prudência o olhar distante e inexpressivo para fora do campo fotográfico, preservando algo potencialmente insinuante. Casadas ou solteiras, segundo Baldi (2004, p.38), as mulheres posavam na maioria das vezes para retratos de meio busto, retratadas ao centro na foto de grupo familiar apenas quando viúvas ou porque seus maridos vivenciavam as guerras; quando retratadas de corpo inteiro exibiam roupas festivas, adornos e acessórios, mantendo quase sempre, as mãos unidas, apoiadas sobre o colo, num gesto que exprime contenção. Eliminavam as cenas cotidianas da vida agrária, onde se encontravam "sujas da terra e da pobreza".

Os fotógrafos que mantinham pequenos estúdios abertos em mais de uma comuna apareciam em um deles aos sábados para atender a clientela que esperava o final de semana chegar. No outro, já ofereciam seus serviços em outra comuna vizinha. Tratamos de serviços fotográficos oferecidos em diversas circunstâncias, com uma clientela ciente da pouca variedade de soluções e oportunidades de representação, justifica Baldi (2004, p.44).

Muitas vezes, a população de uma comuna podia contar com um fotógrafo local, nascido no seio da comunidade que retratava. Nicola de Carlo (1841-1913), nascido na comuna de Ruoti, na província de Potenza, a partir de 1881 passou a percorrer outras comunas para ampliar seus ganhos. Avigliano, Picerno, Bella, Balcano, Savoia e Baragiano inscrevem o trânsito desse fotógrafo que emigrou para os Estados Unidos em 1898; ${ }^{108}$ no ano seguinte o próprio Vincenzo Pastore também deixaria a Itália.

\footnotetext{
108 Nicola De Carlo abriu estúdio em Nova York na Rua 121, Baxter Street, contando com a ajuda de seu filho Giuseppe que já havia aprendido o ofício em Ruoti. Frente à forte concorrência da cidade, se transferiram para Filadélfia onde fundaram o estúdio "Nicola De Carlo e Figli". A atuação de ambos foi marcante no registro de famílias imigrantes. In: Bronzini, Giovanni Battista. Lares, Trimestrale di studi demoetno antropologici. Ano LX, n.4. Firenze: Leo S. Olschki. Outubro-dezembro de 1994, p. 567. Arquivo Comunale di Potenza.
} 


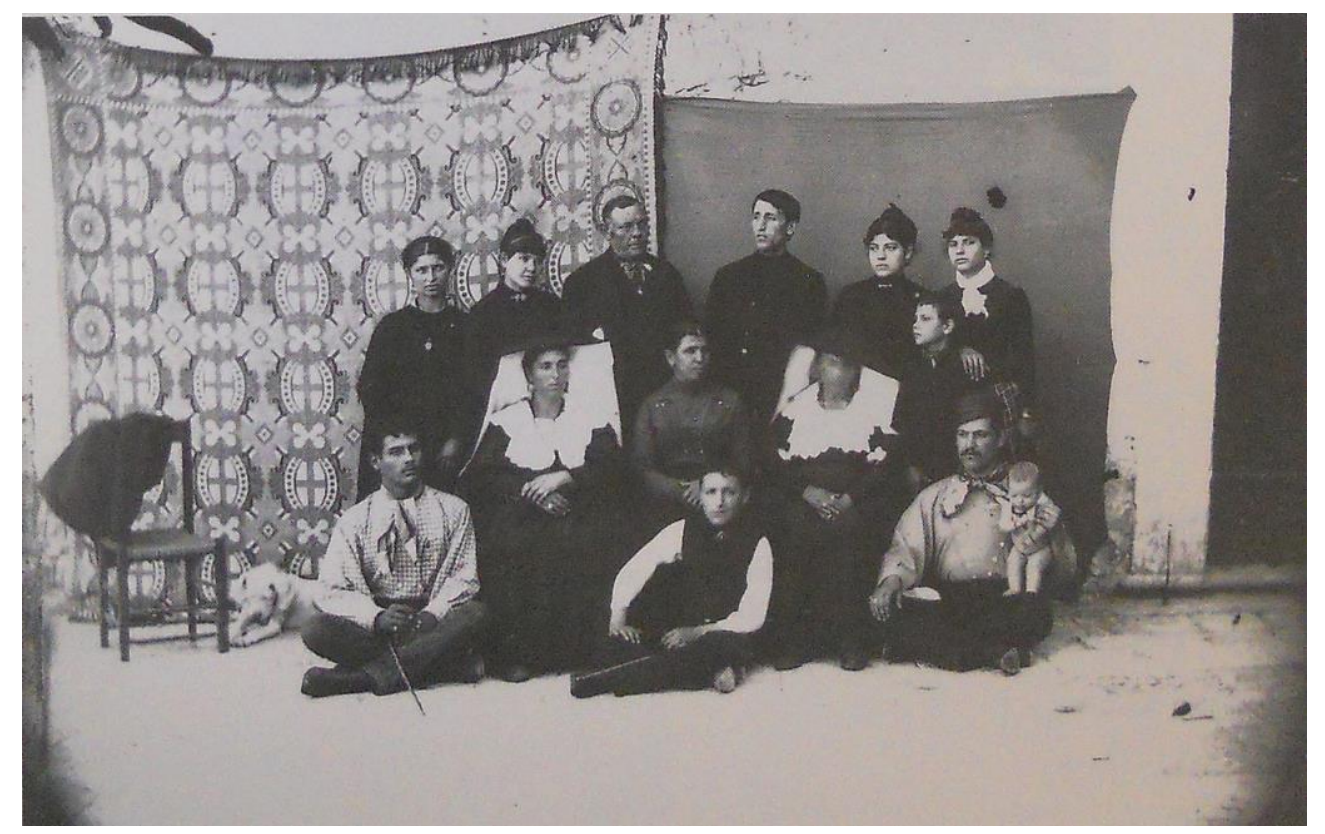

Figura 92:

Foto classificadas em acerco como retrato de família. S/d (C) Foto Nicola de Carlo. In: Bronzini, Giovanni Battista. Lares, Trimestrale di studi demoetno antropologici. Ano LX, n.4. Firenze: Leo S. Olschki. Outubrodezembro de 1994, p. 576.

De Carlo foi também um “contadini”. Quando não estava em seu estúdio, que apresentava simples mobiliários percorria outras comunas, realizando retratos onde se improvisava o cenário de atelier (fig.92). Os panos pregados a parede se forjavam de fundos. Em seus trajes típicos de festa a família era retratada dando a ver o "cerimonial, o evento, a solenidade" do ato fotográfico; momentos em que muitas vezes os retratados em suas comunas "eram constrangidos, obrigados a imitar a pose e os modos burgueses e aristocráticos dos clientes ricos" (Manaro, 1994, p. 572).

O arranjo feito por Nicola De Carlo posicionava os retratados de modo diverso: alguns em pé, três mulheres sentadas em banco ou cadeiras, e outros ao chão. No canto esquerdo o cachorro da família encontrou o seu lugar. Para Manaro fotografias horizontais eram em geral preponderantes na representação dos contadini, quase sempre retratados em família ou em grupos.

Tratamos aqui de imagens que ajudam a recuperar e reconstituir as experiências vividas pelos retratados nas diversas comunas da antiga Lucania. Imagens entendidas por Baldi (2004) como fragmentos que recompõem aspectos da vida, da história e dos costumes ajudando a documentar historicidades da Lucania. Fontes que estão na maioria das vezes, dispersas, destruídas ou que permanecem sob domínio familiar. Uma memória visual que não alcança as estruturas institucionais de guarda. Estudos sobre a fotografia da Basilicata 
apontam como muitas comunas da região não dispõem ainda hoje de investigações capazes de oferecer com profundidade "um perfil orgânico de seu desenho histórico". Dificuldade essa que atingi também as chances de sobrevivência dos documentos fotográficos. A única foto encontrada como produção de Pastore em Potenza, introduzida logo no início desse capítulo, foi aquela que conseguiu chegar até nós, indiciando sociabilidades que se estendiam por toda Lucania.

São múltiplas as razões sugeridas para explicar aquilo que Baldi nomeia como "vazio documental", deixando à sombra inúmeras experiências na história política, cultural e social lucana:

A dificuldade objetiva de se encontrar novas fontes documentais concorreu, sem dúvida, a ausência, por muitos anos, de um sério programa de recuperação e reorganização não só dos arquivos municipais, mas também de aquisição - talvez através da instituição de uma consulta para a valorização do patrimônio documental visual, literário e artístico envolvendo entidades públicas e privadas - de fundos arquivísticos privados que, nesse ínterim, foram muitas vezes perdidos ou destruídos. (Baldi, 2004, p. 9. Tradução nossa)

Em nossas consultas realizadas em diversos arquivos potentinos, por exemplo, nos deparamos com uma quase total ausência de documentos iconográficos. Muitas instituições não dispunham de acervo fotográfico. Outras não tinham sequer uma única foto original, um único álbum familiar disponível aos pesquisadores. A fotografia da Basilicata enquanto fonte para os estudos históricos apenas em fins da década de 1980 passou a despertar maiores atenções, o que de certo modo, ajuda a explicar a ausência do material visual nas maiores instituições históricas potentinas, apesar da surpreendente produção de retratos feitos dentro e fora dos estúdios por toda a região. Ao indagarmos o professor e pesquisador Baldi sobre essa percepção, ele confirmou que de fato fontes escritas foram até recentemente privilegiadas nos estudos da história do cotidiano.

Apesar do pouco avanço nos estudos sobre a fotografia da Basilicata conseguimos indiciar o acirrado circuito da fotografia da região onde Pastore residiu apenas por um ano já que, em 1899, o fotógrafo passou a se anunciar na capital paulista.

Diante de tal contexto, Pastore preferiu imigrar, tentando se distanciar da condição de itinerância. Em sua escolha, Nápoles, Salermo e até mesmo Bari, a sua província natal, foram preteridas a São Paulo que ao menos aparentemente prometia condições mais favoráveis. Mas como a trajetória desse fotógrafo foi marcada por um incessante ato de recomeçar, depois de 
trabalhar por quinze anos na "industriosa"109 São Paulo, Pastore decidiu retornar a sua província natal. No ano de 1914 abriu seu estúdio em Bari, iniciativa que documentaremos a seguir.

\subsection{Pastore em seu "templo de arte": um interessante circuito de exposições}

Contar a história do estúdio Ai Due Mondi-Fotografia Italo-Americana é contar um sonho. Vincenzo Pastore no ano de 1914 reuniu todas as economias acumuladas em São Paulo e abriu seu estúdio na capital da província pugliese. Causou verdadeira comoção entre os moradores bareses. Seu trabalho foi recebido com entusiasmo, reconhecido como uma conquista de toda a região ao sul da Itália.

Na "Piccola Cronata", publicada no jornal Corriere Delle Puglie, mostram-se vestígios do acolhimento dado a Pastore, prestigiado por um público "que julgava com um alto senso de justiça da qual se falava com entusiasmo em toda a província de Bari e fora dela". ${ }^{110}$

O estúdio em Bari ocupava um ponto estratégico nas feições espaciais que a cidade adquiria. A imponente e "magnífica" Rua Sparano, hoje endereçando um circuito comercial de prestígio na cidade, já em 1914, era a principal rua de ligação entre a Estação Central de Trem e a Città Vecchia, que concentrava a maior parte de seus habitantes. Entre esses dois extremos, facilmente percorrido, uma Città Nuova crescia abrigando os símbolos de progresso urbano em expansão: A rua Sparano termina exatamente na principal avenida barese, a Corso Emanuelle II que delimita a divisão entre a nova e a velha cidade.

Além da expansão urbana vivenciada em Bari, outros aspectos ajudam a sondar o desejo de Pastore de retornar a sua província natal. Andar pelas ruas da Città Vecchia, ou pela Praça Humberto I, ligadas pela "Via Sparano", ajuda a entender a dimensão daquilo que Pastore possivelmente tentava resgatar. Bari, ainda hoje é uma cidade resistente a novos costumes, mantendo ainda vivas relações estreitas de vizinhança, laços firmados na proximidade de cada casa com suas portas dispostas lado a lado. Cortinas quase sempre brancas e muito rendadas delimitam a intimidade dos lares e o movimento de gente, sendo muitos visitantes de fora, que caminham nas estreitas e antigas ruas de pedras largas; ruas feitas de quintais onde cadeiras e

109 Coleção Dante Pastore. In: Caderno de Recortes de jornais, p. 53. Jornal Corriere Delle Puglie. 13 de dezembro de 1914. Todas as traduções de recortes de jornais que integram a Coleção Dante devem ser consideradas como tradução nossa

110 Coleção Dante Pastore. In: Caderno de Recortes de jornais, p. 53. Jornal Corriere Delle Puglie. 13 de dezembro de 1914. Tradução Nossa. 
varais dos moradores compõem um cenário de conversas ritmadas pela brincadeira de crianças e pela intensa convivência da qual parecem não abrir mão.

$\mathrm{O}$ primeiro vestígio que ajudou a documentar o retorno de Pastore à sua província, depois de viver por 15 anos em São Paulo, ou seja, uma década e meia ganhando dinheiro no Brasil, foi encontrado na revista A Vida Moderna, no dia 8 de janeiro de 1914. O fotógrafo que tentava de tudo para sobreviver de seu ofício firmou um contrato verbal com a revista paulistana, a qual se desculpava com seus assinantes porque o "sr. Pastore", que havia se comprometido em fotografar todos os assinantes gratuitamente, "fornecendo um exemplar a cada um", teria partido. A revista que tinha como "intuito augmentar o numero de vantagens que offerece aos seus assignantes", ${ }^{111}$ via-se obrigada a explicar o ocorrido.

O fotógrafo teria enviado uma carta ao diretor da revista informando o recebimento de um telegrama urgente obrigando-o a partir para a Itália. Sua demora "no estrangeiro" seria de 3 a 4 meses, prometera. Preocupados com os assinantes pensarem que tudo não havia passado de um engodo querendo os iludir, a revista reafirmava a suposta promessa de Pastore: "estamos certos que logo que regresse da Europa, há de cumprir o que conosco tratou". ${ }^{112} \mathrm{O}$ motivo urgente talvez omitisse a circunstância real da viagem: abrir um estúdio em Bari com uma grande e aclamada exposição, onde aproveitou para mostrar aos seus compatriotas os trabalhos realizados no Brasil.

\footnotetext{
${ }^{111}$ Sic. Revista A Vida Moderna. 8 de janeiro de 1914. n. 203.

112 Revista A Vida Moderna. 8 de janeiro de 1914. n. 203. Foi impresso em outra página, nesta mesma edição do mês de janeiro, outro comunicado avisando aos assinantes da impossibilidade de serem fotografados nos próximos meses, reiterando a cobrança ao fotografo para que continue a realizar os retratos quando de sua volta. No mês de outubro de 1914 anunciam o estúdio de Pastore colocando na capa da revista um retrato feito por ele, mas não mencionam mais a oferta prometida aos clientes de terem um retrato gratuito feito pelo fotógrafo.
} 


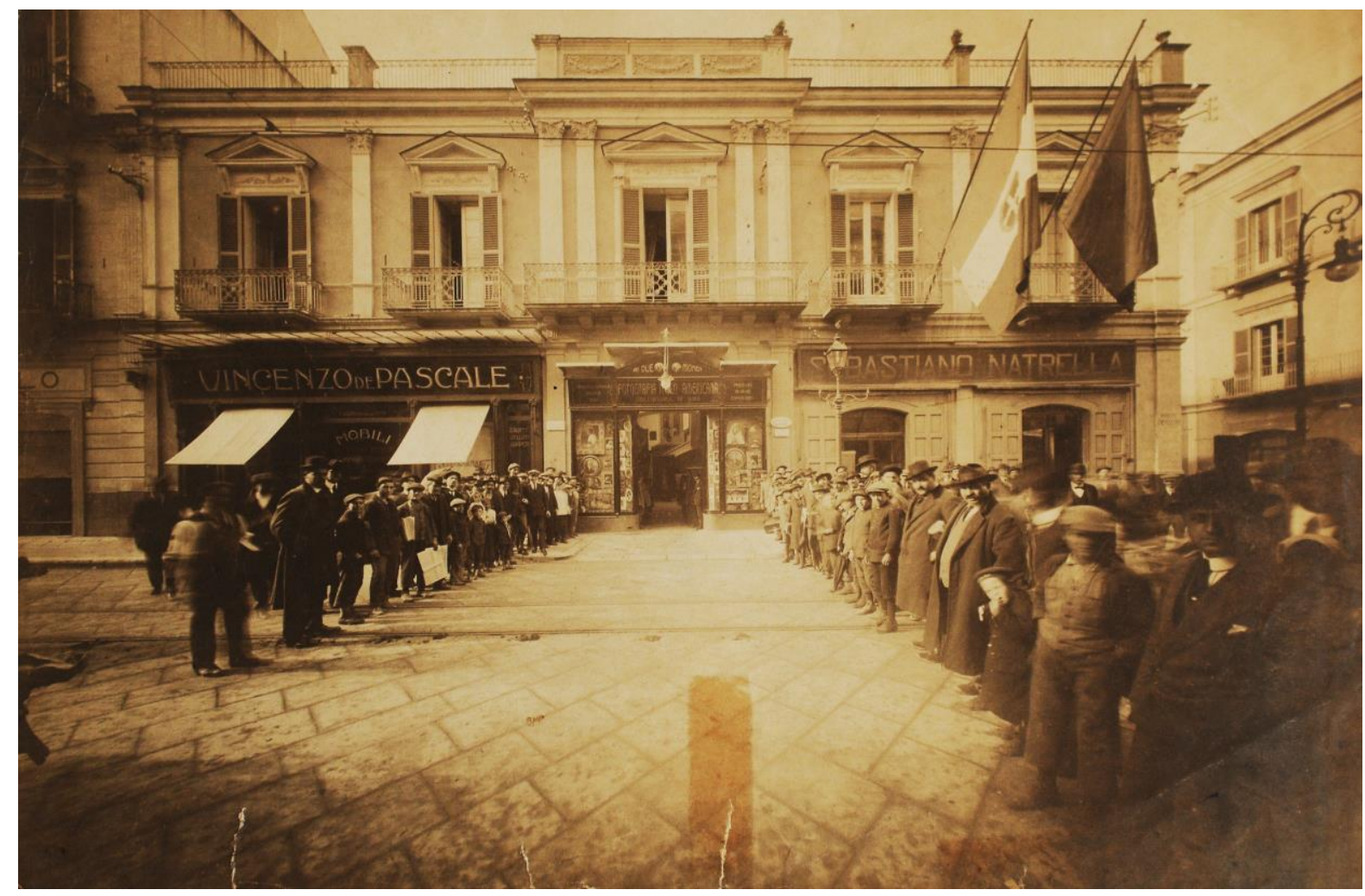

Figura 93: Foto tomada na frente do estúdio de Pastore aberto em Bari na Via Sparano, n. 117, uma das principais ruas comerciais da cidade. Bari, Itália. 12 de abril 1914 () Vincenzo Pastore / Coleção Dante Pastore.

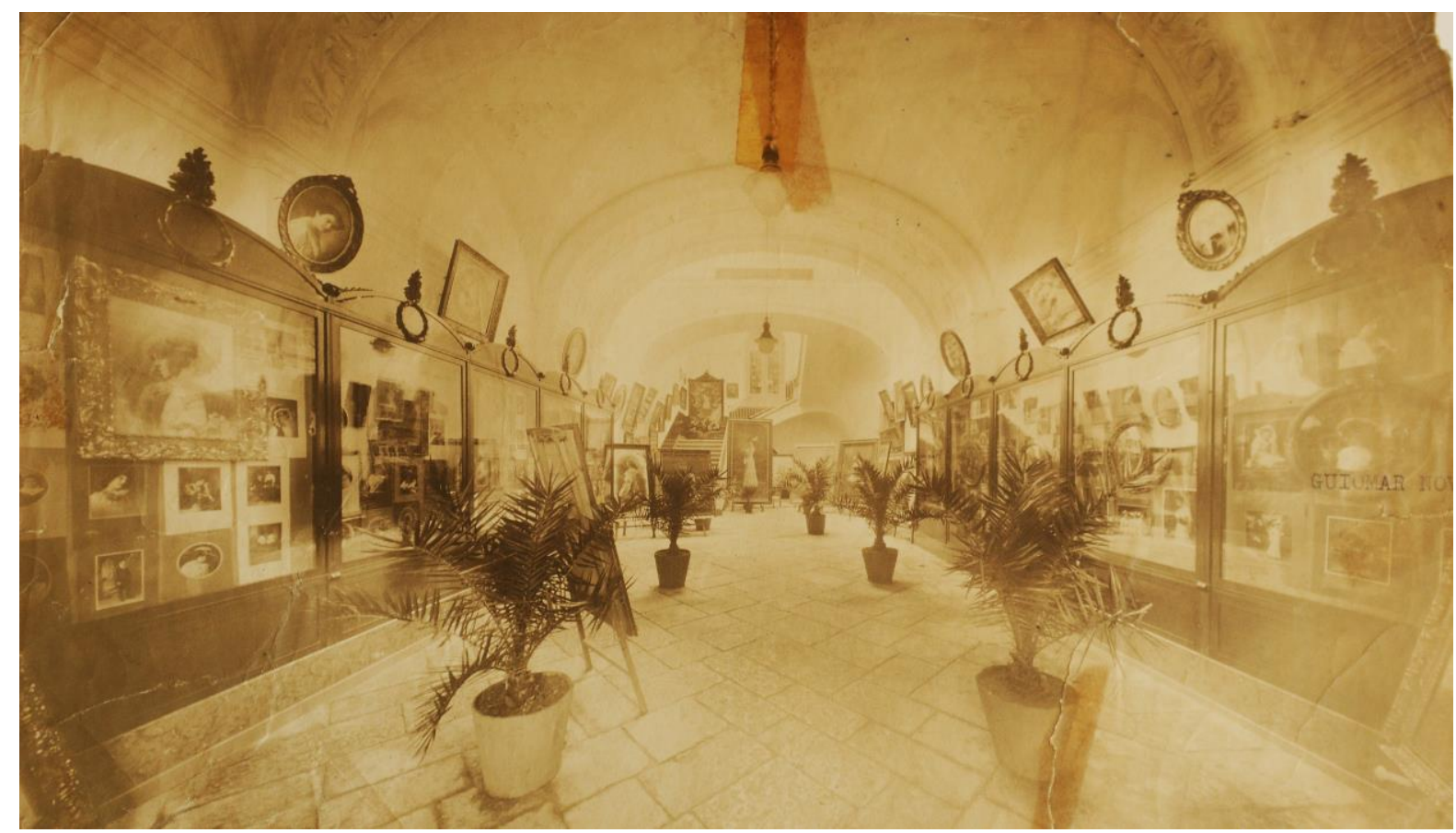

Figura 94: Fotografia feita no piso térreo do sobrado ocupado por Vincenzo Pastore. Nesta passagem que levaria ao primeiro andar o fotógrafo organizou uma mostra permanente de retratos e, pequeno, médio e grande formato, possivelmente realziada no mesmo dia da foto externa acima apresentada. Bari, Itália. Sem data @V Vincenzo Pastore Coleção Dante Pastore. 
O estabelecimento anunciado como uma "bela jóia" foi inaugurado com uma exposição organizada pelo fotógrafo. A população local conferia "estarrecida a mais brilhante expressão artística" produzida pelo cidadão que retornava de sua experiência de imigração, enaltecida em vários textos de divulgação. Retratos em grande formato foram emoldurados ao gosto das exibições mais formais e apresentados no tempo-espaço do quase museu criado por Pastore (fig.94). Um museu aberto ao público que formou fila curiosa do lado de fora para ver a mostra. Pastore não perdeu a chance de organizar e registrar esse momento (fig.93).

No artigo "Il grande e moderno Stabilimento Fotografico del Sig. Vincenzo Pastore", vê-se elogios nada comedidos, demonstrando o quão impactante foi a mostra apresentada sob "feixes de luzes, frisos decorativos, vitrine de luxo, exposições elegantes". ${ }^{113} \mathrm{O}$ trabalho de "beleza fascinante" foi apresentado desde o piso térreo do sobrado, passando pelas escadas ao fundo até se chegar à sala de espera, no andar superior; fotografias com temas variados mostravam "os mais perfeitos e distintos processos da arte". ${ }^{114}$ Vasos decoravam o centro da imagem feita no andar térreo. O repertório visual realizado em São Paulo estava ali exibido aos visitantes bareses. Retratos foram ampliados em grandes quadros com molduras douradas ou em bronze; outros foram fixados nas paredes- vitrines estendidas por toda a entrada. $\mathrm{O}$ artigo parabenizava o distinto trabalho de Pastore, pontuando a rica diversidade da mostra criada para ser permanente, o que sugere o quanto Pastore pouco deseja retornar ao Brasil:

\begin{abstract}
Basta dirigir-se até lá para notar todo o florescimento de fotografias de todos os tamanhos, desde a miniatura até a natural, de todos os estilos, todas as poses, todos os sistemas que as mais avançadas pinceladas da arte produziram sobre papel, sobre tela, madeira, porcelana, zinco, de todos os jogos de luz e sombra: tudo isso recolhido por uma familiar elegância e luxo agrupador e expositivo que leva ao fascínio, ao grito de milagre, ao entusiasmo por esse nosso artista tão jovem e valoroso que desconfianças, infortúnios, dificuldades de todo tipo felizmente superou para dar a Bari aquilo de que ela precisava. ${ }^{115}$
\end{abstract}

Técnicas de fotografia a carvão e fotos em relevo foram citadas em vários artigos como trabalhos inesquecíveis. Afirmava-se que a precisão nos registros em alto relevo e naqueles em tamanho natural foram de uma magnitude que "ainda não se conseguiu na Itália!".

\footnotetext{
${ }^{113}$ Coleção Dante Pastore, In: Caderno de Recortes de jornais.

${ }^{114}$ Coleção Dante Pastore, In: Caderno de Recortes de jornais, p. 29. Risveglio Commerciale. Bari, 21 de novembro, 1914. Tradução nossa.

115 Coleção Dante Pastore. In: Caderno de Recortes de jornais, p. 29. Risveglio Commerciale. Bari, 21 de novembro, 1914. Tradução nossa.
} 
Visitantes afirmaram que se a mostra não era tão grande, havia sido inédita naquele país. ${ }^{116}$ Percorria-se os cômodos do estabelecimento com um "verdadeiro prazer intelectual", deixando a sensação de Bari ocupar um lugar na produção da arte mundial:

Bari, espalhando a cada dia, nas instalações magníficas na Rua Sparano, toda a nossa verdadeira elite e uma multidão de pessoas em êxtase, demonstra ser capaz de entender a arte em todas as suas grandiosas manifestações e de saber bem como compensar os esforços, os suores, a tenacidade e a audácia de seus filhos trabalhadores, talentosos e honestos. ${ }^{117}$

Deve-se ressaltar o volume de artigos e notas saudando a inauguração do estúdio com “admiração e louvor", em nome de todos os cidadãos bareses. Além de ricas descrições de seu interior, denotam a repercussão social alcançada pelo fotógrafo e todo desejo desses agentes de divulgação em superar os limites da província.

Com a instalação da grande filial do estúdio fotográfico italo-americano, Bari inteira teve a impressão de encontrar-se em pé de igualdade com grandes cidades do novo mundo, e com tal perspectiva o entusiasmo e o delírio chegaram ao ponto mais alto. Independentemente do que foi descrito em termos genéricos por outros periódicos, nós quisemos nos demorar um pouco no vasto estúdio fotográfico, que é um verdadeiro ninho de elegância e gosto artístico impressionantes. ${ }^{118}$

O fotógrafo que sonhou em regressar à terra de origem recebeu felicitações vindas também de Milão:

Aqui de Milão, de onde talvez mais do que em qualquer outro lugar, apreciase e admira-se a energia soberba que honra o país com a poderosa arma do trabalho e da honestidade, ao artista valoroso da Puglia enviamos na feliz ocasião a mais viva felicitação com que desejamos à nobre iniciativa que seja correspondida com o maior e mais merecido sucesso. ${ }^{119}$

Ai Due Mondi, Fotografia Ítalo Americana foi o nome colocado ao centro da entrada principal do edifício, anunciado algumas vezes como sucursal do estúdio de São Paulo, que havia sido na verdade fechado. Elvira, em seu diário, afirmou ter sido um golpe de sorte retornarem e conseguiren ocupar o mesmo endereço.

\footnotetext{
${ }^{116}$ Coleção Dante Pastore. In: Caderno de Recortes de jornais, p. 33. Artigo: "Indimenticabile festa del lavoro". Tradução nossa.

117 Coleção Dante Pastore. In: Caderno de Recortes de jornais, p. 33. Artigo "Indimenticabile festa del lavoro". Tradução Nossa.

118 Coleção Dante Pastore. In: Caderno de Recortes de jornais. Tradução Nossa.

${ }^{119}$ Coleção Dante Pastore. In: Caderno de Recortes de jornais, p. 57. Tradução Nossa.
} 
Aqueles que queriam visitar o estúdio ficaram atraídos por duas bandeiras: a italiana e a brasileira. ${ }^{120}$ A experiência adquirida na "cosmopolita São Paulo", dava distinção ao fotógrafo, rompendo com uma conhecida visão naturalizada na introjeção de uma perspectiva eurocêntrica. São Paulo era citada como a referência de modernidade:

Bari inteira soube dar a sua modesta homenagem de afeto e simpatia ao seu compatriota, um trabalhador que, depois de ter trazido o seu trabalho realizado longe de sua terra natal, depois de ter aperfeiçoado e obtido a aprovação da industriosa São Paulo retorna à sua terra, coberto de louros e de um nome invejável. ${ }^{121}$

No "belo cenário" criado no estúdio barese, Pastore fixou um quadro que causou admiração pelos "vários autógrafos com palavras elogiosas de homens iminentes, entre os quais Guglielmo Ferrero, arcebispo de São Paulo, Exmo. Leopoldo Duarte, etc”; o próprio fotógrafo mobilizava o prestigio obtido na São Paulo "industriosa" reunindo cartas de amigos conterrâneos e artigos publicados jornais, enaltecendo "a grandeza e as proezas do estabelecimento", aberto no Brasil.

Em uma bela moldura, pode-se admirar - entre os muitos quadros - um que recolhe os vários atestados emitidos pelas autoridades do Brasil, os muitos artigos de jornais que louvam a grandeza do estabelecimento e a proeza do Sr. Pastore. Nós gostaríamos de publicar a seguinte carta que um nosso concidadão, tendo vivido muito tempo no Brasil, escreveu para Sr. Pastore após tê-lo re-encontrado, com alegria, em Bari. ${ }^{122}$

A carta, testemunha do reencontro e da convivência compartilhada na capital Paulista, estava exposta no quadro acima citado. Além do arranjo desajeitado da confluência entre o português e o italiano, desvelam-se laços de solidariedade construídos além-mar.

Ao eminente Photografo,

Parabeis (congratulazioni) pela bôa recorda con Paulista desejando. Che feliz esito que umito valor mostraste en S.Paulo gloriando a Colonia Italiana. Un seu admirator Paulista. (Pasquale Salvatore- Cavour 126 Bari). ${ }^{123}$

Outros artigos davam destaque à atuação de Pastore no Brasil, onde "manteve sempre em alta o prestígio da nossa Itália". ${ }^{124}$ Algumas vezes se exagerava o período de permanência de

\footnotetext{
${ }^{120}$ Coleção Dante Pastore. In: Caderno Recortes de jornais, p. 26. Reportagem A Bari L'esposizione di un nostro concittadino. Tradução Nossa.

121 Coleção Dante Pastore. In: Caderno de Recortes de jornais, p. 44. Jornal Corriere Delle Puglie. 22 de novembro de 1914. Tradução Nossa.

${ }^{122}$ Coleção Dante Pastore. In: Caderno de Recortes de jornais, p. 33. Artigo "Indimenticabile festa del lavoro".

${ }^{123}$ Coleção Dante Pastore. In: Caderno de Recortes de jornais, p. 33. Artigo "Indimenticabile festa del lavoro".
} 
Pastore em São Paulo. Em "Picola cronaca" afirmam os supostos "trinta anos transcorridos no distante Brasil", onde teria alcançado uma posição "moral e materialmente privilegiada". ${ }^{125}$ Pastore permaneceu no Brasil, contudo por dezoito anos.

$\mathrm{O}$ verso do cartão postal oferecido por Pastore a sua clientela barese (fig.95) indícia o quanto a aproximação de dois mundos vinha como retórica textual e gráfica explorada pelo fotógrafo, conferindo-lhe destacada distinção, sobretudo, em sua terra natal, onde afirmara a sucursal de São Paulo como atributo qualificador.

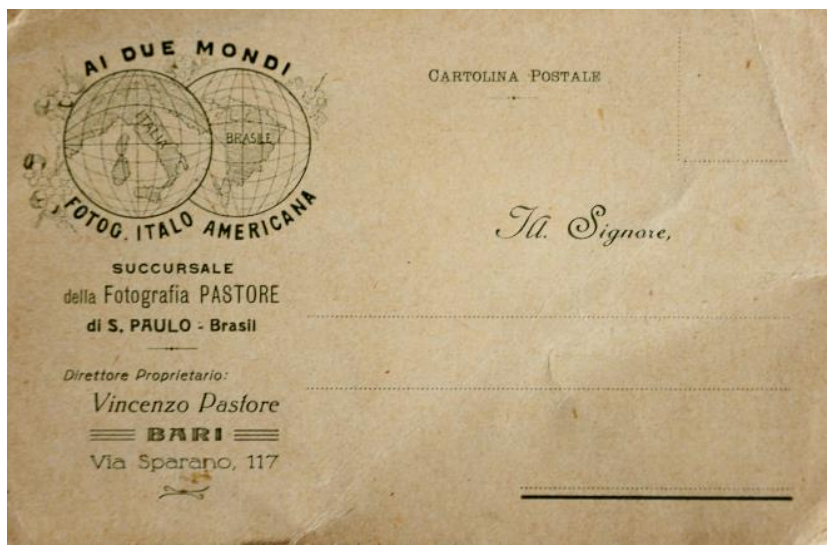

\section{Figura 95:}

Reprodução de verso de cartão postal possivelmente comercializado em Bari, entre os anos de 1914 e 1915. Coleção Dante Pastore.

A cultura dinâmica do retrato, marcada pelo ir e vir daqueles que viviam desse ofício, trancendia a visão de dois continentes na criação da identidade do fotógrafo que "tudo fez para honrar este nosso compatriota, que abandonou toda uma florescida reputação e posição, abandonou clientes e renda promissora, adquiridos pela lida de trabalho honesto para dar o que estava faltando em Bari”. ${ }^{26}$

Ao redor da fachada do estúdio retratos realizados no Brasil foram emoldurados e colocados na vitrine externa. Propomos aqui um recorte na foto para melhor mostrar a variedade de retratos expostos (fig.96) que expressavam o "poder de sua arte” já evidenciado logo na entrada, segundo artigo intitulado “A exposição do nosso concidadão”. Nuançava-se a dimensão do volume de trabalho realizado no Brasil: "A infinidade de trabalho exposto, prova como a arte requintada do Sr. Pastore, proprietário do estabelecimento, nos faz pensar

${ }^{124}$ Coleção Dante Pastore. In: Caderno de Recortes de jornais, p. 36. Artigo "L'inaugurazione di un nuovo Stabilim. Fotografico ítalo-americano". Tradução Nossa.

125 Coleção Dante Pastore. In: Caderno de Recortes de jornais, p. 42. Jornal Corriere Delle Puglie. "Picola Cronaca Alla Grande Fotografia Artica italo-americana". Tradução Nossa.

${ }^{126}$ Coleção Dante Pastore. In: Caderno Recortes de jornais, p. 46. Tradução Nossa. 
com orgulho sobre o fluxo de pessoas de todas as classes que se reuniram para o nosso conterrâneo quando ele estava na América”. ${ }^{127}$

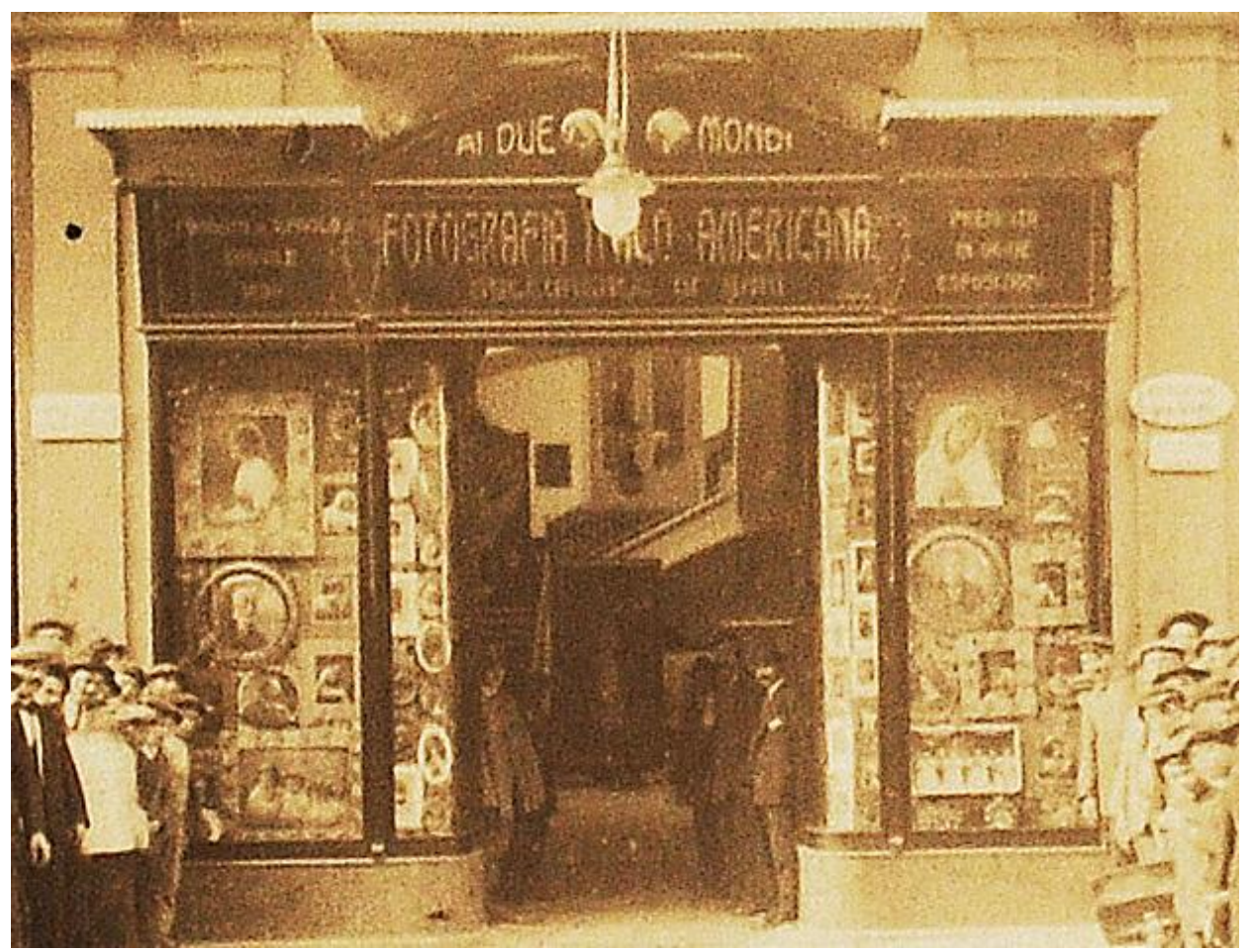

\section{Figura 96:}

Reprodução de detalhe da fachada e da vitrine do estúdio de Vincenzo Pastore. Bari, Itália. 12 de abril 1914. Coleção Dante Pastore.

Outros artigos, no entanto, tentavam distinguir a clientela de Pastore, dando sinais de que na mostra alguns retratos apresentados já teriam sido realizados na Itália:

O número dos trabalhos expostos, todos bonitos, todos valiosos, finalmente revelam não só o trabalho do fotógrafo, mas dão indícios da qualidade e do tipo de clientela que posava do outro lado do oceano e daquela que começou a posar aqui: a grande clientela com a qual só um verdadeiro artista pode se comprometer e pela qual somente ele pode dar o merecido valor ao seu trabalho. ${ }^{128}$

Pastore, ao compor a fotografia do dia da inauguração do estúdio colocou parte dos visitantes e talvez transeuntes curiosos enfileirados, dando perspectiva a foto externa do estúdio. O eloqüente artigo publicado no jornal Corriere Delle Puglie, retrata aquilo que Pastore queria registrar nesta imagem (fig.93): a grande multidão que se concentrou na frente do estúdio, mal era contida pelos agentes de segurança municipais enviados, segundo texto impresso na coluna intitulada "I Sucesssi nel Brasile”. Já no artigo “A Bari L'esposizione di

\footnotetext{
127 Coleção Dante Pastore. In: Caderno Recortes de jornais, p. 47. Nota intitulada "L'ammirazione per La fotografia ítalo-Americana".

${ }^{128}$ Coleção Dante Pastore. In: Caderno Recortes de jornais, p. 49. Jornal Corriere Delle Puglie.
} 
un nostro concittadino”, afirma-se que tal multidão havia esperado à noite, apesar da chuva, para assistir ao cinematografo e participar do programa musical organizado por Pastore. ${ }^{129}$

Detalhes da celebrada inauguração nos aproximam dos esforços do fotógrafo: "Durante o dia, a música tocou sempre no estabelecimento Pastore onde uma grande multidão se concentrou mal contida pelos agentes de segurança enviados para lá pelo Comissário da seção San Ferdinando". A conquista de Pastore era relatada lembrando-se dos "fotógrafos talentosos movidos pelo sucesso longe de sua casa":

A noite foi mostrado ao público um excelente programa cinematográfico que divertiu muito. Assim realizou-se o evento que durante vários dias anunciamos nesta coluna, e tivemos razão para prever que seria tão importante a ponto de impressionar todos os cidadãos. De fato, ontem, em todos os locais públicos da cidade e pelas ruas, o tema das conversas era a inauguração do estabelecimento fotográfico ítalo-americano e a solenidade que havia conferido elementos diversos à cerimônia. Os mais céticos elogiavam o nobre impulso que levou Pastore a criar em Bari uma digna sucursal de seu grande estabelecimento no Brasil e seu valor na arte, que todos puderam apreciar observando as fotografias, cada uma das quais representando uma pequena obra-prima. ${ }^{130}$

Deve ter sido com muita satisfação que Pastore recebeu os numerosos visitantes, entre eles políticos e vários membros da Igreja, que não deixaram de abençoar o novo estúdio: "na conversa também estava presente o bispo Monsenhor Lamberti acompanhado por vários sacerdotes para a bênção do estabelecimento". ${ }^{131}$ Todos tomavam o piso térreo para ver a exposição que expande o conceito de museu: "o público numeroso que se amontoava no salão do piso térreo da exposição espalhava-se também pelos aposentos do primeiro andar". ${ }^{132}$ Champagne foi oferecida a todos os convidados. As fontes indicam a presença do prefeito, de tenentes, vice-cônsul e outras personalidades notáveis de Bari, que percorriam a mostra ao som de músicas que alegravam o ambiente. ${ }^{133}$

\footnotetext{
${ }^{129}$ Coleção Dante Pastore. In: Caderno Recortes de jornais, p. 26. Reportagem A Bari L'esposizione di un nostro concittadino. Tradução Nossa.

${ }^{130}$ Coleção Dante Pastore. In: Caderno de Recortes, p. 25. Jornal Corriere Delle Puglie. N.318. Tradução Nossa.

${ }^{131}$ Coleção Dante Pastore. In: Caderno de Recortes de jornais, p. 36. Artigo "L'inaugurazione di un nuovo Stabilim. Fotografico ítalo-americano". Tradução Nossa.

132 Coleção Dante Pastore. In: Caderno Recortes de jornais. Tradução Nossa.

${ }^{133} \mathrm{Em}$ quase todos os artigos não havia nenhuma economia de elogios, fazendo referência a tais presenças no dia da inauguração: "Ao longo do dia, houve um verdadeiro plebiscito. A benção foi dada pelo Bispo Monsenhor Lamberti em presença das personalidades mais notáveis de Bari, entre os quais: Sua excelência o Senador Balenzanno, o prefeito Comendador Facciolati com o chefe de gabinete Cav. Lamarqne, TenenteGeneral Mazzoli e cav. De Grecis vice-cônsul do Brasil. Após a benção, enquanto a música alegrava as muitas pessoas que admiravam a exposição; Pastore ofereceu champagne às autoridades. Ao valoroso artista que
} 


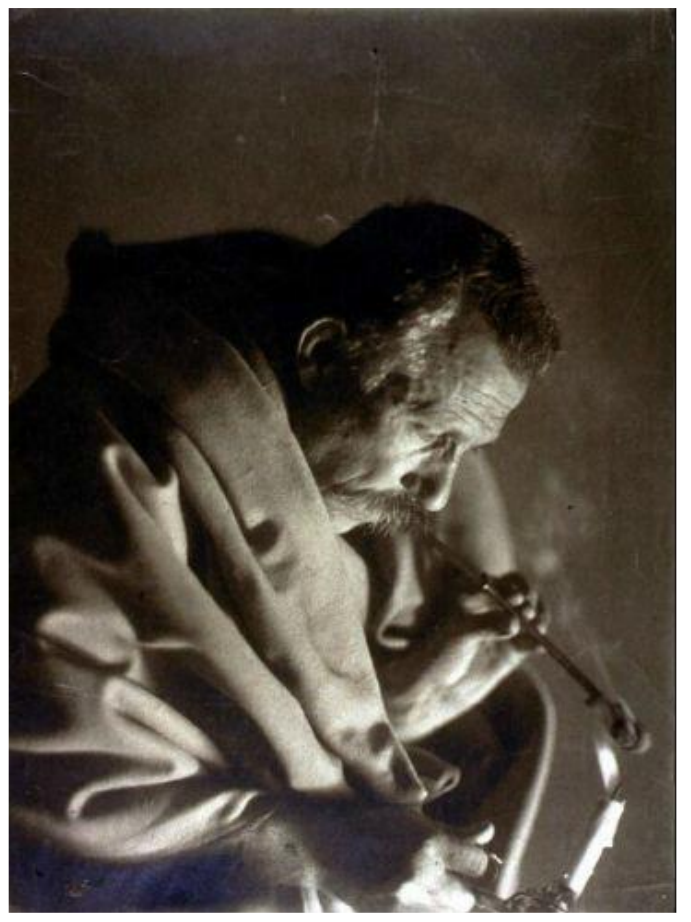

\section{Figura 97:}

Auto-retrato de Vincenzo Pastore.

S/d. Instituto Moreira Salles.

O auto-retrato do fotógrafo (fig.97) foi exposto logo na entrada de seu estabelecimento. O uso da goma-bicromatada enunciava Pastore em diálogo com os procedimentos da fotografia artística:

Mais à frente, ainda à esquerda, o retrato de um fumante, enrugado de frio, que acende seu cachimbo na chama de uma vela, protegido por casaco. Nem as fotografias em porcelana são menos valiosas que as anteriores. Mas Pastore parece inatingível nas fotografias com processo de goma e naquelas com pigmentação colorida. Aquela varanda sobre as escadas é ela própria uma grande revelação do valor do homem que depois ter mantido o nome da Itália elevado no Brasil por tantos anos, retorna à sua terra natal para dar-lhe a glória de seus triunfos. ${ }^{134}$

Em seguida, subia-se para a sala de espera. O artigo "Il grande e moderno Stabilimento Fotografico del Sig. Vincenzo Pastore" descreve a "grande multidão de apreciadores, um elegante público que longamente persistia na rica sala admirando e louvando o artista eminente". ${ }^{135}$

Uma salinha de conversas decorada com tapeçarias e móveis de luxo, estilo Luís XV, formam a entrada. Dois cômodos para toilettes, um para homens e outro para senhoras, mobiliados com um refinado senso artístico e todo o

honra a nossa cidade, seja oferecido o nosso aplauso e o desejo de que os sacrifícios sofridos para alcançar a meta radiante à qual ele chegou sejam largamente compensados". Cf. Coleção Dante Pastore. In: Caderno Recortes de jornais, p. 26. Reportagem A Bari L'esposizione di un nostro concittadino.

${ }^{134}$ Coleção Dante Pastore. In: Caderno Recortes de jornais, p. 26. Reportagem A Bari L'esposizione di un nostro concittadino.

${ }^{135}$ Coleção Dante Pastore. In: Caderno Recortes de jornais, p. 29. Artigo “II' grande e moderno Stabilimento Fotografico del Sig. Vincenzo Pastore". Risveglio Commerciale. Bari, 21 de novembro, 1914. 
conforto da higiene, de modo que cada um dos sexos pode arrumar-se como quiser, no santuário do segredo, hermeticamente fechado, para vir depois posar diante da objetiva. A belíssima máquina, nova para Bari, alonga-se e encurta-se com manivela adequada e, no conjunto da complexa estrutura de fabricação alemã, representa um móvel caríssimo e de grande valor. ${ }^{136}$

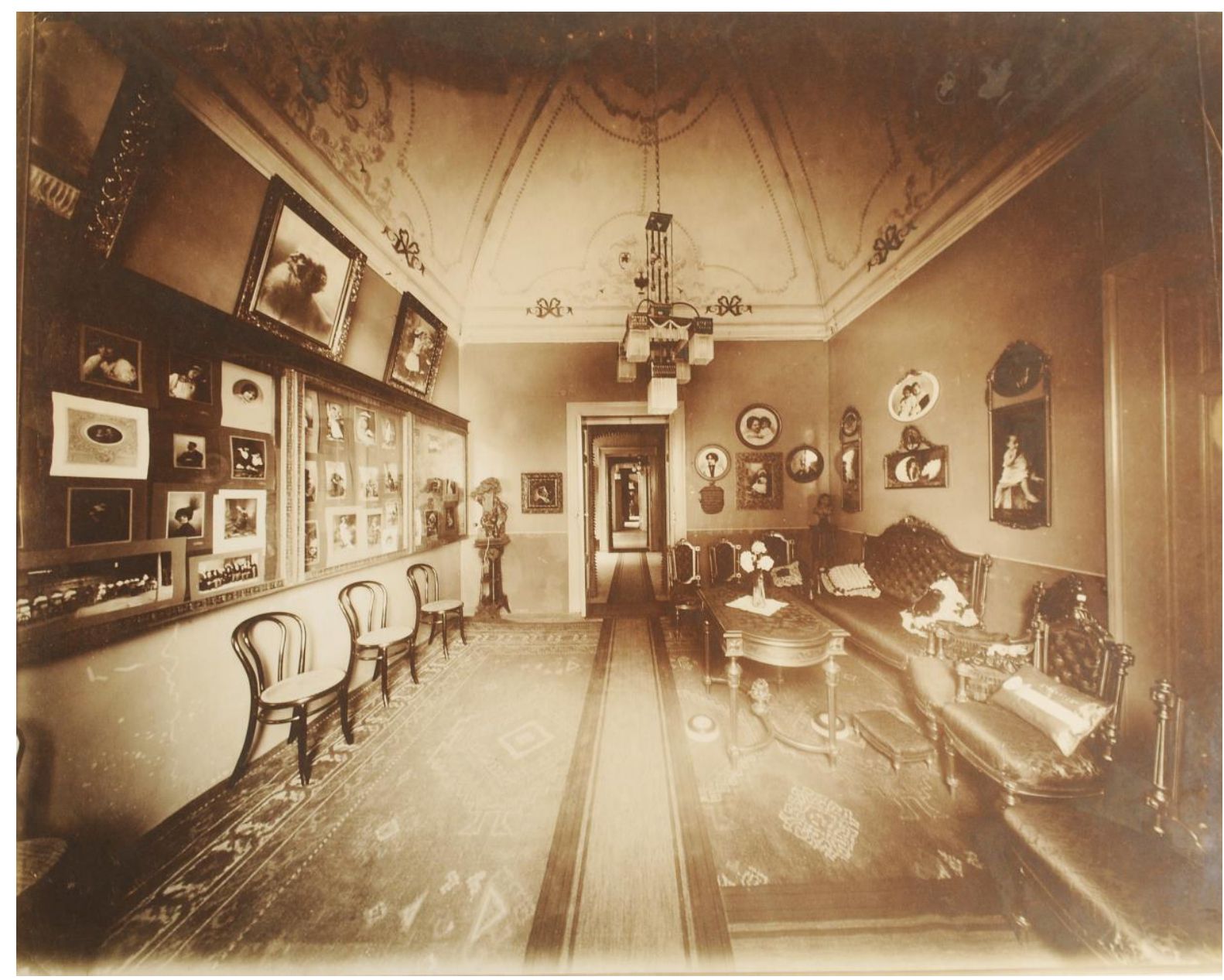

Figura 98: Fotografia da sala de espera do estúdio de Pastore onde se passava de um cômodo a outro, sem intermédio de corredores. Neste espaço Pastore dava continuidade a sua mostra de retratos expostos aos clientes. Bari, Itália. Sem data ( Vincenzo Pastore. Coleção Dante Pastore.

Na fotografia (fig.98) que guarda o cuidado com a decoração, vê-se o teto quadrado em cúpula e o lustre bem centralizado; em perspectiva se revela o ambiente provido de todo um repertório de luxo. Uma cultura material de cunho aristocrática se revela, exaltando uma noção de conforto e bom gosto. O estúdio fotográfico retomava uma trajetória de luxo burguês, formador de noções de elegância e estilo, salienta Vania Carvalho (2008, p. 28-30). Sofás e cadeiras estofados, arranjos com flores, toalha de renda enfeitando a mesa e almofadas coloridas exibiam os ícones de uma boa decoração. O estúdio impunha-se

\footnotetext{
${ }^{136}$ Coleção Dante Pastore. In: Caderno de Recortes de jornais. Tradução Nossa.
} 
socialmente como meio difusor de valores idealizados que aproximavam o ateliê da casa, espelhando também uma conquista do próprio fotógrafo.

Surpreendia a "elegância refinada da sala verdadeiramente chic que alegra toda a mostra", sublinhava nota no jornal Corriere Delle Puglie. ${ }^{137}$ Os visitantes encantaram-se com os móveis de luxo ao estilo vitoriano, mobiliário que simbolizava, ainda segundo Carvalho, estabilidade e ordem, o próprio paraíso, fazendo o contrapeso com as incertezas que rondavam a Europa, talvez dando à Pastore uma possível sensação de estar à salvo, finalmente abrigado em sua própria terra, abrigado em seu "aristocrático estabelecimento fotográfico", ${ }^{138}$ por onde os clientes passavam de um cômodo a outro, sem intermédio de corredores.

Depois da visita feita a essa sala, bebia-se a champagne, oferecida aos convidados. Foram citados os esforços de Pastore e de sua esposa Elvira em fazer com "requinte e elegância as honras da casa". ${ }^{139}$ Segundo o jornal La Provincia Di Bari, o prefeito da cidade, Comm. Facciolati discursou com "magníficas" palavras, brindando e desejando sorte à Pastore. ${ }^{140}$ Após o brinde, oportuno em enalter a capacidade de trabalho do povo italiano, Pastore falou da saudade e da necessidade de retornar à pátria, "com indescritível emoção, faltando-lhe palavras". ${ }^{141}$

As formas de apresentação das fotos expostas na mostra, inaugurada às onze horas da manhã de um domingo assumiram uma forte expressão visual. A profusão de retratos desvelou além do cuidado, a capacidade de investimento de Pastore. O ateliê apresentava uma galeria de retratos sob os mantos do requinte e da sofisticação. Vimos como Pastore seguiu as instruções de um dos primeiros manuais fotográficos traduzidos para o italiano em 1864 . O Manual Liesegang recomendava aos ateliês fotográficos os mesmos parâmetros do ateliê do pintor: "o primeiro cuidado de um fotógrafo profissional deve-se refletir normalmente na localização e na decoração de uma galeria de retratos". ${ }^{142}$ Luigi Gioppi, autor do manual publicado na Itália, em 1891, "La fotografia secondo è processi moderni compredio teorico pratico”, se por um lado, recomendava a metragem necessária e os aparatos para se

\footnotetext{
137 Coleção Dante Pastore. In: Caderno de Recortes de jornais, p. 44. Jornal Corriere Delle Puglie. 22 de novembro de 1914. Tradução Nossa.

138 Título da nota sobre a inauguração do estúdio Italo-americano de Pastore. Coleção Dante Pastore. In: Caderno Recortes de jornais, p. 46.

${ }^{139}$ Coleção Dante Pastore. In: Caderno Recortes de jornais, p. 24. Tradução Nossa.

140 Coleção Dante Pastore. In: Caderno Recortes de jornais, p. 35. Jornal La Provincia Di Bari. 15 de novembro de 1914. Artigo "Una festa del lavoro". Tradução Nossa.

${ }^{141}$ Coleção Dante Pastore. In: Caderno de Recortes de jornais, p. 36. Artigo "L'inaugurazione di un nuovo Stabilim. Fotografico ítalo-americano". Ver também p. 24. Tradução Nossa.

${ }^{142}$ Falzone, 1993, p. 91. Tradução Nossa.
} 
transformar o estúdio num "laboratório industrial", por outro, ao responder "qual forma deve ter um estúdio?", ressaltava o quão importante era proporcionar uma experiência prazerosa e lúdica aos clientes. Esse espaço deveria ser organizado para ativar a imaginação e a fantasia, podendo ser pequeno, mas confortável. ${ }^{143}$

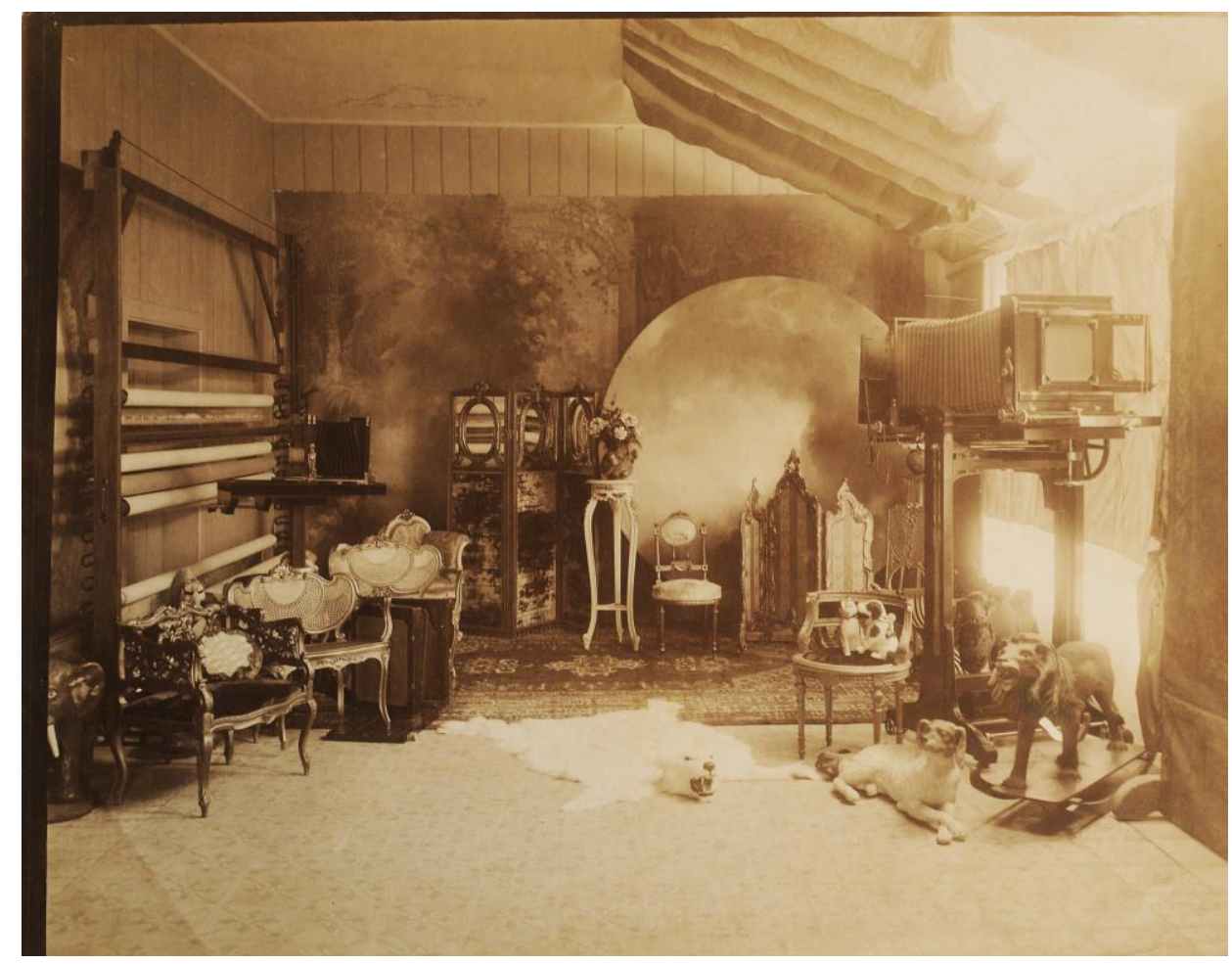

\section{Figura 99:}

Foto interna do estúdio de Pastore talvez realizada pelo próprio fotógrafo. Bari, Itália. Sem data (C) Vincenzo Pastore / Coleção Dante Pastore.

Ao fim do corredor, entrevisto na foto da sala de esperava, chegava-se ao estúdio do fotógrafo. Deve ter sido com satisfação ainda maior que Pastore preencheu esse espaço, investindo no cenário: colocou biombo espelhado e aveludado, panos de fundo com paisagens, cadeiras estofadas, muitas poltronas rebuscadas, mesa lateral apoiando arranjo, tapetes, tudo relembrando o gosto oitocentista aristocrático iluminado pelo abrir das cortinas que encobriam o teto de vidro e a parede lateral à direita (fig.99). Se controlar a luz diurna era essencial ao bom retrato, cabia também na encenação oferecer a lua aos clientes como opção de fundo. Realidades múltiplas podiam ser ali inventadas, ficcionadas.

Essa imagem do estúdio integra a coleção Dante Pastore com a fluidez de aparentemente conduzir ao seu interior. Imagem que agora empresta a ilusão de uma experiência de se poder reviver algo pela fotografia, como se fosse possível visitar e se apropriar daquilo que estivera ao alcance do fotógrafo, à sua disposição dentro do estúdio; Imagem que condensa toda a

\footnotetext{
143 Biblioteca Nacional de Roma. Luigi Gioppi. La fotografia secondo è processi moderni compredio teorico pratico. 1891. Localização: Coll. W.205.56 (1891). Seção de Manuscrito. Tradução Nossa.
} 
duração da foto feita no passado, recuperada no presente, guardada com orgulho pela família. Posse, conquista, posição, narcisismo, procura e realização, pontuam, segundo Blom, o gesto de preservar:

Cada coleção é um teatro de memória, uma dramatização e uma mise-enscène de passados pessoais e coletivos, de uma infância relembrada e da lembrança após a morte. Ela garante a presença dessas lembranças por meio dos objetos que evocam. É mais do que uma presença simbólica: é uma transubstanciação. O mundo além do que podemos focar está dentro de nós e através delas, e por intermédio da comunhão com a coleção é possível comungar com ele e se tornar parte dele. (Blom, 2003, p.219)

Voltemos aos pormenores do estúdio. Os fundos, importantes elementos de ambientação, colocados na lateral desse espaço, seguem o padrão corriqueiro abaixo descrito:

Todos os fundos juntos, esfumados ou desenhados, localizam-se às partes laterais do estúdio, fixados em molduras de madeira especiais; para usá-los quando se desejar sem tanto embaraço e com menos perda de espaço possível, para que seja conveniente todos dever ser anexados e enrolados um após o outro, de modo a ser capaz de movimentá-los com uma corda no fundo selecionado. (Falzone Del Barbarò, 1993, p. 91. Tradução nossa)

Na carta publicada um dia após a inauguração, assinada por Giulio, arcebispo de Bari, vê-se o interesse pela grande câmera, destacada por Pastore no primeiro plano da fotografia guardada pelos descendentes:

Caro senhor,

O subscrito alegra-se e felicita o Sr. Pastore pelo grandioso estabelecimento fotográfico ítalo-americano solenemente inaugurado ontem em Bari. Abençoa o artista, sua esposa e filhos, implorando a ajuda de Deus a eles, com esperança de que em pouco tempo venha a admirar e experimentar pessoalmente a grande câmera fotográfica a qual recebeu as mais lisonjeiras descrições. ${ }^{144}$

O jornal Corriere Delle Puglie deu ainda mais detalhes do cômodo destinado ao estúdio, nuançando expectativas de reconhecimento lançando luz sobre a Itália meridional:

Se a tudo isto se acrescentar a elegância do estilo, a riqueza dos adornos, a beleza da sala de pose, a graciosidade dos gabinetes, todas elas belezas enlevadas pela profusão de plantas e reveladas ou por uma boa luz diurna ou por uma deslumbrante iluminação elétrica, não podemos nos maravilharmos mais se todas as vozes do público concordam em dizer que o

144 Coleção Dante Pastore. In: Caderno de Recortes de jornais, p.41. Jornal Corriere Delle Puglie. 17 de novembro, 1914. Tradução Nossa. 
estabelecimento fotográfico ítalo-americano é o único em Bari e em todo o sul da Itália e digno de grandes capitais italianas e europeias. ${ }^{145}$

O fotógrafo agradeceu veementemente a acolhida de todos os presentes, não apenas aos deputados, senadores, generais do exército ou ao bispo Antonio Lamberti para quem o espaço visitado era um verdadeiro "templo de arte":

Agradeço de coração a todos os cidadãos, ao eleito grupo de senhores e jovens senhoras que com complacência visitaram a exposição no meu estabelecimento, chamado pelo bispo Lamberti "templo da arte", obrigado a todos. Mais uma vez obrigado a toda a população que com a sua ampla intervenção coroou a esplendida festa bem sucedida. ${ }^{146}$

O relato de Pastore, publicado no dia 17 de novembro, mostra expectativas superadas, em um momento de grande satisfação vivida pelo fotógrafo. Sonho, ceticismo, entusiasmo, esforço e gratidão tomavam Pastore:

Eu não sei como devo agradecer dignamente todas as autoridades civis e religiosas que quiseram honrar com a sua presença o meu humilde estabelecimento e dar solenidade à celebração do trabalho que eu havia organizado com muito entusiasmo, mas eu não esperava que tivesse o êxito com tanta solenidade. Durante a minha estadia em Bari me pareceu muito difícil de conseguir abrir um estabelecimento fotográfico, e já o meu pensamento era tomado pelo ceticismo. Mas o sucesso de ontem superou todas as minhas expectativas, a onda de louvor varreu todo o meu ceticismo, uma vez que é capaz de mostrar como o público desta cidade ama, aprecia e cultiva a arte. As autoridades honraram com a sua presença a celebração tornando-a uma verdadeira solenidade e, assim, incentivando-me a perseverar. E por isso de coração, com algumas palavras modestas, eu agradeço a todos eles prometendo que me esforçarei para tornar-me digno de sua estima e honra que então se dignaram a conceder-me. ${ }^{147}$

No dia seguinte, mais uma vez o fotógrafo obteve espaço no jornal para expressar seu contentamento, sem deixar de nuançar uma vida dedicada a fazer retratos: "Trabalhei por muitos anos, mas o meu trabalho tem sido coroado de feliz sucesso. O Brasil, com sua

\footnotetext{
145 Coleção Dante Pastore. In: Caderno de Recortes de jornais, p. 49. Jornal Corriere Delle Puglie. 24 de novembro de 1914. Tradução Nossa.

${ }^{146}$ Coleção Dante Pastore. In: Caderno de Recortes de jornais, p. 41. Jornal Corriere Delle Puglie. Artigo "Dopo L'inaugurazione della Fotografia Italo-americana", assinado pelo próprio Vincenzo Pastore. Tradução Nossa.

${ }^{147}$ Coleção Dante Pastore. In: Caderno de Recortes de jornais, p. 41. Jornal Corriere Delle Puglie. Artigo "Dopo L'inaugurazione della Fotografia Italo-americana", assinado pelo próprio Vincenzo Pastore. Tradução nossa.
} 
população cosmopolita, me aclamou e a terra de Bari que me viu nascer completou meu triunfo". ${ }^{148}$

Para que os clientes donos de "bolsos modestos" não se sentissem intimidados por toda sofisticação e notoriedade do estúdio, Pastore contou com o jornal Corriere Delle Puglie que os encorajava a procurar o Ai Due Mondi. Esse documento indicia tempo de mudanças, preconizando as incertezas e o temor da Grande Guerra que se iniciava:

É necessário, no entanto, que desapareçam preconceitos que animam certa classe de cidadãos e que os tornam hesitantes diante da oportunidade de posarem ou não no estabelecimento fotográfico de Pastore. Quis-se fazer acreditar que lá os preços são fabulosos, nem um pouco acessíveis para bolsos modestos; foi dito que pela soma nem todo mundo seria permitido ser retratado no Italo-americano localizado na via Sparano. Fato que não está correto. No estúdio de Pastore você pode ter fotos de todos os preços, sempre bonitas e retratadas com a mesma máquina. Os preços variam de 8 liras a meia dúzia a 50 liras, deixando claro que as diferenças consistem apenas na preparação e detalhes de ornamento. É natural que o tempo não é mais o mesmo de antes e que a vida mudou em todas as suas manifestações. Daquele estabelecimento não saem trabalhos sobre cartões de sempre, mas conservados em verdadeiros álbuns artísticos adornados com grandiosos desenhos em relevo, fechados em ricas capas. ${ }^{149}$

Outro jornal, Il Giorno, ao apontar a variedade de trabalhos realizados por Pastore, desde foto-miniaturas até ao tamanho natural, também ressaltava os módicos preços, lembrando ao público que as estratégias empreendidas na "cosmopolita" São Paulo seriam reproduzidas em Bari. ${ }^{150}$ Além de montar exposições no próprio atelier Pastore ao divulgar o primeiro concurso de beleza infantil realizado na Itália, repetia sua estratégia empreendida na capital paulista. Em uma das folhas do caderno de recortes feito por Elvira a nota intitulada "Avviso", com o seguinte manuscrito ao lado "Giorno, Napoli, 30 aprile, 1915", colado ao lado de outras notas, convidava meninas de 6 a 12 anos a comparecerem ao estúdio Ai Due Mondi que "criou uma novidade, que certamente será moda nas províncias meridionais". As mães "amorosas e atentas a beleza da infância", eram convocadas a participar de uma "boa ocasião apresentada nesta primavera doce":

\footnotetext{
148 Coleção Dante Pastore. In: Caderno de Recortes de jornais, p. 43. Jornal Corriere Delle Puglie. Carta assinada por Pastore, em 18 de novembro e publicada no mesmo mês no dia 21, em 1914. Nota: "Echi Dell"inaugurazione della Fotografia Italo-Americana". Tradução nossa.

${ }^{149}$ Coleção Dante Pastore. In: Caderno de Recortes de jornais, p. 60. Jornal Corriere Delle Puglie. Tradução Nossa.

${ }^{150}$ Coleção Dante Pastore. In: Caderno de Recortes de jornais, p. 63. Jornal // Giorno. A notal fala de "mitezza di prezzi". Tradução Nossa.
} 
Mães afetuosas das três províncias da nossa Puglia e da Itália Inteira escutem e não deixem de responder ao apelo do nosso conterrâneo que em outros países, em meio a pessoas cosmopolitas lançou o mesmo apelo e todos responderam com entusiasmo, acorreram mães ricas e pobres porque todos, indiscriminadamente, amam seus filhos, a fotografia ítalo-americana.

(...) O primeiro concurso do gênero foi feito em Londres, com um resultado feliz, o segundo em S. Paulo no Brasil, onde teve um sucesso retumbante como provam os jornais locais da época visíveis na própria fotografia, e esse de Bari será o terceiro concurso de beleza no mundo, mas o primeiro na Itália. ${ }^{151}$

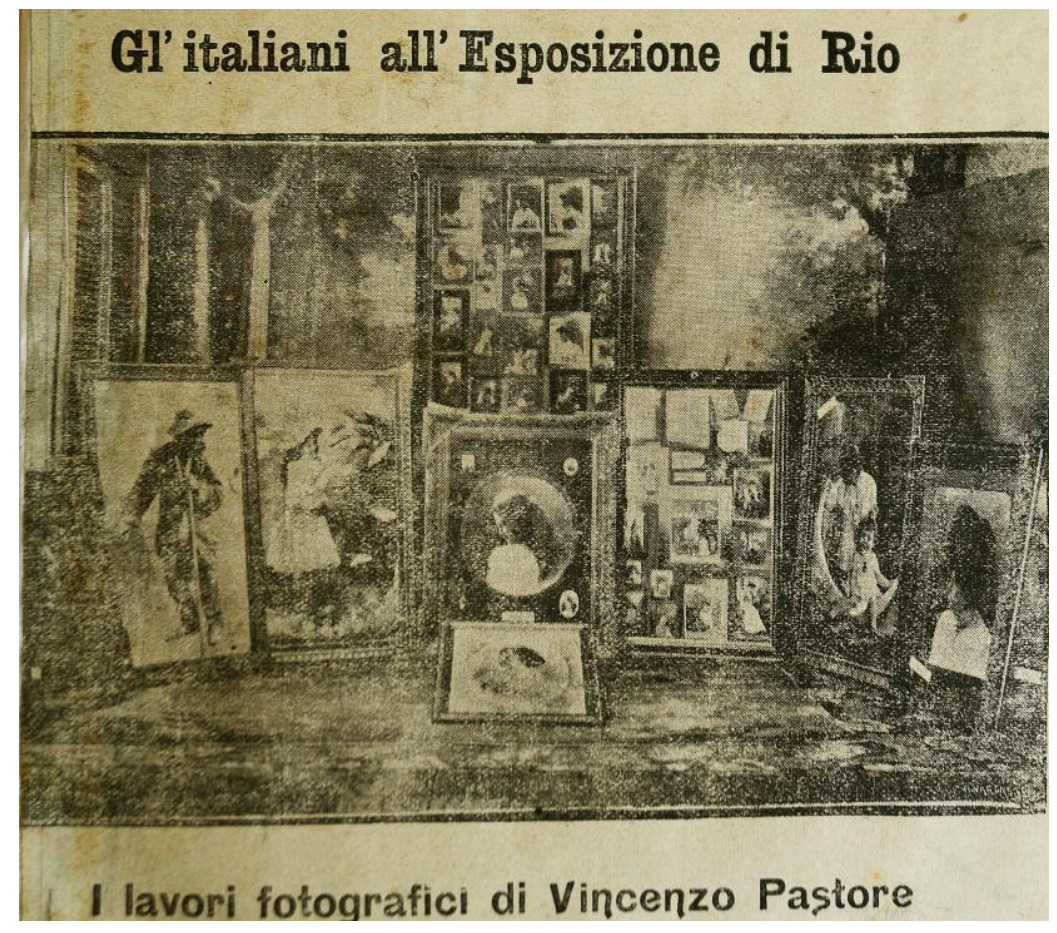

Figura 100: Reprodução de recorte de jornal sobre a participação de Pastore na Exposição Nacional do Rio de Janeiro em 1908. Caderno de Recortes. Coleção Dante Pastore.

Além das medalhas oferecidas, a vencedora do concurso poderia ainda ver o seu retrato exposto na "rica vitrine da rua Sparano dando a ilusão de encontrar-se em Londres ou em São Paulo no Brasil". Pastore, com sua produção de retratos, tentava explorar o circuito de exposições, ora em seu próprio atelier, em São Paulo ora nas vitrines e paredes do estúdio em Bari, aproveitando-se ainda da Exposição Nacional do Rio de Janeiro, em1908. Indiciamos aqui rastros da circulação de suas imagens, na confluência da trajetória das fotos e a do próprio fotógrafo. A presença dos italianos na "Esposizione di Rio" foi noticiada em alguns

${ }^{151}$ Coleção Dante Pastore. In: Caderno de Recortes de jornais, p. 70. Tradução Nossa. 
jornais (fig.100), retratando um dos estandes com os retratos e quadros realizados por Pastore. Um dos artigos publicados perguntava logo no início: Quem não conhece o Pastore?

Todos conhecem o homem simpático que superou as dificuldades e concorrência, que soube e foi capaz de se impor e hoje prevalecer, sempre trabalhando, incansavelmente, bravamente está na linha de frente e na exposição do Nacional do Rio de Janeiro, ocupando o lugar dos nossos melhores fotógrafos e das fotografias de arte. Não é lícito deixar em silêncio os belos retratos, especialmente de uma mulher e efeitos de iluminação sistema Rambrandt, um grupo de crianças, outras crianças que roubam flores, com efeitos de nuvens, com efeitos do mar - uma pequena galeria de arte, que irá atrair a admiração dos visitantes e de todo o valor que já reconhecem. ${ }^{152}$

Entre as imagens reproduzidas lá estava a menina sentada na lua, a moça que teve seu retrato publicado na capa da revista A Vida Moderna e uma infinidade de outros fragmentos visuais que desvelam o envolvimento de Pastore no metier do retrato, participando da tradição das grandes exposições, as novas vitrines definidas por Samain (2001) como "as olimpíadas do conhecimento e do progresso", onde a fotografia era também contemplada como uma conquista e triunfo burguês.

Ao emoldurar fotografias em grandes quadros Pastore apresentava um modo particular de ver o mundo, pela transcendência da obra de arte, contemplativa e expositiva, se apropriando de um modo de exibição de imagens, forjando esse modelo em seu próprio atelier barese, ao reconstruir todo um ambiente visual inspirado nas grandes exposições como aquela que celebrava em 1908 "os trabalhos fotográficos de Vincenzo Pastore”. Kossoy informou sobre o prestígio que se podia obter com a participação em tais eventos:

A exposição, enfim, sempre representou uma oportunidade que viam os fotógrafos de fazerem publicidade de seus estabelcimentos, mormente quando eram premiados. Quando isso ocorria, faziam sem demora incluir em seus anúncios e no verso do cartão suporte de suas fotos, juntamente com o nome e endereço, a menção dos prêmios alcançados. (Kossoy, 1980, p. 78)

Apesar de todos os esforços, de todos os recursos investidos em Bari, Pastore foi forçado a deixar mais uma vez a Itália. A preocupação com os dez filhos e a sua avançada idade para a guerra, levaram Pastore a retornar ao Brasil. No jornal Corriere delle Puglie, o fotógrafo publicou a carta intitulada "Commiato", rastreando a sofreguidão daqueles obrigados a encarar uma instabilidade sem fim:

${ }^{152}$ Coleção Dante Pastore. In: Caderno de Recortes, p. 12. Artigo intitulado “Le Gare del Lavoro”. Tradução Nossa. 
Despedida,

Nesta hora de destino tão solene da pátria sou obrigado a me afastar temporariamente para retornar a minha residência em S. Paulo, no Brasil. Eu fui forçado a tomar esta decisão em desacordo com os meus próprios sentimentos de patriotismo (...) Eu queria esperar até que o destino da Itália pudesse ser cumprido, mas o dever me chama, o dever de um pai que se preocupa com o futuro dos dez filhos, e eu irei cumpri-lo já que a minha idade não me permite dar o meu braço à pátria, para a sua grandeza e da redenção, e que outros mais afortunados do que eu irão escrever com seu sangue a história da Itália.

Mas, antes de deixar esta cidade que unanimemente me aplaudiu, faz penas um ano que eu expus o meu modesto trabalho, sinto-me no dever de despedir-me de todas as autoridades civis, militares e eclesiásticas.

Para todos, sem distinção, minhas humildes e respeitosas saudações. Por fim, a todos os senhores clientes da província e da cidade que me honraram com a sua confiança, a todos os notórios cidadãos de Bari que acolheram a abertura do meu estabelecimento fotográfico com um coro de aprovação lisonjeiro, dirijo a todos as minhas saudações. Eu queria a todo custo deixar um representante meu para dirigir o estúdio, mas devida a condição do tempo presente muitos dos meus colegas responderam ao apelo do nosso amado Soberano, muitos ainda têm de responder e não me tem sido possível encontrar uma pessoa adequada ao feito. Portanto fecho temporariamente o estabelecimento para reabri-lo talvez até mais digno do progresso desta cidade. Fui acusado de ter desprezado a recepção acolhedora, amigável e cordial, e assim pareceria se eu não desse prova da minha gratidão, partindo com a promessa formal de "até mais ver". Sou pouco habituado a hipotecar o futuro, que está nas mãos de Deus, mas se ele quiser estou disposto a manter a minha promessa com a qual me despeço de vocês a quem sou grato. Até logo. Que deus nos conceda a paz honrosa e vantajosa desejada pelo nosso Soberano Amado, de modo que ao meu regresso do distante Brasil eu possa depois encontrar minha amada pátria maior e mais forte! $!^{153}$

Vê-se, por meio desse relato, a esperança de Pastore de em um dia poder reabrir o estúdio em Bari. O desapontamento demonstrado por Elvira sugere o quanto o retorno ao Brasil foi uma surpresa. Seu diário revelou instantes de resignação. Deixou em manuscrito seu olhar sob um véu de puro desalento, entregue à vontade divina:

Comprando o outro caderno que acabou em Bari, nunca imaginei que iria terminá-lo no Brasil! Parece um sonho! Se um anjo tivesse sussurrado no meu ouvido o que iria acontecer, eu teria dificuldade de acreditar! E ainda assim estamos aqui no Brasil mais uma vez e voltamos à vida de sempre de tantos anos na mesma casa, com pequenas variações e nada mais! Daqui por diante não direi mais: "farei isso... depois irei lá... depois farei aquilo" Oh, não! Não direi mais. Direi somente "farei aquilo que Deus quiser". Agora não me resta outra coisa a não ser me conformar em ficar na mesma casa onde tantas vezes reclamei com Vincenzo do pouco trabalho... e Deus

${ }^{153}$ Coleção Dante Pastore. In: Caderno de Recortes, p. 71. Jornal Corriere Delle Puglie. 27 de novembro 1915. Tradução nossa. 
talvez... talvez... quis me punir fazendo-nos ficar aqui, mas sem trabalho, de modo que não posso nem reclamar mais. Seja feita a vontade de Deus! ${ }^{154}$

No dia 23 de novembro de 1915, o passaporte de Pastore traz a data de saída da Itália (fig.101). Pastore regressava acompanhado de toda a sua família. O desembarque se deu mais uma vez no porto de Santos. ${ }^{155}$ Ao chegar à capital, conseguiram recuperar o mesmo sobrado outrora ocupado na Rua Direita. Elvira, em seu diário, num ato de fé, pedia a deus forças para enfrentar as "privações que a crise nos dá", prevendo mais uma vez tempos difíceis, "sem trabalho", ora encarados como punição, ora com resignação, alimentadas por constantes preces. Percorremos todo um conjunto de circunstâncias que demonstraram a dificuldade de Pastore em ganhar a vida fazendo retratos. O diário de Elvira, além de referir-se ao "casamento, que requer tantos cuidados delicados, tantas qualidades profundas, é uma arte sutil e difícil", relembrava um cotidiano repleto de fendas e incertezas frente às situações desestruturantes da vida.

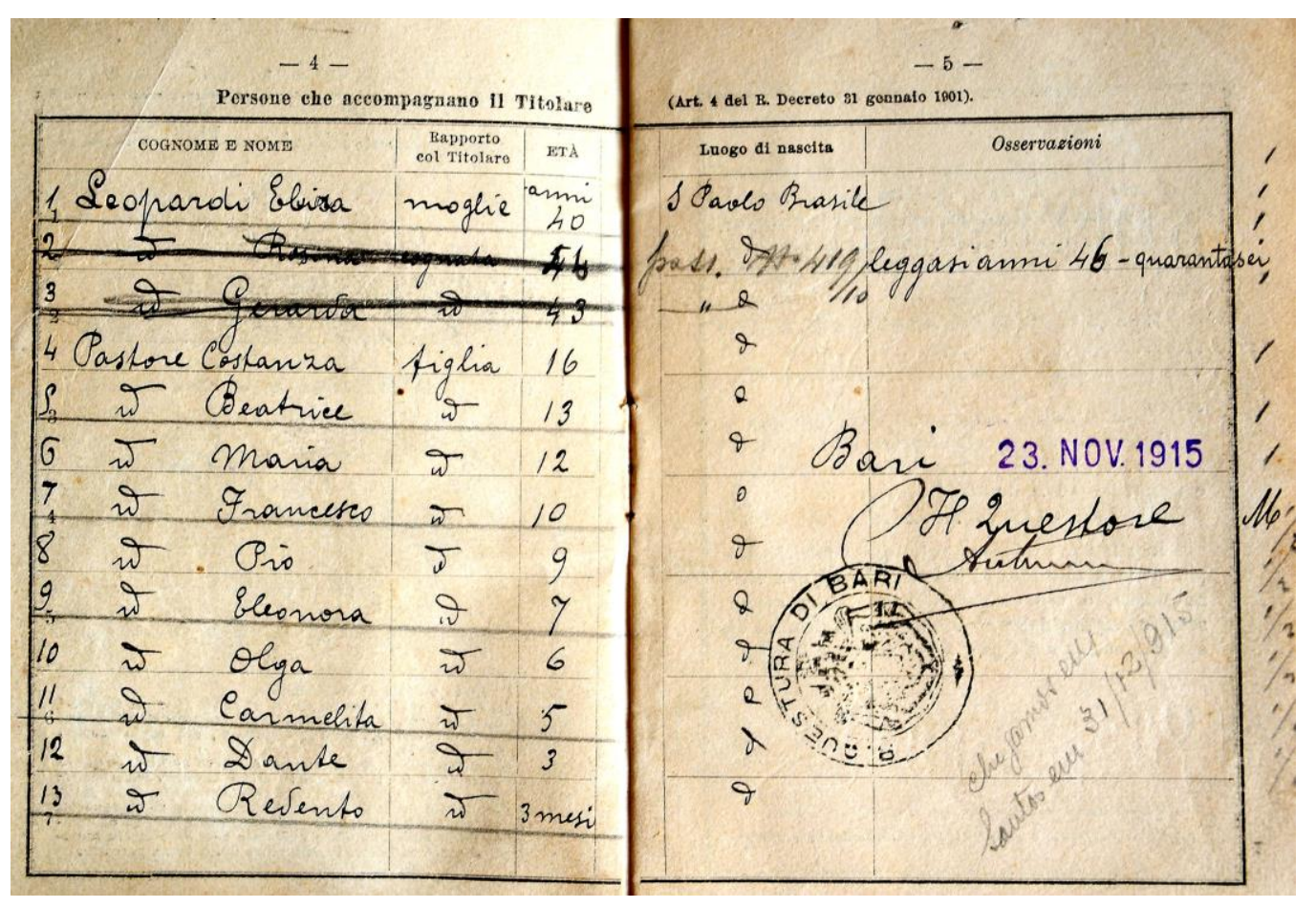

\section{Figura 101:}

Reprodução do passaporte de Vincenzo Pastore. Coleção Dante Pastore.

Pudemos sondar até aqui como Pastore, apesar de todas as dificuldades, foi um homem de posses, com grande capacidade de investimentos, inserindo-se na prática das grandes

\footnotetext{
${ }^{154}$ Coleção Dante Pastore. In: Diário de Elvira. 1918, p. 3115. Tradução do diário feita por Thais Cavalcanti. 155 Arquivo Centro Cultural São Paulo. Cf. entrevista de Constanza Pastore realizada em 1997, pelo pesquisador Ricardo Mendes. Fitas em áudio e transcrições estão disponíveis neste arquivo para consulta.
} 
exposições fotográficas, transcendendo tal prática em seu próprio estúdio aberto em Bari, mas suscetível a realidade flutuante e movediça, nunca imune à instabilidade de tentar viver de seu próprio negócio. Instabilidade conhecida por todos que tentavam viver de modo autônomo e independente. O turbilhão de mudanças não o impedia, contudo de se recompor. Ou melhor, de se recomporem porque essa é uma história feita no plural. A mulher Elvira, os filhos Costanza, Beatrice, Maria Lúcia, Francesco, Pio, Eleonora, Olga, Carmelita, Dante e o caçula Redento, a família que sempre acompanhou Pastore em todas as suas trajetórias.

\subsection{Vincenzo Pastore, "Cavalheiro da ordem da Coroa da Itália": uma trajetória de silêncios em sua província natal}

Apesar de todo destaque que o estúdio de Pastore obteve na imprensa local barese ele é hoje um fotógrafo praticamente desconhecido em sua terra natal. A nomeação como "Cavalheiro da ordem da Coroa da Itália”, pelo duque de Genova, príncipe regente, foi em todos esses anos lembrada apenas pela família. No dia 20 de dezembro de 1916 o documento real enviado de Roma ao fotógrafo, já reinstalado em São Paulo, confirmava a nomeação, uma homenagem pelo estúdio aberto em Bari. O prefeito dessa cidade, no dia 10 de maio do mesmo ano, assinou um decreto aceitando a proposta do ministro da Agricultura, Indústria e Comércio, Gianetto Cavasola, concedendo à Pastore tal título, noticiado pelo jornal o Estado de S.Paulo, no dia 17 de junho de 1916. ${ }^{156}$

Segundo Elvira, o marido jamais imaginava alcançar tal estima e honra: "Ele trabalhou tanto, sofreu tanto para ser respeitado e honrado, para conseguir um título que ele não esperava obter só com o trabalho, e que mesmo assim obteve”. Contundente, Elvira, após ficar viúva, escreveu rigorosa aos filhos:

O dia em que vocês mancharem, mesmo que só com uma mancha pouco perceptível, o nome que aquele anjo lhes deixou, eu os renegarei, eu não lhes darei mais a minha benção, porque não serão mais dignos dela. Deus e a Virgem do Carmo os ajudem a afastar essa desgraça e os abençoe. ${ }^{157}$

Se a trajetória de Pastore em Bari alcançou reconhecimento Real e prestígio aos olhos da esposa, não se inscreveu na história da fotografia da região barese. Foi com uma sensação de frustração que deixei Bari depois de consultar bibliografias, vários acervos e arquivos, sem encontrar nenhum vestígio da experiência de Pastore na capital da província pugliese.

\footnotetext{
156 Cf. Anexo. Figura 284, p. 425.

${ }^{157}$ Coleção Dante Pastore. In: Diário de Elvira. 1918, p. 3198. Tradução feita por Thais Cavalcanti.
} 
Ao conversar com o pesquisador Sergio Leonardi obtive uma resposta categórica: são poucos os estudos sobre a fotografia barese; há poucas fotos em arquivos porque as famílias ainda guardam seus álbuns. Leonardi, em sua pesquisa definida apenas como "indiciaria", não chegou a documentar a atuação de Pastore; apesar de ter acumulado fontes e fotos ao longo de anos de contato com coleções, sobretudo, privadas, nada encontrou sobre Pastore. Tal invisibilidade foi assim explicada:

A reconstrução da história se deu através de relatos oferecidos pelas poucas
cartas, por alguns jornais, documentos de arquivo, poucos espaços
publicitários, em jornais locais da época e, sobretudo, por poucos materiais
fotográficos que ainda hoje se encontram em coleções públicas e privadas. A
dificuldade maior proveniente da falta de fontes está na busca de dados
pessoais dos fotógrafos e das datas relativas aos períodos em que atuaram:
isto é devido ao fato de poucos deles se tratarem de fotógrafos de origem de
Bari. Nem sempre foi possível de se realizar pesquisas no local de origem
dos fotógrafos forasteiros. (Leonardi, 1997, p.7. Tradução Nossa).

Alguns dados começam a surgir e explicar os silêncios historiográficos, que relegaram à sombra a atuação de Pastore em Bari. Além de ter permanecido apenas por um ano na capital pugliese, a família, ao retornar ao Brasil com o início da Grande Guerra, trouxe consigo a produção fotográfica deste fotógrafo que não foi um forasteiro. Ao contrário. Casamassima, região da Puglia, foi o berço de nascimento de Pastore. Dos muitos fotógrafos que atuaram em Bari, segundo Leonardi, são conhecidos apenas alguns nomes, com poucas variantes de informações.

Com o resultado de algumas pesquisas sobre a fotografia barese percebemos como Pastore não foi o único fotógrafo a se instalar numa via de prestígio da cidade. Aqueles que atuavam no métier do retrato em Bari, até as primeiras décadas do século XX, se concentravam nas três ruas mais importantes da cidade, local de moradia "della buona borghesia": Rua Sparano, Corso Vittorio Emanuele, Corso Cavour, chegando ao máximo à Rua Calefati. Endereços onde a "classe comerciante e aristocrática ama passear e se encontrar", explicou Leonardi (1997, p.56). São essas ruas muito próximas, percorridas em curta caminhada. Proximidade que por certo estreitava contatos entre os fotógrafos e dava chance a determinados grupos de forjarem para si e para os outros um lugar social de destaque, gente que se exibia ora por toda extensão da rua Sparano, ora no salão de pose dos estúdios que ali se avizinhavam.

Durante a segunda metade do século XIX Bari recebeu muitos "fotógrafos forasteiros", vindos do norte do país, do estrangeiro, formando uma "primeira geração de fotógrafos", em 
busca de uma menor concorrência. As décadas entre 1850 e 1860, revelam uma prática de intenso deslocamentos de fotógrafos pela região da Puglia vindos de Nápoles, Genova, Veneza, Lombardia e, ainda, alemães e franceses. O fotógrafo Melchiorre Falardi era nascido em Pádua, mas na historiografia da fotografia barese aparece como "vindo de Veneza". (Leonardi, 1997, p.4-11). Manteve estúdio aberto em Bari na avenida Corso Vittorio Emanuele, n.6-8, tendo mantido outro funcinando na cidade de Lecce, na Rua Spezierie, n. 4. Retratar os grupos mais abastados dessas duas províncias puglieses, as mais desenvolvidas da região, surgia para muitos deles como oportunidade para fazer fortuna. ${ }^{158}$ Nesse contexto crescia o "fenomeno del brigantaggio", avolumando-se na região uma produção de fotos também dos ex-combatentes, sobreviventes das guerras pela unificação; no período posterior a fotografia começou a se desenvolver na região.
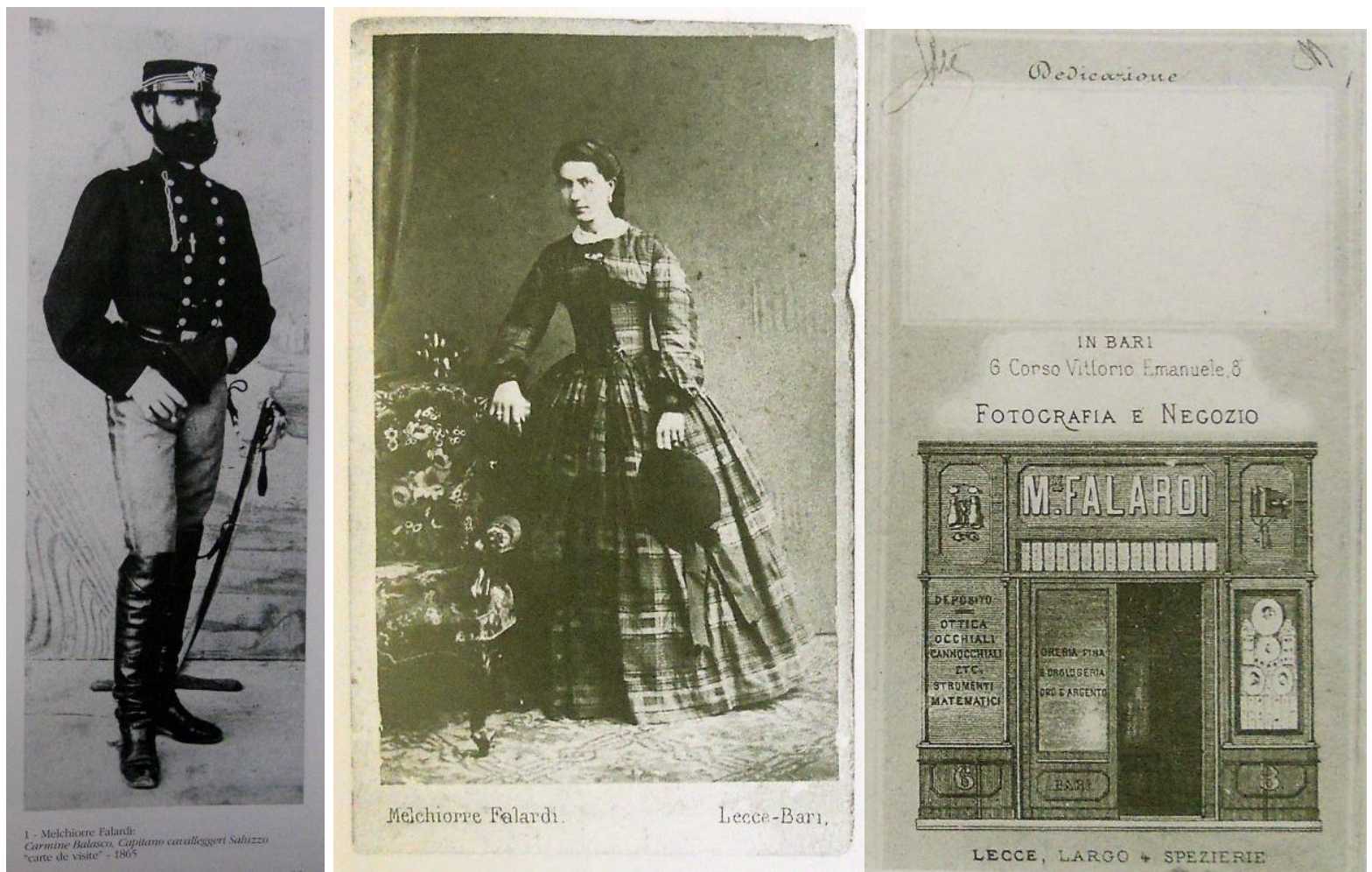

Figura 102, 103 e 104: Fotos tomadas em Bari, província da região da Puglia na Itália. As duas primeiras tomadas em estúdio. A terceira é o verso do cartão suporte onde as fotos eram prensadas. Sem data () Melchiorre Falardi. In: Leonardi, Sérgio. La Fotografia Dell'ottocento a Bari. Bari: Mario Adda Editore. 1997.

A carte-de-visite produzida por Falardi, fotógrafo que provavelmente chegou a Bari por volta de 1870 , dá indícios do retrato que se popularizava na província em que Pastore iria atuar três décadas depois. No entanto, há uma contradição. A foto à esquerda (fig.102) foi

158 La Gazzetta Del Mezzogiorno. 30 de julho de 2010. Reportagem assinada pelo pesquisador da fotografia barense Sérgio Leonardi. "La Puglia che lavora nelle foto ottocentesche". Tradução nossa. 
considerada por Leonardi como um daguerre; a legenda da foto indica, por sua vez, que se tratava de uma carte-de-visite. Se, por um lado, vê-se como técnicas mais avançadas não colocavam em desuso aquelas mais antigas, sugerindo como o desenvolvimento da fotografia se deu de modo não homogêneo no país, por outro, há pouca precisão em tais identificações porque imagens em daguerre não podiam ser reproduzidas em papel. A foto nos interessa porque mostra um referente que ajudou a caracterizar o circuito do retrato subscrito ao fenômeno da fotografia do ex-combatente, prática comum em quase todas as províncias ao sul da Itália.

Melchiorre Falardi no térreo do sobrado localizado na avenida Corso Vittorio Emanuele abriu uma relojoaria e ótica, assim como fez na província de Lecce. No primeiro andar residia a família. No segundo, valendo-se de teto de vidro, o estúdio fotográfico foi instalado. O negócio era variado. Comercializavam fotos, relógios, produtos óticos, e até mesmo instrumentos matemáticos, tudo anunciado no verso da carte-de-visite (fig.104). A sua "Fotografia e Negozio" apontou como em Bari para sobreviver do retrato era preciso acumular tal prática com outras atividades.

Jacques, o fotógrafo francês, dono do atelie "Fotografia Parigiana", antes de se instalar em Bari, havia permanecido também em outras províncias da Puglia, como Lecce e Messina. Fato que indicia como outras províncias e comunas, à sombra da efervescência cultural napolitana, também atraíram profissionais que se dedicavam ao retrato. Giovanni Minazzi, originário da Itália setentrional, da província de Pádua, conterrâneo de Falardi, manteve simultaneamente estúdios aberto em Trani, Bari e na "bella Lecce". Se houve pouca concorrência em meados da década de 1870, como pontuou Leonardi, não houve, contudo, clientela suficiente para manterem seus estúdios em uma única província. Parece-nos que Bari, apesar de apresentar uma maior urbanização comparada a Potenza, dividiu com está província certos aspectos que começaram a traçar um panorama para a fotografia das duas regiões, onde mais uma vez se inscreveram práticas de deslocamentos de fotógrafos obrigados a abrir filias de seus estúdios nas cidades vizinhas.

A partir das décadas de 1860 e, principalmente, em 1870, proliferaram os ateliês fotográficos em Bari, período em que cresceu na cidade, capital da região da Puglia, as funções burocráticas e terciárias incomparável a qualquer outra comuna ou província da região pugliese. No circuito do Grand Tour turístico, de meados de século, esta região foi 
descrita como terra abandonada, como terra inóspita, submetida a um estado de miséria secular, afirma Marina Miraglia (1985).

Ao fim do século XIX Bari iniciou um excepcional crescimento urbano e demográfico. De 34.063 mil habitantes em 1861, passou para um total de 60.575, em 1881; atingiu, em 1910, um total de 103.168 mil habitantes. A atividade fotográfica que se difundiu somente após a unificação do país passava a atrair grupos sociais ligados a aristocracia e a alta burguesia, ao capital mercantil, industrial e financeiro; profissionais liberais, comerciantes e militares integravam os grupos que ascendiam socialmente (Miraglia. 1985, p.11). Observar tal contexto ajuda a explicar o interesse de Pastore em retornar em 1914.

Falardi esteve vinculado à segunda geração de fotógrafos que se instalou na Bari que começava a apresentar um "quadro burguês de uma bela época", uma "Bari debut de siècle" (Miraglia, 1985, p.12). Alguns nomes se destacaram no recorte proposto por Leonardi: Nicola e Michelle De Mattia, Antonio Bachmann, Tommaso Guerra, Vincenzo Guerra, Ludovico Lopez. Nenhuma palavra fazia referência à Pastore.
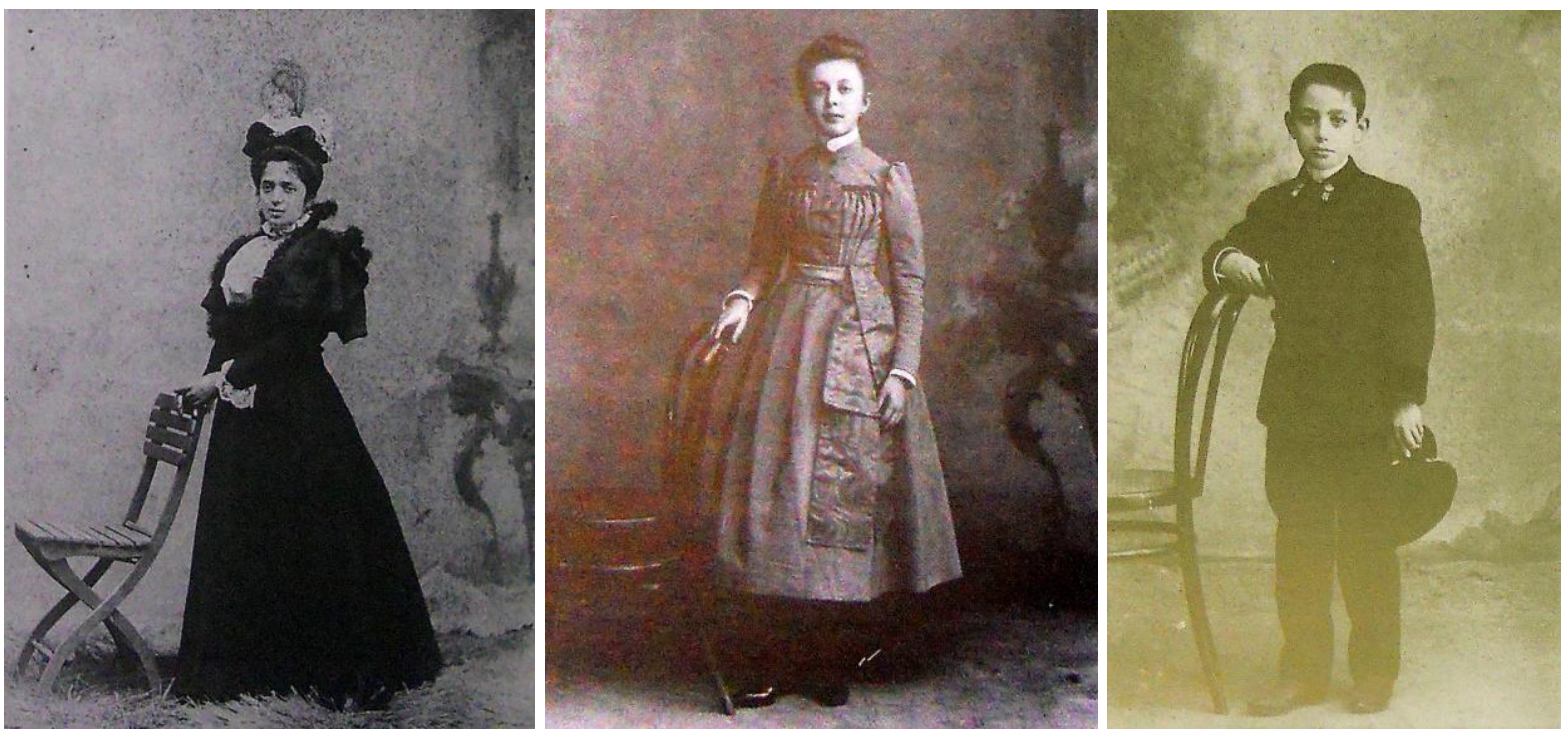

Figura 105, 106 e 107: À esquerda retrato realizado em 1880; ao centro, 1903 () Enrico Bambocci. À direita tem-se a seguinte inscrição: "Ao meu querido professor Rilucco, uma lembrança". 1895 (C) Giuseppe Tarantini. In: Leonardi, Sérgio. La Fotografia Dell'ottocento a Bari. Bari: Mario Adda Editore. 1997.

Antonio Bachmann foi um dos fotógrafos imigrantes de trajetória "misteriosa" afirmou Leonardi. Não se sabe de onde partiu, onde se instalou, quanto tempo permaneceu em Bari, tampouco seu destino posterior. Por volta de 1870 produziu algumas carte-de-visite na cidade, seguindo o "fenomeno del brigantaggio". Em 1880, Enrico Bambocci iniciou o seu percurso 
como retratista barese, nascido em Parma, tendo atuado anteriormente em Nápoles. ${ }^{159}$ Trajetórias de deslocamentos dos fotógrafos foram, como se vê, recorrentes. Em Bari Bambocci abriu seu estúdio na importante rua Corso Vittorio Emanuele, n.54. Se a imagem ao centro (fig106) foi feita dentro do estúdio, aquela que a acompanha, à esquerda (fig.105), foi realizada fora do ateliê, porque o fotógrafo também atendia à domicílio, estendendo o mesmo pano de fundo usado no estúdio em alguma parede ou muro disponível, deixando à vista o chão de gramado irregular. Prática que foi empreeendida por muitos retratistas, os quais atendiam também à domicílio, dentro e fora da província barese.

Chama a atenção os poucos recursos de encenação, tanto nos retratos produzidos nos anos de 1880, como aqueles tomados em início de novo século. Apenas vê-se o uso de cadeiras, postas quase sempre na mesma posição, à direita do retratado. Nada de estofamentos e franjas, nenhuma cortina aveludada, total ausência de tapetes, colunas, ou mobiliário que pudesse evocar uma ascendência social aburguesada.

O endereço do estúdio de Bambocci era o mesmo da casa editorial criado por ele. Alem das carte-de-visite, vistas acima, o fotógrafo vendeu também um álbum com capa de couro contendo 50 fotografias de vistas de monumentos pugliese. Trabalho este feito sob encomenda da prefeitura local que atendia a uma solicitação do "Ministero Della Pubblica Istruzione". A prática como fotógrafo retratista foi agregada a uma prática que seria corrente ao final do século XIX: fotógrafos deixavam por vezes seus estúdios localizados ao norte e se dirigiam a Itália meridional para retratar seus monumentos e arquitetura, retratar as paisagens distantes do país recém unificado, associando a prática fotográfica à tipografia- editora.

O fotógrafo Nicola de Mattia trabalhou ao lado de Bambocci na campanha acima citada. Retratavam as fachadas de catedrais e importantes construções bareses. Ambos editaram álbuns dos monumentos de toda a Puglia. Mas, Pastore, ao chegar a Bari em 1914, não encontrou Bambocci, fotógrafo que participava de muitas exposições nacionais e internacionais, obtendo inclusive algumas medalhas de ouro. Apesar do reconhecido sucesso na cidade, como sugeriu Leonardi, Bambocci deixou Bari, em julho de 1907 emigrando para os Estados Unidos. Abriu primeiro um estúdio em Nova York, tendo atuado anos depois também em São Francisco, na Califórnia. A concorrência diante dos novos estúdios abertos em Bari forçava muitos fotógrafos a "buscarem fortuna na América”, afirmou Leonardi.

\footnotetext{
${ }^{159}$ La Gazzetta Del Mezzogiorno. 14 de janeiro de 2007. "Cosi scomparve da Bari il grande fotografo", 2007, p.
} 22. Tradução nossa. 
A atuação de Angelo, Paolo e Liborio Antonelli, relembram uma prática que envolvia os membros de uma mesma família no métier do retrato barese, como ocorria em Firenze com os irmãos Alinari: Fotógrafos que dividiam o seu tempo retratando clientes em estúdio, à domicílio, deslocando-se ainda entre as comunas vizinhas. Práticas que nos remetem para os retratos produzidos nos terraços das casas onde as famílias mais abonadas tomavam seu chá (fig.108), ou ainda aquelas que simplesmente costumavam reunir o grupo familiar, acomodados nos quintais com menos formalismos (fig.109).
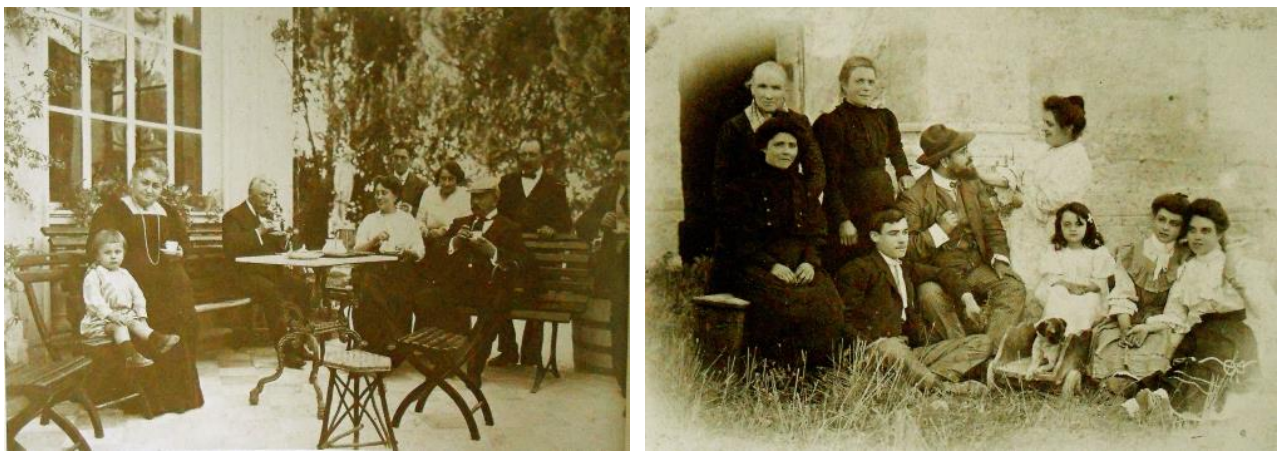

Figuras 108 e 109 retratos de família em áreas externa das residenciais. Bari. Itália. 1900 ( Antonelli. In: Miraglia, Marina. Bari inizio secolo nelle fotografie degli Antonelli. 18831915. Roma: Edizione Quasar. 1985.

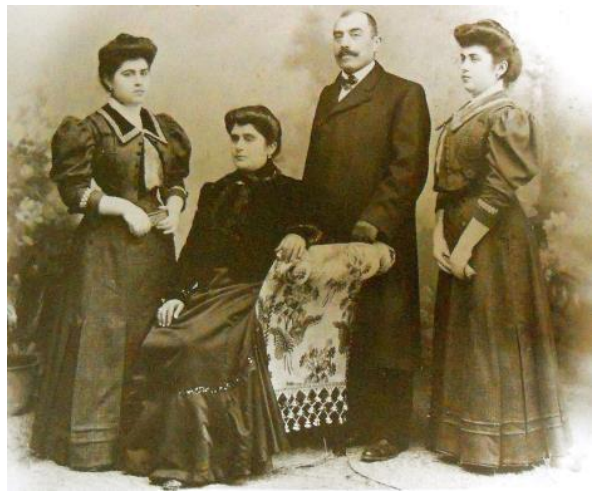

\section{Figura 110:}

Retrato de grupo familiar. Bari. Itália. 1905 (c) Antonelli. In: Miraglia, Marina. Bari inizio secolo nelle fotografie degli Antonelli. 1883-1915. Roma: Edizione Quasar. 1985.

Tratamos de serviços fotográficos prestados por uma empresa familiar envolvida no métier do retrato barese: A família Antonelli, que em 1883, fundou seu primeiro estúdio na cidade, período em que a prática retratista superou o interesse documental sobre o território, frente ao "crescente prestígio burguês". Famílias inteiras se reuniam no estúdio ou fora dela para eternizarem seus vínculos socialmente reafirmados por meio do retrato, meio cada vez mais capaz de fixar e documentar ritos e a cotidianidade mais banal, embora afetivamente significativa da vida doméstica e do próprio tempo livre, afirma Miraglia. 
O retrato de fato correspondia plenamente ao desejo exibicionista da burguesia de ser representada e também celebrada, no momento em que se vêem assumindo-se como protagonista da historia. (...) o grupo familiar testemunha a união patriarcal do próprio gens, que mascara a celebração do rito mundano consumado na bela Bari. (Miraglia, 1985, p. 12-16. Tradução nossa).

A simplicidade do mobiliário de muitos estúdios em Bari ajudou a explicar o entusiasmo na divulgação do estúdio de Pastore que evidentemente oferecia mobiliários mais rebuscados. No lugar de tapetes de palhas ou fibras (fig.111 e 110), vê-se no ateliê de Pastore, o possível tapete persa (fig.99). No lugar de simples cadeiras de madeira (Fig.105, 106 e 107), vê-se móveis ao estilo oitocentista aristocrático. O auto-retrato feito por Angelo Antonelli ajudou a contrastar o aspecto aqui ressaltado (fig.111).

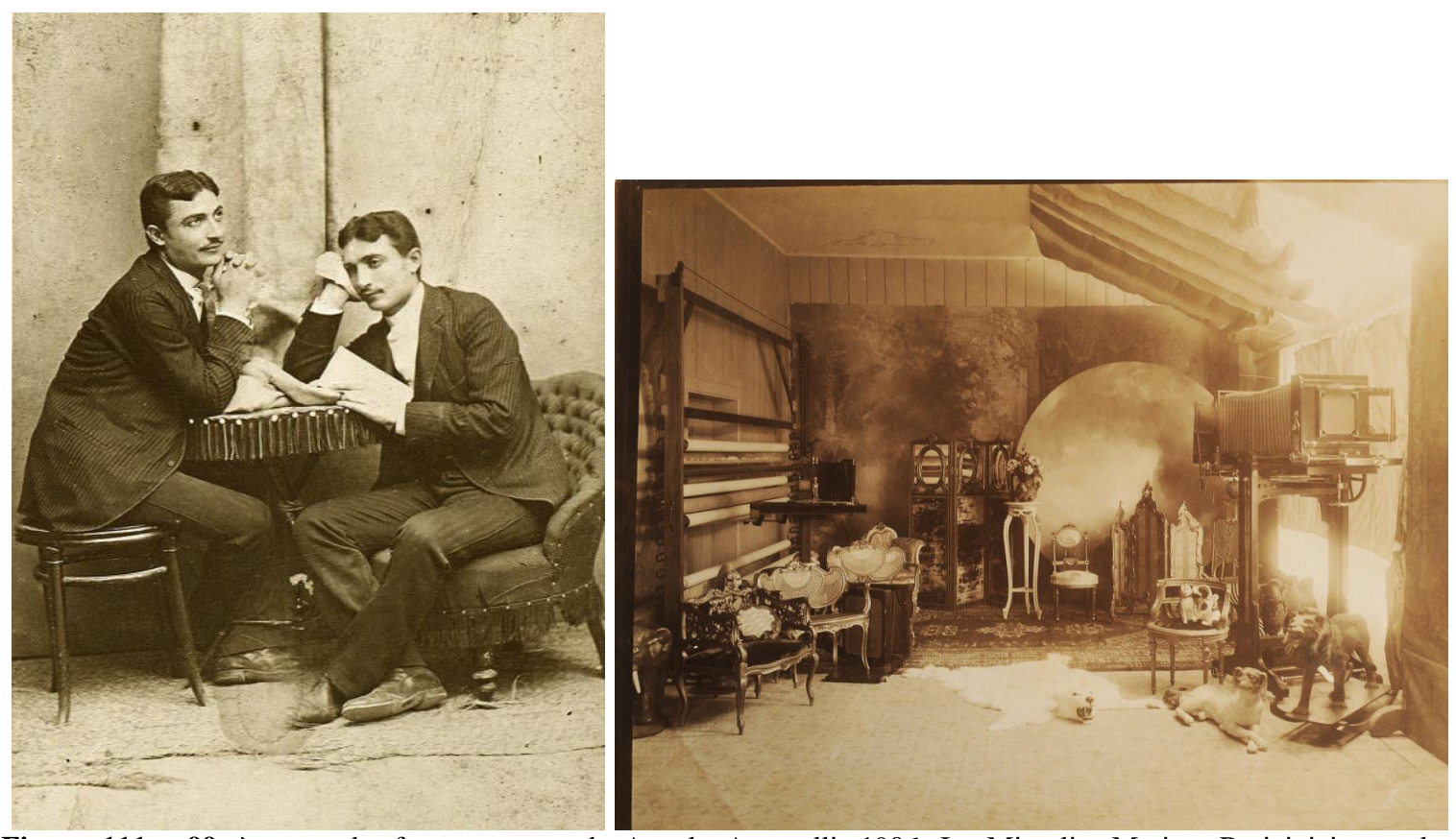

Figura 111 e 99: à esquerda, fotomontagem de Angelo Antonelli. 1906. In: Miraglia, Marina. Bari inizio secolo nelle fotografie degli Antonelli. 1883-1915; à direita figura 99: registro interno do estúdio de Pastore. Possivelmente realziada em abril de 1914, quando o fotógrafo inaugurara seu estúdio. Sem data @ Vincenzo Pastore. Coleção Dante Pastore;

Em 1883, Angelo Antonelli, abriu estúdio na Rua Sparano, número 25, rua comercial que, em 1914, abrigaria o estúdio de Pastore. ${ }^{160}$ Liborio, irmão de Angelo, manteve uma filial do estúdio na Via Piccinni, número 24, a partir 1890; Paolo, irmão de ambos, passou nesta década a atuar ao lado de Angelo; em 1918 atuaria em seu próprio ateliê localizado na Rua Putignani, 16, como indica Chiara Troccoli Previati (1985, p.20). O empreendimento familiar entre os três irmãos "Fratelli Antonelli" foi rompido a partir de 1900 quando Liborio passou

${ }^{160}$ Angelo iniciou sua atuação como fotografo aos dezesseta anos de idade. O estudo iniciado em na Escola de Arte de Nápoles foi interrompido após o acometimento do pai, o conde Pasquele Antonelli da Rutigliano. 
inclusive a adotar o sobrenome da esposa, Giovanna Matteucci, como mencionou Leonardi (1997). A mudança da razão social, talvez indicie a dificuldade de lucros suficientes para os três integrantes da empresa fotográfica que atuaram no métier do retrato barese até $1941 .{ }^{161}$ Encontramos um dos registros em que Liborio, na parte inferior do cartão suporte prensado à foto, (fig.112), desvinculava-se da empresa dos irmãos.

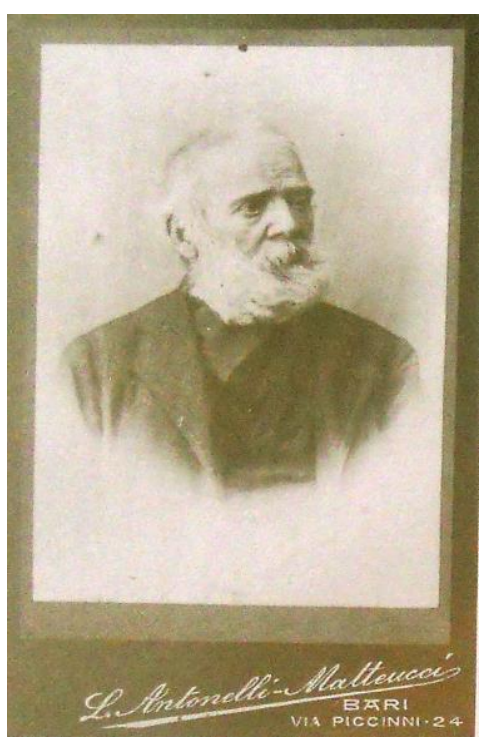

Figura 112:

Retrato de meio busto de Marmete Bambocci pai de Enrico Bambocci. Sem data $\odot$ Liborio Antonelli Matteucci. In: Giovane, Alfredo. Bari de Fanale a gaz. Bari: Edizione Fratelli Laterza Bari. 1982.
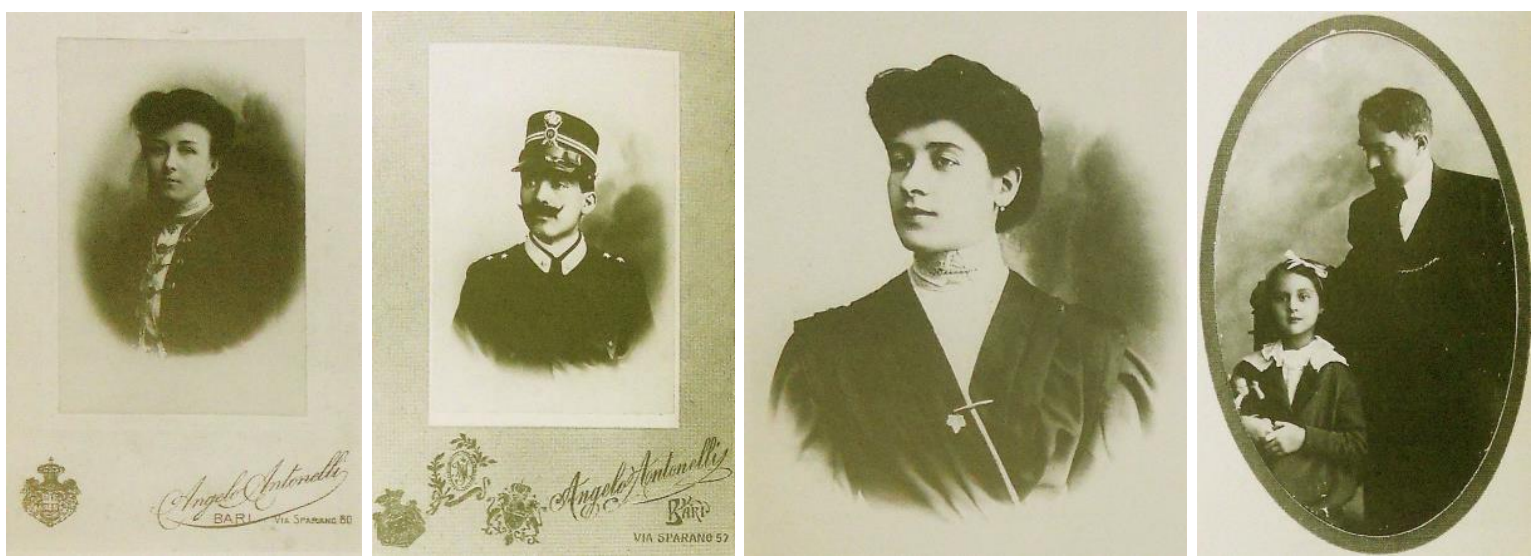

Figuras 113, 114, 115 e 116: Todos os retratos realizados pelo fotógrafo Angelo Antonelli. Na sequencia temos senhora Fonte Laterza, foto com dimensao 7 X10 cm; a seguinte sem identificação do retratado, dimensao 7 x 10; ambas, 1906. Depois Irene Ramunni 9,5 x 14 cm; e por último retrato identificado apenas como Pai e Filha, dimensão 11 X $16 \mathrm{~cm}$; as duas últimas com datação de 1910.

161 Assim como De Mattia e Bambocci, os membros da empresa Antonelli também enveredaram na documentação arquitetônica e monumental de toda a Puglia. Mas foi Liborio que arrematou por meio de compra todo o arquivo de Bambocci, posto a venda antes de sua partida para os Estados Unidos. Após a aquisição do material visual, ou melhor, de todo arquivo de Bambocci, tendo em seu conjunto fotografias de retratos e do território, Liborio o comercializava usando o seu próprio nome. (LEONARDI, 1997, p. 72). 
Vemos na produção de retratos em Bari, predominatemente a carte-de-visite e o formato cabinet; retratos de corpo inteiro e de grupos foram com frequiência realizados. Aqueles tidos como de meio busto foram, contudo, os mais recorrentes, com esfumaçamento nas laterais, prevalecendo contorno circular.

Na primeira década de 1900, Angelo Antonelli, expandiu os negócios de seu atelier. A venda de artigos óticos e fotográficos relembra a atuação de Melchiorre Falardi, enunciando como tanto no Brasil, quanto na Itália, os fotógrafos retratistas acumulavam diferentes frentes em seus empreendimentos. Pasquale, Angelo e Antonio, filhos de Angelo, nas décadas seguintes, deram continuidade ao negócio herdado do pai. Tratamos de uma segunda geração de fotógrafos da mesma família envolvidos com a prática retratistica barese.

Cabe destacar um aspecto delineado na pesquisa de doutorado de Previati que ajuda na sondagem das práticas em torno do retrato barese. Tese que tampouco apresenta vestígios da atuação de Pastore. O filho Angelo, percorria as diferentes províncias fazendo retratos; Pasquele se dedicava ao trabalho no atelie em Bari; e Antonio, concentrava-se mais na documentação de espaços e edifícios públicos. O pai Angelo Antonelli, por sua vez precisou se reorganizar comercialmente frente ao novo mercado amador que surgia:

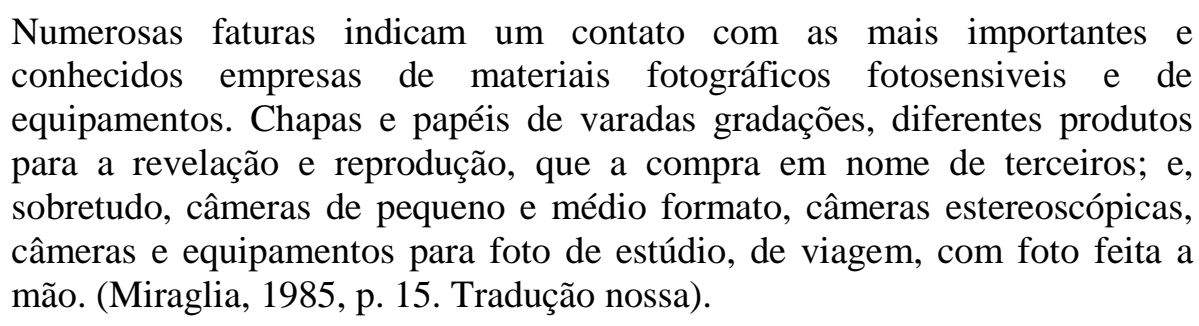

Foi preciso à "A. Antonelli e Filhos" criar a filial aberta na comuna de Brindisi. O Pai Angelo Antonelli tomou à frente nesse empreendimento inaugurado na Rua Independenzia, número 117; depois de 1918, retornou à Bari, ocupando a Via Putignani, número 16, província onde falecera em 1922. Pastore certamente o conheceu. Deve por certo ter trocado uma boa conversa com todos aqueles ligados à família Antonelli, já que Pastore era descrito como um sujeito falante, vestido elegantemente de preto, usando uma longa corrente de ouro em seu colete, e com o sorriso mais afável, estendia a mão perguntando: "non mi conosci? Sono Vincenzo Pastore". 162

Seu estúdio aberto na Rua Sparano, em 1914, deve ter se avizinhado do local de trabalho de Angelo Antonelli e de seus filhos, que desde 1906, estampavam no cartão suporte

162 Coleção Dante Pastore. In: Caderno de Recortes. Recorte de jornal título da matéria "Attraverso I Due Mondi. Vincenzo Pastore Nella Vita e Nell'Arte", p. 31-32. Tradução Nossa. 
das fotos o nome desta rua comercial que começava a se destacar como a mais importante de Bari. Na carta "Attraverso Bari” publicada na sessão "Lettere della Provincia" temos um fragmento que nos apresenta o quanto Pastore, ao inaugurar seu estúdio, reconhecidamente se colocava ao lado dos retratistas mais notáveis da província: "Russo, Antonelli, aquele da via Sparano, e o outro da via Piccinni, são como Pastore artistas valorosos, e eu penso que a presença de Pastore aqui em Bari e de seu novo estabilecimento fotográfico não irá nos desapontar". 163

Se nada encontramos sobre o fotógrafo Russo, a trajetória de Michele Fiorino despontou com maiores vestígios. Poucas foram as chances de Pastore ter encontrado com este fotógrafo que nas décadas de 1880 e 1890 atuava no estúdio localizado na Avenida Corso Vittorio Emanuele. Nos primeiros anos do século XX, Fiorino havia se transferido para a Rua Sparano, número 99. Quando Pastore chegou à cidade para inaugurar em 1914 o estúdio $A i$ Due Mondi- Fotografia Italo-Americana, Fiorino já estava desde o início de 1911, em seu novo estúdio aberto em Torino, na "nella centralissima Piazza Castello" (Leonardi, 1997, p. 84). A prática deste fotógrafo se entrelaçou com as demais até aqui observadas: Práticas errantes, sondadas por vestígios soltos no tempo, revelando ora possíveis momentos de aproximação entre os fotógrafos retratistas, ora contatos distanciados pela dificuldade de se viver do retrato.

Viver da fotografia ao sul da Itália exigia maleabilidade. Se, em Potenza, percebemos o quanto a prática retratística de estúdio vinculou-se à atividade semi-ambulante, em Bari reconstituímos experiências de fotógrafos que abriram reiteradas vezes filias de seus estúdios em comunas e províncias vizinhas, investindo em novos estúdios, inaugurados em novos lugares, disputando uma clientela mais remediada, e ainda, muitas vezes, atendendo à domicilia famílias das camadas médias. Disputas que levavam ao rompimento de sociedades, mesmo aquelas mantidas entre irmãos. Infelizmente encontramos apenas uma fotografia de um cliente de Pastore tomada no estúdio Potentino. Do Ai Due Mondi, ficamos por enquanto apenas com as fotos internas do estúdio, podendo por meio delas, apenas imaginar como era entrar no térreo transformado em galeria, como seria subir à sala de espera sofisticada e chegar ao estúdio propriamente dito. Experiência que possibilita às imagens, ainda guardadas na coleção da família, existir aos olhos de quem tenta ver Pastore, numa experiência que é

${ }^{163}$ Coleção Dante Pastore. In: Caderno de Recortes, p. 66-67. 
sempre fragmentária, ambígua, confirmando não o que o espaço era no original, mas antes como Pastore gostaria de apresentá-lo.

Delineamos uma silenciosa trajetória das imagens: Feitas em Bari, depois atravessaram com Pastore o Atlântico, um fotógrafo que costumava levar seu arquivo em suas idas e vindas entre Brasil e Itália. Fotos que foram guardadas por Elvira, a autora da coleção, que zelosamente montou o “Álbum de Recordações Vicente e Elvira Pastore”. É nesse documento que as imagens do estúdio em Bari vivem, sobrevivem e contam o sonho de Pastore. Imaginamos agora adentrar no piso térreo do estúdio barese para nuançar especificidades que colocam Pastore em intenso diálogo com a prática de uma fotografia que desejava transcender, porque o fotógrafo por vezes recusava a reprodução fiel e quase servil do real.

\subsection{Na "Galeria de Imagens": Pastore entre o pictoralismo e as fotos montagens, desejos de transcendência do fotógrafo}

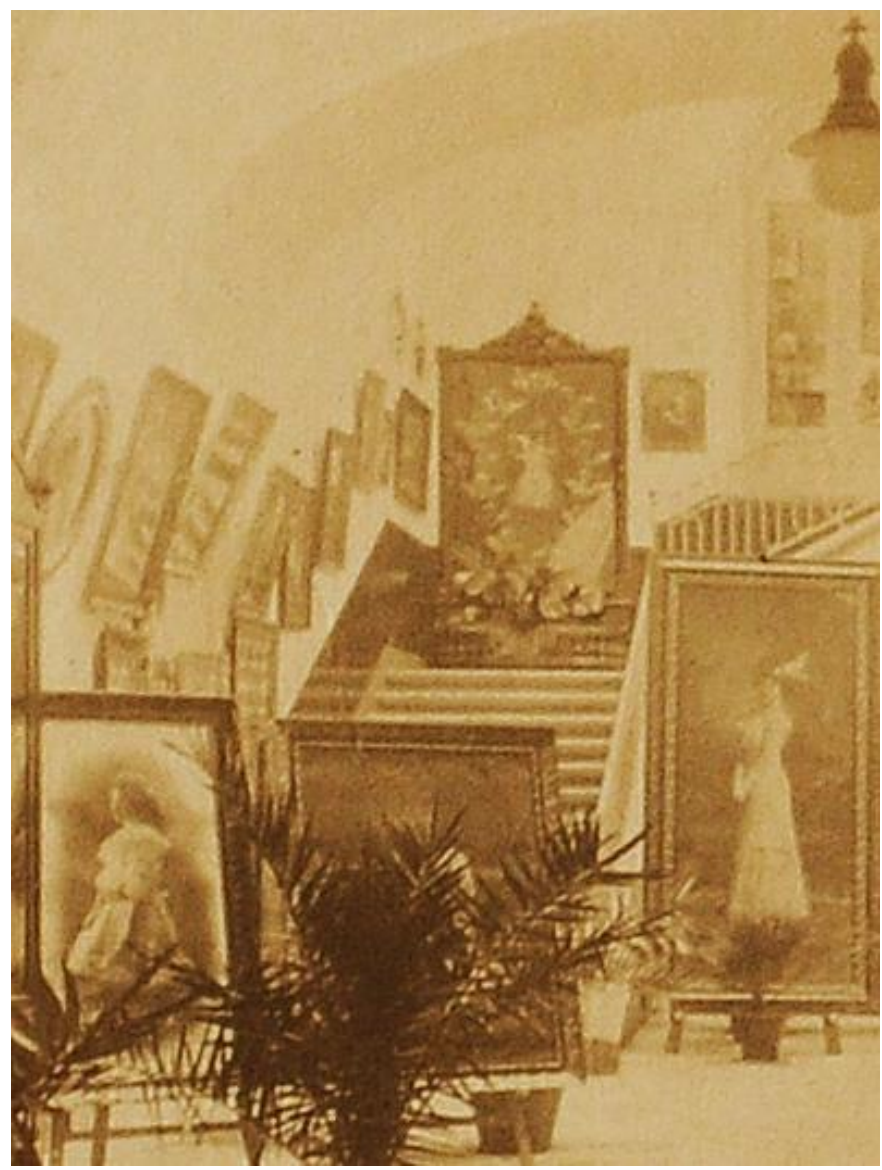

\section{Figura 117:}

Detalhe de reprodução feita foto do piso térreo do estúdio de Pastore aberto em Bari, na Itália. Vê-se retratos em grande formato emoldurados. Coleção Dante Pastore.

Manifestações mais ambiciosas se inscreveram na passagem do andar térreo e nas escadas que conduziam à sala de espera do estúdio inaugurado em Bari (fig.117). Não 
cessavam os esforços de Pastore em apresentar seu trabalho, vislumbrando o prestígio das belas artes. Nas muitas molduras, pouca sobriedade. As fotos foram exibidas em grandes dimensões, com molduras rebuscadas. Reivindicava-se o estatuto de quadros. Segundo Giulia Zanini, a fotografia competia com a pintura por meio de tais "ingrandimento". ${ }^{164}$

O retrato da sua filha Eleonora, colocado ao meio da escada, participou de um interessante trânsito de imagens ativado pelo fotógrafo na mostra criada em Bari, indiciando a inclinação de Pastore para práticas de intervenção no retrato. Organizar mostras e exposições era também parte de uma prática abrangente que intuía colocar a fotografia como arte, posta sobre apreciação e julgamento.Trataremos agora de uma trajetória de imagens que anunciam Pastore ora produzindo fotos-montagens, tentando divertir e surpreender de forma lúdica a clientela que tentava seduzir, ora inclinando-se para um movimento que promovia maior interferência e participação criativa dos fotógrafos no processo de criação e feitura das imagens. Voltar-se para o pictorialismo, que "buscava se apropriar do terreno já reivindicado pela arte" (Krauss, 2002, p.134) foi uma possível estratégia para colocar-se em dia com as questões que marcavam a fotografia em fins dos oitocentos.

No estúdio inaugurado em Bari, vê-se como o desejo de deslumbramento, âmago do pictorialismo, acompanhava à produção de fotomontagens feitas por Pastore, fotógrafo que optou pelo efeito flou, posicionando-se a favor da criação de efeitos estéticos na imagem contra a excessiva precisão, para ele o verdadeiro "suicídio do artista". O fotógrafo que sobrevivia do retrato comercial escreveu "Fotografia ed Arte" (fig.118), um artigo assinado somente com as iniciais de seu nome, VP. Pontuou em seu relato um desejo que se distanciava tanto dos populares "retratos mimosos", quanto da exploração de artifícios excessivos nas cenas de modelos imitando anjos, madonas, heroínas clássicas, que Pastore também experimentou, uma "banalidade que reinava em todas as artes", com razões de ser apenas vendidas, ${ }^{165}$ como explicou o pictorialista Charles H. Caffin, em 1901. Pastore tentava

\footnotetext{
${ }^{164 Z a n i n i, ~ a f i r m a ~ q u e ~ a s ~ r e p r o d u c ̧ o ̃ e s ~ e m ~ g r a n d e s ~ d i m e n s o ̃ e s ~ s a ̃ o ~ d i f i ́ c e i s ~ d e ~ s e ~ r e a l i z a r ~ d e v i d o ~ a ~ n e c e s s i d a d e ~ d e ~}$ correção de lentes em relação as linhas de perspectivas do modelo, podendo segundo a pesquisadora criar uma imagem grotesca e irreal, que resultaria na "ruína do genero artístico". Cf. ZANINI, Giulia. La rivista "La Fotografia Artistica" e il pittorialismo in Italia. Tese de doutorado em Economia e Gestão de Artes e de Atividades Culturais da Università Ca'Foscare Venezia. Ano Acadêmico 2013/2014, p. 64. Tradução Nossa.

${ }^{165}$ Caffin, Charles. La fotografia como una de las bellas artes. 1901. In: Fontcuberta, 2003, p. 90. Caffin foi um crítico de arte interessado pela fotografia pictorialista. Nasceu na Inglaterra no ano de 1854, tendo falecido no mesmo ano que Pastore, 1918. Fazia a distinção entre fotografias utilitárias e as consideradas como artísticas criadas pelos fotógrafos avançados, ou seja, que realizavam suas imagens com pretensão pictural. Nas capas de revistas como A Vida Moderna e A Cigarra, Pastore publicava fotos de moças retratadas como santas, conseguindo assim anunciar ser ateliê.
} 
se posicionar como alguém que conhecia as tendências fotográficas de seu tempo. Seu texto traz sutilezas revelando como o fotógrafo também rejeitou a "reprodução fiel e quase servil" da imagem.

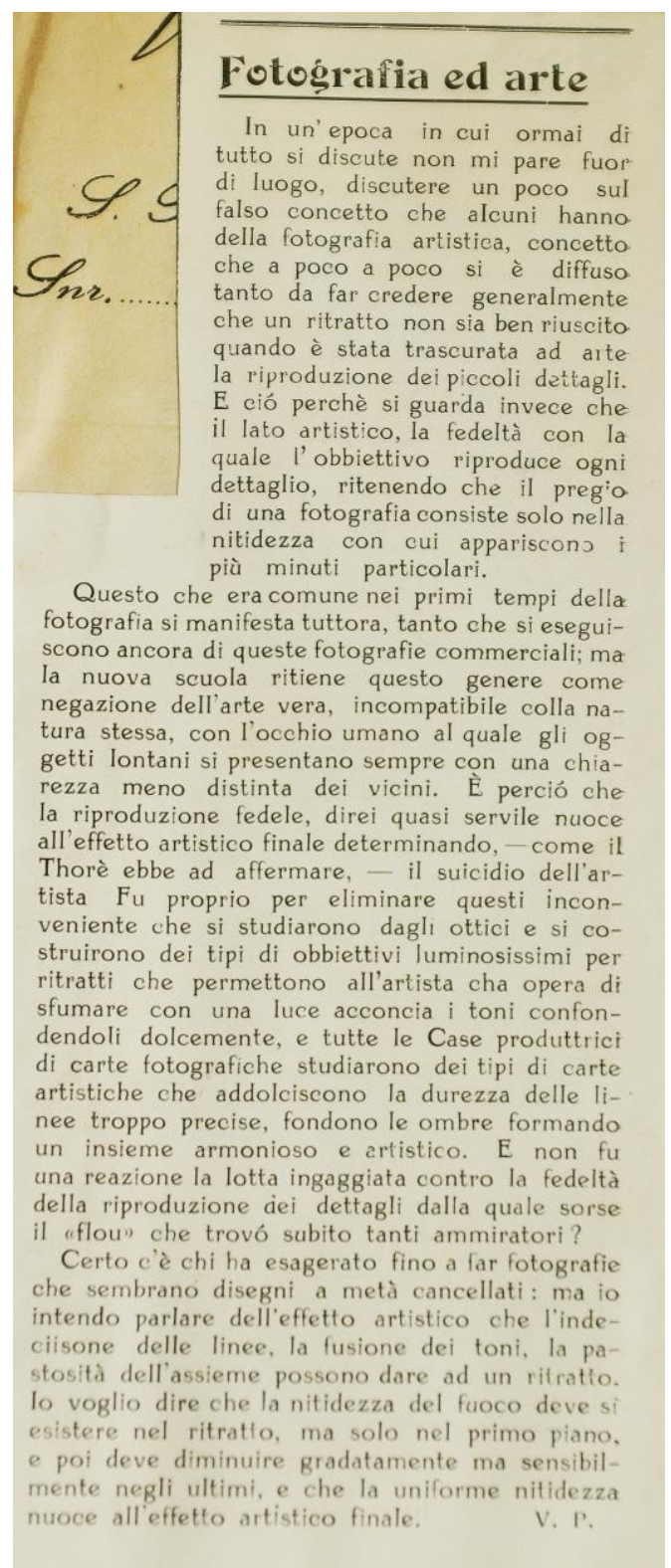

Em uma época em que se discute sobre tudo não me parece inoportuno discutir um pouco sobre o falso conceito que alguns têm da fotografia artística, conceito que difundiu-se pouco a pouco de tal modo a fazer crer geralmente que um retrato não seja bem feito quando foi ignorada a reprodução dos pequenos detalhes. $\mathrm{E}$ isso porque se olha, ao invés do lado artístico, a fidelidade com a qual a objetiva reproduz cada detalhe, considerando que o valor de uma fotografia consiste somente na nitidez com que aparecem as menores particularidades.

Isso que era comum nos primórdios da fotografia manifesta-se ainda hoje, tanto que executam-se ainda essas fotografias comerciais; mas a nova escola considera esse gênero como negação da verdadeira arte, incompatível com a própria natureza, com o olho humano ao qual os objetos distantes apresentam-se sempre com uma clareza menos distinta daquela dos objetos próximos. É por isso que a reprodução fiel, diria quase servil, prejudica o efeito artístico final determinando - como afirmou Thoré - o suicídio do artista.

Foi exatamente para eliminar esses inconvenientes que foram estudados pelos ópticos e construídos tipos de objetivas luminosíssimas para retratos que permitem ao artista que opera esfumar os tons com uma luz adequada, confundindo-os docemente, e todas as Casas produtoras de papel fotográfico estudaram tipos de papeis artísticos que suavizam a dureza das linhas muito precisas, fundem as sombras formando um conjunto harmonioso e artístico. E não foi uma reação a luta engajada contra a fidelidade da reprodução dos detalhes a partir da qual surgiu o "efeito flou" que encontrou logo tantos admiradores? Existe é claro quem exagerou a ponto de fazer fotografias que parecem desenhos apagados pela metade: mas a minha intenção é falar do efeito artístico que a indecisão (sic) das linhas, a fusão dos tons, a pastosidade do conjunto podem dar a um retrato. Eu quero dizer que a nitidez do foco deve sim existir no retrato, mas somente em primeiro plano, e depois deve diminuir gradativamente, mas sensivelmente nos últimos, e que a uniforme nitidez prejudica o efeito artístico final. ${ }^{166}$

A despeito de Pastore ter ganho dinheiro nesse circuito de registros de "banalidades", afinal era preciso sustentar sua família, ao escrever deixou vestígios demarcando sentidos de

\footnotetext{
166 Coleção Dante Pastore. Esse recorte refere-se à figura 118. Caderno de Recortes. Artigo assinado por
} Vincenzo Pastore. Título: Fotografia e Arte. Sem indicação de fonte e sem data. Tradução Nossa. 
uma imagem que também intuía realizar, mesmo precisando sobreviver da fotografia de cunho mais comercial. Esse relato (fig.118) nos aproxima de algo bastante inusitado sobre o repertório imagético: o pensamento dos fotógrafos, aspecto cada vez mais essencial aos estudos da fotografia como aponta Costa (2012). Em sua prática fotográfica, Pastore confluía o fazer de imagens com o dizer de textos que, segundo Rouillé (2009, p.255) organizavam e mantinham vivo o movimento pictorialista. Em defesa de seus ideais artísticos e do papel da fotografia como arte Pastore afirmava que a produção de retratos não poderia ser guiada apenas por fins comerciais, não deixando de questionar a essencialidade da imagem como simples cópia do real. Pastore revelou seu desejo de transcendência (fig.118).

As ideias e tendências teóricas que constituíam o movimento pictorialista, alimentavam todo um circuito de fotos e textos que envolviam Pastore, atento a economia visual de seu tempo:

Os salões e as exposições canalizaram as diversas tendências e, sobretudo, demonstraram a existência de um movimento pictorialista único, coerente e notavelmente organizado. A divulgação dos debates, das tendências e dos pontos de consenso era função de uma abundante literatura fotográfica. As revistas fotográficas, literárias e a imprensa em geral continuavam, como antes de 1890, a dar espaço à discussão sobre os méritos artítiscos da fotografia, mas florescia também uma literatura cujo único propósito era promover o movimento pictorialista por meio de catálogos de exposições, álbuns, portfólios e boltetins das associações fotográficas (...) A estrutura dos boletins seguia geralmente a mesma fórmula: manuais práticos, monografias técnicas ou artigos debatendo incessantemente a célebre questão: “A Fotografia é uma arte?”. (Mello, 1998, p.36)

De modo independente o fotógrafo agia por meio de práticas que deram maior solidez ao movimento. É possível que seu relato tenha circulado de modo isolado, prática comum na época, como mencionou Maria Teresa Villela de Mello:

Como o movimento não se constituiu em torno de um manifesto estético, reunindo muitas vezes uma variedade de técnicas e produções também sensivelmente distintas de um país para outro, as associações, embora servissem de referência ao movimento, não garantiam a uniformidade da produção. A conseqüência direta dessas diferenças, fez com que fotógrafos, isoladamente, ou em associações, viessem a se apresentar como conservadores ou modernistas e, dependendo da conjuntura, essas denominações tornavam-se intercambiáveis. (Mello, 1998, p.37)

O retrato da filha de Pastore aos seis anos de idade apresenta sutilezas do agenciamento do pai (fig.120). O desfocamento produzia um efeito de opacidade e de certa nostalgia 
evocada. Os retoques contornando os ombros cobertos da menina davam formas às sombras projetadas. Essa fotografia revela-se como paradigmática das intenções de Pastore porque se construiu carregada de intenções estéticas, encobrindo detalhes, rompendo o formalismo comum dos retratos mimosos, mais convencionais e populares, sem nenhuma alteração nos aspectos formais do registro. Pastore experimentou o limiar da tensão entre a imagem como fetiche da mercadoria e aquela que renegava a estrita mecanicidade da foto em nome de uma aura aparentemente perdida. Ao apresentar-se como um fotógrafo em sintonia com a fotografia de virada de século, Pastore experimento o aspecto virtuoso, o "fascínio mágico" do retrato, presente quando a fotografia ainda não experimentava sua faceta industrial, serial que resultou numa experiência de total perda do sublime (Benjamin,1994). O seu ato fotográfico tentava aproximar-se daquilo que caracterizava os fotógrafos amadores pictorialistas que fomentaram para Mello (1998, p.38) a "confrontação do indivíduo com o real, e a imagem um produto marcado por este conflito".
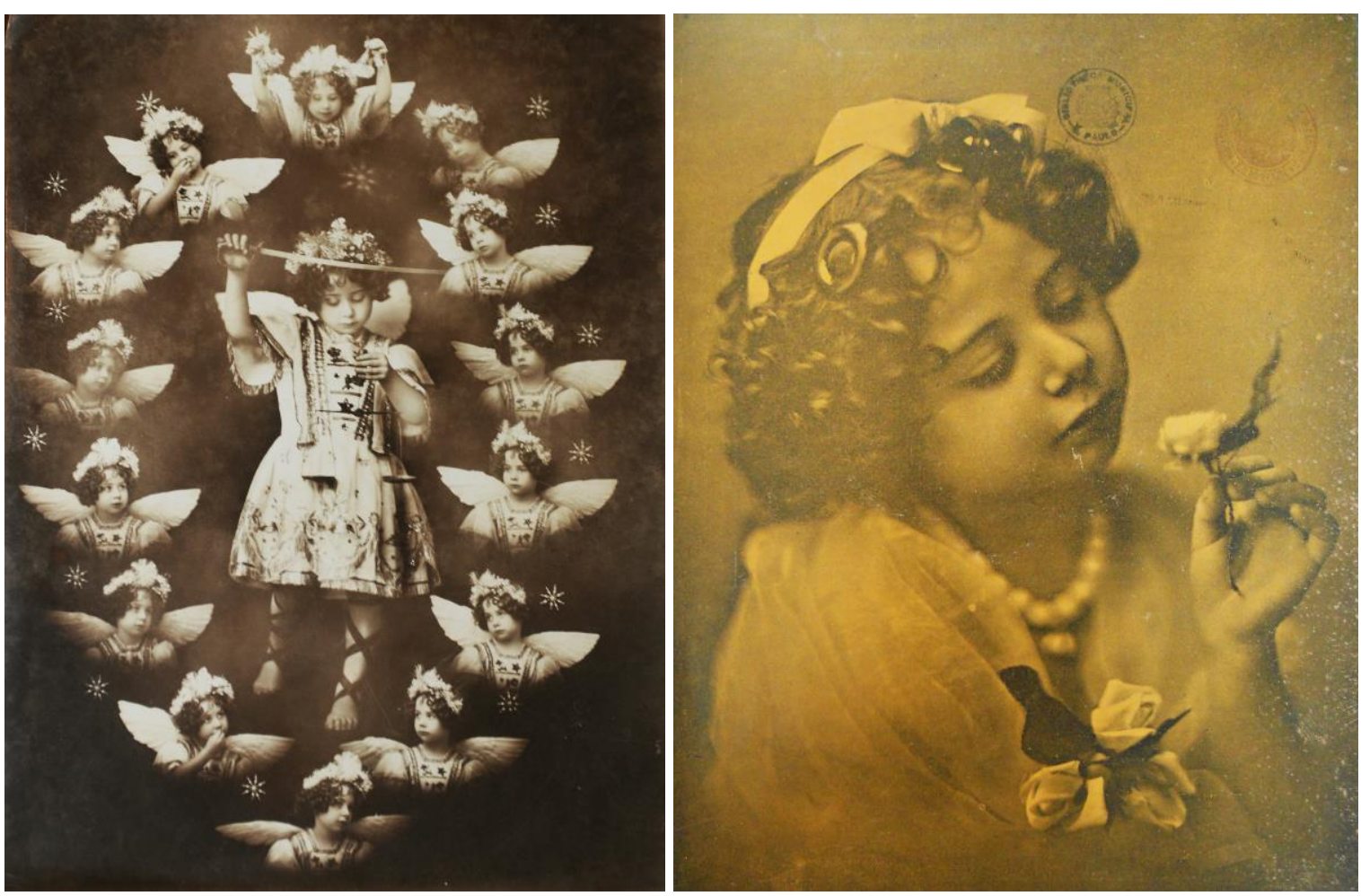

Figura 119 e 120: Fotomontagem feita por Pastore a partir de retratos realizados da sua filha Eleonora. Sem data $\odot$ Vincenzo Pastore. Coleção Costanza Pastore doada ao Mosteiro São Bento; à direita capa da revista A Vida Moderna. Retrato da filha de Pastore Eleonora. Como a seção de classificados fica cada vez mais restrita, os fotógrafos enviavam fotos em troca de anúncios. 10 de setembro de 1914, n. 238 (C) Vincenzo Pastore / Biblioteca Mario de Andrade.

As ondulações nos cabelos eram na maioria das vezes obtidas com ferro de frisar. A fita no cabelo da menina retratada na foto lembra a infância. $\mathrm{O}$ uso do colar de pérolas e o tule de 
seda envolvendo seus ombros antecipam a mocidade, desvelando o desejo do fotógrafo em obter efeitos artísticos no retrato, deixando cachos, panos e adereços pouco nítidos, esfumaçados, alcançados pelo foco impreciso, suavizando-se detalhes. ${ }^{167}$

Vestida com as asas de São Miguel, a menina Eleonora teve sua imagem ainda recriada numa foto montagem. Com entusiasmada admiração os visitantes da mostra apresentada no estúdio Ai Due Mondi, encantaram-se com a "imagem magnífica": "Merece uma especial atenção um quadro magnífico representando um grupo de anjos sendo na verdade uma única menina fotografada em modos diferentes num mesmo negativo. Aquele quadro, como muitos outros, provocaram uma viva admiração". ${ }^{168}$ A realidade, resignificada pelo fotógrafo respondia à natureza múltipla da fotografia. Aqueles que visitavam a mostra em Bari experimentaram uma experiência de encantamento.

A foto descrita na época como uma "imagem magnífica" inscreve como Pastore desafiou a prática do ver, seguindo o modismo da época. Devido à preocupação com o termo, se decidiu seguir o pressuposto indicado por Fabris. A foto-montagem é muitas vezes confundida com a fotografia compósita ou composta. Para se evitar tal erro, Fabris (2011) trata a primeira como produções realizadas apenas com fotografias; o segundo termo se refere às composições formadas entre fotografia e desenho, produzidas no século XIX. ${ }^{169}$

A filha Costanza, a mais velha entre os irmãos, ao destacar como o pai foi "um apaixonado pela sua arte", contou em seu depoimento sobre o mostruário de fotografias comercializadas pelo fotógrafo em São Paulo. "Enchia a casa de gente para saber como é que podia por tantas vezes a pessoa na mesma foto. As pessoas viam e queriam igual". ${ }^{170}$

No retrato de outra filha vemos um ato fotográfico que conjugava uma intenção de realidade fabricada (fig.121). A fotomontagem da menina Olga foi enviada "aos queridos irmãozinhos" que estudavam na Itália. "Olga faz birra, Olga está alegre, Olga chora”, pode ter sido uma imagem apresentada aos clientes que chegavam no estúdio em São Paulo curiosos, não apenas em entender a técnica usada, mas em possuir semelhante retrato em moda. A nota

\footnotetext{
${ }^{167}$ As exigências voltadas às mulheres desde a infância materializavam-se no retrato. A docilidade e meiguice de Eleonora misturam-se aos padrões de vestimenta impostos às crianças com mais de 6 anos. A partir daí, deveriam se apresentar com os trajes similares aos dos adultos, afirma Arend (2012, p.71).

${ }^{168}$ Coleção Dante Pastore. In: Caderno de Recortes de jornais, p. 33. Artigo "Indimenticabile festa del lavoro". Tradução nossa.

${ }^{169}$ Sobre as controversas do uso dos termos ver Balady. Valério Vieira: um dos pioneiros da experimentação fotográfica no Brasil. Dissertação de Mestrado/USP. 2012, p. 129-130.

${ }^{170}$ Entrevista feita pelo pesquisador Ricardo Mendes com Costanza Pastore, em 1994. Gravações e transcrição parcial com alguns descendentes de Pastore encontram-se na Divisão de Pesquisa do Centro Cultural São Paulo.
} 
publicada em jornal, sob o título "De volta da Europa", ao anunciar a volta de Pastore, deu vistas do encantamento provocado também entre os paulistanos:

Ele quis acompanhar sua "reprise" de uma novidade de sucesso garantido: a fotografia animada. É ainda um segredo e não há, portanto, possíveis grandes indiscrições. Com a fotografia animada - derivação da cinematografia - todos poderão ver a própria imagem assumir as diversas fisionomias caracterizadas pela pose, pelo sorriso, pelo choro (...) parabenizamos o nosso excelentíssimo compatriota e lhe desejamos bons negócios. ${ }^{171}$

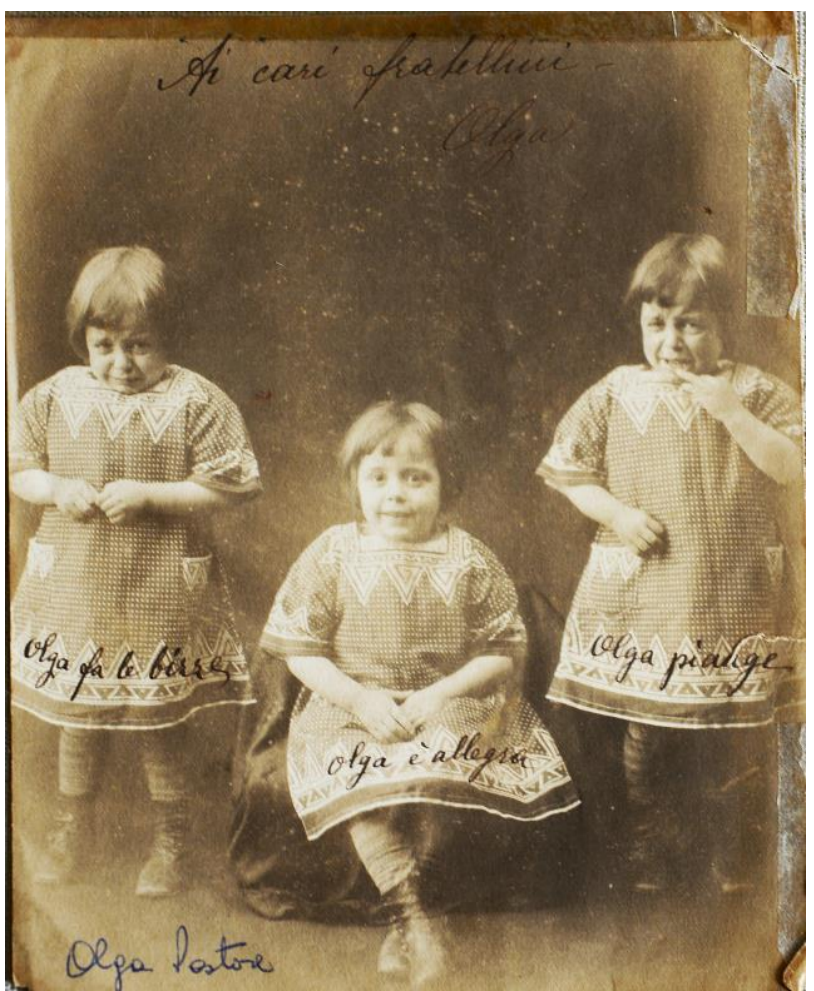

Figura 121:

Fotomontagem a partir de retratos da filha de Pastore chamada Olga. As inscrições foram provavelmente feitas por Elvira, após a reprodução da imagem em papel já que era ela a responsável pelo trabalho no laboratório. A letra é semelhante a encontrada no Diário de Elvira que integra a coleção. Fotografia s/d (C) Vincenzo Pastore. Coleção Dante Pastore.
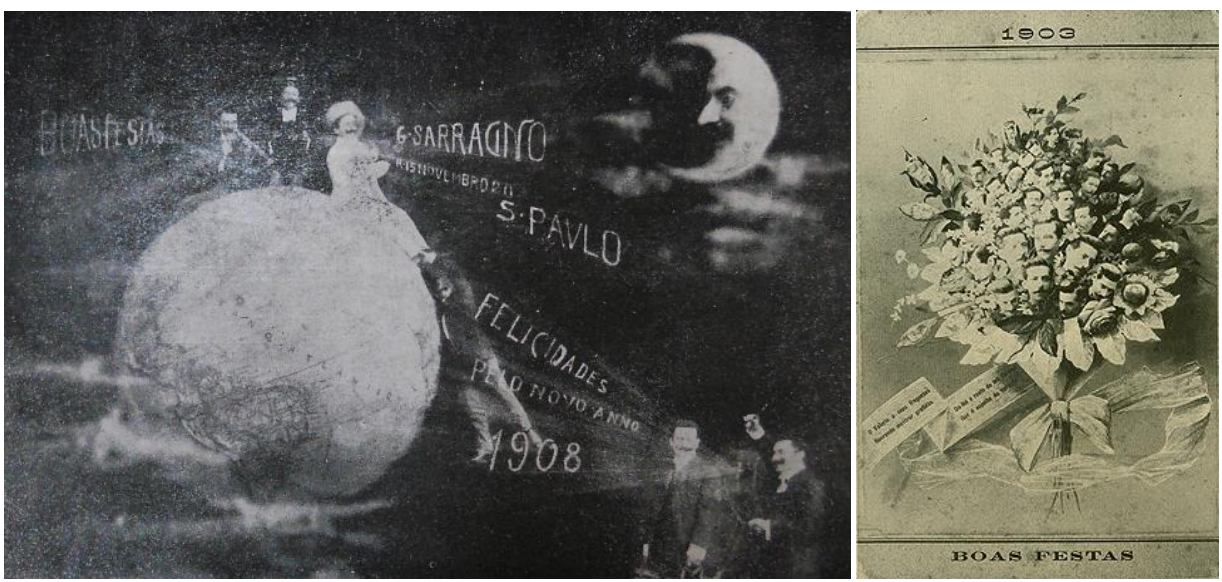

Figuras 122 e 123:

À esquerda foto de $\mathrm{G}$.

Sarracino: Cartão de boas festas publicado na

Revista A Vida Moderna em 15 de janeiro de 1908. N. 31. À Direita Cartão de Boas Festas. 1903 (C) Valério Vieira / Cortesia Acervo Museu Paulista/USP.

\footnotetext{
${ }^{171}$ Coleção Dante Pastore. In: Caderno de Recortes de jornais, p. 15. Tradução Nossa.
} 
Pastore na imagem acima fez uso das técnicas para a produção da chamada fotografia animada, obtida com o uso de objetivas específicas ou quando os fotógrafos se aventuravam numa insistente manipulação da imagem duplicada. Obtinham assim poses de uma mesma pessoa em uma única chapa, ou manipulando a reprodução do negativo no papel sensibilizado em diferentes etapas.

Pastore revela-se como um fotógrafo curioso pelas múltiplas possibilidades da fotografia, submetida a novos fenômenos criativos, aproximando sua fotografia daquilo que via circular em seu tempo. Valério Vieira em 1903 criou o seu famoso "cartão de boas festas" (fig.123). ${ }^{172}$ Diferentes ângulos de seu rosto foram colocados num buque de flores, imagem oferecida como brinde aos clientes. ${ }^{173}$

Para felicitar a chegada de 1908, Sarracino, fotógrafo conterrâneo de Pastore, com atelier na Rua XV de Novembro, se colocou como dono do mundo, ora filmando o planeta terra, ora nele sentado. Ainda colocou seu rosto fixado na lua (fig.122). ${ }^{174}$ Contando com os avanços das técnicas de impressão da imagem, Sarracino propagandeou em revista ilustrada suas técnicas e criatividade, tendo seus méritos destacados nas fotos mais uma vez oferecidas como brindes: "artista caprichoso nos seus trabalhos e extremamente delicado com sua enorme clientela. O seu atelier photographico é bem digno de S. Paulo".

Se Valério antecipou a experimentação de arranjos criativos propostos também por Sarracino, Pastore mostrou-se como um fotógrafo atento a sensibilidade de sua época. Ao distribuir um calendário como brinde às redações dos jornais, Pastore anunciava seu estúdio,

\footnotetext{
172 Vieira foi dono de um estúdio fotográfico marcado por uma trajetória de sucesso, freqüentado por políticos, bacharéis; uma clientela bastante ligada aos grupos das elites. Realizou, além de retratos, fotos panorâmicas e montagens fotográficas que, segundo Balady, evidenciam ações de vanguarda por parte deste fotógrafo, considerado, um dos pioneiros na experimentação fotográfica brasileira. Ver Balady, Sonia Umburanas. Valério Vieira: um dos pioneiros da experimentação fotográfica no Brasil. 2012.

${ }^{173}$ Em 1901 Valério Vieira criou também a célebre imagem "Os trinta Valérios" feita a partir de um negativo de vidro de fundo original, com trinta auto-retratos do autor em situações diversas captadas em outros negativos, montados numa única imagem medindo cerca de $80 \times 60 \mathrm{~cm}$, tida, segundo Balady (2012), como um marco na história da fotografia brasileira, se destacando entre toda sua produção de fotomontagens realizadas entre 1900 a 1905.

${ }^{174}$ Sarracino, "um dos mais importantes fotógrafos da colônia italiana radicados na capital paulista", aluno em Nápoles de Colentano e De Luca, emigrou muito jovem para o Brasil, tornando-se um freqüentador do Liceu de Artes e Ofícios. Sarracino era bastante conhecido na colônia italiana em São Paulo. Ver Kossoy. Dicionário Histórico-Fotográfico Brasileiro. São Paulo: IMS, 2002, p.286. Sarracino foi também um colaborador da revista Kosmos. Em 1904, recebeu medalha de bronze na Exposição Internacional de Saint Louis, pelo retrato de Santos Dumont em tamanho natural, presentes no acervo do Museu Paulista. Na Exposição Nacional de 1908 apresentou retratos de políticos e personalidades da vida social, além de ter realizado as fotografias do livro De Santos a Uma Fazenda, de José Mortari, propagandeando a imigração para a cidade. Livro este patrocinado pelo Estado de São Paulo e pela Câmara Italiana de Comercio e Arte.
} 
além de mostrar o domínio de uma técnica que se popularizava entre os fotógrafos contemporâneos. Notícia que depois chegaria à clientela que passava a desejar as inusitadas reproduções. Infelizmente, não encontramos esse registro fotográfico na coleção da família, mas indiciamos uma prática que aproximava diferentes fotógrafos, divulgando, além do domínio de uma técnica, uma mesma estratégia de publicização dos ateliês.

1 callendiach

Ii noto artista fotografo Vincenzo Pastore -i manda un calendario originalissimo, consistente in una fotografia, che riproduce in ben undici pose dive"se l'effigie dell'amico nostro. Alla fotografia è attaccato un utilissimo blok da sfogliare.
O conhecido artista fotógrafo Vincenzo Pastore enviou um originalíssimo calendário que consiste em uma fotografia reproduzindo em onze diferentes poses um amigo que temos em comum. Junto à fotografia um útil caderno para folhear. (Tradução Nossa.)

Figura 125: Reprodução de recorte anunciando o estúdio do fotógrafo. Caderno de Recortes. Coleção Dante Pastore.

Vê-se como Pastore acompanhava o modismo das fotomontagens em São Paulo, apresentando-as aos seus clientes, oferecendo-as como brindes, chegando depois a exibí-las na galeria de imagens em seu estúdio barese. Seguimos com mais afinco investigando Pastore em sintonia com as tendências fotográficas de sua época.

\subsection{Entre o efeito flou, retoques, pincéis e o esfuminho: Fotografias reinventadas}

Procedimentos de intervenção marcam a prática foto-pictórica. O emprego de novos dispositivos ópticos, lentes de lunetas rudimentares, ou erros cromáticos eram explorados, bem como os defeitos de objetivas, ou a mistura de objetivas convergentes e divergentes para se obter o efeito flou, ou até mesmo as inutilizando, como se faz com as câmeras pinhole, com a imagem captada a partir de uma pequena abertura de uma caixa fechada. Tem-se aqui o “projeto global” de concepção pictórica, como pontuou Rouillè. (2009, p. 258-259).

No início do século $\mathrm{XX}$, a crescente manipulação artística e a experimentação tecnológica, como argumenta Orvell, faziam da fotografia um objeto carregado de efeitos e retórica, "from a passive médium to an active médium". (Orvell, 1989, p. 99). A existência de uma rede internacional, com irradiação na Europa, mas com desenvolvimento acentuado nos Estados Unidos, foi vital para colocar a fotografia entre as belas-artes. ${ }^{175} \mathrm{Se}$ os fotógrafos

\footnotetext{
175 Rouillé, 2009, p. 255. Ver Também Fabris, 2011, p. 8. Nos Estados Unidos o desenvolvimento se acentuou segundo a autora graças ao trabalho de Alfred Stieglitz, que defendia uma fotografia requintada, frente a vulgarização da fotografia pela "ideologia Kodak".
} 
brasileiros não confinaram a fotografia nos limites da representação de seu referente, os fotógrafos italianos também reivindicavam sua participação dentro do movimento. ${ }^{176}$ Importantes vestígios mostram como Pastore acompanhava tais ideias; saiu em defesa do uso diferenciado do foco, posicionando-se como um fotógrafo adepto do "flouismo". ${ }^{177}$

Supomos que o citado Thoré no artigo assinado por Pastore seja na verdade o conhecido crítico e escritor italiano Enrico Thovez, defensor da chamada "fotografia artística", para ele um novo modo de pensar e fazer fotografia. Delineamos brevemente o que era o pictoralismo para os italianos. Em 1898, na "grande Esposizione Torinense", declarou:

Um imenso campo está aberto na terra, no mar e nos céus para a arte fotográfica, que para a pintura está fechado com espinhos penetrantes (...) basta somente o poeta, que coloca na escolha e no estudo dos temas a dignidade, a sensibilidade, a ternura, o gosto severo que outros colocam ou deveriam colocar ao retratar a realidade em pinceladas ou em versos ${ }^{178}$

A despeito da grafia errada do nome desse importante teórico do fotopictorialismo no contexto italiano, Pastore acompanhava o debate em torno da fotografia, conhecendo as perspectivas fotográficas que mais se destacavam no cenário italiano, difundidas por autores de artigos e ensaios publicados em revistas especializadas, que nuançam o espraiar de ideias de um campo visual que se complexificava cada vez mais.

O movimento criado em Paris em 1892, no bojo dos debates que ocorriam no Photo Clube de Paris, tornou-se pertinente no quadro da península itálica. As revistas "Il Dilettante di Fotografia" fundada por Luigi Gioppi, no ano de 1890, em Milão, com uma "linguagem simples, fácil acessível a todos" e "Il Progresso Fotografico", de Rodolfo Namias, fundada em 1894, mostram como na última década do século XIX, o pictorialismo era um movimento que tensionava o debate em torno da prática fotografia na Itália. Dirigida a amadores, mas também a profissionais, publicando artigos sobre questões técnicas, sobre novos

\footnotetext{
176 Fotógrafos brasileiros além do acesso a publicações estrangeiras viajavam com freqüência para o exterior. Durante a década de 1920 a estética pictorialista foram "adotados e divulgados na integra" pela revista Photogramma, por exemplo. Sobre a participação da fotografia brasileira nas experimentações das vanguardas européias ver COSTA, 2008, p. 291.

177 O efeito Flou foi apresentado pelo britânico Alfred Maskell. Cf. Zannier, 1993, pp. 24-25.

178 Thovez, Enrico. Poesia fotográfica. II pensiero di un critico d'arte sulla fotografia nel 1898. APUD. Zannier, Italo. Leggere La Fotografia Le Riviste Specializzate in Italia. (1863-1990). Editora NIS. La Nuova Italia Scientifica. 1993, p. 37.Tradução Nossa.
} 
procedimentos, com publicidade de matérias e equipamentos fotográficos, disseminavam o conceito corrente de arte fotográfica. ${ }^{179}$

Orientações sobre o uso da goma-bicromatada, sobre o uso de cores, sobre processos de viragens e de "vistosos retoques", que por certo desagradariam a concepção pictorialista de Peter Henry Emerson (1856-1936), um dos principais autores e participantes do intenso debate surgido no bojo do movimento, eram realizados para ajudar a colocar em evidencia "l'abilità dell'autore". ${ }^{180}$ Pastore recorreu a tais processos em demasia. A imagem flou, segundo o pesquisador Ítalo Zannier (1993) devia fazer desaparecer a nitidez consentindo à fotografia uma "sublime qualità". Zannier mencionou importantes processos de produção adotados no contexto italiano, a saber, a matriz de formação de Pastore:

Para os fluistas se deve tender a mascarar o máximo possível, com todos os meios, a fotografia: no suporte, que muitas vezes é de papel de desenho enrugado, semelhante ao papel para litografia; na superfície fotossensível, de preferência "granulada" com a goma bicromatada, como em uma incisão; nos tons e nos detalhes, tornados soft pela ótica "aperfeiçoada" fazendo-a anacromática, ou com a aplicação de simples filtros de difusão, até mesmo uma fina gaze colocada na frente da lente; na cor, na maioria das vezes monocromática, obtida com uma viragem química nas mais diversas tonalidades, para atribuir um valor simbólico à imagem, em vez de imitar a natureza, que se gostaria de esquecer como "sujeito" inevitavelmente realista, portanto menos condicionante, como se entende ainda hoje por "mecanicidade" da fotografia. (Zannier, 1993, p. 24-25. Tradução nossa)

\footnotetext{
${ }^{179}$ A revista "Il Dilettante di Fotografia", fundada por Luigi Gioppi, foi inspirada na revista francesa "Les Annales Photographiques"segundo Zannier, 1993, pp. 24-25. Tradução nossa.

${ }^{180}$ Fabris (2011) apresenta duas escolas em disputa no movimento. Henry Peach Robinson (1830-1901) e Peter Henry Emerson, segundo Costa (2012) foram importantes autores que promoveram um rico debate sobre "a legitimação de certa produção fotográfica como manifestação artística", situando duas principais vertentes da estética pictorialista, a partir do final do século XIX. Para Fabris (2011), ambos representam a principal vertente teórica do movimento. Enquanto Robinson "foi defensor de imagens intensamente manipuladas", valendo-se de sua experiência como pintor e depois fotógrafo profissional, criando fotos compósitas com a reunião de cinco negativos, como se vê em "Os últimos instantes", fotografando "como se fosse um tableau vivant teatral", Emerson assumi posição contrária. Obra que o tornou famoso em 1858. A encenação, segundo Fabris, foi realizada toda em estúdio, numa rica encenação que causou um "sentimento mórbido" por parte do público, inclusive censurada pela escolha do tema da morte. Para ele, segundo Costa (2012), não se podia negligenciar as qualidades fundamentais e específicas da fotografia, "adepto de uma fotografia de cunho naturalista que, mesmo recorrendo ao uso do foco diferenciado, era isenta de intervenções extra-fotográficas", indica que demasiadamente a tornava híbrida demais, excessivamente alegórica, quando se recorria a referencias da pintura. Emerson recusava as imagens "eivadas de sentimentalismos", produzidas por Rejlander e Robinson. Em 1886, Emerson, com a obra "vida e paisagem nos campos de Norfolk", iniciou uma postura de combate ao artificialismo pictórico. Considerava a fotografia superior à gravura e ao desenho a carvão, mas criticava o colorido das imagens. Para Balady (2012, p.136) Robinson foi o criador de um "ismo", definidor de um campo da fotografia: o pictorialismo.
} 
O pictorialismo entendido como um movimento ideológico atravessava diversos ensaios publicados em várias revistas que circulavam por toda Itália: "Il Bullettino della Società Fotografica Italiana”, fundada em 1889, comemorava os diversos clubes fotográficos que iam de Roma, a Milão chegando a Torino. "La Camera Oscura", criada em 1882, apesar de privilegiar os aspectos técnicos da fotografia, não deixava de citar "a nova técnica pictorialista, apresentada com curiosidade, sobretudo com um uma reflexão sobre a identidade da fotografia como meio expressivo e não unicamente como meio documental", afirmou Zannier (1993); em defesa da técnica interpretativa do pictorialismo, a revista "La Fotografia Artistica", que circulou entre 1904 a 1917, lançou-se fervorosamente no debate sobre a problemática da estética na fotografia, posicionado-se ao lado dos mesmos pressupostos defendidos pela revista de arte, mensal e ilustrada intitulada "Emporium", fundada em Bergamo desde 1876. Em janeiro de 1898, ano em que Pastore vivia em Potenza, o ensaio publicado sugeria a força do movimento no contexto italiano:

$\mathrm{O}$ valor artístico que a fotografia conquista induz a Emporium a tratar mais uma vez e, especialmente, sobretudo o que é produzido de mais notável neste campo (...) com os inúmeros grupos que dedicam-se com empenho a missão de tornar a fotografia merecedora de um lugar de destaque entre as artes plásticas. ${ }^{181}$

Nas duas primeiras décadas do século XX o desejo de estetizar a fotografia com a "sensazioni di emozioni profonde", passava lentamente a caracterizar a fotografia italiana, como explica Zannier (1993, p.30): "De um pictorialismo baseado na meditação nostálgico, na paisagem romântica, e quando se volta para o retrato, em poses lânguidas mergulhada em fundos escuros e densos, que a granulação da goma-bicromatada permite obter de um modo coerentemente misterioso".

Em 1902, a revista "Il Corriere Fotografico", um "periódico mensal ilustrado com fotografia prática", dedicava-se quase como um manual a temas variados. Tratavam desde fotografia de arquitetura ao retrato, de reproduções à óleo a fotominiatura, engajando-se ao pictorialismo, tido como um movimento de vanguarda, um estímulo a "fare arte". O espírito de "fazer arte" pela fotografia era a meta do concurso criado, em 1899, pelo Touring club Italiano, sob o slogan "pensate prima che fatte", mostrando como o movimento pictorialista

181 Emporium, VII, Bergamo, Janeiro, 1898, p.33. In: Zannier, 1993, p. 29. Tradução nossa. 
italiano esteve também no bojo das questões que envolviam os foto-clubes ligados a fotografia amadora, que propunha com vivacidade uma fotografia feita primeiro no pensamento.

Pastore experimentava certos resultados visuais comuns àqueles que se aventuravam pelo desejo de transcendência, e queriam de modo mais contundente pertencer a arte, no seu sentido mais elevado. A imagem do Ferreiro (fig.126) evidencia como Pastore praticava a subjetividade do artista, seu direito à interpretação, num realismo da cena que vem acompanhado de forte efeito de luz, com dramaticidade estética, dando sinais de como o fotógrafo não estava à margem do "fenômeno complexo e dialético" articulado pelo pictorialismo, interessado pela aparência da imagem e a personalidade inquietante do individuo atrás da câmera (Fabris, 2011, p.8). O fotógrafo tentava participar das práticas que contestavam a oposição entre pintura e fotografia. Uma prática onde encontram-se fotógrafos hierarquizando elementos de cena, criando, compondo, encobrindo detalhes, elaborando contrastes, desafiando a diferença da mão do artista e da máquina do operador, como mencionou Rouillé (2009).

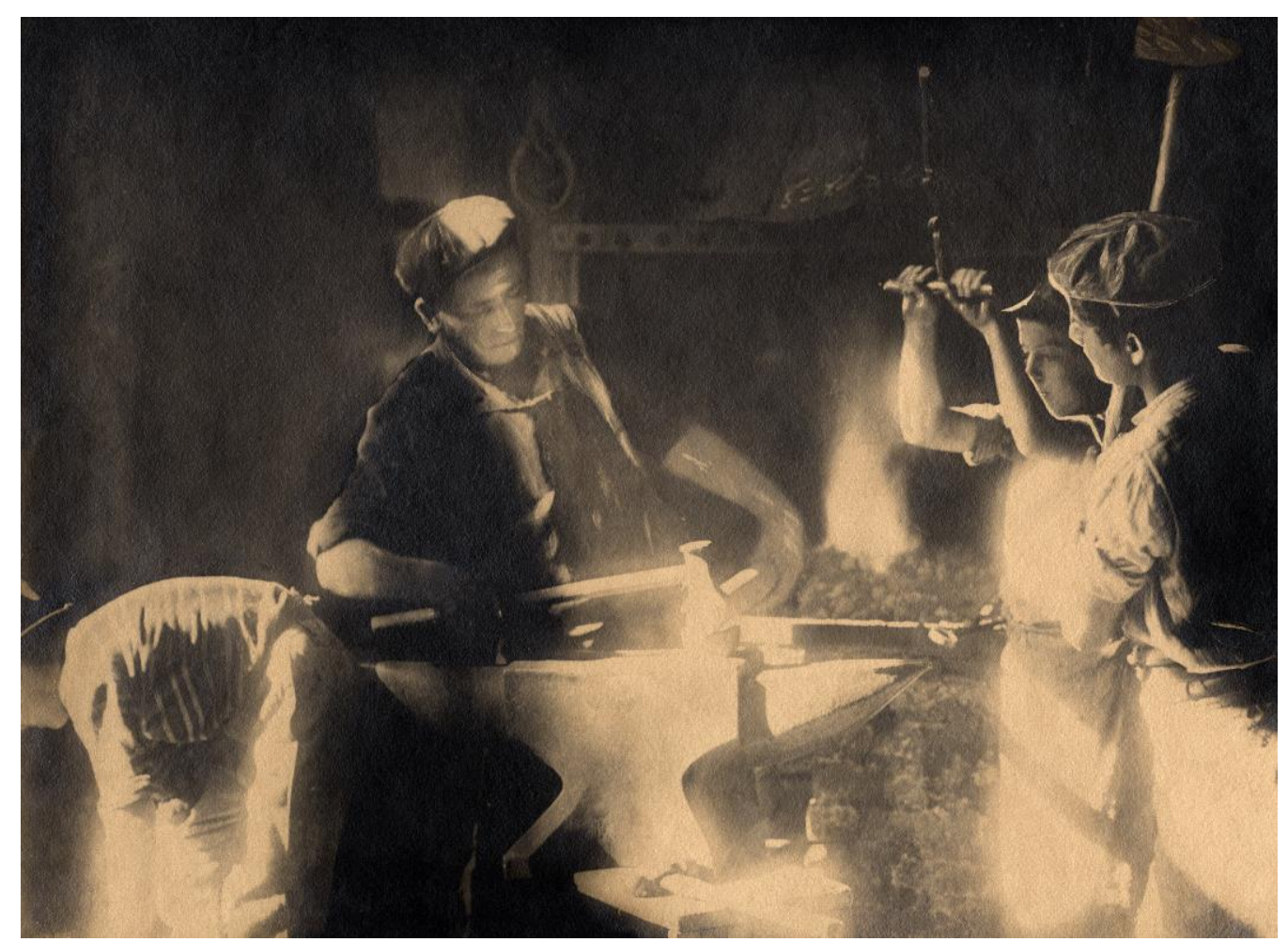

Figura 126:

Retrato de um Ferreiro. Sem data (C) Vincenzo Pastore / Instituto Moreira Salles.

No exercício interpretativo de Pastore, vê-se sinais de diferentes concepções pictoriais. Exageros em retoques, foram bem aceitos na proposta de Robinson. Efeitos mais contidos, 
suavizando as interferências, respondiam aos conselhos de Emerson. ${ }^{182}$ Oscilações que explicam as orientações de Joan Fontcuberta de não tipificar tendências, de não rotular autores. ${ }^{183}$ Cuidado esse para tampouco engessar fotógrafos, alinhando-os exclusivamente a uma única proposta pictórica quando estavam na verdade convivendo com este amplo debate, rico em diferentes tendências e pretensões.

É possível que Pastore tenha saído da linha do Largo do Tesouro, passado pela Várzea do Carmo, cruzado a Rua do Gasômetro rumo ao bairro do Belenzinho, para colocar em cena o ferreiro, talvez fotografado no Brasil. Seria o homem acima retratado um morador da Avenida da Intendência, local descrito por Penteado (2003) como reduto de ferreiros, espingardeiros e fabricantes de arreio, geralmente italianos e portugueses? Se italiano fosse, Pastore deve ter aproveitado para levar aquela conversa sobre a Itália que tanto gostava de ter com seus conterrâneos no Brasil. ${ }^{184}$

Depois de selecionar o seu recorte, Pastore preferiu não dar ênfase às tonalidades cinzas, um dos preceitos pictóricos mais recorrentes apontou Rouillé (2009, p.279). Explorou, todavia os efeitos de fortes contrastes invocando o "teatro de sombras", recusado por alguns pictorialistas que "opacificavam as provas com intervenções manuais". O alto contraste foi visto por alguns pictorialistas como elemento falseador. Tal aspecto, segundo Fabris (2011, p.32), além de demonstrar que não tratamos de um movimento sempre coeso, indicia como alguns pressupostos do movimento, apesar de defenderem o viés experimental do pictórico, vital para o desenvolvimento da fotografia, não obliteravam de modo absoluto a especificidade da imagem técnica em seus vínculos mais estreitos com o real. ${ }^{185}$

Essa fotografia que integra a coleção do acervo do IMS sobrevive como uma reprodução em papel com muitos retoques em branco. Imagem que está colada em papel-cartão de tom

\footnotetext{
182 Cf. Costa, Helouise. A Voz de um fotógrafo. Prefácio. In: Rocha, Regina Maurício. A Poética Fotográfica de Paul Strand. São Paulo: Edusp. 2012.

183 Cf. Fontcuberta, 2003, p. 26.

${ }^{184}$ Em entrevista realizada em 1994 a filha de Pastore, Costanza, desvelou detalhes da subjetividade do fotógrafo. Cf. Centro Cultural São Paulo. Entrevista realizada pelo pesquisador Ricardo Mendes.

${ }^{185}$ Fabris apontou como na década de 1890, na Bélgica, em Londres e em Paris, o movimento embrionário de Paul Périer, ressurge com vigor, após quarenta anos, auge que se estenderia até 1914. Algumas das principais exposições marcaram a iniciativa pictorialista: a Secessão de Munique, 1898, expõe trabalhos fotográficos ao lado de quadros, exemplo seguido pela Exposição Internacional de Artes e Indústrias de Glasgow, em 1901; a mostra organizada pelo Club der Amateur-Photographien, de Viena que, tornou-se modelo para os eventos realizados em Bruxelas, em 1892, em Londres, em 1893, em Hamburgo, em 1893, em Paris, em 1894; o Salão Fotográfico de Londres, inaugurado em 1893, declarava a emancipação da foto pictorialista; em 1893, se dá a primeira Exposição Internacional de Fotógrafos Amadores, mostrando a relação da prática amadorística com o a fotografia pictórica; em 1902, a mostra realizada em Turim já demonstrava a preocupação com a iluminação da exibição, com os tipos de molduras que mais valorizariam a imagem fotográfica. Fabris, 2011, p. 36-41.
} 
bege, com danos nas bordas, mostrando como Pastore era adepto da "ética da intervenção". O retoque pode ser caracterizado como a primeira técnica de intervenção manual, conferindo-lhe grande valor simbólico, assinalou Rouillé:

As intervenções acontecem em todos os estágios do processo fotográfico: no negativo, ao fazer a tomada; no positivo, no momento da impressão. No decorrer de anos, o pictorialismo constituiu, assim, uma longa série de processos bastante disparatados, às vezes até esquisitos, tanto manuais quanto químicos ou ópticos que, no entanto, tem em comum uma mesma finalidade: transformar em arte o mecanismo fotográfico, eliminar o automático do registro, para permitir a interpretação. (Rouillé, 2009, p. 257).

Intervenções que ocorriam em todas as etapas do processo fotográfico, desde a sua captação mecânica até aos recursos de impressão. Raspagem de negativos, o uso da platinotipia, da heliogravura, reenquadramento das imagens nas reproduções, eram alguns dispositivos acionados para problematizar a "relação complexa entre a aparência do mundo exterior e a personalidade do operador”. (Fabris, 2011, p.9).
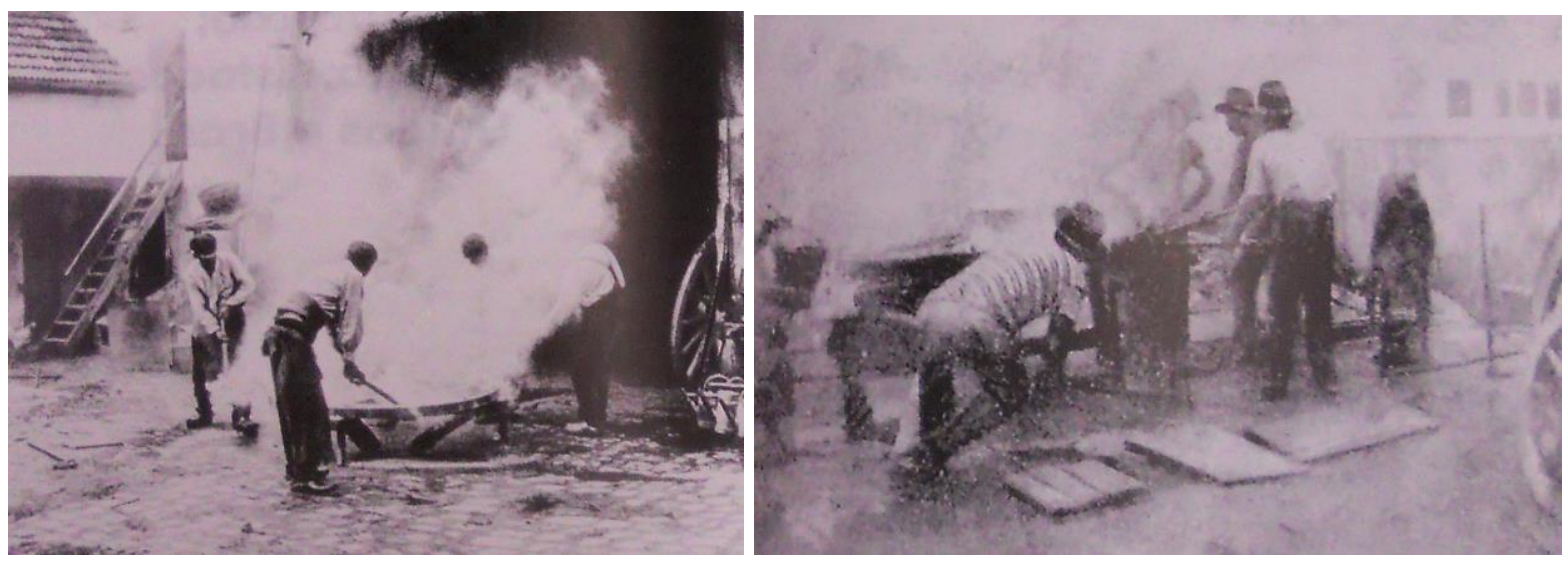

Figuras 127 e 128: à esquerda "Les Charrons". 1904 (C) Albert Gilibert/ Biblioteca Nacional de Paris; à direita, "A Forja". 1926 (C) L. Figueiredo de Medeiros/Revista Photogramma, n.5. In: Mello. 1998.

Fotógrafos recorriam também a "ação do pincel, do esfuminho, do chumaço, e do dedo", encobrindo detalhes, com "uma profusão de sépias e de sanguinas que parecem sair da mão de um aquarelista ou de um desenhista", afirmou Rouillé (2009, p.259). O retrato do ferreiro, em sua oficina, apesar de não apresentar uma datação específica, pode ser aproximado de outras produções que também reforçavam o viéis pictural. Em 1904, Albert Gilibert, fez a sua criação de "Les Charrons", fotografia que integra o acervo da Biblioteca Nacional de Paris (fig.127). Ao registro do cotidiano destes trabalhadores foi emprestado o mesmo procedimento visto em Pastore: interferência, manipulações, evidentes retoques, posturas que revelam atos criativos, colocando fotógrafos no âmago de uma mesma economia 
visual. Do contexto de produção nacional, Mello nos apresenta a impressionante imagem "A Forja", realizada em 1926 por L. Figueiredo de Medeiros (fig.128), mostrando como a clara dramatização da cena fazia parte da economia visual de uma época.

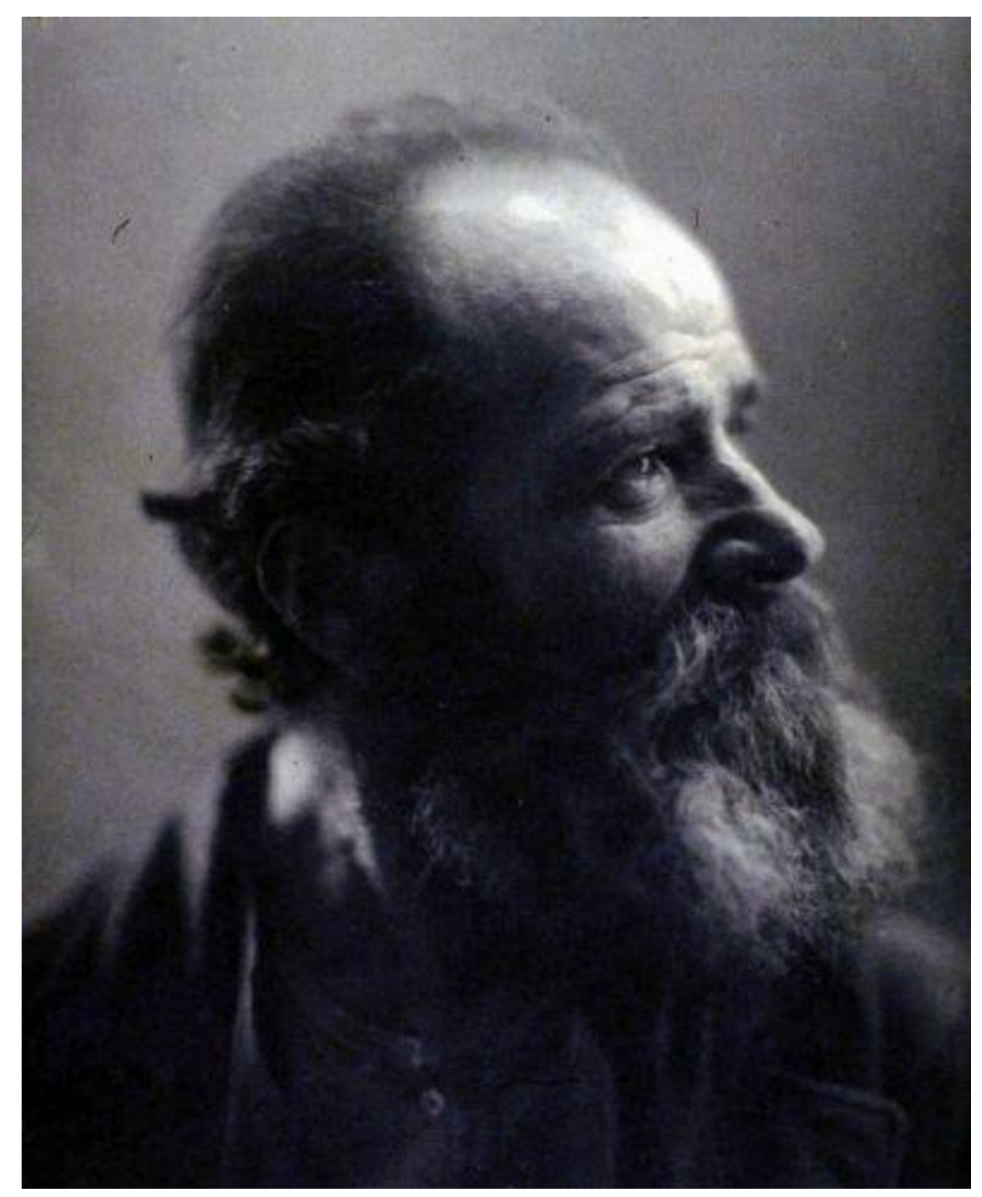

\section{Figura129:}

"Retrato de homem de barba longa e cabelo escuro". Goma bicromatada/Pigmento. 1910 ( ) Vincenzo Pastore. Instituto Moreira Salles.

Muitos resultados que expressaram sentidos estetizantes foram obtidos quando muitos fotógrafos recuperaram o uso da goma-bicromatada, que possibilitava uma maior manipulação do papel de impressão da imagem, usando tintas litográficas de modo artesanal, dando um aspecto mais pictórico ao artefato fotográfico. ${ }^{186}$ Esse aspecto impressionou aqueles que visitaram a galeria de retratos em Bari: "Pastore parece inatingível nas fotografias

\footnotetext{
${ }^{186}$ A técnica da goma bicromatada foi criada em 1894 por Rouillé Ladevèze. O suporte de papel era coberto de goma arábica, sensibilizada com bicromato de potássio. Esta técnica consiste também, segundo Fabris, em "revestir o papel com uma substância orgânica como o carvão, ou outro pigmento, usando um pincel. O carvão misturado ao bicromato endurecia sob a ação da luz. A imagem aparecia quando o papel era lavado com água morna. A revelação era feita, em geral, com um pincel ou com uma mistura de pó de serra e água quente". As zonas sombrias eram branqueadas e depois, com um pigmento oleoso, eram pintadas. Cf. Fabris. $O$ desafio do Olhar. Fotografia e artes visuais no período das vanguardas históricas. São Paulo: Martins Fontes, 2011, p. 33.
} 
com processo de goma as quais tem pigmentação colorida"; ${ }^{187}$ recurso técnico que pode simular uma aparência litográfica.

Nessa reprodução em papel (fig.129), Pastore fez uso da goma bicromatada. Esteve às voltas com os novos "procedimentos enobrecedores", ${ }^{188}$ que interrogavam a natureza da câmera, como explicou Mello, sobre o uso de um dos recursos utilizados pelos pictorialistas:

Com a utilização de novos processos surgidos com o desenvolvimento da técnica fotográfica - como a goma bicromatada e o bromóleo - eles podem controlar as tonalidades, introduzir luzes e sombras e remover detalhes, que parecem muito descritivos. Muitos desses efeitos são acompanhados da utilização de pincéis, escovas, raspadeiras e até dos próprios dedos, com o objetivo de alterar as formas. (Mello, 1998, p. 38)

Vê-se aqui a expressão de um repertório defendido pelos pictorialistas e testado por Pastore: Efeitos de luz, tons claros no pescoço e na parte superios da face contrastam com os tons escuros vistos nas vestimentas, ao redor do rosto e, ainda efeitos de sombra na lateral direita da foto, opondo-se às nuances em tom cinza, deixados em degrade ao fundo. A escolha da pose, o perfil com grande expressividade do olhar distanciado, subtraído do espaço fotográfico. A concepção do retratado com nitidez geral, sugerida por Disderi, foi evidentemente contrariada por nosso fotógrafo. ${ }^{189}$ Bem explicou Kossoy $(1998$, p.83) ao afirmar como as ideias do pictorialismo "não foram empregadas apenas pelos amadores, mas também por profissionais em busca do artístico".

Nessa construção visual, tem-se uma das tendências do movimento considerado como pictorialismo da forma, ou seja, uma tendência que propunha "liberar a fotografia de sua nitidez prosaica e paralisante", ou seja, libertá-la do automatismo da câmera, principal orientação publicada em 1906, pelo Photo Club de Paris, através do livro Objectifs d'Artiste, texto de época analisado por Mello. ${ }^{190}$ Observar a resultado dessa experimentação de Pastore

\footnotetext{
187 Coleção Dante Pastore. In: Caderno de recortes, p. 26. As técnicas do bromóleo com a goma bicromata ou o processo a óleo, resultavam numa aparência de gravura, aquarela, mostrando a busca por referências da pintura. Ver Costa. 2008.

${ }^{188}$ As técnicas da goma bicromatada e do bromóleo eram tidas, nos primeiros anos do século XX, nos Estados Unidos, como técnicas não puramente fotográficas, nuançando perspectivas divergentes do movimento, recusando o emprego de retoques e técnicas da pintura. Vertente precursosra da chamada fotografia direta, ou straight photography. Ver Mello, 1998, p. 39.

${ }^{189}$ Cf. Fontcuberta, 2003, p. 29.

190 Jean Claude Lemagny propôs reflexões que, segundo Mello, ampliaram o horizonte de análise sobre o pictorialismo, entendido a partir de duas tendências: a primeira, trata-se do pictorialismo anedótico caracterizado como praticas de imitação da pintura; a segunda, refere-se ao pictorialimos da forma contra a nitidez do retrato entendido como cópia, espelho do real, constituindo-se como uma rota paralela a da pintura. Cf. Mello, 1998, p. 44-47.
} 
entre a foto pensada e a técnica empregada, nos leva para algumas considerações apontadas em alguns estudos voltados para o movimento do qual o fotógrafo evidentemente dialogou:

Na verdade, o caráter do pictorialimo não se caracteriza pela apropriação das normas estéticas da pintura, mas sim pela busca de uma nova sensibilidade visual que atribui à fotografia um sentido que ultrapassa a representação pura do real. São os sentimentos e as emoções expressas através da suas técnicas que lhe atribuem um caráter artístico. A utilização do flou é um dos exemplos desse campo de experimentação muitas vezes criticado por retirar da fotografia sua nitidez de representação objetiva e clara do real. (Mello, 1998, p. 49)

Relatos de 1853 mostram como os fotógrafos já haviam se lançado nesse intenso debate. William Newton miniaturista e entusiasta do colotipo declarou que a fotografia é "quimicamente bela, mas que deveria ser artisticamente bela", recomendando, segundo Joan Fontcuberta (2003, p.28), que os fotógrafos realizassem as fotos ligeiramente sem precisão de foco, defendendo o efeito flou desde então, para conferir à imagem certa atmosfera, além de outras manipulações em prol dos efeitos pictóricos.

$\mathrm{O}$ uso da goma bicromata foi o procedimento de excelência sobre o automatismo segundo Mello (1998), garantindo ao fotógrafo pictorial a intervenção decisiva de uma personalidade, quer pela feitura de uma prova original, quer pela interpretação do tema. Vê-se em Pastore, frente aos vestígios visuais e escritos apresentados, um artista - fotógrafo preocupado com as relações entre técnica e arte, estruturantes da abordagem pictórica:

Artista fotógrafo: orienta-se pela noção de sublime e busca constantemente o ideal da arte. Sua atitude é a de negar a onipotência da natureza e a de experimentar, através da técnica, sua imagem, antes mesmo de ser impressa. O fotógrafo artista rompe com o registro do real, extrapolando os limites da singularidade do modelo em busca do artístico e do sublime na fotografia. (Mello, 1998, p. 54).

Mesmo em seus retratos mais comerciais (fig.130), temos traços de uma abordagem lúdica e de uma nova técnica tida para o pesquisado italiano Itálo Zannier (1993) como aquela "que faz uma fotografia parecer como uma pintura". A foto-pintura foi outro segmento praticado por Pastore, que pouco hesitava no uso de bastante retoque, experimentado a técnica à óleo que exigia grande habilitade para se alcançar um bom resultado.

Uma lâmina incomum plastificada cobre essa reprodução em papel (fig.130), podendo ser até mesmo uma gelatina funcionando como uma camada de proteção a toda gama de 
retoques feitos, principalmente no buque de flores. Mestre Julio, que ajuda a ver melhor essa imagem, explica o procedimento empregado:

Foram usadas aqui, aparentemente, as três técnicas possíveis em fotopintura, que é a presença de pigmentos líquidos a base de anilina, óleo e pastel, pigmentos secos. Os pigmentos líquidos a base de anilina, que é o tom de pele, desapareceu com o tempo deixando apenas a marca dos vermelhos a pastel na face da menina, no canto dos olhos e nos lábios, e nos cabelos o pigmento seco preto misturado com vermelho e a borracha para fazer os acabamentos de luz. O arranjo do vestido feito a óleo, os vermelhos e amarelos também desbotaram ao decorrer do tempo, nesta ampliação em preto e branco feito em papel N. ${ }^{191}$

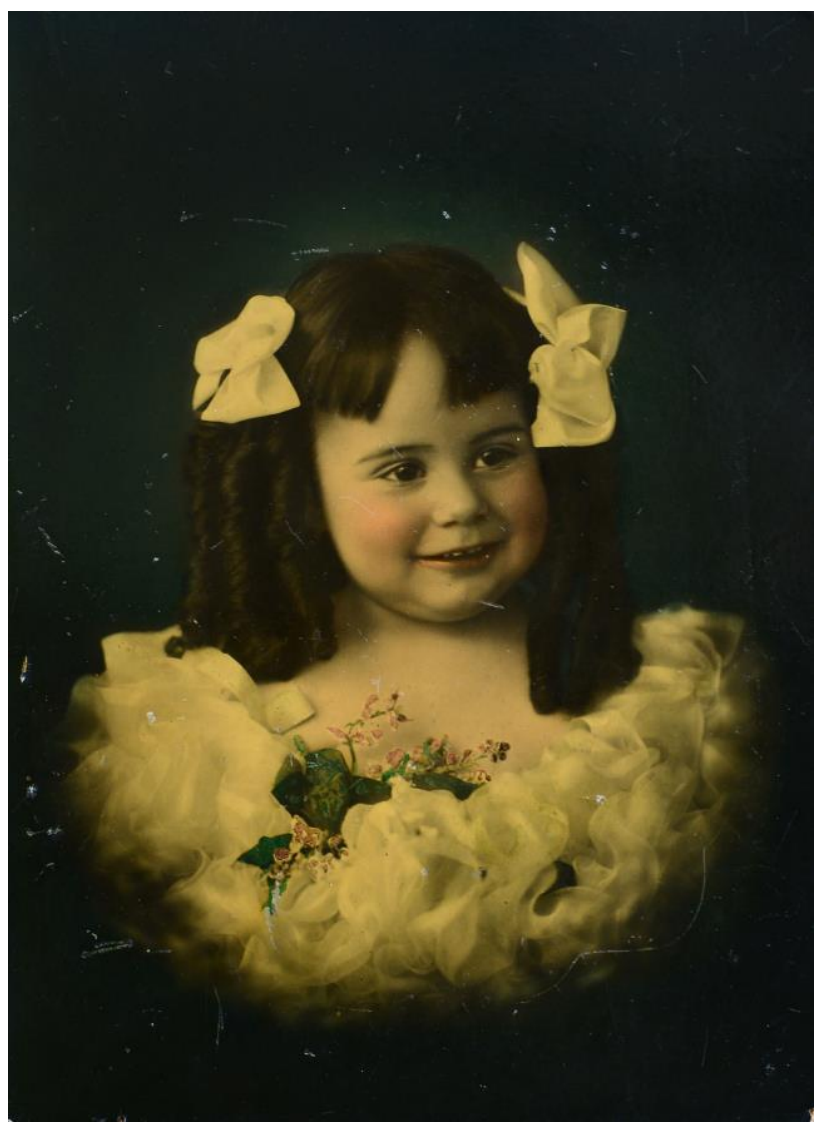

Figura 130:

$\mathrm{O}$ nome Maria vem como identificação à lápis no verso, podendo se tratar da filha de Pastore chamada Maria Lucia. Sem data (C) Vincenzo Pastore. Coleção Dante Pastore.

Helouise Costa e Renato Silva (2004, p.26) explicaram certos aspectos dos diálogos imbricados entre as artes e a fotografia. Esta por algumas décadas abdicou de sua própria identidade dado aos processos de pigmentação controlada: "A solução encontrada pelos

191 Observações feitas por Julio Santos conhecido como mestre Julio, especialista em foto-pintura, dono do Áureo Studio, herdado do pai. Vive da fotografia há mais de quarenta anos em Fortaleza, articulando as novas tecnologias da representação digital com as técnicas antigas e refinadas da foto-pintura, segmento da fotografia que ainda sobrevive contando com as ferramentas virtuais que empregam em seus próprios termos a nomenclatura da foto-pintura. 
pictorialistas na busca de uma fotografia artística resultou em uma verdadeira imitação dos padrões da pintura do século XIX: romantismo, naturalismo, realismo e impressionismo desfilavam de forma algo patética, nos salões do mundo inteiro".

A aproximação de alguns textos de época, de autores que apresentavam diferentes versões sobre a natureza artística da fotografia, mostra que atuavam de forma livre em sistemas de representação que compartilhavam certas convenções. Na afirmação de Henry Peach Robinson, defensor de uma abordagem pictórica mais intervencionista, evidencia-se certas afiliações: "até certo ponto, seria discutível o grau em que a fotografia imita a pintura, o grau em que ambas simultaneamente seguem os preceitos deste zeitgeist". Na afirmação de Peter Henry Emerson, que assumiu uma vertente tida como fotografia naturalista, ${ }^{192}$ título do artigo publicado em 1889, vê-se como, mesmo defendendo uma maior especificidade para a fotografia, ou seja, menos intervenções, retoques e manipulações, Emerson não negligenciou a rede de influências recíprocas entre a fotografia e as outras artes como a pintura à óleo, aquarelas, como a gravura ou água-forte:

\begin{abstract}
A influência da fotografia sobre a pintura tem sido maravilhosa, como se pode ver na maioria dos desenhos em movimentos. É prática comum entre os pintores tirar fotografias de seus modelos e projetar reproduções destas sobre uma tela para fazer esboços de contornos. Também é prática comum entre os pintores estudar as tonalidades delicadas da fotografia (...) seu efeito sobre a pintura de miniaturas foi fulminante, já que a fotografia quase acabou com ela. Deve-se recordar que a fotografia a matou apesar de muitos dos melhores pintores de miniaturas terem adotado a nova arte como puderam. A fotografia também tem causado infelizmente uma grande produção de aquarelas, óleo e águas fortes ruins. Este é um uso desonesto da fotografia, contudo, muito comum. (...) A influência da pintura sobre a fotografia tem sido muito grande e positiva como um fator na produção dos conhecimentos estéticos, mas convenções que nem sempre resultam positivamente. ${ }^{193}$
\end{abstract}

Emerson propôs um divisor entre a prática da fotografia comercial e aquela assim orientada: "os fotógrafos devem receber instrução artística, como os melhores têm feito". Artistas treinados, que trabalham aspirando prazer estético, desejando se aproximar das artes, formaram nesta perspectiva as atribuições que qualificam um artista fotógrafo.

Acreditamos ver Pastore, mesmo com o volume de uma produção mais comercial, desejando se aproximar das artes, sobretudo, em relação aos materiais e aos procedimentos

\footnotetext{
192 Fotografia naturalista surgiu em reação ao artificialismo dos cânones clássicos da pintura em tomadas vistas nas fotos compósitas de Robinson e Oscar Rejlander. Cf. Mello. Arte e fotografia: o movimento pictorialista no Brasil. 1998.

${ }^{193}$ Emerson, Peter Henry. Fotografia naturalista 1889. In: Fontcuberta, 2003, p.70-71
} 
que dominava. Fotos miniaturas, em porcelana, platinotipias, foto-pinturas e, principalmente o uso da goma-bicromatada expressam suas ambições. Para Emerson, trata-se este de um procedimento que contava pigmentos da mesma natureza que as águas fortes e aquarelas utilizadas por pintores e litógrafos, proporcionando uma riqueza de tons escuros contrapostos aos claros. A goma-bicromatada, entendida como um "processo híbrido" daria a direção, segundo Emerson, do futuro da fotografia pictorialista, autor que chegou a perguntar: "é demais pedir tudo isto aos fotógrafos: composição, iluminação, valores, tons, texturas e procedimento?".
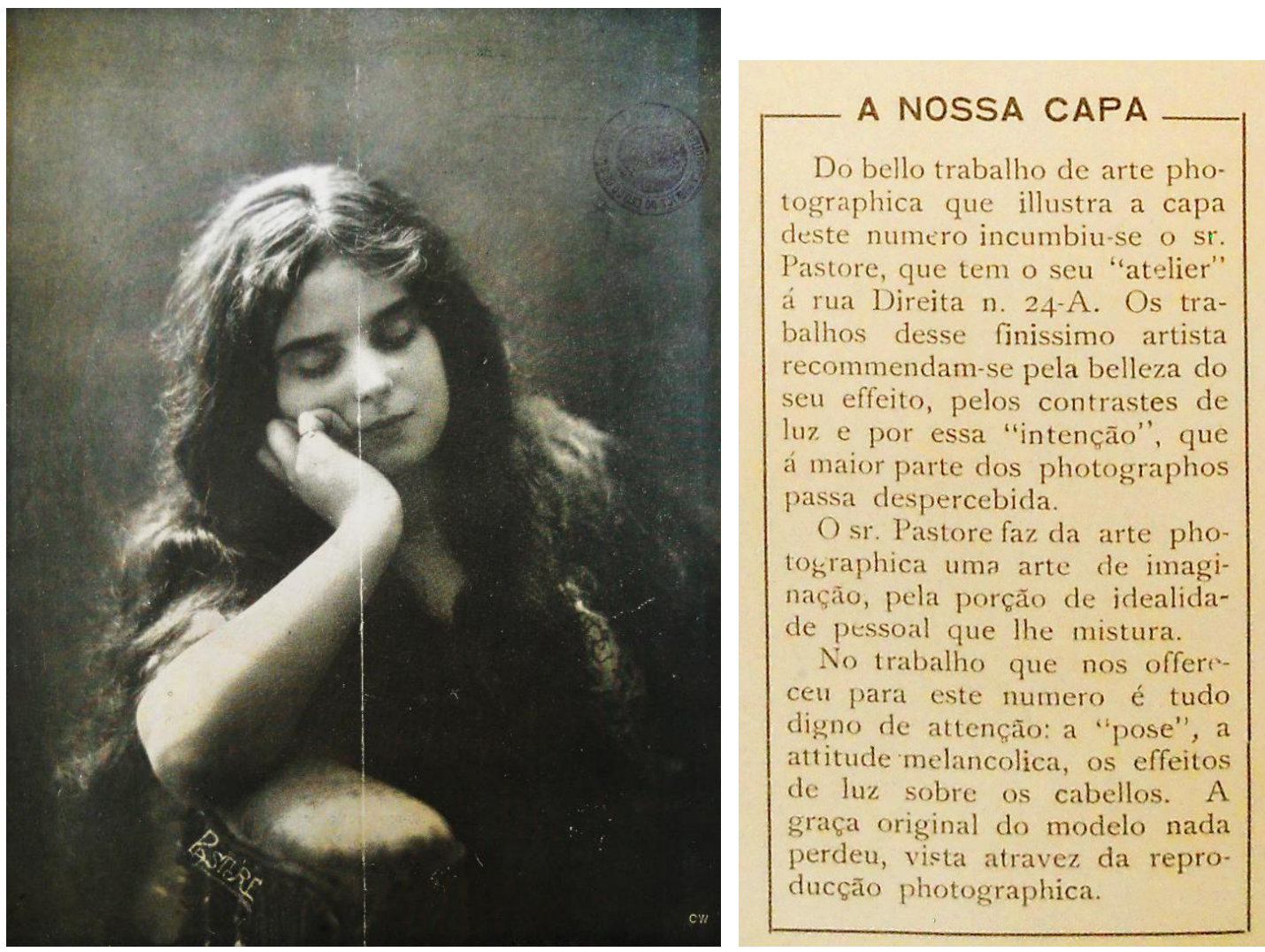

Figura 131 e 132: fotografia de Anna Candida Bueno, publicada na capa da Revista A Vida Moderna. N.250, no dia 03 de Dezembro de 1914. As capas das revistas tornavam-se neste período um espaço para anunciar os ateliês fotográficos na capital paulsita. Acervo Biblioteca Mario de Andrade.

Se Pastore teve uma de suas fotografas coloridas premiada na Exposição de Milão, como informa o recorte de jornal guardado por Elvira, ${ }^{194}$ vimos o fotógrafo em outros momentos (fig.131) buscando uma expressão artística a partir de um procedimento de menor interferência, seguindo pressupostos indicados em uma das mais importantes revistas de difusão do pictorialismo na Itália, "La Fotografia Artistica", espaço que diferenciava aqueles dedicados à fotografia por uma "paixão pessoal", ou seja, os fotógrafos amadores e entre

${ }^{194}$ Cf. Caderno de Recortes. Coleção Dante Pastore, p. 11. 
aqueles definidos como profissionais pagadores de impostos; segundo a revista, ambos objetivavam atingir o cume de artistas- fotógrafos. ${ }^{195}$

O fotógrafo artista será aquele que estudará a pessoa, que intuirá suas características mais íntimas, que não produzirá apenas uma fotografia que se assemelhe fisicamente, mas que criará uma obra na qual a pessoa encontrará não somente suas características físicas, mas também pessoais, às quais é adicionado o próprio sentimento do fotógrafo. (Zanini, 2013, p. 48. Tradução nossa)

O comentário publicado na parte interna da revista A Vida Moderna, ao indiciar como Pastore era visto em seu tempo, nos ajuda a inventariar determinadas visões sobre a fotografia. Forjava-se socialmente uma consciência do papel do fotógrafo, da qualidade de seu trabalho. A beleza de efeitos e contrastes de luzes, a intenção de produzir arte, contandose com a capacidade de imaginação, de criação do sujeito-fotógrafo, como o texto mencionava, davam os fundamentos para a compreensão de uma prática idealizada como artística, cristalizando noções e sentidos sobre a imagem, ao passo que legitimavam certos resultados visuais.

A cumplicidade silenciosa entre retratista e retratada dá luz a confiança ali alcançada, sendo outro aspecto que explicitava a qualidade do fotógrafo. Pastore parece ter lido o conselho de Lièbert, para quem a maior veracidade da imagem seria obtida com "conversas com o modelo". Talvez esse tenha sido o ponto de partida para se atingir "feições íntimas", "expressões mais leves", "qualidade artística", 196 compondo assim um "bello trabalho de arte photographica", onde tudo é "digno de atenção": a pose, a atitude melancólica, os efeitos de luz sobre os cabelos, afirmava a revista; ${ }^{197}$ as indicações pautadas na revista "La Fotografia Artistica" desdobravam-se na prática de Pastore.

Debruçamos-nos até aqui sobre vestígios que documentam como esse fotógrafo esteve envovido com as principais questões de movimento tido, por um lado, como conservador, já que pictorialismo não propunha rupturas com as percepções artítiscas precedentes, mas por outro, como um movimento de vanguarda, na medida em que dava vazão à interpretação expressa pela sensibilidade individual do fotógrafo, defende Mello (1998, p.44). O movimento deve ser compreendido na trama de suas especificidades afinal, segundo a autora, "produziu impactos na técnica fotográfica, pois para atender as exigências da fotografia

\footnotetext{
195 “La Fotografia Artistica”, Numero III, Marzo 1907, p. 40. In: Zanini, 2013, p. 47. Tradução nossa.

196 Grangeiro. 2000, pp. 113-114.

${ }^{197}$ Revista A Vida Moderna. 3 de dezembro. 1914, n. 250.
} 
artística foi necessário um aperfeiçoamento de procedimentos, equipamentos e materiais, desde a melhoria da câmera à utilização de novos processos de impressão" de imagens, bem como novas posturas frente aos aparatos técnicos-mecanicos interrogados. Produzira então um impacto também na produção de Pastore, como tentamos demonstrar.

Se os processos mais engajados da manipulação da imagem-arte não foram rejeitados por Pastore, tampouco o fotógrafo se esquivou dos retratos fotográficos de cunho mais realista, assumindo a linguagem do instantâneo, na sua produção mais emblemática, a série fotográfica realizada nas ruas da capital paulista. As reflexões que se desdobram a seguir mostram como Pastore voltou-se para a vida cotidiana, para o trabalho na cidade, para cenas da imigração, do pós-abolição, buscando uma relação mais ágil nos jogos da encenação, fora das paredes do estúdio ou do rigor da pose, experimentando novos domínios técnicos associados às suas concepções estéticas; domínios que promoviam novas concepções da prática de fotografar e ser fotografado. Trataremos agora da série de fotos produzidas nas ruas de São Paulo, sondando como esse fotógrafo observou uma cidade mergulhada nas suas contradições e na fluidez de certas fronteiras, resguardando da invisibilidade vivências autônomas e instáveis, como a sua própria experiência constituída nas teias de constantes atos migratórios. 


\section{Capítulo 3 \\ Da galeria de imagens à foto guardada}

\subsection{Vincenzo Pastore, fotógrafo do cotidiano}

Às cinco horas da tarde, Pastore costumava deixar seu estúdio. ${ }^{198}$ Saía pelas ruas da cidade, munido de sua câmera em punho para fotografar aqueles que faziam a vida de todo dia trabalhando de forma autônoma e improvisada na São Paulo de 1910. Talvez o fotógrafo, com seu espírito andante, tenha percorrido o Triângulo Central e seus arredores por um mês, dois, ou completado ano. ${ }^{199}$ Sabe-se, contudo, que a sua série fotográfica, colocou-se no tempo como a sua produção mais emblemática.

Tratamos de um conjunto de imagens que existiu por quase nove décadas dentro de uma caixa de papelão, mantidas pelos descendentes do fotógrafo na intimidade das relações familiares. Apenas em 1996 abandonaram seu status de fotos guardadas, quando foram incorporadas como coleção do Instituto Moreira Salles. ${ }^{200}$

Estamos diante de uma série fotográfica não inscrita no circuito de produção de fotos encomendadas. Não mantiveram vínculos institucionais comuns à fotografia paulistana do período, de víes promocional, como aquela alinhada à produção da Light; Não deram corpo à álbuns comparativos estruturados num discurso que contrapunha o velho e o novo, como signos respectivos do colonial preterido frente ao progresso que se edificava, perspectiva comum à visualidade da época. Fotos que não cumpriram solicitações governamentais, tampouco formaram álbuns de lembrança, que reiteravam visualmente a conquista sob o espaço urbano. ${ }^{201}$ Fotos que não foram nem mesmo veiculadas como cartão postal ou publicadas em jornais. As fotos de Pastore possuem uma especificidade que atordoa o pesquisador porque lidamos com uma coleção sem circulação documentada em seu contexto de produção. Suas imagens mostram como nem toda fotografia do início de novo século destinava-se à comemoração. Imagens que forçam o intérprete a ver de outro modo, a criar

\footnotetext{
198 Relato de Flávio Varani, neto de Pastore, no curta-metragem Flávio Varani: Projeção, de dez minutos, dirigido por Paulo Cesar Toledo. Disponível na web em http://vimeo.com/69511937, com password: flavio1. Foi ele o responsável pela doação das fotos ao IMS.

${ }^{199}$ A região do Triângulo é composta pelas Ruas Direita, São Bento e XV de Novembro.

${ }^{200}$ As fotos foram doadas ao acervo do Instituto Moreira Salles. No capítulo quatro será analisado como essas fotos reaparecem e como foram reativadas em outra temporalidade.

${ }^{201}$ Sobre a circulação de fotografias em cartões postais ver Lima, Solange. O circuito social da fotografia. Estudo de caso II. In: Fabris, Annateresa. Fotografia Usos e Funções no século XIX. 2008.
} 
novas problematizações, mostrando como o historiador social, ao lidar também com imagens, precisa abrir mão de ideias prévias sobre o fotográfico, e se ater, ou melhor, respeitar a própria natureza da documentação visual.

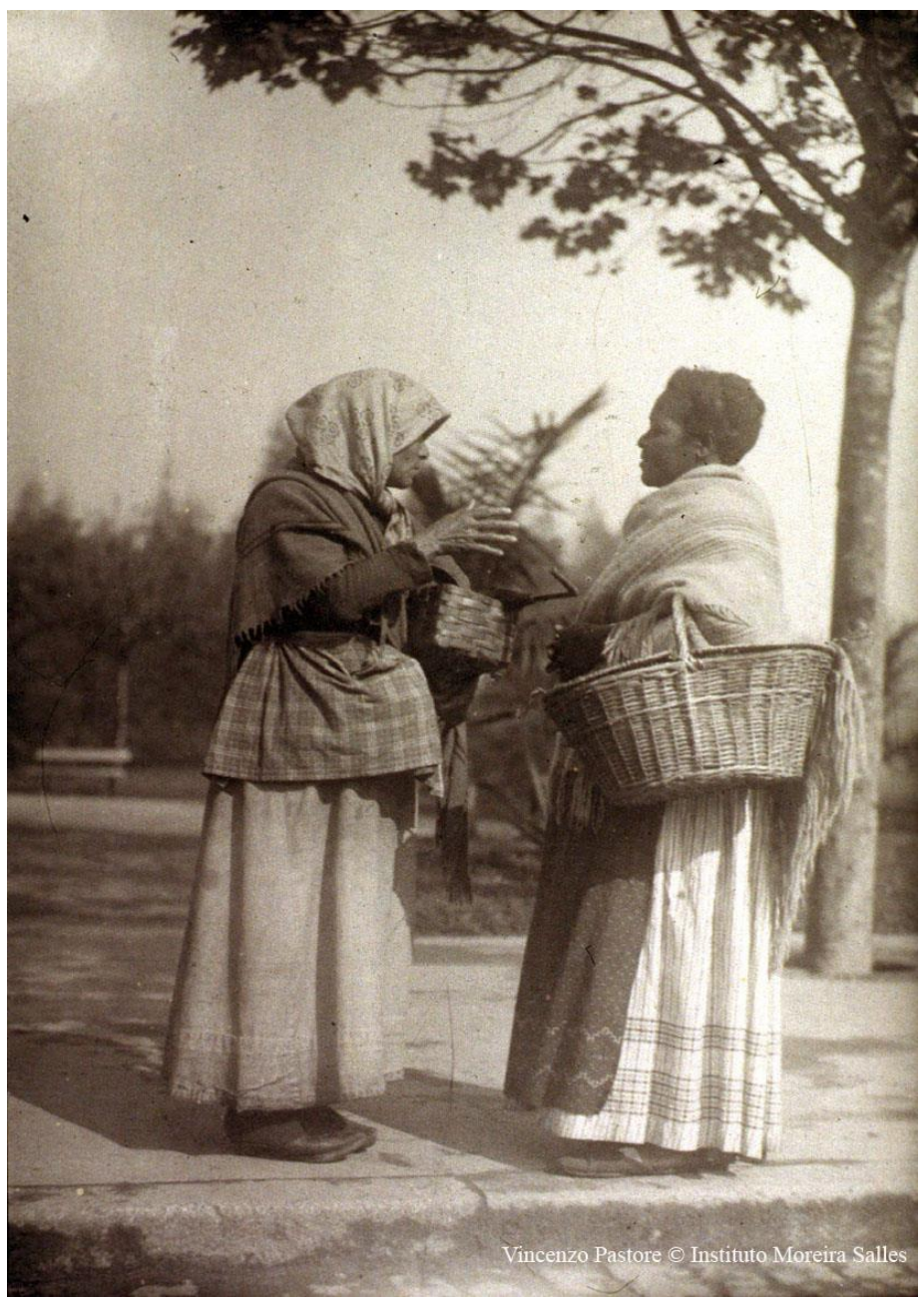

\section{Figura 133:}

"Duas mulheres conversando".

Proximidades do atual parque D. Pedro II. 1910 @ Vincenzo Pastore/Instituto Moreira Salles.

A série realizada entre os anos de 1908 a 1914 traz essa fotografia (fig.133). Setenta e três fotos integram a coleção. Quando reativadas em outra época, exibidas em 1997, na galeria do Espaço Higienópolis, após a doação feita ao instituto, algo inédito e revelador surgiu nesse circuito contemporâneo onde tais fotos foram apropriadas e consumidas: O material visual criado por Pastore indiciava de modo contundente a fluidez típica das vivências daqueles que sobreviviam de trabalhos ocasionais, temporários, pouco estáveis. Trata-se de experiências sociais exploradas pelo fotógrafo, não relegadas ao segundo plano fotográfico. Fotógrafo que com sua câmera se aproximava dos retratados de modo surpreendente.

Deste modo, parece de pouca contribuição ancorar esta interpretação na aproximação da produção de Pastore com as fotografias de Guilherme Gaensly, Aurélio Becherini, ou ainda 
às fotos de Militão Augusto de Azevedo. A natureza diversa de tais produções, empenhadas na valorização de elementos arquitetônicos e paisagísticos que representassem o crescimento urbano, se coloca como aspecto nodal empurrando a investigação para outra problematização: $\mathrm{O}$ que temos como especificidade em Pastore? O que o fotógrafo, quando saia às ruas, procurava na cidade? Por que suas imagens não encontraram espaço de circulação nos anos de 1910? Parece necessário apontar o quanto a composição dessa produção visual, estruturou-se numa fotografia que buscava sintetizar a realidade urbana por meio de registros do cotidiano de trabalho, seguindo convenções visuais voltadas para a representação dos tipos sociais, propondo outro olhar para cidade, para os seus pormenores e suas tensões: o fotógrafo ora registrava o vendeiro de aves tomando seu café da manhã (fig.173), ora flagrava pessoas proibidas de ocuparem os espaços públicos da cidade (fig.155), nuançando como sua produção não se encerra na categoria do tipo.

Para o pesquisador Ricardo Mendes (2004) a associação entre rua e fotografia ganharia novos desdobramentos. A vida urbana paulistana desde o fim do século XIX passara a adquirir uma nova forma, defende Mendes. Instantâneos de ruas e fotos de eventos sociais começariam a compor as páginas das revistas ilustradas, onde surgiam "aqui e ali" os tipos populares. Fora do comum, para Mendes foram as cenas de rua retratadas por Pastore. Sua coleção doada ao IMS, de modo preponderante, registrou a presença dos populares pelas ruas e mercados da cidade.

Interrogar a especificidade da produção de Pastore, ajuda a revelar um fotógrafo que pensava a cidade em suas contradições, em sua característica particular de forte convivência entre o rural e o urbano. Um fotógrafo que acompanhava as notícias pelos jornais e depois saia às ruas para registrar demolições, e ainda os casebres que sobreviviam na rua da Esperança ou no Vale do Saracura, onde tem-se atualmente a Avenida Nove de Julho, mostrando o interesse de Pastore também pelo centro expandido. Nessa construção visual o moderno não apagava os traços mais antigos da urb paulistana. Na perspectiva de Ulpiano Bezerra de Meneses (1996), abordagens menos "deformantes" dependem de compreensões mais abrangentes: a cidade, segundo o autor, deve ser entendida como um complexo de fenômenos diversificados e de articulações multiformes, aspectos articulados em toda série fotográfica. O material visual a seguir analisado ajuda na formulação de compreensões sobre a cidade não entendida como uma "categoria estável e universal”, premissa frágil e esvaziada de historicidade, como defende Menezes. 


\subsection{Poses negociadas: o fotógrafo e seus retratados, agências em construção}

Já foi dito que Pastore captava instantâneos num estilo jornalístico, retratando a população mais simples, diante de fundos sem charme (Kossoy, 2002). A suposta falta de charme atribuída a tais imagens encobre uma especificidade dessa coleção. A cidade era pretexto, notavelmente secundarizada. O fotógrafo privilegiava as sociabilidades que tensionavam as novas relações citadinas: Era a experiência de desterro, a vida errante de uma leva considerável de homens e mulheres egressos da escravidão e de imigrantes campesinos buscando abrigo na cidade que atraíram o olhar de Pastore.

Desatentos por vezes, cabisbaixos e apenas aparentemente indiferentes à presença da câmera, os sujeitos sociais fotografados tornavam-se o referente principal do retrato. $\mathrm{Na}$ construção visual elaborada e escolhida pelo fotógrafo é clara a recusa ao rigor da pose, da encenação, da contenção. A conceituação de Mauad, ajuda-nos a entender a noção de fotografias de retratos. Segundo a autora, essa definição se dá devido ao senso de individualidade e de diferença que a imagem expressa. A composição de retrato não se trata apenas de enquadrar o rosto ou a pessoa, defende Mauad (2008, p.41-42). As chances de melhor documentá-los, depende dos atributos fixados na imagem: "É necessário distingui-la das demais, da multidão, atribuir-lhe um valor que, ao diferenciá-lo como um ser humano, a identifica como sujeito social".

A mediação rompe o sentido do simples contato. Conhecer e elaborar expressões, para Mauad (2008, p.37), centraliza o papel do fotógrafo e a sua experiência subjetivada frente ao universo social que retrata. A fotografia não é reflexo simples e equivalente do referente registrado, afinal "o fotógrafo assume uma postura em face da realidade social que fotografa".

Pastore destacou as mulheres levando seus cestos ao braço (fig.133). São possíveis vendeiras, retratadas de corpo inteiro, em situações corriqueiras. Já nessa primeira imagem apresentada, o fotógrafo privilegiou os aspectos matérias que cercavam os indivíduos. São claros os indícios das condições da vida material, das posses e ocupações de muitos deles, faceta que domina o mise en scène mediado por Pastore e por aqueles que participavam do instante da foto.

O instante da conversa entre as duas mulheres (fig. 133) revela em contrapartida o próprio fotógrafo, atento aos gestos inesperados, espontâneos, às mãos agitadas tentando acompanhar a fala que aproximava mulheres negras e brancas, não apartados socialmente. A 
série fotográfica expressa muitas circuntâncias de fotos negociadas, feitas sob acordos estabelecidos em possíveis conversas entre o fotógrafo e as retratadas, decidindo conjuntamente a pose, o instante em que iriam simular a desatenção (fig. 134 e 135).
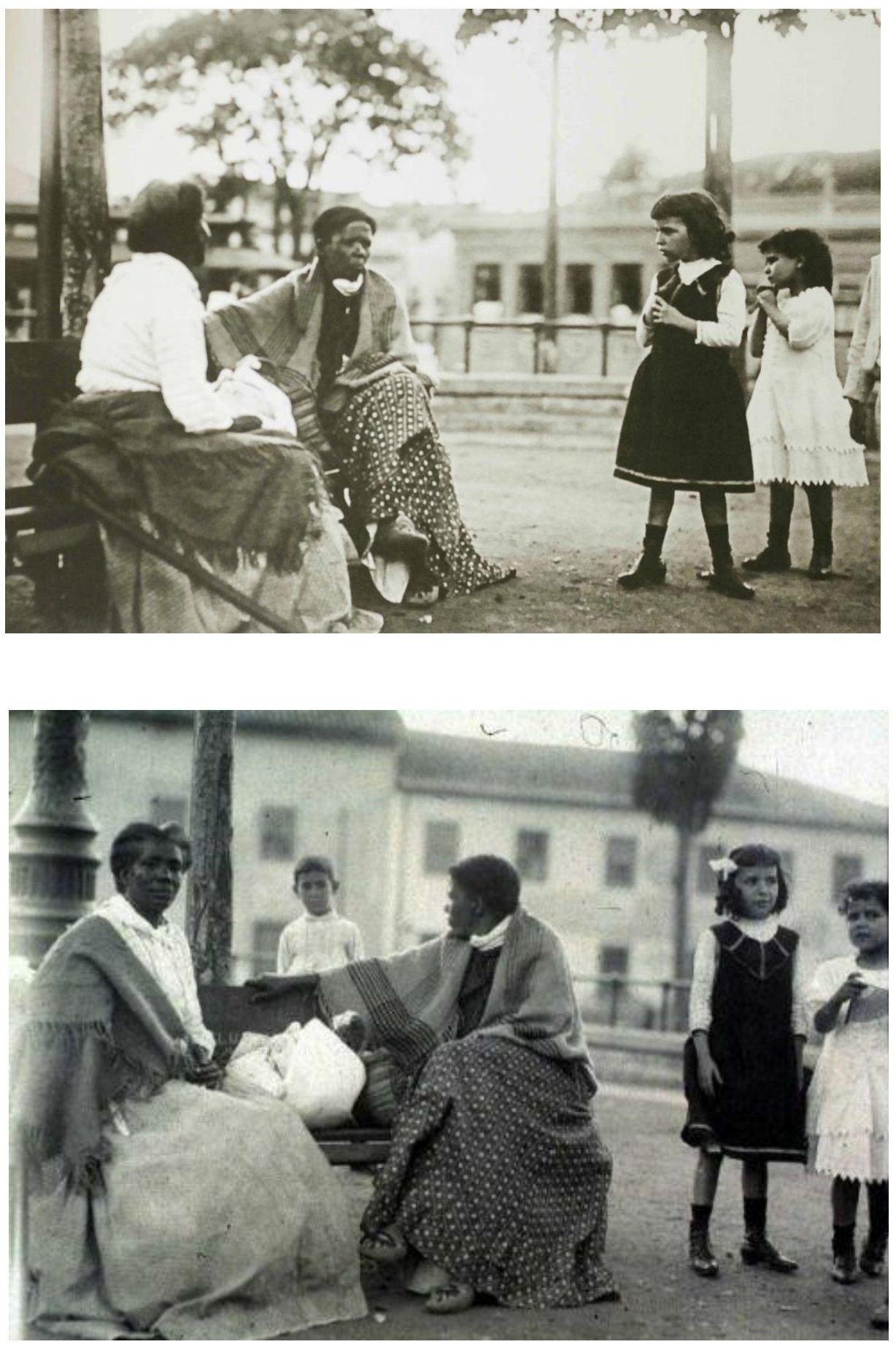

\section{Figuras 134 e 135:}

"Mulheres descansando em banco de praça". 1910 ○ Vincenzo

Pastore. Instituto Moreira Salles.

Pastore aqui experimentava aproximações incomuns à fotografia do período voltada para os populares, propondo diferentes unidades compositivas. Chegava bem perto das mulheres, que revezavam o momento de olhar para o fotógrafo. A construção da cena se 
desdobrava em aproximações em ruas e bancos de praça, com o fotógrafo de câmera na mão levada bem próxima ao corpo. São essas interações que surpreendem.

Os diferentes grupos sociais que conviviam entre si cobrem toda a dimensão visual criada, fontes repletas de minúcias que ajudam a reconstituir experiências sociais obscurecidas. São muitas vendeiras de verduras e aves, homens negros levando cestos com frutas e raízes, ou à espera de trabalho, e ainda outros esperançosos de vender nos mercados populares os excedentes produzidos em suas pequenas roças; grupos que se deslocaram rumo às cidades em expansão, contando com aquilo que Perez (2006) nomeia como tradição caminhante para sobreviver. ${ }^{202}$ Saídos do campo, da violência da escravidão, ou da pátria que lhes negava sorte e acesso à terra, no caso dos imigrantes, pátria relembrada muitas vezes por uma "miséria danada" ${ }^{203}$, tais grupos reconstruíram suas existências na capital paulista que os acolhia em experiências desafiadoras e pouco favoráveis.

Neste capítulo, investigamos as teias de relações sociais que estiveram no horizonte do fotógrafo, observando vivências insinuadas, deixadas como sutilezas de um tempo e de uma cidade reconhecida como espaço de coexistência no cotidiano de trabalho nos mercados, nas ruas e na venda feita de porta em porta. Afinal, não se pode apagar a vocação do material visual em se fazer pertinente como documento histórico, portador daquilo que Michel Frizot (1998) chama de "índice provocante", nuançando mesmo que de modo fragmentário e parcial, horizontes de historicidade de personagens anônimos.

Não há uma descrição rigorosa de cada imagem que compõe a série fotográfica. A descrição estará presente de modo implícito, afinal "descrições e explicações se interpenetram", como bem defende Baxandall (2006, p.62). Nessa perspectiva, toda descrição reflete a ideia que se faz de uma obra. Diferentes experiências individuais e diferentes capacidades de observação interferem nesse processo, que se dá sempre de modo subjetivado. Uma descrição sistemática de cada imagem pareceria incorrer em riscos desnecessários, sem contar a redundância vista muitas vezes na escolha de tais procedimentos. Nessa interpretação, que também resulta de um ato de percepção, optamos, por tratar cada registro de modo relacional a partir de "um fio condutor do que parece ser a trama dos

\footnotetext{
${ }^{202}$ A Tradição Caminhante foi apontada por Peres em seu estudo sobre as migrações para a cidade de São Paulo após a década de 1930. A falta de perspectiva na terra de origem, segundo a pesquisadora, mobilizava o deslocamento para as cidades grandes. A Lei de Terras de 1850 determinava a compra como único meio de se obter a propriedade da terra, proibindo a aquisição de terras devolutas. Cf. Peres. 2006, p. 16. Sobre deslocamentos e fugas de escravizados, ver Machado, 2010.

${ }^{203}$ Nas lembranças das primeiras gerações de imigrantes calabreses e sicilianos chegados ao Brasil a baixa Itália era lembrada pela miséria. Cf. Moreno, 1996, p.24.
} 
acontecimentos" que envolvem a produção das imagens, interpeladas também a partir da especificidade de sua materialidade.

\subsection{O olhar fotográfico de Pastore: sutilezas insinuadas em sua narrativa visual}

Nos caminhos da coleção, os negativos nunca foram encontrados. O que se tem como materialidade sobrevivente são as cópias feitas em papel. A ausência dos negativos, a matriz de todas as reproduções, impossibilita precisar qual o equipamento usado. Carlos Lemos (1997) sugeriu um possível uso de câmera caixão com negativo de vidro. As fotos da coleção foram feitas em emulsão de gelatina-prata, reproduzidas em papel, com dimensão de $9 \mathrm{~cm} x$ $13 \mathrm{~cm}$, na maioria. Para o IMS trata-se de possíveis provas. As cenas sobrevivem como "cópias" únicas, sendo poucas as repetições realizadas.

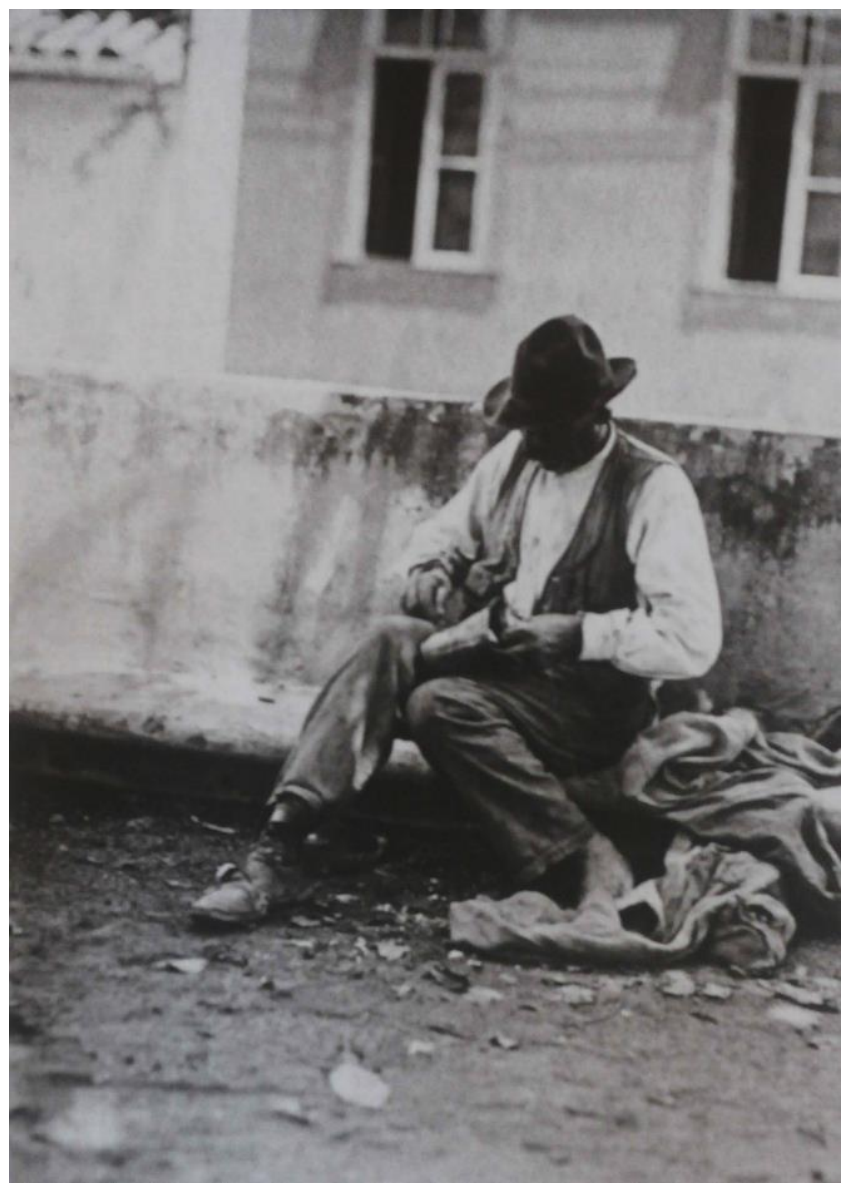

\section{Figura 136:}

"Homem costurando seu próprio sapato". Sem indicação de logradouro.

1910 () Vincenzo Pastore/Instituto Moreira Salles.

Equilibrou-se na série a preferência entre o formato horizontal (trinta e quatro imagens) e o vertical (trinta e nove), equilíbrio conferido também pela unicidade temática: o valor as cenas cotidianas e ao trabalho feito nas ruas dá coerência ao conjunto visual criado. $\mathrm{O}$ 
tipo de câmera adotada proporcionava, como apontamos, maior aproximação do fotógrafo com os sujeitos sociais retratados. Aproximação feita de modo sutil, aparentemente respeitosa. Pastore se colocava no mesmo plano do retratado insinuando certas sutilezas, como a do homem que costurava o seu próprio sapato (fig.136).

Essa fotografia inscreve um importante aspecto da coleção. Retoma cenas antes conhecidas por poucos relatos documentados, como o de dona Inez, em seu ato de relembrar as primeiras décadas do século XX, em São Paulo, momento em que o homem retratado por Pastore vivia. Nas lembranças dessa senhora negra, já idosa, vê-se como estar calçado devia lhes dar mais confiança frente a um comportamento social tão arraigado de valorização das aparências.

Dona Inez mostra as estratégias que usava para escapar dos preconceitos enraizados pela mentalidade escravista na paulicéia de início de novo século. Em sua tentativa de se integrar socialmente não enfrentou a hierarquia social existente sem medo ou expectativas. Dona Inez contou que, às vezes, os sapatos "eram nossos, às vezes eram emprestados, às vezes, quando dava também o sapato, eu tirava do guarda-roupa da patroa. Mas como doía os pés! Roupa apertada vá lá, mas sapato é a perdição!” (Bernardo, 1998, p. 47). Ambos os vestígios históricos, orais e visuais, expressam a força desses códigos sociais de distinção, ainda presentes no imaginário nacional.

Esse retrato revela-se como uma afirmação. Era preciso improviso para se integrar ao mundo dos livres. O gesto colocado em cena inscreve um importante elemento no reconhecimento da cidadania. O fotógrafo rastreou subjetividades historicamente construídas, mas num conteúdo imagético criado sob a condição de uma vida livre. O fotógrafo vai se revelando, interessado em sondar aquilo que Wissenbach (1998, p.53) nomeou como a própria "realização de desejos" e ambições de "posse de objetos que lhes haviam sido proibidos quando eram escravos". Costurar o próprio sapato, importante símbolo de distinção, foi um gesto relevante de afirmação e recusa em andar descalço. Talvez dali, ao rés do chão, o retratado tenha espiado a curiosidade do fotógrafo, dando-lhe pouca confiança. Era preciso ser escorregadio na tessitura social urbana; ser hábil em aprender rapidamente a lidar com poucas posses e paradeiro incerto.

Essas primeiras imagens apresentadas já delineiam o quanto Pastore se aproximou de certas minúcias vistas em relatos históricos voltados para sociabilidades difíceis de alcançar. O registro do breve instante de convívio no comércio e venda de quitutes, doces, frutas e 
prendas domésticas (fig. 133), evoca os segredos de um aprendizado herdado pelas diferentes gerações, quer saídas da experiência da escravidão, quer da imigração. Da venda ambulante muitas mulheres passariam a tirar o seu sustento. Um trabalho que tinha início na esfera doméstica, depois concluído nas ruas. As possíveis vendeiras foram quase emolduradas pelas folhas e pela guia do calçamento, revelando uma sutil composição, numa imagem que retoma tempos mais antigos, com notável profundidade de campo.

Pastore mais uma vez nos lembra de dona Inez, entrevistada pela pesquisadora Terezinha Bernardo. D. Inez desde os oito anos de idade foi empregada doméstica em uma casa de família. Arrumava, lavava, limpava e cozinhava. Foi depois levada para a casa da avó, seguindo responsável pelas mesmas atividades. Desde menina os mais velhos a colocavam para trabalhar no tanque, na cozinha, por toda a casa. Na vida contínua de trabalho exaustivo, dona Inez passou a trabalhar como marmiteira, saindo também às ruas para vender doces.

Os passos que levaram dona Inez para a venda de doces na rua, depois das jornadas de trabalho em casa, remetem à mesma contingência que envolvia a vivencia de Dona Risoleta, nascida no dia 20 de março de 1900. O pai veio vendido no tempo do cativeiro. Sua mãe nasceu livre. Além de lavar roupa para fora, a mãe fazia farinha de mandioca e de milho para vender, e assim criar os filhos, seguindo uma longa tradição da mulher como arrimo da família. $^{204}$

Pastore nos faz lembrar Sérgio Buarque de Holanda ao representar visualmente tais experiências, descortinando as camadas de historicidade intrínsecas ao fotográfico. $\mathrm{Na}$ descrição de Holanda sobre os hábitos oitocentistas da gente de São Paulo, lá estavam elas, as "pretas de quitanda" no centro da cidade, vendendo comidas tradicionais: "biscoitos de polvilho, pés-de-moleque, furundum de cidra, cuscuz de bagre ou camarão, pinhão quente, batata assada ao forno, cará cozido..." ${ }^{205} \mathrm{O}$ doce de laranja, as tachadas de goiabada que cozinhava muito bem eram todos vendidos em caixinhas pelas ruas da cidade (Bosi, 1994). Mulheres que já nas décadas finais do século XIX, solicitavam à Câmara Municipal o direito de deixar o Largo do Carmo para o Pátio do Colégio, para venderem mais facilmente suas

\footnotetext{
${ }^{204}$ Encontramos vestígios da trajetória de vida de dona Risoleta no estudo de Ecléa Bosi (1994), que promove a chance de uma maior inferência sobre as subjetividades de pessoas que cresceram na São Paulo de início de século XX, tratando-se de um estudo voltado para relatos, testemunhos e rememoração de experiências vividas na capital paulista. Sobre a tradição da mulher como arrimo da família ver Dias (1995).

205 Sérgio Buarque de Holanda descreveu hábitos urbanizados oriundos de heranças mais antigas, como o gosto por formigas aladas, conhecidas como iças, assadas e vendidas ao lado dos doces oferecidos pelas negras quitandeiras que muito surpreendia aos forasteiros. Cf. HOLANDA. Caminhos e Fronteiras. 1994, p. 55-59.
} 
mercadorias. A recusa dada em resposta vinha acompanhada de uma justificativa: a presença das vendeiras atrapalharia o trânsito (Bruno, 1954).

Começamos a descortinar um fotógrafo que rastreou ações e incursões de muitas mulheres frente às contingências de sobrevivência, nuançando um contexto antigo de incerteza e preconceitos pontuados no estudo de Lorena F. S.Telles:

No contexto de industrialização incipiente que auferia poucas oportunidades econômicas às mulheres, escravas, libertas, livres pobres e imigrantes disputaram a sobrevivência do trabalho desqualificado e mal pago, que compreendia as atividades de subsistência desvalorizadas na economia de exportação que produzia para o lucro. (Telles. 2013, p. 47).

Apesar das quitandas terem sido afastadas do centro nos anos finais dos oitocentos, Pastore registrou a presença de vendeiras em cenas que apenas lentamente iriam se diluir no novo século. Se nos arredores do Teatro São José, a fileira de tabuleiros, repleta de frigideiras, panelas e caldeirões, foi-se apagando do cenário citadino, como documentou Bruno (1954). Pastore se deparou com as práticas das caminhantes, resistentes em manterem seu antigo modo de sobrevivência.

O fotógrafo retratava aquilo que a Belle Époque recusava porque era avessa às cenas típicas. Era de seu feitio incorrer no erro das generalizações. Mas Pastore insistiu em mostrar como nos primeiros anos do século XX, muitos homens e mulheres venciam, dia após dia, as limitações de uma economia baseada na mobilidade e na informalidade, se recusando em ver tais experiências citadinas de modo generalizante. Documentou uma economia de abastecimento interpelada como expressão máxima da cidade, como expressão de uma modernização peculiar de São Paulo, destacada em primeiro plano.

\subsection{Entre panos, quinquilharias e muitas vassouras: Brechas de resistências na São}

\section{Paulo que recebia Pastore}

O fotógrafo compôs uma imagem da cidade a partir de um viés interpretativo preciso. O mesmo tema regia a tomada dos diferentes clichês costurados sob um mesmo interesse: o envolvimento das pessoas retratadas com seus afazeres nas ruas, quase sempre em suas práticas de trabalho, em seus movimentos espontâneos. É como se o fotógrafo fizesse uma invocação: olhemos para as coisas que estão aqui. 
São Paulo cresceu assim: Frente a um mercado formal que se constituía paulatinamente, com o desenvolvimento industrial marcado por períodos de avanço e retrocesso. ${ }^{206}$ As atividades de ganho nos espaços públicos foi a garantia de sobrevivência de um vasto contingente populacional, não incorporado aos setores formais de trabalho.

Quando Pastore chegou pela primeira vez em São Paulo, em 1894, a cidade contava com 13 fiações de algodão, uma fiação de lã, quatro fundições, uma fábrica de fósforos e algumas serrarias. Das 52 firmas realmente industriais existentes na capital, apenas 11 empregavam mais de cem trabalhadores. Três fiações, uma fábrica de cerveja, três de chapéus, uma de fósforos, outra de fundição; as duas últimas se tratavam de oficinas ferroviárias. ${ }^{207}$

Os operários moradores dos cortiços e cômodos de aluguel no Brás, Bom Retiro, Barra Funda e Belenzinho, bairros repletos de imigrantes, contavam com postos de trabalho em algumas olarias produtoras de tijolos destinados às novas construções. Fábricas de tecidos empregavam em seus teares o trabalho de crianças. Havia ainda ofertas de trabalho em alguma cervejaria, como a Germânica dos irmãos Reichert, futura Companhia Antártica. Indústria nacional era, portanto, incipiente, insatisfatória frente à crescente demanda por bens de consumo. ${ }^{208}$

As fábricas de vidro que ofereciam os recipientes para as cervejarias e aquelas de tecido, trabalhavam com o sistema de encomendas, "pois não se arriscavam a produzir para estocar", afirma Penteado (2003, p.122). Era comum "falências e súbitos fechamentos de fábricas, que os lançavam ao desemprego, de um momento para outro, sem qualquer garantia". Foi preciso, para uma leva de trabalhadores nas cidades, encontrar formas de sustento mais imediatas, impelidos para uma cultura mais independente, adaptando-se aos trabalhos temporários.

O setor de serviços tornava-se destino para a maioria da população negra e para parte significativa da leva de imigrantes saída do campo frustrada com a promessa de acolhida e fortuna; sem contar o contingente de nacionais socialmente brancos e pobres, também

\footnotetext{
${ }^{206}$ A população nacional negra passaria a atuar de forma mais efetiva no setor industrial a partir da década de 1930. Cf. ANDREWS, 1998. As crises econômicas nas últimas décadas dos oitocentos levaram muitas indústrias a desaparecerem. Um novo impulso foi sentido a partir de 1900. CF. BRUNO, 1954, v. 3, p. 1.133.

${ }^{207}$ Cf. BERNARDO, 1998, p. 21. Dados do relatório oficial datado de 1895, Cf. DEAN, 1971. As fábricas de bebidas em 1926 contavam com o seguinte quadro: 1.366 delas contavam com seis operários somente; apenas 109 unidades fabris contavam com 12 operários. Cf. DEAECTO, 2002, p. 87.

${ }^{208}$ Cf. DEAECTO, 2002, p. 40. A atividade comercial era crescente na cidade. O aumento da população provoca um aumento na demanda de gêneros alimentícios, mas também por bens duráveis. Apesar do fomento à industrialização, o Brasil fecha a Primeira República importando produtos básicos para sua economia.
} 
destituídos da propriedade da terra. Grupos que formavam mão de obra não especializada, disponível para a oferta de serviços. Sobre os anos finais do século XIX e início do XX, Wissenbach (1998) ajuda-nos a caracterizar este processo histórico, explicando aspectos socioeconômicos e culturais que se desenvolveram na cidade, num momento peculiar da formação da força de trabalho nacional:

\begin{abstract}
Nessa época, o adensamento de populações nas grandes cidades ocorreu sem que houvesse uma correspondência na expansão da infraestrutura citadina e na oferta de empregos e de moradias, transformando esse avolumar menos num desenvolvimento e mais num inchaço, o que acentuou o contraste entre as desigualdades sociais que se fizeram presentes. Estreitas ainda nos seus cenários coloniais, vivendo fases de uma industrialização incipiente, numa economia aferrada mais aos setores de serviços e aos negócios da exportação do que as atividades produtivas propriamente ditas (...) as transformações se deram no contexto de uma urbanização abrupta que se cimentava em formas improvisadas, levando o viver nas cidades a ser marcado pelas contingências de um provisório que muitas vezes se convertia em estruturas perenes. (Wissenbach, 1998, p.91)
\end{abstract}

O comércio ambulante era parte da experiência citadina, não como contradição ao urbano, mas intrínseca ao seu processo de expansão, sendo antes uma especificidade dessa dinâmica. O fotógrafo, em grande parte da série que compõe a coleção, acionou os sentidos do rural no urbano, revelando sujeitos históricos que se integravam na dinâmica citadina permeada por vicissitudes que não os abatia, movimentando-se de modo espontâneo nesse contexto, mas num pertencimento marcado por tensões.

O mesmo ímpeto que fazia as estradas de ferro avançarem do interior paulista ao porto de Santos impulsionou o aumento populacional, a partir da segunda metade do século XIX. A cidade retratada por Pastore tornava-se pólo de atração para imigrantes arregimentados desde meados da década de 1880, alterando significativamente os dados demográficos da cidade. De 31.385 habitantes em 1872, passou para 47.697, em 1886. 12, 290 imigrantes passavam a integrar este contingente, constituindo um quarto da população. Em 1890, chegou-se a um total de 64.934, um crescimento de 36\% em apenas quatro anos. Entre 1890 e 1900, momento da chegada de Pastore à Capital, a população subiu para 239.820. Contingente populacional adensado, sobretudo pela chamada Grande Imigração entre os anos de 1880 e 1920; Em 1893 
os imigrantes compunham, após a primeira onda de imigração de italianos, mais da metade da população local, chegando a representar em 1920, 36\% da população da capital. ${ }^{209}$

Tratamos de uma população que se diversificava. Levas de homens e mulheres pobres e negros saídos do campo ajudavam a adensar o contingente urbano. Grupos heterogêneos em convivência numa cidade que desde 1870 começara a apagar seus aspectos coloniais. Ampliar a rede ferroviária, implantar bondes a tração animal, sanear a Várzea do Carmo, cravada entre o núcleo antigo da cidade e o bairro do Brás, desapropriar os moradores da Rua das Casinhas, explicam as reformas e melhoramentos urbanos da gestão João Teodoro Xavier. "Extirpar os sintomas incômodos da pobreza urbana" para Dias, permeia o projeto modernizador colocado em prática desde o fim do século XVIII. (1985, p.102).

No período em que Pastore retratava as redes de abastecimento na capital paulista o poder municipal tentava restabelecer o uso de placas aos vendedores ambulantes, uma vida em trânsito de difícil controle e fiscalização. Contudo, tais ações quase sempre ficavam a reboque das "práticas andejas", ${ }^{210}$ porque tratamos de seres sociais ágeis que se apropriavam dos espaços escapando de ações normativas. Defendiam aquilo lhes pareceria pertencer por direito, ou seja, viver do comércio na cidade.

O prefeito do município de São Paulo, usando das atribuições que lhe são conferidas por lei, resolve restabelecer a disposição constante do Acto n.5 de 28 de setembro, de 1896, assim concebida: "os contribuintes do imposto de ambulantes serão obrigados a trazer de modo visível, uma placa pela qual se possa fiscalizar a effectividade do pagamento do imposto. ${ }^{211}$

O vendedor de aves Victor dos Santos foi flagrado sem licença no dia 15 de maio de 1909, quando passava pela Rua da Boa Morte. ${ }^{212}$ Foi multado e sua mercadoria apreendida. Defendeu-se dizendo ter deixado a licença em casa. No dia seguinte, ao tentar reaver a sua mercadoria, apresentou uma licença de outrem. O fiscal, pouco convencido com o falso documento, manteve a apreensão.

A política de zoneamento de 1911 acompanhava a racionalização do traçado urbano para acirrar o controle sobre os vendedores, tropeiros e ambulantes. $\mathrm{O}$ uso de pequenos cestos

209 LOVE, 1982, p. 43-44 e 122. As primeiras levas de imigrantes chegaram ao Brasil após a crise que assolou a Itália. A região do Veneto é sempre citada devido ao fato, de muitos de seus pequenos camponeses e meeiros, terem sido lançados para proletarização da mão-de-obra campesina, submetidos a um processo violento de expropriação da terra. A partir de 1882, iniciou-se "uma corrente ininterrupta". Ver Morse, 1970, p. 241.

${ }^{210}$ Termo utilizado por Sergio Buarque de Holanda (1994) ao tratar das práticas sociais dos vendeiros que ocupavam as ruas da cidade como vendedores ambulantes nas últimas décadas do século XIX.

${ }^{211}$ Arquivo Histórico e Municipal de São Paulo. Ato Municipal n. 442, 4 jan. 1912.

${ }^{212}$ Arquivo Histórico e Municipal de São Paulo. Papéis Avulsos. Caixa de 1909. 
na venda de rua ajudava a não chamar a atenção dos guardas municipais que tentavam fazer valer a proibição dessa atividade nas ruas centrais, conforme Ato Municipal de número 362, promulgado em de 30 de julho de $1910 .{ }^{213}$

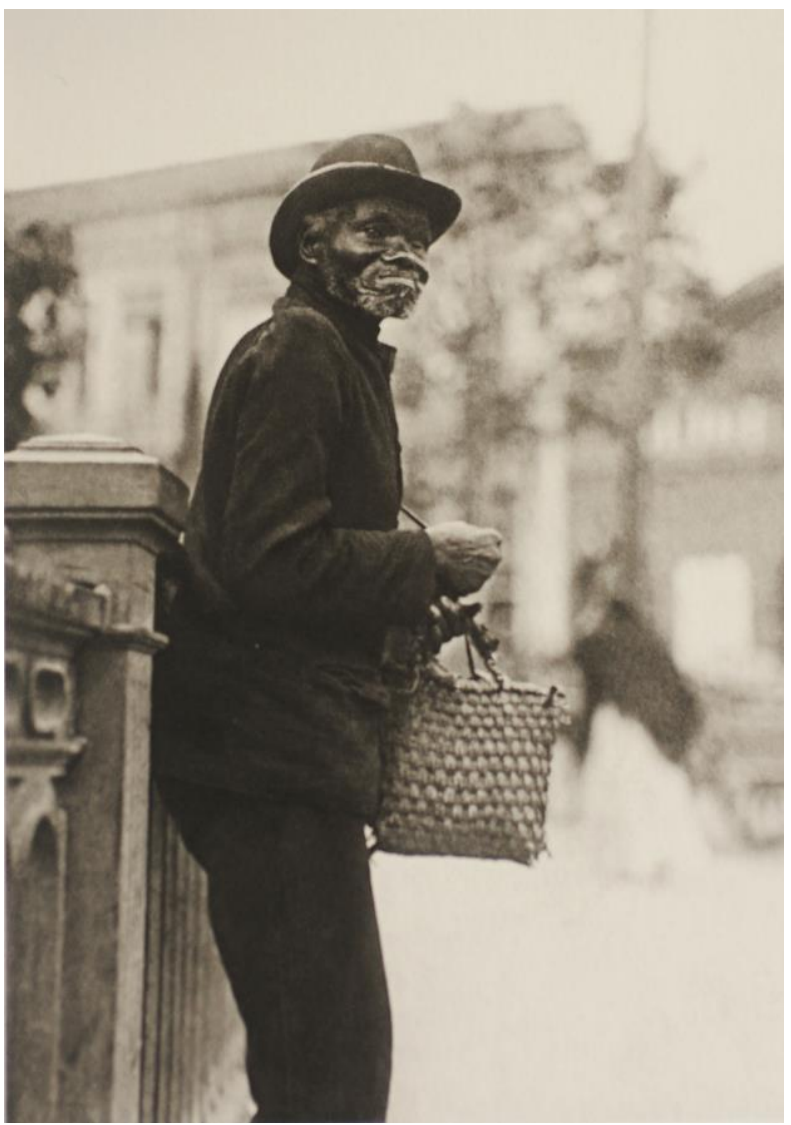

Figura 137: "Retrato de homem idoso recostado em grade metálica da Rua São João" em frente ao Bijou Salão, à Direita. Fotografia/Papel. 1910 @ Vincenzo Pastore/Instituto Moreira Salles.

Pastore retratou o homem negro, já idoso que tentava garantir o seu modo autônomo de trabalhar e viver (fig. 137). No estudo de Bernardo (1998, p.118), vê-se como na memória dos "velhos negros" o trabalho firmava-se em suas lembranças. "Eles trabalharam, trabalharam muito, em qualquer tipo de serviço, e, para conseguir trabalho, tiveram muito trabalho". Aos oito ou nove anos de idade "faziam comida para mãe, eram engraxates, jornaleiros, aprendizes de sapateiro, marmiteiros, meninos de recados".

O senhor encostado na grade de ferro fundido leva seu cesto ao braço. Os muitos rasgos nas pontas do cesto são as marcas do quanto era usado, surrado, desgastado pelo ir e vir de um possível vendeiro angariando seu sustento na Rua São João. Talvez, ele tenha sido um morador dos quartos de cômodos alugados em casas sob o risco iminente de desapropriação para a viabilização do projeto de remodelação, que visava tornar essa rua uma

\footnotetext{
${ }^{213}$ Arquivo Histórico e Municipal de São Paulo. Cf. artigo $8^{\circ}$.
} 
grande avenida. ${ }^{214}$ Talvez, seria ele um morador de um casebre localizado na Várzea, local da habitação de muitos considerados "caipiras". Talvez, morasse em bairros ainda mais distantes. Teria Pastore retratado um momento de descanso desse homem, talvez saído da Várzea do Carmo, subido a Ladeira de São João, passando pelo Largo do Rosário até atingir a rua onde foi fotografado, refazendo caminhos da íngreme Ladeira do Açu? $?^{215}$

Ou teria chegado à cidade vindo da Sé pela Ponte do Açu, passado pela antiga Imperatriz, tomado a Boa Vista à direita, alcançado o Largo São Bento, atravessado a ponte até chegar à São João? Se na primeira quadra dessa avenida tomasse à direita, seguindo à frente chegaria ao Largo do Paissandu. Santa Ifigênia estava mais adiante. Ou quem sabe tenha ficado perambulando, às voltas do mercado da São João, inaugurado em 1890, pejorativamente descrito como "muito concorrido, pequeno e sem gosto" (Pinto, 1979:167). Esse ponto de venda de muitos verdureiros colocou fim ao vaivém na Rua das Casinhas, reduto das antigas quitandas de verduras, legumes, frutas, de leite, de aves e ovos como documentou Bruno (1954, p.1.144).

Talvez sem recursos suficientes para montar uma barraquinha e contribuir com o fisco, o homem fotografado contava apenas com suas andanças esperançosas pelas quadras próximas do burburinho e agito do mercadinho da São João, depois transferido para baixo do Viaduto de Santa Ifigênia. Olhando a foto no original, ficou ainda mais evidente a presença da mulher negra, no último plano da imagem. De vestido branco, com xale preto levado às costas, quem sabe esta mulher também negra, aparentemente com mais idade, seguisse rumo ao mercadinho de frutas e verduras do Açu, que alcançou o Anhangabaú, em práticas de abastecimento ocupadas por muitos homens e muitas mulheres, que encontravam condições de trabalho nem sempre favoráveis.

Mercadorias eram constantemente apreendidas e licenças verificadas por guardas fiscais de qualquer distrito. Conforme o Ato $\mathrm{n}^{\circ}$ 396, de 6 de maio de 1911, essa subdivisão do espaço urbano em quatro zonas e quarenta distritos foi uma estratégia de fiscalização, somada

\footnotetext{
${ }^{214}$ A Rua São João foi submetida aos projetos de melhoramentos na gestão Duprat. Os interesses do prefeito que substituiu Antonio Prado colocaram à frente da prefeitura novas obras. O novo prefeito, Raymundo Duprat, empenhou-se em ampliar a Avenida São João, um antigo desejo seu desde os tempos em que assumia o cargo de presidente da Câmara.

${ }^{215}$ A Ladeira de São João era antes chamada de Açu. Cf. SOUZA, 1954, p. 62-65.
} 
ao desejo de identificação dos não contribuintes. Além do uso de placas, exigia-se, em 1910, período em que Pastore espreitava a venda ambulante, o uso de uniformes. ${ }^{216}$

Mas a margem de autonomia de suas experiências era tamanha que tais vendeiros escapavam dos níveis de controle e quantificação, que valem ser observados, porque indiciam a pulsão das sociabilidades pertinentes ao Pastore. Documentos municipais indicam o aumento da atividade ambulante nos anos de 1910. Os vendedores de gravatas para terem a concessão das devidas licenças neste período eram obrigados a pagar aos cofres públicos o valor de $100 \$ 000 .{ }^{217} \mathrm{O}$ quadro demonstrativo da arrecadação mostra que em 1906 o montante incorporado aos cofres públicos com a tributação dos ambulantes foi de 206:410\$000; ligeira queda foi apresentada nos anos de 1907 a 1909, respectivamente de 195:000\$000 e 184:762\$000; ${ }^{218}$ a arrecadação de 1910 apresentou números maiores somando um valor de 203:890\$000. ${ }^{219}$

A oscilação da arrecadação dos impostos cobrados dos ambulantes difere dos valores sempre crescentes na concessão de licenças. De 189:566\$000, em 1906, os cofres públicos conseguiram obter, em 1909, a soma de 268:083\$00, chegando em 1910, a 351:767\$000 de impostos arrecadados. Conseguiram contabilizar, com o fornecimento de 1.620 carteiras aos vendeiros ambulantes, no ano de 1909, a importância de $810 \$ 000 .{ }^{220}$

Os vendedores de amendoim passaram de 6 registrados em 1909, para 10, em 1910; mercadores de aves que, em 1909, somavam 81, em 1910, oficialmente chegaram a total de 47, diminuindo quase a metade na soma da arrecadação nessa "espécie de occupação": de 2:400\$00 foi arrecadado, em 1910, apenas 1:330\$000. A quantidade dos ambulantes vendedores de doces, empadas, pastéis em tabuleiros, de 134, em 1909, passou, em 1910, para 194 no total de registros. Ficou inalterado o número pouco expressivo de 11 vendedores de cestos, vassouras, escovas e objetos de vime. Os "mercadores de gêneros alimentícios em

\footnotetext{
216 Arquivo Histórico Municipal de São Paulo. Determinações expressas nas leis municipais números 1.397, 1.398 e 1.428 , de 1910.

${ }^{217}$ Arquivo Histórico Municipal de São Paulo. Ato Municipal no 468, de 17 de maio de 1912.

${ }^{218}$ Arquivo Histórico Municipal de São Paulo. Cf. Relatório anual de 1909 enviado pelo prefeito Antonio Prado à Câmara Municipal, p. 96.

${ }^{219}$ Arquivo Histórico Municipal de São Paulo.Cf. Relatório anual de 1910 enviado pelo prefeito Antonio Prado à Câmara Municipal, p. 4.

220 Tabela explicativa da arrecadação no exercício de 1909. Relatório anual de 1909 enviado pelo prefeito Antonio Prado à Câmara Municipal, p. 56.
} 
diminuta escala" que compunham apenas 8 no total, em 1909, chegou a apenas 1 matriculado no ano de $1910 .{ }^{221}$

As atas da Câmara municipal apontam a dificuldade de se controlar e tributar a prestação de serviço feito nas ruas. O relatório de 1909 indica a arrecadação de 3:360\$000 obtida pela prefeitura, devido a apreensão das mercadorias dos vendedores que atuavam sem licença. ${ }^{222}$ Proporcionalmente se arrecadava mais com as apreensões do que com a soma tributária de cada ocupação oficializada.

Em 31 de julho de 1912 foi aprovada a lei $n^{\circ}$ 1.576. Por determinação do prefeito Raymundo Duprat, em cada quarteirão da cidade estava prevista a presença de um inspetor auxiliar da fiscalização municipal. Se a incumbência à principio dizia respeito à limpeza pública e particular, algo precisa ser sublinhado: cada fiscal teria direito a $20 \%$ sobre a importância das multas impostas e devidamente arrecadadas. Prestar mais atenção nos vendedores ambulantes podia aumentar inclusive a renda mensal dos agentes da fiscalização.

Vê-se como a mobilidade era condição para sobreviverem. A proteção dependia da capacidade de se tornarem quase invisíveis, artimanha necessária às práticas de errantes, que lhes custava certa agilidade e manobras quando se deslocavam fazendo incursões em espaços proibidos. Desembaraço, desenvoltura e vivacidade eram segundo Peres (2006), atributos necessários diante das situações sociais que envolviam os grupos errantes em meio a sistemas complexos de interação.

Na Praça da República, Pastore flagrou de perto a presença de um tocador de realejo cercado de olhares curiosos (fig.138). À esquerda vemos o garoto, com cesto levado ao braço, logo em primeiro plano. O comércio ambulante feito por crianças foi interrompido por um instante. $\mathrm{O}$ olhar demorado ficou seduzido pela magia acionada à manivela. Mas, para se exercer tal função, fazendo das ruas um modo de vida, era preciso requerer concessão de licença à prefeitura. Justino Marciano, por sofrer de cegueira, solicitou isenção do imposto para tocar música; José Sanches, "aleijado", tocador de realejo também obteve isenção concedida. Todos tinham como restrição a circulação no perímetro central, ${ }^{223}$ região da cidade

\footnotetext{
221 Ver relatórios anuais de 1909 e 1910 nos documentos anexos apresentados no final da tese onde são apresentadas tabelas completas para os anos de 1909 e 1910, indicando a quantidade de vendedores ambulantes para cada tipo diferente de mercadorias vendidas, bem como a importância da arrecadação para cada "espécie de ocupação".

${ }^{222}$ Ver Relatório anual de 1909 enviado pelo prefeito Antonio Prado à Câmara Municipal, p. 20.

223 Ver Papéis Avulsos. 1908. Local: 2046 e 2047. Arquivo Histórico Municipal de São Paulo. Acervo manuscrito.
} 
que a cada década criava medidas para apagar a imagem da atividade ambulante, vital para parte significativa de seus moradores.

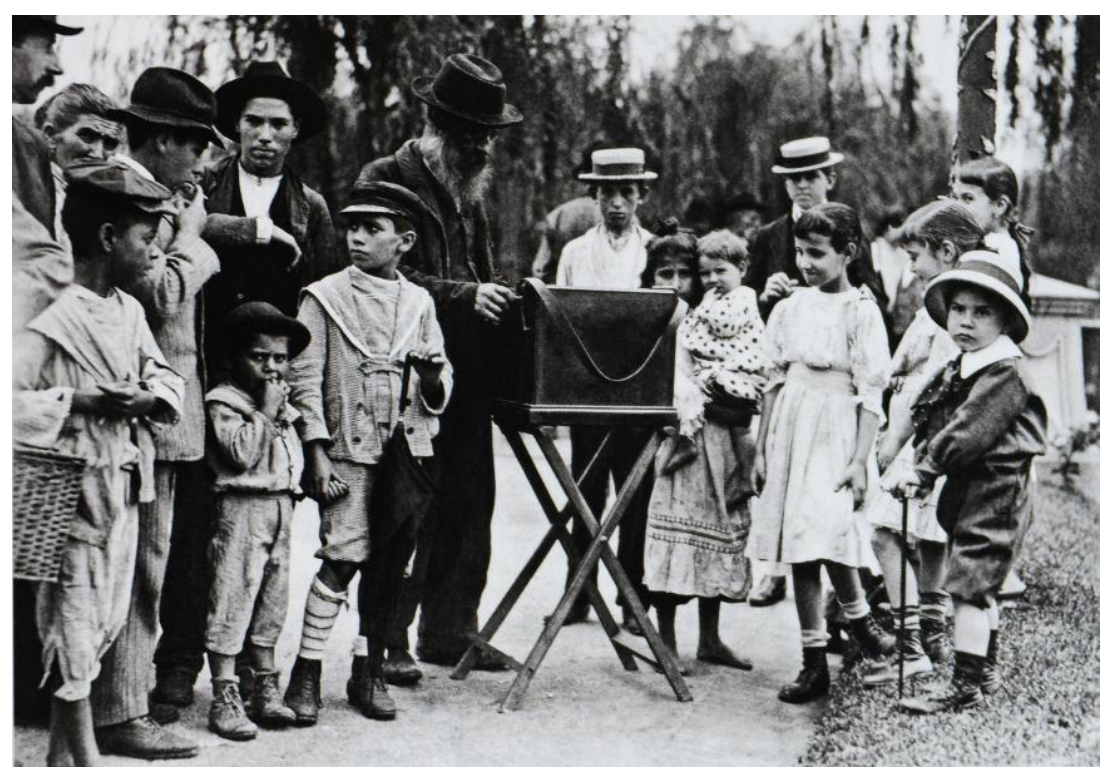

\section{Figura 138:}

"Grupo de pessoas ao redor de realejo, na praça da República". Foto que retrata a presença de tocadores de realejo trabalhando na capital paulistana por volta da década de 1910. À direita, vemos Francesco Pastore, filho do fotógrafo (C) Vincenzo Pastore/IMS.

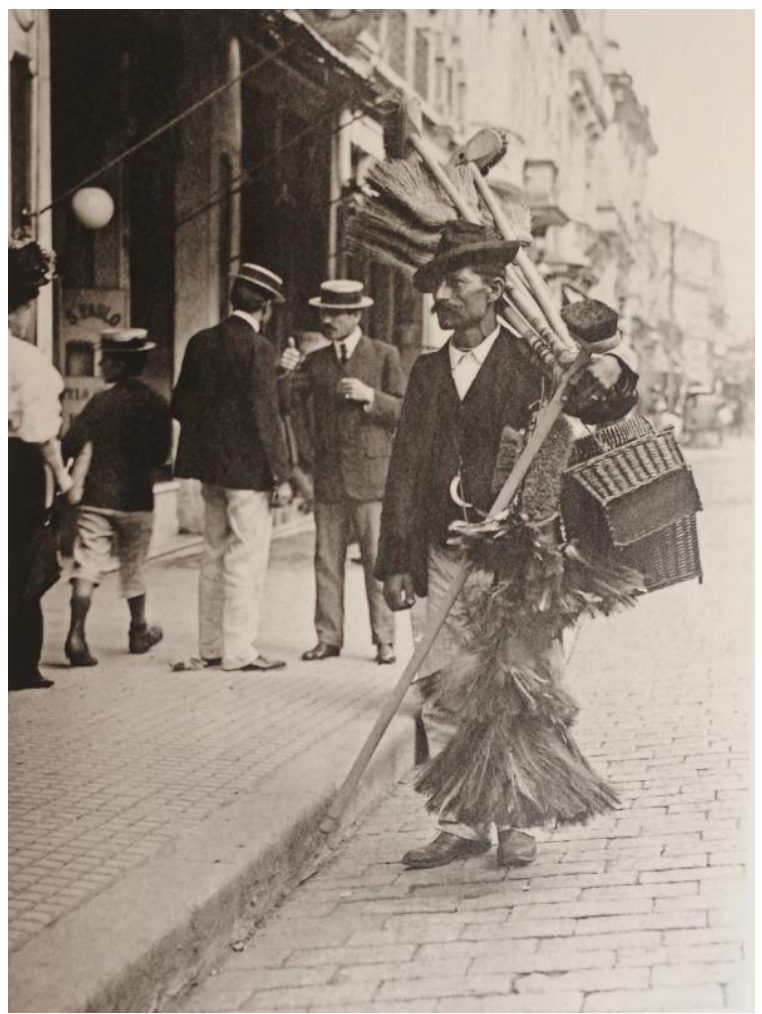

\section{Figura 139:}

"Vendedor de vassouras em rua do centro da cidade"; a indicação de paralelepípedos indica a possibilidade de se tratar de uma rua do Triangulo Central. 1910. (C) Vincenzo Pastore/IMS.

$\mathrm{Na}$ arte de sobreviver do ganho na rua, vender cestos, espanadores, escovões e muitas vassouras, compõe outra cena urbana, também flagrada por Pastore acima da Colina (fig.139). Esta imagem rastreia agencias sociais silenciosas, obscurecidas. Oliveira mencionou o quanto eram práticas feitas até mesmo em parcerias. Na casa "ao pé da Sé" vivia, em fins do século 
XIX, D. Maria das Dores, mulher "solteira, idosa, arranjara sua sobrevivência alugando dois cômodos da sua casa e, ao que tudo indica, fazendo doces ou quitutes para vender" (2005, p. 38). Entre as variadas latas de assar biscoitos, os tachos de cobre, as colheres de pau, os muitos panos de prato e balaios de vime, "quantas vassouras" foram lá encontradas. Maria vendia de tudo, até o dia em que morreu sozinha. Ninguém se deu conta de sua ausência, mencionou Oliveira. Não se sabe se Maria saía às ruas para vender o variado conjunto de mercadorias inventariadas ou se era essa uma função delegava a outrem.

O homem retratado seguia por uma das ruas comerciais do triângulo. O calçamento e a guia indicam melhoramentos. Há mais a se observar. O vendedor que cruzou o caminho de Pastore usava também amuletos e patuás, buscando, como bem sugeriu Wissenbach (1998, p.52), “proteção adicional”. É possível se reconstituir, a partir dessa imagem, práticas culturais africanas carregadas de significados pessoais e crenças enraizadas socialmente, permeando experiências repletas de rezas, mandingas e crendices incorporadas para se combater maus-olhados. Amuletos eram carregados junto ao corpo como um bem material, como o direito de uma posse garantindo-lhes proteção contra furtos, receio comum entre os ambulantes.

Entre os vendedores de aves, amendoim torrado, açúcar de algodão, vendedores de vassouras também aparecem nos relatos de memoralistas, que ativaram importantes camadas de recordações da cidade. O perspicaz vendedor de vassouras fazia-se presente, marcando as lembranças do então menino Jorge Americano (2004, p.111): “Ouve-se um grito estridente. Este pregoeiro fala francês: 'fraternité, Égalité, vassourité, la facilité de la famille'. Não é francês, não sabe francês, mas era o vassoureiro preferido, porque lhe ensinaram aquelas imbecilidades", que são na verdade, expressão de uma língua viva. Da voz do italiano, vendedor de cestos, vassouras, balaios e espanadores, outros trechos de cançonetas ecoavam com graça, indiciando a nova língua aprendida na rua. No final do ano ele cantava vendendo de porta em porta versos que espelhavam, na confluência das duas línguas, a improvisação de se viver na experiência de desterro:

Ano nuovo, inculata nuova!

Il tempo passa, Il lusso cresce,

La miséria aumenta

e la morte trionfa!

Ano nuovo, inculata nuova! (Penteado, 2003, p.207) 


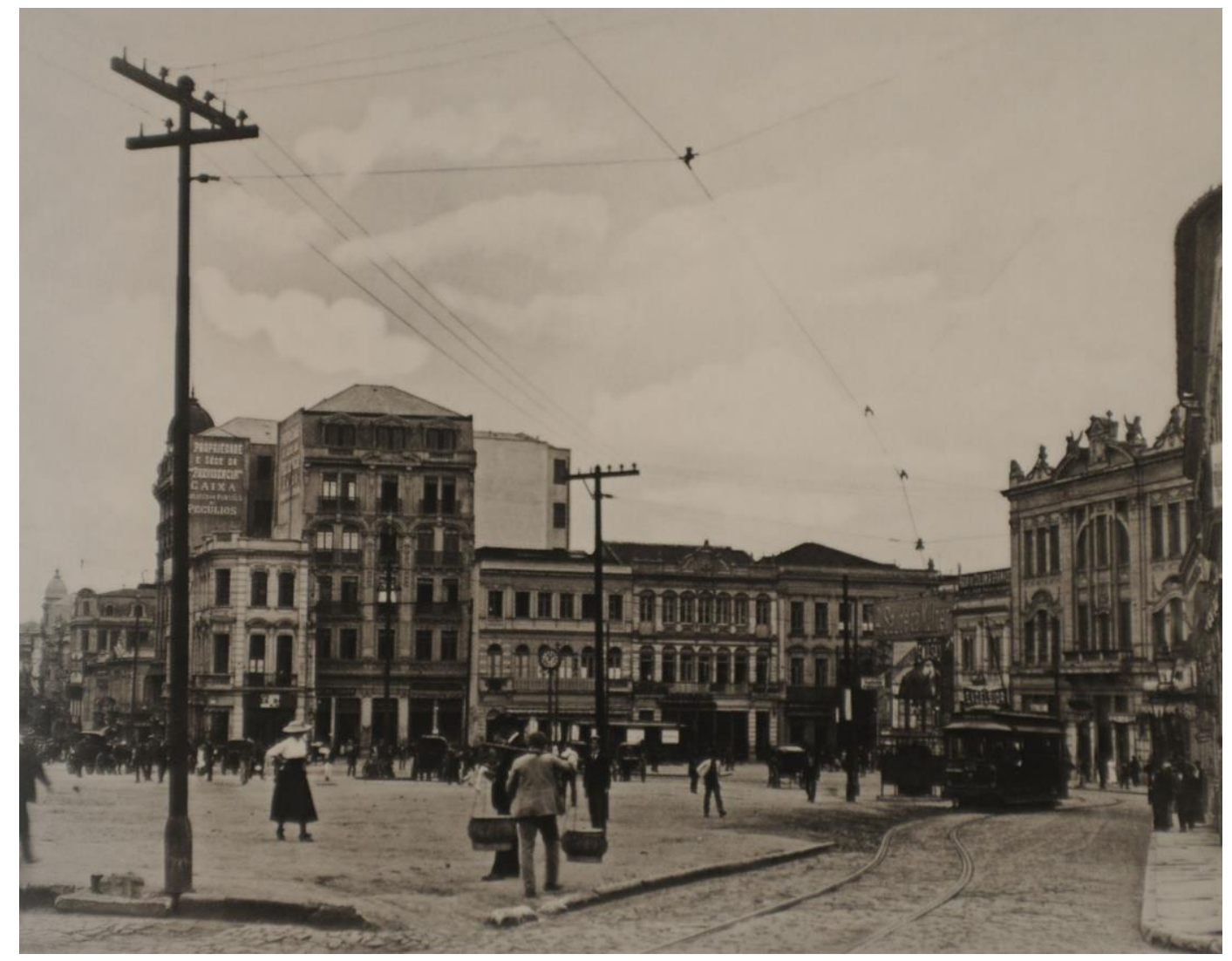

Figura 140: "Largo da Sé". Segundo descrição do instituto, trata-se de trecho da atual praça da Sé, após a demolição da antiga catedral e da igreja de São Pedro da Pedra. À esquerda, embocadura da Rua 15 de Novembro; o edifício com mansarda indica esquina com largo do Tesouro. À direita da imagem, quadra atualmente ocupada por edifício da Caixa Econômica Federal, com rua da Fundição, atual Floriano Peixoto, ao fundo.1912. (C) Vincenzo Pastore/IMS.

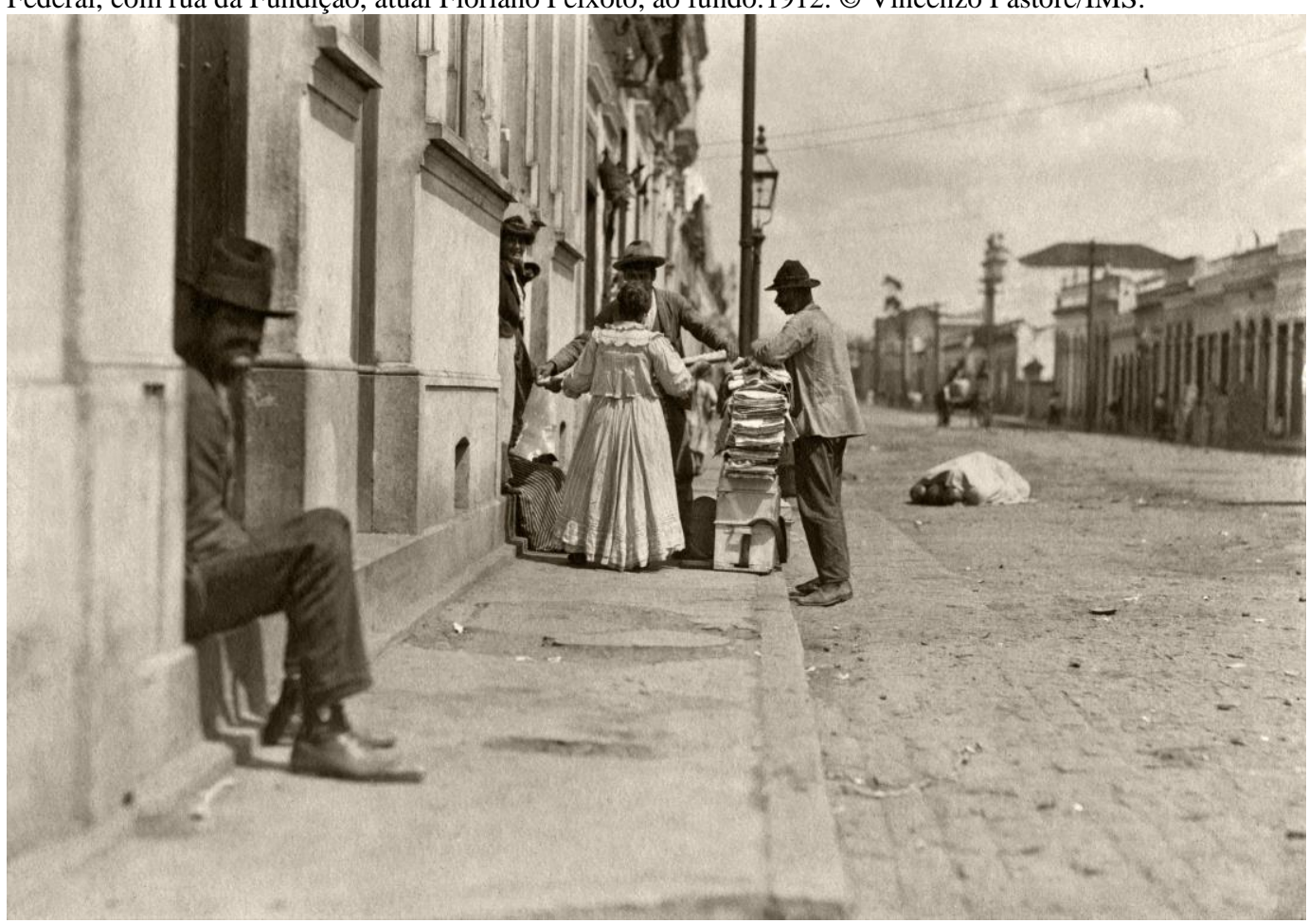

Figura 141: "Vendedores ambulantes de tecido". De um lado casas térreas, de outro os sobrados, numa cidade de múltiplas convivências. 1910 (C) Vincenzo Pastore/IMS. 
Ainda acima da colina, outras experiências acenaram à Pastore, um agente social que dividia com seus retratados a condição de ser um imigrante, um caminhante na cidade, apreendendo uma realidade que pessoalmente conhecia: a vida marcada pela fluidez, pelo ir e vir, pelo trabalho autônomo e provisório. Aspectos que promoveram em Pastore uma possível identificação com os sujeitos sociais que retratava. É possível que tenha tido com eles aquela conversa sobre a Itália que tanto gostava de ter com seus conterrâneos no Brasil, afirmou sua filha Costanza, quando lembrava do pai. ${ }^{224}$

Se Penteado (2003, p. 209) lembrou dos "negros vendendo sorvetes e entoando pregões africanos", afinal a cidade é também palco de lamentos e recordações individuais repletas de significados, por volta de 1910, Pastore retratou um deles levando às costas enormes panelões (fig.140). O homem negro retratado caminhava resistente pelas ruas da Sé, fazendo valer o seu direito de sobreviver de modo independente.

A narrativa criada por Pastore revela múltiplos contextos, vestígios visuais que nos levam a aferir como camadas de experiências diversas são dadas em processos de urbanização distintos, que fogem à regra do trabalho nas fábricas. Se Pastore retratou esse homem trabalhando sozinho rumo ao sul da Sé, não deixou de privilegiar em seu recorte algo tão escondido das tramas sociais da capital auriverde: Pouco se falou do imigrante vendedor de tecidos mascateando ao lado do homem negro, um possível assistente. Cena que não escapou do fotógrafo, realizada talvez, sob sol a pino.

$\mathrm{Na}$ lida diária de empurrar o carrinho ou carregar caixas de tecidos convivências foram construídas. Na fragmentação de suas comunidades tradicionais, o trabalhador negro e o imigrante, antes enraizados nas práticas camponesas, lançaram-se para uma experiência comum. Compunham a leva saída do interior ou chegada ao porto de Santos, em busca de melhores condições de vida. ${ }^{225}$ Trajetória que era também a do próprio fotógrafo, que reconhecia pelas ruas outros sujeitos históricos que dividiam com ele as mesmas ambições.

$\mathrm{Na}$ composição da narrativa visual de Pastore como um flaneur pela cidade, tem-se uma leva de trabalhadores: brasileiros e imigrantes italianos, espanhóis, portugueses, alemães e

\footnotetext{
${ }^{224}$ Em entrevista realizada em 1994 a filha de Pastore, Costanza, desvelou detalhes da subjetividade do fotógrafo. Cf. Centro Cultural São Paulo. Entrevista realizada pelo pesquisador Ricardo Mendes.

${ }^{225}$ Marcia Maria Cabreira de Souza afirmou que muitos dos mascates de origem árabe, sírios ou libaneses, não estavam inseridos nas atividades comerciais em suas terras de origem. Essa foi uma imigração sem ligações com a cultura cafeeira tendo assumido características marcadamente urbanas, apesar da maioria da população árabe imigrante ter uma origem rural segundo a pesquisadora. 0 maior fluxo desse contingente de imigrantes se deu entre os anos de 1911 e 1913, "fase marcada pela repressão turca contra os libaneses", mas estendeuse até a década de 1940. Cf. Souza. 2002, pp. 3-15.
} 
sírios, expressando toda a complexidade do fenômeno da imigração, não a encerrando como sempre afortunada e de pleno sucesso. ${ }^{226}$ Estamos diante de sociabilidades que remetem a própria experiência do fotógrafo.

Pastore documentou relações entremeadas pela camaradagem e pela necessidade. Eram muitos os interessados pelo algodão tropeiro, baetas de diversas cores, brim, merino francês, caxemira, damasco de lã, tecidos negros, pano de ponche, xales e rede, mantas e cobertores. As pequenas e variadas vendas do pequeno comércio, fazia-se a crédito, envolvendo consumidores de panos e quinquilharias que levavam o produto para a casa e pagavam depois. $^{227}$

Pastore descortinou como era possível atender a essa demanda de tecidos, vendendo-se de porta em porta (fig.141). Na calçada vemos o mascate negociando o preço com a senhora. Abaixo da guia, o ajudante carregava a caixa de tecidos. O revestimento de macadame começara a ser substituído. A imagem materializada e perdida no instante seguinte rastreou aquilo que os historiadores documentaram por meio de fontes escritas: a prática de muitos comerciantes sírios e libaneses de mascatearem pelas ruas de forma autônoma, "se desfazendo do seu estoque à medida em que os seus artigos vão sendo vendidos". ${ }^{228}$ Muitos deles percorriam os bairros fora do Triângulo Central, empurrando seus carrinhos ou levando seus caixotes com suas fazendas compradas no atacado.

O itinerário era variado. Chegavam à Penha passando pelo Brás, indo também a Santana e outras localidades. Depois com as economias acumuladas muitos se fixaram em

\footnotetext{
${ }^{226}$ Os anos de 1880 a 1920 são considerados como o período do auge imigrantista. Antes disso, em 1886 já constituíam um quarto da população da cidade; em 1893 compunham, após a primeira onda de imigração de italianos, mais da metade da população. Os estrangeiros, em 1920, representavam $36 \%$ da população da capital paulista. O período da chamada Grande Imigração (1880-1920) promoveu um intenso deslocamento via atlântico de um verdadeiro "exército de trabalhadores", promovendo uma "quase inevitável proletarização dos pobres do campo". Cf. ALVIM. Imigrantes: A vida privada dos pobres do campo. In: Novais e Sevcenko. História da Vida privada. V. 3. 1998.

227 Em inventário analisado por Oliveira, encontramos João identificado como crioulo alfaiate, a escravizada Ritinha, Emília alugada da madame Rosa, ou Francisca quituteira. Todos apareciam na lista dos devedores. Oliveira nos apresenta como a escravidão urbana "assumia uma série de peculiaridades" onde escravizados podiam comprar nas mesmas lojas que seus senhores. No inventário feito, em 1875, a cargo da morte do lojista português Antonio Villela Vieira foram documentados outros escravizados com crédito. Dessa vez tratava-se de uma loja de fazendas, localizada na Rua da Quitanda, 23. Marianno, escravizado pelo barão Tietê tinha seu nome na lista ao lado "das pretas Eva da Rua de São João e Francisca quituteira; Maria cuscuz; Aninha a preta, a Benta, cozinheira; Cypriano carpinteiro; Nazareno Typografo (...)". Oliveira. 2005, p. 129-130.

${ }^{228}$ Souza explica a diferença entre os mascates sírios e libaneses e os prestamistas judeus chamados de Klienteltshik. Estes atuavam nos subúrbios e diferentes bairros na cidade, já aqueles além da cidade se dirigiam também às áreas rurais e para outros estados do país. Existe também a diferença entre a pratica dos mascates e do caixeiro viajante. O primeiro vendia de porta em porta o pequeno estoque; os segundos recebiam comissões sobre as vendas realizadas sob um sistema de encomendas. Cf. Souza. 2002, p. 19-20 e p. 111.
} 
estabelecimentos próprios, em pequenas lojas ou armarinhos com endereço fixo que tanto podia ser a Rua Vinte e Cinco de Março como endereços no alto da colina. ${ }^{229}$ Mas nem sempre suas trajetórias eram marcadas pelo sucesso comercial: "houve aqueles que tiveram sorte, e outros que não tiveram. Teve famílias que viveram pobres e terminaram pobres, só que ninguém conta essas famílias". 230

O mascate retratado por Pastore, quando passava em frente das casas térreas de pequeno comércio, algumas de molhados simples, talvez incomodasse muitos proprietários, tamanha era a concorrência na atividade comercial citadina, como apontam algumas fontes. Os negociantes de armarinhos, fazendas e perfumaria, estabelecidos no distrito de Santa Ifigênia, bairro do Bom Retiro, Rua dos Imigrantes e dos Italianos, fizeram um abaixo assinado, encaminhado ao prefeito. Se auto-definiam como "cumpridores da lei municipal, como contribuintes sentindo-se lesados nos seus interesses por diversos ambulantes, desprovidos de licenças, os quaes iludem a vigilância dos senhores guardas fiscaes deste município". ${ }^{231}$

Esses ambulantes foram acusados de se aproveitarem da ausência dos fiscais que paravam para o almoço ou se dirigiam às repartições. "A referida mercadoria a baixo custo, que nos compramos por atacado e como somos carregados de impostos e alugueis não podemos vender pelo preço que eles vendem”, reclamavam os proprietários. Exigiam que fiscais à paisana passassem a vigiar o bairro das 11 horas da manhã até às 5 horas da tarde para assim "aprender em flagrante os infratores", os caminhantes.

Os fiscais se defendiam dizendo que haviam percorrido os lugares designados fazendo muitas apreensões de mercadorias, levadas ao depósito municipal, destacando em sua fala oficial, as dificuldades da realização de seus serviços, bem como o volume das apreensões. Eram obrigados a dividir muitas ruas; queixavam-se da "quantidade das quinquilharias apreendidas", revelando o quanto era custoso fiscalizar a região da Várzea "devido a fácil fuga para o matto e para as casas que ali existem", inclusive de fregueses "os quaes lhes dispensam apoio e tolhem assim a vigilância do fiscal".232

A natureza conflitiva da prática ambulante se evidencia lentamente na documentação interpelada. Aqueles flagrados sem licença eram, na verdade, empregados de Cecílio Rib,

\footnotetext{
${ }^{229}$ Com o auxilio das redes ferroviárias os mascates seguiam também rumo ao interior. Cf. Deaecto. 2002, pp. 114-115.

${ }^{230}$ Entrevista realizada por Souza com Sr. Ibrahin Cury, imigrante nascido em Homs em 1907, tendo chegado ao Brasil em 1924. Cf. Souza. 2002, p. 112.

${ }^{231}$ Sic. Arquivo Histórico Municipal de São Paulo. Seção de Polícia e Higiene. 1909. Caixa 53.

232 Sic. Arquivo Histórico Municipal de São Paulo. Seção de Polícia e Higiene. 1909. Caixa 53.
} 
estabelecido na Rua dos Immigrantes, n. 196, nome presente no abaixo assinado contra os ambulantes. Deste modo, encontramos um comerciante que lucrava com a venda na sua loja própria, mas também colocava ambulantes nas ruas, depois denunciando uma prática com a qual ele mesmo encontrava meios de se beneficiar.

Essa multiplicidade de identidades que se forjavam na cidade, entre seus casebres e sobrados, entre suas estreitas ruas, pontes e avenidas alargadas, revela um cotidiano tenso, onde os diferentes grupos concorriam, num mercado que impulsionava a economia interna. Um comércio que ajudava a amenizar as crises cíclicas de carestia, provocando constantes aumentos de preços dos alimentos, como explica Pinto (1994). Experiências citadinas espreitadas por Pastore que oferece ao intérprete um material visual que ajuda a dialetizar um tempo, um espaço, reconstituindo processos históricos e relações sociais.

Começaremos a traçar agora uma reflexão para a especificidade do material visual construído, já nuançada neste último enquadramento (Fig. 141). O fotógrafo colocou-se próximo do homem sentado na soleira da porta, à esquerda. Se este tomou o primeiro plano da imagem, aparece, entretanto com pouca nitidez, desfocamento que delineia certas escolhas formais por parte do fotógrafo, atípicas na comparação com outras produções dos contemporâneos de Pastore: ao compor retratos de sociabilidades tão vibrantes, se aproximando de modo evidente de tantos retratados, propôs um olhar de confronto, interrogando o próprio fazer fotográfico, desafiando procedimentos técnicos, como sublinharemos a seguir.

\subsection{Traços da especificidade da série fotográfica: atitudes e invenções assumidas por} Pastore

Em suas incursões pelas ruas, Pastore apresenta-se como um fotógrafo que desafiava práticas mais antigas de representação. Dava as costas às convenções, as formas preestabelecidas do retrato oitocentista, ao recusar a pose e lançar os corpos retratados para a experiência do movimento, da fragmentação.

As duas imagens apresentadas bem indiciam um importante traço da série: o caráter de foto instantânea adere fortemente ao conteúdo das fotos (fig.142 e 143). O fotógrafo interpretava a cultura do instantâneo que associava avanço técnico com linguagem visual 
atenta ao tempo, ao movimento e às novas possibilidades de apreensão do corpo. Pastore experimentou câmeras portáteis, que promoviam a linguagem da estantaneidade da foto.
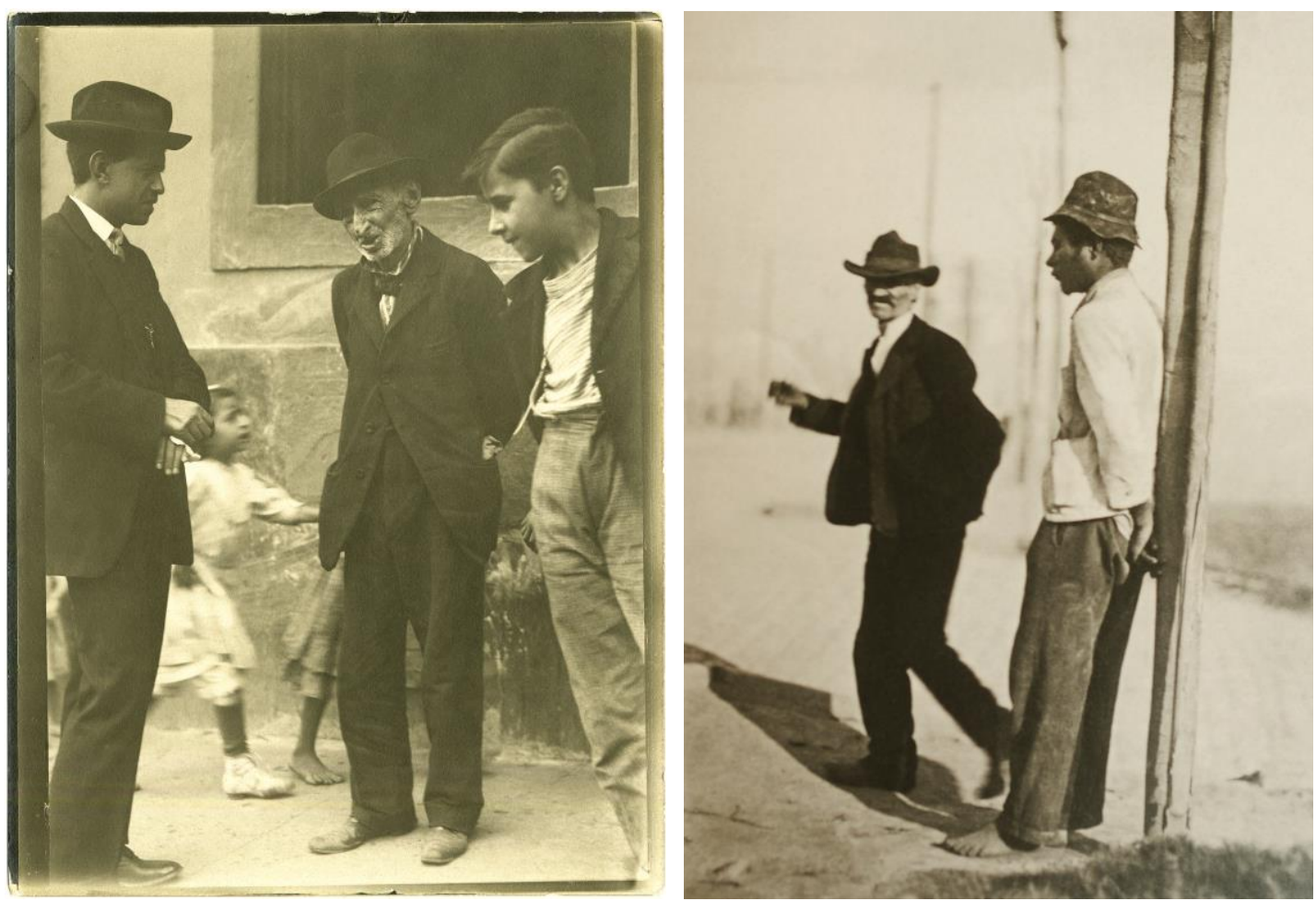

Figura 142 e 143: à esquerda "Grupo de Pessoas na Calçada"; à direita, "Retrato de dois homens, um apoiado em poste e outro caminhando". Documentação feita próximo ao Mercado dos Caipiras. Segundo descrição do Instituto a foto provavelmente realizada na região da várzea do Carmo, em processo de urbanização, que aparece em outras imagens no conjunto. 1910 @ Vincenzo Pastore/Instituto Moreira Salles.

O fotógrafo escolheu aparatos mecânicos mais ágeis em captar gestos e ações corriqueiras, dado aos novos condicionantes técnicos de negativos mais sensíveis, com seus aparatos mecânicos mais ágeis. Seu olhar fotográfico afirmava uma prática autônoma, independente de padrões visuais recorrentes na representação de cenas urbanas. É preciso dar foco para a seguinte hipótese: parece claro que as escolhas formais do fotógrafo apontam para uma prática de experimentação de técnicas e procedimentos, orientados inclusive por teóricos da fotografia italiana. Aproximar as fotos de Pastore dos discursos reproduzidos no período orienta a análise para a economia visual que marca as tensões da fotografia de virada de século.

Em 1904, a revista "La Fotografia Artistica", defendia o novo gênero que surgia: a instantaneidade na fotografia, como uma nova forma de análise e de visualização do real. $\mathrm{Na}$ sua edição de dezembro daquele ano, tentou pontuar esta prerrogativa: “A pintura não está pronta a captar e fixar o desenho em um minuto; o artista fotógrafo, ao contrário, pode fixá-la 
para sempre na sua leve chapa instantânea". ${ }^{233}$ Se de modo geral a técnica que popularizava a fotografia foi criticada pelo movimento, no contexto italiano, surgia num ambiente de maior aceitação.

Para Zannier (1985), aos fotógrafos da península foi sugerido experimentar as possibilidades da foto instantânea. Foi esse um dos caminhos de afirmação de uma singularidade da fotografia. Essa nova capacidade expressiva da imagem surgia no recorte de Pastore, que não hesitava em propor enquadramentos diferenciados, tampouco em incorrer em novas linguagens, levando para as ruas o efeito flou que experimentava no estúdio.

Andre Rouillé pontuou uma distinção entre "instantâneos e poses", menos devido às evoluções técnicas, que possibilitavam maior rapidez na tomada do registro, do que uma ruptura na busca pela representação do movimento que promovia uma prática fotográfica de outra natureza: de um lado a pose, do outro os novos cortes fotográficos propostos. Se a pose remetia às convenções do retrato, o olhar para novos recortes procede de uma análise, afirma o autor. No cerne de tais questões lançadas desde 1880, estava em jogo uma nova "possibilidade de percorrer o espaço-tempo para ai cortar, extrair, subtrair imagens" (2009, p.228). Acreditamos que Pastore em suas incursões pelas ruas da capital, posicionou-se desafiando a configuração de um novo espaço fotográfico, um novo ato fotográfico proposto no instante do corte espacial eleito.

Philippe Dubois sugeriu uma conceituação vinculada à noção do espaço na fotografia, delimitado visceralmente pelo corte, uma subtração realizada pelo fotógrafo, que tem seu ato assim descrito:

O espaço fotográfico não e determinado, assim como não se constrói. Ao contrário, é um espaço que deve ser capturado (ou deixado de lado), um levantamento no mundo, uma subtração que opera em bloco. (...) Seu gesto consiste antes em subtrair de uma vez todo um espaço "pleno", já cheio de um contínuo. Para ele a questão do espaço não é colocar dentro, mas arrancar tudo de uma vez. (...) Em outras palavras, bem aquém de qualquer intenção ou de qualquer efeito de composição, em primeiro lugar o fotógrafo sempre recorta, separa, inicia o visível. (Dubois, 1993, p. 178)

Deste modo, entendemos o ato fotográfico inicial de Pastore, ou seja, o instante do corte, da captação, da escolha como um gesto altamente transformador. Não só recusava a pose convencional, a encenação, como intervinha na própria forma corporal representada: os

\footnotetext{
${ }^{233}$ La Fotografia Artistica. Ano I, n. 1. Dezembro de 1904. In: Zannier, 1985, p. 267. O autor pontuou de modo preciso como a fotografia instantânea potencializou o surgimento da fotojornalismo, da foto publicidade e, em última instância, o próprio desenvolvimento do cinema após 1930.
} 
corpos aparecem desarticulados, retratados parcialmente, em fotos que se revestiam de tomadas em flagrantes. Pastore "arrancava" sua cena-objeto propondo um visível inédito, oposto da visualidade que circulava na época.

Se o espaço fotográfico para Dubois é "literalmente talhado de uma vez e ao vivo", Rouillé (2009) submete tal gesto a uma escolha. Os cortes dos instantâneos mostram Pastore analisando os movimentos dos caminhantes vistos no segundo plano fotográfico (fig. 142). Pose, contenção, domínio de cena se diluem. Corpos são fragmentados. Vê-se na foto uma nova atitude que delineia uma dimensão experimental, expressão de uma proposta fotográfica desafiando as possibilidades do retrato que ora ocultava, ora revelava os sujeitos em cena.

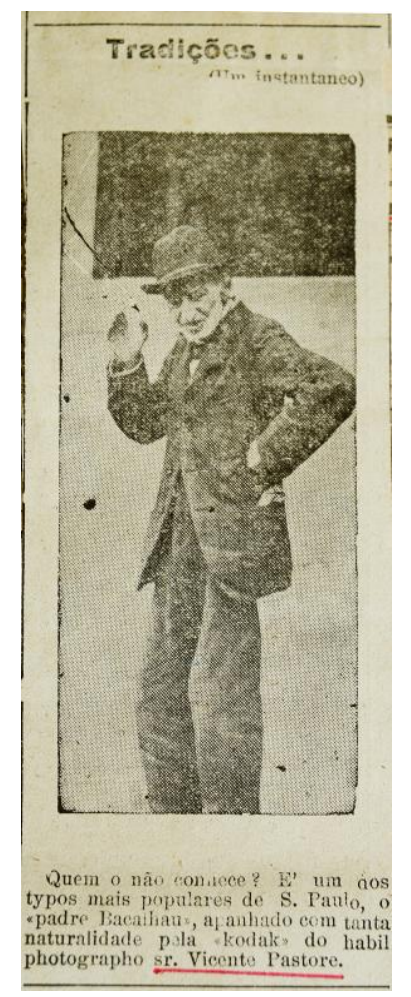

\section{Figura 144:}

Recorte de jornal. Caderno de Recortes. Coleção Dante Pastore.

Tratamos do registro do padre Bacalhau feito nas ruas da cidade, foto que integra a coleção do fotógrafo no Instituto Moreira Salles. Mas há um segundo registro do dito padre, talvez tomado no mesmo dia, publicado em jornal e integra, por sua vez, o caderno de recortes feito por Elvira (fig.144). Há algo a ser pontuado. Essa imagem publicada difere de modo evidente da foto sob a guarda do IMS, desvelando como as fotos da coleção apresentam aspectos formais não apreciados no período. A opção da revista se deu por outro recorte. A nota intitulada "Tradições... Um instantâneo" perguntava: "Quem não o conhece? É um dos 
typos mais populares de S. Paulo, o 'padre Bacalhau', apanhado com tanta naturalidade pela Kodak do hábil photographo sr. Vicente Pastore". ${ }^{234}$

As câmeras portáteis seduziam também os fotógrafos profissionais. A cultura Kodak promoveu uma crescente demanda também no Brasil, disseminando a prática das hand cameras. ${ }^{235}$ Se por um lado não se sabe ao certo a marca da câmera usada na realização da coleção do IMS, vê-se, por outro, como Pastore flertou com as técnicas da foto instantânea. Nota-se como a escolha da foto para a publicação seguiu as convenções do retrato deixando, contudo, os pés do padre recortados, talvez assim já captados pelo fotógrafo, que experimentava novas linguagens e aparatos mecânicos; Indicia-se ainda como Pastore, apesar de dominar técnicas aprimoradas da fotografia, talvez não deixasse de transitar entre as novas técnicas empregadas, valendo-se de aparatos instrumentais que atendiam ao universo amador, mas que estimulavam os fotógrafos profissionais a se engajarem nas práticas de uma linguagem diferente, remetendo a espontaneidade da foto instantânea. Vê-se também a intenção do veículo em sugerir que imagens captadas com a tecnologia moderna eram veiculadas pelo jornal.

Em outro registro, Pastore trazia para o primeiro plano (fig. 143) a presença de homem negro, de pés descalços, usando chapéu de coco. Ao ser retratado encostado em um poste emprestou, por meio deste gesto, uma interessante observação à analise de Frehse (2011, p.489). Ao tratar de um conjunto fotográfico que julgou pertinente para se compreender a rua como um advento da modernidade, a autora tomou as fotos de Pastore como representação construída sob a configuração de uma nova "técnica corporal". Nessa perspectiva, os

\footnotetext{
${ }^{234}$ Coleção Dante Pastore. Caderno de recortes, p. 18.

${ }^{235}$ A cultura Kodak tornou possível, aos fotógrafos, circularem de forma independente pelas ruas, clubes, festas, eventos, registrando o que pudesse surgir nos novos circuitos da imagem, promovendo uma "invasão de privacidade". Os fotógrafos passavam a ter um olhar investigativo munidos de "hand cameras". Ver Widegoder, Meir. Paul Strand's New York Portraits. Private Eye - Public Space. History of photography, v. 27, n. 4, winter. 2003, pp. 349-361. Segundo Pereira, foram criadas leis nos Estados Unidos e Alemanha para regulamentar a prática fotográfica. Alem disso, o amplo sucesso da comercialização das câmeras no Brasil, ocorreu sem propagandas desses produtos, o que não inviabilizou uma forte distribuição do produto. (Ver Pereira, 2010, p. 59). Com a invenção da Kodak, em 1888, cem fotografias podiam ser tiradas de uma só vez. A máquina já trazia acoplado o rolo de filme, enviado e revelado em Rochester, nos Estados Unidos. (Ver Chalfen, Richard. Snapshot versions of life. Ohio: Bowling Green State University Popular Press, 1987). A técnica do instantâneo alcançou um barateamento ainda maior e uso ainda mais simplificado com a criação da Pocket Kodak, à disposição de fotógrafos profissionais e amadores, ao custo de 5 dólares. A câmera Brownie, direcionada para crianças, era vendida em 1900 por 1 dólar. O modelo mais popularizado foi, sem dúvida, o Folding Pocket, com as lentes ligadas ao corpo da câmera, quando fechado, tornava-se um estojo com alça disponível. "Take a kodak with you", popularizava-se na década de 1910. Ver Pereira, Adriana Maria Pinheiro Martins. A Cultura Amadora na virada do século XIX: a fotografia de Alberto Sampaio (Petrópolis/ Rio de janeiro, 1888-1914). Doutorado. FFLCH-USP. 2010.
} 
retratados persistem e se acomodam, apropriando-se das ruas de modo inovador: não estavam apenas de passagem, pontuou Frehse. Havia na composição de Pastore para a autora a "permanência física" sucessivamente reiterada nos diferentes registros. Os sujeitos sociais retratados encostavam-se em cavaletes, apoiavam-se nos postes de luz elétrica, "deixam-se ficar; não transitam" apenas.

Se hoje o intérprete toma tais imagens como fonte para se pensar a cidade, são representações de práticas sociais ainda pouco documentadas. O fotógrafo se aproximou daqueles que estiveram à espera de algum serviço. Carregar ou descarregar a mercadoria de alguma carroça era serviço prestado por muitos homens negros que se deixavam ficar próximos dos mercados de abastecimento.

As diferentes faces paulistanas enredavam-se na narrativa visual voltada para um extrato da população que não tinha lugar certo na economia, submetida a práticas itinerantes, "sem habitação específica, ligados a ofícios flutuantes, sem lugar fixo de trabalho" (PINTO, 1994, p. 151). A espera de um serviço temporário podia ser interrompida quando a prefeitura implementava obras de reparos, como a que ocorreu na avenida Lins de Vasconcellos. Foi preciso "organizar uma turma de trabalhadores e carroças", ${ }^{236}$ para a execução da obra. Fazer parte da "turma" improvisada podia ser um alento, interrompendo a prontidão e a expectativa de uma oferta inesperada de trabalho.
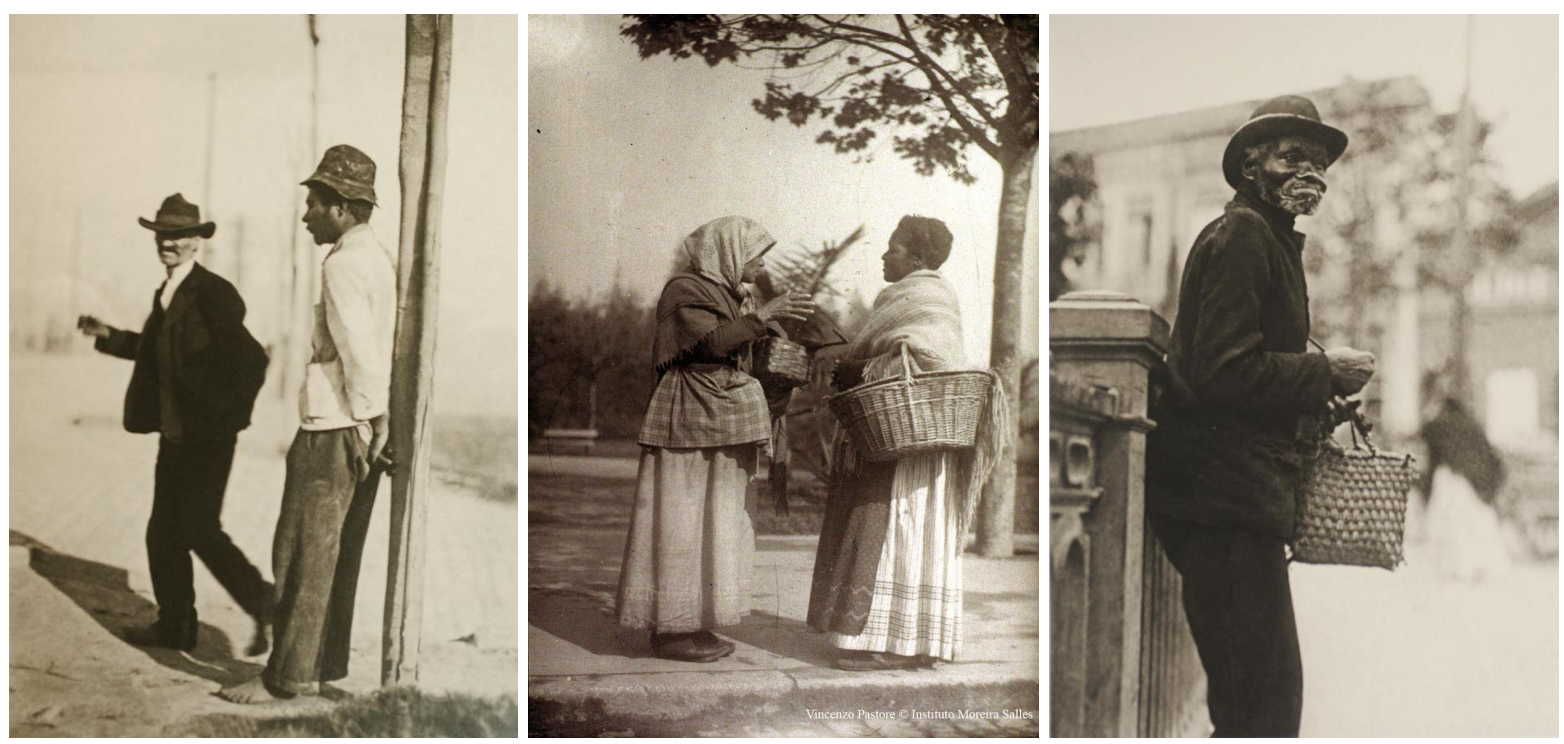

Figuras 143, 133 e 137: à esquerda "Retrato de dois homens, um apoiado em poste e outro caminhando"; ao centro "Duas mulheres conversando" e à direita "Retrato de homem idoso recostado em grade metálica da Rua São João". 1910 @ V Vincenzo Pastore/Instituto Moreira Salles.

${ }^{236}$ Arquivo Histórico municipal de São Paulo. Conselho de Vereadores. Caixa 48. 20 de março de 1909. 
É clara a tentativa de Pastore em prolongar nessa imagem o plano de fundo, numa tomada em perspectiva acentuada (fig.143). Pastore deu intensidade à sombra projetada na foto. Mas ela enuncia algo mais, sobretudo, quando aproximamos este registro de outros que também integram a coleção. Nessa composição, Pastore não quis detalhes de construções ao fundo; o efeito nevoado eliminou a definição de contornos dos postes instalados. Vê-se a insistência de uma atribuição proposta pelo movimento pictorialista, em sua recusa pelos símbolos da modernidade. Os pictorialistas, segundo Rouillé (2009), desviavam-se deles.

Outra foto ajuda a indiciar certas práticas de Pastore. Na imagem ao centro, quando as folhas ao fundo perdem seus contornos e detalhes, Pastore nos lembra uma das acepções de um dos maiores influenciadores do movimento. Henry Peach Robinson, nos anos de 1860, quando o movimento ainda não apresentava uma organização que lhe desse unicidade e uniformidade, afirmava que era preciso corrigir "a naturalidade excessiva da natureza" (Mello,1998, p.28).

Delineia-se o traço de uma especificidade em Pastore, que ao sair às ruas, dava continuidade às tentativas de obter em seus retratos os elementos de composição das imagens que construía em seu ateliê: massas, linhas, tons, formas, luz, sombras, compõem a retórica visual do pictorialismo, experimentada pelo fotógrafo. Foram estes pressupostos reativados inclusive nas diretrizes do movimento no Brasil, que firmava lugar nessa economia visual que envolvia nosso Pastore. A partir de 1910, tais concepções passaram a ser divulgadas pelo Photo Club do Rio de Janeiro. A escolha dos temas foi apontada por Mello: "paisagens, marinhas, cenas de nu, cenas de gênero, naturezas-mortas, retratos, etc" (1998, p.69).

$\mathrm{O}$ movimento pictorialista no Brasil está diretamente associado à criação dos fotoclubes. ${ }^{237}$ A fundação do Photo Club do Rio de Janeiro, no ano de 1910 foi segundo Mello (1998), o marco inicial do movimento no Brasil. Em 1916, em Porto Alegre, com a fundação do Photo Club Hélios, o movimento pictorialista passou a ser divulgado ao sul do país. Em julho de 1923, associando-se ao Photo Club do Rio de Janeiro, surgiu o Photo Club

\footnotetext{
237 O fotoclubismo, com seu percurso ainda pouco documentado, iria desembocar de modo mais organizado nas décadas anteriormente citadas no Rio de Janeiro e, numa segunda fase, em São Paulo, nos anos de 1945 a 1960. Associações que nasceram vinculadas a prática pictórica, presente inclusive, nas revistas ilustradas, diferentemente da Europa, onde a prática estava intrinsecamente ligada à foto-amadora e aos fotoclubes. A abrangência do tema surpreende. Naturezas - mortas, marinhas, paisagens, retratos, cenas de gênero e arquitetura, frutas, flores, luar, efeitos do sol, reflexos d'água, sombras, cenas domésticas, fotos de pessoas idosas, interiores de igrejas, estudos de mãos e nus, compunham um amplo repertório do pictorialismo no Brasil, nas décadas de 1920 e 1930, período em que o movimento foi sistematizado no país pela prática do fotoclubismo In: COSTA. Helouise. Pictorialismo e imprensa. In: Fabris. 2008, p. 265.
} 
Brasileiro, reunindo o nome de muitos fotógrafos engajados nacionalmente no movimento. ${ }^{238}$ Por meio desses espaços, o pictorialismo no Brasil, seguiu organizando-se até 1940, propondo, segundo Mello, muitas conversas em torno das relações entre arte e fotografia. $\mathrm{O}$ estilo pessoal do autor foi sublinhado pelos fotógrafos brasileiros pictorialistas como a principal característica de uma obra de arte feita também fotograficamente:

É o estilo que permite ao artista exprimir seu sentimento, sua personalidade, sua individualidade. Se a fotografia não trouxer a marca do artista, não será uma fotografia artística. Neste sentido não é a originalidade do assunto que confere valor à obra. $\mathrm{O}$ mérito reside principalmente no modo pelo qual o artista experimenta e interpreta o tema. (Mello, 1998, p. 69)

Para Ângela Magalhães e Nadja F. Peregrino houve uma reciprocidade temática entre a produção fotográfica realizada no Photo Club Brasileiro e aquela que orientava os pintores acadêmicos. Composições realistas, de conteúdo social, retratando costumes e tipos raciais formam o panorama temático compartilhado pela pintura, que emprestava da sintaxe fotográfica os elementos de composição que remetiam à foto instantânea; na fotografia acenavam os cânones da pintura, que se renovava em outras práticas. Desenha-se uma interessante economia visual que difundia certos preceitos fotográficos:

Sob a perspectiva de uma analise mais restrita, vemos que os modelos estéticos adotados pelo Photo Club Brasileiro, aproximam-se dos padrões figurativos da Escola Nacional de Belas Artes. Cenas de gênero, de costumes e cenas pitorescas distribuem-se entre a produção dos foto-clubistas a partir de áreas temáticas comuns aos pintores brasileiros. (Magalhães e Peregrino. 2004, p. 37-38).

Outro aspecto deve ser mencionado: o procedimento técnico escolhido. Essas três tomadas apresentam um plano de fundo desfocado. Opção para dar relevo aos retratados em primeiro plano, destacando suas vestimentas, os contornos dos corpos, num jogo de claro e escuro, de luz e sombra projetadas ao chão, em efeitos de muito contraste de luz.

Dos corpos retratados Pastore propôs novas formas figurativas, afinal, sombras projetadas seriam bastante exploradas poucas décadas depois como elemento de composição pictural. Acreditamos ver o fotógrafo realizando fotografias não desprovidas de sentido estético, ou seja, fora do estúdio o fotógrafo criou efeitos valendo-se de recursos propriamente

238 Exposições coletivas, cursos teóricos e práticos, palestras sobre questões estéticas e técnicas, excursões fotográficas e a realização dos primeiros salões de fotografia no país, formam, de modo consistente, a atuação dos sócios envolvidos no Photo Club Brasileiro, que ainda reforçavam os vínculos com os fotoclubes estrangeiros. Cf. Mello, 1998, p. 70. 
fotográficos, tendo em mente possivelmente as referências conceituais de uma proposta fotográfica que não queria se mostrar alheio.

A não nitidez absoluta de todo enquadramento fotográfico coloca Pastore em diálogo com um campo marcado por divergentes posições quanto aos procedimentos fotográficos. Rouillé (2009) mostrou a existência de escolhas estéticas antagônicas, opondo os adeptos da nitidez àqueles em defesa do efeito flou. Pastore saiu em defesa deste último, até mesmo escrevendo, como vimos no capítulo dois. Tais procedimentos divergentes também dividiam os fotógrafos pictorialistas no Brasil, afirma Mello (1998).

$\mathrm{O}$ artigo assinado por VP mostra como o seu pensamento confluiu para uma fotografia interpretativa. Vê-se como muitos experimentos foram realizados por fotógrafos também profissionais, não ligados ao movimento fotoclubista, como fez Pastore que não teve uma ligação em associações ou foto-clube documentada. Giulia Zanini (2013), sobre o fotopictorialismo na Itália, mostrou como o movimento se desenvolveu nesse país, a partir de 1892, ligado aos experimentos de fotógrafos amadores, que se dedicavam à fotografia no tempo livre, tendo capacidade de investimentos em experimentos de maior custo, já que eram oriundos de grupos mais abastados: comerciantes, magistrais, industriais e engenheiros. Estiveram livres também das exigências de uma clientela em busca de fotos mais convencionais, como as típicas fotos posadas em estúdio. Apesar dos fotógrafos profissionais não contarem com tais benesses, não deixaram de participar das inovadoras técnicas de experimentação. 239

O relato escrito deixado por Pastore indicia como nosso fotógrafo era um leitor de textos e artigos de autores italianos, que circulavam e difundiam as teorias fundantes do movimento na Itália, que também opunha duas diferentes práticas, o fluismo e o nitismo, lembrando que esses são termos historicamente datados, pertinentes ao debate em torno da fotografia.

\footnotetext{
239 Giulia Zanini, em sua tese de doutorado, analisou o desenvolvimento da foto pictorialismo no contexto italiano, tendo como fonte principal, a importante revista ilustrada, de difusão das teorias e das principais concepções nacionais e internacionais do movimento: a chamada "La Fotografia Artistica", editada mensalmente, redigida em italiano e, também, na língua francesa. A primeira edição foi publicada em janeiro de 1904, sendo a última em fevereiro de 1917. Textos escritos por colaboradores de toda Europa e fotos pictóricas eram impressos nesta revista que apresentava um formato de $33 \times 24 \mathrm{~cm}$. Artigos sobre questões técnicas da representação fotográfica foram também veiculados. Cf. Zanini, Giulia. La rivista "La Fotografia Artistica" e il pittorialismo in Italia. Tese de doutorado em Economia e Gestão de Artes e de Atividades Culturais da Università Ca'Foscare Venezia. Ano Acadêmico 2013/2014. Tradução Nossa.
} 
O fotógrafo afirmou que a qualidade de uma foto não "consiste somente na nitidez com que aparecem as menores particularidades, se olha, ao invés do lado artístico"; expressou sua crítica contra "a fidelidade com a qual a objetiva reproduz cada detalhe". Usando a palavra, Pastore demarcou sua filiação contra a noção da foto como "cópia fiel, servil do real", na defesa daquilo que chamou de uma "nova escola" proposta por Thovez, crítico de arte italiano. Segundo os pressupostos dessa escola, Pastore considerava o nitismo "como negação da verdadeira arte, incompatível com a própria natureza, com o olho humano ao qual os objetos distantes, apresentam-se sempre com uma clareza menos distinta daquela dos objetos próximos", afirmou Pastore. ${ }^{240}$

Foram estas as concepções defendidas por Henry P. Emerson, marcantes no contexto italiano, assim explicadas no estudo de Zanini:

O pesquisador evidenciou como o olho humano não vê tudo que lhe oferece a visão: quando ele dá foco em determinados elementos, outros consequentemente aparecem desfocados; isso deve ocorrer no processo fotográfico, e é isso que dá a imagem seu caráter emocional, caráter fundamental, pois uma fotografia pode ser definida como arte. (Zanini, 2013, p. 32. Tradução Nossa).

As três fotografias (figuras 143, 133 e 137) indiciam uma prática fotográfica que se opunha a automaticidade do resultado. Não se tem contornos com linhas precisas ao fundo. A foto ao centro, mesmo tomada a favor da luz, indica uma interferência ao fundo, tendendo à direita ao branco mais excessivo. Destacou-se assim, a presença da mulher negra, posicionada em primeiro plano. Tal efeito indicia uma manipulação para dar relevo ao perfil dessa senhora retratada. Em oposição, no mesmo plano de fundo, à esquerda, prevaleceram tons de cinzas, que ajudaram a delimitar de modo diferenciado as linhas de contorno do corpo da outra vendeira. Esses resultados visuais desvelam um fotógrafo que não queria obter uma fidelidade no registro da realidade que representava. Em sua interpretação, atuava como um intermediário entre o tema/objeto e o medium, postura que define, segundo Mello (1998), a prática dos artistas-fotógrafos que afirmavam o caráter artístico da fotografia.

Quando encontramos Pastore citando Thovez, que defendia a livre interpretação do artista-fotógrafo, despontam indícios das convenções que formaram o fotógrafo, um possível leitor de textos em defesa da expressão e da poesia da arte fotográfica. Thovez posicionava-se contra aquilo que mencionava como a cegueira de muitos fotógrafos:

${ }^{240}$ Cf. artigo Fotografia ed Arte. Caderno de Recortes. Coleção Dante Pastore. 
Muitos fotógrafos estão cegos pelo critério vulgar de que a perfeição resida na definição das linhas, na precisão dos detalhes, escolheram a realidade mais fortemente iluminada, conseguindo por meio da nitidez suprimir o céu, as nuvens, a vaporosidade dos planos distantes e, com eles, aquela poesia que por acaso encontrava-se ali. Ai daquele que não tem todos os planos no foco! Ai daqueles que ultrapassam o tempo de pose! ${ }^{241}$

Em muitas imagens da coleção encontramos Pastore defendendo uma fotografia menos escrava da realidade, como propunha Thovez.

Não pode haver, portanto, fotografia poética senão aquelas feitas por poetas. A escolha, foi dito, é quase uma invenção. E nessa arte, da qual está excluída qualquer possibilidade de técnica virtuosa, a escolha é tudo: nela deve revelar-se toda a personalidade do autor, sua sensibilidade artística e sentimental. (Thovez. 1898. Apud. Zannier, 1985, p.280)

É nítida em Pastore a tentativa de distinção entre percepção e realidade, prerrogativa central no pensamento de Thovez, o qual, segundo Marina Miraglia (2011, p.78), claramente afirmava "não se pode colocar foco simultaneamente no que está próximo e distante".

Pastore, em seu artigo, apresentava-se como um conhecedor do artifício que muito agradava aos pictorialistas: o soft-focus, usado desde meados do século XIX. Essas escolhas revelam atitudes contra uma noção de fotografia estritamente documentária, em defesa de uma representação autoral, sem renegar o realismo representativo. Superar o "vinculo mecânico do meio", argumento central em Thovez, foram gestos que colocaram a fotografia num “contínuo laboratório de pesquisas de seus próprios limites", afirma Miraglia.

\begin{abstract}
A fotografia pictorialista contradizia a onipotência da máquina e a mecanicidade da imagem, a qual explorava conseqüências em direção opostas, ou seja, orientando a atenção aos valores estéticos da fotografia, em uma implícita reversão da relação entre técnica e elemento lingüístico, capaz de determinar a estrutura da imagem. (Miraglia, 2011, p. 80. Tradução Nossa)
\end{abstract}

O fotógrafo saia às ruas, embebido de referências mais antigas, já postuladas desde meados do século XIX, quando a fotografia artística já apresentava procedimentos técnicos e efeitos estéticos para afirmar o primado da independência do fotógrafo frente à mecanicidade da foto. Rouillé pontuou as orientações que se atualizavam no auge do movimento pictorialista, entre os anos de 1890 a 1920, herdeiro de uma "uma corrente radical da arte

\footnotetext{
${ }^{241}$ Ver sessão de Obras Raras na Biblioteca Nacional de Roma. Enrico Thovez. L'Arte all'esposizione del 1898. N. 9, pp.67-70. In: Zannier, 1985, p.280. Na Biblioteca Nacional de Roma consta este manual escrito por Thovez. Tradução Nossa.
} 
fotográfica" manifestada deste os anos de 1850, com Paul Périer, um dos vice-presidentes da Sociedade Francesa de Fotografia. (2009, p.249). O autor mencionou algumas orientações estéticas pertinentes ao movimento: com o uso do colótipo ${ }^{242}$, um negativo onde a imagem surge positivada em papel, buscava-se atenuar detalhes das provas. $\mathrm{O}$ fluismo expressa uma busca de resultados em oposição à nitidez dos produtos industriais. Foram essas as novas práticas e idealizações que levaram os fotógrafos a realizar tomadas ao ar livre, em estudos também visuais de árvores, matagais, rochedos, lagos, riachos, constantemente atentos à texturas e efeitos de atmosfera, propostos em registros definidos como céus tempestuosos, neve, elegendo-se formas abstratas e forte contraste de luz e sombras.

Mas Pastore dialogava, de modo mais específico, com as referências da fotografia italiana. Desde a Exposição de Turim, realizada em 1898, o país peninsular já apresentou a fotografia artística separadamente daquelas classificadas como técnicas e científicas. Em 1899 foi realizada a Exposição Nacional e Internacional de Firenze, associada também ao II Congresso Fotográfico que deu continuidade aos debates desenvolvidos no ano precedente em Turim. Segundo Zanini, (2013) nomes de fotógrafos nacionais envolvidos nas propostas da fotografia artística foram nesse momento divulgados, sob a proposta da criação de uma cultura fotográfica italiana, bem como a criação de uma escola fotográfica para ser aberta em Firenze, o centro da cultura artística italiana, depois dividindo com Turim tal posto. A fotografia artística seria depois consagrada nessa cidade pela Exposição Internacional de Arte Decorativa e Moderna de 1902.

Zanini, em sua pesquisa de doutorado, apontou o ambiente tensionado entre fotógrafos amadores e profissionais no contexto italiano:

Associa-se a esse problema, aquele ligado à figura do fotógrafo profissional, que se sente ameaçado pelo desenvolvimento da fotografia amadora. Por isso, propõe-se a instituição de uma confederação nacional de fotógrafos profissionais que tenham como objetivo proteger e qualificar a obra fotográfica artística e seu perfil econômico e moral. Debate-se ainda sobre os temas de natureza jurídica e, portanto, sobre a definição de autor e de obra artística no Direito; o termo autor é substituído pelo de produtor, entendido como "aquele que tem direito de chamar de sua a produção fotográfica, pois saiu de sua empresa, e é obra de sua pessoa ou de seu pessoal, ou foi feita sob sua direção com os meios por ele fornecidos". Trata-se de uma temática reservada ao profissionalismo, que tende a proteger as obras por ele produzidas contra o fenômeno da fotografia amadora que está tendo grande sucesso. (Zanini, 2013, p.34. Tradução Nossa)

\footnotetext{
242 Procedimento criado por William Henry Fox Talbot no ano de 1841, tratando-se de negativo sobre papel.
} 
O jovem crítico italiano, Enrico Thovez, lido em toda Itália e possivelmente citado no artigo assinado por Pastore, tomou lugar nesse debate. Isso se deu de modo mais contundente, quando passou a escrever sua coluna na revista "A arte decorativa moderna", criada em 1902, revista mensal e ilustrada, voltada para a discussão de temas quer de arte e arquitetura, quer de decoração. Mas talvez Pastore, assim como muitos fotógrafos na Itália, conhecesse mais as análises de Thovez sobre a fotografia pictorialista por meio dos dois ensaios mais famosos publicados em 1898, Poesia fotografica e Fotografia pittorica, momento em que Pastore se encontrava em Potenza. Na defesa do valor estético da fotografia Thovez afirmou:

A fotografia pode ser considerada uma arte somente se for como todas as artes, poesia. [...] Toda harmonia de cor, de forma, de pensamento e de sentimento que faz vibrar nossos nervos de comoção agradável é poesia, poesia tão mais alta, quanto mais refinados e educados os sentidos que a percebem. (Scritti d'arte di Enrico Thovez. 1895-1922. Apud Zanini, 2013, p. 37. Tradução Nossa).

Zanini em seu estudo sobre o pictorialismo, no contexto italiano, explicou o quanto Thovez procurou, contudo, diferenciar a arte fotográfica da pintura:

Existem, portanto, características especificamente ligadas à prática fotográfica, que a diferenciam totalmente da pictórica; o branco e preto, ou seja, a supressão da cor, o claro-escuro, a tridimensionalidade, ou seja, a visão unívoca que a lente nos oferece, ao contrário dos olhos humanos que têm uma visão dupla, o efeito desfocado, dado pela possibilidade da lente de ver igualmente nítido, tanto os objetos em primeiro plano quanto os em segundo plano e, última característica fundamental, a possibilidade de escolha. Portanto, essas características nos mostram como a fotografia na realidade esteja menos ligada à reprodução exata da realidade quanto possa parecer em um primeiro olhar. Os fotógrafos amadores podem dar uma interpretação pessoal a essas características, utilizando-as de acordo com sua vontade, para dar sua interpretação da realidade que está diante deles; assim, não se fala mais de reprodução, mas de interpretação. (Zanini, 2013, p. 37. Tradução Nossa)

O fotógrafo, ao retratar um número considerável de pessoas sob uma das antigas pontes da Praça da República, próxima da Avenida Ipiranga, como sugere a identificação do IMS, imprimiu formas abstratas, pouco nítidas como aconselhou Thovez. Pastore ao compor inúmeros reflexos na água, aproximava-se dos atributos recorrentes entre os pictorialistas. A interpretação artística toma o lugar da imitação servil, afinal, o instante da tomada da foto era também um momento para a intervenção do fotógrafo, que imprimiu aqui seu víes interpretativo. Importantes textos haviam circulado definindo desde 1869 a fotografia de expressão, "aquelas que sugerem à mente em um desses dias bonitos (...) quando o sol brilha 
com uma luz branca (...) um dia desses em que para o fotógrafo a sorte ajuda a arte", escreveu Robinson. Pontos claros e escuros produzidos pela forte luz do sol devem ser retratados criando harmonia, ditava esse importante teórico e precursor dos ideais pictorialistas. Ao percorrer os jardins públicos, Pastore deu vista a um dos marcadores das políticas de embelezamento da cidade que buscava cada vez mais ares cosmopolitas.

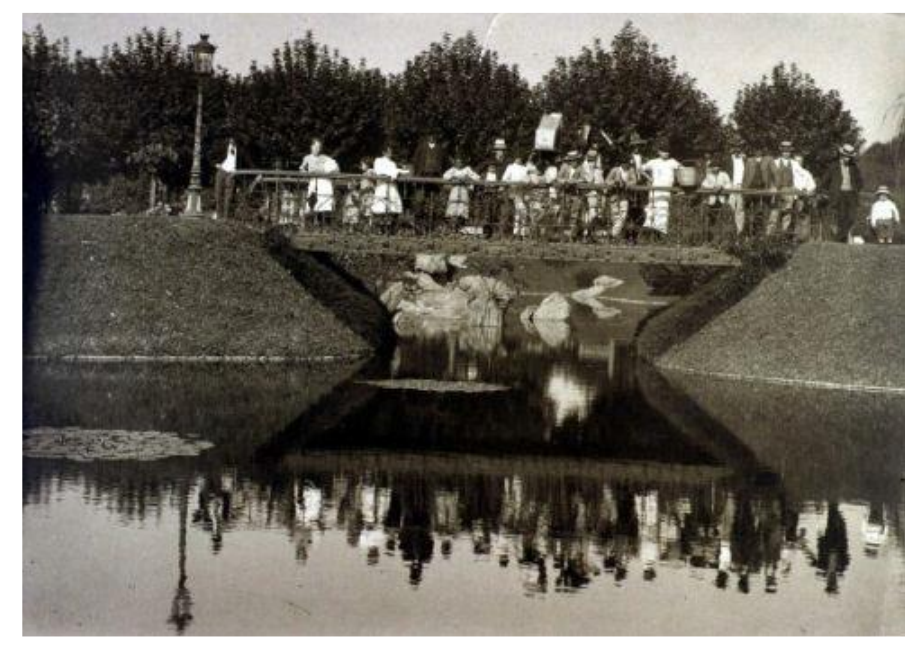

\section{Figura 145:}

"Grupo de pessoas sobre ponte da Praça da República”. 1910 (C) Vincenzo Pastore/Instituto Moreira Salles.

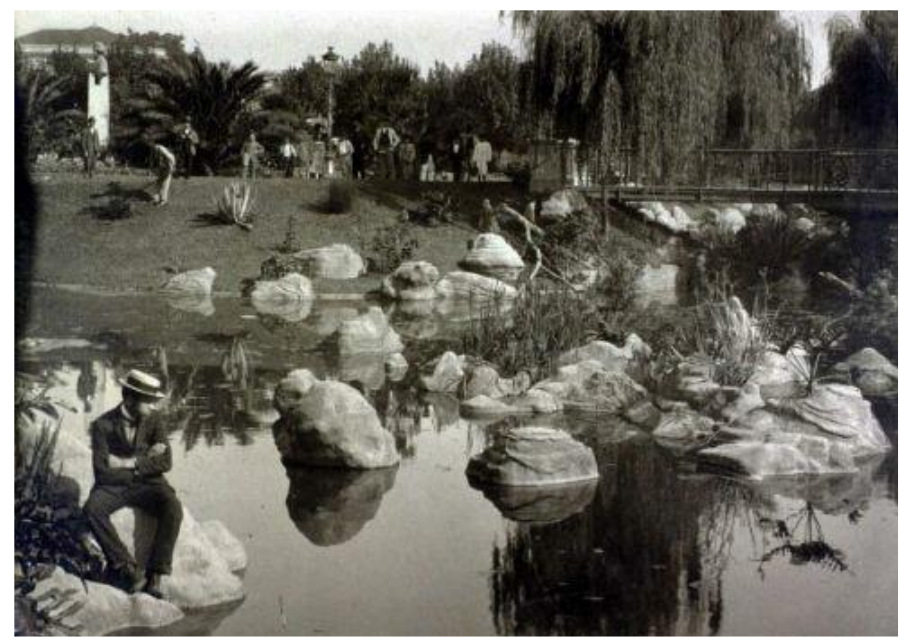

\section{Figura 146:}

"Ponte sobre lago na Praça da República. 1910 ○) Vincenzo Pastore/Instituto Moreira Salles.

Outras tomadas revelam a abrangência da coleção que integra o acervo do IMS. Na seguinte composição (fig.147) vê-se Pastore buscando o céu superexposto, com uma maior intensidade de luz, opondo-se aos rochedos fixados em primeiro plano. A explosão de luz na parte superior da fotografia parece dominar a atenção do fotógrafo para os efeitos de iluminação ali concentrados, pouco se irradiando para os outros planos da foto. A técnica empregada explorava a profusão de detalhes, numa imagem que lembra certos atributos da composição pictórica da qual Pastore parece se filiar: a foto pictural, segundo Rouillé (2009), 
silenciosa, afastada da civilização, composta de árvores nodosas, de anfractuosidades dos rochedos.
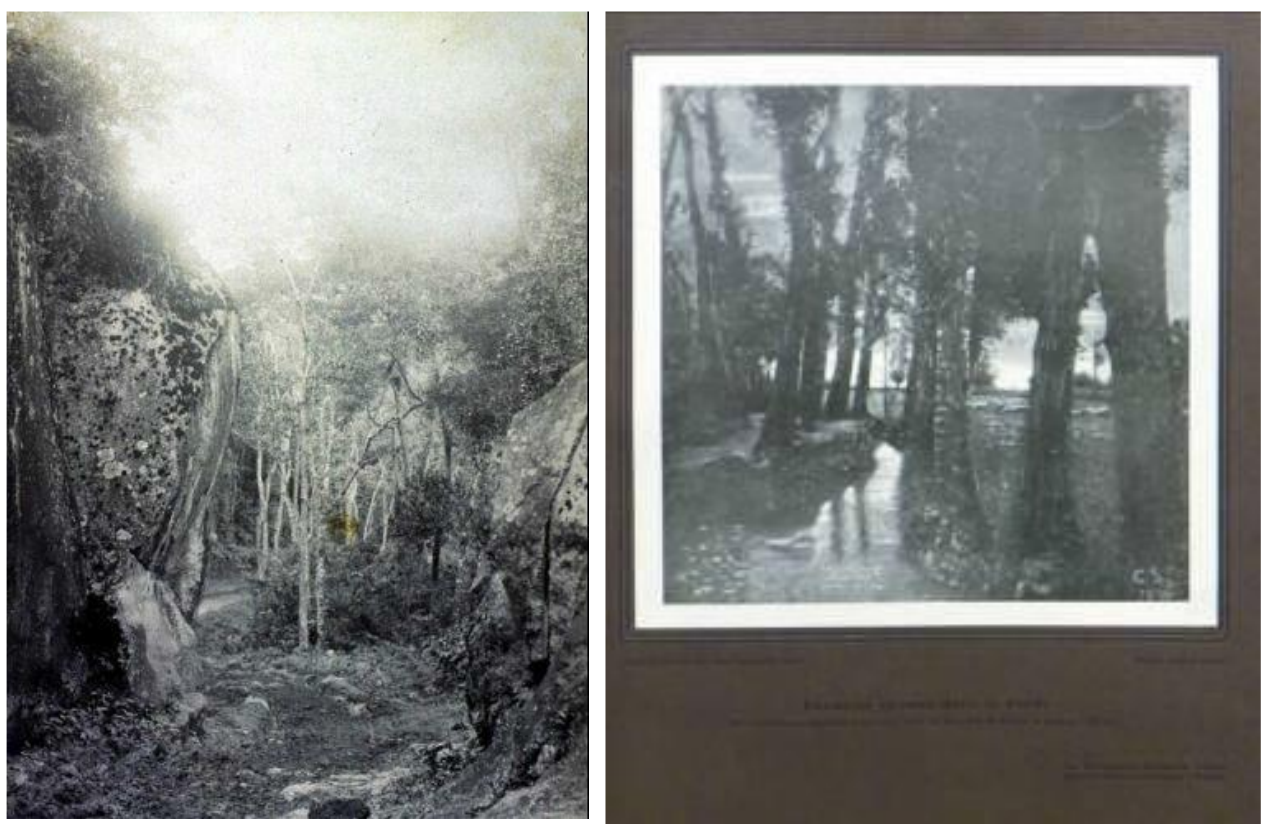

Figuras 147 e 148:

à esquerda "Rochas em meio à mata". 1914 (C) Vincenzo Pastore / IMS; à direita "Tavola fuori texto". 1906 (C) Cesare Schiaparelli. In: Zanini. La rivista "La Fotografia Artistica" e il pittorialismo in Italia. 2003.

$\mathrm{Na}$ parte superior da foto, vê-se uma forte projeção da luz. No restante do campo fotográfico temos a predominância de tons excessivamente acinzentados. Os troncos finos concentrados ao fundo em linhas verticais somadas às oblíquas reforçam tons de branco, com foco menos preciso, quando comparado aos grandes blocos rochosos, talvez granito, revestidos de liquens incrustantes comuns na mata atlântica. Esses elementos deixados em primeiro plano oferecem a sensação de profundidade que Pastore desejou obter ao retratar esta trilha. Quando o fotógrafo realizou esse registro, voltado para aspectos da vegetação rupestre, tentou indiciar os diferentes planos dados em perspectiva, a partir de expressivos efeitos de luz. ${ }^{243}$ Imprime-se aqui traços de um fotógrafo que, também em sua prática fora do estúdio, experimentou os princípios e as concepções pictóricas, como a textura. A imagem realizada por Cesare Schiaparelli (fig.148), conterrâneo e contemporâneo de Pastore, que inclusive assinava artigos publicados na revista "La fotografia Artistica", em uma das edições de 1906,

\footnotetext{
${ }^{243}$ Aparentemente esta vegetação trata-se de uma mata (tipo capoeirão), alterada. Não há lianas, nem parece ocorrer epifetas, por isso pode se tratar, segundo a geógrafa Sueli Furlan, que gentilmente fez uma avaliação dessa imagem, de uma mata semidecidual de planalto, com árvores de troncos finos. No chão vemos um material de decomposição na trilha.
} 
mostra como a prática dos fotógrafos pictorialistas na Itália, reproduzia os temas essenciais aos cânones do movimento. ${ }^{244}$

Independentemente do resultado da prova feita por Pastore, explicitam-se traços do temperamento artístico de Pastore, absorvido pela pretensão da foto como arte. Talvez o fotógrafo estivesse treinando, investindo tempo e trabalho, tempo e fadiga como afirmou Charles Caffin, crítico de arte inglês interessado pelas fotografias pictorialistas. Talvez Pastore estudasse a teoria e depois a colocasse em prática, como faziam os fotógrafos tidos como "avançados", que deveriam, nessa perspectiva, ter antes de tudo, "uma mentalidade aberta”. ${ }^{245}$ É, contudo claro, o quanto Pastore dialogava com a economia visual de seu tempo.

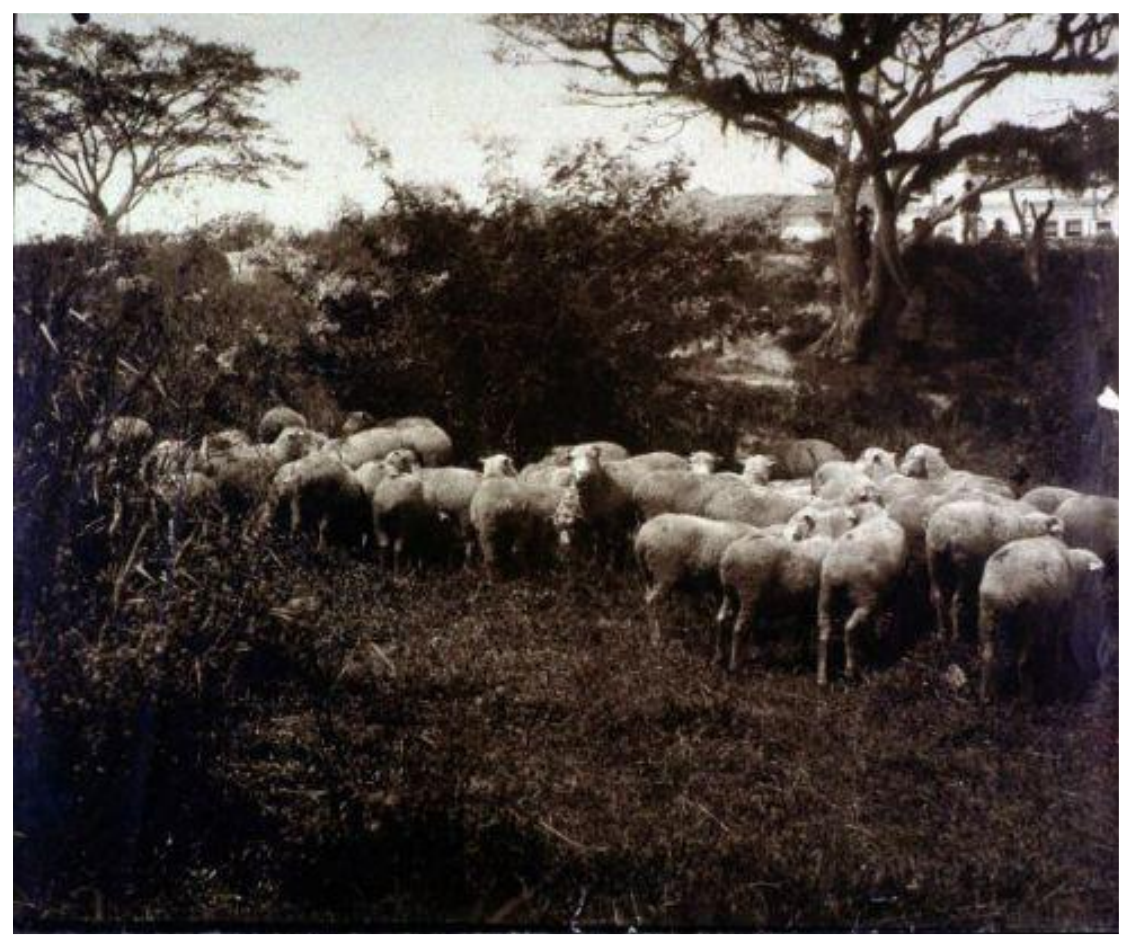

Figuras 149: "Rebanho de ovelhas", nas próximidade da Várzea do Carmo. 1914 @ Vincenzo Pastore / IMS.

A imagem do rebanho de ovelhas e carneiros foi realizada provavelmente na várzea do Carmo, em direção ao Glicério (fig.149), dando a ver uma noção idealizada da natureza, retratada pelos traços bucólicos ainda presentes na região. Idealização proveniente dos aspectos rurais profundamente destacados na abordagem da foto pictorialista.

A preponderância da vegetação em primeiro plano, inscreve aspectos dos arredores da capital desvelando incursões de Pastore em direção da região sudeste da cidade. Ao fundo,

\footnotetext{
${ }^{244}$ A revista não tinha como objetivo fazer frente à pintura. Na primeira edição o editorial afirmava que não esperavam obter um triunfo da fotografia sobre a pintura. Assumiam o papel de um veículo impresso comprometido em ajudar no aperfeiçoamento das práticas fotográficas na Itália. Cf. Zannier, 1995, p. 282. ${ }^{245}$ Cf. Caffin, Charles. La fotografia como una de las bellas artes. 1901. In: Fontcuberta, 2003, p. 90.
} 
além das edificações, pessoas sentadas parecem observar a cena retratada que mostra como Pastore também compôs cenas de paisagens, optando pelas formas difusas do campo retido no espectro do urbano paulistano. Segundo o pesquisador italiano Italo Zannier (1993, p.30), ovelhas pastando, pôr do sol, riacho em contra-luz, marcam o repertório do movimento pictorialista na Itália. Segundo Giulia Zanini, a foto de paisagens, para os pictorialistas italianos, registrava uma experiência vivida pelo sujeito-fotógrafo: “A representação da paisagem não é entendida como uma simples reprodução mecânica da realidade enfrentada, mas é apreciada por sua capacidade de se reproduzir emoções e sentimentos, quando vivenciava a cena" $(2013$, p.59).

Foram essas propostas manifestadas em Pastore que deixou no plano de fundo, à direita, a árvore de galhos tortuosos, tendo incluído outra um pouco menor, à esquerda. Ambas potencializam os efeitos de contrastes, quando justapostas ao céu; contraste como elemento essencial àqueles que se faziam como artistas-fotógrafos.

Uma das normas "obedecidas à risca pelos pictorialistas" era não colocar "o horizonte no meio da prova" e seguir a afirmativa "equilibre a composição", explica Costa (2008, p.272). Pastore seguia a natureza e o gênero da pintura neoclássica, reproduzindo em papel fotográfico a profundidade pitoresca. A reprodução medindo $24,1 \mathrm{~cm}$ x $30,1 \mathrm{~cm}$, em processo químico tido como gelatina/prata, mostra como o fotógrafo levantou a linha do horizonte e conseguiu assim equilibrar a luz e a composição numa única tomada. A dificuldade para resolver esse problema técnico no registro de planos de luz tão diferenciados, foi uma das razões da prática de fotomontagens como explica Pavan (2008, p.251): os fotógrafos realizavam diferentes tomadas para cada plano, montando depois na reprodução em papel a paisagem completa. A chapa de colódio impossibilitava uma mesma tomada de uma paisagem e de um céu. O azul preponderante, segundo Fabris (2011, p.24) também contaminava as outras cores.

Mas não foi a profundidade da paisagem pitoresca, retratando árvores, nuvens ou cenas pastoris, elementos caros aos pictorialistas, que deu corpo à narrativa de Pastore. Sua atenção voltou-se para cenas que desvelam aspectos de um passado escravista, bem como da experiência da imigração, quando muitos aprenderam a sobreviver de suas atividades ambulantes fazendo da via pública seus espaços de ocupação, circulação e sociabilidades, como veremos na interpretação que segue adiante. 


\section{60 cotidiano de trabalho dominando o recorte da narrativa}

Algumas interpelações surgem quando as duas seguintes imagens são contrapostas. Aproximá-las expõe tomadas realizadas em série. O homem retratado isoladamente à esquerda, ajudou também a compor outro plano fotográfico. Essa contraposição de imagens inscreve o desejo do fotógrafo por tomadas múltiplas, cercando uma cena, cercando contingências variadas.

Pastore mais uma vez interrogava as possibilidades do movimento dos corpos (fig. 150). Deixou as moças em primeiro plano invadirem o retrato, propondo recortes que em nada se filiam às imagens publicadas nas revistas ilustradas, onde apenas as moças apareceriam, em cena com aparência de flagrante. Na imagem à esquerda (fig.137) lá estava Pastore próximo do retratado, solicitando um olhar para sua câmera, estreitando contado, talvez treinando a língua nativa, como fazem os viajantes.
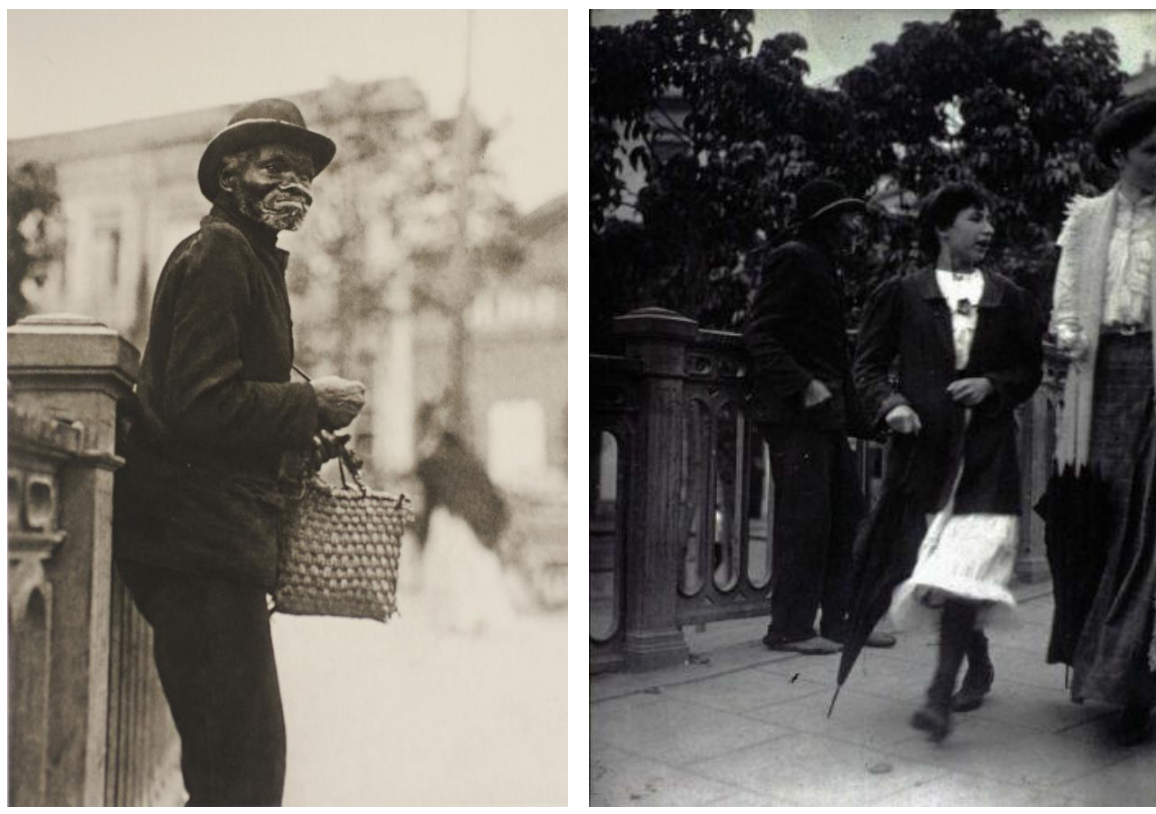

Figura 137 e 150: "Retrato de homem idoso recostado em grade metálica da Rua São João" em frente ao Bijou Salão, à Direita; à esquerda "Duas mulheres passando por homem idoso, apoiado em grade metálica da Rua São João".

Fotografias/Papel. 1910 @ Vincenzo Pastore/Instituto Moreira Salles.

Pastore, em seus experimentos, revelou como não esteve interessado por cenas únicas. Criou mais de um registro diante de uma mesma cena, reforçando o aspecto serial e documental visto na coleção. A fotografia já no século XIX, de acordo com Lugon (2007), "quando se tratava de responder a imperativos documentais, de dar o máximo de informações sobre um tema, uma região, um acontecimento, a tendência natural era multiplicar as tomadas de vista". Quando se tem enunciadas descrições gerais de um acontecimento, detalhes de uma ação, e ainda, permanências de aspectos geográficos ou temáticos, vê-se aspectos que ajudam 
a caracterizar as séries fotográficas, já realizadas antes do século XX afirma Lugon, seguindose aquilo que o autor chama de "princípio de acumulação", inerentes aos usos documentais da imagem.

O fotógrafo revelava fendas sociais. O vendeiro (fig. 137) deixou-se ver e retratar na venda ambulante que enredava homens negros, tão escondidos na historiografia do pósAbolição. A não circulação dessa imagem possivelmente pode ser explicada porque se vê uma configuração de aspectos citadinos que se queriam invisíveis. Desprezavam-se as ocupações que se distanciavam da polarização entre empregador - operário.
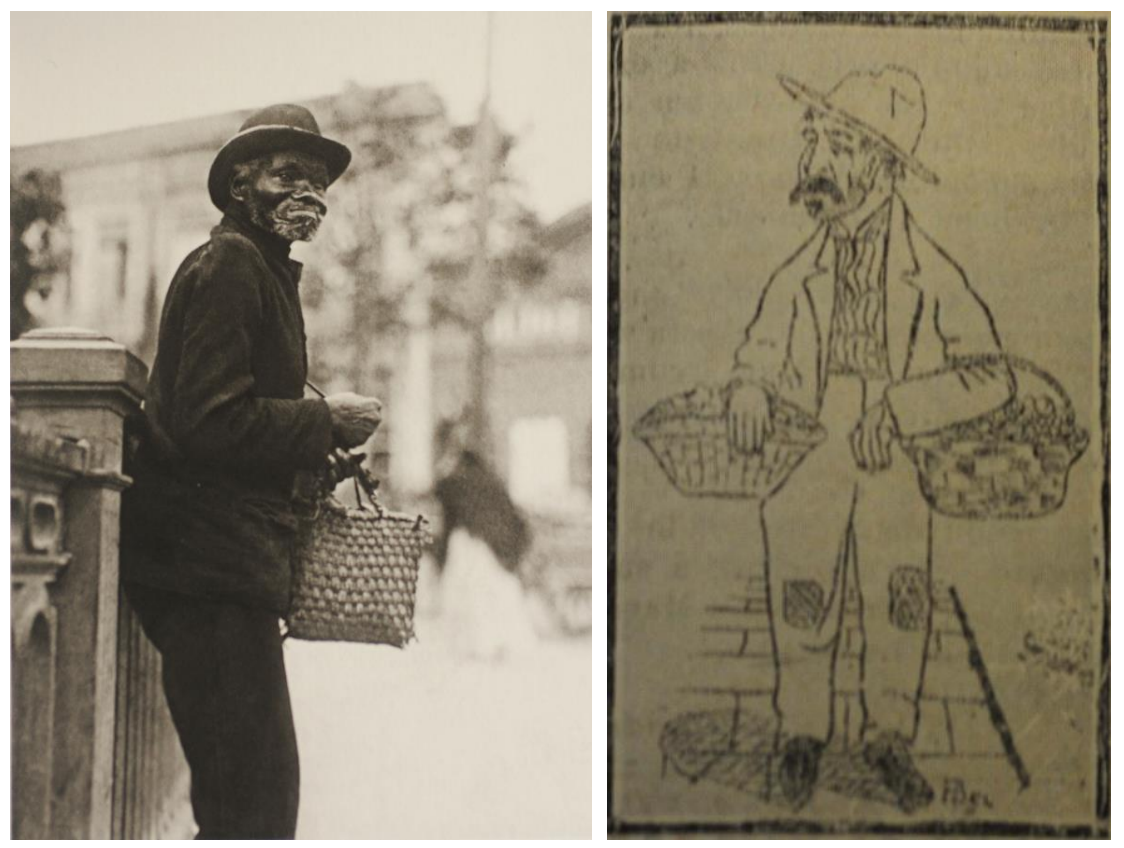

Figura 137 e 151: Reprodução do desenho publicado no Jornal A Capital. 22 de setembro de 1913.

O preconceito étnico racial nas tramas sociais se amalgamava aos princípios desqualificadores do trabalho feito no cotidiano das ruas. Pastore quando se propunha a fazer retratos das personagens citadinas, voltou-se para práticas de uma alteridade renegada socialmente, como sugere o texto que acompanha o desenho publicado no jornal $A$ capital (fig.151). O título "As manchas de São Paulo" também manifesta rastros de preconceito:

Pensam que é o Sr. Wenceslau Braz a vender as verduras do Xico Sales? Não. É uma das vergonhas que se passam em São Paulo. Vendedores de frutas, com enormes cestas, tomando conta da calçada, obrigando as famílias a irem no meio da rua. Quando se acabara com isso, ó Civilização? (Jornal $A$ Capital. 22 de setembro, de 1913)

Desvelam-se visões pejorativas em relação àqueles que viviam do trabalho improvisado, obrigados a enfrentar a recusa de determinados grupos em aceitar as peculiaridades próprias 
do processo de urbanização nacional, onde muitas pessoas mantinham suas experiências sempre em trânsito, em constante mobilidade, empurradas para a infixidez, como bem documentou Dias (2001).

A charge representa o vendedor ambulante reforçando traços acaipirados: chapéu de sol, roupas remendadas, ombros caídos; imagem que pouco expressa a malícia e a sabedoria de produzir e depois andar pelas calçadas e novas ruas repletas de paralelepípedos, onde conseguiam, aqui e ali, um ganho a mais. Desse modo, o desenho publicado em 1913 retoma a descrição dos "caipiras", feita pelo viajante Saint-Hilaire em 1822, revelando a permanência de certas visões sobre os moradores dos bairros distantes que produziam em suas roças e vendiam suas mercadorias nos mercados e ruas da cidade:

Notando-se nos traços de alguns deles os caracteres da raça americana (índios), seu andar é pesado e eles têm um ar rústico e desajeitado. Os citadinos têm pouca consideração por eles, designados pelo injurioso apelido de caipiras que provavelmente se origina da palavra curupira, pela qual os antigos habitantes do país denominavam os demônios malfazejos que habitavam as matas. (Saint Hilaire. Apud Santos, 1998, p. 101)

Segundo o pesquisador Carlos José Ferreira dos Santos (1998), assim como as lavadeiras, os caipiras incomodavam com seu modo de vida os grupos mais abastados. Estes queriam evitar a sua circulação nas ruas e praças remodeladas, submetidas às políticas de embelezamento. Incomodo estendido também à população negra que também fazia das ruas da cidade o espaço escolhido de trabalho, como Pastore insistentemente documentou.

Olavo Bilac, exemplificando as idéias evolucionistas em voga, também elegeu as cenas que difamavam o Brasil. Ao se referir aos bilhetes postais vendidos no navio Chili, no deslocamento Brasil-Europa, não conseguiu disfarçar o pensamento de seu próprio tempo. A desqualificação do trabalho ambulante autônomo confluía com a mentalidade racialista, expressando como a cidade pode ser entendida como um campo de forças. A indignação se dava porque em tais postais,

Não há paisagens da nossa terra, a não ser uma ou outra reprodução da estafadíssima alameda de palmeiras do Jardim Botânico; o que neles há é uma abundância fenomenal de figuras de índios e de pretos africanos, e estes, boçais e tristes, vendendo bananas, ou traçando chapéus de palha. (Velloso, 2010, p. 64)

Ao eleger esse repertório Vincenzo Pastore foi o fotógrafo deste cotidiano visto e interrogado por meio de sua fotografia onde confluíram à atenção ao registro de tipos sociais, 
dando a ver cenas de trabalho pouco documentadas. O cavalo que puxava uma carroça da limpeza pública foi retratado caído no chão (fig.152); o fotógrafo colocou essa fotografia na dimensão do político porque o urbano, elemento da modernidade, aparece como falho na visão de Pastore. O cavalo empacava fatigado, constrangendo a República.

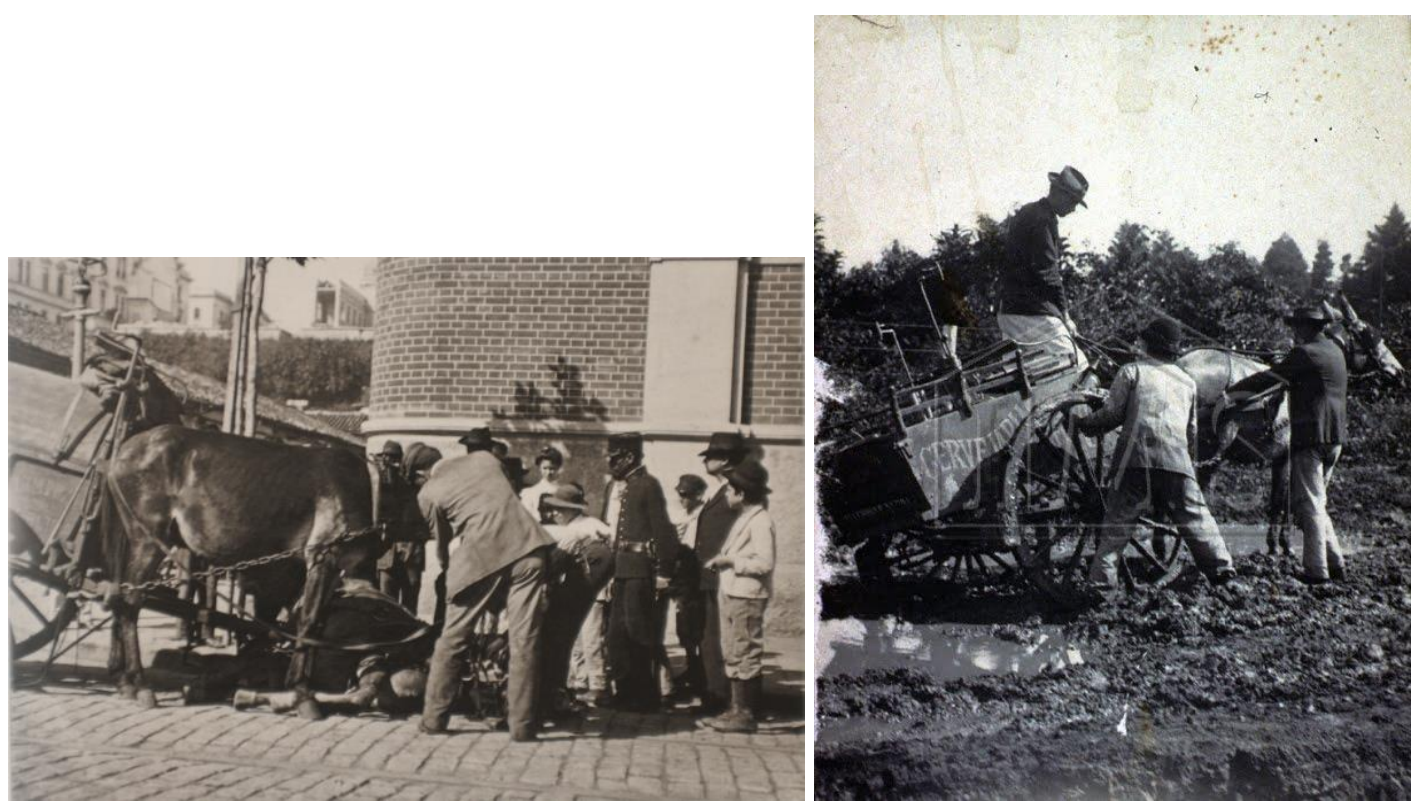

Figuras 152 e 153: À esquerda "Cavalo da carroça de limpeza pública caído no chão"; à direita "Carroça de cervejaria atolada na lama”. 1910 @ C Vincenzo Pastore/Instituto Moreira Salles.

Ao referenciar o comércio de cervejaria que crescia e se destacava como um novo hábito, fruto da onda imigratória, Pastore registrou como a sua distribuição não se valeu somente da rede ferroviária que tanto incrementava o comércio citadino. A carroça atolava numa via enlameada (fig.153). A carroça de cerveja atolada na lama e a ajuda oferecida pelos dois homens que puxavam uma das rodas, não é uma encenação. É fotografia flagrante da São Paulo em início do século XX, demonstrando, como explica Lérias (1988), como o crescimento demográfico confluía para novos setores da economia com estruturas de funcionamento bastante precárias. ${ }^{246}$ Pastore registrava de certo modo acontecimentos que se

\footnotetext{
${ }^{246}$ Entre os imigrantes o vinho importando da Itália era preferido em detrimento do nacional. Ver Moreno. Memórias de Armandinho do Bixiga. São Paulo: Ed. SENAC. 1996, p. 33. A cerveja Bass era uma marca famosa que trazia uma enorme "contribuição inglesa para a mesa paulistana", desde as ultimas décadas de século XIX. Ver MORSE, Richard. Formação Histórica de São Paulo. De comunidade à metrópole. São Paulo: Difusão Européia do Livro. 1970, p. 181. Outros fabricantes menores "garantiam o seu producto tanto na capital como no interior". Ver anúncio de cervejaria publicado no jornal $O$ Estado de S. Paulo. 4 de outubro de 1900, p. 4. Estas teriam que enfrentar a concorrência da "Comp. Antarctica Paulista, localizada na Rua Bavaria, 17". Sobre essa importante marca ver Revista A Vida Moderna. 15 de fevereiro de 1910, n. 69. O consumo de vinho também cresceu em abundância, assim como as áreas de cultiva da uva nos arredores da cidade. Ver Bruno. V.3, p. 1106.
} 
aproximam das queixas que indicam as tensões apontadas por alguns moradores insatisfeitos com as obras de alinhamento das ruas.

O abaixo assinado enviado à Câmara Municipal por proprietários, negociantes e residentes da região de Santana, ao reclamarem da largura de 8 metros, comum nas principais ruas do centro, deu sinais da precariedade sondada por Pastore. A largura ideal para atender o trânsito de carroceiros "que não são poucos os que diariamente por ali passam" seria de 10 metros. Entre os assinantes que apelaram para o "bom senso" estavam os seguintes carroceiros: Luiz Romano, Vicente Tasso, Guiseppe Cardenuto, José Guiséa, Antonio Russo.

Senhores vereadores, V.V.Exas. não conhecem a rua em questão, isto é, na qualidade da terra dessa rua, é uma terra preta barrenta, que quando os tempos chuvosos, fica intransitável, e com a largura somente de 6 metros os vehiculos com muita difficuldade poderam encontrar-se (...) A rua Dr. Cesar era uma rua torta e agora com o novo alinhamento mais torta ficou. ${ }^{247}$

Um ano depois, mais de trinta carroceiros dirigiram à prefeitura uma representação exigindo providencias para por fim ao mau estado da Rua Bella Cintra, esquina com a Vasco da Gama, repleta de "buracos feitos pelas últimas chuvas". Reclamavam: "la virou uma carroça e quase apanhou o condutor (...) e os pobres homens pagam impostos". ${ }^{248}$

Quando Pastore fez seu recorte na Rua Direita, em 1910, tinha a certeza do registro que faria: Retratar coletores de lixo, em primeiro plano! (fig.154). Não foi a circulação da gente elegante e tampouco os cafés, as confeitarias, as lojas chiques de moda, os bancos ou as prestigiadas casas comerciais que atraíram o fotógrafo imigrante. Sua escolha voltou-se para aqueles que moravam longe, no alto da Mooca, no alto do Ipiranga. Há vozes e memórias que relembram estes bairros como local de moradia da população negra, como lugares descampados, "onde a turma tinha um terreninho depois do monumento", comentou o sr. Amadeu, nascido no Brás, em 1906, no comovente relato dado à Bosi (1994, p.144).

O fotógrafo registrou os muitos "arranjos de sobrevivência" de muitos imigrantes, sobretudo italianos, revelando a forte presença desse contingente nessa atividade. Deu visibilidade a contingências sondadas por Azevedo (2009, p.90), que pontua uma "mudança no perfil social que compõe a categoria": no fim da década de 1910, os carroceiros, antes na maioria homens negros e seus descendentes eram substituídos por imigrantes, ou por seus filhos nascidos no Brasil.

\footnotetext{
247 Arquivo Histórico Municipal de São Paulo Cf. Papéis Avulsos. 22 de agosto de 1908. Localização: 2056. Acervo manuscrito.

${ }^{248}$ Arquivo Histórico Municipal de São Paulo. Cf. Fundo CMSP - 1909. Conselho de Vereadores. Caixa 48. 13 de janeiro de 1909. Acervo manuscrito.
} 


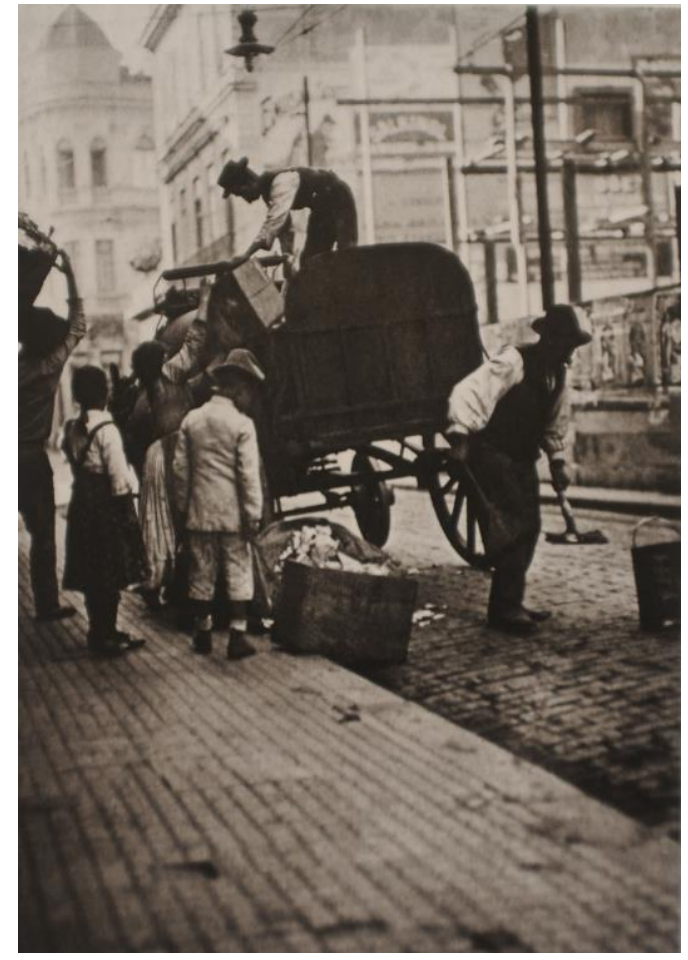

Figuras 154: "Carroça de coleta de lixo". Foto tomada na Rua Direita já submetida aos melhoramentos propostos para a região do Triângulo Central, feita entre o largo da Misericórdia e a Rua São Bento. 1910 @ Vincenzo Pastore/Instituto Moreira Salles.

A limpeza e a desobstrução das ruas ficavam a cargo dessa categoria de trabalhadores que Pastore quis fotografar. Depois de varrida a frente das casas, montes de lixo eram formados no meio da rua à espera do carroceiro passar. Se a chuva chegasse primeiro espalharia ciscos e todo lixo recolhido. Quando se observa o quanto essa imagem era parte de um contexto repleto de polêmicas que envolviam esses trabalhadores, vê-se como Pastore não estava alheio às questões que alcançavam grande repercussão social. ${ }^{249} \mathrm{~A}$ memória da sua filha Costanza, guarda a lembrança do pai lendo jornais, acompanhando as notícias sobre o cotidiano da cidade. ${ }^{250}$

Foram inúmeras as queixas indignadas contra os carroceiros, ora por uma suposta postura inadequada, ora pelos serviços mal prestados, ou até mesmo pelo barulho que provocavam, perturbando os lares. Reclamava-se da poeira levantada quando passavam. Os estalos de chicotes incomodavam igualmente. No dia 14 de julho de 1912 a prefeitura aprovou

\footnotetext{
${ }^{249} \mathrm{O}$ grupo de cocheiros e carroceiros era bastante diversificado, pois entre eles conviviam trabalhadores livres, escravizados e libertos, e ao longo da segunda metade do século XIX, foram empregando entre eles trabalhadores imigrantes. Os trabalhadores de transporte, submetidos às regulamentações municipais foram "frequentemente apontados como transgressores, imprudentes e causadores de acidentes". Preconceitos depois transferidos, aos condutores de bondes de tração animal, amenizados somente após a instalação dos bondes elétricos que passaram a exigir uma maior qualificação dos motorneiros. Ver SANTOS, 2009, pp. 86-88. ${ }^{250}$ Centro Cultural São Paulo. Ver entrevista realizada pelo pesquisador Ricardo Mendes, em 1997.
} 
no ato n. 474 , a proibição dessa prática. Os infratores que insistiam em chicotear os animais pagariam multa $20 \$ 000$ reis. $^{251}$

As queixas de diversos moradores da Rua Major Sertório e adjacências, não encobriram a altivez com que tais trabalhadores seguiam pelas ruas, sentindo-se como reis:

Recebemos esta justa reclamação, que ipis-litteres, publicamos, pedindo providencias contra esses lixeiros malcreados que desrespeitam as senhoras, como se fossem reis da cidade;(Jornal A Capital. 12 de setembro, de 1913).

Taes carroças ao nosso parecer são anti-hygienicas, porque na sua função levantam nuvens de poeira, estragando todas as casas, fazendo respirar aos transeuntes que se acham a noite fora de casa, uma quantidade enorme de pó e deixa-os tambem quase cegos; os passageiros que se acham nos bondes devem immediatemente abaixar as cortinas se não quiserem ter a mesma sorte dos que estão pelas ruas; (Jornal A Capital. 16 de setembro de 1914).

Eles são uns grandes especuladores. Imagine, Sr. redactor, que elles não tiram mais do que uma lata de kerozene com lixo, de cada casa e quando pomos na rua duas latinhas, podemos ficar certos que os bandidos não tiram mais do que uma e então, dizem elles: se quizer que leve a outra tem que dar uma gorgeta, ou mata-bicho. Ora, essa é bôa: então não somos nos que contribuímos para lhes serem pagos os seus ordenados no fim de cada mez para esse fim, com o fabuloso imposto do lixo? (Jornal A Capital. 22 de agosto de 1913).

Residentes da Rua Fernandes da Silva no Brás ficaram indignados com o "desleixo" dos empregados da limpeza, que passavam pela via como "gatos sobre brazas", ${ }^{252}$ reclamações que se assemelhavam àquelas em relação à limpeza realizada na movimentada Rua XV de Novembro:

A varredura é feita de maneira quase inconcebível (...) a mais leve reflexão ensinaria que a limpeza se deve fazer em horas de pouco transito, isto é, a noite ou pela madrugada", evitando-se o "desgosto de toda gente que atravessa a principal artéria de São Paulo com o lenço no nariz e fugindo dos varredores impertinentes. ${ }^{253}$

As queixas feitas aos jornais em relação aos serviços de limpeza denunciam pormenores do cotidiano. A "retirada dos lixos e da varredura não são sufficientes", no Largo São Bento. O cheiro como memória da cidade, revela-se na descrição desse local de parada de muitos

${ }^{251}$ Cf. Arquivo Histórico Municipal de São Paulo. Legislação Municipal 1912.

${ }^{252}$ Arquivo Histórico Municipal de São Paulo. Cf. Seção de Polícia e Higiene. 1909. Caixa 53. 5 de janeiro de 1909.

${ }^{253}$ Arquivo Histórico Municipal de São Paulo. Cf. Seção de Polícia e Higiene. 1909. Caixa 53. 4 de janeiro de 1909. 
animais, tido como um local de limpeza incompleta, não seguida de lavagens, reclamava o fiscal. ${ }^{254} \mathrm{O}$ registro dos carroceiros feito por Pastore na Rua Direita, à luz do dia, estaria de algum modo reiterando tais queixas, não tendo encontrado, contudo, espaço de circulação?

Moradores recorriam aos jornais, posicionando-se contra o "péssimo systema que tem as carroças da limpeza publica de fazer a arrecadação do lixo na Avenida Celso Garcia desprezando a travessa em que residem". O lixo encontrado há dias ficava em "monturas mais ou menos grandes, desprende mau cheiro extraordinário e, devido a isso, em constante ameaça à saúde pública". ${ }^{255}$ As crenças dos miasmas se viam popularizadas em início de século XX, numa São Paulo que se pensava acolhedora, e exigia de si grandes feitos.

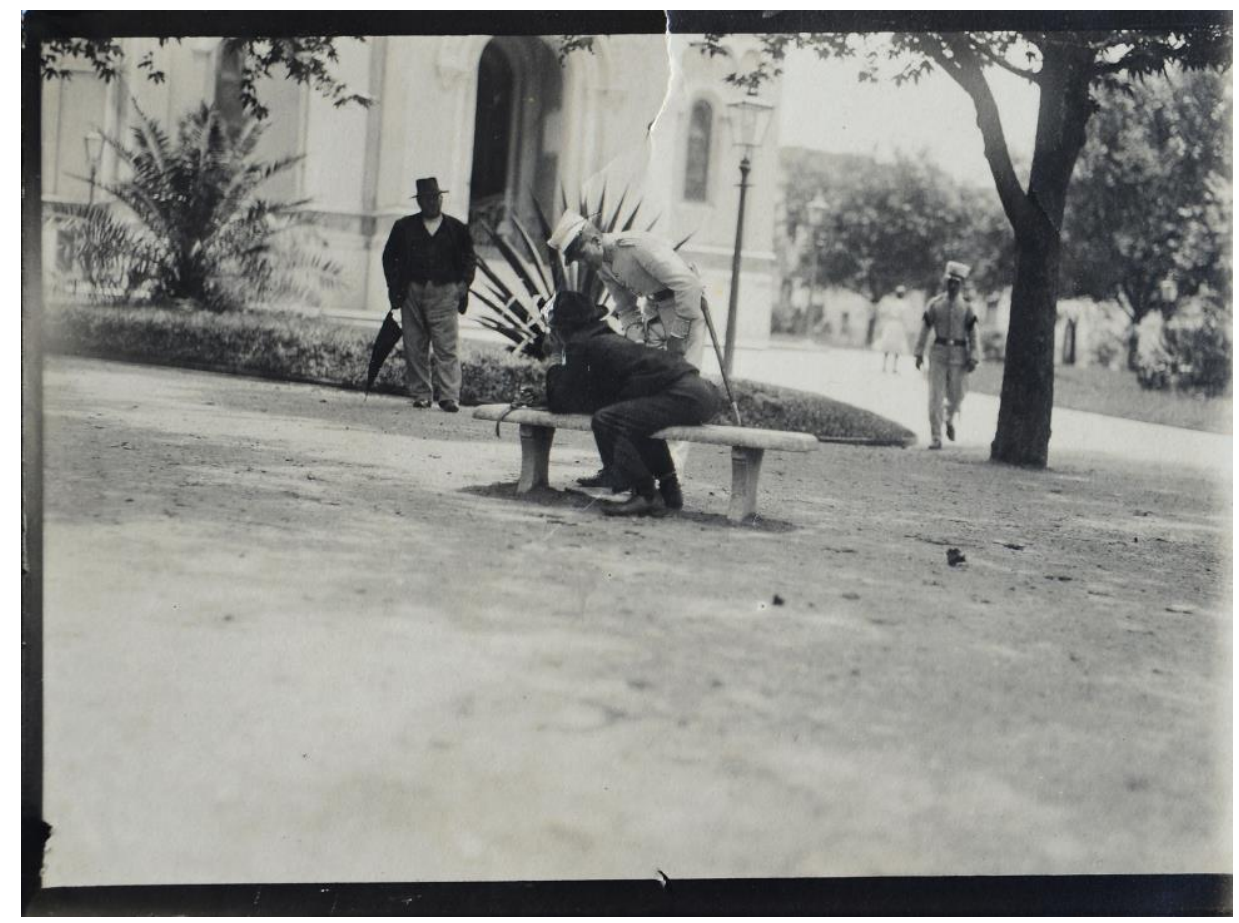

Figura 155: Homem sendo abordado por guarda municipal. Sem data ou referência do logradouro. ()

Vincenzo

Pastore/Coleção Dante Pastore.

Pastore pareceu atento às múltiplas tensões do cotidiano da paulicéia. Outro breve instante flagrado por Pastore (fig.155) pode remeter dessa vez às "Queixas do povo", que já começava a se irritar com a presença impositiva do fiscal no Largo do Arouche. Recorreram ao jornal para dar repercussão a sua denúncia contra os “empregados da prefeitura”. Estes, afirmavam os queixosos, "além de serem indelicados e supinamente grosseiros, ainda entendem que podem impedir que se sentem nos bancos daquele logradouro, cavalheiros e familiares com quem não simpatizam". 256

\footnotetext{
${ }^{254}$ Arquivo Histórico Municipal de São Paulo. Cf. Seção de Polícia e Higiene. 1909. Caixa 53.

${ }^{255}$ Arquivo Histórico Municipal de São Paulo. Cf. Seção de Polícia e Higiene. 27 de março de 1909. Caixa 53.

${ }^{256}$ Seção de policia e higiene. 1909. Caixa $n^{\circ}$ 53. 15 de fevereiro de 1909. Acervo de manuscritos Arquivo Histórico Municipal de São Paulo. Recorte Jornal São Paulo.
} 
Essa imagem não integra a coleção no acervo do IMS. Ainda é uma imagem guardada pelos descendentes do fotógrafo, que aponta um modo de interação de Pastore com a cidade e com seus transeuntes. O enunciado do texto publicado no jornal "São Paulo" trazia as reclamações dos frequientadores do Largo do Arouche. Reclamações que podem ser remetidas a essa imagem inédita, realizada possivelmente no Largo do Paissandu. Descortina-se aqui a participação do fotógrafo nas múltiplas vivências da cidade, nuançando traços das camadas mais obscuras do conhecido embate fundado na aparência do indivíduo ou de grupos socialmente desqualificados, proibidos de permanecerem em certos espaços da cidade. $\mathrm{O}$ fotógrafo exercitava, por meio do registro visual, uma observação dos aspectos reveladores de contingências históricas enraizadas na cultura, atento a todas as notícias publicadas na imprensa local. Seguia pelas ruas em busca das contradições de uma cidade moderna onde grupos e ambições distintos conviviam lado a lado. A São Paulo de Pastore era negra, imigrante, repleta de fissuras e impasses.

A ligeira distância da cena retratada, bem como a predominância de linhas em diagonal, denotam a esperteza da foto feita sem alarde, com o fotógrafo passando, ao menos inicialmente, quase despercebido pelos sujeitos sociais envolvidos na trama do ocorrido: $\mathrm{O}$ fotógrafo flagrou o guarda municipal em sua ronda atrapalhando aqueles que faziam do espaço público terreno de suas sociabilidades. Pastore expunha aquilo que a modernização queria tornar invisível, mas que lhe era particular, presente no cotidiano das ruas.

Tratamos de uma narrativa fotógrafica inusitada ao retratar as feições do cotidiano dos meninos engraxates. Pastore não quis destacar a famosa estação da luz, construída com material importado da Inglaterra. Priorizou as sociabilidades de seus arredores. Imperou a presença dos meninos carregadores e engraxates (fig.156 e 157). A espera por serviço guardava tempo para jogar bolinhas de gude. A sensibilidade do fotógrafo para o outro e para a situação instável presente nas ruas o levou a pegar o bonde que saia da Rua Direita, onde se localizava o seu estúdio fotográfico, dali seguindo pela Rua do Comércio, da Quitanda, pelo movimentado Largo São Bento, rumo a Ladeira do Açu, depois atravessando a Rua do Seminário e Alegre, para finalmente chegar ao ponto da Estação da Luz. ${ }^{257}$

\footnotetext{
${ }^{257}$ Em 1872 a Companhia Carris de Ferro, que se tornaria posteriormente Viação Paulista foi a responsável pela instalação das primeiras linhas de bonde na cidade, ligando o Largo do Carmo à Estação da Luz. Rede de transporte depois administrado pela Light, que substituiu os bondes puxados por animais pelos elétricos.
} 

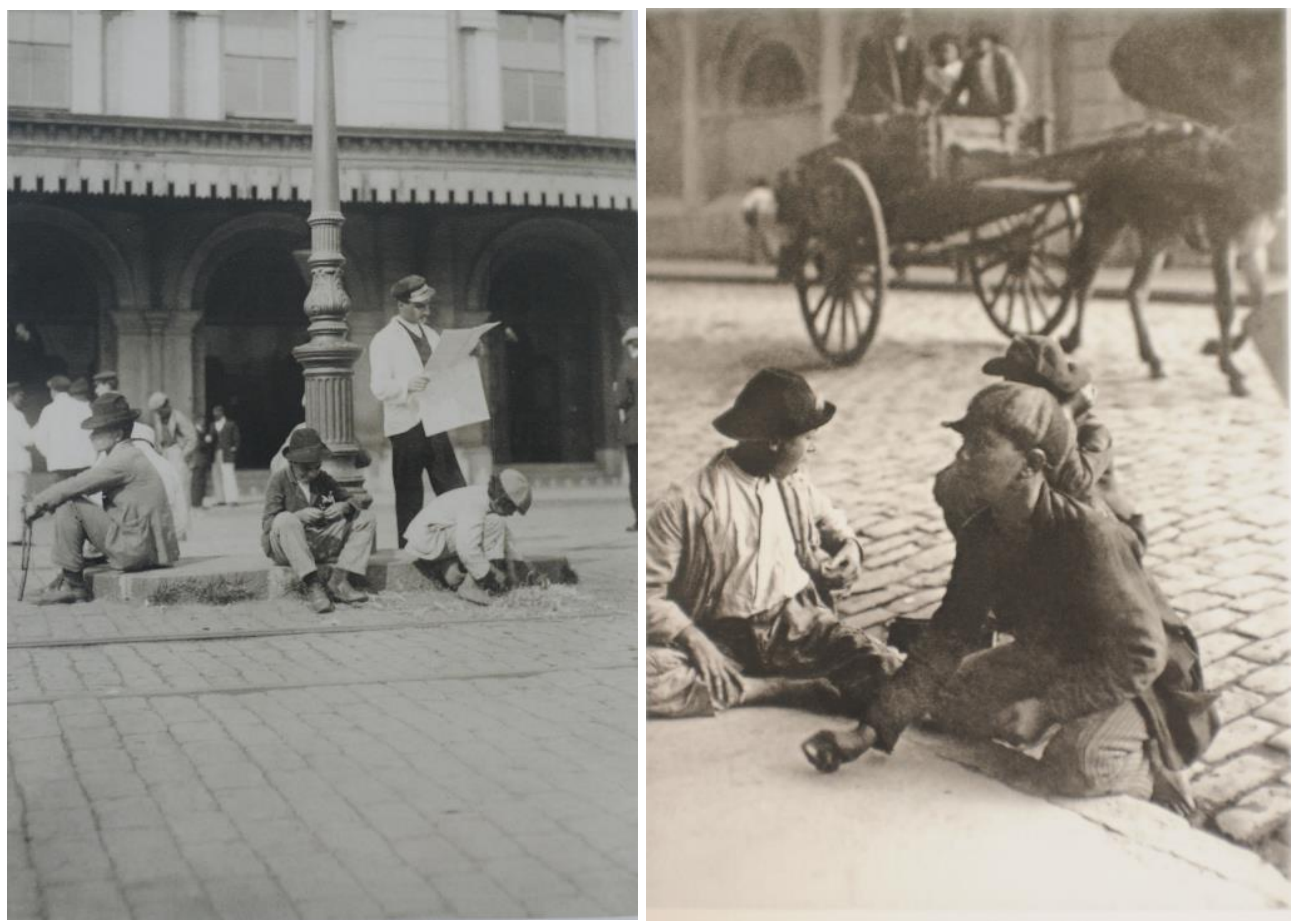

\section{Figuras 156 e}

157: À esquerda

"Ferroviário lê

jornal, cercado por

carregadores de

malas, em frente à

Estação da Luz"; à

direita "Pequenos

prestadores de

serviço jogando

bola de gude, em

frente à estação da

Luz. 1910 ()

Vincenzo

Pastore/Instituto

Moreira Salles.
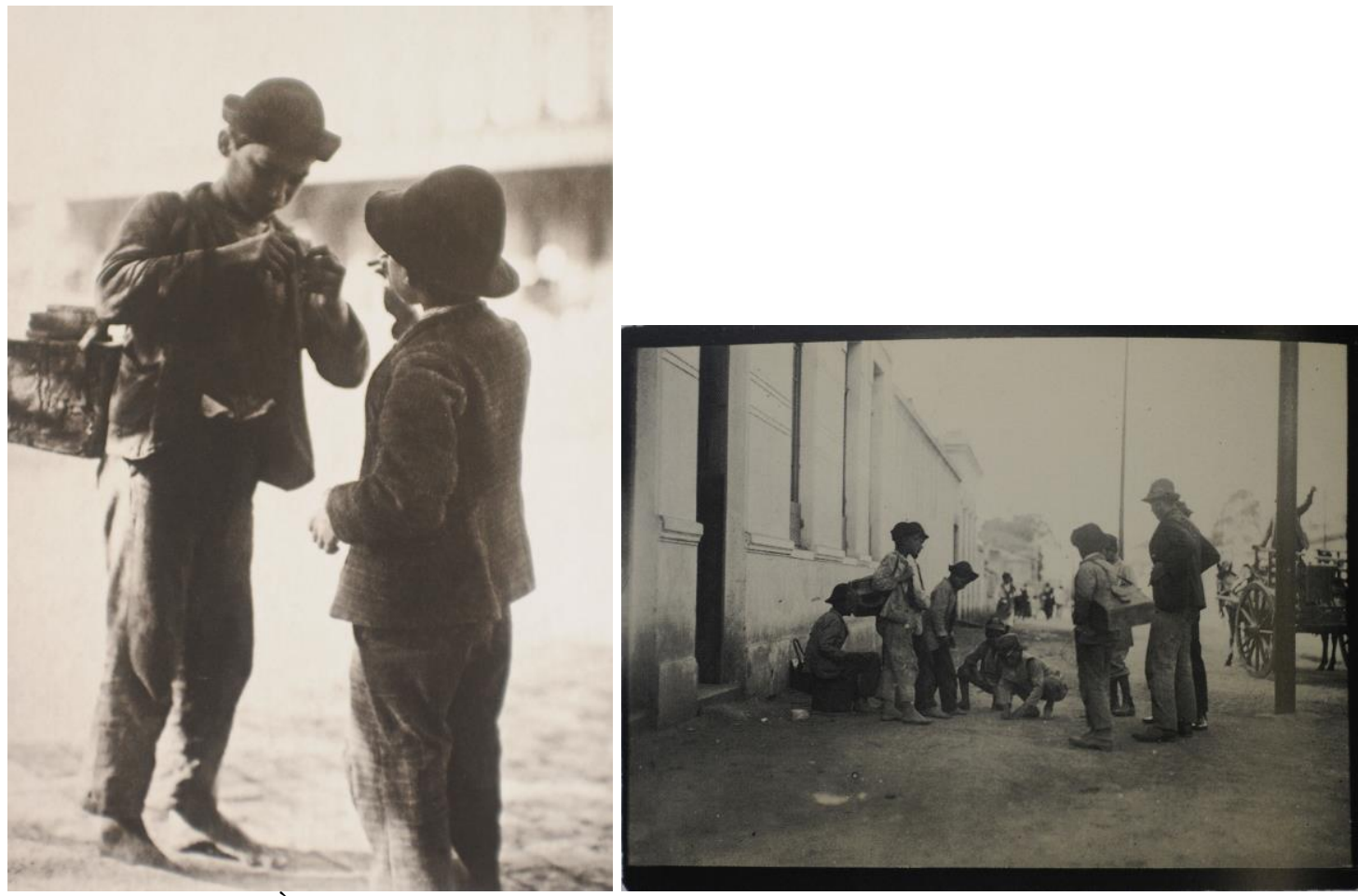

Figuras 158 e 159: À esquerda "Garotos Engraxates"; à direita, "Meninos engraxates jogando bolinha de gude" em logradouro não identificado. 1910 @ Vincenzo Pastore/Instituto Moreira Salles.

Tem-se a configuração de espaços com tomadas salpicadas de irreverência, dando a ver meninos tão à vontade, tomando as calçadas, ou encarando a lente do fotógrafo, como fez o garoto, na parte superior, à direita (Fig.157). Seu rosto, totalmente desfocado, aparece em 
primeiro plano, invadindo a lente fotográfica. Sua face e as abas de seu chapéu encobriram a cabeça do cavalo que puxava a carroça, elemento de cena que preencheu o último plano da imagem, de onde se vê outros olhares dirigidos ao fotógrafo. Nota-se a valorização dada ao conjunto dos diferentes planos que a compõe. A espontaneidade não foi um traço episódico emprestado às composições. Foi central em toda narrativa visual criada, onde desponta a autonomia de Pastore, avesso às convenções da pose, aos padrões de enquadramento, aos cânones do pictorialismo, que em suas contradições, não assumia a "concepção de fotografia como arte da vida real, do dinamismo" (Mello,1998, p.115).

O fotógrafo, em tais cenas, surpreende (fig.158). Em outras fotografias produzidas no período, por fotógrafos contemporâneos, tem-se com maior evidencia a presença de meninos que carregavam trouxas de roupas; outros levam cestos e balaios talvez vendendo doces, usados na entrega de quitutes, da cachaça ou de qualquer outro produto, sugeriu Santos (1998). Foco aos engraxates vê-se em Pastore. Chama atenção o destaque dado aos caixotes, em registros que revelam como eram carregados. Nesse registro surgem tonalidades fortes, escuras, num branco excessivo ao fundo, expressando contraste, com incidência de luz lateral à esquerda, que iluminou o caixote de engraxar sapatos, reforçando o nó, o sentido essencial desse material visual: o cotidiano de trabalho.

Tem-se visualmente nuances de contingências que envolviam meninos que trabalhavam com 10 a 14 anos de idade na maioria, em atividades que seriam depois ocupadas por homens adultos, sobretudo, imigrantes ou já uma segunda geração de descendente de italianos (Bruno, 1954). Revela-se o olhar do fotógrafo atento para a cultura material que cercava os meninos. Aspecto que se repete em toda a narrativa fotográfica.

Os efeitos de luz super-exposta encobrem o edifício e os paralelepípedos ao chão (fig. 158), retratados de forma pouco nítida. A ousadia de um enquadramento recortando o corpo do menino retratado à direita, dando a ver o outro que trabalhava descalço à esquerda, flagrados num momento de interação e convívio, qualificam a configuração da cena e de sua clara proposta estética: A leve silhueta descortinou a ousadia de Pastore. Efeito este que iria configurar o vocabulário pictoralista, sobretudo, após a década de 1920, experimentada por Pastore entre 1908 e 1914.

As duas mulheres vendeiras (fig.160), que agenciavam a própria condição de existência em seu caminhar diário pelas ruas da cidade, encontraram os passos do fotógrafo, que seguia dando maior vazão ao efeito de leves silhuetas. Poucas décadas depois seria esse um efeito de 
luz bastante explorado pela fotografia moderna, que buscaria novas concepções de linguagem a partir das tendências de vanguarda fotográficas da primeira metade do século XX. ${ }^{258}$

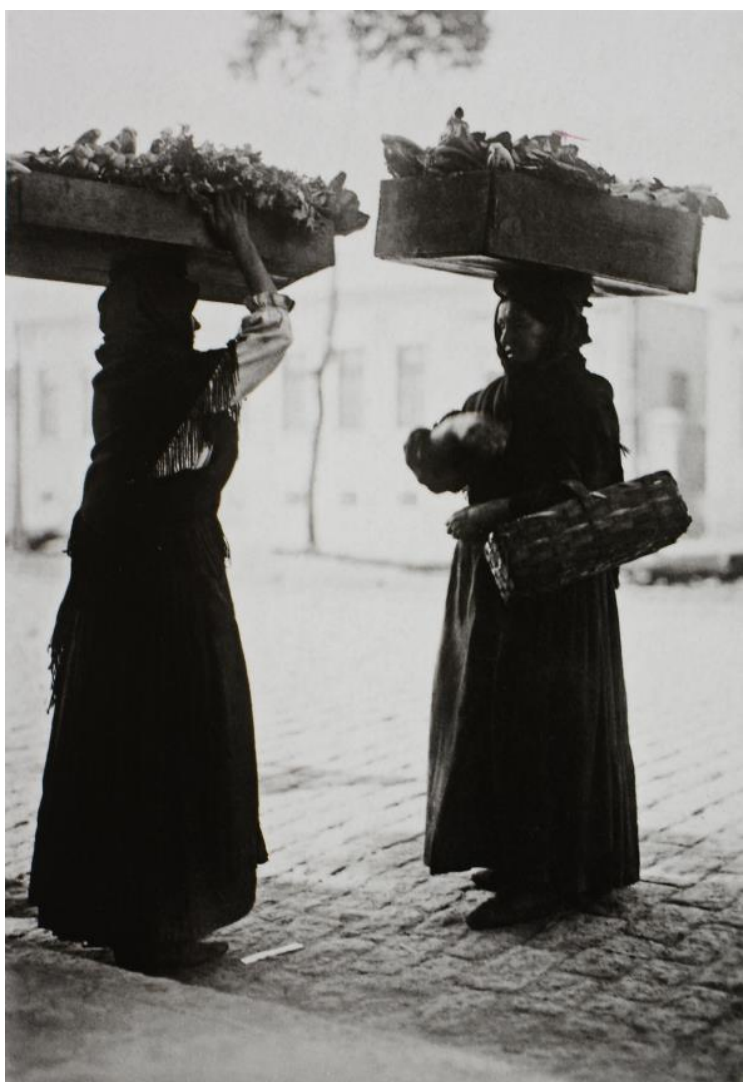

Figura 160: "Vendedoras de verduras". Foto realizada possivelmente nas proximidades do atual parque D. Pedro II. 1910 @ V Vincenzo Pastore/Instituto Moreira Salles.

Segundo Enrico Thovez, crítico literário e poeta nascido em Turim, no ano de 1869, que também, dedicou-se à pintura, tendo escrito inúmeros artigos e ensaios sobre arte, a fotografia exige capacidade intelectual e sensibilidade. "Na arte fotográfica a escolha é tudo", afirmou:

Uma reprodução fotográfica subtrai da realidade, em primeiro lugar, a cor, elemento importantíssimo. Trata-se, em muitos casos, de uma perda, em outros casos, um ganho. Subtraindo a cor, a fotografia extrai, de certas cenas apagadas ou desagradáveis, uma beleza de claro-escuro antes inapreciável. E não só isso: imagina-se que a fotografia deva respeitar cuidadosamente esse claro-escuro, mostrar perfeitamente a forma dos objetos, mas não é assim. Uma dose maior ou menor de sais de prata na emulsão, uma maior ou menos duração de exposição à luz, uma revelação mais ou menos intensa são suficientes para exagerar o valor das luzes em relação às sombras, dando um relevo maior para a realidade; ou então atenuá-las, tornando quase imperceptíveis o contraste, de forma a tornar o tempo cinza em um fortíssimo efeito de sol. (E. Thovez. L'arte all'esposizione del 1898. $\mathrm{n}^{\circ}$ 9, $\mathrm{p}$. 67-70. Tradução nossa)

\footnotetext{
${ }^{258}$ Sobre a fotografia moderna ver estudo de Helouise Costa e Renato Rodrigues da Silva (2004). Os autores tomam o conceito de fotografia moderna para pensar o desenvolvimento da fotografia dentro dos movimentos fotoclubistas de 1940 a 1950.
} 
Para se alcançar um resultado artístico esse autor, defendia uma prática fotográfica de transgressão e confronto da técnica e do próprio aparato fotográfico em nome de atributos capazes de criar "tesouros ainda intactos" por meio de "desfocamento, super- exposição e contra-luz". Observando os apontamentos de Thovez contra a noção de fotografia como cópia fiel da realidade, desvelam-se certas atitudes adotadas por Pastore:

(...) Aparentemente a fotografia deveria respeitar escrupulosamente o claro e o escuro, mas não o faz (...) $\mathrm{O}$ olho humano vê de forma distinta objetos próximos, desfocando outros (...) Se há algo de artístico na fotografia é em quanto transmite ao menos em parte a intuição do fotógrafo, o seu ponto de vista, a atitude e a situação em que foi realizada e compreendida (...) A escolha é quase uma invenção. (Thovez, Poesia fotografica, 1898, p.277 Apud Zannier, 1985, p. 266. Tradução Nossa)

Charles Caffin definiu como "fotógrafos avançados" aqueles com pretensões artísticas:

(...) Devem entender as leis da composição e também as quais afetam a distribuição de luzes e sombras; o seu olho deve ser treinado para distinguir valores, isto é, os diversos efeitos de luz sobre os objetos e materiais distintos e as mudanças graduais da cor de um objeto, mais próximos ou mais distantes. Esses valores implicam conhecimentos técnicos que podem ser adquiridos; deve além do mais ter um sentido instintivo da beleza da linha, da forma e da cor, que podem ser desenvolvidos por meio de estudos e, finalmente, do dom natural da imaginação, que concebe um tema belo ou usa a técnica e a intuição para expressá-lo. (La Fotografia como una della las bellas artes. 1901. In: Fontcuberta, 2003, p. 93)

No retrato das vendeiras, os casebres ao fundo foram quase totalmente obliterados pelo branco excessivo (fig.160). O fotógrafo optou em apresentar apenas as linhas das janelas, dos telhados, de algumas paredes laterais, bem como aquelas do calçamento. A única árvore surge como um elemento de preenchimento do plano de fundo. O tronco inscreve uma linha vertical pouco nítida, num arranjo onde o fotógrafo sublinhou as formas e os contornos escuros das vestimentas usadas. Os caixotes repletos de verduras e o cesto deixado ao braço esquerdo de uma das mulheres deram mais uma vez as formas de uma cultura material destacada.

Caixotes que parecem pesados. Precisava-se de panos enrolados protegendo a cabeça do contado direto. A tonalidade mais escura quase escondeu o rosto da mulher à direita retratado num quase perfil, não fosse a entrada de luz lateral, vinda da esquerda, projetando efeitos de sombra no lado oposto da face. 


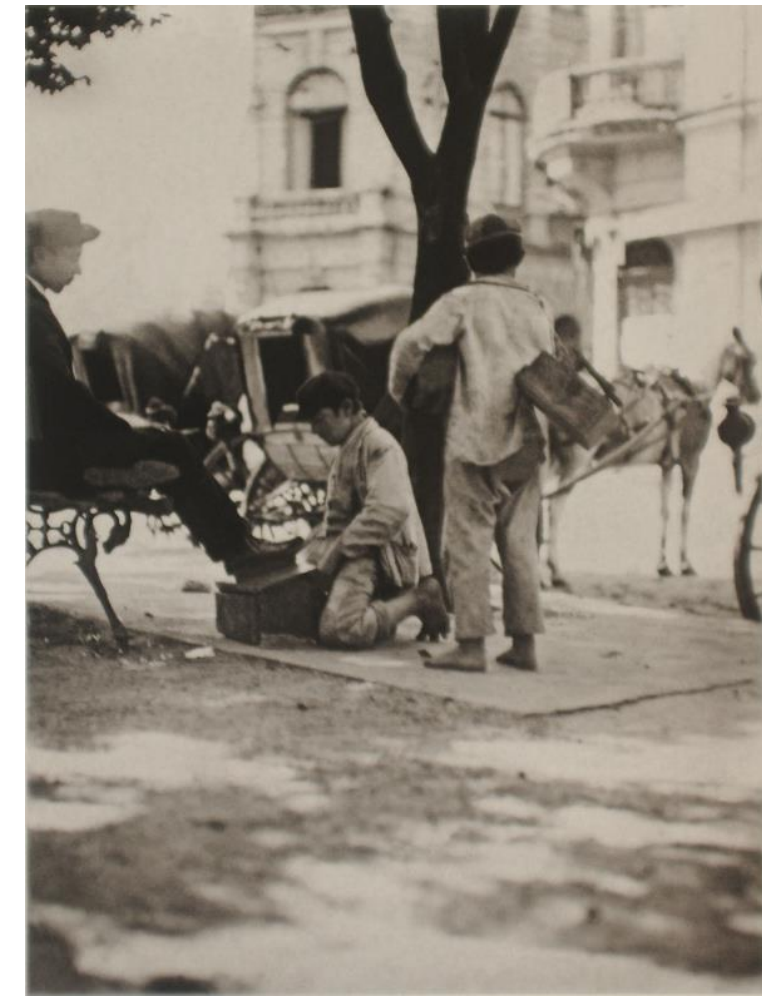

\section{Figura 161:}

"Meninos Engraxates" trabalhando no Largo São Bento. Ao fundo nota-se os carros de aluguel. 1910 @ Vincenzo Pastore/Instituto Moreira Salles.

Quando nos voltamos para as composições do trabalho feito por crianças, vê-se ainda a intenção do sujeito da narrativa, o fotógrafo, que escolheu posicionar os meninos num espaço forte do quadro fotográfico, centralizados entre o primeiro e o último plano da imagem (fig.161). Evidente foi o jogo de sombras das folhagens projetadas em primeiro plano ao chão, num evidente contra luz. Sombras que proporcionaram maior equilíbrio à composição. Teríamos nessa configuração um vestígio de como Pastore interrogava a especificidade da técnica fotografia, valendo-se daquilo que era a matéria-prima aos pictorialistas, ou seja, o "império da luz" que é predominantemente "o elemento básico de uma obra de arte fotográfica, sobre o qual deve assentar a sua estética. A luz é a essência da fotografia, é o componente que a diferencia das outras artes plásticas”, explicou Mello, sobre uma das tendências da foto pictorialista (1998, p.120).

Parece clara a intenção de Pastore em pouco destacar às folhagens, tendo no corte do espaço fotográfico deixado a árvore em si, ausente. O volume foi dado quase que exclusivamente aos troncos, em tons escuros, delineando sua espessura, além de se opor aos tons claros das vestimentas dos meninos. São esses atributos que expressão as pretensões de um fotógrafo que almejava se apresentar em sintonia com as questões fotográficas de seu tempo. 
Enquanto alguns fotógrafos pictorialistas privilegiaram efeitos de luz noturna, como se nota nos desdobramentos após a década de 1920, Pastore que realizou a sua série no auge do movimento datada por Costa e Silva (2004) entre 1890 a 1914, recorreu reiteradas vezes, aos efeitos de sol, com tomadas ora explorando contra-luz, ora contrastes excessivos. Em sentido oposto, tons de cinzas quase sempre predominaram em primeiro plano, contrastando com as fortes nuances escuras, reforçadas no plano médio (fig.161 e 159). O branco quase excessivo, no jargão fotográfico tido como "fundo estourado", aparece em último plano, aspectos que confluem como uma característica de sua narrativa fotográfica.

Esse experimento formal levado a cabo por Pastore mostra a intenção de explorar efeitos de luz. A experiência de fotografar em contra-luz para Helouise Costa (2004, p.41) quebra primeiro a unidade da cena, para depois deixar "evidente a interferência do fotógrafo na sua execução". O fotógrafo, entretanto, contrariava alguns preceitos pictorialistas que recomendavam, por exemplo, o registro do céu em tonalidades acinzentadas para melhor se destacar as nuvens. O céu como um elemento fundamental na paisagem da foto pictural não deveria nunca ser retratado pela tonalidade branca, monocromática informa Mello (1998). Mesmo quando, vê-se tomadas feitas à favor da luz do sol, como mostram algumas imagens, ainda assim prevalece a mesma distribuição de tons escuros e claros, dos cinzas à baixo da metade da prova, do preto centralizando o motivo e do branco estourado ao fundo.

No Largo São Bento, Pastore registrou cenas de trabalho de meninos engraxates (fig.161), observados pelo fotógrafo. Suas experiências estiveram apagadas nas representações textuais de muitos memoralistas que descreviam a Rua São Bento apenas como espaço do agitado comércio, dos belos prédios, dos tilburys estacionados ou bondes que percorriam todo o seu trajeto. Esse registro documentou o serviço oferecido em banco de praça, num despojamento que desvela o uso do espaço público como meio de sobrevivência. É bastante pertinente a interpretação de Frehse (2011) para quem essas atividades registradas por Pastore devem ser consideradas como prestação de serviços modernos, caracterizando-se como um novo tipo de movimentação. Meninos engraxates ou vendedores de jornais figuram, nesta perspectiva, um recente modo de circulação, ${ }^{259}$ ocupando postos de trabalho que ajudam a compor a própria imagem da cidade. Dos meninos engraxates vê-se uma nova postura

\footnotetext{
259 Em seu estudo Frehse tentou compreender como os transeuntes fotografados num vasto conjunto de fontes fotográficas vivenciaram o advento da modernidade. A autora reuniu cinco conjuntos fotográficos: os álbuns de Militão, Gaensly, o álbum de Afonso, fotografias de Pastore e outras realizadas por fotógrafos anônimos e publicadas na revista A Cigarra. Ver, Frehse, 2011, p. 485-486.
} 
corporal proposta por Pastore: "entre a calçada e a sarjeta, seus corpos insinuam familiaridade com esse espaço, da qual a permanência regular é vigorosa companheira" (2011, p.490).

Mas tais cenas de trabalho, de gênero, resgatando aspectos da visualidade de tipos sociais, caberiam na retórica da fotográfica pictorialista? Rouillé (2009) afirmou que os fotógrafos-artistas tiveram suas produções "desprovidas de consistência humana". Preceito reiterado pela pesquisadora Marina Miraglia (2011). Cenas de gênero e registros dos extratos populares expressariam um excessivo realismo, mantendo-se fora da esfera da foto pictural, marcada pela fuga do debate social, político-ideológico. Mas há relatos que se contrapõe a tais premissas, sobretudo frente à analise mais pontual do contexto italiano.

Relatos de Henry P. Robinson publicado, em 1869, no artigo "Propósito picturial en fotografia", documentou certa liberdade dada ao fotógrafo na escolha do tema a ser retratado: "Pretendi provar que as mesmas leis de equilíbrio, de contraste, de unidade, de repetição, de repouso e de harmonia atuam sobre todas as boas obras sem levar em conta o tema". ${ }^{260}$ Exigia, por sua vez, a clareza da importância do ponto de vista do fotógrafo na feitura da imagem que deve ser realizada de modo subjetivado:

\begin{abstract}
Embora a técnica esta devidamente dissimulada, o olho treinado pode descobrir e admirar os numerosos e hábeis recursos que tem sido adotados para ressaltar algo belo ou para dar maior proeminência ao ponto central do tema (...) se o ponto de vista admiti um primeiro plano pitoresco, através do qual um tema principal não pictórico pode converter-se em uma imagem interessante. (Robinson. Propósito picturial en fotografia In: Fontcuberta, 2003, p. 54)
\end{abstract}

No contexto italiano temos o artigo "La fotografia artistica in campagna", assinado por A. Valerio, publicado na revista "La Fotografia Artistica" em janeiro de 1913, que aconselhava o uso de chapas corretas para não se obter fotografias monocramáticas, apenas em branco e preto, sem as variações de nuances em cinza. Cuidado que deveria ser tomado para que os assuntos eleitos pelos fotógrafos apresentassem uma variedade de tonalidades, prerrogativa do quanto a fotografia era também capaz de traduzir diferenças cromáticas, indo além do claro e escuro. Paisagens, retratos e cenas de gênero, de acordo com esse artigo, integravam o conteúdo pictorialista na Itália. Tal abrangência de temas pode explicar aquilo que Zanini (2013) pontuou como algo recorrente, que gerava incômodo nas participações da Itália em muitas exposições realizadas antes de 1910: A falta de estilo e uniformidade de

260 In: Fontcuberta, 2003, p. 58. 
pensamento. Apenas após a Exposição Internacional de Turim-Roma, de 1911, o pavilhão dos italianos, comparados aos demais, começaria, segundo a revista "La Fotografia Arstistica", a não ter mais nada a invejar das outras nações.

Uma das ideias propostas na revista italiana La Fotografia Artistica indicia a amplitude de temas oferecidos aos fotógrafos pictorialistas nesse contexto. Pediam aos leitores, aos estudiosos e aos amantes da fotografia, segundo Zanini (2013, p.74), que colaborassem na formação de um museu fotográfico, vital para o desenvolvimento da fotografia artística no país. Nos meses de março, abril e julho de 1908 e, depois, em fevereiro de 1909, na coluna "Da l'Osservatore", publicaram o artigo "Le applicazioni pratiche della fotografia. Proposta di un Museo fotografico documentário”, sugerindo uma amplitude do repertório a ser fotografado.

Zanini explicou as principais ideias em defesa deste projeto, importante ao nuançar o quanto as cenas de gêneros e de tipos sociais, poderiam se adaptar ao conteúdo da fotografia pictórica, numa proposta aparentemente abrangente, envolvendo toda Itália:

Falamos sobre este museu afirmando que terá um programa vastíssimo, de continua evolução porque se ocupará de obter fotografias originais, de interesse artístico, cientifico, etnográfico e social. Serão conteúdos de obras as quais será possível estudar as diversas civilizações, suas descobertas, seu modo de vida em trabalhos artísticos produzidos graças aos quais será possível reconstruir interessantes mundos desconhecidos. Este museu deve estar localizado em Turim, mas é um projeto ambicioso que deveria se espalhar em todas as regiões da Itália com a ajuda de entidades públicas e privadas. (Zanini, 2013, p. 54. Tradução nossa)

Para Zanini, se por um lado se falava de organização de documentos fotográficos, sob a lógica quer colecionista, quer enciclopédica, se opondo ao conceito de fotografia artística, por outro, no contexto italiano, acreditava-se que tal associação resultaria em algo positivo: como fonte de exercício para os fotógrafos com senso estético mais apurado poderem treinar o próprio talento.

Ítalo Zannier (1985, p.135), em seu estudo sobre o comércio editorial da fotografia italiana nas duas últimas décadas do século XIX, mostrou o quanto a divulgação de manuais ajudou a difundir a prática fotográfica no país. Se por um lado, esses manuais práticos alimentavam aquilo que o autor chamou de "conceito de fotografia fácil", por outro, expandiam as noções de fotografia como arte. Se os fotógrafos amadores foram os grandes consumidores desses textos, sendo para Zannier os grandes responsáveis pelo crescimento da 
prática fotográfica na Itália, os profissionais também recorriam a tais materiais impressos com o mesmo objetivo em estudá-los: melhorar a sua capacidade criativa. ${ }^{261}$

A exigência artística mencionou Zannier foi incorporada por todos, em cuja prática se difundia a cada dia, em todas as "classes":

Os manuais supriram deficiências organizacionais e institucionais, e
representaram, junto com revistas periódicas, o único lugar de estudo,
educação e intercâmbio cultural para a fotografia, mantendo vivo o interesse
por esta arte e ciência, estimulando a pesquisa individual, que se dirigia
especialmente ao campo artístico, em que muitos dos nossos fotógrafos se
afirmaram agradavelmente, desde os primeiros anos da massificação, até o
pós-guerra. (Zannier,1985, p.137. Tradução nossa)

Talvez Pastore, um leitor dos manuais de Enrico Thovez, ao percorrer os arredores do Triângulo Central estivesse motivado por este investimento: treinar a sua técnica, aproximarse das discussões fotográficas que via circular, experimentar novas dimensões visuais, sem abrir mão das intenções estéticas em sua fotografia mais documental, gênero que começaria a ser resgatado em toda primeira metade do século XX.

\subsection{O fotógrafo nos arredores de vegetação rasteira: cenas pitorescas da Várzea do Carmo ao Ipiranga}

Pastore percorreu os arredores observando experiências de grupos plurais, interessado em retratar aqueles que enfrentavam a lida na terra, de enxada nas mãos. O fotógrafo documentou o aprendizado de homens e mulheres egressos da escravidão, um momento em que acumularam a experiência de tirar das pequenas roças a produção do próprio alimento, prática formadora de uma economia própria (fig.162).

O fotógrafo, no pós-Abolição, localizou e deu visibilidade a esses sujeitos, portadores de um saber outrora acumulado. Plantar, colher e depois vender o milho produzido nos arredores, depois levados à vibrante região dos mercados de abastecimento da cidade, compõe modos de viver também compartilhados pelos imigrantes camponeses que buscavam na cidade maiores chances de sobrevivência.

\footnotetext{
261 Entre os autores de manuais fotográficos alguns nomes se destacam pelo número considerável de publicações: Luigi Gioppi, Bettini, Pizzighelli, Rodolfo Namias, Giovanni Muffone e Ulrico Hoepli. Frente a ausência de espaços de formação para o estudo da fotografia, a circulação de manuais ajudava a minimizar este problema, afirma o autor. Cf. Zannier, 1985, p. 135.
} 


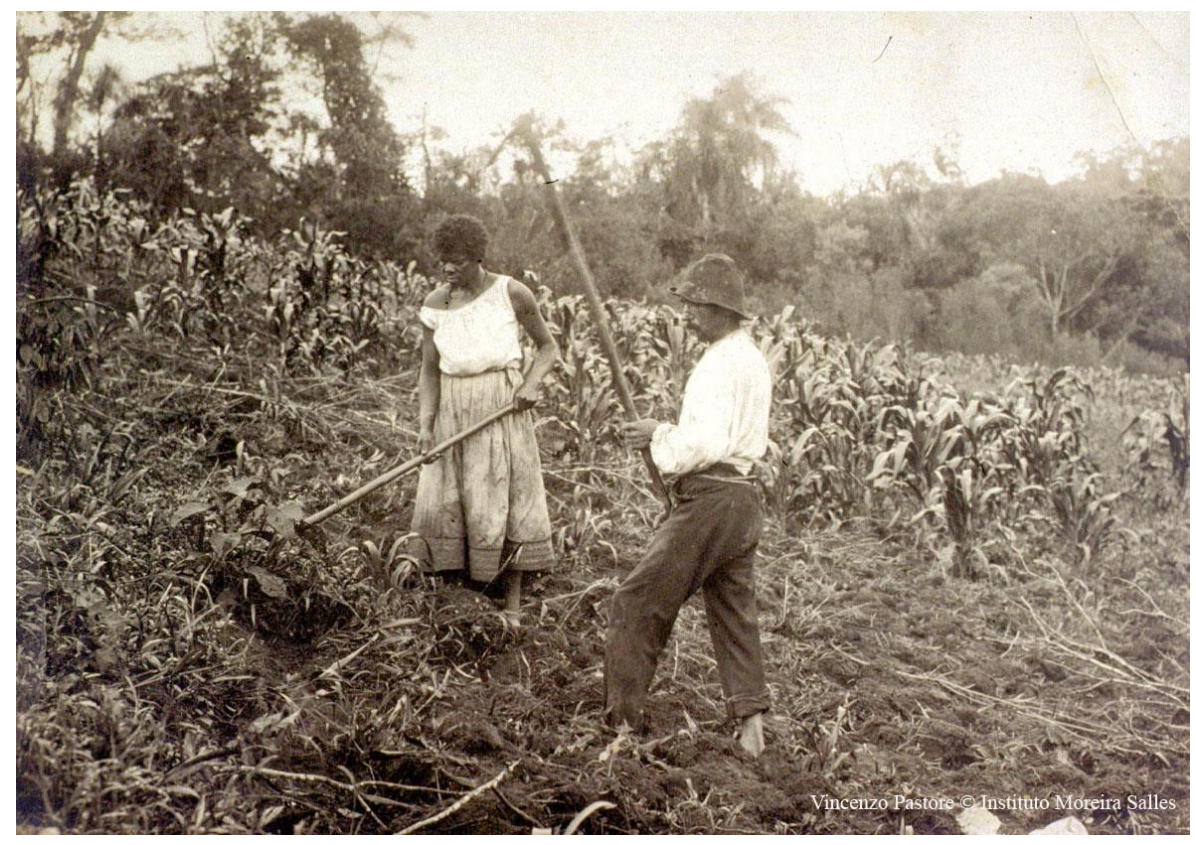

Figura 162: "Casal trabalhando em plantação de milho" um trabalho cotidiano feito nas roças nos arredores do Triângulo Central. Sem identificação precisa de logradouro. 1910 () Vincenzo

Pastore/Instituto Moreira Salles

Algumas de suas fotos se contrapõem aos relatos escritos oficiais, que quase sempre reiteravam em afirmar como aspecto principal das camadas populares não empregadas nas fábricas, uma suposta ausência de "meios conhecidos de subsistência". Há uma vasta historiografia que já pontuou o quanto, negros e brancos pobres nascidos no Brasil foram descritos de modo pejorativo, como "vagabundos", embriagados, ociosos, sem vocação para a especialização. ${ }^{262}$ Em Pastore, a população nacional se desdobra em cenas de trabalho. A enxada, os cestos e caixotes levados com as mercadorias produzidas, explorados nas composições fotográficas, denunciam Pastore atento às pequenas posses de muitos trabalhadores em convivência nos arredores, comercializando aquilo que produziam nos bairros distantes do Triângulo Central.

Sucessivos planos foram articulados nessa imagem descortinando o cuidado com o equilíbrio dos diferentes elementos que compõem a foto: o primeiro plano foi deixado para a cena de trabalho; o segundo para a plantação e, por fim, no último plano, a vegetação nativa, numa tomada da linha horizonte sugerindo certa profundidade. Dividindo o centro da imagem, numa tomada angular quase totalmente frontal, vê-se a mulher ligeiramente à esquerda, a poucos passos em relação ao homem, retratado de perfil, posicionamento este bastante usual na série fotográfica.

262 Cf. SANTOS, Carlos. Nem tudo era italiano, São Paulo e Pobreza (1890-1915). 1998; LAPA. Os excluídos. Contribuição à História da Pobreza no Brasil (1850-1930). 2008; ANDREWS. Negros e brancos em São Paulo (1888-1988). 1998. SANTOS, Gislene. A invenção do ser negro. Um percurso das ideias que naturalizaram a inferioridade dos negros. 2002. 
Olhar essa imagem no original ajudou a notar como o fotógrafo se preocupou com as linhas, formas, tons e textura da foto. Produziu poucos contrastes tonais no céu retratado em último plano. Na parte superior manteve o tom de cinza um pouco mais destacado, acentuando, mais abaixo, na parte superior central à direita, uma leve tonalidade de branco, que daria maior delineamento aos contornos das árvores e folhagens ao fundo, pouco nítidas, expressando certa fluidez e o quanto a noção de efeito flou o acompanhava.

A pequena área iluminada funcionou como um elemento diferenciador entre o plano médio e o último. Na sequência, temos os efeitos de texturas sugeridas, uma das qualidades fotográficas mais preciosas para Emerson. ${ }^{263}$ Ao destacar as diferentes folhagens o fotógrafo, ao propor esse enquadramento transversal, provocou três divisões em linhas diagonais: vê-se no primeiro plano a terra misturada aos galhos sendo preparada para futuras plantações; no plano médio, restam as plantações do milho talvez já colhido. Em último, a vegetação da região, ainda sobrevivendo. Ao fim e ao cabo, a tomada dessa cena equilibrou os valores relativos entre céu e terra, retratados de modo não falseado. O céu, com o aparente retoque, escapou do branco puro e todo o primeiro plano dos escuros exagerados.

Pastore espreitava os arredores da cidade que ampliava seus limites. Muitas famílias, em busca de aluguéis acessíveis, passavam a ser vizinhas de quartos, nos bairros mais distantes do centro, área de maior prestígio. A prática de famílias inteiras alugarem cômodos numa mesma residência estreitava convívios para as bandas do Brás, do Bom Retiro, do Glicério, da Penha, vista mais adiante. Suscetível às cenas corriqueiras, ao dia a dia, o fotógrafo documentou hábitos de morar, entretecendo em sua narrativa aspectos do social, do pitoresco e de experiências tantas vezes sorrateiramente deixadas à sombra (fig.163).

O grande número de elementos informativos distribuídos em diferentes planos sublinha o caráter documental dessa fotografia, tomada com boa profundidade de foco, pouco contraste entre claro e escuro. A boa nitidez reforçava o efeito realista provocado. Ao prolongar o primeiro plano o fotógrafo, evidentemente preocupou-se com os efeitos de percepção que iria provocar reproduzindo o seu próprio caminhar: deslocou-se da trilha desenhada no chão de terra batida, colocando-se entre a vegetação rasteira, antes recorrente na paisagem da capital.

${ }^{263}$ Cf. Fontcuberta, 2003, p. 85. 


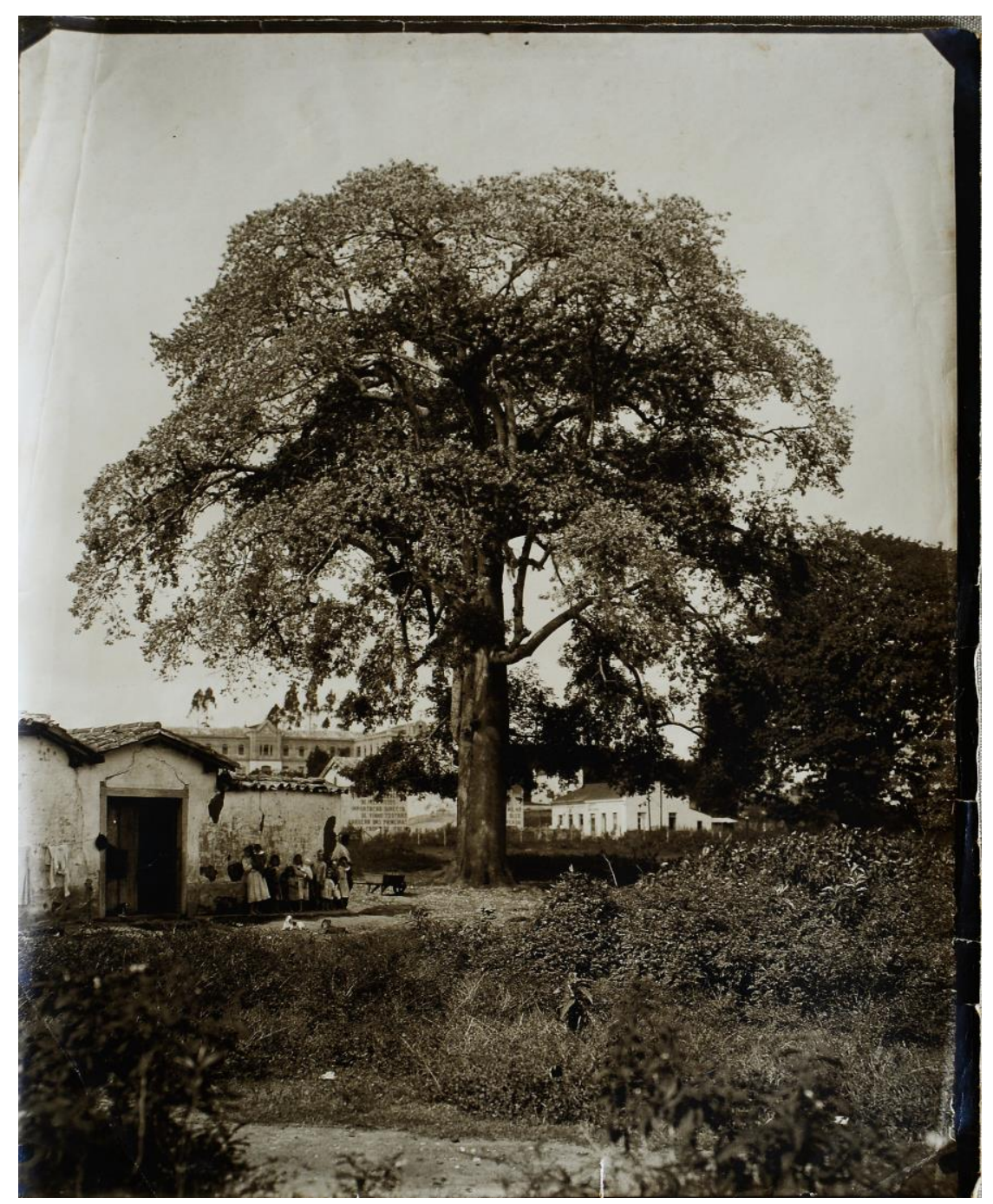

\section{Figura 163:}

Fotografia em papel, com ligeira oxidação das bordas. Ao fundo, possivelmente Instituto Bom Pastor, no Ipiranga. S/d.Fotografia localizada no acervo da família, hoje sob a guarda de Maria Lucia Pastore e José Roberto Varani. () Vincenzo Pastore/Coleção Dante Pastore. ${ }^{264}$

A árvore organizou o eixo central da imagem, tornando-se o principal ponto de referência da vista criada. Segundo Krauss (2006) a prática do estereoscópio promoveu o uso do termo "vista". ${ }^{265}$ As escolhas tomadas por Pastore aproximam esse registro das imagens estereoscópicas, muitas vezes verticais, inserida na prática do fenômeno das vistas, onde se via a escolha por pontos de referencias verticais e profundidade criadora de efeitos de perspectivas.

Pastore não retratou apenas o "lugar extraordinário", a "maravilha natural" como um fenômeno particular, comum nas vistas oitocentistas (Krauss, 2006, p. 160). Imprimiu seu

\footnotetext{
${ }^{264}$ Essa possível identificação de logradouro foi apontada por Paulo César Garcez Marins.

${ }^{265}$ A vista fotográfica estava ligada à função empírica, aos estudos de topografia, onde a intenção autoral era preterida à observação com total objetividade. Foi a partir da configuração de um discurso estético e de uma ressignificação por parte dos museus e galerias, que o termo paisagem se coadunava à vista, mas forjando um conceito de artista/autoria, perdendo-se a originalidade discursiva anterior.
} 
ponto de vista, num enquadramento central, colocando-se em relação ao espaço, afirmando um preciso recorte: ao definir o campo da imagem, evidentemente o problematizou, dando ao espectador a visão de quem caminhava naquele primeiro plano generosamente acomodado na foto, conduzindo o seu olhar, atraído a percorrer deste ponto inicial todo o espaço fotográfico. ${ }^{266}$ Pastore se colocava em relação à cidade, como sujeito ativo, apreendendo suas sociabilidades.

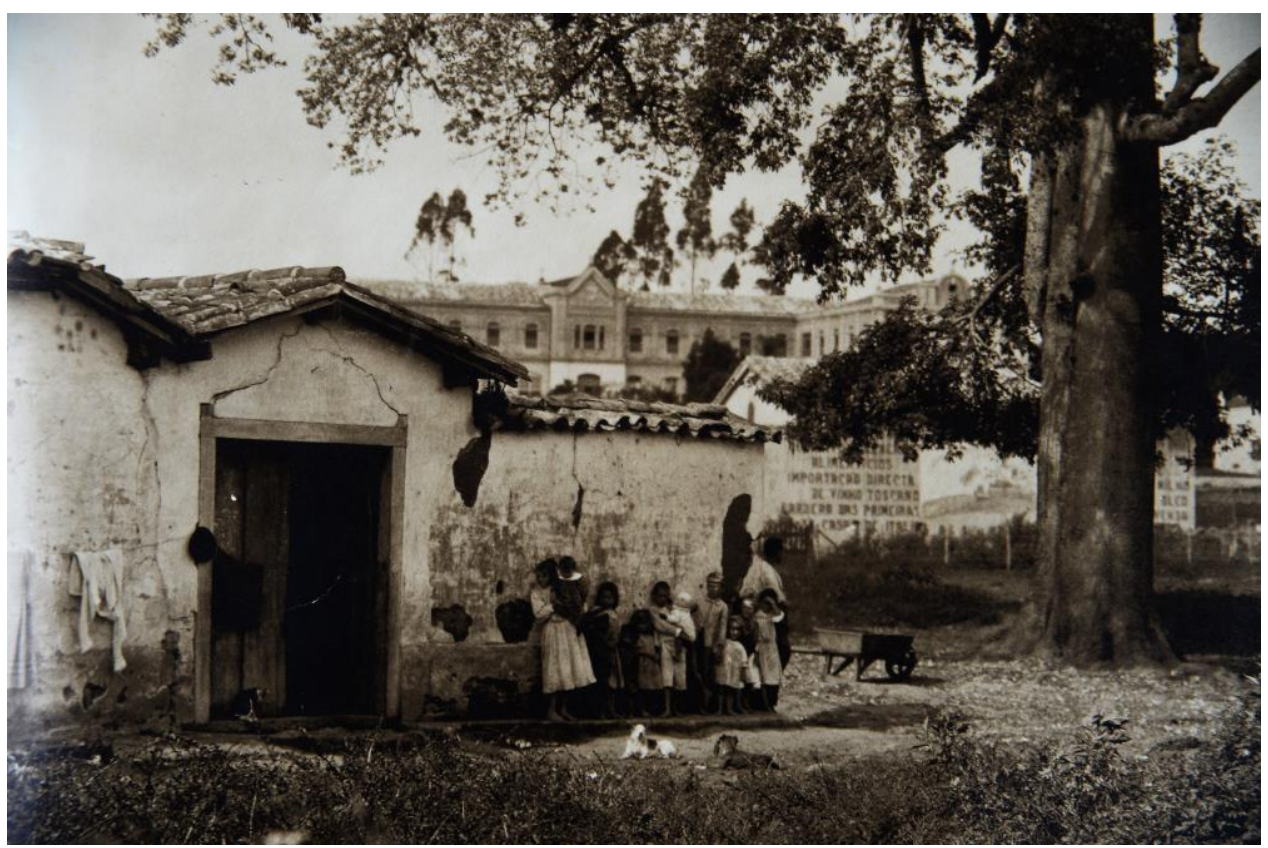

Figura 164:

Detalhe de foto (fig.161) de Vincenzo Pastore, sem data. Ao fundo, vê-se, possivelmente, o Instituto Bom Pastor, no Ipiranga, demolido em 1980 Coleção Dante Pastore.

Há que se destacar o casebre de portas largas, despontando como um motivo aparentemente secundário, posto em oposição à grandeza da árvore centralizada. No entanto, é possível ter nessa composição um traço caro às regras clássicas seguidas por muitos fotógrafos pictorialistas, como aponta Mello (1998): a composição deve equilibrar-se com o motivo principal disposto no plano intermediário da imagem. O casebre então ganha relevo. Esta no ponto atrativo da fotografia.

O varal estendido junto à parede de taipa mostra os sinais irreversíveis da passagem do tempo na habitação rural, o avesso da cidade acima da colina, mas ainda tão perto dela (fig.164). Na duração de um instante, Pastore flagrou crianças brincando. Devem ter

266 Tratamos aqui de um vocabulário controlado empregada por Lima e Carvalho (1997) como parte de uma metodologia cunhada para os estudos de imagens a partir de descritores formais e icônicos facilitando a compreensão de padrões visuais de representação. Os arranjos de enquadramento são sugeridos como ponto de vista central, diagonal, ascensional, descensional, ponto de vista do close, da câmera alta e da rotação de eixo. 
surpreendido o fotógrafo andarilho, particularmente interessado na composição da paisagem distante do prestígio do Triângulo Central.

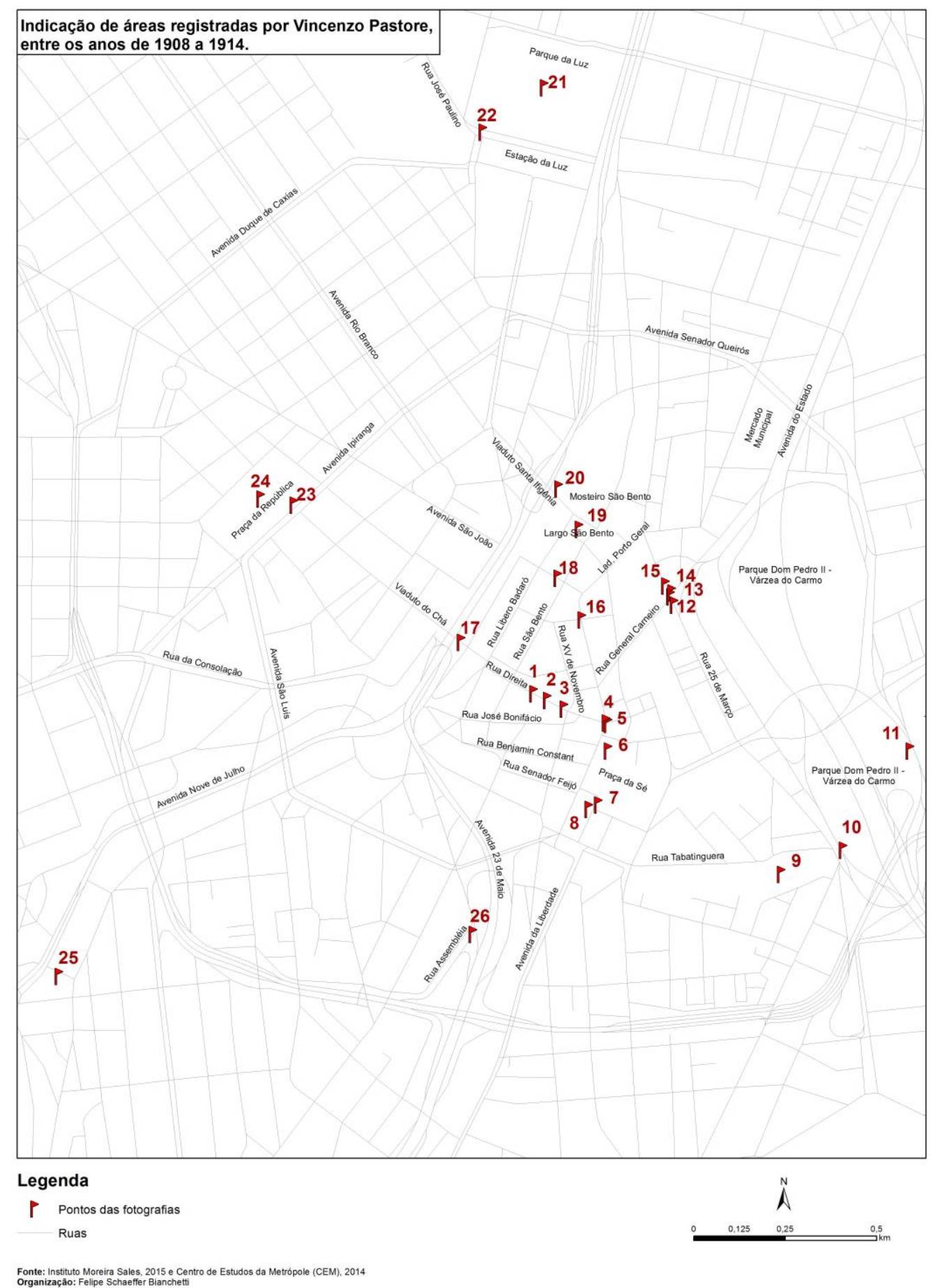

Figura 165: Mapa criado por Felipe Scheeffer Bianchetti, indicando as ruas do Triângulo Central e de seus arredores fotografados por Pastore. A marcação inicia-se na Rua Direita em direção à Sé. 
As outras construções ao centro da imagem, e ainda aquela disposta ao fundo, possivelmente tratando-se do Instituto Bom Pastor, localizado no Ipiranga, constituem as linhas horizontais da composição. Destacá-las revelou outros indícios, mais precisos de sociabilidades que Pastore se aproximou, saindo do seu estúdio na Rua Direita, indicada no mapa com o número 1, até chegar ao Ipiranga, bem adiante da Rua Tabatinguera, indicada com o número 9. Demarcamos a prática de deslocamento do fotógrafo, que extrapolava os limites das áreas centrais indicados na seguinte representação (fig. 165).

Se o fotógrafo caminhou em busca do aleatório, acabou por fixar um campo de conteúdo e relações que pede decifração. A inscrição feita nos muros das casas localizadas no plano intermediário da imagem mostra como os habitantes dos arredores da cidade encontravam modos de garantir ganhos, dimensionando papéis sociais ocupados. A “importação de vinho toscano direto das primeiras casas da Itália” era anunciada de um lado, retomando a vivência de muitos lombardos e toscanos fixados nos bairros de São Paulo, que se dedicavam ao pequeno comércio de vinhos, óleos e comestíveis, modos de viver reproduzidos de sua terra natal na experiência da imigração sondada por Alvim (1986).

Na extensão do muro, vê-se a oferta de milho e coco registrada bem à esquerda, em letras por vezes ilegíveis, num registro que submerge como um flagrante da vida social, nuançando práticas que mobilizam o olhar e a atenção para a história social do cotidiano, do trabalho, do desenraizamento. Se a figura 162 mostra o instante de trabalhar a terra no cultivo do milho, essa foto inédita (fig.163) descortinou as estratégias utilizadas para vendê-lo. Os muros dos arredores, para as bandas do Ipiranga, serviam para o pequeno produtor anunciar o que plantava, vendia e colhia. Pastore deixou vestígios que mostram outros espaços de ocupação e comercialização de produtos agrícolas produzidos nas áreas distantes. Não eram apenas comercializados no Mercado dos Caipiras, ou vizinho Mercado da Vinte e Cinco de Março. Eram vendidos ali, nas teias de relações criadas nos arredores longínquos.

Infelizmente, trata-se de experiências citadinas pouco documentadas, mas essenciais àqueles que sobreviviam das atividades comerciais de abastecimento local, na extensão das novas áreas de ocupação da cidade. ${ }^{267}$ Experiências que Pastore observou de perto, ativando a função da foto documentária comprometida como forma de se inventariar o mundo.

267 Cf. ALVIM, 1986, p. 141-143. A cidade de São Paulo, entre os anos de 1902 a 1910, apresentou um crescimento de $49,4 \%$ de propriedades adquiridas por imigrantes italianos residentes na cidade, mostrando uma expansão da propriedade urbana neste segmento social que buscava ampliar sua rede de sociabilidade 
Essa é uma fotografia (fig.163) que não integra a série de fotos de rua feita por Pastore, localizada no acervo do Instituto Moreira Salles. É uma imagem inédita guardada por seu filho, Dante Pastore, já falecido. Fotografia deixada como herança a sua filha, Maria Lúcia Pastore Varani, que guarda essa imagem. Chama a atenção o uso do negativo em formato maior, quando comparado à maioria das fotos que integram a coleção do IMS, na maioria entre $9 \mathrm{cmX} 12 \mathrm{~cm}$. Essa foi especificamente ampliada com $22,5 \mathrm{~cm} \mathrm{X} 30 \mathrm{~cm}$, sugerindo aparentemente uma ousada composição em descompasso com o tempo da Belle Époque.

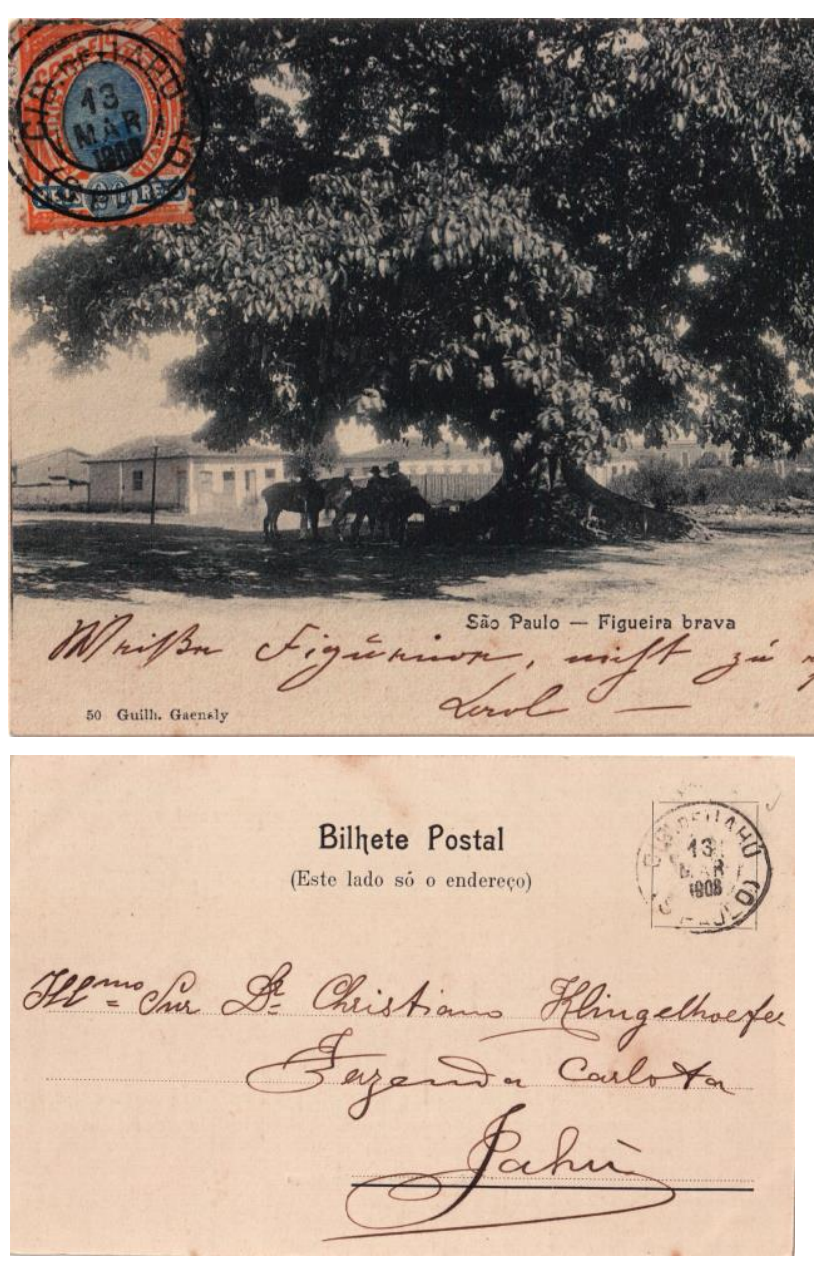

\section{Figura 167:}

Figueira Brava. 1901. @ Guilherme Gaensly. Verso de cartão Postal impresso. Acervo Apparecido Salatini.

Vanessa Costa Ribeiro (2012), ao tratar em seu estudo sobre a circulação de fotografias da Várzea do Carmo ao Parque Dom Pedro II, apresenta um cartão postal produzido por Guilherme Gaensly, o qual nos ajudou a ampliar compreensões da imagem

rompendo o isolamento das áreas rurais, buscando mais médicos, igrejas e escolas, sociabilidades que, segundo Alvim, merecia ter sido pesquisado de modo mais aprofundado. 
produzida por Pastore. ${ }^{268}$ Talvez este fotógrafo estivesse reproduzindo imagens seguindo um "padrão paisagístico" que viu circular na capital (fig.166). As vistas parciais que valorizavam elementos da natureza como a arborização nativa refletem para Ribeiro um padrão de representação estável detectado na produção visual da região entre os anos de 1890 a 1910. O cartão postal de Gaensly e a foto de Pastore remontam a padrões visuais recorrentes no período, inclusive quando "os tipos humanos que circulavam pela várzea" como "lavadeiras, caipiras e tropeiros" surgem nos arranjos de tais representações (idem, 2012, p.53).

O carimbo no verso do bilhete postal (fig.167) e o selo prensado à frente, delineiam a circulação da imagem de Gaensly no ano de 1908. A várzea, seus moradores e todo o ambiente pitoresco valorizado aproximam os fotógrafos num circuito de comercialização de imagens que talvez Pastore tivesse vislumbrado. Descer as colinas rumo aos arredores e às sociabilidades da Várzea, ou dirigir-se ao Ipiranga, talvez guarde a intenção de compor cenas que pudessem ser oferecidas em postais como "Lembrança de São Paulo". ${ }^{269}$

A narrativa do fotógrafo oferece ao intérprete, apesar das distâncias insuperáveis entre o historiador e suas fontes, indícios da inserção social de trabalhadores que buscavam nas ruas maneiras de ganhar a vida, mostrando como a territorialização da cidade era multifacetada, abrigando diferentes modos de se viver, compostos por muitas teias, redes e conexões estruturadas no meio urbano, nos quais Pastore se inseria e reconstruía visualmente.

O Brás, antes local de abrigo para escravizados fugidos, tornou-se no novo século, bairro de moradia daqueles que fugiam dos custosos aluguéis. Pastore, desceu ladeiras. O mapa (fig. 165) representa mais vez os caminhos trilhados pelo fotógrafo que deixava seu estúdio (marcação 1) e deslocava-se pela ladeira Porto Geral (entre numeração 15 a 19), ou pela General Carneiro (indicação 14), seguindo rumo ao Parque Dom Pedro, indicado com número 10 a 14, retratando então as lavadeiras que ocupavam as extensas margens do

268 Guilherme Gaensly (1843-1928) foi muitas vezes considerado como um fotógrafo estrangeiro-brasileiro. Nasceu na Suiça, em 1843, mas chegou ao Brasil aos quatro anos de idade. Trabalhou primeiro em Salvador entre 1860 até os primeiros anos de 1890 e, em São Paulo, até o ínicio da década de 1920. Manteve sociedade até 1900 com o fotógrafo Lindemann. Dedicava-se à produção de retratos de estúdio e depois, na capital paulista o fotógrafo atuou comissionado pela Light.

${ }^{269}$ Entre as últimas décadas do século XIX e dos anos de 1910, Gaensly realizou as quatro seguintes séries de cartões postais assim intituladas: Lembranças de São Paulo, com a fotografia impressa sobre cartão com a técnica de fotogravura, ficando uma parte da frente do postal destinado também a mensagem; Guilherme Gaensly, série em que foi reduzido o espaço para a mensagem escrita na frente do cartão dividindo espaço agora maior para a foto; e ainda as séries A e B produzidas entre 1910 a 1920, com as fotografias já ocupando toda a frente do cartão ficando o verso destinado para o selo postal, endereço e mensagem do remetente. Cf. Frehse, 2011, p. 443-444. 
Tamanduateí com seus esforços diários de trabalho (fig.168). O fotógrafo deixou entrever o quanto os aspectos mais antigos da velha província resistiam, apesar de tudo.

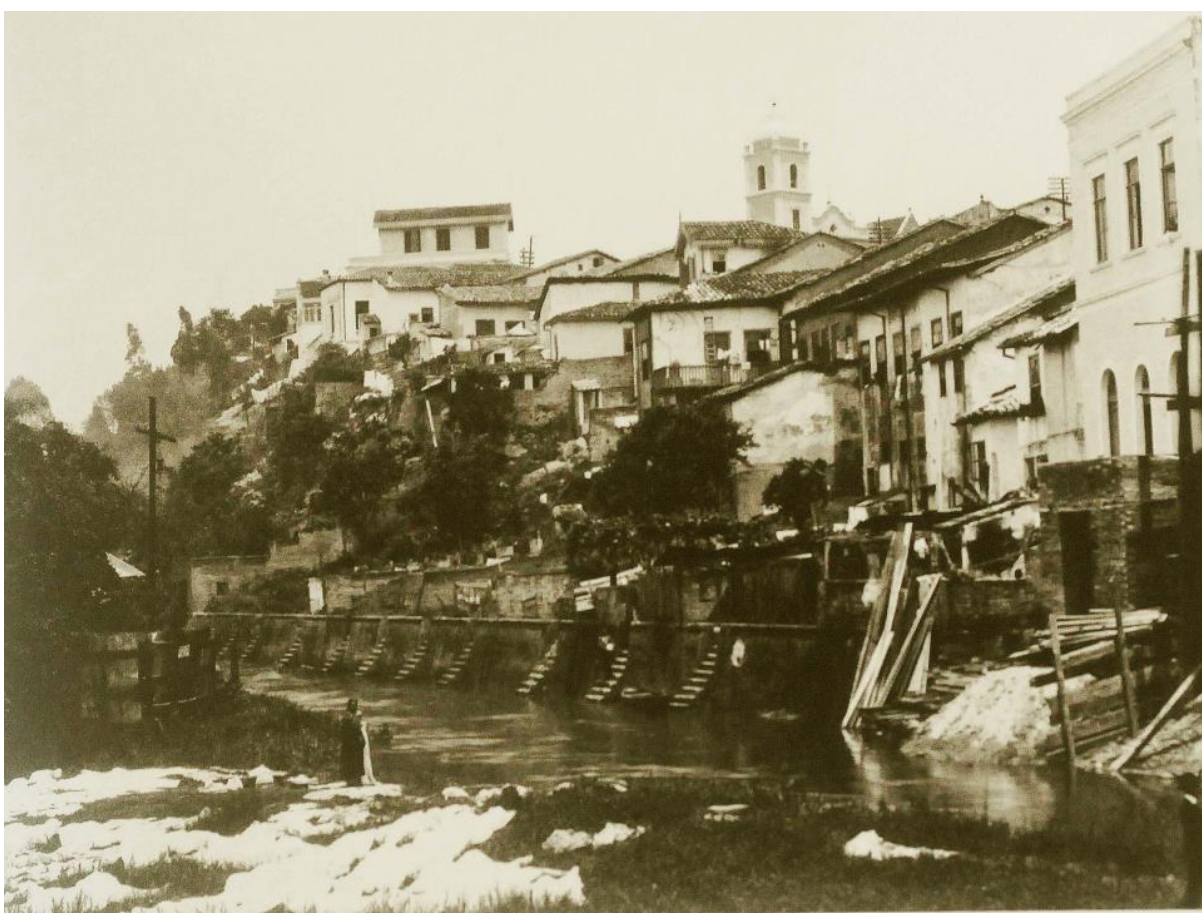

\section{Figura 168:}

"Casario e lavadeiras às margens do Rio

Tamanduateí", região da várzea do Carmo, próximo ao Parque D. Pedro II. 1910. ()

Vincenzo

Pastore/Coleção IMS.

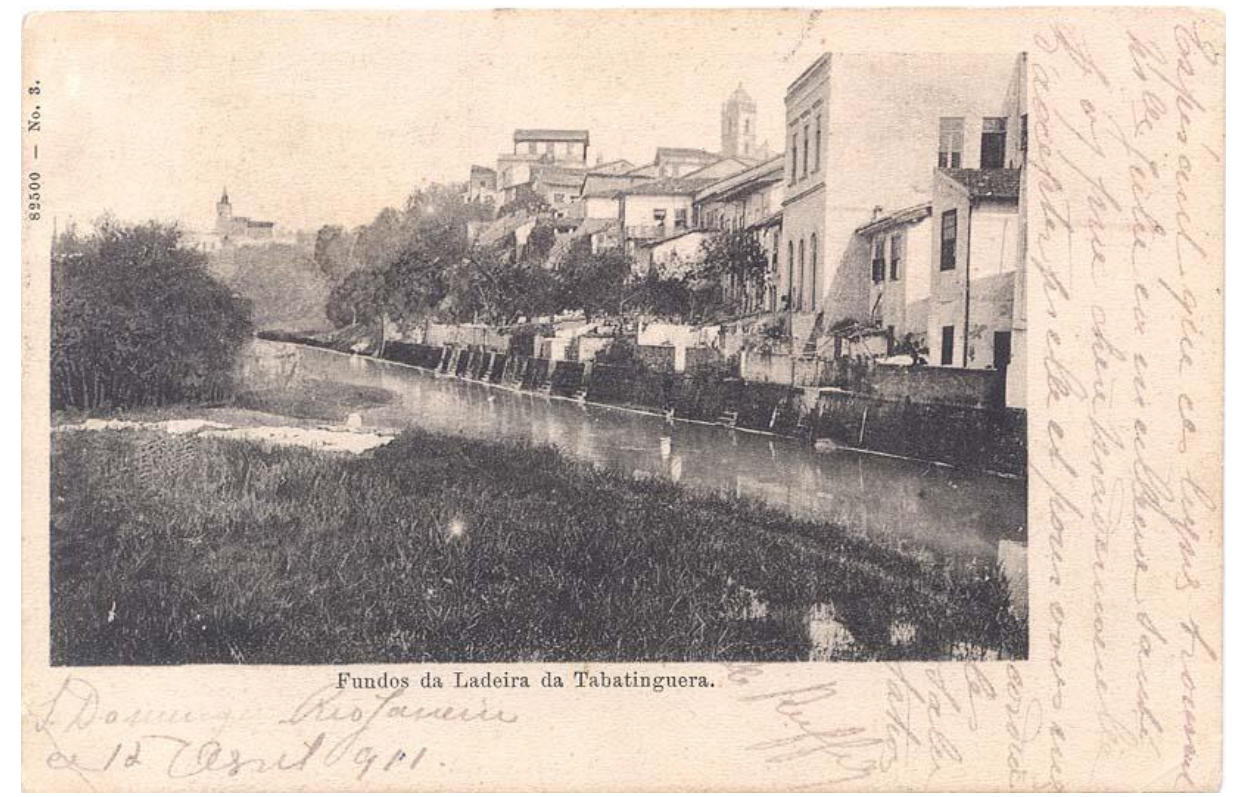

Figura 169: Fundos da Ladeira da

Tabatinguera. Cartão Postal Impresso, 1900 (c) Guilherme Gaensly Acervo Museu Paulista - USP.

É possível que Pastore tenha tentado participar do mesmo circuito de circulação de imagens anunciado por Guilherme Gaensly (fig.169), fotógrafo que oferecia "fotografias de todos os sistemas, cópias e aumentos de todos os tamanhos, para além de uma grande coleção de vistas de São Paulo" (kossoy, p.2002). 
Ribeiro interroga Pastore articulando seu repertório como híbrido, as vezes se aproximando do gênero tido como "padrão paisagístico", acentuado os aspectos formais também vistos no cartão postal produzido por Guilherme Gaensly, que tampouco negava os aspectos coloniais sobreviventes na cidade. A autora pontua a recorrência de elementos icônicos e formais entre os dois registros aproximados: "Pontos de vista em diagonal, a formulação de cadência em função da repetição regular dos telhados do casario e das escadas; o formato horizontal em retangular e o efeito da singularidade" (2012, p. 56).

Mas em Pastore se vê ainda mulheres vivendo em múltiplas contingências históricas. Suas figuras não foram representadas como motivos secundários. É notável a presença de tantos panos estendidos em primeiro plano (fig.168). Talvez o fotógrafo buscasse melhor equilibrar a margem esquerda do rio, mostrando-se mais uma vez atento aos aspectos materiais que cercavam o cotidiano de muitas mulheres. Nos estudos desenvolvidos pela história social, Telles diminuiu o silêncio sobre tais experiências na transição do trabalho escravo para o livre, desvelando aspectos importantes de suas vivências:

Para a maioria das libertas e descendentes de escravas, que os senhores não agraciavam com lotes de terras, não restavam muitas opções (...) Distanciarse das experiências pregressas do cativeiro parece ter motivado as decisões de mulheres adultas e libertas, inseridas no amplo processo de deslocamento espacial facilitado pelas vias férreas: migravam do território circunscrito da dependência a antigos senhores, rompendo, na capital, os antigos laços de submissão. (Telles, 2013, p.106).

Nos fios de sua interpretação as lavadeiras "constituíam a vida ativa da cidade":

Enfrentando a lida diária de longas caminhadas, expostas ao frio, à chuva e ao sol a piano, equilibristas de trouxas pesadas e prazos de entrega, as lavadeiras foram fundamentais à sociedade da higiene, com seus lençóis e roupas brancas. Circulando nas imediações urbanas, em direção às beiras de rios e chafarizes, à procura de emprego, eram impelidas às ruas pelas necessidades do ofício, dependentes de si mesmas e dos parcos ganhos auferidos do exercício desse trabalho desqualificado. (Telles, 2013, p.106).

Era preciso vigor nesse cotidiano da urb. Era preciso vontade de enfrentamento para que fossem como aprofunda Telles (2013, p.35), "agentes de si e da história de sua época". No Arquivo do Estado de São Paulo encontramos um relato carregado de observações parciais e pejorativas, sobre as lavadeiras. Mas, de modo velado, despontam atos de resistências: não foi com passividade ou com desanimo que Anna Pagano, tentava sustentar seus três filhos, Miguel, 12 anos de idade, Antonio de 10 e Constantino de 8. "É lavadeira, vivendo em extrema miséria, sem meios para manutenção dos filhos, que se vestem de trapos" foi a 
descrição feita ao juiz de órfãos sobre a família que vivia na Rua Santa Rosa, n.16, onde "residiam diversas famílias".

Anna foi mais uma mãe a integrar o grupo das mulheres sós e sem recursos, que sonhavam em ver o filho mais velho aprender um ofício: “o mais velho está aprendendo o ofício de sapateiro, sem nada ganhar ainda, porém". ${ }^{270}$ No tempo do cativeiro eram elas, as mulheres negras escravizadas que sabiam economizar suas pequenas rendas, acumulando constantemente seus pecúlios, muitas vezes destinados a compra das alforrias. As mulheres davam logo um jeito de negociar o preço da liberdade de seus filhos, de seus companheiros, deixando a sua própria para depois, documentou Dias (1995). Em liberdade, os esforços se voltaram para especializar a mão-de-obra dos filhos, ou como apontou Bernardo (1998, p.185), o desafio era também economizar com sacrifício para comprar um pequeno terreno e depois levantar cada cômodo. Aos poucos se fazia o casebre que abrigaria a família. Tentavase fugir dos insustentáveis aluguéis recorrendo-se a inúmeras estratégias de sobrevivência: a "poupança não se restringiu a economizar dinheiro, mas a guardar tijolos, janelas, portas, ladrilhos e cimento".

Ao centralizar na imagem os casebres pobres, de quintais voltados para a beira do rio Tamanduateí, Pastore fez o recorte da cidade que o recebia (fig.170). Vê-se na imagem o mesmo cotidiano que envolvia o trabalho de Anna, a lavadeira que enfrentou a justiça para não perder a guarda dos filhos. A Várzea foi retratada por Pastore como espaço de trabalho, desprezando as visões da época que a definiam como o local da feiúra e da sujeira, espaço repugnante e perigoso, local de natureza a ser domesticada. ${ }^{271}$ As obras de retificação com a construção de seu canal gradualmente levariam ao desaparecimento das cenas reafirmadas na narrativa do fotógrafo, interessado pela presença das lavadeiras vistas nas composições de tipos e aspectos. ${ }^{272}$

\footnotetext{
${ }^{270}$ Arquivo do Estado de São Paulo. Maços de Processos de Orphãos. Número 10726. 31 de julho de 1911.

${ }^{271}$ Relato prefeito Washington Luis Apud. Torres. 1969, pp. 181-184.

272 Com as intervenções no rio Tamanduateí, iniciadas entre 1848 e 1851, desapareceram às "sete voltas" dadas pelo rio. As obras retomadas em 1896 a 1915 finalizaram as drenagens e áreas de aterro. Ver Souza. Márcia Maria Cabreira Monteiro de. O povo da caixa e a 25 de março: memórias da imigração síria e libanesa em São Paulo. Tese doutorado. FFLCH-USP, 2002, pp. 40-41.
} 


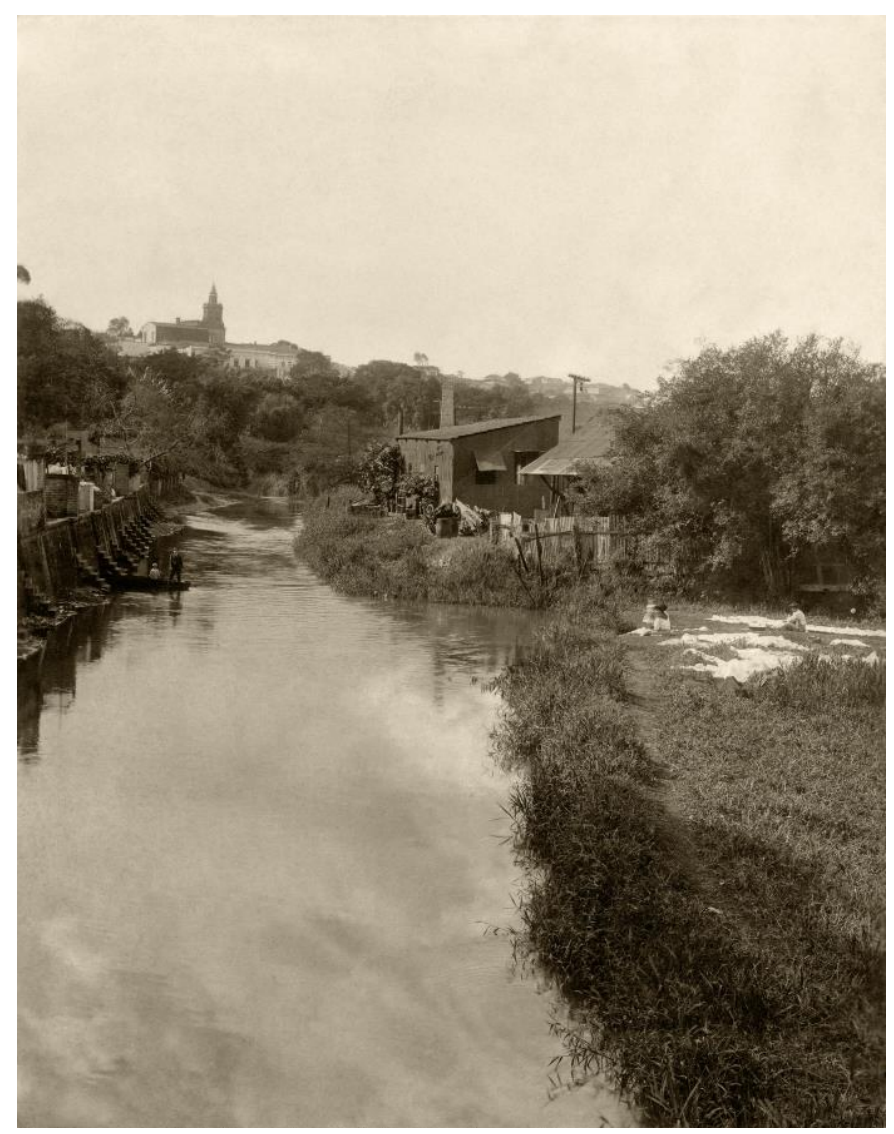

Figura 170: "Rio Tamanduateí antes da retificação". Fotografia em Papel. À direita vê-se uma mulher, possivelmente uma lavadeira, às margens do Rio, próximo ao atual Parque D. Pedro II. Ao fundo, casebres no bairro do Brás. 1910 () Vincenzo Pastore/Coleção IMS.

Apesar da centralidade das águas do rio, o que confere um caráter pitoresco a essa imagem, as duas mulheres sentadas, próximas às roupas brancas dispostas ao chão, mostram um repertório em continuidade. Na região próxima ao Glicério, vê-se o rio ainda cercado do casario em direção a área central da cidade. Do barraco de madeira junto à margem, avista-se a chaminé e o cercadinho de ripas delimitando posses dos habitantes daquele espaço, num tempo quando ainda não lhes faltava o principal recurso de suas sobrevivências autônomas. ${ }^{273}$ Vê-se ainda, um forte traço de linhas verticais representadas pelo rio. Olhar do espectador é levado ao encontro dos casebres do bairro do Brás, até chegar à linha do horizonte. Lá estava Pastore, abaixo da Sé, mais vez próximo ao Parque D. Pedro II (entre número 10 e 11 no mapa).

A pluralidade de sujeitos históricos que viviam do comércio ambulante, de pequenos expedientes, ou lavando roupa para fora, tiveram suas vivências documentadas por Pastore que não deixou de rastrear modos de viver e morar dando visibilidade da presença da

\footnotetext{
273 Segundo Ricardo Mendes, responsável pela organização e classificação de todas as imagens de Pastore pertencentes ao acervo do Instituto Moreira Salles, essa fotografia tem uma "composição formal da fotografia que remete à fase pictórica do autor". Foi usado o processo fotográfico conhecido como goma bicromatado/ pigmento.
} 
população negra e imigrante na cidade, ressaltando aspectos de uma economia popular, que enredava toda a família no trabalho. Fazer o doce em casa para vender na rua, lavar a roupa colocando os filhos para cuidar das peças estendidas nos varais ou nos matos às margens dos rios, nas várzeas onde moravam são práticas recorrentes de muitas mulheres lavadeiras envolvidas em negociações informais; uma vez que cumpriam suas entregas, recebiam com freqüência o pagamento depois, ${ }^{274}$ Uma vez que sobreviviam de trabalhos desqualificados e mal pagos, persistiam no sonho de especializar a mão de obra dos filhos.

\subsection{O fotógrafo nas proximidades dos mercados: zonas de contato e interações na sinuosa geografia paulistana}

Das margens dos rios da cidade, Pastore retratou casebres pobres, abrigos dos "seres andejos" (Holanda, 1994, p.56), progressivamente forçados a ocupar os bairros distantes, de onde seguiam rumo aos mercados para tirar dali o sustento de forma independente. Em seu cotidiano, o isolamento era apenas aparente. Na trajetória de tais movimentações, vimos também peixeiros desprendidos, dissimulando esforços na briga por um espaço para vender o seu peixe, oriundo do Anhangabaú, ou das vívidas águas que confluíam até o Tietê, ou aquelas que corriam pelo Rio Tamanduateí.

A pesca avulsa era prática comum e necessária frente à conjuntura de carestia de alimentos e às constantes altas dos preços dos aluguéis, crescentes nas décadas iniciais do século XX. O encarecimento da vida forçava práticas improvisadas de sobrevivências. Os peixeiros ambulantes no Mercado Grande precisavam ser ágeis ao driblar a fiscalização, afinal o progresso não abria mão de maiores arrecadações:

Existem no dito mercado lugares reservados para os peixeiros que pagam impostos. Esses lugares, porem, são insufficientes e, os pobres commerciantes veem-se atarantados com os concorrentes de outra companhia de pesca e com os peixeiros avulsos que, na hora da distribuição, invadem os seus compartimentos, ou quando não o conseguem espalham a sua mercadoria não somente sobre as bancas que não lhe pertencem, mas também nos corredores quando são dos fiscaes impedidos na calçada da rua (Jornal A Capital, 1913).

O atrevimento daqueles "peixeiros avulsos" e as atitudes irônicas de muitos trabalhadores diante da lei nos lembra Thompson (1998, p. 69) em seus estudos que explicam

\footnotetext{
${ }^{274}$ Era comum nas práticas de trabalhos autônomos exercidos na capital paulista de se receber o pagamento dias depois da tarefa cumprida, prática freqüente entre lavadeiras, engomadeiras, alfaiates... Cf. OLIVEIRA, 2005, pp. 133-150.
} 
como as relações sociais entre diferentes grupos se dão "menos como uma batalha encarniçada e inflexível entre antagonismos sociais irreconciliáveis que um campo de forças societal". Ao sondarmos o cotidiano retratado por Pastore, percebemos experiências vivenciadas nos "limites do possível”, como escreve Thompson, limites no qual os grupos mais empobrecidos, de forma vigorosa e autêntica, típica daqueles obrigados a enfrentar normas impostas verticalmente, desafiavam a instabilidade e as ameaças trazidas com as medidas de disciplinarização do trabalho e das ruas. Medidas que alcançavam pouco controle: apropriação e transgressão eram corriqueiras para parte dessa população que não pode ser entendida somente sob a conceituação apressada de pobres ou de grupos despossuídos tão somente.

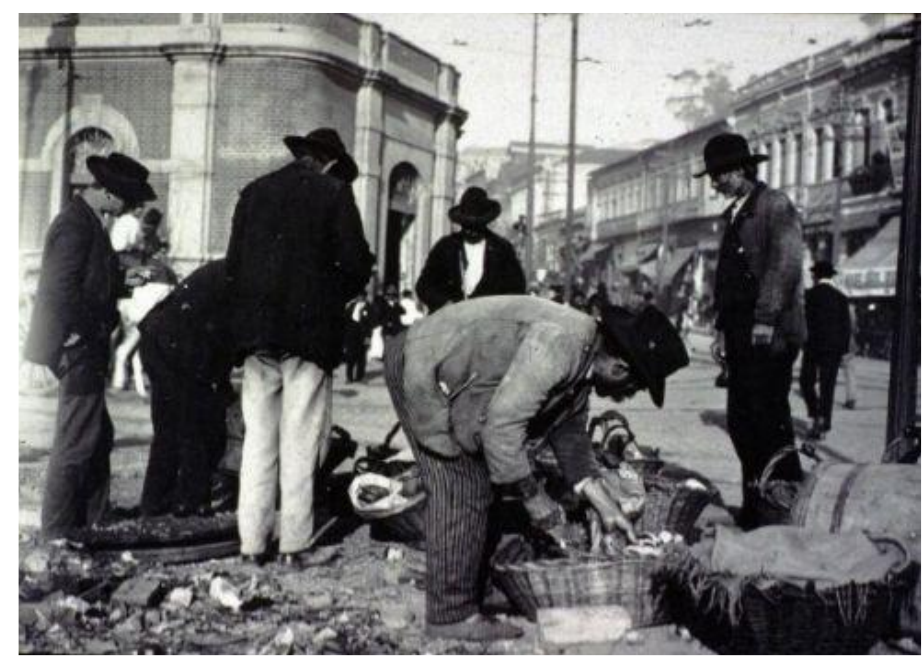

\section{Figura 171:}

Fotografia em Papel. "Comércio em frente ao Mercado Municipal", esquina das Ruas 25 de Março e General Carneiro (C) Vincenzo Pastores/Instituto Moreira Salles.

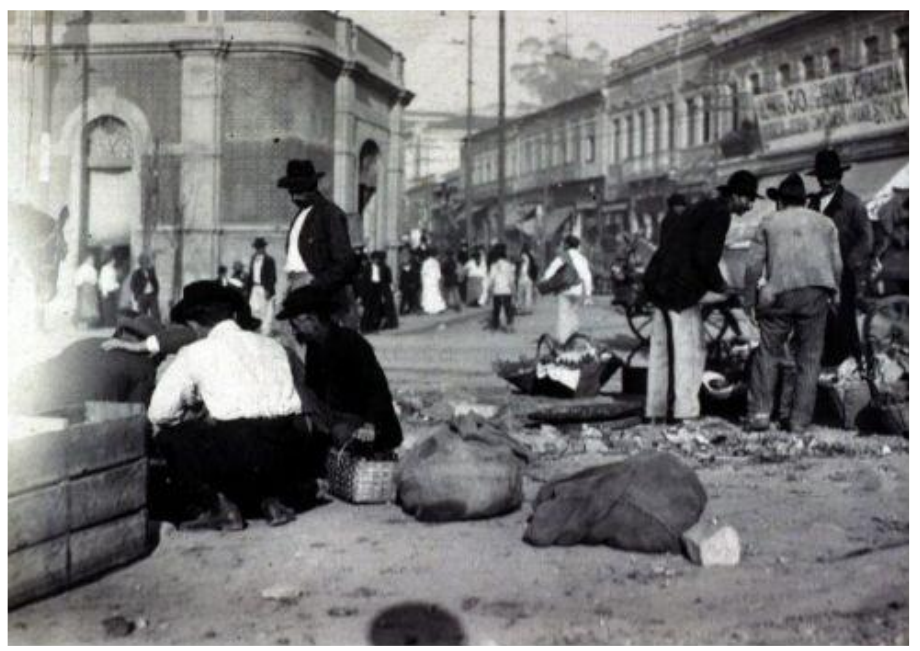

Figura 172: "Movimento em frente ao Mercado Municipal", esquina das Ruas 25 de Março e General Carneiro. 1910 @ Vincenzo Pastores/Instituto Moreira Salles.

No mercado dos peixeiros na escadaria do Carmo, muitos vendedores de peixes driblavam a fiscalização nas calçadas, invadiam compartimentos não destinados a eles, disputavam as bancas com ousadia e certo descaso diante da indignação de seus concorrentes, na zona oriental da cidade. Lá se concentravam os mercados e a redes atacadistas, compondo 
as redes de trabalho e de abastecimento. Redes de negócios que Pastore desejou ver de perto, sondando a disputa por espaços onde espalhavam no chão sacos e caixotes, muitos cestos cobertos com panos rústicos de grossos fios, que protegiam os artigos levados aos consumidores. O fotógrafo parecia querer diluir a cisão entre o urbano e o rural. As pequenas posses de muitos vendedores ambulantes em atividade nas esquinas e travessas do Mercado da Vinte e Cinco de Março e do Mercado dos Caipiras foram documentadas, elegendo-se aspectos de uma cultura material colocada em primeiro plano (fig.171).

Na maioria das vezes, prevalece à opção por planos individualizando os retratados. Aqui temos imagens mais contextualizadoras (fig.172), dando a ver, de modo mais abrangente, o burburinho cotidiano ao pé das ladeiras. Pastore se embrenhava nesse contexto.

Entre os peixeiros que viviam de suas atividades ambulantes, segundo Penteado (2003, p. 45-46), muitos eram italianos, bareses de Polignano a Mare, centro de pescadores na Itália, "gente alegre e barulhenta, devota de São Vito Mártir". Gente que deve ter trocado uma boa conversa com Pastore, com o conterrâneo fotógrafo, compartilhando o mesmo idioma, mesmos gestos de devoção, mesmo desafio de sobreviver na experiência da imigração, quando organizaram um comércio "para tudo e para todos" (BRUNO, 1954, p.1.168).

Não existia na cidade uma rede comercial distribuída de forma abrangente. Os mercados localizavam-se nas áreas centrais e suas imediações. Não atendiam às necessidades da população que vivia nos bairros de natureza residencial. Ruas e ruas se seguiam sem uma casa de comércio. Os mercados e seus arredores, somados à venda feita de porta em porta, por toda a cidade, completavam a rede de abastecimento da capital (Oliveira 2005).

Nas práticas errantes da venda ambulante, contava-se também com os arredores do barracão do Largo São Paulo, com o mercado no Largo da Concórdia, este menos frequentado apesar de ser considerado, nos anos de 1900, como o mais elegante, "rodeado por duas galerias interiores, com madeiramento em forma de xadrez, com quatro portas de entrada e quarenta e oito janelas" (BRUNO, 1954, p.1.144).

Muitos pescadores e caipiras vinham do Brás rumo ao concorrido Mercado Grande, o velho conhecido Mercado dos Caipiras, localizado entre as ruas Vinte e Cinco de Março e Lourenço Geneco, ao fim da Rua General Carneiro, tendo logo à frente o Mercado do Peixe (PINTO, 1979, p.167), constituindo-se como um espaço de paisagem movimentada onde se desenrolavam diferentes apropriações sociais.

Ao longo do tempo o espaço da rua 25 de março adquiriu diferentes usos e significados. Conforme foi mostrado até agora, a área onde hoje se encontra essa rua 
já foi leito do Tamanduateí, depósito de lixo, área residencial, área de comércio, primeiro de pescadores e lavradores depois de mascates italianos, alemães, judeus, portugueses e árabes (SOUZA, 2002, p.91).

O olhar de Pastore buscava pormenores, curioso por gestos particularizados, individuais, na intimidade de cada retratado (fig.173). O fotógrafo ao provocar efeitos de realidade guardou a presença deste senhor próximo ao Mercado dos Caipiras, um instante do café da manhã de um possível vendedor de aves, aparentemente desatento à presença da câmera.

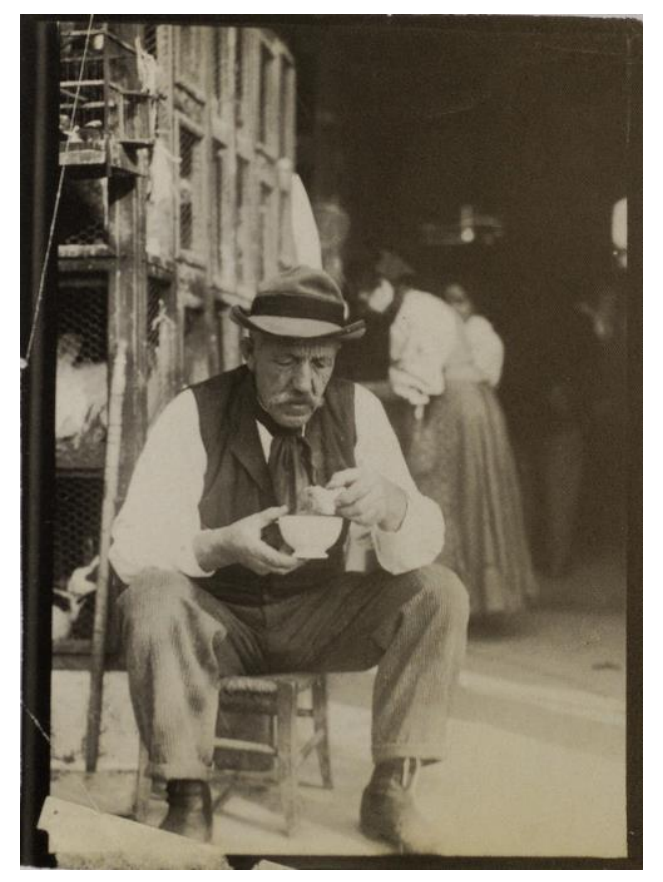

Figura 173: "Homem sentado, comendo, próximo às gaiolas com galinhas"; foto realizada próximo a uma das entradas do Mercado dos Caipiras, por volta de 1910. (C) Vincenzo Pastore/Instituto Moreira Salles.

A aparência de flagrante, a desatenção do retratado, a não centralização total do motivo, deslocando a personagem da centralidade da foto foram gestos conscientes do fotógrafo, num enquadramento incomum para a época. ${ }^{275}$ Uma das moças ao fundo não deixou de espiar o instante da tomada da foto. Talvez, pouco imaginou o quanto integraria a composição, que experimentava novos enquadramentos e inovadora atitude fotográfica.

O café da manhã desse senhor pode indiciar uma prática cotidiana. Sabe-se dos tantos vendeiros, moradores dos bairros distantes como Penha, Santana, Santo Amaro, Guarulhos, Nossa Senhora do Ô, ou da Várzea vizinha, que cedo levantavam para se dirigir aos mercados das regiões mais centrais da cidade, onde punham à venda seus produtos agrícolas, medicinais artesanais, madeira inclusive. Segundo relato de viajantes, às onze horas da manhã muitos

\footnotetext{
275 Segundo Rocha, alguns retratos realizados por Paul Strand, em 1916, nos Estados Unidos, na série Portrait, apresentaram um descentramento da pessoa retratada, com cortes em partes da figura. Enquadramento também tido como incomum na época. Cf. Rocha. A poética fotográfica de Paul Strand. 2012, p. 143-147.
} 
eram ainda encontrados no velho mercado. ${ }^{276}$ Teríamos aqui um quase ato falho de quem se descuida e toma a foto como um duplo, um instante imbricado ao real vivido? Ou seria mais o gesto de reconhecer em Pastore a habilidade de preservar cenas tão inusitadas, tão singelas, tirando da invisibilidade sociabilidades ocultadas? A assertiva da foto como fragmento do passado reforça o valor da representação.

O aspecto rural da cidade era visto por uma mansidão de homens chegados a pé ou trazendo suas carroças puxadas por mulas com cangalhas; muitos carros de bois e outros tantos velhos pangarés com alguma força para ajudar no sustento de muitos verdureiros ambulantes que tomavam os mercados. Carroças chegavam do Brás, da rua Lavapés, no Bexiga, ou das margens do Tietê, no reduto de Belém, ou Vila Maria. Muitos deles como observou Penteado (2003, p.65), chegavam das regiões da Penha, do Tatuapé ou de locais ainda mais distantes: Nazaré, Mogi das Cruzes, Santa Isabel, Poá, Itaquaquecetuba, Guarulhos, Itaquera, vindos também de Cotia, de Guarulhos, de Santo Amaro ou Itapecerica, ou ainda de Parnaíba.

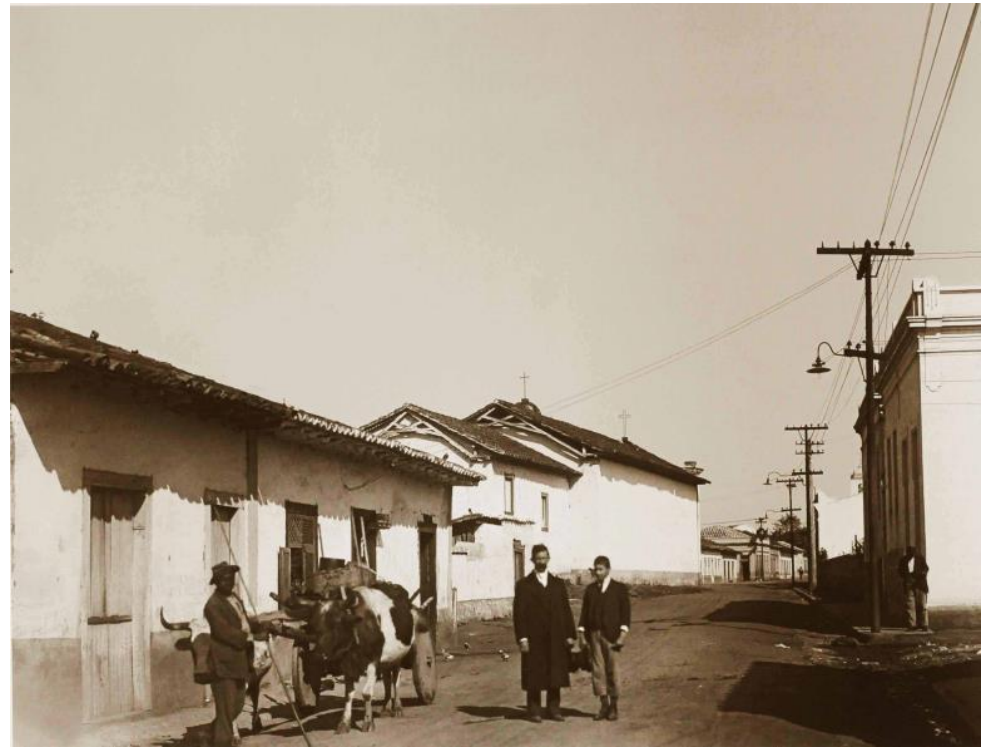

Figura 174: Rua da Penha, tendo ao fundo a antiga igrejinha da Penha. Casebres com janela de rótulas à esquerda da foto. $1905-1912$ ( Aurélio Becherini

A mobilidade era exigida de muitos trabalhadores egressos do campo. Foi preciso na cidade aprender a trocar de profissão com agilidade: Ser carregador, vendedor de galinha, entregador, ou, quem sabe, às vezes, se oferecer como ajudante de pedreiro, matador de insetos e ratos, carregador de entulhos ou ainda capinar matos, lavar casas, rachar lenha à domicílio. Práticas mal remuneradas. Eram serviços pesados, empregados também por imigrantes. Pedreiros, pintores, carpinteiros, marceneiros... Foram muitas as experiências de 
improvisação. A pouca ou nenhuma especialidade não diminuía a esfera de atuação de homens jovens ou mais envelhecidos (Fig.174).

O fotógrafo Aurélio Becherini também retratou os arredores da urbe como meio de subsistência para homens negros idosos vindos da região distante da Penha. A vara do guião conduzia os bois. Na canga rústica via-se a inscrição G. C. C. Santos. A presença dos "carros de bois que guinchavam pelas ruas sopesando enormes cargas e guiados por míseros cativos que empunhavam compridas varas com um ferrão na ponta" (Pinto, 1979, p. VIII) aparece nos relatos memorialistas como uma cena da São Paulo antiga, associada ao tempo dos lampiões suspensos em madeira, tempos de uma "pobre aldeia", abrigo da mocidade da Academia do Largo São Francisco.

Denunciam-se as camadas sobrepostas na fisionomia urbana. Janelas de rótula, por volta de 1910, eram ainda vistas nas casas térreas dos arrabaldes. Reproduziam os ideais de recato e distinção, rompendo as "fronteiras sutis" entre a casa e a rua. Com elas viabilizava-se uma prática de comunicação e sociabilidade já documentada por Paulo César Garcez Marins (2011). No momento da foto estavam totalmente abertas, sem disfarçar as condições matérias dos menos abonados. De uma delas, o menino assistia ao carro de boi passar, atraído primeiro pelo "chiar monótono e irritante" ainda ouvido em início de novo século, palco de um vaivém constante pela cidade: nas lembranças de Penteado (2003), vê-se o vendedor de mel numa carrocinha; os tripeiros, na maioria, velhos bareses, que empurravam suas carroças ao passo que tocavam uma buzina de chifre de boi pelos arredores da cidade, já que até mesmo os açougues foram afastados das ruas centrais, a partir de 1890, assim como os mercados empurrados para a Rua Rangel Pestana e para os bairros do Bom Retiro, Barra Funda, Brás, Mooca e Cambuci. Os tintureiros ao recolherem roupas entre uma casa e outra, cruzavam com os amoladores. Estes chamavam a atenção da freguesia tocando gaita. O pipoqueiro assobiava; o vendedor de amendoim falava rápido; o popular vendedor de bananas imprimia sua marca aos berros: "Banana do Carabina, freguês! A cinco por um tostão" (Penteado, 2003, p.206).

Práticas sinuosas, "existência andeja", como apontou Sérgio Buarque de Holanda (1995), são rastreadas não de modo fácil; aproximação somente obtida com uma cuidadosa sondagem da experiência de um "gênero de vida" quase sempre observados "pelas fímbrias ou pelas sombras, num olhar espiado, indireto, que nos leva a sentir mais do que ver, a exuberância do que permanece invisível", escreve Peres (2006, p.58). 

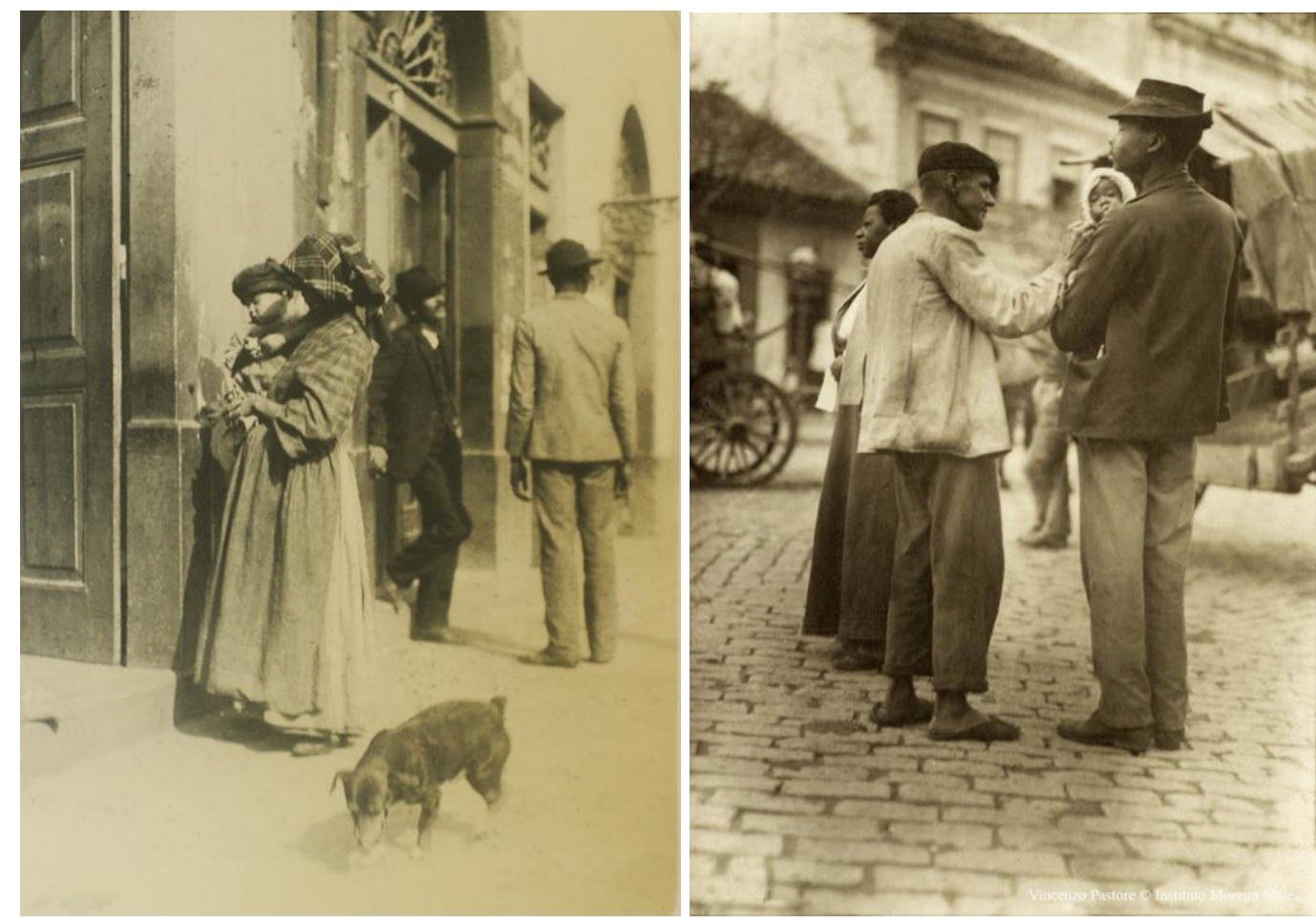

Figuras 175 e 176: À esquerda "Mulher com criança no colo"; à direita "Mulher e dois homens com bebê"; Possivelmente fotos feitas próximas ao Mercado dos Caipiras, 1910 @ Vincenzo Pastore/Instituto Moreira Salles

Pastore espiava essa realidade vibrante, como um ser também andejo, interessado por cenas fugazes, dando visibilidade à interação entre brancos e negros, nos momentos de encontro nas calçadas e soleiras das portas de estabelecimentos comerciais, como vemos algumas vezes em segundo plano (fig.175). Sabe-se que italianos e negros conviviam também na Barra Funda. Moravam no bairro. Sabe-se como nas primeiras décadas do século XX, a família negra, como afirma Bernardo (1998) ainda apresentava a mesma estrutura de períodos de escravidão. A presença da mulher e dos filhos a compunha. Mas Pastore deu mais a ver. Quis retratar possíveis pais levando seus filhos, em flagrantes gestos de afeto e sociabilidades difíceis de alcançar (fig.176).

Para chegar ao Mercado Grande na Rua Vinte e Cinco de Março ou se aproximar do Mercado dos Caipiras, quase anexo àquele, Pastore talvez tenha descido a antiga Ladeira da Constituição, depois chamada de Florêncio de Abreu. Poderia ter escolhido a ladeira Porto Geral ou ainda a General Carneiro, antes chamada de Ladeira João Alfredo. Todas essas davam acesso ao Mercado dos Caipiras, repleto de peixes e hortaliças postos à venda, avizinhando-se de raizeiros, todos formando um imenso fluxo de comercialização. ${ }^{277}$

277 Existia ainda o Mercado Rural de Pinheiros, criado depois da aprovação da lei no 1.240, de 20 de setembro de 1909, na gestão de Antônio da Silva Prado. Tropeiros vindos também de Santo Amaro, que seguiam antes 
O investimento no Mercado da Vinte e Cinco de Março garantia a alimentação da população da várzea, de baixa renda na maioria, abastecendo a cidade também acima da colina. No Mercado dos Caipiras se comercializava verduras e frutas. Além de cachimbos, panelas de barro e colheres de pau, mercadorias citadas por Bruno (1954, p.1.145), lá se encontrava também farinha de mandioca, milho, doces de frutas, aves domésticas, papagaios, araras, macacos, ouriços, ervas medicinais, como aponta Penteado (2003, p. 46). O toucinho, o feijão, o porco ou farinha costumavam ser encontrados nas casinhas enfileiradas à esquerda da Ladeira do Carmo, nesse comércio que atendia a demanda por alimentos básicos nas últimas décadas dos oitocentos. Vendas arrendadas eram submetidas, segundo Oliveira (2005, p. 70) às cobranças municipais feitas aos sitiantes que as sublocavam. Homens negros para as bandas do Brás comercializavam os capins produzidos nesses arredores. ${ }^{278}$

Ao se observar tais práticas, uma visualização cartográfica da cidade se ilumina. $\mathrm{O}$ fato de Pastore ser um fotógrafo que vivia no centro da cidade talvez o tenha colocado mais facilmente em contato com essa realidade cotidiana. Podia se deslocar da Rua Direita, onde matinha seu estúdio e residência, indicada no mapa (fig.165) com o número 1, passando pelo Largo São Bento, com indicação 19, em direção à Estação e ao Parque da Luz, indicação 21 e 22; com facilidade chegava ao Largo da Sé, indicado entre os números 6 ao 7, podendo seguir pelas ladeiras que levariam à região dos mercados, com indicações de 12 à 15 .

O olhar imigrante de Pastore, ao descer as ladeiras da colina, deve ter observado toda a extensão de declive da ladeira Porto Geral. À esquerda, mulheres e homens punham-se nas calçadas - alguns em pé, outros sentados -, todos com cestos ou pequenos tabuleiros, rodeados de clientes, como mostram muitas imagens feitas no período. O fotógrafo era um espectador de tais contingências. Ao pé das colinas Pastore parecia querer ver de perto, como se quisesse descrever ações de sobrevivência com mais profundidade (fig. 177, 178 e 179). As pessoas encontram-se de costas, de perfil, aparentemente apenas atentas ao trabalho, organizando seus produtos, convencendo os compradores. Esses recortes particularizados evocam sentidos menos generalizantes da urbanização.

rumo ao largo Treze de Maio, a partir de 1910 seguiriam rumo a esse novo mercado. A municipalidade aplicava o mesmo regulamento e taxas cobradas dos tropeiros do Mercado da Vinte e Cinco de Março, exclusiva para cada um deles. As andanças dos fiscais que controlavam as guias de acesso indiciam estratégias para se garantir uma maior arrecadação.

${ }^{278}$ Mecanismos de interação social confluem na organização dos espaços. O movimento na região da rua Vinte e Cinco de Março levou a construção do Depósito Municipal, obra aprovada pela lei no 1.250, em outubro de 1909, expressando a importância deste local de abastecimento, caminho obrigatório para se chegar ao Brás e seguir rumo à Penha e depois ao Belenzinho. 

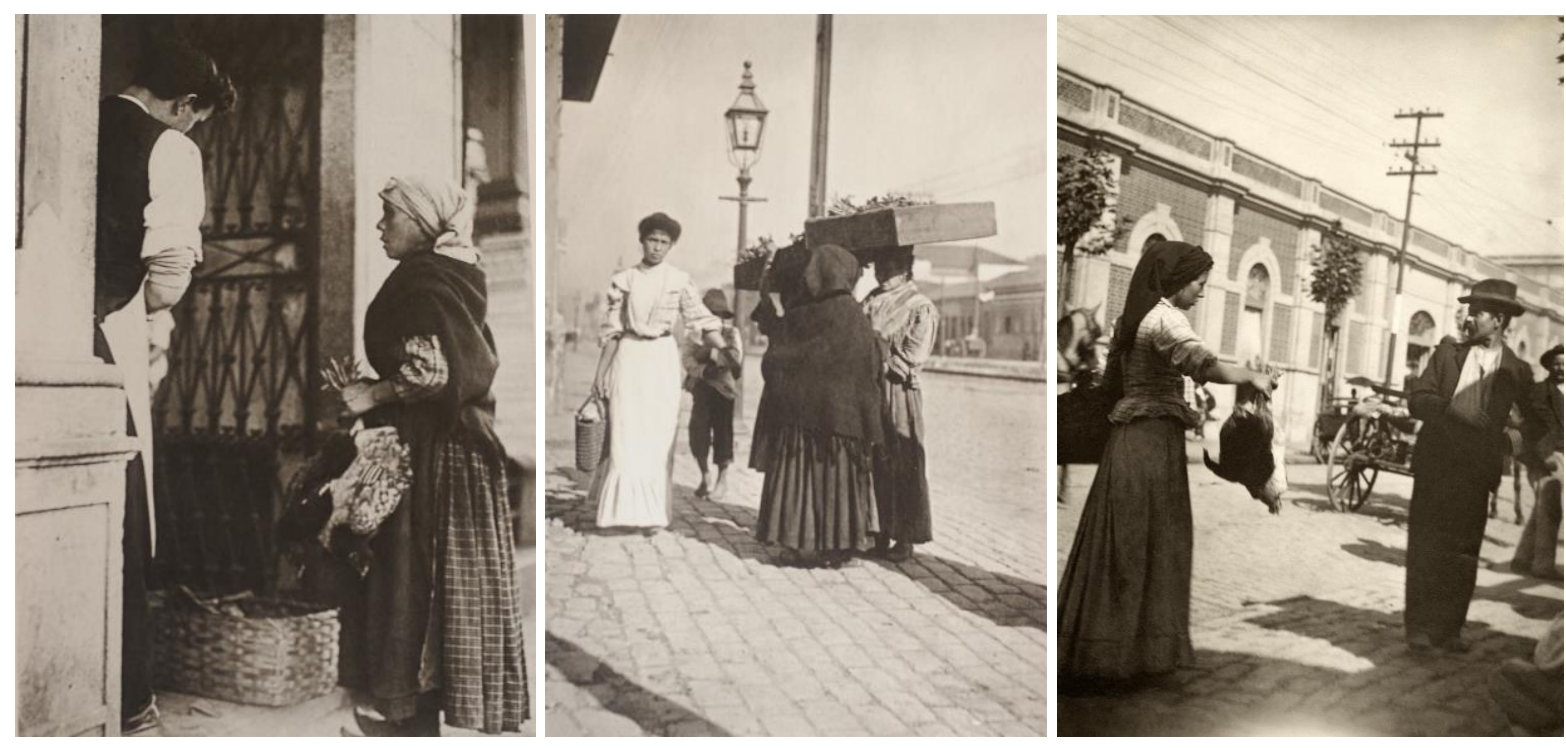

Figuras 177, 178 e 179: À esquerda, "Vendedora de galinhas em porta de estabelecimento comercial"; Na imagem centralizada, "Grupo de mulheres, vendedoras de verduras e transeunte" possivelmente voltado das compras feitas na região dos mercados. À direita, "Vendedora de galinha" em cena de rua adjacente ao Mercado Municipal, 1910 @ Vincenzo Pastore/IMS.

Pastore documentou a presença de muitas mulheres nas ruas transformadas em lugar de encontro, trabalho, lugar de conversas. Sua narrativa nos impele a sondar as experiências de muitas imigrantes, que saiam às ruas negociando o melhor preço das verduras produzidas nas chácaras embrenhadas nos matos da Penha, onde criavam porcos e vacas. ${ }^{279}$ Galinhas branca, vermelha, carijó, carijozinha, eram oferecidas aos clientes. Os caixotes de verduras e frutas eram levados sobre as cabeças, na lida de sol a sol, protegendo-se dele como podiam nos longos trajetos feitos a pé até os mercados, região que já anunciava a sua vocação de área de grande circulação e concentração de pessoas, característica mantida até hoje.

Se a imagem à direita (fig.179), revelava ao fundo os muros de tijolos aparentes, trazendo um aspecto do mercado reformado em 1907, como afirmou Frehse (2011), a mulher que carregava o seu grande cesto com muitas galinhas (fig.177) talvez tenha sido retratada num momento de entrega de suas mercadorias acima da colina. Talvez a sua lida diária fosse mesmo bater nas portas de clientes que talvez já esperassem a vendeira passar. Tratamos de um comércio autônomo e improvisado que poderia ser lucrativo. $\mathrm{O}$ pedido do farmacêutico Bento de Sousa e Castro, enviado à Câmara Municipal, mostra expectativas em torno da

\footnotetext{
279 Ver estudo de Bernardo sobre o cotidiano de trabalho guardado nas memórias de homens e mulheres idosos, negros e imigrantes. Bernardo, 1998, p. 45.
} 
atividade ambulante. Solicitava em seu requerimento concessão por um período de 20 anos para "utilizar automóvel apropriado para a venda pelas ruas de aves, frutas e verduras". 280

Foi anexado ao pedido uma fotografia do carro "com tela de arame e motor suficiente para conduzir a carga e o operador". O percurso já havia inclusive sido traçado: "percorrer os subúrbios, onde ocorrem aglomerações de operários, passando perto das fábricas nas horas das refeições". Letras "garrafaes" seriam colocadas nos carros especiais para aves e outros para frutas e verduras, com preços "ao alcance de todo público". A solicitação que revela o desejo de lucrar com o abastecimento da cidade foi indeferida, sob a alegação oficial de se tratar de "actos de commercio sobre os quaes ninguém pode ter concessão". 281

Se Pastore ajuda a reconstituir essas sociabilidades na época postas na invisibilidade é preciso observar a série fotográfica para além do conteúdo visual documentado. Apesar de todo esforço para se compreender as sociabilidades vistas por Pastore, a interpretação não pode se encerrar nesse viés, como bem orientou Meneses (1996). Entender as práticas fotográficas e os processos históricos que envolvem Pastore e todo imaginário imbricado em sua forma de ver e pensar o mundo é o procedimento que nos parece necessário no estudo das imagens, inferência que leva agora para outro enfoque reflexivo voltado para a circulação das imagens sustentadas em certas convenções visuais.

\subsection{A imagem nos caminhos de sua longa duração}

Entre a pauta dos pictorialistas, que se manifestavam por meio da revista italiana "La Fotografia Artística", conselhos foram dados os fotógrafos com ambições pictóricas:

É importante que o estudo da história da arte desde sua origem até aos movimentos atuais, para assim existir um conhecimento abrangente do academicismo histórico, não para se produzir uma cópia dos mestres do passado, mas para se apresentar um trabalho original que manifeste o próprio percurso da fotografia. (Zanini, 2013, p. 54. Tradução Nossa)

Acreditamos ver Pastore apresentando-se como um profissional em diálogo com tais orientações que valorizavam a tradição pictórica precedente, estabelecida pelas belas artes. Se as cenas de paisagens constituem uma imagem clássica da pintura, as cenas de gênero e tipos

\footnotetext{
${ }^{280}$ Arquivo Histórico Municipal de São Paulo. Ofício n 101 de 26 de julho de 1908. Ver Papéis Avulsos. 1908. Localização 2052. Acervo de manuscritos.

${ }^{281}$ Arquivo Histórico Municipal de São Paulo. Ofício n 101 de 26 de julho de 1908. Ver Papéis Avulsos. 1908. Localização 2052. Acervo de manuscritos.
} 
sociais acompanharam as produções de muitos artistas em suas telas à óleo, em suas aquarelas, gravuras, na produção de muitos litógrafos, desdobrando-se depois em produções fotográficas. Desse modo, essa investigação, começa a se inclinar para o potencial icônico de tais representações, do qual Pastore também fez uso, demonstrando o quanto sua prática fotográfica era híbrida.

O espaço urbano e os tipos humanos foram segundo Costa e Silva (2004, p.18), os principais temas registrados na produção fotográfica do século XIX. São estas premissas que confirmam que "havia a intenção explícita de documentar o mundo e representá-lo em suas variáveis sociais e materiais". A fotografia oitocentista documentou experiências que haviam sido antes aconselhadas por Diderot: "procurem as cenas públicas, observem as ruas, os mercados, as casas e ficarão com a idéia exata do verdadeiro movimento nas atividades da vida". 282

Se está orientação foi à princípio subjacente às propostas temáticas estetizadas pela pintura, seria depois incorporada nas produções de imagens fotográficas, que adaptavam-se à tais concepções. Tratamos, portanto, de convenções que atravessavam a visualidade oitocentista, aproximando a fotografia das demais formas de representação. As imagens criadas por Pastore reativaram os mesmos aspectos documentados em muitas estampas litográficas de circulação mais antiga: a linguagem dos corpos como definiu Turazzi (2002, p.31), se multiplicava através do traçado dos "gestos, atitudes, roupas, atributos e ocupações". Como não falar da força de tais convenções?

A tradição das representações de costumes e de tipos sociais, entendida como uma busca de síntese de outra cultura está, de certo modo, associada à tradição do livro ilustrado que tanto alimentou esse imaginário visual, depois retro-alimentado pelos livros que também estampavam fotografias, nos remetendo para um circuito social de imagens enraizadas na cultura.

Nesse circuito, a representação fotográfica também passou a operar com a categoria do tipo, ainda mais vulgarizada, pelo crescente acesso à imagem. Esse repertório representando tantos vendeiros foi visto nas estampas que circulavam avulsas ou organizadas em álbuns no século XIX, o século das imagens segundo Le Men (1996). Tem-se assim um repertório fundado a partir das convenções estabelecidas, primeiro, na produção de aquarelas, gravuras e

282 Diderot, Denis. Essais sur la peinture. Paris. 1785. APUD Turazzi, 2002, p. 22. 
litografias, depois ampliado pela fotografia, que rapidamente se tornou o maior meio de difusão de imagens pertinentes a essa economia visual:

A gama de técnicas de impressão tradicionais, da primitiva xilogravura até o desenvolvimento da água forte e da gravura no final da Idade Média, deu um poder progressivamente ampliado de multiplicação à imagem visual ao longo dos séculos. Mas o século XIX trouxe à lista de técnicas a uma conclusão triunfante, adicionando, em primeiro lugar, a litografia, e depois rapidamente a suplantando pelo processo reprodutivo da fotografia. (Bann, 2001, p.16. Tradução nossa)

A existência dos homens como tipo foi marcante no horizonte das artes e das representações de modo abrangente. Foram construções visuais de cunho reducionista que espelharam o desejo de apresentar o mundo a partir da constituição de imagens sintéticas, ou seja, trata-se de uma narrativa visual que historicamente se impunha como materialidade constituída como o relato de hábitos e costumes populares, mas também de aspectos colocados diante do fotógrafo como algo relevante a ser registrado.

Os fotógrafos talvez tomados por um instante de sobressalto, viam diante de si uma imagem que os requisitava, respondendo como imagem do trabalho conjugada ao tipo social, figuras metonímicas de uma vasta iconografia que mostra o quanto a percepção é historicamente construída, vinculada a processos de constante construção e desconstrução das subjetividades. O fotógrafo como observador do mundo toma lugar neste processo, como delineia Crary (2013, p.150) para quem a percepção "torna a síntese obrigatória; é uma automatização que, sob outras formas, persiste ainda hoje com força total". O autor ao tratar da construção da visão do observador, manifestou o quanto as práticas do ver, intensificam e legitimam sistemas de convenções visuais. Lugares comuns de representação resistem, estabilizando visões e tendências que se desdobraram num gênero de fotografia; um traço que remontava ao século XIX, como prática cultural universal de valorização das formas etnográficas e também paisagísticas.

Nesse sentido, talvez seja pertinente ver Pastore também como um viajante inspirado em relatos ainda mais antigos, que sintetizavam o mundo pela configuração do tipo social, visto nas séries de quadros pintados na França, Inglaterra, Itália, Espanha por volta de 1770 em diante, não deixando mais de se reproduzir como um gênero quer pictórico, quer literário, quer fotográfico. ${ }^{283}$

\footnotetext{
${ }^{283}$ |lustrações gráficas, de costume popular, têm origem nos seicentos, junto com a literatura 'riflessa' ou burlesca, se tingem de idílico no século XVIII e de vaguesa e pitoresco romântico na primeira metade dos
} 
A figuração do costume popular na produção de inúmeras gravuras foi na Itália chamada como 'arti per via', constituindo-se como um conjunto de imagens formadoras de um gênero, que teve larga difusão na Europa, a partir das últimas décadas do século XVIII, segundo D. Miller (1970). Não iremos tratar de modo aprofundado sobre a pintura caracterizada como de paisagem, que progressivamente passou a conjugar o pitoresco natural com o pitoresco humano. Imagens que passaram a existir e a configurar a denominada representação de gênero, responsável por um fenômeno de circulação de imagens emblemático nos anos setecentistas.
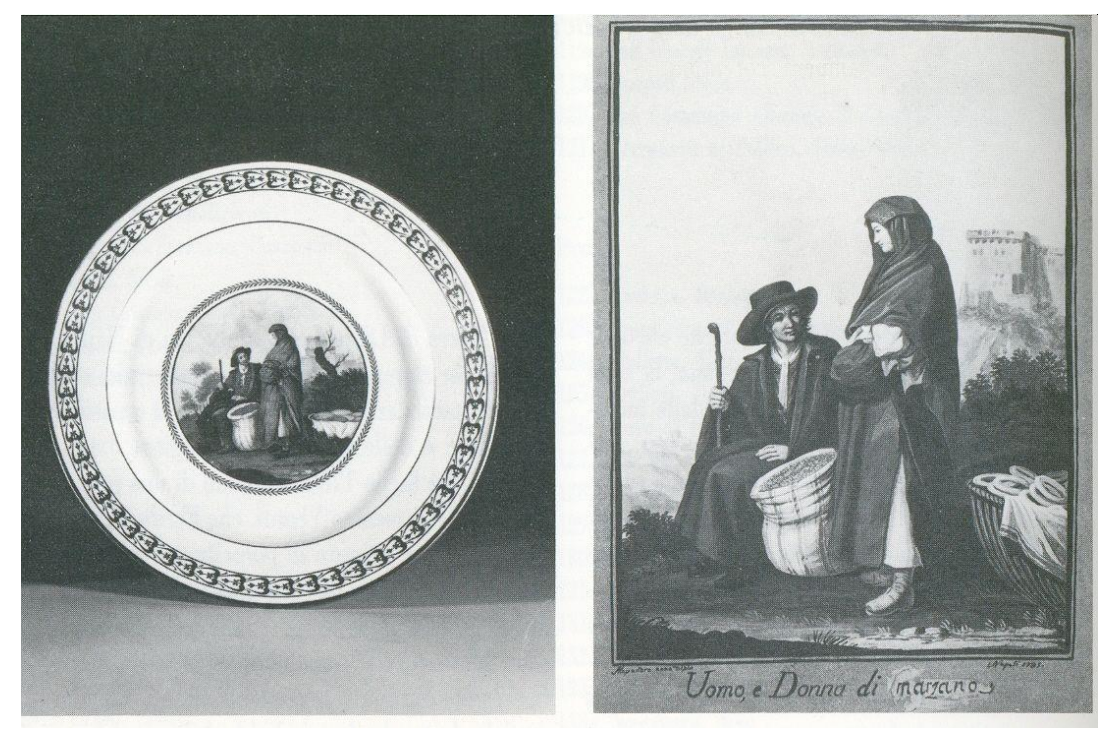

Figura 180 e 181: "Uomo e Donna de Marzano". Obras encomendadas pelo " 1 'Servizio delle Vestiture”. Nápoles.

Mas vale apontar brevemente as referências de imagens produzidas com feições tipificadas, individualizando sujeitos sociais na configuração de imagens entendidas, no contexto italiano, como de costume local. Aproximá-las daquilo que Pastore foi capaz de interpretar na terra de acolhida ilumina possibilidades de compreensão da série do fotógrafo.

Em 1782, por exemplo, foi organizada uma missão para ilustrar os diversos modos de vestir dos habitantes das diferentes províncias que compunham os reinos de Nápoles e da Sicília. Missão que durou por 15 anos resultando em variadas publicações. ${ }^{284}$ Foi essa uma iniciativa fomentada pelo rei Ferdinando IV como parte de uma política econômica e cultural interna, de clara função didática, para mostrar as paisagens e ilustrar as condições das várias províncias. A circulação dessas imagens por toda a Europa firmava-se como demanda

oitocentos. Cf. B. Croce, Nella Napoli Borboniva degli ultimi tempi, in "Napoli Nobilissima”, N.S., vol. II, fasc. IXX, 1921, p. 129. Tradução Nossa.

284 Cf. Catálogo produzido por Masdea, Maria Cristina. Le Vestiture del Regno di Napoli: Origini e fortune di um genere nuovo. 1991. 
obrigatória promovida também pelo Grand Tour. ${ }^{285}$ Imagens que além de serem publicadas em diferentes impressos foram ainda reproduzidas em porcelanas (fig.180). Gravadores e pintores, envolviam-se cada vez mais na comercialização de imagens de gênero, enredadas na produção de vistas e paisagens por todo velho continente. ${ }^{286}$

Trata-se de uma linguagem intercambiada, permeando as formas de representação projetadas nas décadas posteriores: a ausência de um fundo rebuscado, imagens equilibrando a distribuição dos elementos do quadro, com composições que ambicionavam generalizações, além de comunicarem ações individuais ou de certos grupos sociais, formam um padrão visual para representá-los. Os elementos visuais organizados marcavam uma distinção social dos grupos anônimos que adensavam o contingente das cidades, expressos também na forte valorização das indumentárias, conduzindo a elaboração da cena guiada impregnada de clara intenção documental do povo, de hábitos e dos costumes.

Rastreia-se brevemente, um interessante circuito de circulação de imagens voltadas para a paisagem humana que desvela aspectos vistos também em Pastore: a autonomia da figura retratada em relação ao contexto, este evidentemente secundarizado, fixado no último plano da cena; aspectos da convenção pictórica estão explícitos também na oposição entre o claro e o escuro, contando ainda com certas recorrências: formas de silhuetas, valor conferido aos trajes típicos, pessoas retratadas de perfil, simulando uma desatenção à presença do artista. Vê-se signos da própria linguagem figurativa, como bem mencionou Maria Eliza Linhares Borges:

Mais que outros períodos históricos, o século XIX potencializou as práticas de produção, reprodução, alterações e consumo de imagens, há muito facilitadas pela invenção da imprensa e a proliferação de oficinas de impressão. O surgimento da litografia em 1798, a produção de retratos a partir da técnica do fisiotraço, amplamente utilizado, até as duas primeiras do século XIX, e a democratização do retrato fotográfico no formato de

\footnotetext{
${ }^{285}$ Vale destacar como além das cenas da vida cotidiana, a descoberta de Pompéia e Herculano e por conta da beleza natural, sobretudo a exuberância do Vesúvio, foram produzidas muitas vistas feitas das muitas incursões de artistas para tais regiões. Citamos aqui duas importantes publicações resultantes destes investimentos: Campi Phlegraei (1776-79) de Sir William Hamilton (fenômenos vulcânicos), com ilustrações de Pietro Fabris, artista voltado para o gênero pitoresco de forte sensibilidade pré-romântica, com interpretações sem nenhum caráter de denúncia social e Voyage Pittoresque (1781-86), do abbé de Saint-Non, com ilustrações feitas por um grupo seleto. Foram obras que se tornaram principais veículos de difusão do interesse por Nápoles e seu reinado.

${ }^{286}$ No ano de 1783 o rei de Nápoles começou a encomendar dos pintores Alessandro D’Anna e Antonio Berotti a tarefa de documentar os costumes do Reino. Foram encarregados de reproduzir fielmente os 'verdadeiros' costumes do Reino, destinados a serem traduzidos nas porcelanas da Fábrica Real, reproduzidas também em estampas reais. Cf. Catálogo produzido por Masdea, Maria Cristina. Le Vestiture del Regno di Napoli: Origini e fortune di um genere nuovo. 1991.
} 
carte de visite, em meados da década de 1850, não são atos isolados. Revelam o crescimento da demanda por meios mais baratos e ágeis de produção e impressão de imagens. Exprimem a socialização do hábito de ler e interpretar os atos sociais a partir de signos próprios da linguagem figurativa. (Borges, 2008, p.320 Apud Hirszman, 2011, p.128)

Essas pinturas oriundas das edições de exemplares setecentistas foram depois reelaboradas por Giacomo Milani, diretor dos pintores da Real Fabbrica de Porcellana, publicadas sucessivamente pela Stamperia Real, em 1832, em um álbum intitulado Costumi Diversi di alcune popolazioni de’ Reali domini di qua del Faro. ${ }^{287}$ São esses modelos de representação que não tiveram apenas um valor decorativo. $\mathrm{O}$ víes documental depois se repetiria nos oitocentos em álbuns que, posteriormente iriam apresentar poucas variações, expondo intensamente os mesmos padrões de elaboração de cena. Às séries foram incorporadas características do folclore napolitano como o baile da tarantella e cenas de vendedores ambulantes, depois tornando-se recorrentes na fotografia, como veremos no capítulo seguinte.

Conseguimos investigar o quanto esse repertório visava alimentar o circuito do Grand Tour e a ávida curiosidade sobre os povos meridionais. Surgia ao sul da Itália uma variedade extraordinária de representações que reforçavam identidades locais, retratando-se figuras singulares ou em grupo, dias festivos, representações sínteses da vida cotidiana, em novos documentos: gravuras reais em guaches pequenos, porcelana, mas também em inúmeras estampas.

Esse fenômeno na Itália foi assim explicado:

Neste âmbito merece uma colocação sobre a representação do costume popular; este tema, que comparece como elemento marginal ainda no interior das vistas ou de cenas da vida cotidiana, gradualmente e em relação a um aumento de interesse, vem conquistar um espaço próprio, transformando-se enfim em um pequeno, mas definido filão figurativo.

$\mathrm{O}$ interesse pelos costumes populares é um fenômeno tipicamente setecentesco, de âmbito europeu, que conflui de uma longa e já consolidada tradição de publicações que ilustravam eruditamente os vários modos de vestir do povo antigo e moderno. A curiosidade iluminista pelo inédito, o

\footnotetext{
287 Para evitar o comércio ilícito destas imagens o reino colocava sobre as estampas saídas das prensas reais uma interdição, na tentativa de bloquear qualquer tentativa de falsificação, destinando em 1795 a venda exclusiva ao mercador Vincenzo Talani. Segundo Maria Cristina Masdea, Talani se associou com um negociante de gravuras, o romano Nicola Gervasi, publicando em 1796, com datação falsa, a Raccolta di Sessanta più belle vestiture che si costumano nelle provincie del Regno di Napoli. O volume, que leva a data de 1793 no frontispício, no qual está o índice analítico dos costumes das províncias, é dividido em duas partes, de 30 quadros, cada um deles precedido de uma 'antiporta'. Os desenhos originais foram executados, na maior parte, por Alessandro D’Annae, em Roma. Cf. Masdea. 1991, p. 54.
} 
novo, o 'exótico' levou a um renovado interesse sobre a questão, que ampliou-se, incluindo até os costumes do povo, coisa pouco conhecida e documentada. (Masdea, 1991, p. 43)

Pastore, quando saiu às ruas, não se submeteu à reação pictorialista de ordem romântica que buscou as formas e assuntos belos, central na representação de paisagens, caras ao movimento. Esteve antes estimulado pelas referências das imagens sínteses, oferecidas como modelos emblemáticos da história da pintura, repletas de cenas do cotidiano, da 'arti per via' dignificando trabalhadores, protagonistas em muitas composições que se atualizavam no transcorrer das décadas sucessivas, frente à crescente demanda por imagens souvenirs. No âmbito da circulação italiana, como veremos a seguir, tais convenções visuais marcaram a produção dos fotógrafos por toda a segunda metade do século XIX, desdobrando-se na prática fotográfica até as primeiras décadas do século XX.

Quando olhamos para a fotografia de rua produzida no contexto da Itália, vê-se como a série produzida por Pastore na capital paulista, na verdade, vai de encontro à fotografia de rua presente na cultura visual da terra de origem do fotógrafo, herdeira de uma tradição antiga, fortemente relacionada às cenas de costumes produzidas continuadamente em diferentes temporalidades, consumidas no desenrolar de muitas décadas. Foi preciso redimensionar o escopo de compreensão do material visual eleito quando nos deparamos, nos arquivos italianos, com fotos que remetiam a série do fotógrafo criada em São Paulo. Propomos a seguir, uma abordagem atenta aos processos históricos que permeiam a constituição do material visual posto em análise tentando demonstrar como Pastore, ao retratar as sociabilidades sondadas ao longo desse capítulo, foi antes de tudo, um típico fotógrafo italiano.

Se essa abordagem partiu dos aspectos mais particulares e fragmentários da série, agora delineará, na prática de Pastore, manifestações sociais mais abrangentes, padrões e tendências visuais que podem envolver a narrativa criada, encoberta sob o véu de um modelo imaginário criador das formas de ver, pensar e representar o povo e o movimento das ruas.

Arriscamos aqui uma primeira consideração: Se a fotografia de Pastore foi no Brasil, considerada como única, inédita e comovente, como veremos no capítulo cinco, quando aproximadas daquilo que se produzia na fotografia italiana, é corriqueira, trivial. Uma leva de fotógrafos amadores e profissionais foi arrastada por um repertório que acreditaram valer apena preservar e colocar intensamente em circulação por toda Itália. As chances de melhor compreender Pastore parecem se ampliar frente a uma visualidade que nos lançou em novos 
horizontes, conduzindo a análise para os agenciamentos de fotos mobilizadas no circuito visual italiano, que possibilita certa inferência: A fotografia que constituía a matriz de formação de Pastore, começava naquele contexto a politizar o espaço, mostrando a presença de grupos heterogêneos convivendo nas cidades. Mesmo tratando-se de fotos souvernir, em tais imagens, certas ideias e valores começavam a aderir nas práticas fotográficas, provocando múltiplos sentidos numa visualidade pertinente ao quadro italiano. Pastore reconheceria em São Paulo os papéis informais de muitos de seus conterrâneos, que antes mesmo da experiência da emigração já vivenciavam uma sobrevivência improvisada no ganho na rua, na venda ambulante, onde produziam as suas condições de existência. O sentido de identificação, projeção e ancoragem permeiam a produção realizada na capital paulista, vista, a seguir à luz das contingências que cercavam Pastore ainda na Itália. 


\section{Capítulo 4}

\section{Pastore e a tradição da fotografia de rua italiana}

\section{1 "Uma fotografia que se pode abraçar": o encontro com fontes inesperadas}

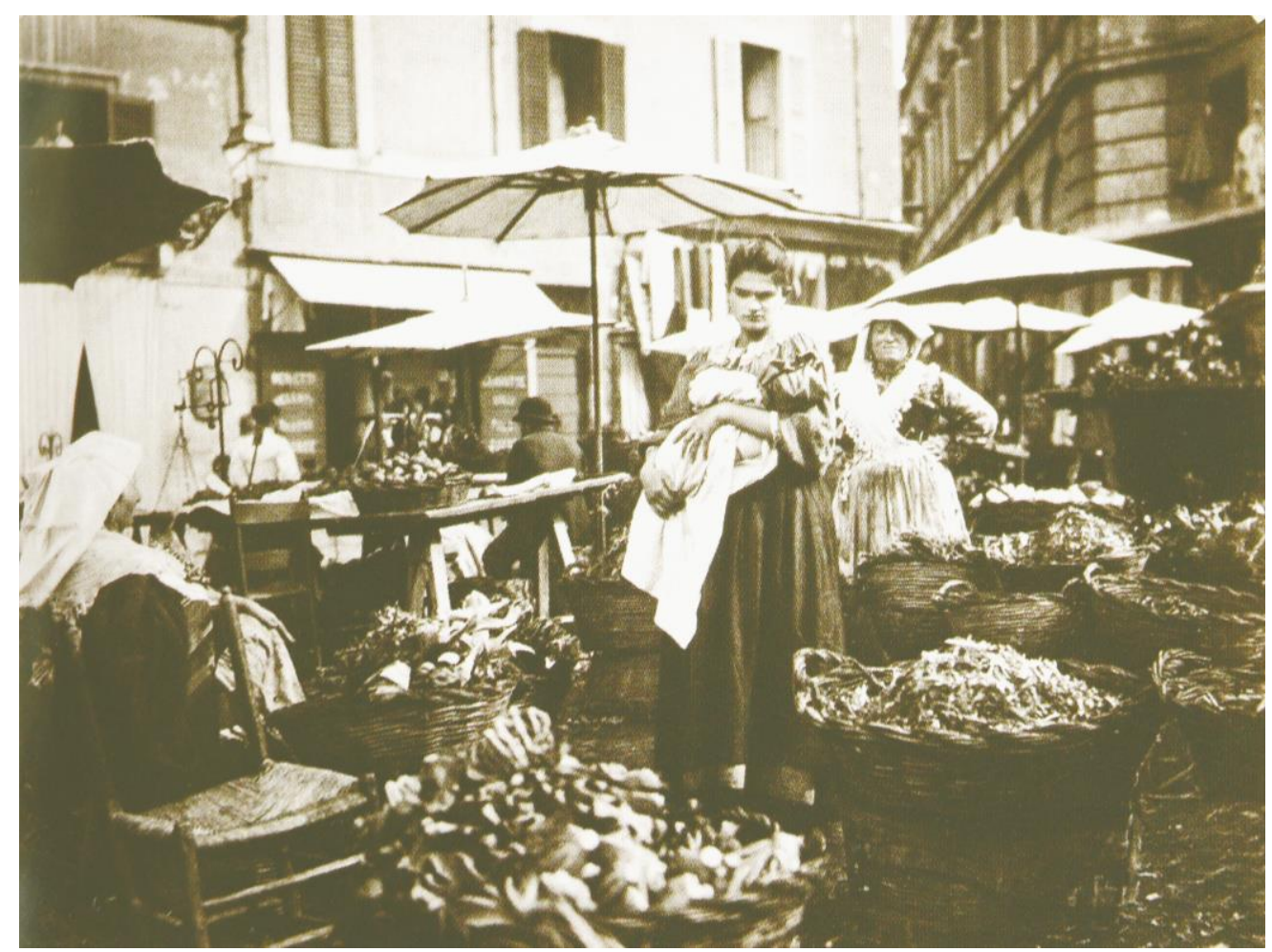

\section{Figura 182:}

Mercado Piazza di Campo de Fiori. Roma. Vendedoras de frutas, verduras e ervas. $1885-1890$ (C) Alinari. Arquivo Touring Club Italiano. In: Luoghi, volti, gesti e costumi. Collezione fotografica di Alberto Manodori. Editora. Fondazione Pietro Manodori. 2008.

A coleção de fotografias formada por Alberto Manodori (1866-1935) ajudou a inscrever um trânsito de imagens na Itália, entre as últimas décadas do século XIX e as décadas iniciais do século XX. Trata-se de uma visualidade como parte de uma experiência que envolveu múltiplos agentes: fotógrafos e retratados, colecionadores de fotos e fotógrafos donos de tipografias, fotógrafos amadores e profissionais e, ainda, fotógrafos pintores, descortinando relações sociais em torno da produção e circulação de imagens fotográficas com forte potencial icônico: a representação de tipos sociais conformando cenas urbanas. Fotos que foram adquiridas no circuito do souvenirs, desvelando uma demanda que envolvia múlitplos agentes que legitimavam a convenção de representações das cenas de trabalho realizado nas ruas, feiras e praças citadinas. Acreditamos que essa rede observada, nuança aspectos para melhor se compreender a série produzida na capital paulista por Vincenzo Pastore. 
Lidamos a princípio com uma coleção familiar guardada pelos descendentes de Manodori, ${ }^{288}$ acolhida por essa interpretação como uma fonte rica à pesquisa, por revelar paradigmas visuais que, de algum modo, reverberaram em Pastore. As fotos que deram origem à coleção, hoje publicadas em livro, possibilitaram certa inferência: pensar a fotografia italiana como a matriz de formação do fotógrafo que tratou São Paulo seguindo as convenções que trazia de seu país de origem, repleto de imagens sínteses do cotidiano urbano.

O registro feito pela renomada empresa dos irmãos Alinari (fig.182) foi o primeiro vestígio a sugerir dimensões de práticas fotográficas que remetem à Pastore. A imagem "Vendedoras de frutas, verduras e ervas", produzida na Itália, entre 1885 a 1890, foi classificada pelos próprios fotógrafos como "tipos e costumes"; imagem depois estampada sob um sistema de legitimação através da publicação de catálogos, livros, álbuns e exposições de fotografias que circulavam nesse país até as décadas inicias do novo século.

Frente a uma demanda que se desdobrou por muitas décadas, Roma ofereceu à prática do colecionismo cenas pitorescas, de tipos e costumes, produzidas no seio de uma sociedade que se modernizava. Os fotógrafos da empresa Fratelli Alinari fotografaram vendeiras de verduras, ervas e raízes, na Praça Campo di Fiori. O registro da Praça Monte d'Oro (fig.183) desvelou instantes da barraca de peixe cercada de possíveis compradores, foto publicada no catálogo da empresa em 1892. Deve ter sido vendida como imagem avulsa porque passou a integrar os arranjos da coleção de Alberto Manodori. Apontamos para uma circulação de imagens sustentadas por um trânsito de fotografias usadas como suportes para representar o país, nuançando traços do imaginário da época.

\footnotetext{
${ }^{288}$ Alberto Manodori Sagredo, o bisneto de Alberto (1866-1935), preservou a coleção recebida como herança do pai, Marco Gerardo Manodori, filho de Pietro Manodori. Tratamos aqui de uma coleção familiar guardada por quatro gerações, hoje intitulada como Coleção Alberto Manodori. Além de fotos o herdeiro guardou também os equipamentos fotográficos usados pelo pai, um fotógrafo amador. Fotos e câmeras formam hoje o acervo de Fundação Manodori. Os descendentes também estiveram envolvidos no ato de colecionar porque ajudariam a ampliar a coleção iniciada por Alberto Manodori nas últimas décadas do século XIX e nas primeiras do XX.
} 


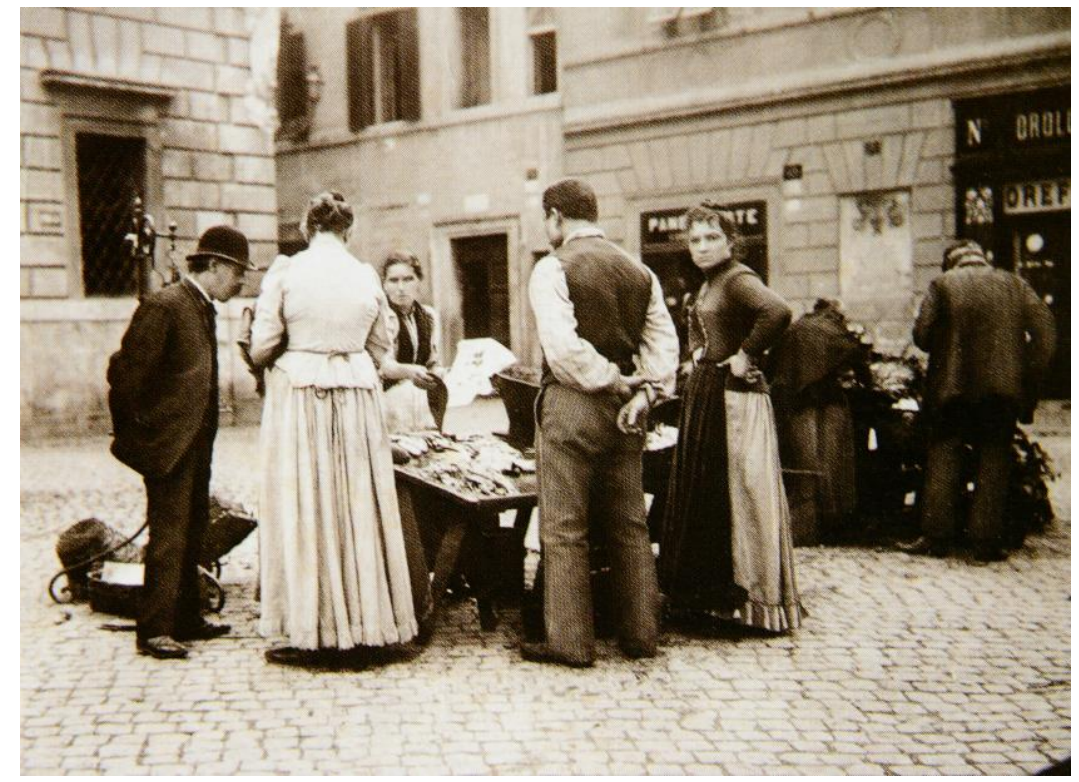

Figura 183: Barraca de peixe na Praça Monte d'Oro, em Roma. 1880 ๑ Ed. Alinari. In: livro Luoghi, volti, gesti e costumi. Collezione fotografica di Alberto Manodori. Editora. Fondazione Manodori. 2008.

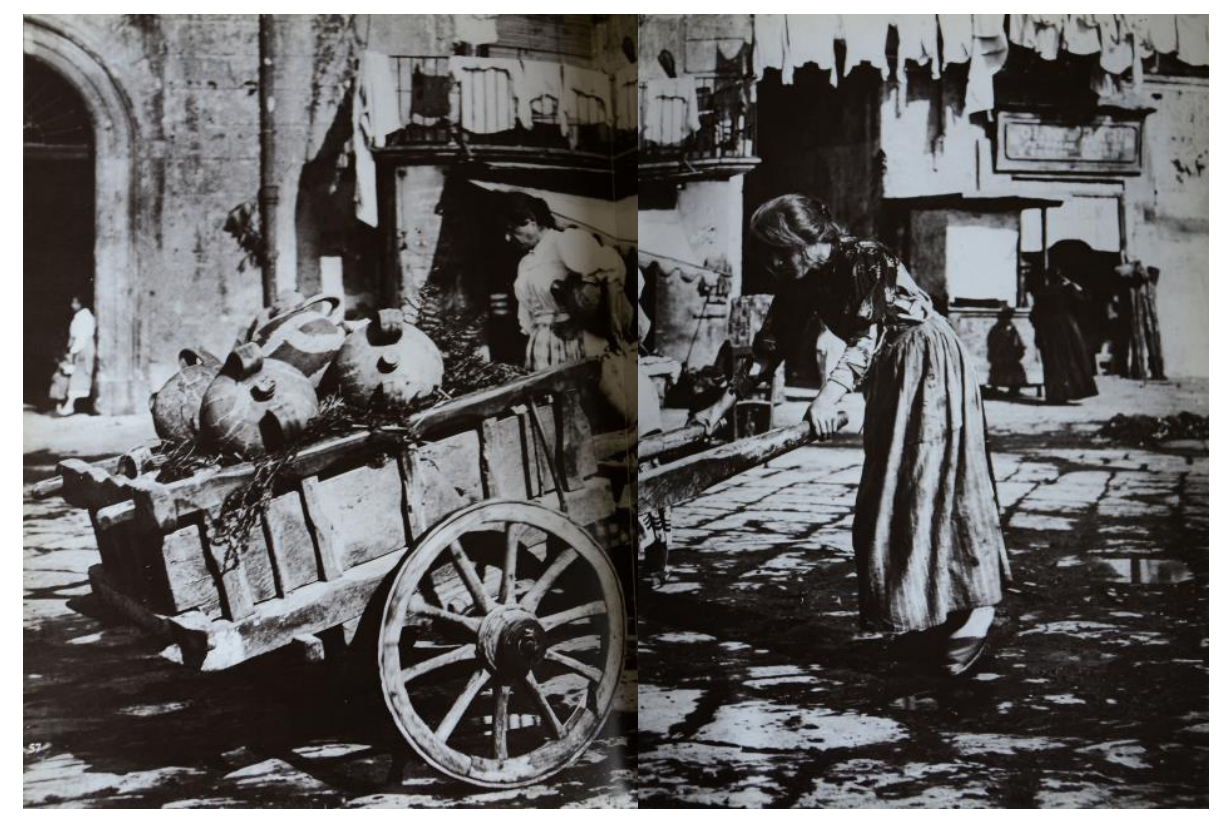

\section{Figura 184:}

Vendedorade água mineral. Nápoles. Arquivo Touring Club Italiano. 1885-1890. () Ed. Alinari. / Arquivo Touring Club Italiano.

Convenções visuais começam a se destacar. Os Alinari, importantes retratistas de Firenze, realizaram uma volumosa produção visual na cidade romana, que em cinqüenta anos, triplicou a sua população, num processo de urbanização que não alterava, segundo Landi (1989) sua essência de usos e costumes tradicionais precedentes. Se o fotógrafo destacou-se pela enorme produção de álbuns fotográficos representando a Roma monumental, histórica, cercada por suas antigas muralhas, colocou também em circulação imagens entendidas pelos costumes, fotos destinadas a um público amplo, voltadas para um consumo facilmente documentado. 
As sociabilidades que atraíram Pastore eram as mesmas que dominavam todo o repertório visual elaborado em Veneza, saindo da Toscana a Roma, de Lazio a Torino, da Puglia passando pela Basilicata, pela Calábria e, também, fortemente presente nas representações visuais das ruas de Nápoles, chegando ao antigo reino da Sicília. A abrangente produção de imagens dos "vendittore in via" ou do "lavoro per strada" coloca Pastore como um partícipe de uma tradição de imagens comercializadas como souvenir, estruturando inúmeros álbuns fotográficos. Esse repertório que circulou intensamente como fotos de costumes aproxima uma geração de fotógrafos da qual Pastore pode se filiar.

As funções descritivas ativadas reforçavam o caráter documental e indicial do aparato fotográfico. Alguns atributos são marcantes quando aproximamos as fotos de Pastore daquelas produzidas na Itália: as escolhas por enquadramentos de menor contextualização do ambiente, recortes de planos médios, o forte senso de objetividade, a operação de uma mesma temática; indiciam-se convenções em diálogo a partir de representações tidas na Itália, como "tomadas da realidade", aspecto central na caracterização dessa visualidade em trânsito entre os oitocentos e os novecentos.

A imagem da vendedora de água mineral que percorreu as ruas de Nápoles (fig.184) invoca todo um repertório literário, mas também visual napolitano, repleto de vendedores de cereja, de castanha, de uva, de tremoço, massas... Imagem que delineia os passos dos irmãos Alinari que viajaram pelo sul de toda Itália, buscando cenas que revelassem a teia de trabalho diário nas províncias e comunas, sobretudo, meridionais. Fotos também comercializadas avulsas e, a partir de 1880, reproduzidas em cartões postais. Além de fotografarem, a empresa Fratelli Alinari editava e publicava toda essa produção, comercializada dentro e fora da Itália. Estúdio, tipografia e editora, compunham a tríade que definiu sua atuação. As 2.400 imagens estampadas diariamente, em 1899, sugerem a capacidade de produção visual dessa empresa, como pontua Miraglia (1985, p.11); empresa que envolvia os irmãos Leopoldo, Giuseppe e Vittorio Alinari, que desde muito jovens se envolveram no negócio da família.

Uma dinastia de fotógrafos e editores com empreendimentos bem estruturados e evidente capacidade industrial se inscreve na história social da fotografia italiana, não apenas da Toscana, onde os irmãos Alinari mantinham seu famoso estúdio. Nos anos de 1840 até os primeiros anos do século seguinte circulariam na Itália inúmeras fotografias de paisagens, arquitetura, reproduções de arte e também cenas de gêneros e costumes destinadas, segundo a pesquisadora Gabriele D'Autilia (2012, p.82), ao circuito dos souvenirs. 
O fotógrafo Carlo Brogi também se voltou para a temática do trabalho ambulante, como vemos na seguinte imagem (fig.185), realizada entre os anos de 1870 e 1880 . Destacam-se os mesmos atributos formais articulados por Pastore (fig.171).
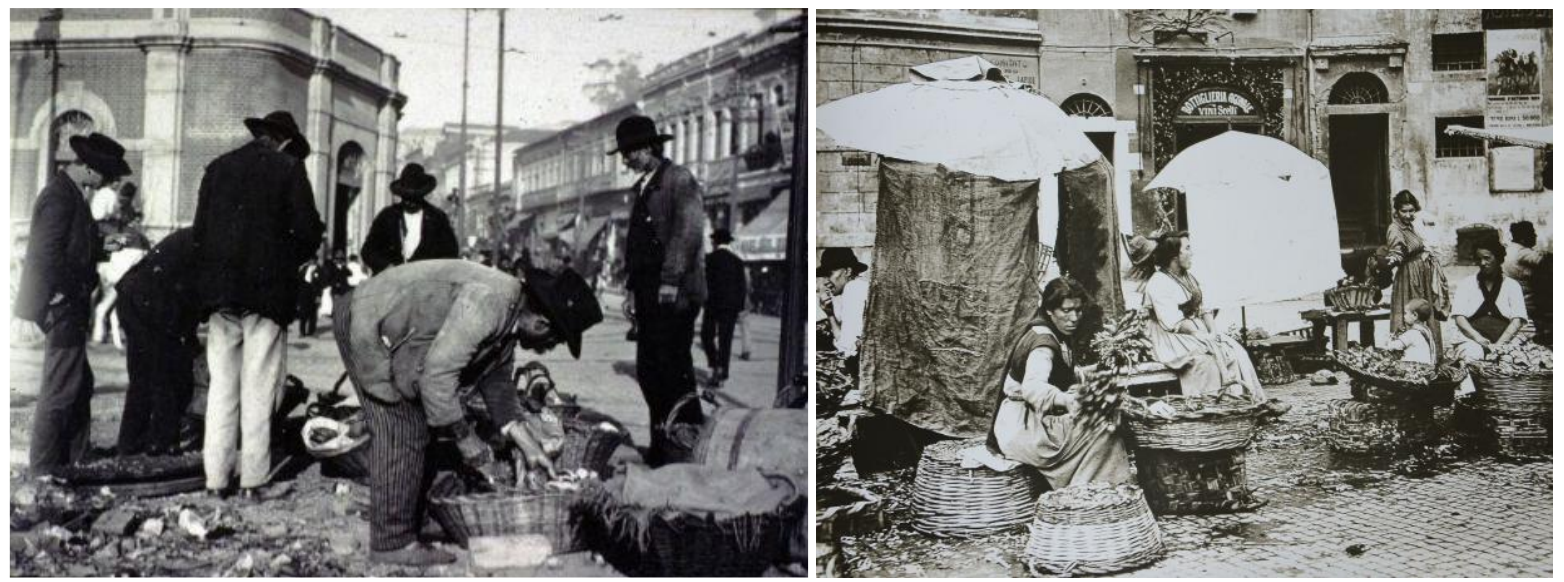

Figura 171 e 185: Foto à esquerda Rua 25 de Março. 1910 ( ) Vincenzo Pastore / Instituto Moreira Salles; à direita Coleção Brogi. Arquivo Alinari. Firenze. 1870-1880. In: Luigi, Magni e Settimelli, Wladimiro. Roma e il Lazio Archivi Alinari, 1989.

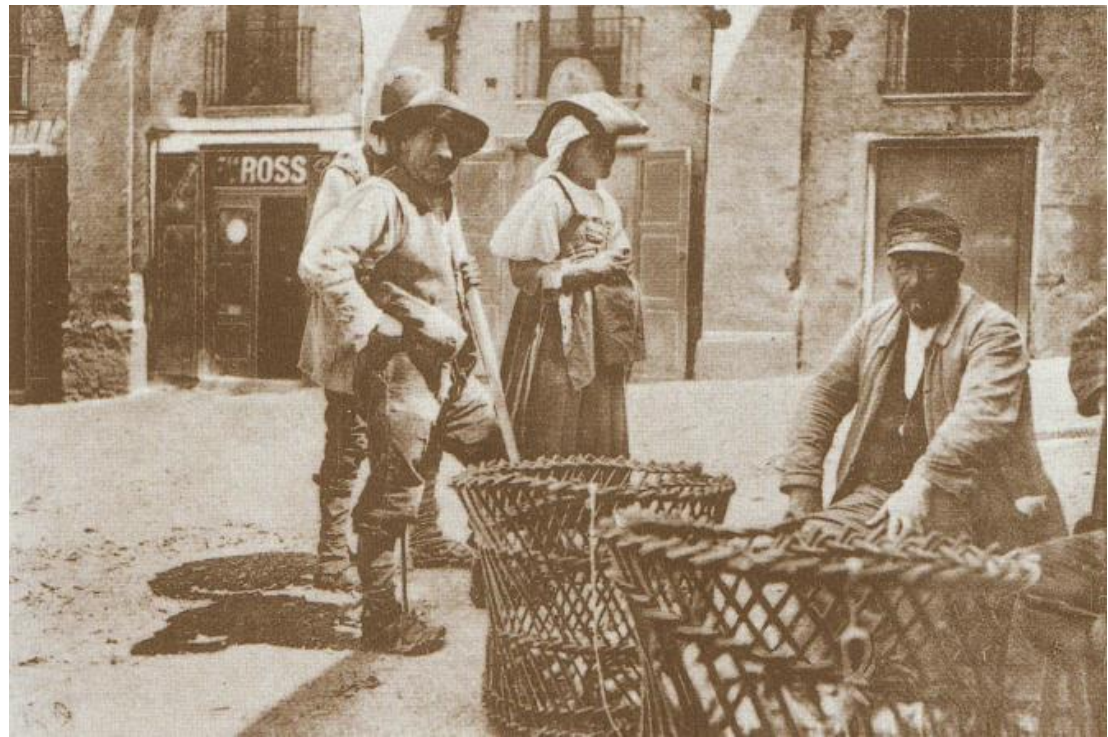

Figura 186: Fotógrafo não identificado. Potenza. 1906. Editore Vincenzo Garramone. In: Luccioni, Luigi. $L a$ Basilicata ...com'era. Aspetti territoriale urbani ed umani della Basilicata in um album di immagini d'epoca. (18961945). Roma: Edizione Atena. 1988.

Chama atenção o mesmo enquadramento, a opção por planos médios, em duas fotografias que valorizam gestos espontâneos. Fotos tomadas sob a aura da foto flagrante com clara preocupação voltada para a cultura material posta em primeiro plano, dando a ver as pequenas posses de muitos trabalhadores envolvidos nas redes de abastecimento urbano. Encontramos Pastore dialogando com a fotografia italiana produzida entre diferentes gerações de fotógrafos de uma mesma família. Os fotógrafos Giocomo Brogi, um grande retratista com estúdio em Firenze, com sucursais em Roma e Nápoles, dividia o ofício com o seu filho Carlo Brogi, ambos interessados nas teias de sociabilidades do comércio ambulante. 
A descoberta desse repertório visual nos conduziu para uma investigação que acabou por nos remeter aos postais produzidos em Potenza no ano de 1906 (fig.186). Poucos anos antes Pastore havia atuado na capital da Basilicata. Manifestam-se aqui práticas fotográficas que documentam intensamente a improvisação de papéis informais envolvendo homens e mulheres nas atividades do comércio de rua.

A vastidão desse repertório visual indicia aspectos da construção do tipo como um ícone visual, construção que depende da saturação deste visível, de circuitos que sustentem as formas recorrentes comuns no processo de invenção do outro. É no circuito do turismo que se dá a saturação de representações de pessoas e objetos, de pessoas em suas ações cotidianas de trabalho, uma visualidade decorrente do avanço industrial, técnico que amplifica a possibilidade de ver e representar o outro, uma visualidade vestida com a insígnia de informar, de dar a ver, mapear e inventariar para apontar diferenças. Trata-se do desejo de reconhecer o mundo por meio de imagens. Falamos de identidades forjadas pela fotografia, uma experiência mecânica afirma Donald Lowe (1986, p.79), mas também social.

É na dimensão das práticas e das ações sociais que se deve pensar o fotográfico, observando-se a importância que todos os objetos assumem socialmente. Alfred Gell (1998) aponta como as agencias sociais podem ser investidas por meio das coisas, dos objetos socialmente produzidos. Para o autor é a cultura submetida à práxis, ambas também constituídas por artefatos criados e compartilhados, produzindo efeitos em sistemas de circulação. O autor, ao pensar a dimensão fenomenológica da cultura material, trata da categoria de agência, que cada vez mais se traduz como uma preocupação do campo da história, num movimento incessante de revisão de seus métodos e procedimentos:

No lugar de comunicação simbólica, eu coloco toda a ênfase na agência, na intenção, na causalidade, no resultado, e na transformação. Eu vejo a arte como um sistema de ação, destinada a mudar o mundo em vez de codificar proposições simbólicas sobre ele. A abordagem centrada na 'ação' em relação à arte é inerentemente mais antropológica do que a abordagem semiótica alternativa, pois está preocupada com o papel mediador prático dos objetos de arte no processo social, e não com a interpretação de objetos 'como se' fossem textos. (GELL, 1998, p. 06. Tradução Nossa).

São esses aportes teóricos emprestados para se pensar relações sociais mediadas por imagens, redimensionando a prática e o olhar fotográfico de Pastore. A série por ele criada começa a se acomodar na avassaladora iconografia italiana coberta pela regularidade deste repertório visual, entendido pela pesquisadora Pagnotta (2009) como uma verdadeira 
"tendência de representação dos profissionais ambulantes e dos hábitos das camadas populares", em tomadas voltadas para cenas urbanas, destinadas a turistas, num gênero fotográfico classificado pela historiografia italiana como o pitoresco. Veremos a seguir como a imagem ligada a uma circulação intensa reforça a construção do tipo social, depois, quando submetida a certos agenciamentos no contexto italiano, ajudaria a instituir certos estereótipos.

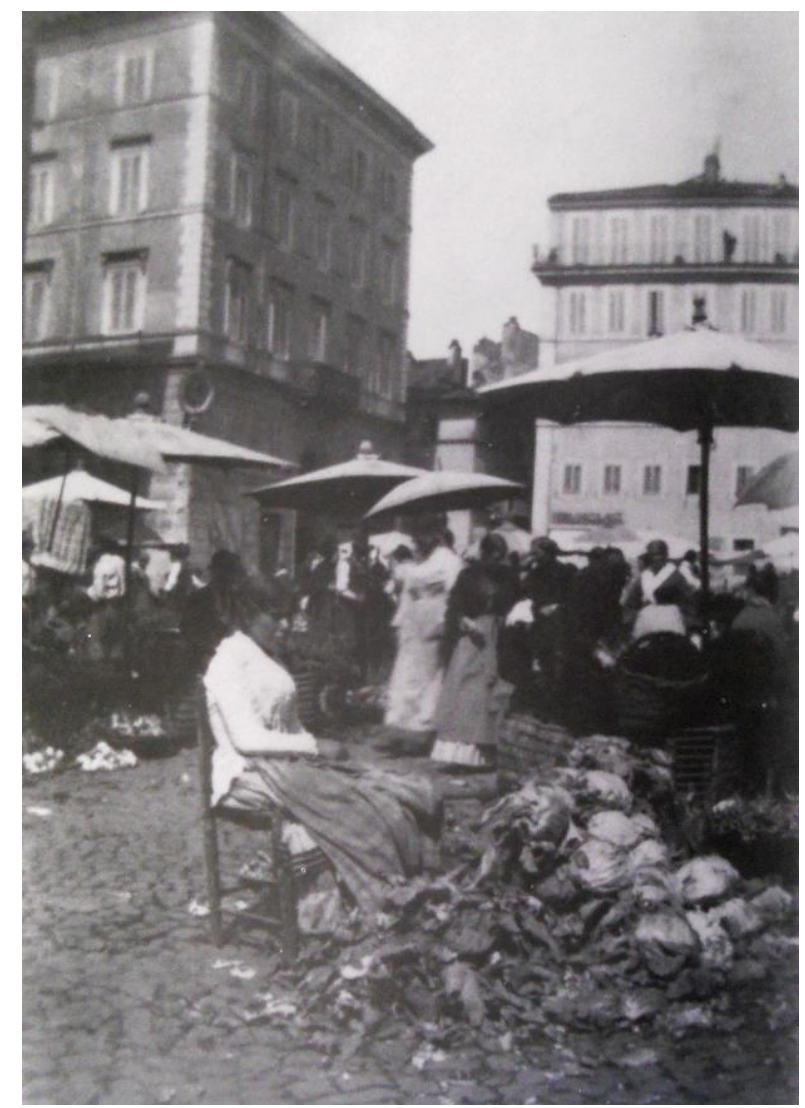

Figura 187: Foto de Mario De Maria. Roma. Campo di Fiori. 1882- 1887. In: Del Balbarò, Michele Falzone e Tempesta, Claudia. Marius Pictor Fotografo. L'album fotografico di Mario De Maria. 1882-1887. Editora IFotolibri/Longanesi\&C. 1979.

Ao se observar a força deste circuito que em tudo envolve Pastore, encontramos o pintor- fotógrafo Mario De Maria, pseudônimo Marius Pictor, voltado para o mesmo espaço e pela mesma contingência que interessava à empresa de Alinari: com sua câmera instantânea, De Maria fotografou o burburinho da Piazza Campo de Fiori, até hoje conhecida como o lugar da feira livre de Roma. Essa interface entre a fotografia e a pintura, sublinha a força dessas convenções visuais manifestas numa rede de imagens interessada pelas novas atitudes e pelas formas de sobrevivência do "tipici mondo popolare" (Zavattini e Monti, 1979, p.57).

A foto instantânea de De Maria (fig.187) ajuda a observar este gênero da fotografia italiana onde encontramos fotógrafos amadores e profissionais, mas também pintores recorrendo ao meio fotográfico. Sondaremos então o cerne de inter-relações complexas que 
aproximam e tensionam diferentes práticas e linguagens voltadas para um mesmo conteúdo visual, intensamente posto em circulação por toda a segunda metade do século XIX, encontrando meios de se renovar no início do novo século. Correspondências que depois ficaram em suspenso, porque a referência italiana não tardou em ser superada, como veremos mais à frente.

\subsection{O mosaico visual do Grand Tour: rastros de um intenso trânsito de imagens}

As experiências sociais, mas também culturais são mediadas na sua dimensão que é também visual, mediação que se dá entre os sentidos e seus suportes, que se materializam e agem no campo social com eficácia. São estes pressupostos definidos por Ulpiano Bezerra de Meneses (2005), autor que aponta a necessidade de se pensar o visual a partir de "redes de imagens" constituídas socialmente. É pertinente a esse campo teórico observar o que o autor chama de um "conjunto de imagens-guia de um grupo social ou de uma sociedade num dado momento e com a qual ela interage". O termo visualidade proposto por Meneses remete à existência de relações sociais mediadas por imagens, formadoras de ambientes visuais circunscritos a determinadas "condições técnicas, sociais e culturais de produção, circulação e consumo".

Acredita-se que Pastore nos leva a pensar a trajetória da fotografia italiana reverberando em outro lugar. Não falamos de um olhar estrangeiro retratando o Brasil, mas sim como Pastore, em sua experiência de imigração, retratava as sociabilidades vibrantes da capital paulista pensando na Itália, porque se trata de uma semântica visual que remete às cenas emblemáticas da iconografia italiana, repleta de representações de práticas autônomas de sobrevivência. Um repertório visual de duração amplamente explorado em contingências variadas, onde através do tempo, convergiram diferentes sentidos que aderiam aos seus diferentes suportes.

Evitamos o termo influência, noção rechaçada por Michael Baxandall (2006, p.80). Para o autor seria esse um modo simplista de interpretação das imagens, reduzindo-as a uma condição de passividade, afinal para o autor há sempre uma "marca da individualidade de um artista" com uma "percepção particular das circunstâncias". Entretanto, não se podem eliminar dimensões históricas que permeiam determinadas intenções. 
As imagens são aqui compreendidas a partir da noção de "tradição da obra", como explica Jacques Derrida (2012), para quem o pensamento está sempre ligado aos atos de interpretação, está sempre envolvido na produção da arte em geral. As condições históricas precedentes ajudam a inaugurar algo novo, incorporadas naquilo que Derrida nomeia como "experiência da obra".

(...) cada vez que há um avanço, um acontecimento, arquitetural ou pictórico, seja em uma obra particular, ou uma nova escola, seja um novo tipo de acontecimento artístico, o pensamento está envolvido. Isso envolve o pensamento em sentido da memória da história e da tradição da obra, ou da arte em geral. Mas isso não quer dizer que os artistas conheçam história, ou que os diretores de cinema devam conhecer a história do cinema, mas o fato deles inaugurarem alguma coisa, de eles produzirem um tipo de obra que não era possível, digamos, vinte anos antes, pressupõe que em suas obras a memória da história do cinema está não obstante registrada, e portanto que ela foi interpretada: é pensamento. (Derrida, 2012, p.47)

Nesse sentido, temos pressupostos teóricos que se aproximam, afinal, Baxandall (2006, p.86) também sublinhou como a percepção de quem produz a imagem é também construída por uma experiência culturalmente orientada, afinal, este autor leva a pensar as convenções que permeiam a visualidade. Muitos elementos podem se confundir na atitude do artista, "um ser social inserido em determinadas circunstâncias culturais".

Seguindo esses pressupostos, não se tenta compreender a intenção de Pastore como um "estado psicológico real ou particular", mas sim, o quanto a sua narrativa remete para uma intencionalidade maior, que deve ser entendida, seguindo Baxandall, como um campo de "condições gerais de toda ação humana", relacionando atos, objetos e circunstâncias, constituídos por manifestações nem sempre conscientes, motivadas por convenções estabelecidas. A intenção para Baxandall está ligada a um repertório historicamente adquirido, ressaltando-se mais a importância das obras em si, do que os relatos explicativos ou informativos sobre as razões particulares ou individuais, enfoque quase sempre simplificador.

A coleção Manodori indicia além da guarda de fotos entre gerações, a própria difusão de cenas de costumes nos álbuns familiares, nas coleções particulares, formados ao gosto do colecionismo da época. Alberto Manodori viajou por toda Europa e Oriente, formando sua coleção com imagens de aspectos e costumes. Trata-se de uma coleção com imagens em grande formato, em formato carte-de-visite e postais. Nela encontram-se fotografias de avenidas e palácios, construções e monumentos, arquitetura e esculturas, ou tudo que fosse 
considerado como "antichità", numa experiência diante de paisagens sempre fascinantes, em ruínas ou não.

Até meados de 1850 retratava-se, sobretudo, a Itália arqueológica. Segundo D”Autilia, tais representações dominaram a fotografia italiana até o fim da década de 1940. Fotógrafos renomados como os Fratelli Alinari ou os alemães Giorgio Sommer e Edmond Behles, desde o final da década de 1850, faziam suas incursões por diversas províncias italianas, envolvidos num projeto tido como enciclopédico, mas também turístico. Os catálogos Alinari, produzidos em 1896, ainda traziam a seguinte subdivisão: na primeira parte, estátuas, vistas, igrejas, palácios, relevo; na segunda, desenhos e reproduções de pinturas (Zevi,1977.).

Após o início da unificação do país, em 1865, o repertório visual se amplifica, não mais condicionado a imagem do "il bel paese", que fascinava viajantes e estudiosos desde o século XVII. Na composição da imagem do "belo país" há uma sistemática produção visual sobre o território e sobre um enorme panorama humano a partir de cenas de gênero, célebres como expressão de toda Itália: o Grand Tour, pós unificação, promovia o "reflexo no qual a Itália começaria a assumir uma consciência sobre si mesma". 289
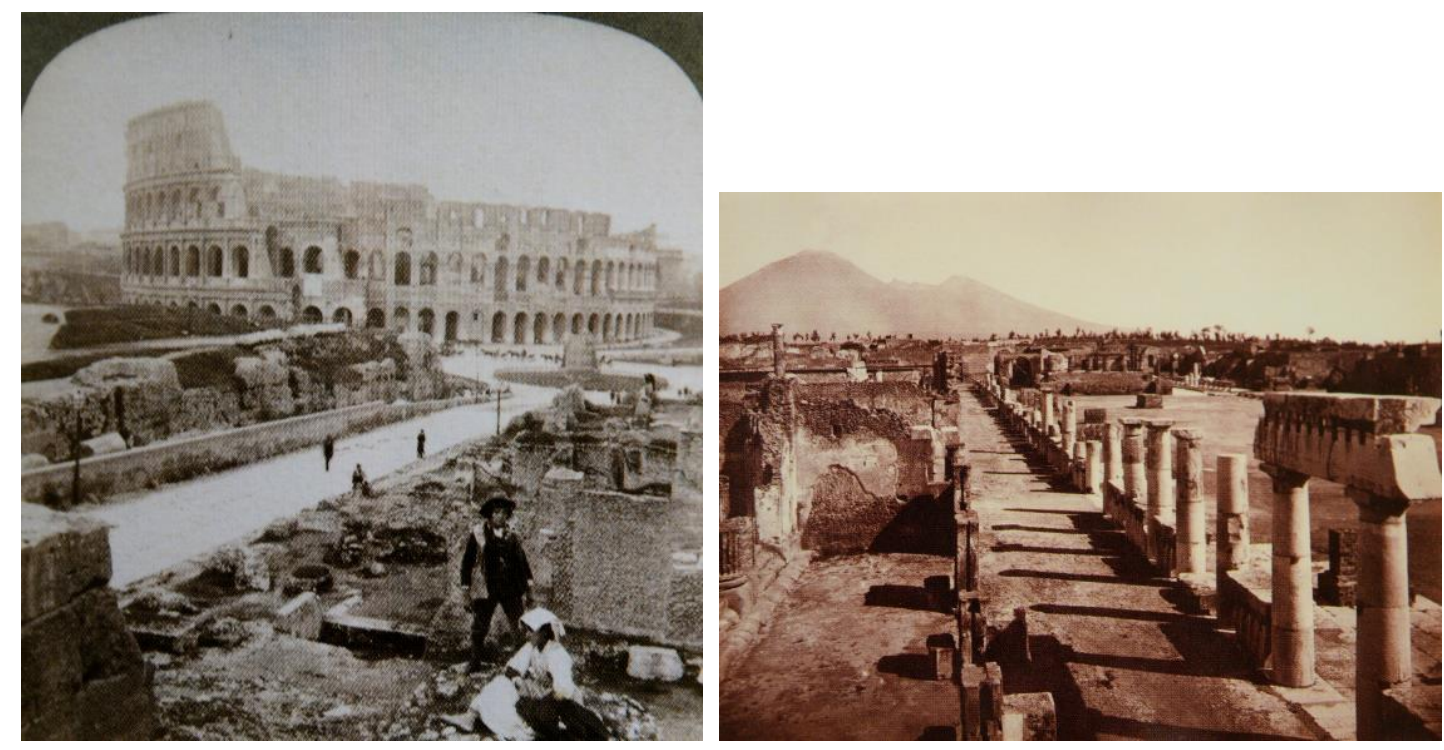

Figuras 188 e 189: Foto anônima à esquerda; imagem estereoscopica 1900. Roma; à direita Foto G. Sommer. Foro Civile. Pompei. 1870. In: Luoghi, Volti, gesti e costumi. Collezione fotografica di Alberto Manodori. Editora. Fondazione Pietro Manodori. 2008.

\footnotetext{
289 De Seca. L'Italia nello specchio Del Grand Tour. In: Annali della Storia d"Italia. V. II paesaggio. Editora Einaudi, Torino. 1982, p. 135. APUD. D'Autilia, Gabriele. Storia della fotografia dal 1839 a oggi. Editora Piccola Biblioteca Einaudi. 2012, p. 36. Toda a bibliografia na língua italiana citada neste capítulo deve ser consideradas como tradução Nossa.
} 
A seleção de imagens da coleção de Alberto Manodori é bastante reveladora dessas trajetórias visuais. Há no álbum a imagem estereoscópica feita em 1904, retratando o Colisseu, foto sem indicação de autoria (fig.188); há também uma sequência de imagens de monumentos realizadas por G. Sommer, em Pompei, (fig.189), num arranjo que aproxima fotógrafos anônimos ao lado daqueles que eram donos de importantes casas comerciais. Sommer era um fotógrafo ítalo-tedesco, que produzia catálogos em cinco diferentes formatos, dando prioridade aos aspectos monumentais e arqueológicos (Fanelli, 2007.)

A presença dos sujeitos sociais em primeiro plano começaria, contudo, a tomar as representações de monumentos, tornando-se o ponto de referência para toda a composição (fig.188). São essas as características das imagens tidas, segundo Fillipo Zevi (1977, p. 253) como "veduta animata", vistas animadas, equilibrando na composição a presença de populações locais, tendo como referência os monumentos que se deslocavam sem perder sua força preponderante.

Entre os anos de 1870 a fins da década de 1880, Sommer produziu catálogos em cinco diferentes formatos: fotos em albumina, impressas como fotolitografias, tomadas em negativos de vidro a base de colódio, eram depois distribuídas em catálogos montados em grande formato, com dimensão de 28x38; ou em tamanho médio, tendo 19x25. Os álbuns apresentavam imagens estereoscópicas e panorâmicas. Nos catálogos realizados entre 1882 e 1891, prevalecia imagens em grande formato, muitas com banhos de viragem a ouro, além de imagens em diapositivo (Fanelli, 2007). Nos catálogos produzidos após 1903, a produção de carte-de-visite de Sommer já era inexistente. Traço também visto na coleção de Manodori.
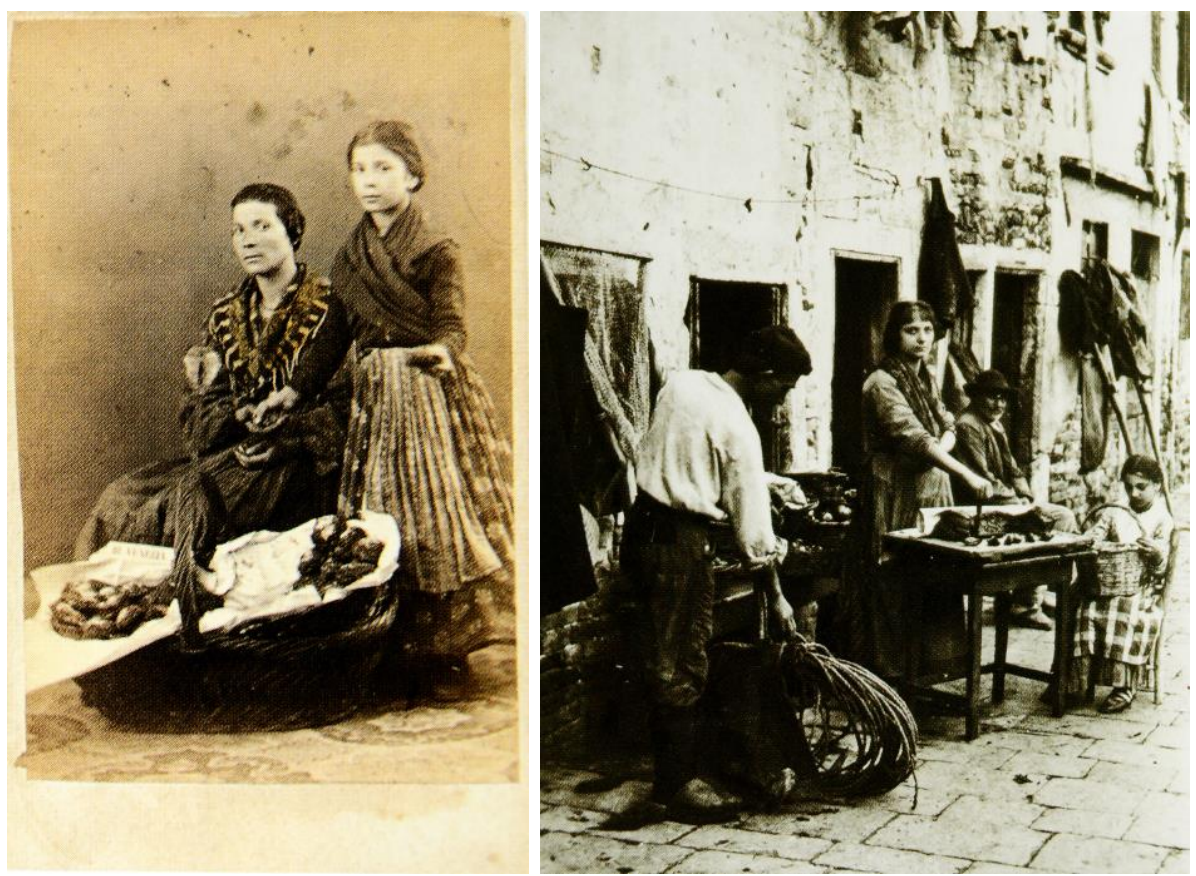

Figuras 190 e 191: à

esquerda fotografia anônima retratando "vendedora de doces". Veneza. 1870. À direita foto realizada também em Veneza retratando "vendedora de abóbora grelhada". 1900 C C. Naya. In: Luoghi, Volti, gesti e costumi. Collezione fotografica di Alberto Manodori. Editora. Fondazione Pietro Manodori. 2008. 
Há no álbum inicialmente a apresentação de algumas carte-de-visite, produzidas em 1870 (fig.190); depois há uma numerosa predominância de fotografias instantâneas tomadas nas ruas, poucas décadas depois, indiciando não somente o gosto do colecionador pelas fotos de costumes, mas o quanto esse repertório se atualizava e se renovava em novos domínios tecnológicos (fig.191). Segundo D’Autilia (2012) a "ética da foto instantânea" potencializou esse circuito fotográfico repleto de paisagens humanas, onde também encontramos Pastore.

A carte-de-visite de 1870 retrata a "vendedora de doces" em pose no estúdio. A foto tomada em 1900 retrata a "vendedora de abóbora grelhada", uma representação que buscava maior aproximação do cotidiano das ruas, inscrevendo as atualizações no campo da fotografia que ainda precisava conter certos gestos e movimentos, afinal, seus aparatos técnicos eram pouco ágeis para captar movimentos excessivos.

Esse repertório era sustentado por uma nova clientela, "i viaggiatori” que fomentava a demanda por tais imagens. A crença da fotografia como documento, dava fôlego a uma cultura visual de forte expressão na visualidade da época. Segundo Zevi (1977, p. 250) a partir de 1890 os álbuns e catálogos não mais abandonariam a documentação do trabalho pelas ruas, em diversas províncias, formadas por muitas comunas, e capitais se urbanizando.

A grande diversidade de atividades produtivas nesses espaços constituía-se como um elemento de grande curiosidade. A crise da agricultura e a progressivo crescimento da indústria na Itália, sobretudo setentrional, provocavam um novo fenômeno colocando em contato, nos principais centros urbanos, "contadini" e "cittadini", ou seja, moradores do campo ou da cidade, um contingente humano submetido a inter-relações entre o urbano e o rural. Se esse aspecto é notável na feitura das imagens criadas por Pastore em São Paulo, por toda a Itália, se tem registros de muitos fotógrafos ajustando o foco em situações sociais semelhantes. As atenções estavam voltadas para os populares:

Pequenos artesãos, trabalhadores de serviços e transportes, comerciantes modestos e agricultores absorvidos pela indústria, que se agregam em alguns bairros, muitas vezes isolados de outros contextos, ou se alojam próximos aos centros históricos em habitações degradadas e insalubres. (Zavattini e Monti, 1979, p.57. Tradução Nossa)

Os usos e funções políticas das fotos produzidas na Itália desvelam uma nova perspectiva sobre o espaço público. Menezes (2003) faz uma ressalva: "não basta colocar o visual no centro das preocupações”, ou ter a cultura como traço forte. É preciso, segundo ele, articular ambas, entender a "mediação de significados e valores", entender a natureza 
conflitiva do visual. O fortalecimento desse sistema de representações voltadas para a imagem urbana foi assim pontuado por Menezes:

A cidade continuou a alimentar o imaginário visual, mas são agora aspectos parcelares, fragmentos que deslocam, para a representação parcial, as antigas visões de síntese, portadoras das glorias da cidade. Além disso começaram a tomar dianteira as representações, mas que dos espaços urbanos, das atividades características da cidade, as "cenas urbanas". (Meneses, 1996, pp. 144-155)

Trata-se de um complexo sistema de imagens que atua e forma percepções, mas também discursos sobre o mundo, constituídos não de modo abstrato, mas nos suportes também visuais, materiais, como dimensão da própria cidade. Menezes (1996) defende que "é falsa a polaridade entre o real e o imaginário", problematizando a noção de cidade que é artefato, campo de forças e também representação. A força desse circuito envolve toda essa iconosfera promovida por práticas de produção e consumo de imagens.

Assim como o olhar dos fotógrafos italianos, o olhar do colecionador, do viajante, ou seja, o seu modo de também ver o mundo, motivaram igualmente a existência desse circuito de circulação de imagens, como bem explicou Meneses:

O olhar, portanto, institui seu próprio objeto. A imagem não só é instituída historicamente, como é também, instituinte. Daí, para um verdadeiro dimensionamento histórico, a necessidade de estudar o circuito da imagem: sua produção, circulação, apropriação, em todas as suas variáveis. (Menezes. 1996, 154)

Se o avanço da técnica fotográfica permitia se retratar "la vitta di tutti i giorni", a produção de fotos de costumes, da vida de todo dia, avançava em dois sentidos: de um lado o chamado Grand tour, que se atualizava ainda em fins do século XIX, com viajantes, também agentes nesse processo, que percorriam Roma, Veneza, Firenze, Pompei, Nápoles, Palermo, pagando muitas vezes apenas por imagens avulsas, levadas como souvenir, que circulavam ainda em catálogos, livros e exposições; por outro lado, quando os diversos paese se fizeram como um único reino, organizando-se politicamente com a unificação finalizada em 1870 com a anexação de Roma, em 1861, “de um ângulo ao outro da Península”, começava-se a encarar o seguinte desafio, segundo Wladimiro Settimelli (1989): “fizemos a Itália, agora desejamos fazer os italianos". Caberia à fotografia, dado ao seu intrínseco caráter de verossimilhança, certificar as paisagens e as estratificações culturais e sociais do país. 
A fotografia passava a ocupar o seu papel de "ator social produzindo efeitos", criando a imagem dos italianos. Identificar aquilo que Meneses (2005) chama de "imagens referência, recorrentes, catalisadoras, identitárias" ou ainda "icônicas e emblemáticas" problematiza as relações sociais mediadas por imagens, em configurações de tipos sociais que se tornavam icônicas nas representações de cenas urbanas. Lidamos aqui com um campo teórico que pode ser aproximado dos pressupostos apontados por Alfred Gell (1998) quando o autor defende o conceito de agência para pensar as imagens num procedimento crítico que não a toma em separado das manifestações sociais que colocam a fotografia na dimensão das práticas sociais, na contingência da concretude das experiências vividas.

Gell ao se "recusar a discutir a arte em termos simbólicos e de significados" afirma a necessidade de se dar "ênfase na agencia, nas intenções, causas, resultados e nas transformações" para além dos efeitos de estetização que obviamente carregam. Deter-se aos efeitos específicos que provocam, como atuam e se desenrolam na vida social, coloca-se, também para Meneses, como problematização pertinente.

No contexto de uma Itália unificada caberia à fotografia testemunhar, contar e ilustrar a abrangência do Estado unificado. Foi essa a retórica de persuasão que caracterizou a fotografia italiana até fins do século XIX, submetida a um complexo sistema de exibição e circulação de imagens; sua natureza indiciaria dava fôlego as apropriações mobilizadas nesse circuito de imagens, com a Itália assumindo como sublinha Settimelli (1989, p.11) uma dupla vocação, constituindo-se como "luogo fotografico", ou seja, como um lugar de vocação para ser fotografado. Seus habitantes seriam observados pelo viés da curiosidade, dentro de um fenômeno particular que pontuava a função pública de tais imagens.

Claudia D’Autilia (2012) chega a afirmar que a fotografia italiana é uma extraordinária amostra de estereótipos, nacionais e regionais, social e culturalmente condicionada como instrumento de nation building. Não se construía a representação apenas do indivíduo, mas de um grupo, de diferentes modos de ser, tentando expressar potencialmente o que era o próprio país. Imagens, portanto, que respondiam a premissas políticas. É esse o ambiente social que confere valor a tais imagens, distribuídas de modo abrangente.

É preciso evitar o equívoco de pensar a fotografia apenas como uma estratégia pedagogizante, como indica D"Autilia (2012, p.83), porque a fotografia assume sempre a "sua estrada criativa e comercial”. A sistemática produção de catálogos fotográficos e a intensa circulação de postais construiu aquilo que a pesquisadora chamou de "mosaico visivo" com 
enorme capacidade de inventariar e divulgar em diferentes níveis, local, nacional e internacional, o país peninsular unificado criando aquilo que ela definiu como um "estilo fotográfico". Nessa perspectiva a produção da fotografia das empresas da família Alinari, dos Brogi, mas também de muitos fotógrafos anônimos, não foi apenas uma catalogação da nova Itália, mas se realizava como "documento civile" criando, experimentando aquilo que se afirmaria em diferentes temporalidades como paradigma fotográfico, se movendo e se realizando de modo dinâmico e polissêmico. A fotografia manifesta a sua capacidade de não ser apenas agenciada, assumindo seus agenciamentos neste processo. Tratamos de um período onde a função documental da fotografia era fortemente ativada, fotografia entendida como prova e testemunha objetiva.

É preciso pontuar como essa fotografia esteve relacionada a campanhas fotográficas direcionadas mais expressivamente para as regiões meridionais. O interesse paisagístico vinha acompanhado pela atenção às diversidades culturais em campanhas que passavam a fomentar a produção de imagens voltadas para cenas pitorescas. Imagens que intuíam sintetizar diferentes modos de viver entre a cultura urbana e a campesina, imagens impressas em álbuns intitulados como "Ricordo d'Italia", circulando em diferentes meios de difusão como livros ilustrados, livrarias, óticas, casas comerciais de estampas e de produtos fotográficos, num intenso circuito de distribuição de imagens que se estendia de Roma, Genova, Veneza, a Torino, a Palermo e de Nápoles a Paris. A realização de imagens pitorescas de toda Itália promovia o crescimento de editoras italianas, mas também internacionais que produziam catálogos e cartões postais impressos em "fotocolotipia ou com procedimento tipográfico a retina".

Sommer, no álbum de 1886, ofereceu quarenta imagens de costumes, que circulavam também como postais avulsos, retratando carros de boi, vendedores de castanha, mulheres com vestimentas típicas, vendeiros de ervas, famílias preparando macarrão, engraxates e também a troca a troca de casais na típica "tarantella" (Fanelli, 2007, p.35). O álbum de 1891, era tomado por imagens de vendedores ambulantes, pescadores e lavadeiras, repertório que evidentemente atravessava toda a produção de Vincenzo Pastore.

Na grande Exposição Nacional organizada em Firenze, a primeira capital italiana, logo após a unificação, considerada como o centro fotográfico mais importante em meados do século XIX, a fotografia teve papel considerável. Ajudou a configurar a imagem de todo o território. Representava-se a Itália monumental de norte a sul bem ao gosto do Grand Tour, 
desde meados do século XVIII. A Itália, cada vez mais, foi representada de acordo com o pesquisador italiano Giovanni Fanelli, pelas cenas de gênero pictórico voltadas aos costumes:

Essas roupas, mesmo remetendo constantemente a uma tradição áulica, oferecem-se como prazeroso souvenir, como ícone de uma noção genérica de popular e como ávidas curiosidades turísticas aptas a suscitar ou a reavivar a lembrança de uma etnia muito singular, diversa e distante. (Fanelli, 2007, p. 35. Tradução Nossa)

O desejo de fotografar aspectos sociais, ou melhor, retratar os costumes, como uma específica peculiaridade das cidades das diversas regiões, se verifica mais especificamente após a década de 1880, momento em que se ampliou o repertório do viajante e se modificou a tradição do Grand Tour. Tratava-se antes, de uma pratica restrita aos "intelectuais ricos e aos aristocráticos", viajando muitas vezes por um ano ou muitos meses; depois os novos grupos emergentes, viajavam em excursões de poucos meses ou apenas semanas, dispostos apenas a pagar o preço de pequenas réplicas e nada mais além de uma fotografia, como afirma Settimeli (1989, p.17).
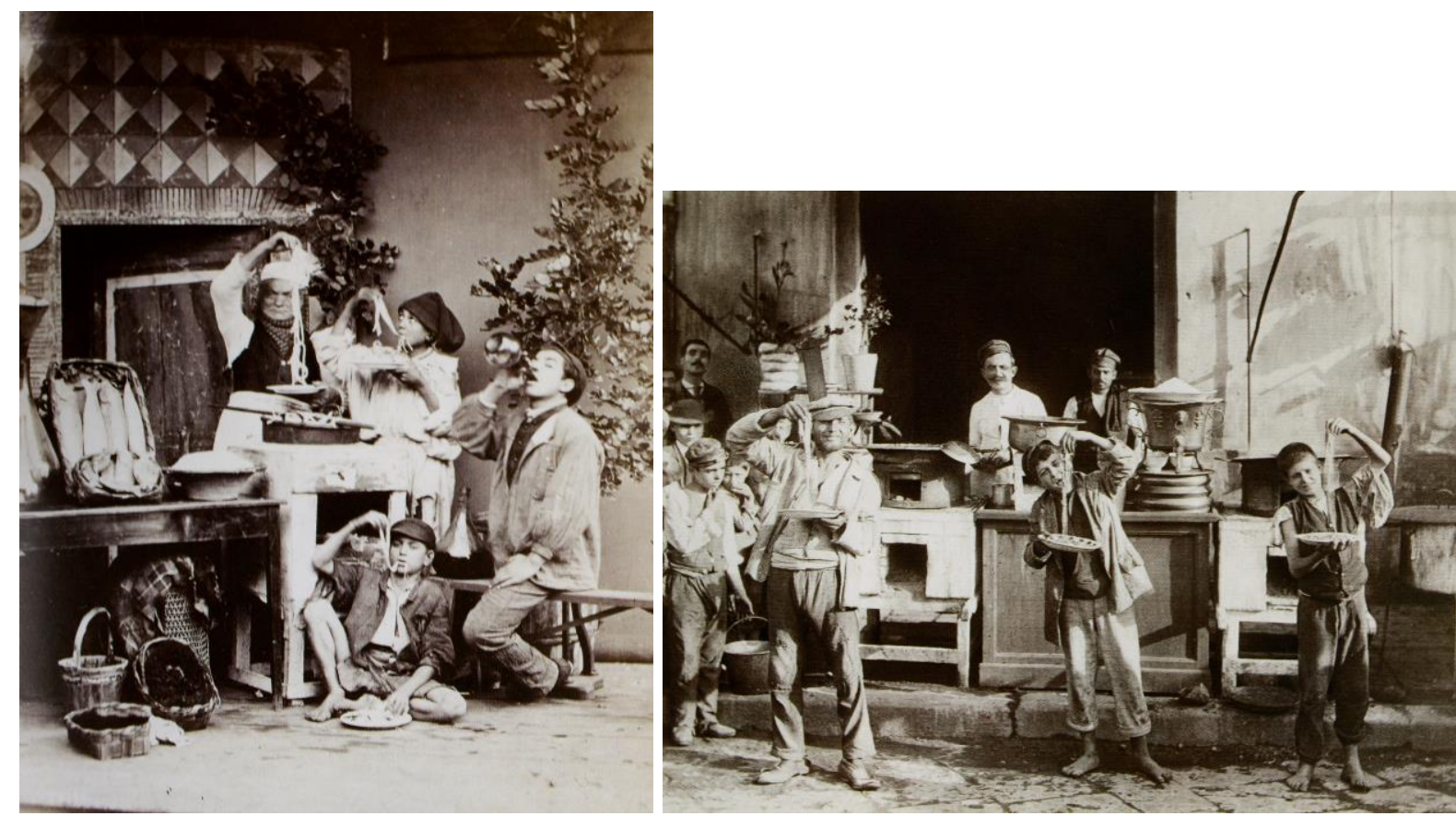

Figuras 192 e 193: Foto à esquerda "Mangiatori di maccheroni", 1886 (C) Giorgio Sommer. In: catálogo Volti e Figure. Il ritratto nella storia della fotografia. Editora Apax libri. Aión. 2009; foto à direita "Napoli Maccheronaio napoletano", 1880 (C) Carlo Brogi. In: catálogo Volti e Figure. Il ritratto nella storia della fotografia. Editora Apax libri. Aión. 2009. Ambas as fotos reprodução da página 75.

O consumo de viajantes europeus, mas também dos novos grupos que ascendiam socialmente na Itália, promoveu a produção de cenas de gêneros estereotipados, com o 
elemento humano tomando a centralidade das imagens, assumindo uma função "primordialmente coreográfica", afirmou o pesquisador Alberto Baldi (1996, p.149). Na nova sensibilidade visual que surgia sobre Nápoles tinha-se a configuração da imagem do "il maccaronaio, l'acquafrescaio" exibindo-se para a foto, afinal colocar-se em pose tornava-se cada vez mais um código social amplamente compartilhado. O tipo endossaria o estereótipo.

Em 1886, o fotógrafo Giorgio Sommer, que já se dedicava a cenas de gênero desde 1857, realizou em Nápoles uma típica foto destinada ao Grand Tour (fig.192), tida pela historiografia italiana como um exemplo do gênero pitoresco. Essa composição em tudo evoca a encenação, envolvendo todos os retratados, nessa foto intitulada "mangiatori di maccheroni”. O fotógrafo Carlo Brogi (1850-1925), em 1880, intitulou na margem de sua foto (fig.193) a legenda "Napoli - Maccheronaio napoletano", com o negativo identificado com o número de 10.458, rastreando o volume de sua produção. Por toda a segunda metade dos oitocentos era comum ver vendedores pelas ruas cozinhando ovos, peixes, arroz, sopas, vegetais. Brogi registrou em uma calçada de Nápoles uma verdadeira estrutura para o cozimento de macarrão, numa cena que assumiu evidentemente a função coreográfica apontada pelo pesquisador Alberto Baldi.

Apesar de estereotipadas, as cenas de costumes registraram sociabilidades e formas improvisadas de sobrevivência. Muitas famílias passavam a madrugada preparando as massas para a feitura do pão e das conhecidas "pastas". O preparo na calçada, a beira da estrada era prática para fugir do calor das áreas internas. Essa representação remetia a existência de pequenos negócios, o próprio desejo de independência econômica, indo muito além de expressar um hábito alimentar típico da cultura napolitana.

A despeito de constituírem registros mais estereotipados, no percurso dessa visualidade, diminuía-se a força da referência. Os fotógrafos nas ruas passavam a buscar cada vez mais cenas não posadas, em movimentos que caracterizariam uma fotografia apta em captar a espontaneidade das sociabilidades, chamando a atenção dos fotógrafos, à serviço de uma crescente demanda visual.

\subsection{A pulsão das ruas atraindo os fotógrafos por toda a península itálica}

Registros de costumes circularam por toda a década de 1890. Em 1891, o fotógrafo anônimo retratou o vendeiro sob os arcos da Piazza Vittorio, em Roma (fig.194). O grande 
cesto servia de apoio as suas mercadorias; Em 1896, o fotógrafo Gaetano Senni retratou o vendedor de panelas, num enquadramento que destacava a sua barraca, descontextualizada de toda efervescência da Piazza Campo di Fiori (fig.195). Vê-se os mesmos ângulos mais particularizados também recorrentes na produção de Pastore.
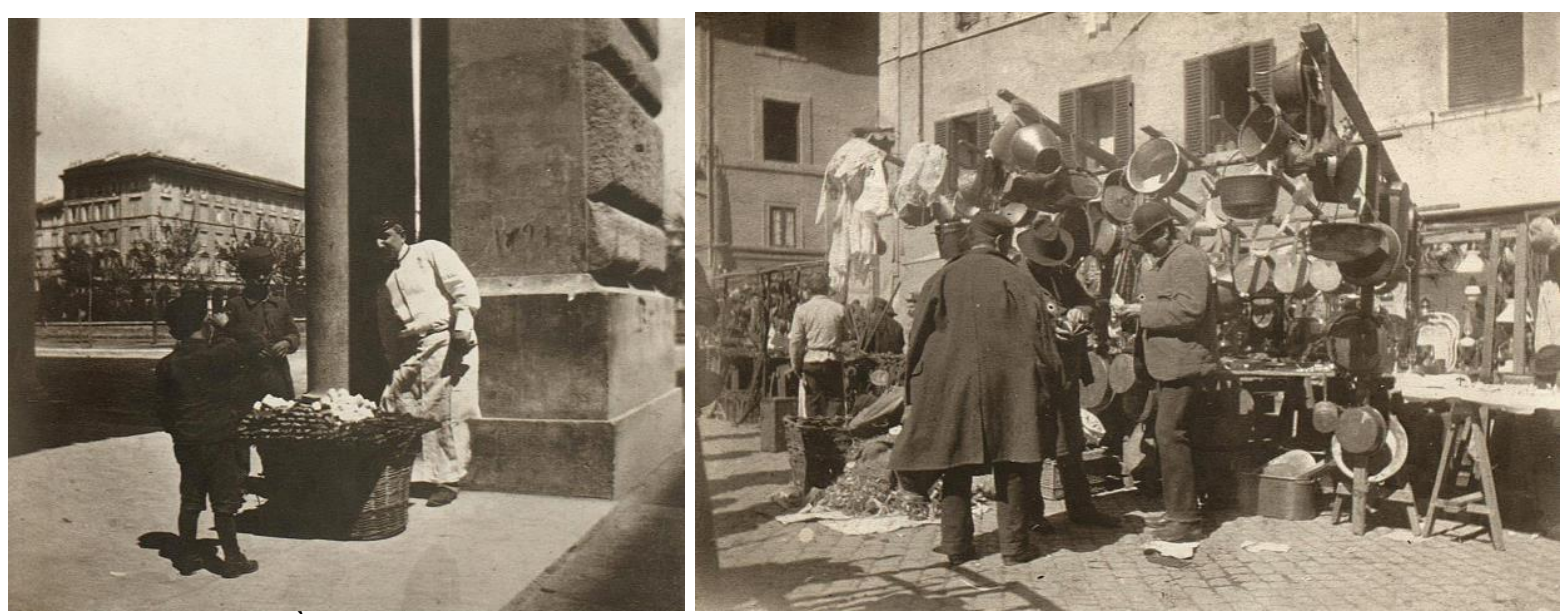

Figuras 194 e 195: À esquerda o "Bruscolinaro" sob os arcos da Piazza Vittorio. 1891 (C) foto anônima; à direita, vendedor de panelas. Mercado Campo Di Fiori. Roma. 24 de março de 1896 () Gaetano Senni. Ambas as reproduções In: La Fotografia a Roma Dalla Origini al 1915. Roma. Editora Colombo. 1983.

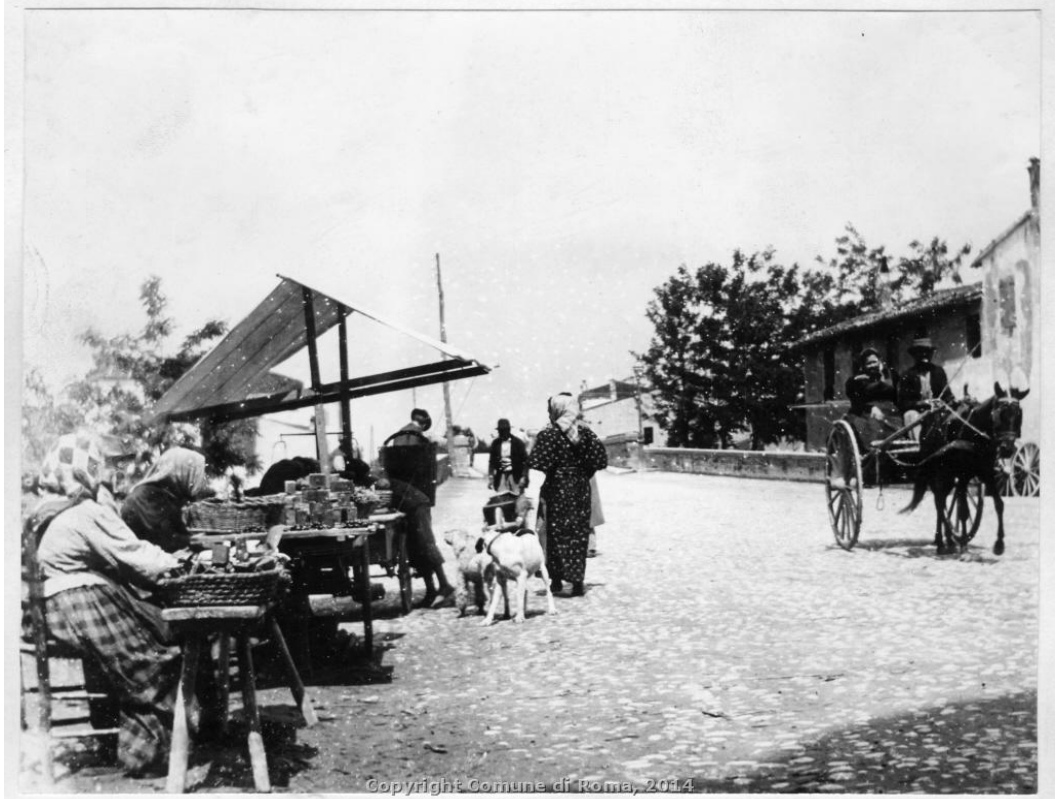

Figura 196: Vendedores ambulantes. 1890-1899. (C) Conrado Giuseppe e Fornari Felippo / Arquivo Comunale de Roma/Museu de Roma

Vê-se como entre os vendeiros, alguns já haviam adquirido entre suas posses uma barraca com cobertura (fig.196). Com tal artifício protegiam a si próprios e as suas mercadorias postas à venda. Conrado Giuseppe e Fornari Felippo foram identificados como autores dessa foto produzida entre os anos de 1890 a 1899. No recorte escolhido lá estavam elas: mulheres que usavam banco de madeira como apoio de seus pequenos cestos, que 
levavam uma variedade menor de produtos, totalmente expostos. Apenas lenços as protegiam na cena de costume que registrava um cotidiano de trabalho não encenado.

Alinari, poucos anos antes, retratou vendeiros ambulantes de peixe. A tenda se expande pela foto como importante elemento estético de composição (fig.197). Seu uso para proteger as mercadorias disponíveis no comércio de rua foi aprovado desde meados de 1850, incluindo o uso de guarda-sol. O fotógrafo buscou imagens posadas, projetando certa idéia de imobilismo, uma característica da produção do período. Tratava-se de uma necessidade devido ao tempo de exposição, mas também como expressão de uma mentalidade que atribuía uma suposta passividade e pouca autonomia aos habitantes locais, como indicou D”Autilia (2012).
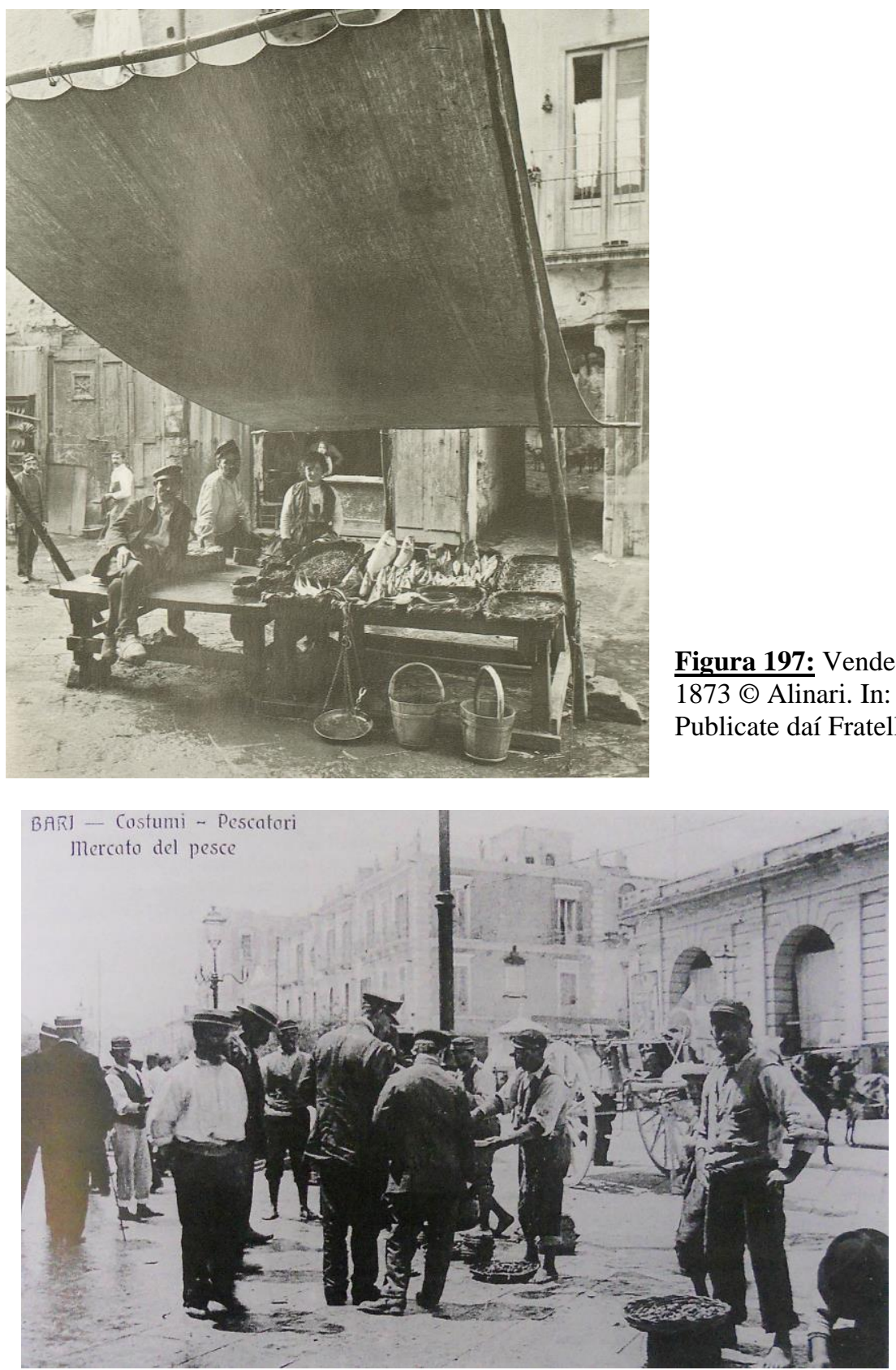

Figura 197: Vendedores de peixe em rua de Nápoles. 1873 ( ) Alinari. In: Catalogo Generalle Delle Publicate daí Fratelli Alinari.
Figura 198: Bari. Fototipia, 10x15. 1900. (C) Enrico Bambocci. In: Leonardi, Sérgio. La Fotografia Dell'Ottocento a Bari. Bari: Mario Adda Editore. 1997, p.67. 
Em 1900, Bari, a província natal de Pastore, era também representada pelo mesmo conteúdo que interessou a Alinari na década de 1870 em Nápoles. Os extremos ao sul da península aproximavam-se na elaboração de um mesmo referente. A imagem "CostumiPescatori, Mercato del pesce" (fig.198) circulou como um postal estampando a foto realizada por Enrico Bambocci que já contava com maiores aparatos técnicos para retratar cenas de um cotidiano de maior espontaneidade. ${ }^{290}$

Enrico Bamboccio tinha a sua própria casa editorial na principal rua barese; ocupava o número 54 na Corso Vittorio Emanuele. O estúdio de Pastore ocuparia, catorze anos mais tarde, a Rua Sparano, que desembocava na rua em que Bamboccia mantinha seu estúdio e tipografia. Talvez Pastore tivesse conhecido apenas as imagens que Bamboccia produziu e estampou porque no ano de 1907, este fotógrafo seguiu para Nova York, ficando nos Estados Unidos até 1931, ano de sua morte (Leonardi. 1997, p.66).

No livro "Bari la zita mè" encontramos outra foto feita por Bamboccio retratando Bari, entre os anos de 1900 a 1910 (fig.199). O título expressa possivelmente o uso em dialeto que pode ser entendido como "Bari, la città mia", podendo ser traduzido como "Bari minha cidade" ou ainda "Bari minha terra". O comércio de rua se estendia na visualidade barese revelando uma realidade cotidiana conhecida por Pastore e pelos seus fotógrafos contemporâneos, também seduzidos pela força desse repertório que caracterizaria cada vez mais as províncias ao sul da Itália, onde a economia informal dominava.

Bambocci, retratou ainda o vendeiro cercado por seus cestos, tendo ao lado a carroça que o ajudava a transportar suas mercadorias. A mesma situação representacional aproxima essa imagem da produção de Lopez (Fig.200). São essas fotografias que não alcançaram a qualidade técnica das grandes casas comerciais de fotografia, mas, são importantes nessa análise porque compartilhavam das mesmas convenções, com semelhantes noções de enquadramento e composição de cena.

\footnotetext{
290 Nas décadas de 1880 e 1890 a província plugliese recebeu duas campanhas fotográficas. Monumentos e obras de arte foram retratados por Nicola Di Matia, fotógrafo da região que produziu cinqüenta imagens que integrariam o catálogo de 1885; Romualdo Moscioni, fotógrafo que atuava em Roma, esteve em Bari em 1891, atuando também em Foccia e Benevento. Giorgio Sommer, Fratelli Alinari e também Giacomo Brogi, na década de 1880, estiveram na região. Este último realizou a vista do porto barense. (Leonardi, 1997, p, 63). Tradução Nossa.
} 


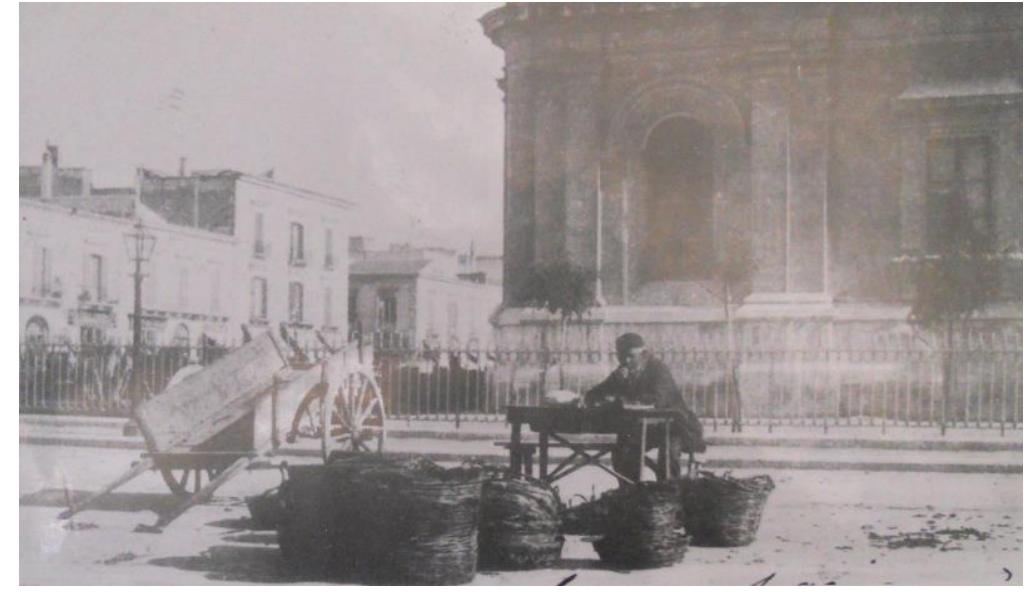

Figura 199: Vendedor em uma rua de Bari. 1900 () Bambocci / Archivio A. Giovine. In: Giovine, Alfredo. Bari la zita me. Bari: Edizione Fratelli Laterza. 1981.

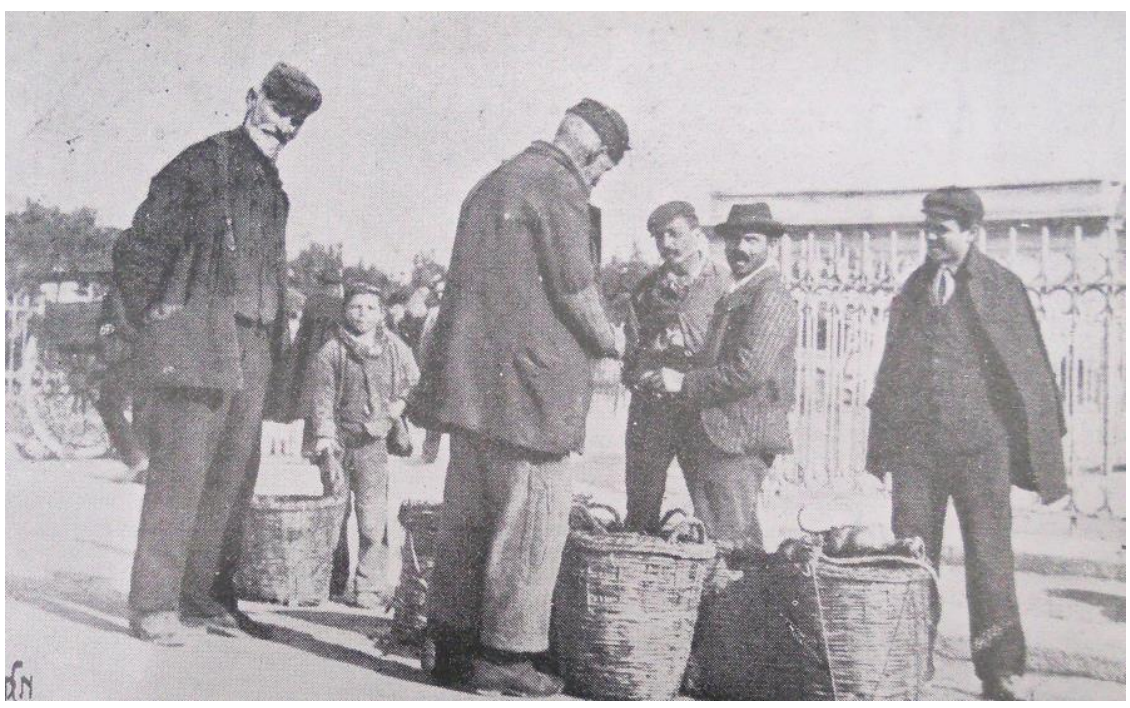

Figuras 200: Vendedores na Avenida Corso Cavour em Bari. Foto intitulada Venditori di Ricci. S/d (C) Lopez / Archivio A. Giovine. In: Giovine, Alfredo. Bari la zita me. Bari: Edizione Fratelli Laterza.1981.

Lopez, na Avenida Corso Cavour e Bambocci, por meio da produção de suas imagens que circulavam em postais barese, escolhia recortes na horizontal; a cidade era tida apenas como pano de fundo. Em primeiro plano, tem-se as realidades de trabalho improvisado nas calçadas, a representação de papéis sociais masculinos, envolvendo adultos e crianças, uma mão-de-obra nem sempre incorporada nas contingências da industrialização incipiente. Pastore em São Paulo e os fotógrafos que retratavam Bari no início do novo século, reproduziam as mesmas referências visuais, nas mesmas fendas sociais de uma economia estruturada em diferentes práticas de trabalho.

A imagem à esquerda, (fig.201) realizada nas ruas de Bari, no primeiro decênio de 1900, apesar de não apresentar a identificação do fotógrafo, sequer do logradouro, interessa porque vê-se semelhanças temáticas, bem como os mesmos atributos formais, vistos em Pastore (fig.179): Fotos verticais, tomadas num enquadramento deslocado do ponto de vista central, priorizando maior vazão ao campo de fundo com uma tomada ascensional, com as fachadas das construções ajudando a compor ambas as fotos em semelhante arranjo. É 
evidente o esforço em documentar os sujeitos sociais em interação, ocupando mais uma vez todo o primeiro plano das imagens, fotografados de corpo inteiro, de costas, muitas vezes de perfil, em gestos não simulados. Nos diferentes planos, vê-se o movimento de gente e das carroças, desvelando o quanto os fotógrafos se empenhavam em representar espaços de sociabilidades vibrantes, dando maior dinamismo à cena. A freqüente representação de animais pelas ruas, puxando carroças, num intenso circuito de transporte de mercadorias, toma as cenas de costumes na Itália, recorrentes como representação das cidades, numa fase incipiente de seu desenvolvimento.

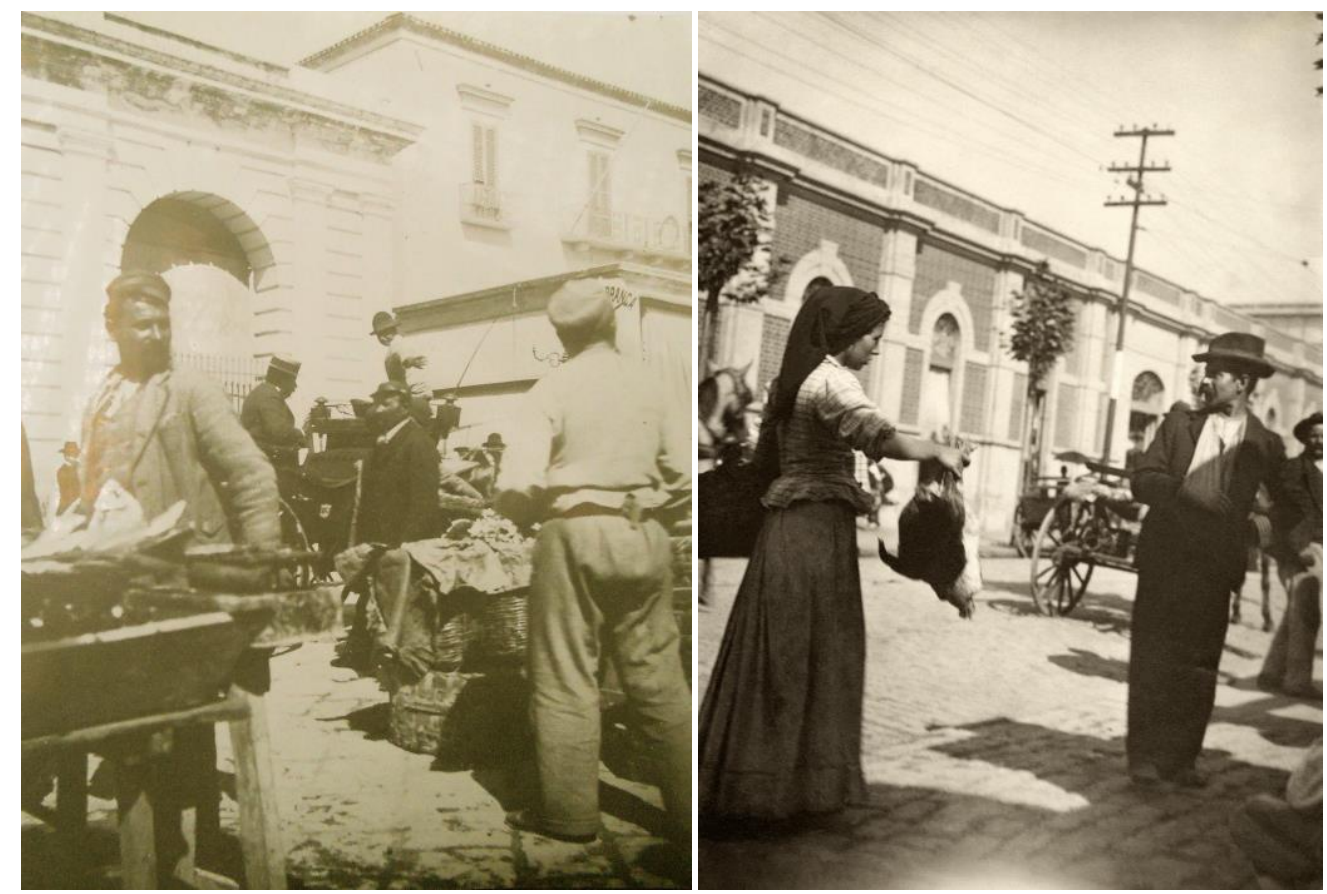

Figuras 201 e 179: Foto anônima à esquerda.

Vendeiros na cidade de Bari. Archivio A. Giovine. In: Giovine, Alfredo. Bari la zita me. Bari: Edizione Fratelli Laterza.1981; à direita Vendedora de galinha em rua adjacente ao Mercado Municipal, provavelmente 25 de Março, junto ao Mercado dos Caipiras. 1910 (C) Vincenzo Pastore / Instituto Moreira Salles

O colecionador e viajante Alberto Manodori adquiriu fotos de profissionais anônimos e outras realizadas pelas casas comerciais fotográficas de maior destaque no país. A empresa Alinari, que já sobrevivia há meio século, fazia circular a seguinte imagem (fig.202) realizada em Palermo no ano de 1900, intitulada "carretto da vino". Em 1870, o fotógrafo Sommer realizou a fotografia 6251 (fig.203). O carroceiro posava ao lado do carro de boi, no ano em que o fotógrafo produziu o seu primeiro catálogo fotográfico; três anos depois editaria o segundo, reproduzindo imagens feitas entre 1860 a 1867, incluindo as novas tomadas realizadas no ano de 1873. Esse catálogo trazia imagens de Roma e Nápoles, indo do número 1 ao número 136, apresentando uma segunda sequência de negativos numerados entre 136 a 3.302. Essa imagem foi publicada pela primeira vez no Catálogo Sommer - Napoli, identificada como "carro com boi e asno", em 1882, com o negativo de numero 6251. No 
catálogo de 1886, a mesma foto recebeu, contudo, outra numeração, 11.624. O fotógrafo estampava fotos que havia realizado desde meados de 1860, fato que ajuda a explicar, segundo Fanelli (2007), a pouca clareza da numeração indicada; mas há algo mais a destacar: tal imagem se inscreve em uma precisa trajetória ao longo da segunda metade do século XIX: atravessava décadas, impressas em diferentes suportes que mantinham esse repertório vivo, ativo, em circulação também avulsa.
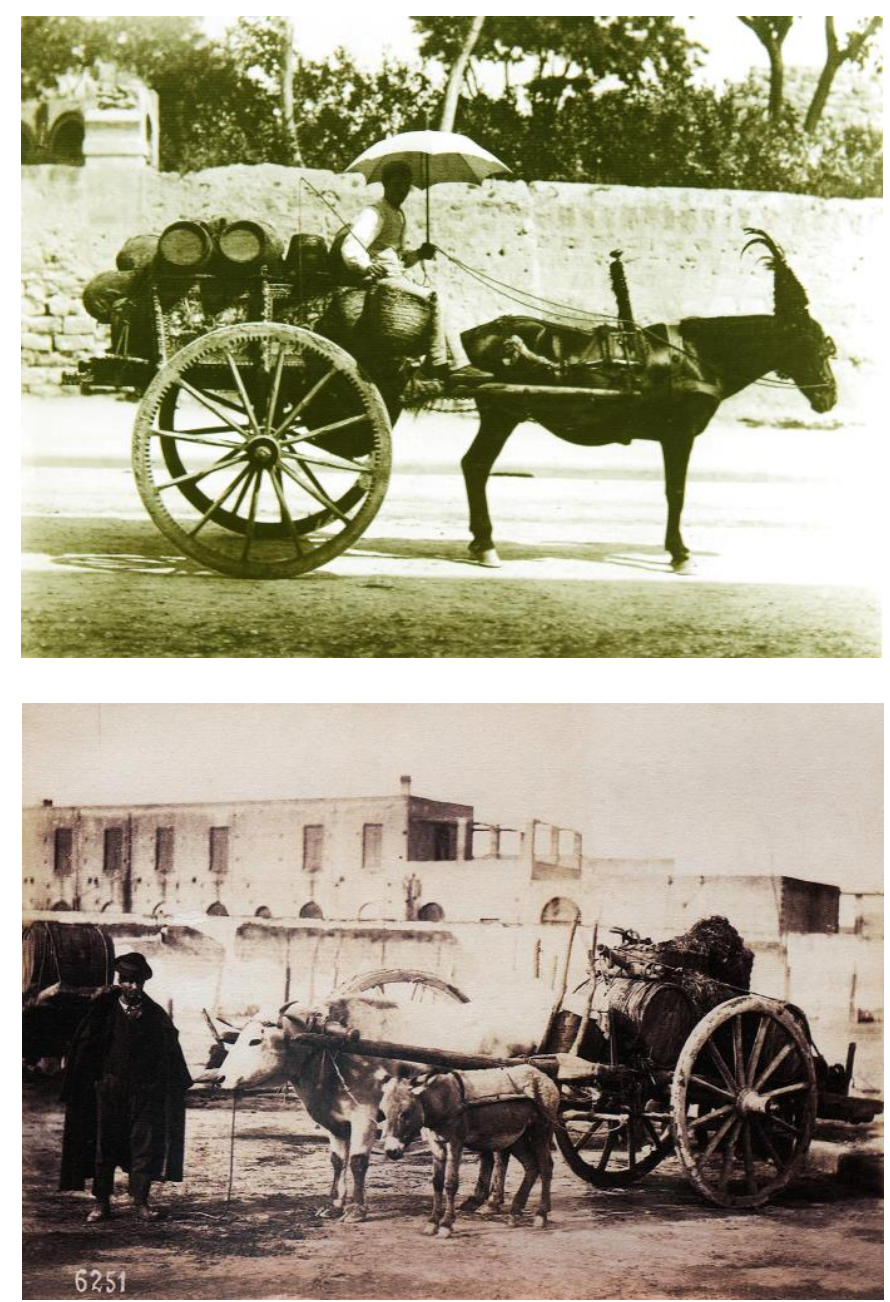

Figuras 202: Carroça de Vinho. Foto tomada em gelatina de brometo de prata. Palermo. 1900 (C) Fratelli Alinari. In: Luoghi, Volti, gesti e costumi. Collezione fotografica di Alberto Manodori.

Editora. Fondazione Pietro Manodori. 2008.

Figura 203: Fotos G. Sommer. 1870. In: Fanelli, Giovanni. L'Italia virata all'oro attraverso le fotografie di Giorgio Sommer. 2007, p. 121.

Em sua segunda etapa de circulação impressa, e melhor documentada, a foto "carro de boi e asno" foi publicada em outro catálogo ao lado de quarenta fotografias identificadas pelo fotógrafo como fotos de costume: Fotos de vendedores ambulantes de castanhas, de ervas, de engraxates, preparadores de macarrão ou dançarinos de tarantella. ${ }^{291}$

\footnotetext{
291 Foram impressas inúmeros registros de museus como o de Nápolis, do Vaticano, do Museu Nacional de Palermo, fotos de pontes, monumentos, ferrovias e fontes, castelos, igrejas e praças de diversas cidades italianas, na maioria reproduzidas no formato 19 × 25, destinadas a curiosidades turísticas. Cf. Fanelli, Giovanni. L'Italia virata all'oro attraverso le fotografie di Giorgio Sommer. 2007, pp. 31-35. Tradução Nossa.
} 
Dez anos depois, em 1880, o fotógrafo Carlo Brogi, também se voltou para este conteúdo (fig.204). Retratou o carroceiro com rédeas na mão. As muitas inscrições em RC, marcadas nas laterais, indicam talvez as iniciais do proprietário. Imagem que circulava em cartão postal, tendo sido antes numerada pelo fotógrafo como a foto 19.253 , com o título "Nápoles. Carroça carregada de caixas de macarrão", inscrito na margem inferior da foto.
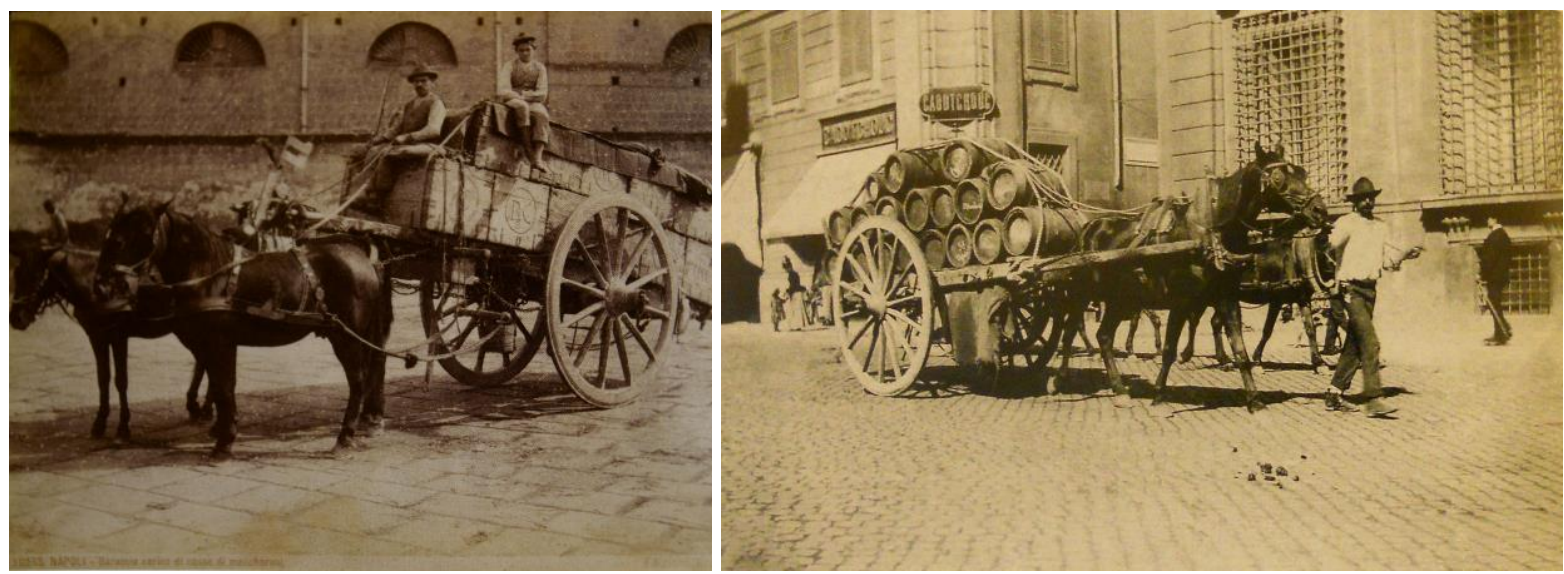

Figura 204 e 205: Foto à esquerda "Nápoles. Carroça carregada de caixas de macarrão", 1880 @ Carlo Brogi. In: catálogo (org) Pagnotta, Linda. Volti e Figure. Il ritratto nella storia della fotografia. Editora Apax Libri. Aión. 2009. Foto à direita autoria não identificada. 1890. In: Storia Fotografica di Roma. 1900 a 1918. Dalla Belle Époque alla Grande Guerra. Editora Intra Moenia. 2003.

A imagem do carroceiro integrava essa visualidade do novo século. Em 1900, a entrega ou a venda de vinhos era feita em carroças puxadas a cavalos que atravessavam a Piazza Venezia, atraindo a atenção do fotógrafo anônimo (fig.205). Essa cena retratada reitera o repertório de muitos cartões postais que registravam o lugar, o costume e a gente da Itália. Talvez os fotógrafos anônimos atendessem a uma demanda ainda mais abrangente, já que este conteúdo visual tomava também a tela dos pintores, que recorriam à fotografia no processo criativo de suas pinturas.

Mario De Maria foi um pintor que realizava inúmeras fotografias usadas como modelos para seus estudos pictóricos. Valia-se de sua câmera instantânea para registrar a presença de carroceiros que cruzavam as pontes de Roma (fig.206). Chama atenção a mesma escolha temática em evidente diálogo com a produção de Pastore, que também se interessou pelos carroceiros que transportavam cerveja pelas ruas esburacadas e repletas de lama da capital paulista (fig.153), compondo também o cotidiano de trabalho dos carregadores de lixo na Rua Direita (fig.154). 

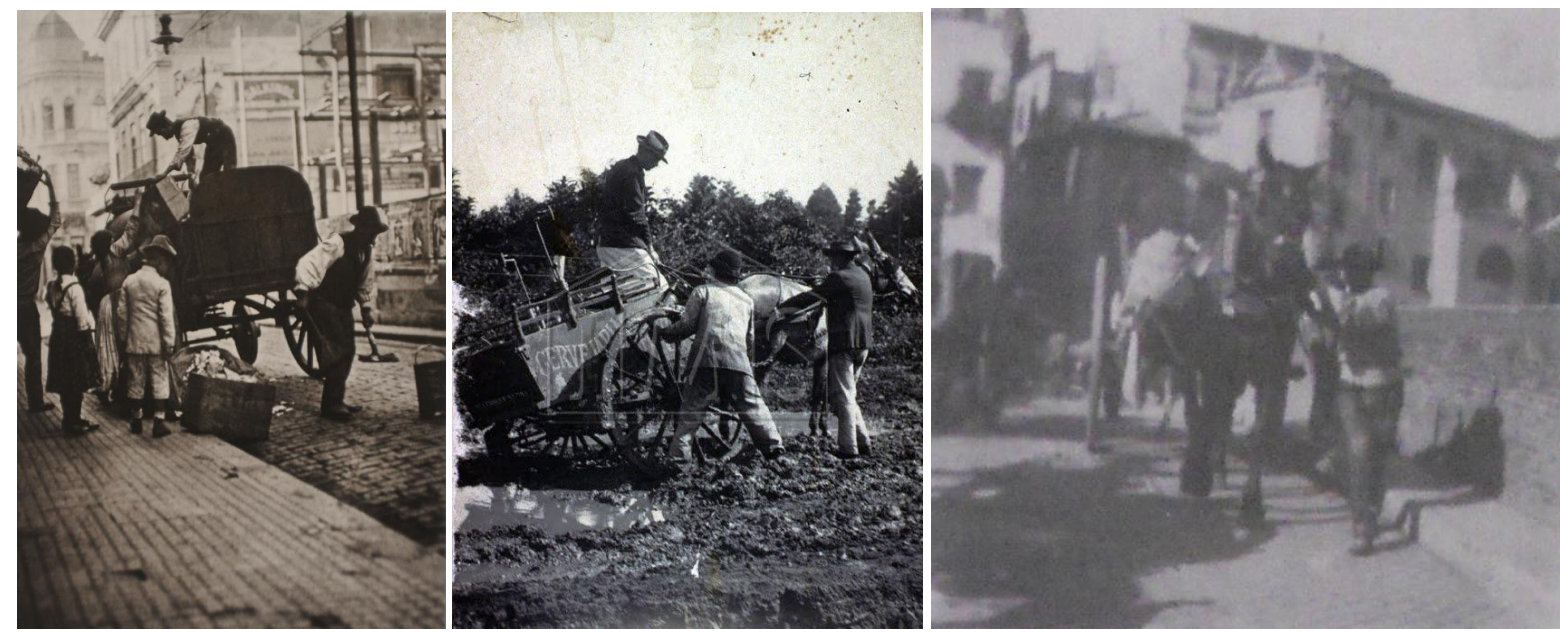

Figuras 154, 153 e 206: à esquerda carroça de coleta de lixo na Rua Direita; ao centro, carroça transportando cerveja. Ambas, 1910 (C) Vincenzo Pastore / Instituto Moreira Salles. À direita Foto Mario De Maria. In: Del Balbarò, Michele Falzone e Tempesta, Claudia. Marius Pictor Fotografo. L'album fotografico di Mario De Maria. 1882-1887. Editora IFotolibri/Longanesi\&C. 1979, p.51.

Quando o pintor Ettore R. Franz fotografou barqueiros no rio Tevere (fig.207), de onde inúmeros peixeiros, residentes em Trastevere, tiravam seu sustento, vê-se outro conteúdo produzido na Itália lembrando o de Pastore em suas andanças pela capital paulista (fig.209). Dessa vez foram os barqueiros, numa paisagem pitoresca posta ainda em exibição pelo fotógrafo Carlo Brogi (fig.210), e também pelo pintor- fotógrafo Mario De Maria (fig.208), o qual repetidas vezes, registrou as margens próximas ao Porto de Ripeta, que até fins do século XIX, garantia pelas águas do Tevere o fluxo de produtos alimentares, assim como a circulação de pessoas.

Ao final do século XIX, as barragens e pontes de alvenaria construídas em Roma ampliaram as possibilidades de trabalho para muitos barqueiros que transportavam e descarregavam madeira e outros produtos como vinho, azeite, verduras e legumes, castanhas, etc. Essas embarcações eram também voltadas para a intensa atividade da pesca, numa via fluvial importante para o abastecimento da cidade atraindo muitos pintores, marcante na “Roma Pittoresca” de Ettore R. Franz. A força de tal repertório levou Tempesta a considerar o rio Tevere como "a verdadeira alma de Roma, que o povo via como teatro de seu próprio drama", já que as inundações foram documentadas em muitas imagens do pintor (Del Balbarò e Tempesta, 1979, p.15). 

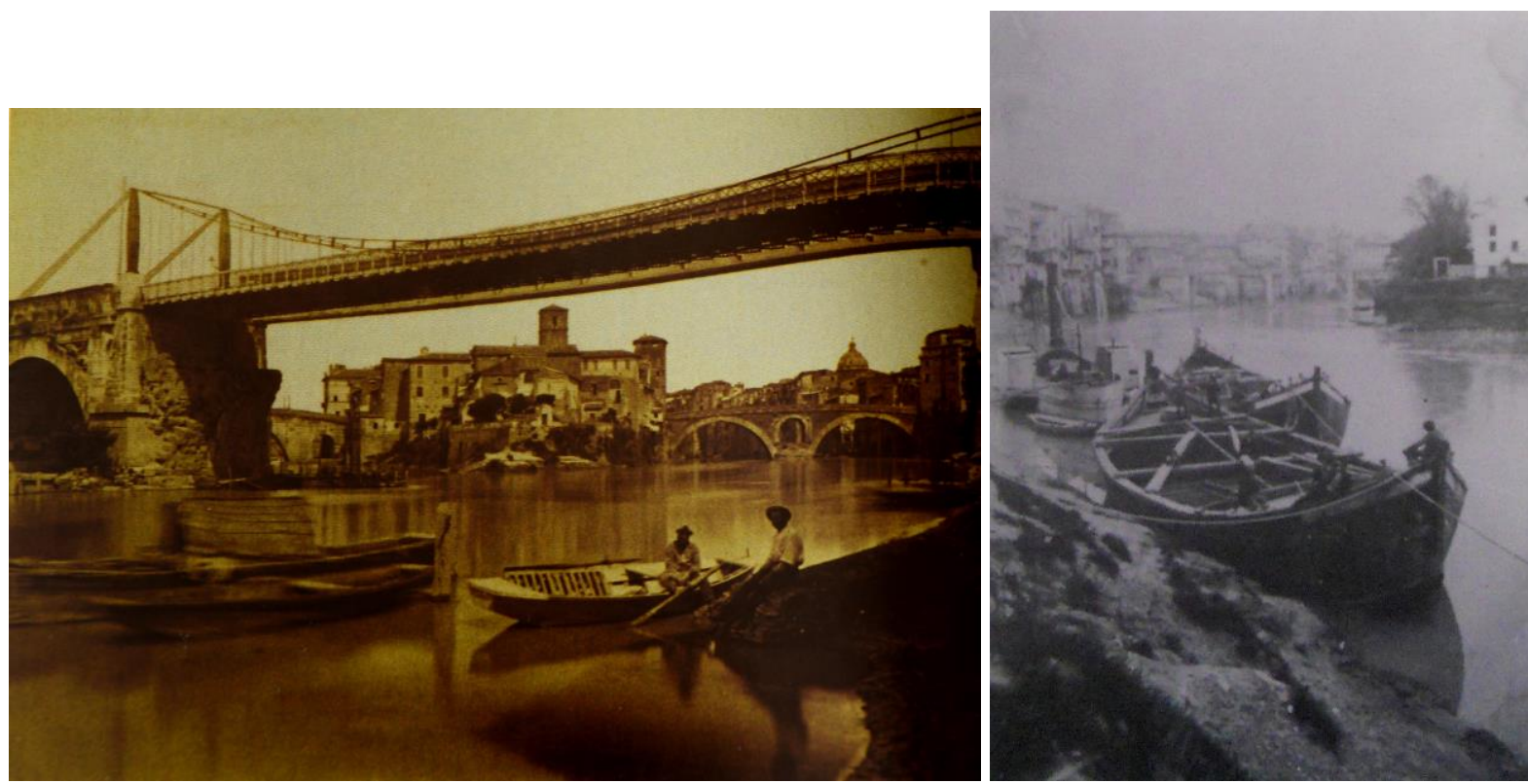

Figura 207 e 208: à esquerda fotografia realizada pelo pintor Ettore Roesler Franz. Barcos ao sul do rio Tevere. Reprodução do livro Itinerari nella Roma pittoresca di Ettore Roesler Franz. Palombi Editora. 2012; à direita foto feita pelo pintor Mario De Maria. In: Del Balbarò, Michele Falzone e Tempesta, Claudia. Marius Pictor Fotografo. L'album fotografico di Mario De Maria. 1882-1887. Editora IFotolibri/Longanesi\&C. 1979, p.51.
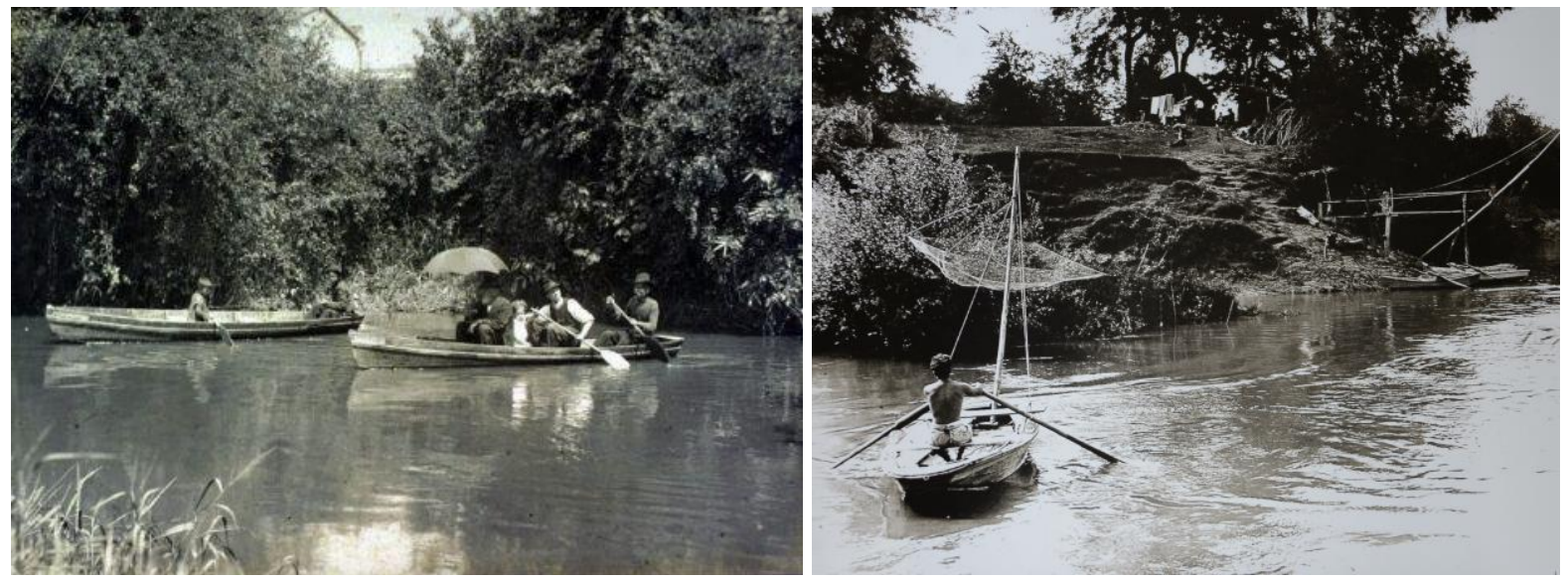

Figuras 209 e 210: Foto à esquerda "Barcos no rio Tamanduateí", 1910 @ C Vincenzo Pastore / Instituto Moreira Salles. Foto à direita, Coleção Brogi. Arquivo Alinari. Firenze. In: Roma e il Lazio Negli Archivio Alinari. 1989.

O contexto urbano em transformação tornava-se central no projeto artístico de Ettore, autor de uma série de aquarelas que expressavam como "o saber e a habilidade popular foram por longo tempo eficazes instrumentos de sobrevivência cotidianas”. Melancolia e impotência diante das transformações dos espaços urbanos e de seus modos de vida levaram Ettore, a compor aquilo que Donatella Occhiuzzi (2012, p.26) chamou de "poetica delle perdita".

Revelam-se sentidos que aderiam ao fotográfico. As cenas do Tamanduateí, retratadas por Pastore, em seu processo de acomodação posterior, na década de 1990, como veremos 
mais a frente, foram igualmente ativadas como imagens que traziam o sentido de uma perda, de uma visão nostálgica da cidade.

Assim como encontra-se em Pastore a difusão de cenas de tipos e aspectos documentaram os laços estreitos de um sistema produtivo que ligava campo e cidade, na iconografia italiana encontram-se produtores das regiões vizinhas da capital romana se deslocavam em longas viagens. Embarcações e carroças saiam de diferentes comunas vizinhas rumo à província romana. $\mathrm{O}$ carreto do verdureiro foi fotografado por Giuseppe Primoli na travessia da Ponte Milvio. A linha de trilhos de trens puxados a cavalo, inscrita em primeiro plano, levava a Piazza Del Popolo. Vê-se a presença das duas mulheres, à direita da foto, surgindo como elemento essencial na configuração das cenas de costumes (fig.211). A legenda que acompanha a imagem sugere que talvez se deslocassem levando seus cestos, rumo a algum dos mercados da capital romana, como mencionou Bruno Brizzi (1989).
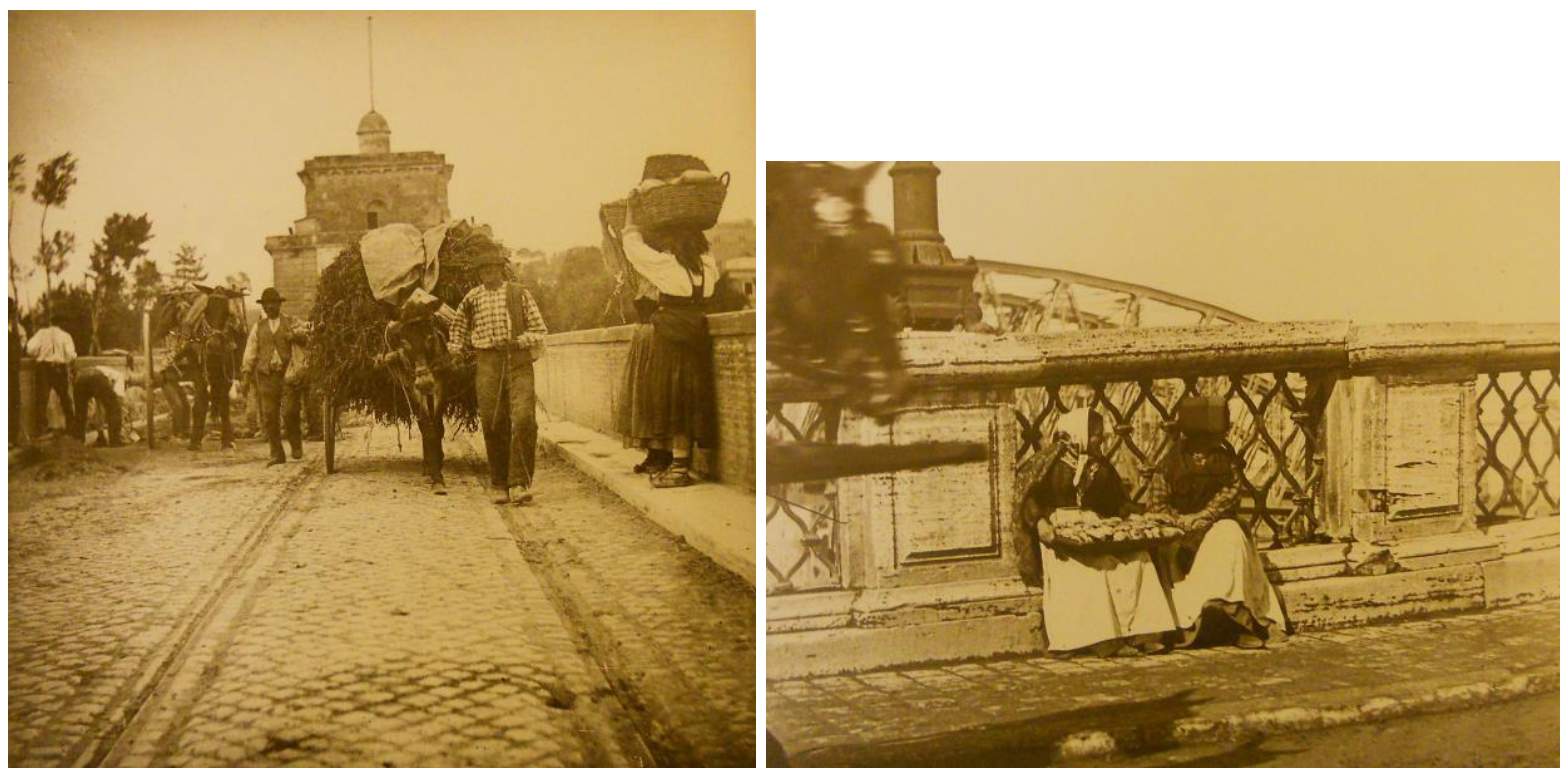

Figura 211 e 212: ambas as fotos foram realizadas por Giuseppe Primoli. À esquerda, 1890. Ponte Milvio; à direita Venditrice ambulante a Ponte Sant'Angelo. Sem data. Fondazione Primoli. In: Brizzi, Bruno. Il Tevere. Um secolo di Immagini. Editora Colombo. 1989.

Em outro registro, desta vez tomado na Ponte Sant'Angelo (fig.212), Primoli escolheu para a sua foto outras vendedoras ambulantes. Desviaram olhares que antes talvez tenham flagrado o fotógrafo. De seus tabuleiros garantiam o próprio sustento em Roma. O seguinte cartão postal de 1902 retratava, contudo, as vendedoras de ovos em Potenza (Fig.213). A presença de muros que cercam as principais ruas da cidade como a Via Pretoria, Rosica e Rua Del Popolo mantinha vivo o aspecto de burgo medieval da capital potentina, representada pelo trabalho ambulante feito por muitas mulheres. 

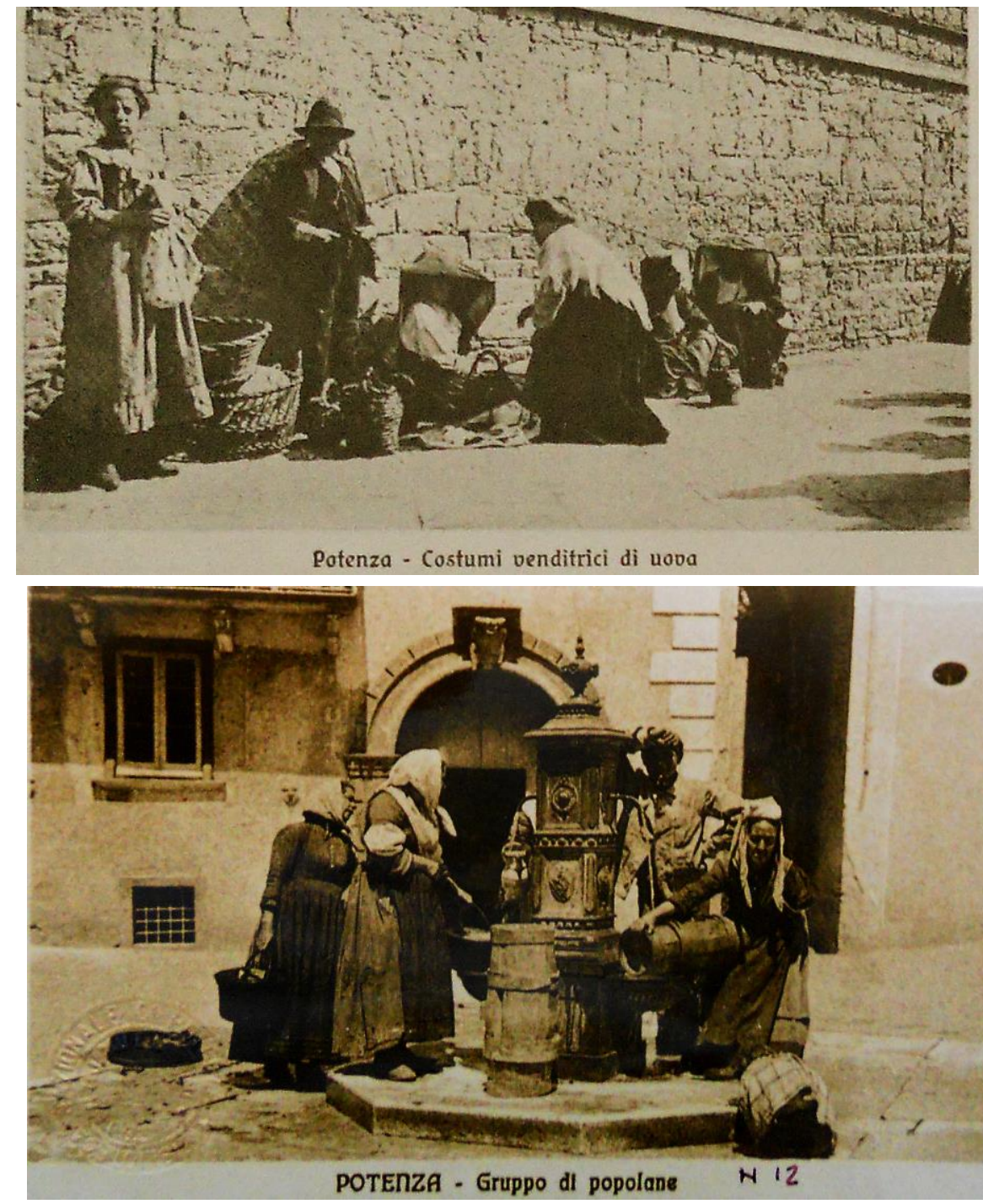

Figura 213: Foto anônima. Potenza. Vendedora de ovos. Cartão postal de 1902. In: Luccioni, Luigi. Saluti Da Potenza. Potenza: La Buona Stampa. 1983.
Figura 214: foto não identificada. Cartão Postal. Potenza. 1900. Biblioteca Nacional de Potenza.

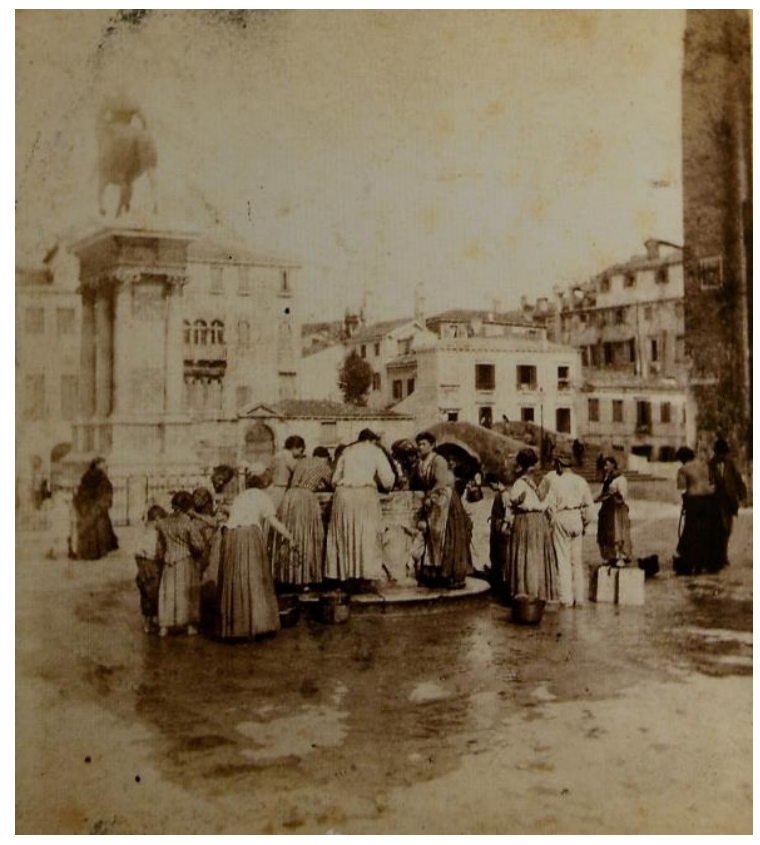

Figura 215: Fotografia intitulada "mulheres no poço do Campo San Zanipolo" integrando a coleção de Alberto Manodori, foto sob suporte de cartão rígido. $1870 @$ C. Naya. In: Luoghi, Volti, gesti e costumi. Collezione fotografica di Alberto Manodori. Editora. Fondazione Pietro Manodori. 2008. 
Os cartões postais potentinos de início de século registravam aquilo que Luigi Luccioni (1983, p.23) chamou de uma simplicidade de costumes, de hábitos de vida fortemente comunitários. Apesar de todo o volume de postais que estampavam os avanços das ruas centrais de Potenza, a representação das “donne in costumi”, seguia em moda. Próximas aos chafarizes, fontes e lavadouros, onde buscavam água e lavavam suas trouxas de roupa, as mulheres eram constantemente retratadas. Imagens que apenas aparentemente se referem a costumes lucanos. Em outras regiões de toda a Itália, eram esses os espaços da configuração de suas imagens.

Nos arranjos da coleção Manodori o postal veneziano produzido em 1870 pelo fotógrafo C. Naya (fig.215) trazia a imagem estereoscópica de "mulheres no poço do Campo San Zanipolo”. Imagem, quando comparada ao postal potentino de 1900 (fig.213), rastreou três décadas de circulação de um mesmo repertório visual. Trata-se de uma visualidade socialmente difundida, fazendo com que "gerações inteiras conhecessem o país" por meio de imagens formadoras de uma "educação visual sob este enquadramento, sob estes cânones de interpretação da paisagem", com sujeitos sociais postos em exibição, configurando-se como um "componente da própria cultura italiana", que chegaria por toda a primeira metade do século XX como uma cultura de massa (Zevi,1977, p.255).

Tenta-se observar agora a composição da visualidade voltada para as mulheres, um repertório que atravessava a produção de fotógrafos amadores e profissionais e também de fotógrafos-pintores, relações entre a fotografia e pintura nem sempre apaziguadas, apesar de evidentemente próximas no contexto da cultura visual italiana.

\subsection{Figuras femininas na interface da Fotografia com a Pintura}

Para diminuir as incertezas daquilo que sempre se tem como invenção de um discurso sobre o objeto buscamos outras aproximações. O registro das vendedoras de aves nas ruas agitadas pelo comércio de abastecimento em Nápoles (fig.216), feito pelo pintor fotógrafo Eugenio Buono, ${ }^{292}$ interessado pelas sociabilidades das camadas populares, lança-nos para o

292 Eugenio Buono (1861-1948), nascido quatro anos antes de Pastore, é considerado um pintor paisagista tendo exibido seus trabalhos em importantes mostras. Em 1887, participou da Exposição Nacional de Veneza com a obra "Casa delle vestali"; em 1891 levou a Milão a obra "Case Bianche"; quatro anos depois na mesma cidade apresentou "Dintorni di Napoli"; em 1910, na Bienal de Veneza, expôs sete obras no total, entre elas "Rittorno della pesca", apresentando, portanto, cenas de costumes, em toda a sua trajetória como artista. No arquivo da família foram encontradas fotos que variavam entre de $4 \times 6$ até $13 \times 18$, em condições de 
mesmo conteúdo que interessou a Pastore na rua adjacente ao Mercado Municipal em São Paulo (fig.177). Como não ser tocado pela semelhança de tais materiais visuais? Como não ver em Pastore a veia, a pulsão, a vibração da fotografia italiana ainda viva e atuante em novo século, ativada além-mar?

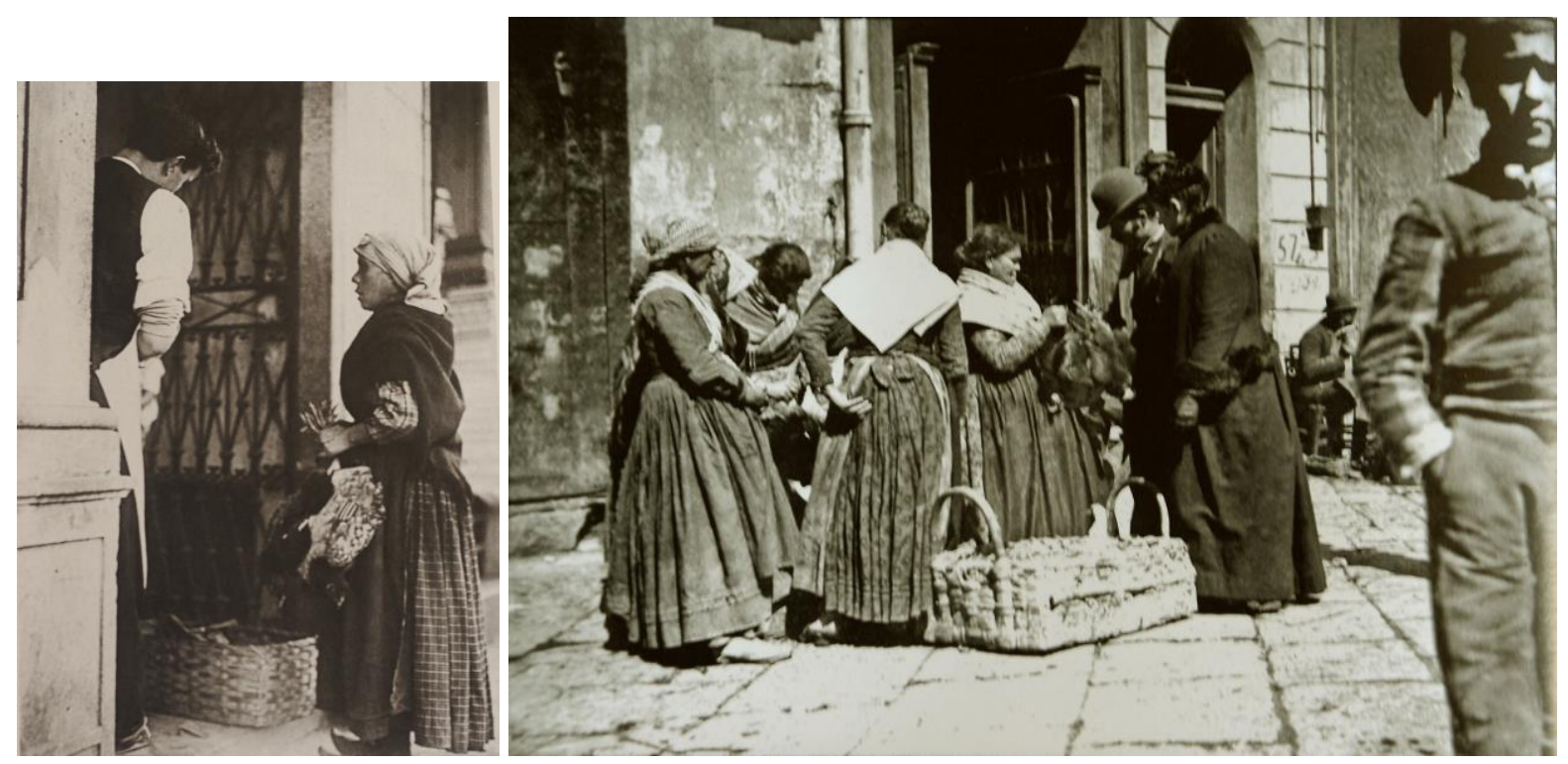

Figuras 177 e 216: Foto à esquerda mulher vendeira de aves ou fazendo uma suposta entrega. 1910 ๑ Vincenzo Pastore / Instituto Moreira Salles. Foto à direita de Eugenio Buono. In: Italia inédita di un secolo fa. Napoli, Venezia, Palermo, i borghi di Caiazzo e di Cerreto Sannita nelle lastre ritrovate di Eugenio Buono. Napoli: Edizioni Intra Moenia. 2008.

O conteúdo eleito pelo colecionador Alberto Manodori revela a combinação de tempos, ritmos e narrativas fotográficas que contam as vivencias femininas em suas constantes aparições no trabalho feito nas ruas. O retrato da vendedora ambulante de louças foi adquirido para essa coleção (fig.217). Os irmãos Alinari teriam solicitado uma cena simulada? Próximo aos varais estendidos ao fundo, o fotógrafo era observado no instante em que a moça, em 1880, talvez tenha se deixado retratar nas ruas de Nápoles, num momento de possível descanso.

conservação tidas como ruins, coleção onde predominam retratos das camadas populares, entre eles, muitos pescadores. As fotos da coleção da família foram inventariadas e digitalizadas por um grupo de pesquisadores da Università di Napoli Federico II; hoje a coleção, com retratos das camadas populares, muitos pescadores, mas também de militares, pinturas tidas como de caráter social, integra o Centro Studi Nadar. Sorbo, Luca e Scateni, Luciano. Italia inédita di un secolo fa. Napoli, Venezia, Palermo, i borghi di Caiazzo e di Cerreto Sannita nelle lastre ritrovate di Eugenio Buono. Napoli: Edizioni Intra Moenia. 2008, p.08. A representação de peixeiros é um repertório que também constitui a produção de fotografias e pinturas realizadas no trabalho do artista italiano Ettore Roesler Franz, nascido em Roma, em 1845, pintor de inúmeras aquarelas que tiveram como matriz imagens fotográficas usadas como modelos, como ponto de partida e seu trabalho, essenciais no processo de elaboração de suas criações pictóricas. Cf. Occhiuzzi, 2012, p. 26. Tradução Nossa. 


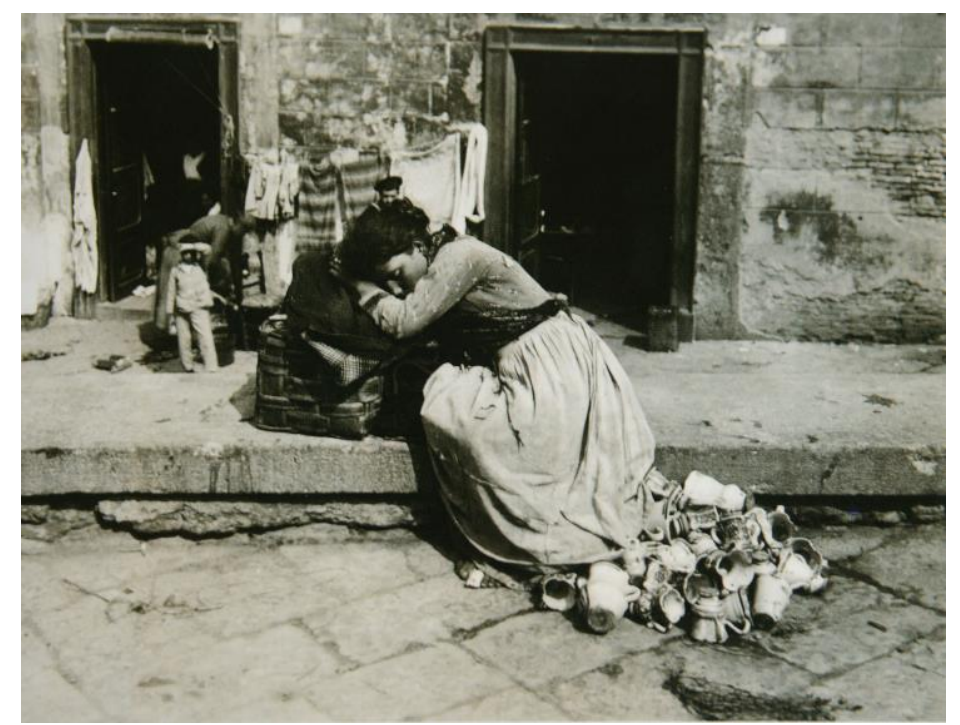

Figuras 217: Mulher vendedora de louças talvez em um momento de descanso. 1880 (C) Alinari / Coleção fotográfica de Alberto Manodori. (1866-1935). A coleção teve início com seu pai Pietro Monodori. Reprodução do livro Luoghi, volti, gesti e costumi. Collezione fotografica di Alberto Manodori. Editora. Fondazione Pietro Manodori. 2008.
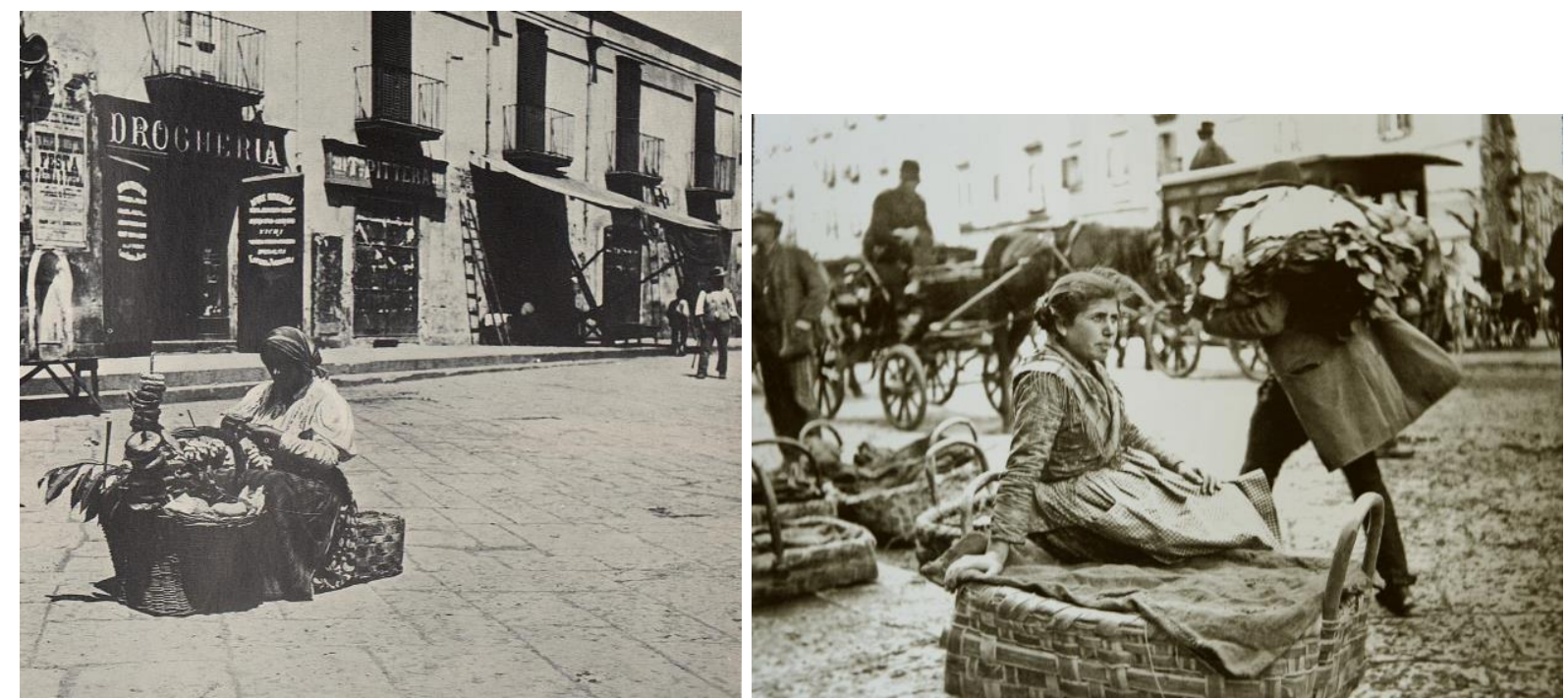

Figuras 218 e 219: à esquerda vendedora de Pastarelle em Nápoles. 1873 (C) Alinari. Coleção Alinari, Firenze. In: Catalogo Generalle Delle Fotografie Publicate dai Fratelli Alinari. 1873; à direita vendeira sentada sob grande cesto. Nápoles. Sem data (C) Eugenio Buono. Reprodução do livro Italia inédita di un secolo fa. Napoli, Venezia, Palermo, i borghi di Caiazzo e di Cerreto Sannita nelle lastre ritrovate di Eugenio Buono. Napoli: Edizioni Intra Moenia. 2008.

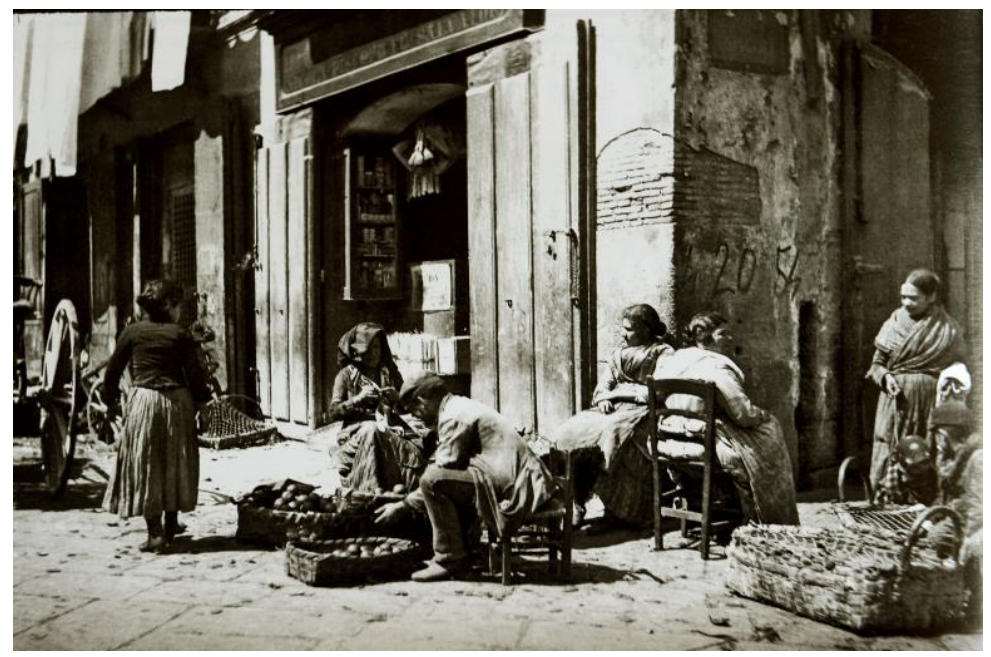

Figura 220: Foto realizada em Nápoles por Eugenio Buono. In: Italia inédita di un secolo fa. Napoli, Venezia, Palermo, i borghi di Caiazzo e di Cerreto Sannita nelle lastre ritrovate di Eugenio Buono. Napoli: Edizioni Intra Moenia. 2008. 
Nos caminhos dos serviços prestados nas ruas napolitanas, viu-se o vendedor ambulante de pão ou até de guarda-chuva que levava no ombro a caixa de ferramentas; havia aqueles que concertavam panelas, pratos, potes e ainda outros que faziam reparos em sapatos. Mas Alinari, voltou-se para a vendedora de "pastarelle" (fig.218), populares biscoitos de leite não muito doce, assados em forno de lenha. Essa foto foi publicada em catálogo, em 1873, tendo circulado também como um cartão postal napolitano.

Buono, pintor que recorreu à negativos de vidro com camadas de gelatina e sais de prata, em exposições que sempre priorizavam luzes contrastadas, também se interessou por muitas mulheres vendeiras em Nápoles. Sua composição priorizava ora perspectivas individualizadas, como a da moça sentada sobre o grande cesto coberto com lona, usada para proteger a sua mercadoria (fig.219), ora ampliava seu foco, atento aos ritmos de sociabilidade entre aqueles que acomodavam à vontade suas cadeiras e cestos a espera da aproximação dos clientes (fig.220). Três décadas antes Alinari havia percorrido a mesma região, possivelmente as mesmas ruas e travessas, tendo encontrado a vendedora de "pastarelle" que preferia vender sozinha. Essa mesma teia de trabalho diário, sem fim, retratando papéis sociais femininos, remetem a Pastore.
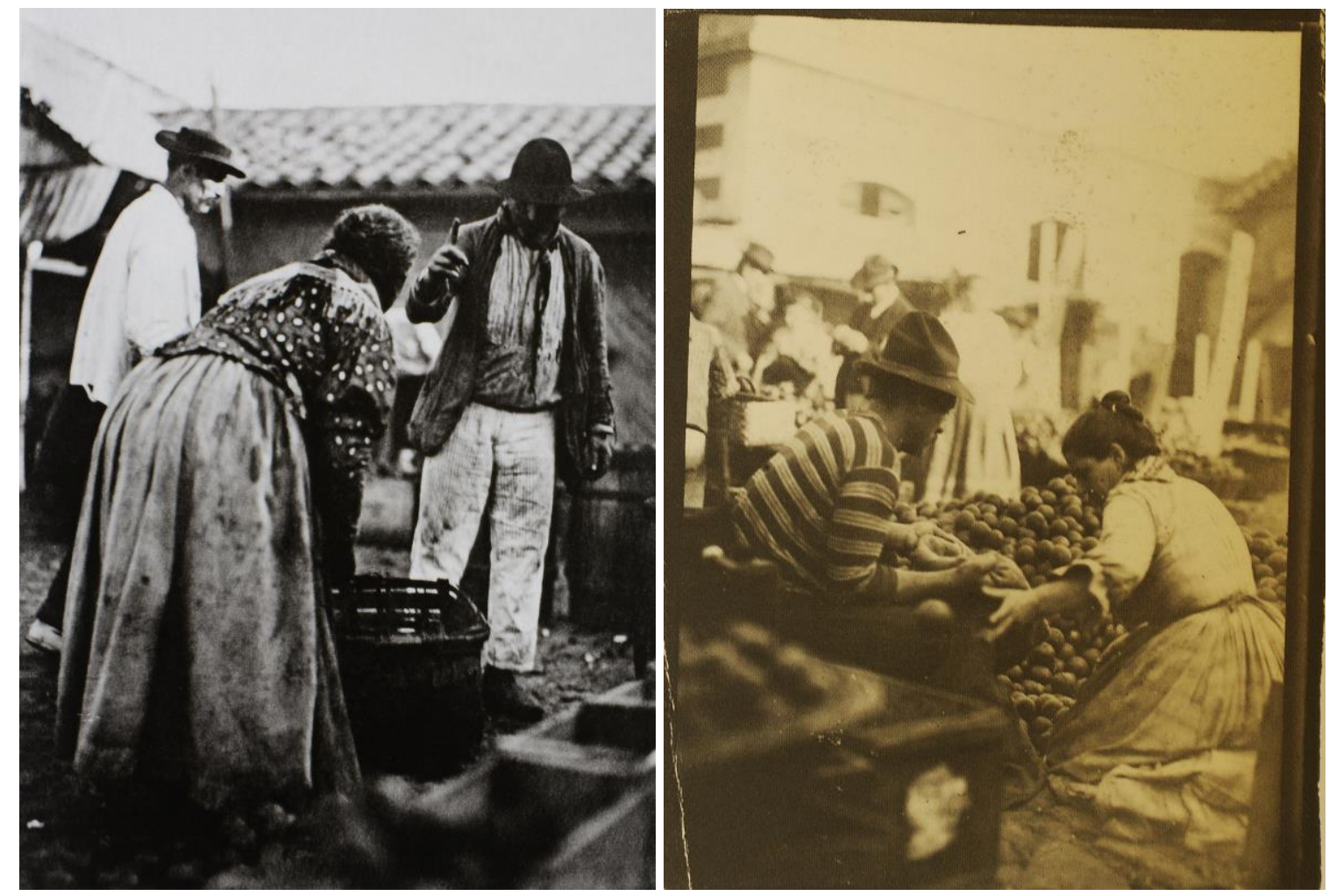

Figuras 221 e 222: à esquerda "Mulher de costas conversa com homem"; à direita "Comércio de frutas no mercado dos caipiras". Ambas, 1910@ Vincenzo Pastore / Instituto Moreira Salles. 
Pastore também se voltou para recortes mais particularizados, centralizando a presença dos retratados que ora surgem totalmente de costas, ora debruçando-se sob o trabalho cotidiano e desgastante (fig.221 e 222). Corpos em movimento deram maior dinâmica à cena, num arranjo visual de menor controle, em flagrantes gestos inerentes ao ato da foto instantânea, onde tudo competia com a paisagem real do trabalho.

Alberto Manodori traria para sua coleção particular a foto produzida em 1900, sem autoria identificada, retratando o vendedor ambulante de peixe, em Veneza, cercado de possíveis clientes, e da mulher que talvez o ajudasse na venda (fig.223). Chama atenção a valorização dos trajes escuros femininos. Pastore também reforçou a densidade das vestimentas usadas em contraposição a pertinente astúcia de se levar os caixotes à cabeça. $\mathrm{O}$ fotógrafo parece atraído pela composição proporcionada pelas vestes das mulheres que inscrevem sua presença no ganho das ruas, já modificadas pelos desejos de melhoramentos.

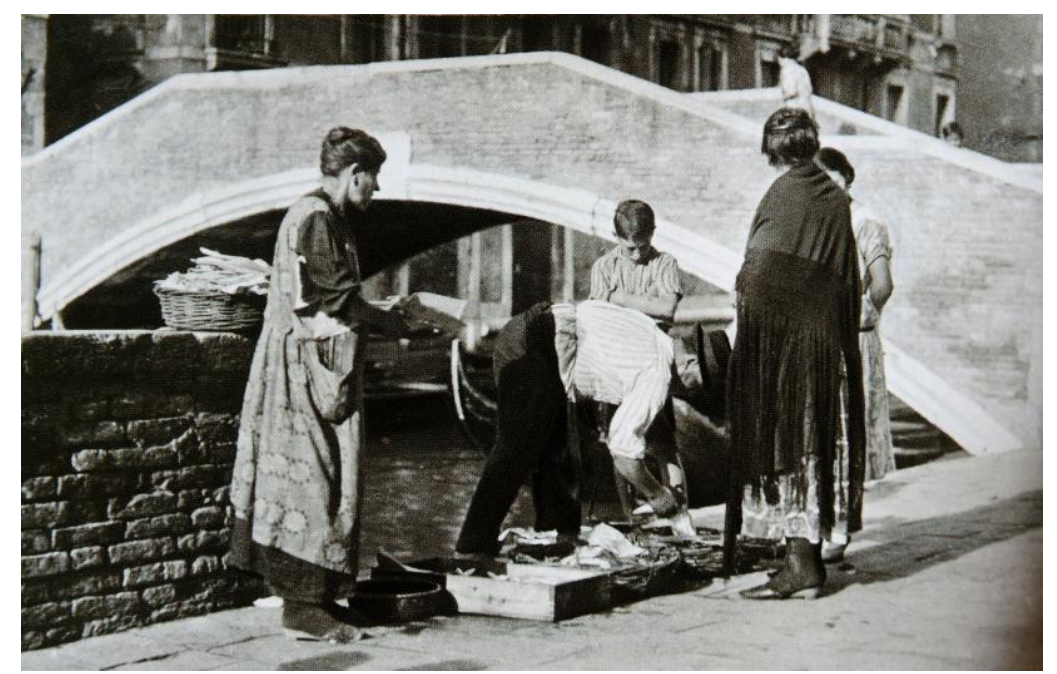

Figura 223: Fotógrafo anônimo. Vendedor ambulante de peixe. Veneza. 1900. Coleção fotográfica de Alberto Manodori. (1866-1935). A coleção teve início com seu pai Pietro Monodori. Reprodução do livro Luoghi, volti, gesti e costumi. Collezione fotografica di Alberto Manodori. Editora. Fondazione Pietro Manodori. 2008.
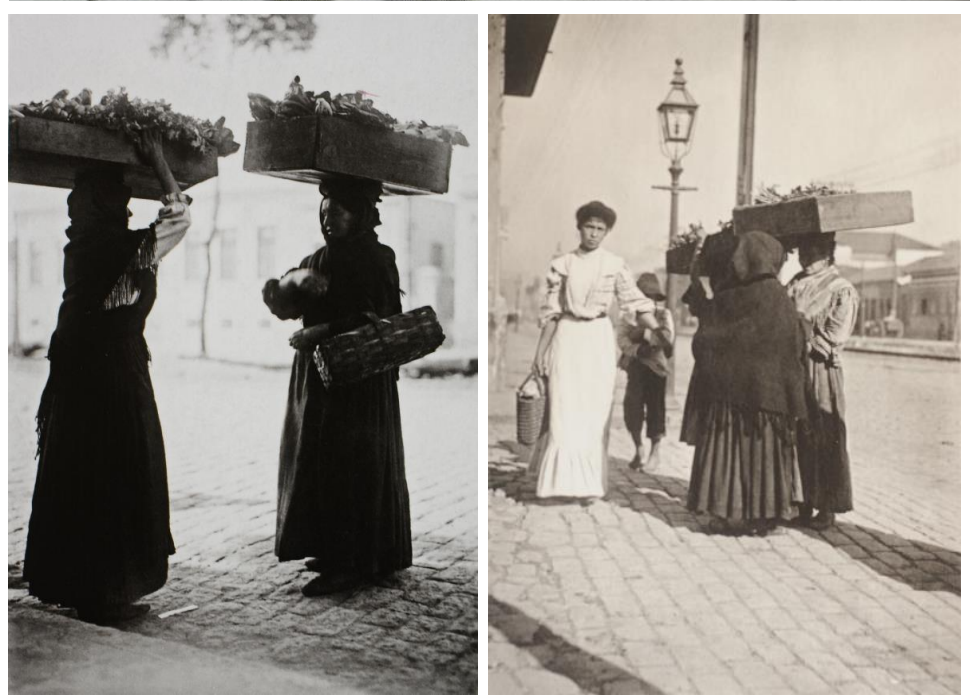

Figuras 160 e 178: à esquerda

"Vendedoras de verduras". Muitas delas andavam pelas ruas da capital paulista com seus caixotes carregados de verduras talvez produzidas em suas pequenas roças ou compradas a preços baixo nos mercados populares da cidade, depois distribuídos de porta em porta num comércio que impulsionava a economia popular. 1910 @ Vincenzo Pastore / Instituto Moreira Salles. 
A rica iconografia voltada para cenas de costumes em diversas comunas e províncias italianas elucida como era recorrente a valorização compositiva dos trajes de muitas mulheres caminhantes, sugerindo as poucas chances de se tratar de composições apenas circunstanciais.

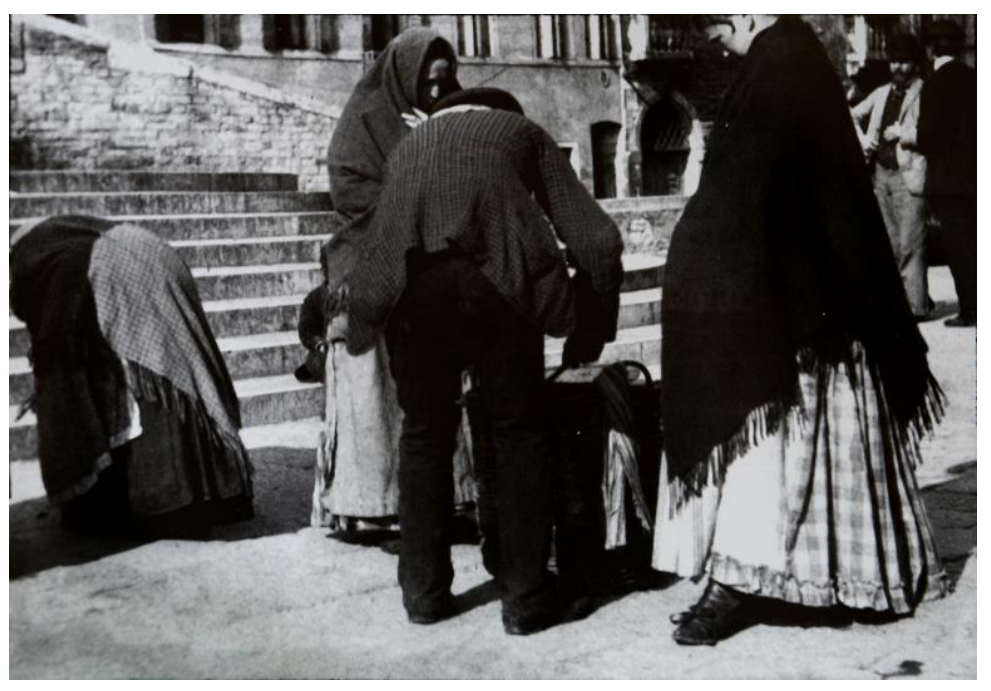

Figura 224: Vendeiro em Veneza. Sem data. $\odot$ Eugenio Buono. In: Italia inédita di un secolo fa. Napoli, Venezia, Palermo, i borghi di Caiazzo e di Cerreto Sannita nelle lastre ritrovate di Eugenio Buono. Napoli: Edizioni Intra Moenia. 2008.

Se o fotógrafo anônimo na Veneza de 1900 retratou o peixeiro, Eugenio Buono, na mesma cidade, voltou-se para o mesmo tema do trabalho, reiterando as formas das figuras femininas, retratadas nos diferentes planos de costas ou de perfil (fig.224). Dava-se mais volume as vestes, encobrindo outras impressões. Não há apenas uma alusão às suas figuras; elas se mantinham como uma constante na representação dos costumes. Enunciam-se aproximações entre Pastore e Buono dado aos enquadramentos distantes do rigor da pose, sempre contida, repetitiva.

Buono primeiro fotografava, e depois fazia desse suporte, a matriz para sua produção de aquarelas, essas mais conhecidas a sua produção fotográfica. O pintor-fotógrafo ao se voltar para as cenas cotidianas "delle persone umili", nos revela aspectos da interface de duas artes que mais se aproximavam a se distanciar (fig. 225 e 226). Infelizmente, nem sempre encontramos a respectiva matriz fotográfica com a pintura criada no ateliê de Buono. As seguintes imagens, exemplificam recortes e escolhas que pautavam essa inter-relação visual, priorizando papéis sociais femininos. A pintura de inclinação realista voltada para a concretude da vida social promoveu na Itália uma grande demanda por imagens fotográficas, uma arte assim explicada: “o realismo mandará a posteridade o nosso costume, os nossos hábitos”, afirmava o pintor Adriano Cecioni, em 1905. 


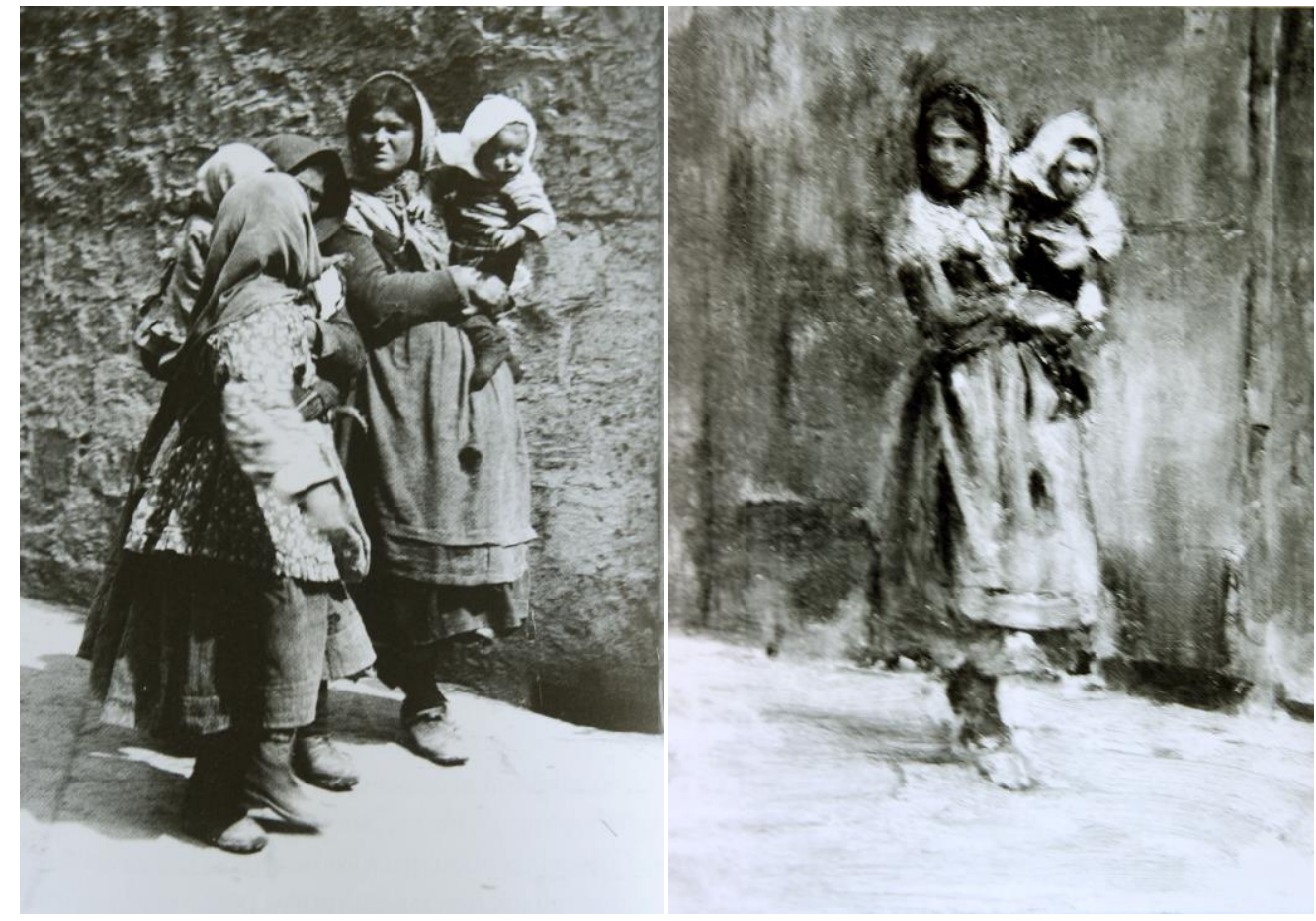

Figuras 225 e

226: à esquerda fotografia e à direita pintura em aquarela realizadas por Eugenio Buono. In: Italia inédita di un secolo fa. Napoli, Venezia, Palermo, $i$ borghi di Caiazzo e di Cerreto Sannita nelle lastre ritrovate di Eugenio Buono. Napoli: Edizioni Intra Moenia. 2008.

$\mathrm{Na}$ fotografia vemos mulheres levando seus filhos (fig.225). Trajes típicos foram mais uma vez destacados na escolha do recorte fotográfico. Na cena pictórica (fig.226) Buono, no entanto, ressaltou a presença apenas de uma delas, que já no registro fotográfico, evidentemente se destacava, apesar do leve deslocamento para o segundo plano da imagem. $\mathrm{O}$ movimento da criança levada ao colo, olhando em sentido oposto ao de sua mãe, aparece nos traços dado na pintura, associada à matriz fotográfica.

Se Veneza, Palermo e Nápoles, regiões que se urbanizavam atraíram Buono, a pobre comuna de Cerreto Sannita, da região da Campania, na pequena província de Benevento, também esteve na rota de suas viagens (fig. 227, 228 e 229). Eugenio Buono, contemporâneo de Pastore, fotografou na Itália, entre a última década dos oitocentos e os primeiros anos do novo século, cenas consideradas por Luca Sorbo e Luciano Scateni, (2008) como "instantes de pesquisas sobre a vida cotidiana".

Ao privilegiar os traços da vida agrária e pastoril desta comuna de tradição feudal, Buono, reiteradas vezes, voltou-se para a representação do trabalho feminino. Assim como Pastore, Buono as retratou sempre de corpo inteiro, levando seus cestos, aparentemente pouco notando a presença do fotógrafo, traço que ajuda a caracterizar ainda mais a "ética do instantâneo", em visualidades que, para D”Autilia (2012, p.110), fundem a individualidade no tipo geral, o verdadeiro "espírito" da fotografia oitocentista, sobrevivendo nos novecentos. 

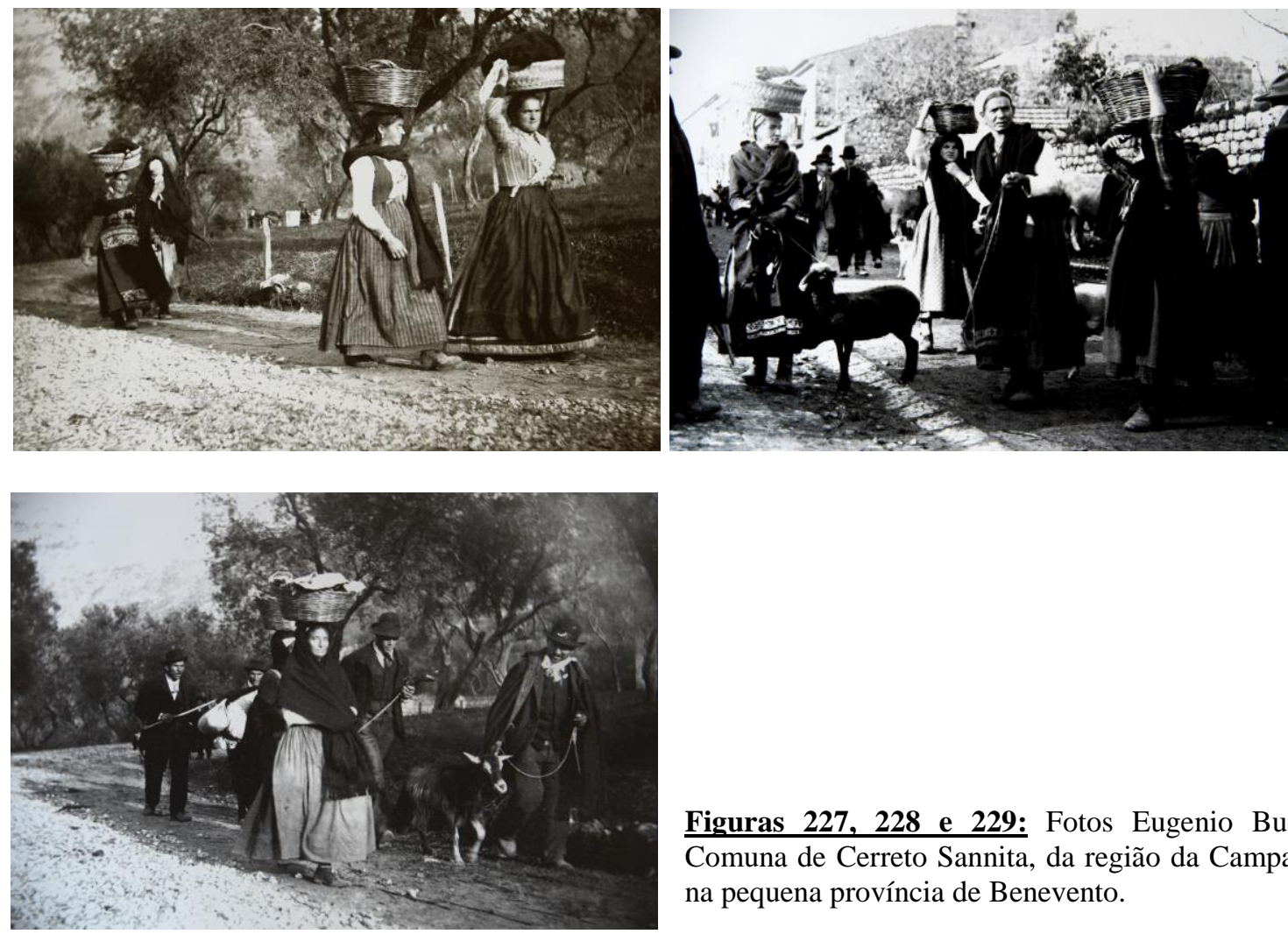

Figuras 227, 228 e 229: Fotos Eugenio Buono. Comuna de Cerreto Sannita, da região da Campania, na pequena província de Benevento.

Temos na maioria dessas imagens a apresentação de sujeitos históricos que a invadem, as tomam por completo, em situações de pouco formalismo, traço que atravessa a produção de Pastore, mas também a de seus conterrâneos como Brogi, Alinari, Sommer e fotógrafos anônimos, que rompiam por sua vez com o rigor da pose predominante nos oitocentos. Notase, de modo geral, como nenhum fotógrafo destituía-se da construção visual relacionado mulheres aos seus trajetos e às suas práticas diárias de trabalho, fossem novas ou mais idosas, surgiam dando continuidade a formas antigas de sobrevivência.

As seguintes mulheres tiveram seus passos trilhados na comuna de Terracina, na região de Lazio (fig.230). Foram fotografadas pelo pintor Mario De Maria. Sua produção fotográfica foi pouco reconhecida tanto no período de sua produção, quanto posteriormente, assim como Buono. Se no início de sua carreira De Maria mostrava em algumas exposições seu interesse pictórico por cenas noturnas, contraponto ricos e densos efeitos de luz, depois quando chegou em Roma, começou também a fotografar, voltando-se para as ruas, engajando-se naquilo que parte da historiografia denominou como "espírito de viajantes românticos, provenientes do norte, vivendo em Roma as eternas sugestões que reforçavam o senso de precariedade que a cidade oferecia de si”, marcante em toda cultura visual italiana, repleta de cenas de trabalho feminino (Del Balbarò e Tempesta. 1979, p.15). 


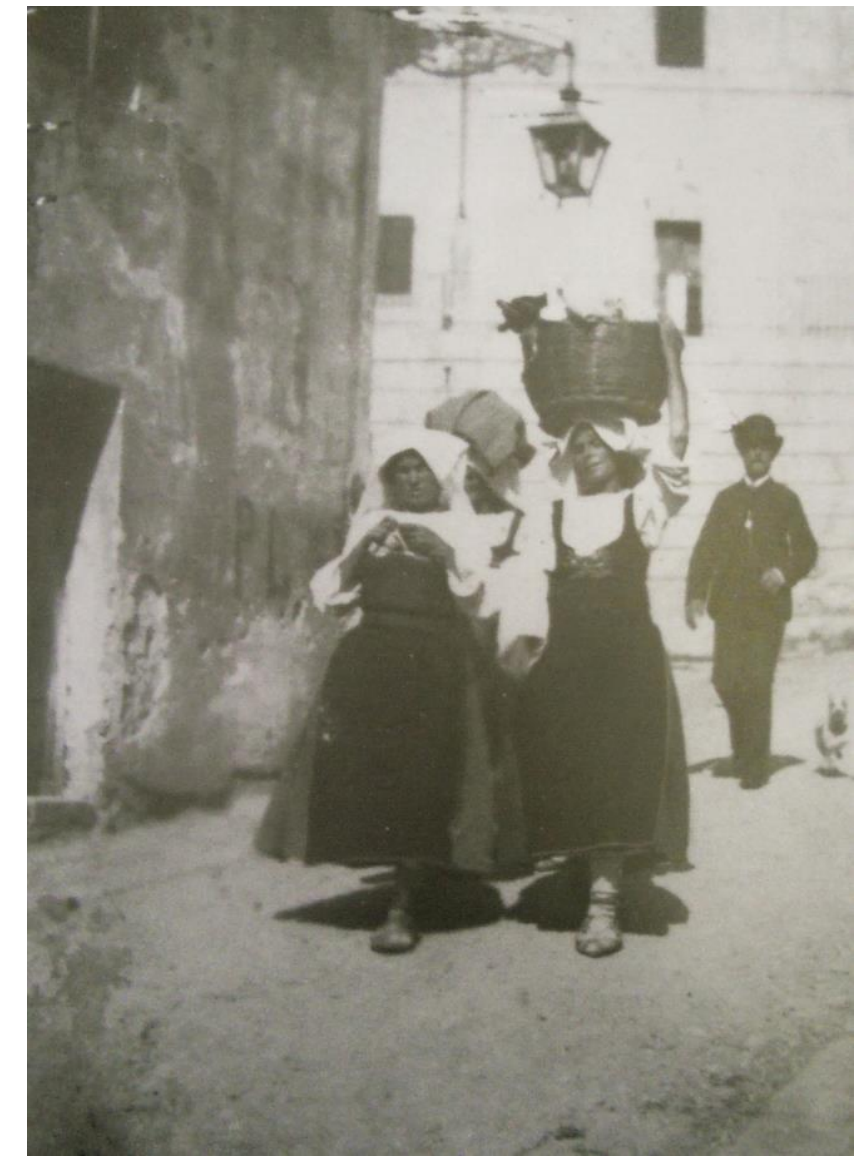

\section{Figuras 230:}

Mulheres retratadas na comuna de Terracina. Rua/beco Terracina. 1882- 1887 (C) Mario De Maria. In: Del Balbarò, Michele Falzone e Tempesta, Claudia. Marius Pictor Fotografo. L'album fotografico di Mario De Maria. 18821887. Editora IFotolibri/Longanesi\&C. 1979.

Sabe-se que De Maria além de produzir carte-de-visite, com reproduções entre 9x12, e outras na dimensão 13x18, usava uma máquina adicional Eastman, experimentando a técnica da foto instantânea. Fotografias realizadas por outros profissionais também foram encontradas no acervo guardado pela família de De Maria, apresentando dimensões entre 12 x16 e 18x24, retratando, sobretudo, as cenas de paisagens; fato este que pode indicar a sua total autoria das fotos de costumes.

A ausência sistemática de ordenamento ou organização das 235 fotografias, sendo 55 realizadas em estúdio, todas sem os respectivos negativos, levou Del Balbarò e Tempesta (1979) a indagarem o uso do termo álbum fotográfico para o conjunto das fotos realizadas por De Maria, pintor que deixou Bologna para se radicar em Roma. A adoção do termo se deu após o trabalho das autoras de aproximar e reordenar as fotos com suas respectivas pinturas, ambas as produções submetidas a uma homogeneidade cronológica e agrupadas nos seguintes subtemas: retratos, 20; ambiente de estúdio, 14; nudez, 14; vista de Roma, 53; de Campagna romana, 9; de Terracina, 20; de Subiaco, 12; de Albano e Montecompatri, 6; Tivole, 28 e, por último, de Nettuno, Capri, Vigo di Fassa, constituindo 7 no total. 
O corpus documental produzido por De Maria foi tratado por Del Balbarò e Tempesta (1979) como "reportagens da cidade", testemunhos de suas viagens. Perspectiva que relembra o argumento de D"Autilia (2012, p.149) que chegou a afirmar que o "fotojornalismo não nasce contemporaneamente a publicação das primeiras reportagens”. Tais premissas, no entanto, podem nos afastar da especificidade do trabalho de De Maria, inserido em outro contexto de produção; seus registros fotográficos se inscrevem na verdade em outro circuito de recepção de imagens, voltado para o mundo das belas artes, submetidas às convenções visuais de sua época.

O trânsito de Mario De Maria entre a pintura e a fotografia expressa a própria “cultura da imagem" na sociedade italiana, segundo Ferrari, visualidade construída a partir de uma narrativa tecida de modo orgânico entre as duas linguagens, numa interação na qual cada uma delas conseguia manter seus aspectos peculiares. Segundo Oreste Ferrari (1979) De Maria tinha uma "refinada percepção dos procedimentos específicos dos dois processos". A fotografia em seu trabalho, não foi apenas um "dispositivo instrumental". As imagens apresentavam em seu conjunto indícios de uma clara valorização estética análoga a pintura, mantendo o seu "significado autônomo", sem enveredar, segundo Ferrari (1979), para as “ambigüidades" dos pictorialistas.

Imagens legitimadas pelo seu valor testemunhal, noção que acompanhava a produção do período. O efeito causado pela primeira visão da cena fotográfica foi o que De Maria tentou reproduzir em suas pinturas. Em 1911, Marius Pictor, pseudônimo do pintor, escreveu, deixando vestígios de uma percepção subjetivada que entendia a fotografia como parte fundamental em seu processo de criação: "a arte é apenas a objetividade de uma emoção, a obra de arte não é nada menos que o veículo que conduz novamente a eterna emoção resguardada pela fotografia, que foi o estimulo de sua criação, e guiou a mão do artista paralisando o cérebro". ${ }^{293}$ A fotografia representava para o artista uma inspiração que podia depois ser verificada, como salientou Falzone Del Barbarò (1979, p.24).

Sugeri-se um importante aspecto da relação do pintor com a sua fotografia, entendida como vital em seu processo criativo. Ela guardava o ineditismo de um momento, um sentimento depois revivido na feitura da pintura. A fotografia estaria embebida desse papel de guardar o instante da visão inédita, o instante da inspiração decorrente do primeiro contato do artista com o mundo. Tem-se ainda verificável uma noção ampliada da foto como evento. De

293 Casareo. Lettere ad arti. 1889, p. 8. APUD. Del Balbarò, Michele Falzone e Tempesta, Claudia. Marius Pictor Fotografo. L'album fotografico di Mario De Maria. 1882-1887. 1979, p. 16. Tradução Nossa. 
Maria não pensava a fotografia apenas como uma janela para o mundo, mas como um possível meio de se resgatar, recuperar e fazer reviver emoções, interrompendo o pensamento.

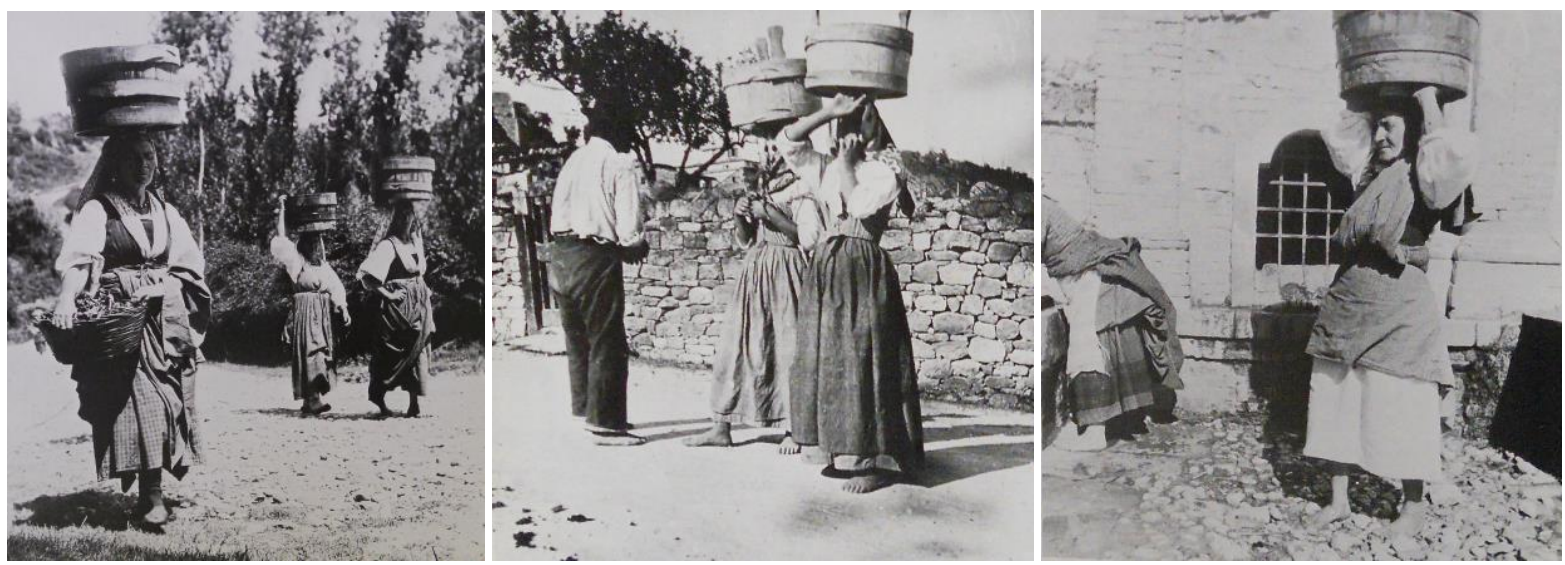

Figuras 231, 232 e 233: Imagens realizadas na comuna de Orsogna. 1895 a 1900 ๑ Francesco Paolo Michetti. In: Miraglia, Marina. Francesco Paolo Michetti Fotografo. Torino: Einaudi Letteratura 43. 1975.

O famoso pintor Francesco Paolo Michetti (1851-1929), assim como Buono, não destruiu as fotografias usadas no processo criativo de suas pinturas, prática corriqueira entre os artistas oitocentistas. Na ordenação das fotografias que integraram a coleção Michetti foram criadas pelo próprio artista trinta diferentes seções temáticas, uma delas classificada como "popoli". ${ }^{294}$ As tomadas de uma mesma cena em diferentes ângulos deram a sua produção fotográfica um caráter serial evidente. Vê-se mais uma vez a presença feminina como uma referência canônica às cenas de costumes do povo.

Michetti fotógrafo, segundo Miraglia (1975), teve uma trajetória fotográfica continua e ininterrupta. Produziu imagens em câmeras estereoscópicas, dominava técnicas mais complexas como fotografias monocromáticas, à carvão e até mesmo os populares carte-devisite, estes comuns nas representações de tipos e tradições regionais, até 1900. O pintor descobria na fotografia "uma expressão visiva autônoma e completa" (1975:25). Michetti lentamente concentraria sua atenção no processo fotográfico. Inicialmente experimentava a fototipia. Depois buscou meios mais econômicos como a fotolitografia, depois utilizou a zincografia para reproduzir as imagens de "pessoas simples e do viver cotidiano".

${ }^{294}$ As suas fotografias foram descobertas em 1966 por Raffaele Delugo, um funcionário de belas artes do convento de Francavilla a Mare que ajudava a organizar uma mostra sobre o artista naquele ano. Na coleção nem sempre é correspondente a existência do negativo e da reprodução. In: Miraglia, Marina. Francesco Paolo Michetti Fotografo. Torino: Ed. Einaudi Letteratura 43. 1975, p. 8. 


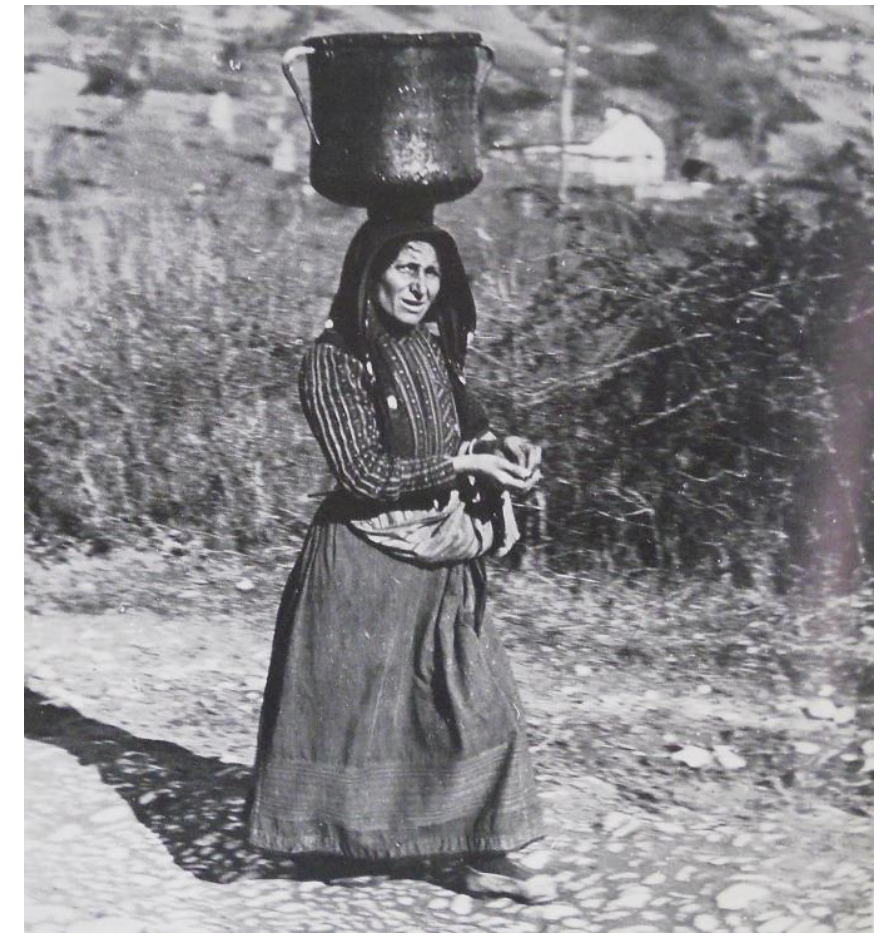

Figura 234:

Mulher levando água. Comuna de Orsogna. 1895 a 1900 (C) Francesco Paolo de Michetti. In: Miraglia, Marina. Francesco Paolo Michetti Fotografo. Torino: Einaudi Letteratura 43. 1975.

A realização de inúmeras fotos instantâneas delineia "l'ansia di vita" de Michetti, interessado em retratar figuras em movimento, cenas depois recriadas em telas. A fotografia foi assim um meio vital de expressão do pintor, que após 1900 intensificou não sua prática pictórica, mas deu sequência aos seus estudos de movimento e de cor na fotografia. Michetti, para Miraglia (1975, p.34) não fotografava para compor imagens modelos para suas pinturas, mas interrogava a própria natureza da fotografia, cada vez mais preocupado com "situações, gestos e expressões".

Mulheres com seus filhos, igrejas, festas religiosas, peregrinos, procissões, feiras, barcos, pesca e até mesmo vacas, compõe as classificações feitas por Michetti, em produções fotográficas realizadas entre os anos de 1895 a 1900. Orsogna é uma delas, indiciando como o Michetti tinha a fotografia como um meio de realização de estudos de costumes em diversas comunas, interessado em documentar mulheres em fontes d'agua (fig.231, 232 e 233), ou levando seus jarros e panelas sobre as cabeças (fig.234). Miraglia, talvez com certo exagero, chegou a afirmar que "a fotografia de reportagem é, em certo sentido, condicionada e subordinada ao interesse pictórico" (1975, p.28). Michetti seria para a pesquisadora a referência italiana dessa premissa. Talvez a autora, defendeu essa hipótese levando em conta como fotógrafos e pintores-fotógrafos se infiltravam na experiência, viajando entre diversas comunas, vivenciando esse cotidiano intensamente. 
Se Michetti retratou muitas mulheres na comuna de Orsogna, o fotógrafo anônimo documentou um grupo delas ao redor de uma fonte em Roma (fig.235). Momentos de descanso e conversas entretecem uma trama diária de trabalho e exaustão, atravessando uma ampla produção visual.

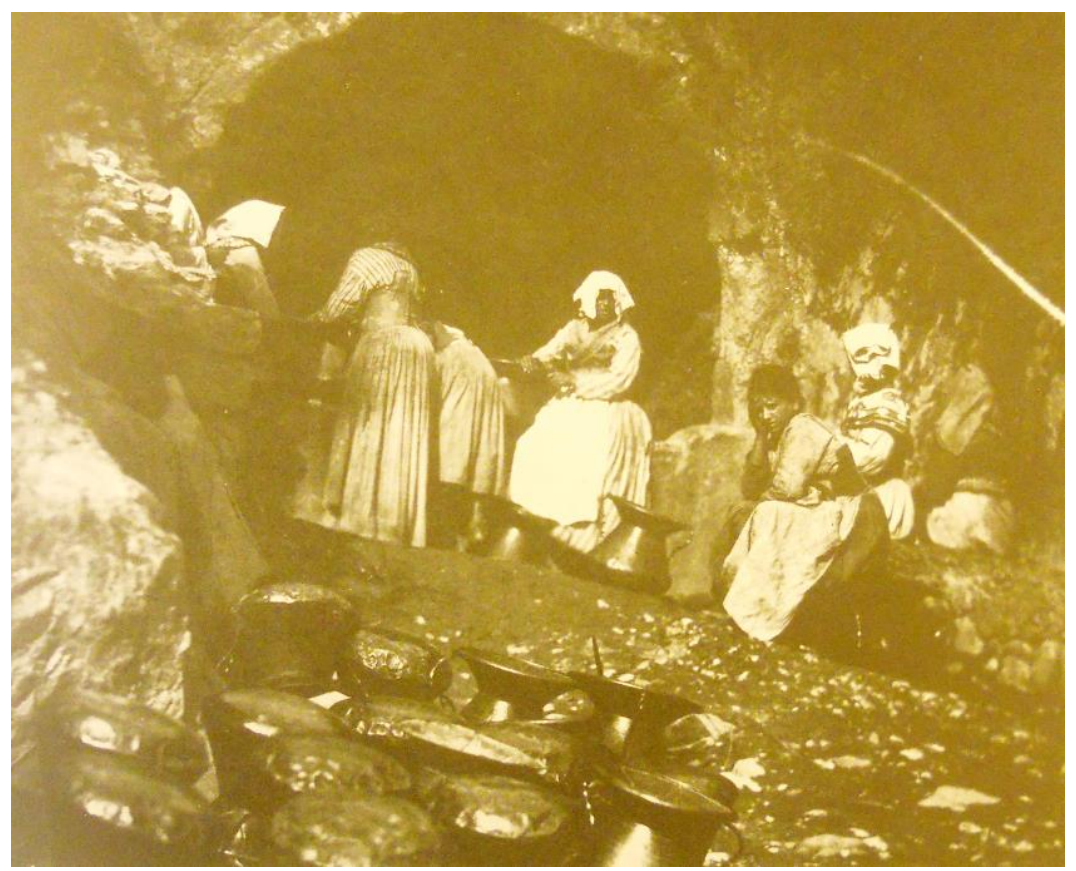

Figura 235: Fotógrafo não identificado. s/d. Comuna Olevano Romano na região de Lazio, na província de Roma. In: Brizzi, Bruno. Lazio Scomparso. Edizioni Quasar. 1977, p. 105.

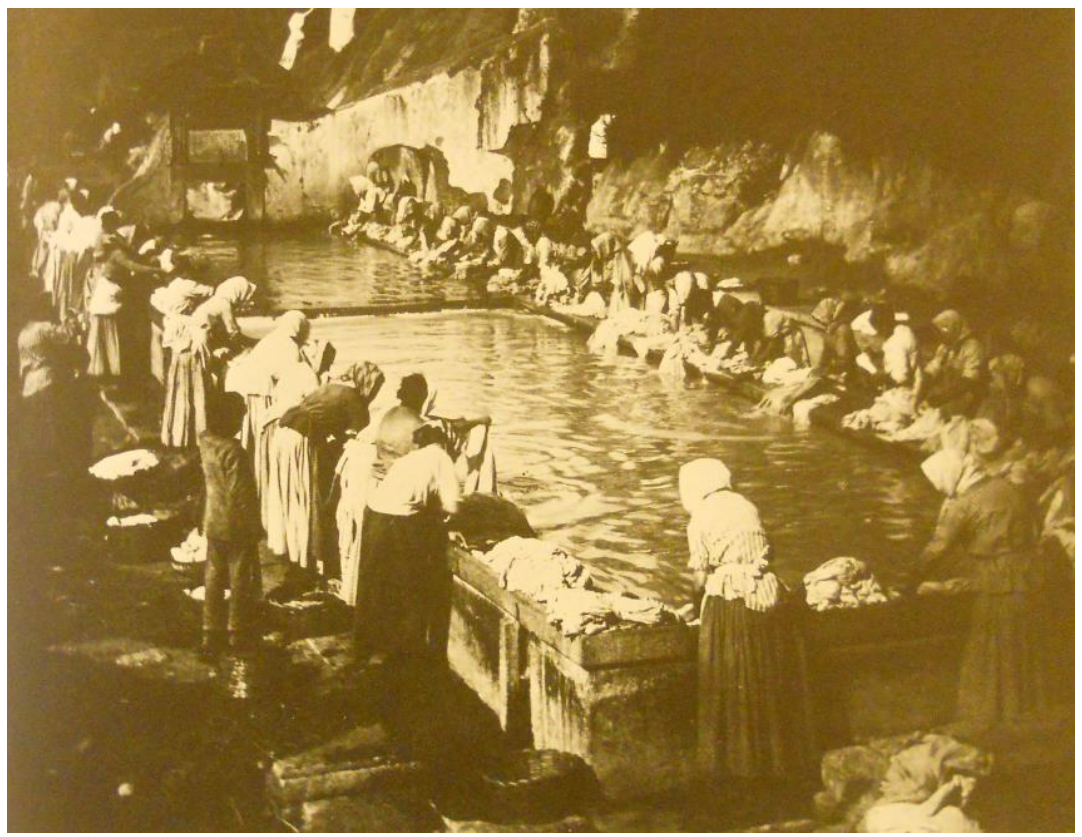

Figura 236: Fotógrafo não identificado. Marino, Donne al Lavatoio. In: Brizzi, Bruno. Lazio Scomparso. Edizioni Quasar. 1977, p. 35.

O fotógrafo anônimo deixou em primeiro plano os muitos potes de cerâmica. Enquanto algumas se voltaram para a fonte, outras, vistas à direita da foto, pareciam cansadas, possivelmente à espera de abastecer seus repositórios. Retratadas ora em fontes, ora em 
lavadouros públicos, as cenas pitorescas do cotidiano feminino foram as prediletas da fotografia da virada de século. Nesta (fig.236) vê-se um grupo ainda maior no lavadouro público em Marino, comuna da região de Lazio, feita por um fotógrafo também não identificado.
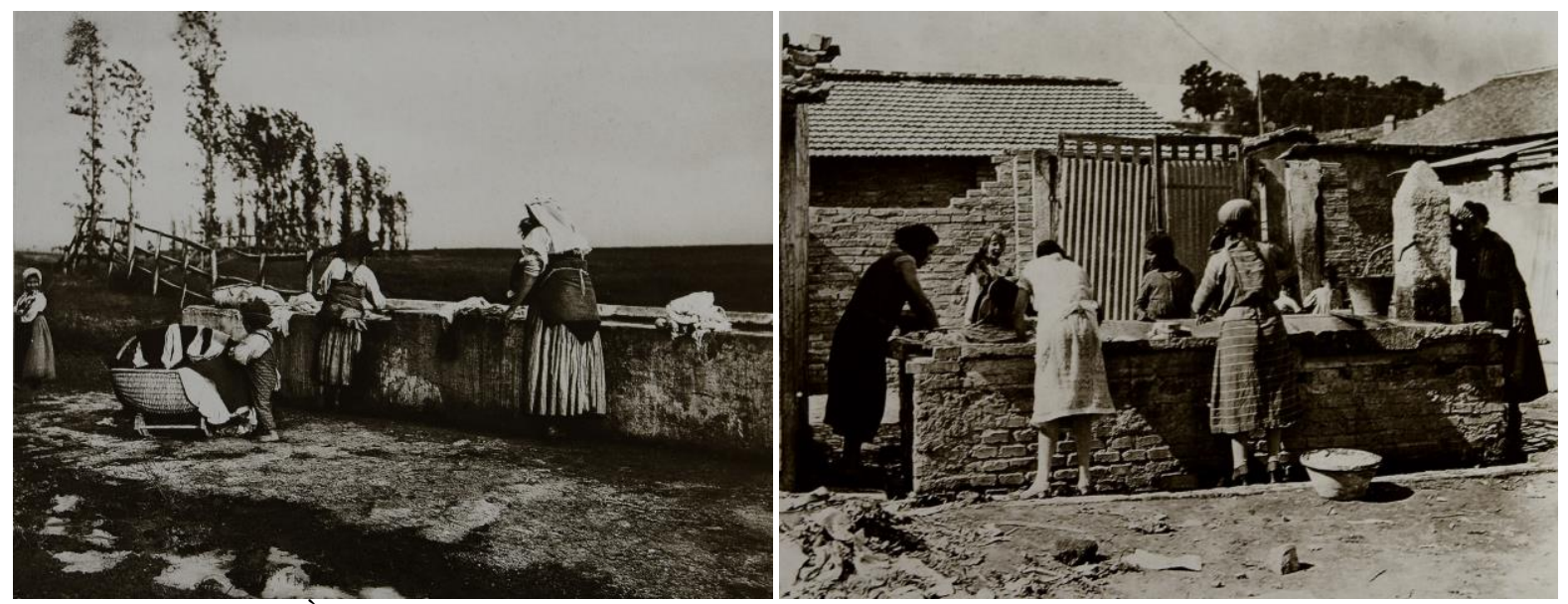

Figuras 237 e 238: À esquerda: mulheres lavadeiras na Via Tuscolana. Fontanile nella Campagna. @ Alinari / Coleção Alinari. Firenze. À direita Tipos e costumes de Roma e Província. @ B Brogi / Coleção Brogi - Archivio Allinari. In: Settimelli, Wladimiro. Roma e il Lazio Negli archivi Alinari.1989, p. 112.
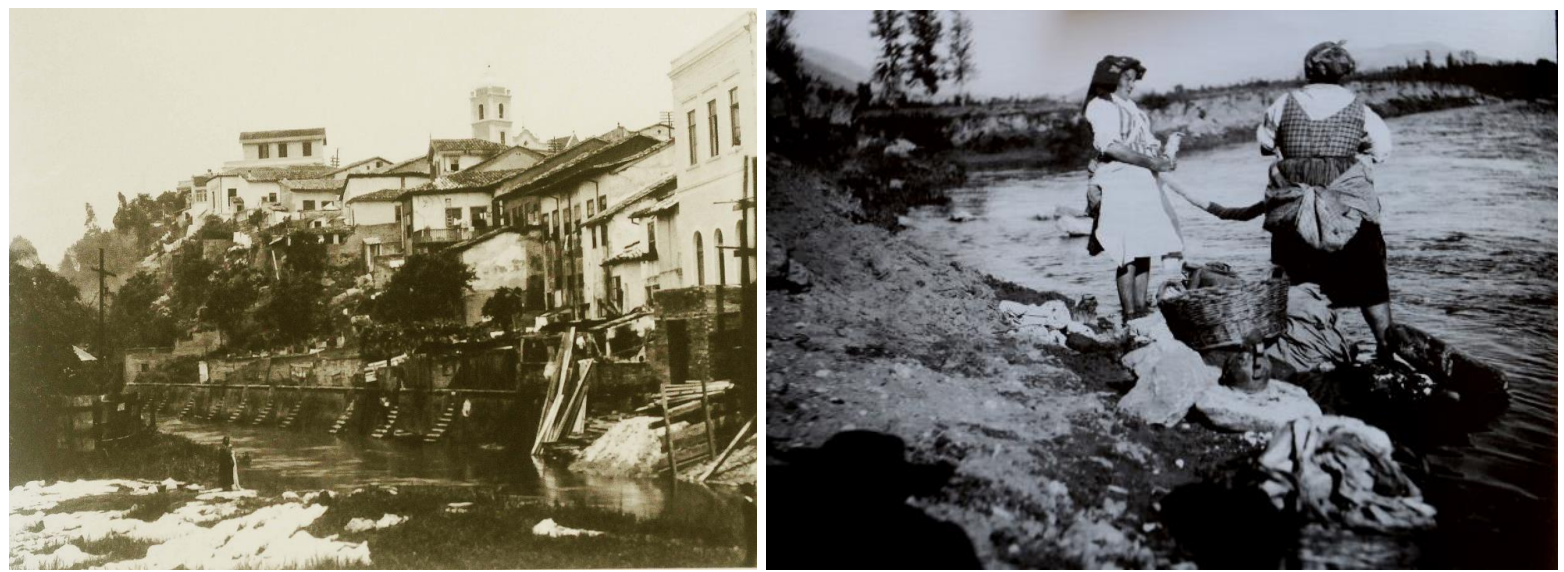

Figuras 168 e 239: Foto à esquerda lavadeira trabalhando às margens do rio Tamanduateí. 1910 ( Vincenzo Pastore / Iinstituto Moreira Salles; à direita comuna de Caiazzo. 1900 @ Eugenio Buono. In: Sorbo, Luca e Scateni, Luciano. Italia inédita di in secolo fa. Edizioni Intra Moenia. 2008, p. 44.

Nas décadas de 1870 a 1890, tal repertório era publicado nos catálogos e posteriormente nos postais produzidos pelas casas comerciais fotográficas dos irmãos Alinari (fig.237) e Brogi (fig.238). Em 1900, Eugenio Buono realizou a imagem das lavadeiras da Comuna de Caiazzo (fig.239); próximo a 1910 eram as margens do Tamanduateí que tomavam a composição de Pastore (fig.168) espaço que depois desapareceria do cotidiano de trabalho das mulheres pobres. A intenção documentarista e também cientificista, impunha-se lentamente à curiosidade; a visualidade nas últimas décadas do século XIX, voltou-se para os movimentos 
humanos para afirmar as diferenças culturais de modo positivo, criando a imagem do italiano bom e trabalhador.

\subsection{Quando os novos sentidos superam o referente e rompem a tradição}

Delineamos ate aqui o como a fotografia tomava lugar numa experiência visual de fronteiras rarefeitas, num contexto material de enorme riqueza, expressando uma rede de produção e circulação que indicia como a foto nunca foi mal recebida pela pintura, como Stephen Bann já pontuou, ao tratar da convivência entre ambas (Bann. 2001)

Tratamos de um conteúdo que permanecia e atravessava diferentes décadas, chegando ao novo século. Mas é preciso pontuar como isso não ocorreu de forma estática, afinal fotografias são portadoras de sentidos moventes, determinados pelos usos e circulação, específicos da representação. Tais imagens circularam primeiro como souvenir, ajudando a configurar a imagem do país unificado; depois seguiram em sua trajetória posterior como fontes de denúncia social, inaugurando, na Itália, em início do século XX, uma noção de humanismo visual, traindo assim o referente inicial.

Nos novecentos começava a se radicar concepções que indicam as ambigüidades da fotografia, mostrando como o peso da tradição também se diluía em novos sentidos que aderiam ao fotográfico.

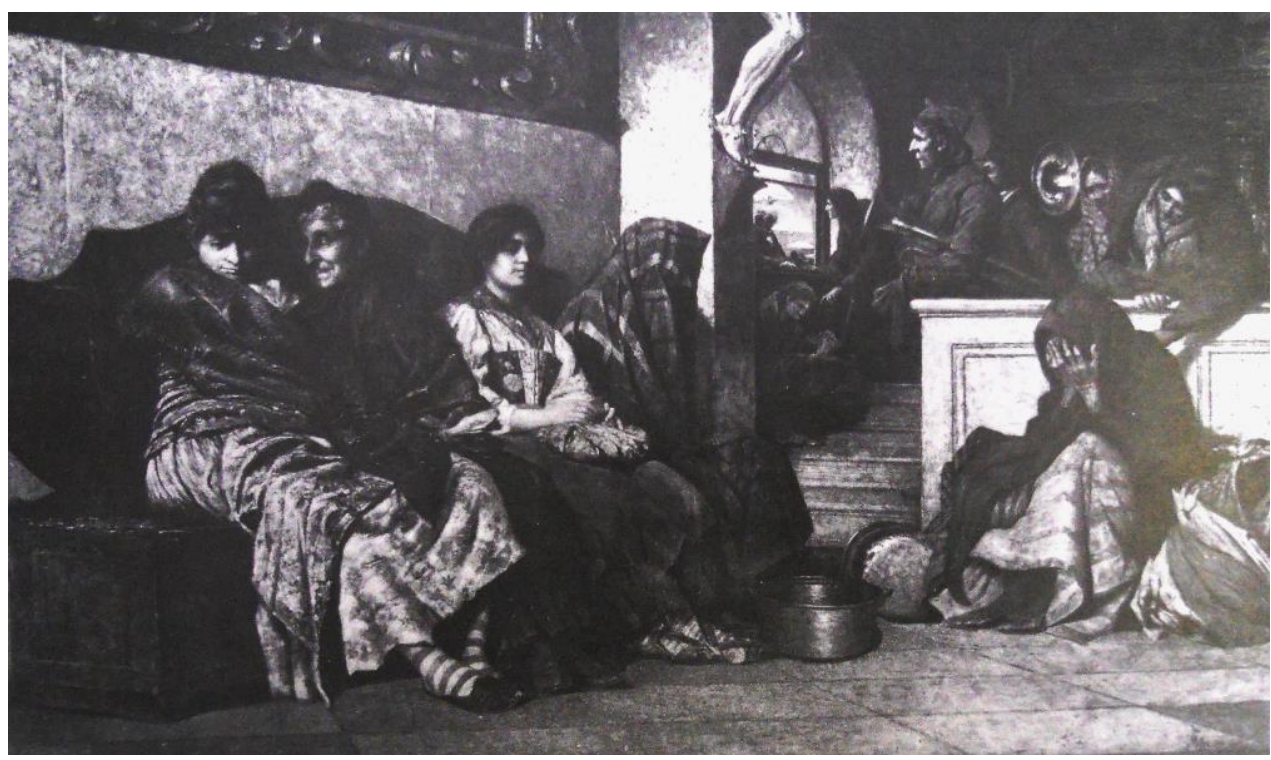

Figura 240: Donne al Monte di Pietà. Pintura a óleo. 1886-1920 @ Mario De Maria. In: Del Balbarò, Michele Falzone e Tempesta, Claudia. Marius Pictor Fotografo. L'album fotografico di Mario De Maria. 1882-1887. Editora IFotolibri/Longanes i\&C. 1979, p.10.

A pintura a óleo trabalhada por De Maria entre os anos de 1886 a 1920, caracterizandose como uma obra inacabada, indicia a articulação de novos significados construídos 
(fig.240). Para sua composição o pintor-fotógrafo realizou uma série fotográfica dentro de seu atelier. Imagens fotográficas fragmentadas foram depois contextualizadas na feitura da obra final. A obra Donne al Monte di Pietà foi aclamada pelo público quando apresentada em 1909, na VIII Bienal de Veneza, que homenageava o pintor com um mostra retrospectiva de todo seu trabalho; obra hoje exposta na Galeria de Arte Moderna de Roma. Essa produção emblemática do pintor foi considerada na época, segundo Del Balbarò e Tempesta (1979, p.23) como uma possível inspiração social e humanitária de De Maria.

O esforço do pintor era tido como evidente:

Acentuar o dado verídico oferecido pelo sujeito até fazer emergir o motivosímbolo da mulheres: a dor, a necessidade, a vergonha, a fome. O poder de denuncia social intrínseco ao conteúdo o deixava indiferente, até mesmo como um impedimento à estética de De Maria que trabalha a pintura longamente, procurando sempre inspiração e a deixando, contudo, inacabada. (Del Balbarò e Tempesta, 1979, p.19. Tradução Nossa)
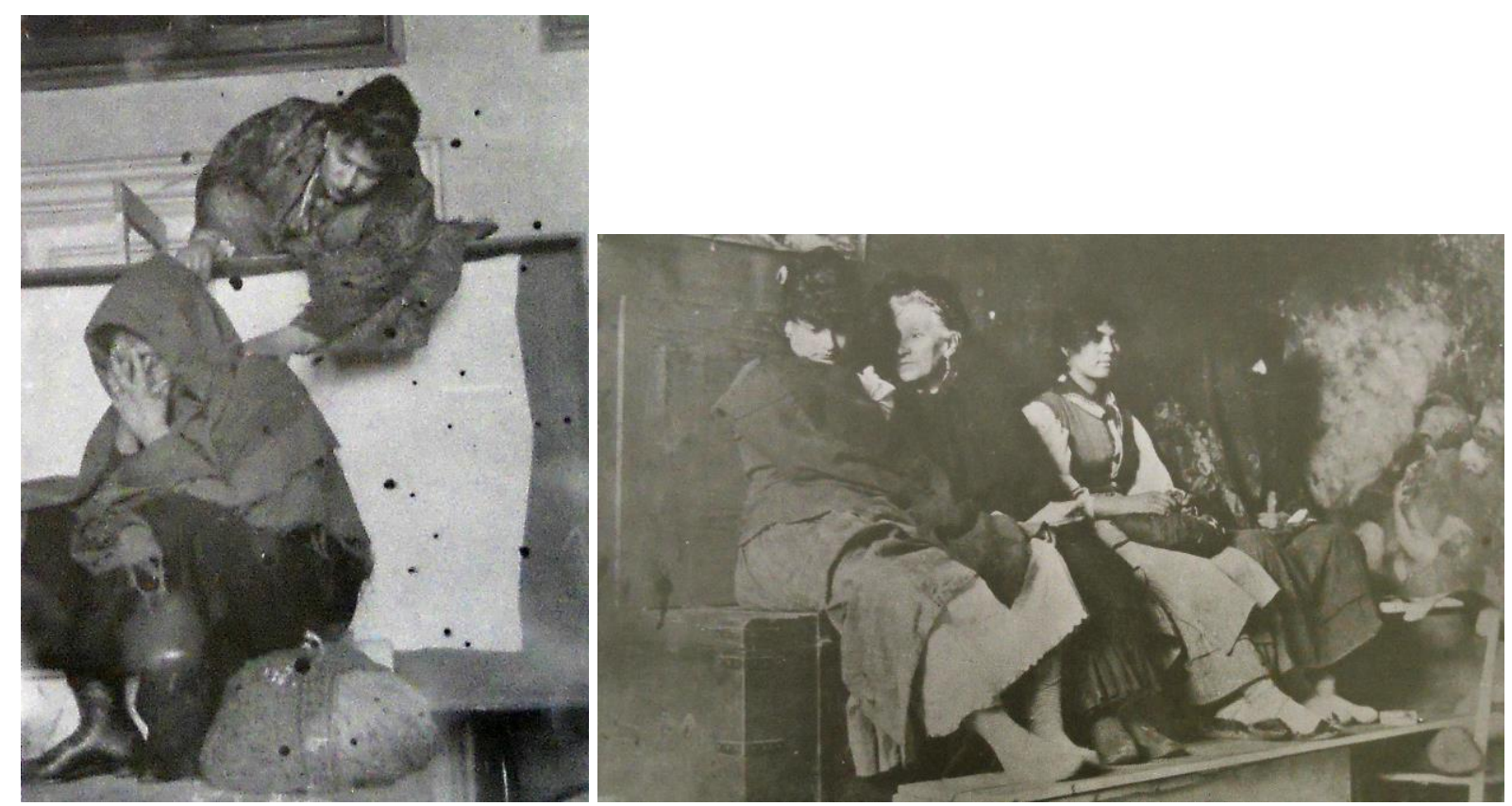

Figuras 241 e 242: composição de imagens que integram a série de fotos para a realização da pintura Donne al Monte di Pietà, realizadas no ateliê de Mario De Maria. 1886. In: Del Balbarò, Michele Falzone e Tempesta, Claudia. Marius Pictor Fotografo. L'album fotografico di Mario De Maria. 1882-1887. Editora IFotolibri/Longanesi\&C. 1979, p.11 e 33.

A série de imagens fotográficas fragmentando cada gesto e posição das retratadas, nunca foi mantida em sigilo pelo artista. Em uma das imagens (fig.241) o uso de fundo branco destacava a personagem e a dramatização da cena, momento em que uma delas encobriu o rosto com suas mãos. Há na série a valorização das cenas que De Maria acompanhava pelas 
ruas. Depois, em estúdio, recriava a realidade da Roma que vivenciava, afirmou Del Balbarò e Tempesta (1979).

Fica claro o efeito de realidade que De Maria queria provocar. O pintor que percorreu com sua câmera instantânea as ruas de Roma viajou ainda pelas comunas vizinhas e levou ao interior do estúdio, fragmentos materiais da vida cotidiana. A presença de trouxas de roupas, panelas, cesto e a própria representação das mulheres com suas longas saias, de ombros cobertos com seus xales escuros, apontam como o fotógrafo-pintor estava atento a cultura material como um importante signo da representação dos tipos populares.
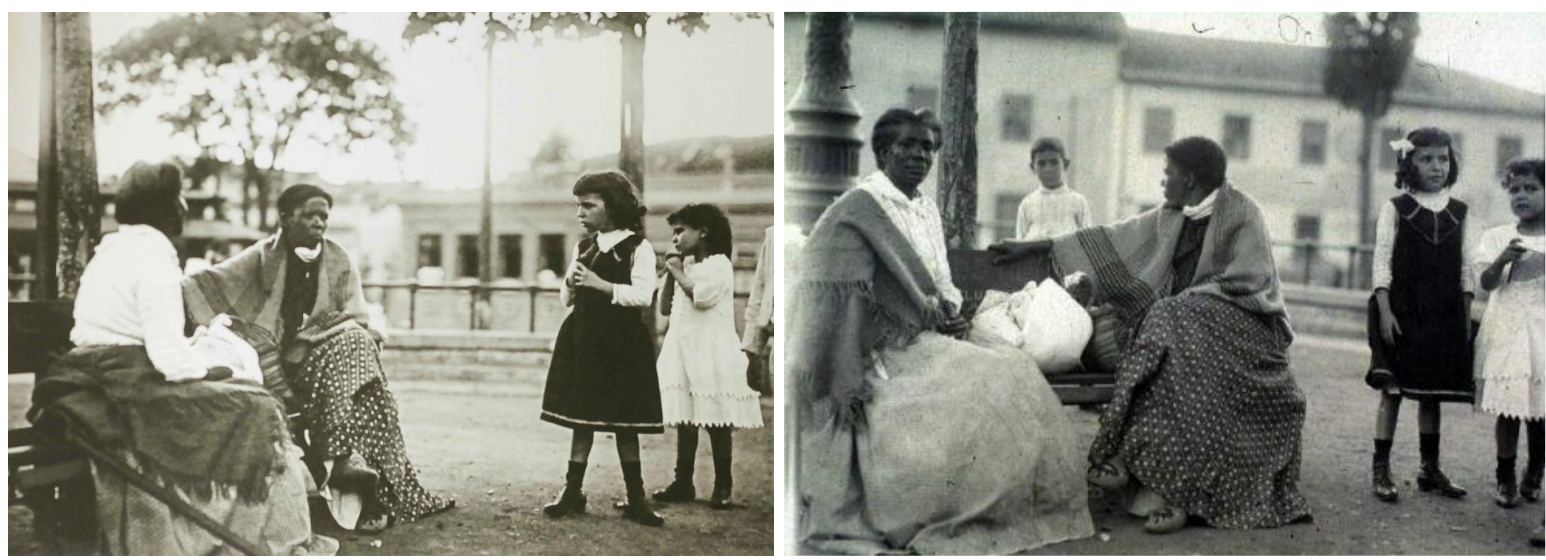

Figuras 134 e 135: "Mulheres descansando em banco de praça". 1910 @ Vincenzo Pastore. Instituto Moreira Salles.
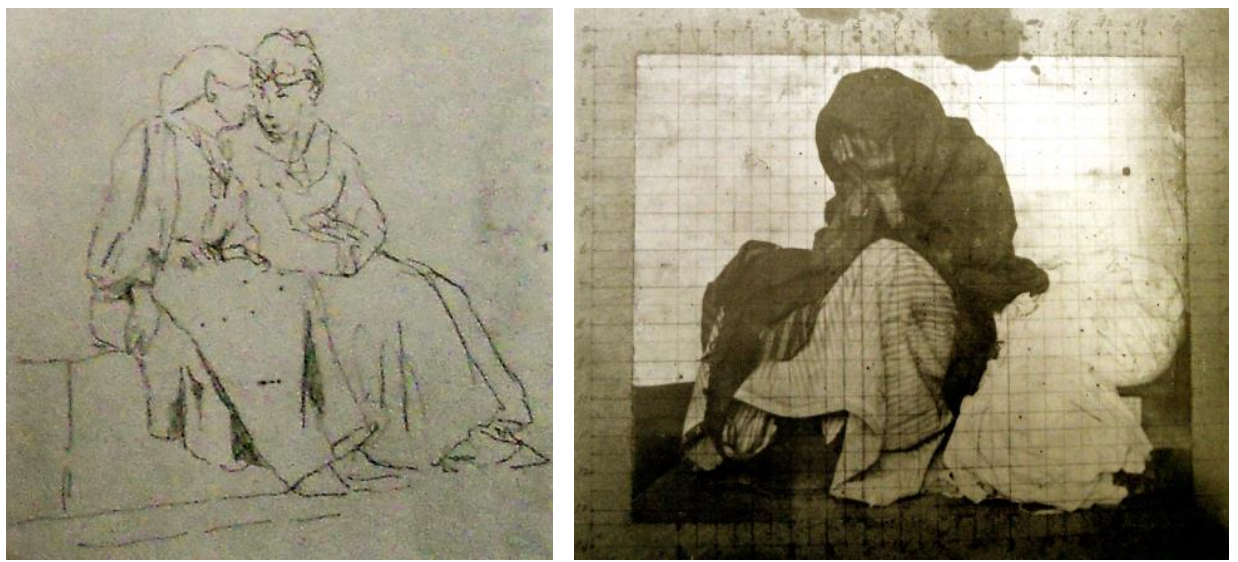

Figuras 243 e 244:

Reprodução de desenho e fotografia realizados por Mario De Maria para a realização da pintura Donne al Monte di Pietà. 1886-1920. In: Del Balbarò, Michele Falzone e Tempesta, Claudia. Marius Pictor Fotografo. L'album fotografico di Mario De Maria. 18821887. Editora IFotolibri/Longanesi\&C. 1979 , p.11 e 13.

A valorização dos panos e xales usados por muitas mulheres esteve presente em algumas composições de Pastore, que retratou na capital paulista muitas mulheres negras em seu cotidiano de trabalho e convivência, na concretude de relações sociais próximas daquelas observadas por De Maria.

Surgem nessas construções visuais, enredadas por uma trama de diferentes linguagens, contando com a participação das mulheres em suposta interação simulada em estúdio por De Maria, ou flagradas nas ruas por Pastore, indícios que enunciam a convivência entre os 
grupos, os laços de solidariedade firmados em relações cotidianas, evocados por gestos de proximidade, ou no sutil gesto de se estender a mão e tocar a outra, figurando gestos furtivos.

Esboços feitos em desenho (fig.243) mostram como o artista já preparava o quadro desde 1884, transitando entre o desenho, a fotografia e a pintura. As fotos da série foram submetidas à técnica da grade quadriculada (fig.244), procedimento formal e acadêmico das belas artes, empregado sobre um detalhe fotográfico que posteriormente integraria a tela, obra que transitou entre o estúdio e o circuito institucionalizado das artes, que acolhia e difundia a tendência humanística vista em Marius Pictor.

O tipo, a força do estereótipo se desacralizava quando o trabalho do pintor-fotógrafo foi exibido em 1909, sob a premissa da denúncia social que começaria a ser forjada de modo mais evidente em início do novo século. A referência começava a ser traída porque o universo da fotografia passaria a ancorar-se na vida social, descobrindo-se como "arma" nos novecentos. A produção fotográfica realizada na Itália, progressivamente abria mão de uma concepção de fotografia realística para enaltecer a imagem dos sujeitos sociais do campo, criando representações do povo "heróico em sua miséria", afirmou D”Autilia (2012, p.41). ${ }^{295}$

A autora chegou a afirmar que "a fotografia se descobre como uma arma no século XX e irá combinar este poder em inúmeros registros, da sátira cáustica ao humanismo visivo", acentuando-se cada vez mais uma observação crítica das relações sociais. Tornava-se crescente a intenção de narrar, de cercar um tema e apresentar uma realidade fragmentada imbuída da crença do virtuosismo da foto documento.

Nessa visualidade, vê-se como os sentidos são moventes, construídos no bojo das relações sociais, por agentes que participam ativamente na produção de seus bens culturais, criadores de uma cultura material que por meio de seus artefatos potencializa as formas de existir, de se ver, de ver o outro e entender o mundo. No trânsito de tais imagens o pesquisador pode sondar a própria inconstância da foto, que vai traindo a referência, superando-a.

Esse repertório paradigmático foi marcado por diferentes nuances, assumindo noções nem sempre homogêneas segundo D”Autilia (2012, p.11-12), ora oscilando inicialmente de modo mais pejorativa, para diferenciar "o povo" dos grupos dirigentes e da "luce dell'elite

\footnotetext{
295 Essa segunda concepção está fortemente associada à criação do Instituto Luce fundado nos anos de 1920, na Itália, na efervescência das ideias fascistas em ascensão. Ver D’Autilia, 2012, p.50.
} 
pensante", noção pontuada em meados dos oitocentos, ora numa concepção heróica da cultura rural, formando a imagem do italiano bom, fraterno e trabalhador, dentro e fora do país.

A situação social da Itália meridional com os pequenos proprietários perdendo a posse de suas pequenas propriedades e a consequente emigração, discutida em todo o país, apresentava-se para os fotógrafos, segundo a pesquisadora italiana Marina Miraglia, como uma "oportunidade de compreensão do problema social pela fotografia". A pesquisadora, ao tratar da trajetória do pintor- fotógrafo Francesco Paolo di Michetti, afirmou que em sua fotografia, diante dessa contingência de deslocamento da população das comunas mais empobrecidas do sul da Itália, há "uma chave de leitura, de interpretação mais que histórica, psicológica”. (Miraglia, 1975, p. 39)

Uma dimensão política do uso da fotografia começava a se nuançar com mais força. Se esse repertório abandonava seus sentidos ligados a uma representação de costumes e do pitoresco, num desdobramento que a empurrava para uma categoria de foto social, outros discursos, no entanto, ainda aderiam à fotografia. Essa visualidade passava a ser empregada para apontar diferenças entre o norte industrial, com fotos internas de fábricas e de operários, e o sul campesino, com uma fotografia que passou a documentar a unidade da família, enquadrando os indivíduos na paisagem natural, em práticas artesanais e rudimentares de produção, quase sempre representados com seus instrumentos de trabalho, constituindo-se como tópico central da fotografia de grupo e de família, como vimos no capítulo dois.

A difusão de imagens de uma Itália empreendedora se industrializando foi contraposta a representação das condições meridionais, que se opunha a imagem da fábrica. Sentidos reiterados amplamente com o início da Primeira Guerra Mundial. O material visual retratando as províncias do norte, neste período, materializava-se como afirmação de uma Itália moderna. (D’Autilia, 2012, p.110).

A fotografia italiana entrou em novo século voltada para descrição das condições materiais de vida, prevalecendo um tom de denúncia social. A produção da foto instantânea ampliava a noção de que tudo era passível de ser fotografado. Na paisagem decisiva da era da instantaneidade na Itália, segundo D”Autilia, predominaria a figura humana, o trabalhador, o trabalhador ambulante. Muitos saiam do pictorialismo para o protojornalismo. D"Autilia (2012) nomeou alguns envolvidos neste processo: Filippo Rocci, Francesco Chigi, Gioacchino Iacono, Francesco Meli, Michele Giaconia, Alfonso Lombardi Satriani, Giuseppe Palmieri. Giuseppe Beltrami, em Milão, com uma pequena máquina $42 \times 42$, assim como outros tantos 
fotógrafos em início de novo século, usavam seu equipamento como um caderno de viagem, voltados para a "realtà sociale".

Os cartões postais produzidos por diferentes fotógrafos entravam em novo século reiterando as típicas cenas de gêneros dos oitocentos. Um fragmento do passado tradicional atuante na modernidade. Em 1899, Veneza apresentou a sua primeira exposição Nacional de cartões postais ilustrados impressos a partir de fototipia, heliogravura ou zincografia, este um processo tido como mais econômico. Mas tais suportes passavam cada vez mais a expressar um traço da fotografia italiana que se caracterizaria como "realismo social", ou "rebeldia humanitária", e ainda "pietismo cristão". 296

Marina Miraglia defende que o novo século trazia um germe originário das investigações tidas como proto-reportagens. Essa sensibilidade para a vida cotidiana, para o "modus vivendi", para as condições materiais antes mascaradas pela fotografia de gênero que construía, sobre a premissa do realismo representativo, "a imagem genérica da subalternidade", configurando uma tradição iconográfica formadora de uma tipologia étnica italiana, passava a evocar a forma de denúncia social por meio de imagens. Surgiu uma nova forma de se documentar as contradições sociais típicas daquilo que Miraglia (1993, p.113) chamou de "urbanizzazione selvaggia". Posição que reitera a abordagem de D’Autilia (2012, p.112) para quem a fotografia italiana, nas primeiras décadas do século $\mathrm{XX}$, passava a ser pensada frente a "urgência de uma Itália que precisava ser reconstruída".

Nesse período, a documentação visual produzida na Itália foi considerada por Miraglia como mais crítica, intimamente ligada com a necessidade de ilustrar reportagens. Se antes, tratava-se de uma iconografia ligada à literatura de viagem, ao consumo de turistas e à busca de síntese dos indivíduos e do território unificado, também ligada ao cientificismo da época, entra no novo século, aproximando-se de uma reportagem social.

A prática dos fotógrafos e a intenção de alguns jornalistas de usarem fotos em suas reportagens foram argumentos para a autora defender sua posição. Em visita a comuna de Agrigento, o jornalista Adolfo Rossi, do jornal A Tribuna, em 1893, ajudaria a inscrever aquilo que D"Autilia sugeriu ser uma representação que se inclinava para a denúncia social, não só no "espírito como no método"; uma fotografia entendida como "um espírito

\footnotetext{
${ }^{296}$ Segundo a autora circulavam no mundo na passagem do século mais de 25 milhões de cartões postais no mundo. Cf. D’Autilia, 2012, p. 137. As traduções vêm dos seguintes termos em italiano: "verismo sociale", "ribellismo umanitario" e "pietismo Cristiano".
} 
testemunhal das desigualdades", abandonando as camadas de significações mais antigas que a projetavam para as cenas pitorescas e de costumes.

Visto que o diretor da 'Tribuna' mostrou-se sempre tão cheio de sensibilidade para com as crianças maltratadas, eu lhe peço aqui, publicamente, a permissão de dedicar alguns dias a esses infelizes carusi $^{297}$ : é preciso visitar todas essas minas de enxofre, fotografar os pequenos miseráveis para provocar em toda a Itália um grito de horror que coloque fim a essa crueldade, que mostre de que lágrimas goteja o dinheiro vindo das minas de enxofre. ${ }^{298}$

Se a fotografia, em 1893, começava a apresentar uma nova vocação, forjando-se um novo papel social para o fotógrafo, em 1908, a Federazione Nacionale de Stampa italiana inseriu estes profissionais no quadro do jornalismo; dois anos depois nasceu a Associazione Giornalistici Fotografi, organizando uma importante exposição em 1911. O fato de tais atribuições terem sido depois extintas em 1926, ou terem tido seus estatutos modificados, a prática de "raccontare il mondo", ou seja, narrar o mundo pela imagem, continuaria com vigor no cenário italiano, apontou D"Autilia (2012, p.153). Essa “iconografia del popolare" tida como um topos representacional, exaltando o pitoresco, passaria a forjar, como mencionou Miraglia uma "nova sensibilidade instituída pela fotografia".
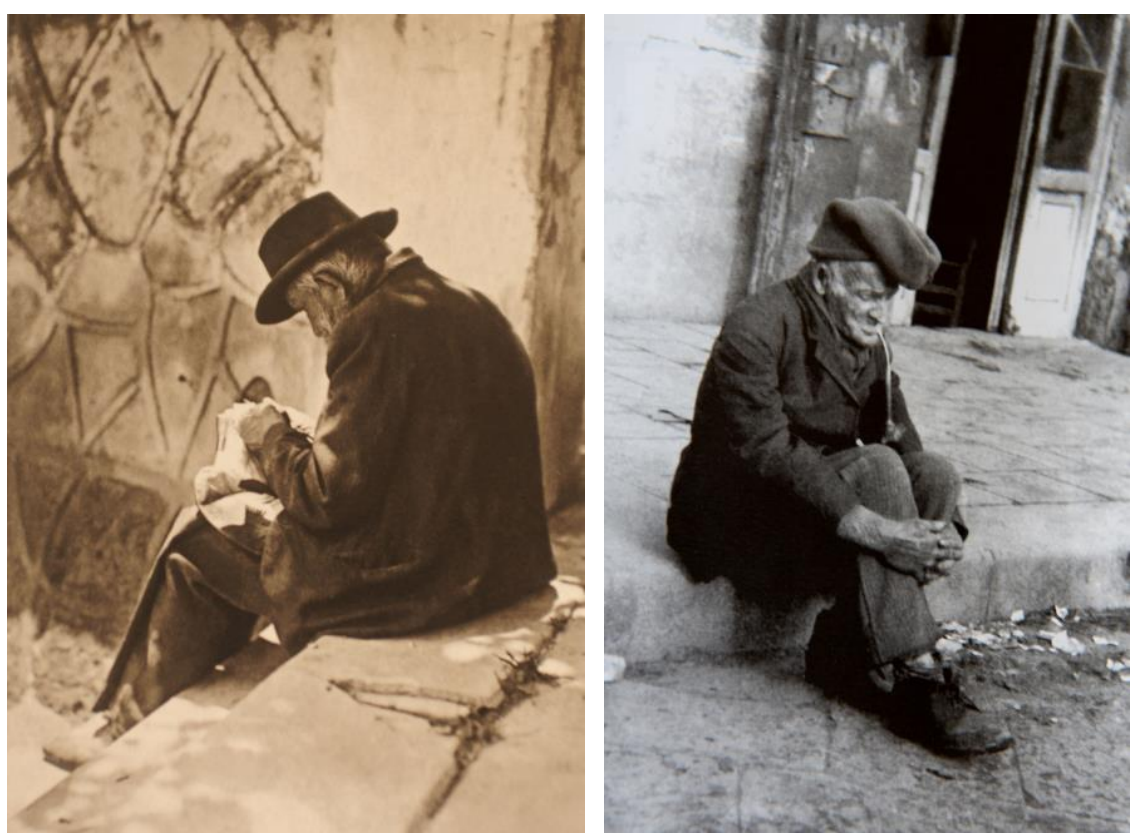

Figuras 245 e 246: Foto à esquerda: "Idoso sentado em degrau de escada". Local não identificado da capital paulista. 1910 (C) Vincenzo Pastore. Instituto Moreira Salles. Foto à direita:homem sentando em guia de calçamento em Nápoles (C) Eugenio Buono. In: Italia inédita di un secolo fa. Napoli, Venezia, Palermo, $i$ borghi di Caiazzo e di Cerreto Sannita nelle lastre ritrovate di Eugenio Buono. Napoli: Edizioni Intra Moenia. 2008.

Pastore não escapou da mentalidade de sua época. Ao compor fotos que remetiam à foto flagrante, na cultura da foto instantânea, fixou em sua narrativa a presença dos mais idosos, vistos na capital paulista, ainda mais vulneráveis à instabilidade que os cercava (fig.245). A

\footnotetext{
${ }^{297}$ Termo siciliano que significa "garotos".

298 Jornal La Tribuna. 16 de outubro de 1893. Título da matéria: "La situazione in Sicilia". APUD. D’Autilia. 2012, p. 152.
} 
fragilidade que os acompanhava vinha no registro de Pastore lembrar aquilo que Bruno apontou como "escassos e acanhados meios de subsistência" diante do anonimato da multidão que se avolumava na capital paulista (1954, p. 447). O pintor fotógrafo Eugenio Buono, interessou-se pelo mesmo conteúdo visual em Nápoles (fig.246). Pastore e Buono, guardam fragmentos de instantes quase perdidos no tempo. Quando tocados por tais imagens, evitaram que seus retratados caíssem no "ofuscamento da memória”, estratégia comum em São Paulo, no processo de invenção da identidade da cidade, forjada, segundo Elias Tome Saliba (2004, p.570), por arranjos sociais eficazes em eliminar "a transparência do passado, selecionando imagens consensuais que foram se tornando cada vez mais opacas à percepção social”.

Ambas as fotografias, dividiam os mesmos aspectos formais. A escolha por fundos neutros ressaltava nuances mais íntimas, introspectivas, acentuando o grau de dramatização das cenas. Mas, se Buono, inclinava-se para a nova sensibilidade fotográfica que surgia na Itália, Pastore, por sua vez, mobilizava suas fotografias num circuito específico de circulação de imagens, distantes da noção de denúncia social que crescia na Itália. Suas fotos foram agenciadas em outro circuito o que impõe outros parâmetros analíticos. Uma delas foi emoldurada e levada em 1908 à Exposição Nacional do Rio de Janeiro (fig.247). A trajetória de suas imagens não se inclinaria para a fotografia documental de intervenção ou denúncia social.

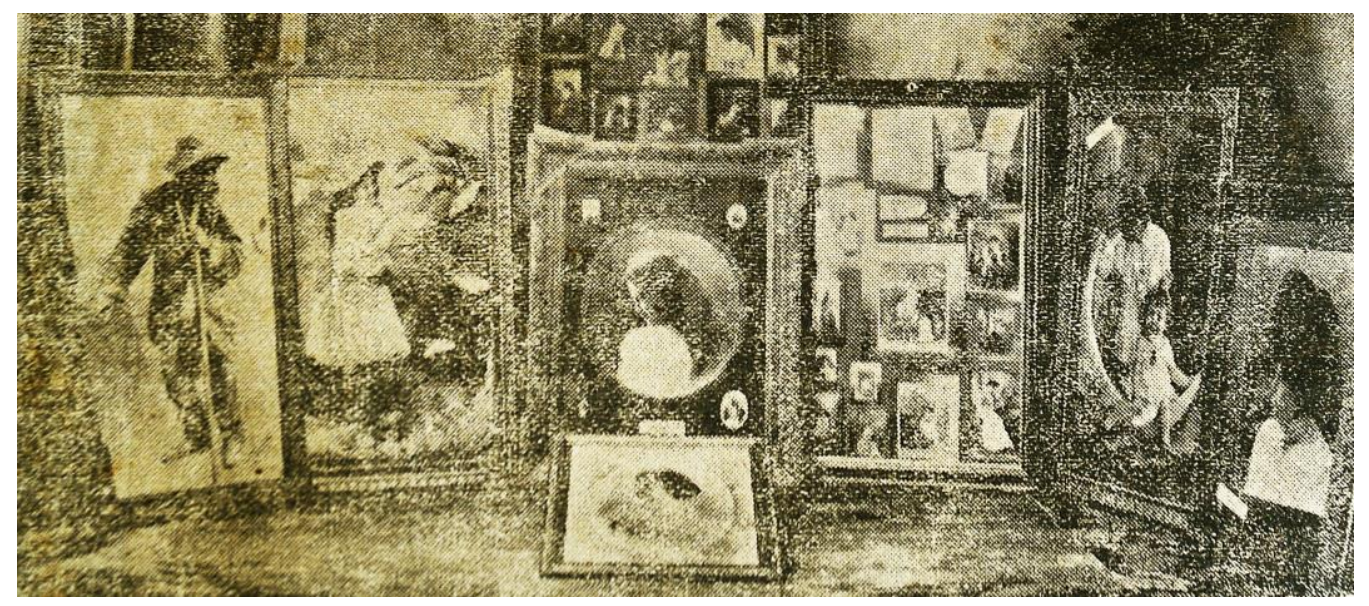

Figura 247:

Detalhe da reprodução de fotografia publicada em 1908, em jornal italiano. Caderno de Recortes coleção Dante Pastore, p.16.

Observar a "trajetória das coisas" e os sentidos atribuídos em seu tempo preciso de produção e circulação ajuda a melhor documentar a historicidade dos artefatos, como bem apontou Appudurai:

(...) temos de seguir as coisas em si mesmas, pois seus significados estão inscritos em suas formas, em seus usos, suas trajetórias. Somente pela análise dessas trajetórias, podemos interpretar as transações e os cálculos humanos que dão vida às coisas. Assim, embora de um ponto de vista teórico 
atores humanos codifiquem as coisas por meio de significações, de um ponto de vista metodológico são as coisas em movimento que elucidam o seu contexto humano e social. (Appadurai, 2008, p. 17)

Deste modo, as análises que seguirão tentam sondar sentidos mais precisos das fotos de Pastore, sublinhando compreensões a partir dos circuitos investidos pelo fotógrafo, no qual suas fotografias conseguiram se inscrever socialmente. Observaremos como as fotografias de Pastore se movimentaram no tempo, interrogando trajetórias mais específicas e particulares das fotos. Caminho metodológico que forma aquilo que Appadurai problematizou como "biografia cultural das coisas", desenhando-se assim a própria "história social das coisas', sempre atrelada às trajetórias dos objetos culturalmente produzidos e postos em circulação, a partir de relações sócio-culturais mediadas por meio da materialidade visual produzida, que também expressa "mecanismos de reprodução das relações entre pessoas" (Appadurai, 2008, p. 54).

\subsection{Quando a referência não explica tudo: camadas de complexidade do ato fotográfico de Pastore}

Apresentamos um importante vestígio que ajudou na investigação dos desdobramentos, ou melhor, das "rotas" para tratar de um termo de Appadurai (2008), trilhadas por algumas das fotos de Pastore, que circularam dentro de estruturas mais antigas de representação e de práticas fotográficas: o espaço das grandes exposições, campo de recepção de imagens de costumes.

A foto do senhor fotografado nas ruas, apoiando-se em seu cajado foi levada a Exposição Nacional de 1908. Imagem que se inscreveu historicamente neste circuito, o lugar, segundo Benjamin, da "peregrinação ao fetiche da mercadoria". ${ }^{299}$ Apesar de Pastore ter

299 Benjamin, Walter. Angelus Novus. Saggi e Frammenti. Editora Einaudi: Torino. 1995, p. 151. APUD. D’Autilia, Gabriele. Storia della fotografia dal 1839 a oggi. Editora Piccola Biblioteca Einaudi. 2012, p. 168. Comemorava-se o primeiro centenário da abertura dos portos. Para se verificar os avanços culturais e econômicos de cada estado da federação álbuns, fotografias e catálogos foram exibidos aos mais de um milhão de visitantes. A cidade era aqui entendida como espetáculo. Era o "Brasil em exposição" para os próprios brasileiros, desejosos em contemplar a própria modernização em curso. Tratava-se este, segundo Pereira, "de um longo e intenso processo de educação de sentidos e, sobretudo da visão". Pereira, Margareth da Silva. A exposição de 1908 ou o Brasil visto por dentro. Artigo disponível na internet: http://www.ufrgs.br/propar/publicacoes/ARQtextos/pdfs revista 16/01 MSP.pdf Foi exibido o panorama com a vista da capital paulista, de 11 metros de extensão, do fotógrafo Valério Vieira. Este fotógrafo também levou retratos em grandes ampliações. Ver revista A Vida Moderna. Julho. 1908, n. 42; nessa mesma edição foram 
documentado uma dinâmica social de sobrevivência, deixando um importante testemunho sobre as sociabilidades retratadas, ampliou uma das imagens feita nas ruas da cidade, emoldurando-a em um grande quadro, depois exposto em um dos estandes do pavilhão de São Paulo, “o maior e mais luxuoso” da Exposição Nacional na capital do antigo Império.

Entre os retratos e fotomontagens, Pastore levou à cidade carioca, a fotografia de um homem usando chapéu, com trajes simples e cajado na mão, num fundo completamente neutro, com iluminação equilibrada e sem contrastes, com a presença única do retratado, emprestando a esta fotografia, os aspectos característicos do gênero pitoresco, retomando de forma ambígua, a temática dos tipos sociais, num sistema preciso de recepção.

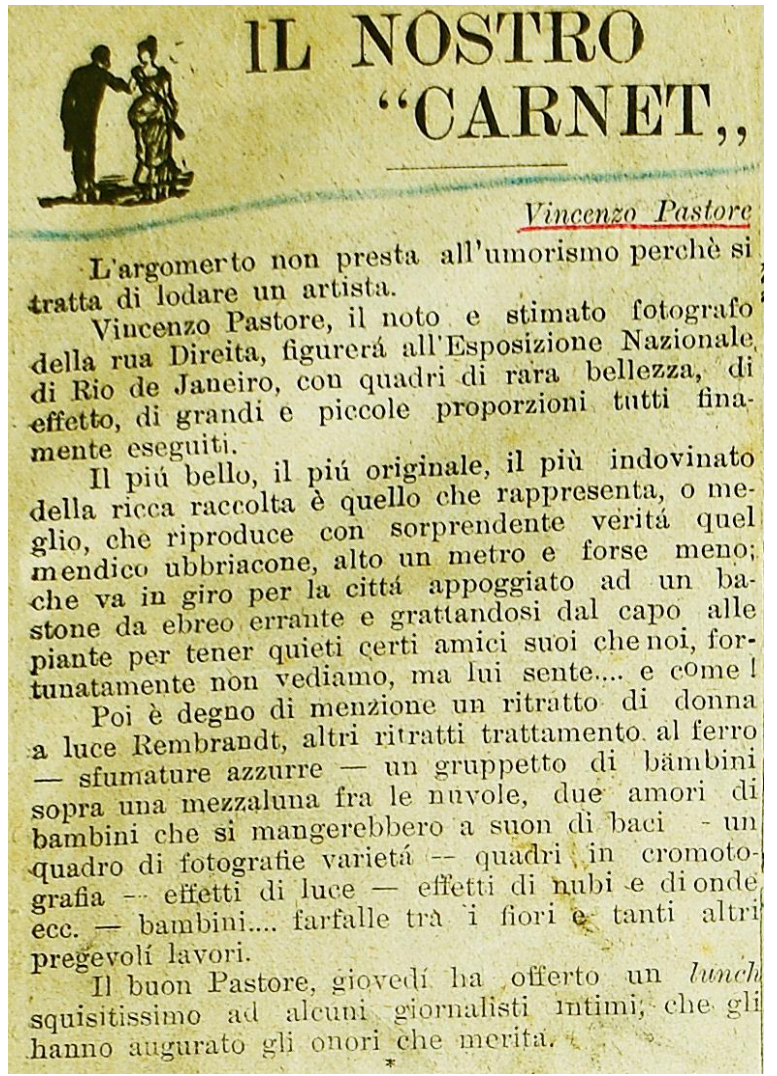

Nosso caderneta.

$\mathrm{O}$ Argumento não se presta ao humor porque se trata de reverenciar um artista com louvor. Vincente Pastore, conhecido e respeitado fotógrafo da Rua Direita, irá participar da "Exposição Nacional do Rio de Janeiro" com imagens de rara beleza, de grande efeito e proporções detalhadamente e finamente executadas.

O mais belo, o mais original, a mais esperada e rica coleção que representa, ou melhor, que reproduz com surpreendente verdade aquele mendigo, beberrão, um metro de altura e talvez menos, que anda pela cidade apoiado com uma vara judaica, um ser errante, coçando-se da cabeça aos pés, para tirar tranquilamente alguns amigos dele que, felizmente, não vemos, mas ele sim ... e como! Em seguida, é digno de mencionar um retrato de uma mulher a luz de Rembrandt, outros retratos foram tratados com ferro-esfumaçamento azul - um grupo de crianças retratadas numa lua crescente nas nuvens, dois amores de crianças que comem ao som de beijos uma variedade de quadros de fotografias - com em efeitos de cromatografia - efeitos de nuvens e ondas etc. - Crianças ... borboletas entre as flores e muitas outras obras valiosas.O bom Pastore, quinta-feira ofereceu um almoço requintado para alguns jornalistas que lhe ofereceram as honras que merece. (Tradução nossa) ${ }^{300}$

publicadas também alguns retratos do fotógrafo Sarracino também enviadas a mesma exposição. Somaram 11.286 expositores.

300 Figura 248. O recorte de jornal estava em folha separada da fotografia com os quadros exibidos na exposição. Não temos como saber o texto escrito acompanhava a fotografia que trazia como título "Gl'italiani all'Esposizione di Rio. I lavori fotografici di Vincenzo Pastore". Coleção Dante Pastore. Caderno de Recortes, p. 11. 
Conseguimos documentar um dos circuitos que Pastore vislumbrou quando ainda vivia no Brasil, mostrando possíveis sentidos conferidos a uma das fotografias referentes a coleção do IMS. O seguinte relato, publicado em jornal sob o título "Il Nostro Carnet", comemorava a participação de Pastore na exposição citada. A foto do senhor retratado de cajado na mão, segundo relato jornalístico integrava a "mais bela", a mais "original" e "rica" coleção apresentada. É clara a associação à vida pastoril, quando se descreve o cajado como a vara judaica.

Se, por um lado, reverenciavam o fotógrafo, por outro, surgem certas percepções e sentidos obscuros, carregados de negatividade, recorrentes nas representações dos tipos populares. $\mathrm{Na}$ descrição da foto, o pitoresco confluiu para o pejorativo mostrando como as idéias pairam no ar, nos seres e nas representações de modo duradouro. Os despossuídos de bens materiais no relato seguiam associados à mendicância, à bebedeira, ao desleixo. Tais atribuições foram ainda mais reforçadas no seguinte relato, que pouco encobriu os sentidos ambíguos vistos nas descrições do homem tido como um "desgraçado, um degenerado, um miserável, um pedaço de um homem":

(...) podemos destacar algums belos trabalhos, com grande efeito. Vamos começar a partir do retrato de um velho bêbado que todos em São Paulo e países vizinhos conhecem porque é o mais terrível dos castigos: o ridículo. Ele é um desgraçado, um degenerado, um miserável, um pedaço de um homem, se tal se pode dizer, vai apoiando-se em uma vara encostado numa parede: ele não pede caridade, mas deixa claro que tem necessidades. ${ }^{301}$

O "tipo repulsivo", segundo o relato publicado, "ascendeu a imaginação do artista que fez um quadro, um belo quadro, um exemplo de realismo completamente livre do convencionalismo, que vários dias atraiu elogios de desconhecidos, recebendo elogiosos méritos". O realismo enaltecido no relato faz da Exposição Nacional de 1908 o mesmo salão burguês fiel à crença na verdade latente da fotografia, tida como "nem fantasia, nem disfarce, a verdade nua". 302

Há ainda outro traço de historicidade da série. O desdobramento dessa imagem realizada por Pastore indiciou a capacidade da fotografia de transcender para outro lugar, porque depois de apresentada nesse circuito de exibição de uma "quantidade ilimitada de personagens", como afirmou Benjamin, sobre as grandes exposições, a foto foi exposta na

\footnotetext{
${ }^{301}$ Coleção Dante Pastore. In: Caderno de Recortes, p. 12.

302 Coleção Dante Pastore. In: Caderno de Recortes, p. 12.
} 
mostra realizada pelo próprio fotografo em seu estúdio aberto em Bari. Um sobrado - galeria, um sobrado - museu, que abrigou a mostra permanente de Pastore.

Para Ricardo Mendes (1998), a série também não assumiu um caráter de denúncia social. Segundo ele Pastore tinha como intenção: "voltar para a Itália e levar um material diferenciado daqui: tipos populares, folclóricos, gente pobre" dado ao apelo que poderiam exercer na Europa, premissa que pudemos confirmar como veremos mais à frente.

Seguir no rastro das práticas investidas pelo fotógrafo ampliou os horizontes de compreensão sobre a sua trajetória. A observação da sua prática reforçou ainda mais o quanto é impossível criar um lugar social fixo para Pastore, que não cabe numa única definição, que se lançava em diferentes contingências, investindo suas imagens em diferentes circuitos. Seu filho caçula, Dante Pastore, ao responder a pergunta de Mendes "por que ele gostava tanto de fotografar tipos de rua", indiciou a existência de um possível "salão" em São Paulo, onde tais cenas eram expostas; depois, Dante concordava com Mendes que podia se tratar, na verdade, de um mostruário, fixado na entrada do ateliê, "meio de lado". Ao sugerir uma prática tão em moda nos oitocentos, o filho de Pastore, talvez recuperou, por meio de uma lembrança entrecortada, confusa, marcada também por esquecimentos, a tentativa do pai em tentar comercializar suas imagens de tipos sociais ainda no Brasil:

Quem passasse na rua tinha que ver. Não tinha jeito. Então parava gente, viam, uns iam até tirar fotografia porque viam os tamanhos, de todos os tamanhos de fotografias, tipos, não é. E de gente também, que as vezes ele conseguia na rua (...) enfim conservava uma certa audiência com essa gente, que era gente pobre, gente... para tirar fotografia e ficar nessa exposição dessa entrada grande que tinha. ${ }^{303}$

O pesquisador Ricardo Mendes se esforçou e ganhou algo mais da memória de Dante: "nesse trecho da Rua Direita tem um vendedor de vassouras, tem gente fazendo mudança com carroça, tem essas coisas". O filho caçula do fotógrafo, ao tentar responder às indagações ansiosas por melhor ver Pastore, revivia os espaços que levavam ao estúdio do pai, no segundo andar do sobrado: "aquele quadro estava exposto logo que tinha a escada que então ia para o primeiro andar". 304

\footnotetext{
${ }^{303}$ Entrevista feita por Ricardo Mendes com Dante Pastore encontrada na íntegra no acervo do IMS, no Rio de Janeiro. Lauda 24.

$304 \mathrm{O}$ armazém citado trata-se da loja $\mathrm{O}$ Bon Marché, que ocupava o piso térreo do sobrado. Separadamente tinha uma entrada que dava acesso ao primeiro andar, residência da família. No segundo andar ficava o estúdio de Pastore. 0 mostruário ficava na entrada.
} 
Por meio de tais lembranças vemos indiciada a possibilidade de tais imagens se encaixarem nos arranjos formais pré-determinados em álbuns que abrigavam coleções de vistas, paisagens exóticas, de costumes com muitas carte-de-visite, depois fotos em formato cabinet e cartões postais. Suportes para coleções particulares de cidades e povos, vendidos como souvenir de viagens, cumprindo-se "a vocação de item colecionável", inerente a uma prática fotográfica cada vez mais popularizada e legitimada, que surgia como síntese do mundo, segundo Carvalho e Lima (2000, p.20). Imagens há décadas comercializadas como lembrança.

Será que temos aqui Pastore se aproximando em sua prática do fotógrafo Ferrez quando este se dispôs a também retratar os burburinhos das regiões dos mercados? Será que em tal aproximação vê-se como a referência italiana não explica tudo? Ou melhor, será que em tal aproximação, vê-se como esta convenção era vibrante também no Brasil, mostrando que tratar de Pastore significa percorrer um terreno nada tranqüilo?
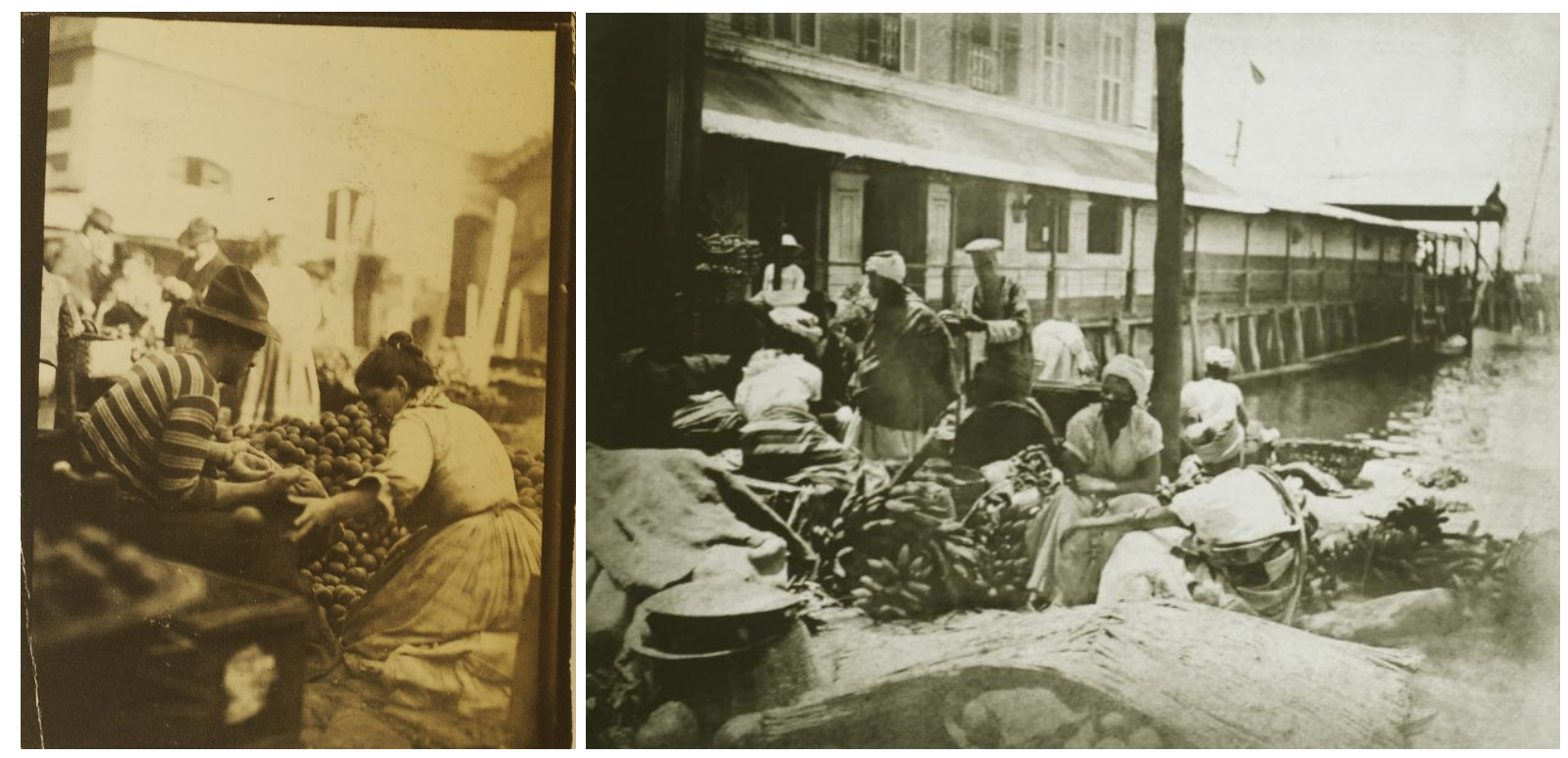

Figuras 222 e 249: Vendedores no Mercado dos Caipiras. 1910 @ Vincenzo Pastore / IMS; à direita Mercado na Beira do Cais. Rio de Janeiro. 1875 @ Marc Ferrez / IMS.

Os fotógrafos no Brasil saiam também às ruas, preocupado em mostrar um mundo além daquele produzido na artificialidade do estúdio fotográfico. Uma iconografia que colocava em cena sujeitos em suas ações corriqueiras, valorizando a cultura material que os cercava, composições que destacavam os produtos vendidos, representando uma interação social vinculada aos aspectos de uma cultura popular da sobrevivência, atraindo os fotógrafos em contingências variadas: Ferrez se voltou para o Mercado na beira do cais, no Rio de janeiro 
(fig.249); Pastore preferiu pontos de entroncamentos entre a cidade nova e o velho centro paulistano (fig.220).

Esse entrecruzar de produções feitas por Ferrez, em 1895 e depois por Pastore próximo a 1910, mostrou uma visualidade não inaugurada por Pastore. Vê-se o quanto a fotografia era também um modo de expressão paradigmático, inscrevendo um trânsito de códigos visuais universais. Essa visualidade em diálogo pode ser assim entendida.

Inscreve-se em cada período histórico um inconsciente visual que determina os cânones da representação figurativa. As representações sociais estariam introjetadas nos códigos imagéticos que predominariam por longas gerações, sobreposições, imbricamentos, sucessões, em um revezamento cuja compreensão demandaria uma periodização com o concurso de múltiplos tempos. (Debray, 1993, p. 91)

Pastore talvez tenha fixado suas imagens em seu mostruário, na entrada de seu estúdio, como retomaram as lembranças do tempo do menino Dante, que se recordava do pai retratando a gente de São Paulo, "gente pobre (...) na grande entrada que tinha". Talvez o relato de Dante venha confundir ainda mais o desafio de entender Pastore e as múltiplas camadas que o constituem porque também encontramos Pastore enviando fotos ao rei e ao santo padre, em diálogos escritos e visuais, aproximando Brasil e Itália.

Se a trajetória dessa pesquisa teve início pensando o fotógrafo dentro do estúdio para depois espreitar a sua atuação nas ruas da capital, propomos agora um rápido movimento de retorno, voltando-nos para sua prática mais uma vez dentro do salão de pose. Outras nuances surgem, exigindo mais fôlego, mais aprofundamento da interpretação, porque Pastore é camaleão, movediço, avesso a fácil compreensão. Falar de Pastore é tratar das dimensões múltiplas da fotografia, entendida no plural, nos caminhos que aproximavam Brasil e Itália, na interface de uma trama que faz crescer a sua intrínseca ambigüidade.

\subsection{Fotos e cartas: redes de contato possíveis de se indiciar}

Tratamos de quatro imagens que ajudam a aprofundar as dimensões do ato fotográfico de Pastore. As duas imagens da mulher negra com seu filho (fig. 250 e 251) e as outras duas retratando um grupo de índios bororo (fig. 252 e 253), diferenciam-se do restante da série até aqui analisada. Além de realizadas em estúdio, tiveram uma interessante recepção 
documentada. Recepção aqui entendida não como método, mas como problema, como sugeriu Meneses, conduzindo a análise para as redes de contatos criadas pelo fotógrafo.

Pastore enviou tais fotografias ao rei da Itália e ao papa, respectivamente. O consulado da Itália no Brasil emitiu um documento oficial, no dia quatro de agosto de 1904, parabenizando o gesto de Pastore. Na coleção preservada por Elvira e pelos filhos do fotógrafo, fotos e cartas oficiais revelam certos agenciamentos de Pastore.
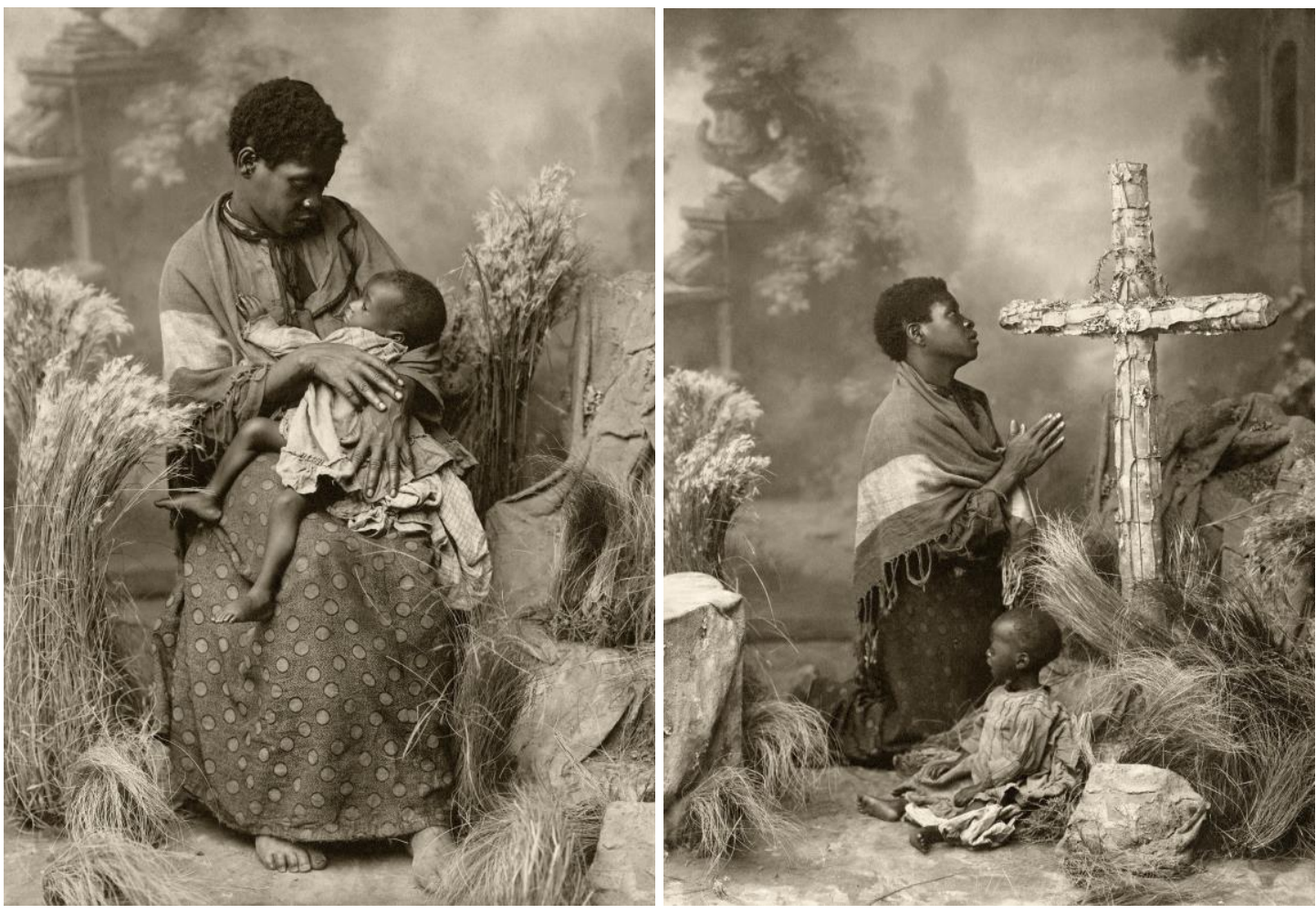

Figuras 250 e 251: à esquerda "Retrato de mulher com criança no colo"; à direita "Retrato de mulher diante da cruz, com criança chorando ao lado". Fotos possivelmente enviadas ao rei da Itália ou ainda expostas pelo fotógrafo na entrada de seu estúdio. 1905 @ () Vincenzo Pastore / IMS.

Em carta timbrada, em nome de "sua maesta il Re", Pastore recebeu o agradecimento pelas fotos enviadas no mês de maio daquele ano. Sua majestade, o rei, ao expressar "sentimentos devotos" deixou um registro das práticas de Pastore, das relações firmadas por meio do material visual produzido em sua experiência de imigração.

Sua excelência o Ministro da Casa real informa que o senhor Vincenzo Pastore enviou em maio, a sua majestade, o rei, foto de grupo de negros; está oferta acompanha a expressão de sentimentos devotos e me convida a demonstrar uma palavra de agradecimento em nome real. ${ }^{305}$

${ }^{305}$ Coleção Dante Pastore. In: Caderno de Recortes. Reprodução da carta em anexo, figura 287, p.427. 
Pensar a fotografia como um objeto material que participou ativamente das relações sociais, portanto, pensar o fotográfico na dimensão das práticas matérias nos ajuda, segundo Meneses (2002) a melhor compreender a própria trajetória dos fotógrafos, visceralmente envolvidos nesse campo de interações mediadas pela fotografia, pela cultura material. Cartas oficiais remetidas da Itália e fotos feitas no Brasil formaram essa rede de contatos investidos por Pastore.

Não sabemos ao certo se as imagens citadas "Foto de grupo de negros" se referem especificamente as imagens acima apresentadas. De qualquer maneira a carta de agradecimento real dá visibilidade a uma imagem, talvez com sua materialidade desfeita em seu percurso, imagem talvez igualmente realizada sob luz controlada, sob arranjos e composições que colidem para um campo de ícones autorizados.

O fotógrafo colocou no centro de sua representação, uma mulher negra que levava o filho nos braços (fig.250). Não é, no entanto, a mãe negra carregando a criança branca, representação emblemática da iconografia oitocentista sobre a mulher negra e escravizada. Pastore subverte o ícone. É o próprio filho da mãe egressa da escravidão, reivindicando seu direito ao aleitamento. Pastore registrou recusas antigas que envolviam mulheres negras e seus filhos legítimos, mulheres relembradas na representação pelo xale de baeta, pela roupa de simples panos, pelos pés descalços, códigos visuais evidentemente retomados pelo fotógrafo nessa encenação. Explicita-se também o estilo art nouveau, quando o fotógrafo se apropriou de um repertório do campo, de traços bucólicos, uma convenção estética e uma moda de início de século, mas também uma clara noção que resgatava uma "poética iluminista do pitoresco", como defendeu Maria Hirszman (2011, p.109) onde indivíduo e o seu ambiente confluíam. Temos em Pastore um olhar típico do viajante em tudo retomando a produção de fotos etnográficas.

O pitoresco, num universo amplo das representações, tomou lugar na definição de habitantes e de paisagens, nem sempre buscando o belo, mas antes, cenas variadas e com detalhes curiosos, singulares, explicou Valéria Lima (2003, p.212). Nos relatos e descrições dos viajantes, ou naquilo que se pode chamar de literatura de viagem, se produzia um repertório esteticamente agradável, numa forma de síntese que propunha não só a descrição e identificação, mas a formação de identidades, fundadas na alteridade, ou seja, na definição e caracterização do outro, do não europeu. Princípios de hierarquização de povos e culturas 
problematizam o conceito do pitoresco. Colonialismo, cientificismo, eurocentrismo, em consonância nos oitocentos, aumentam o grau de complexidade do termo.

Nas formas do exótico criado por Pastore não se vê, porém, a alteridade, comum aos registros oitocentistas. A codificação representava uma mãe simulando sua reza, pedindo de joelhos proteção (fig.251). Apesar de sugerir a continuidade de padrões das carte-de-visite dos tempos do Império, o conteúdo iconológico é outro. A mulher negra diante da cruz implora auxílio, lembrando a realidade que a afligia. Fato impensável nos suportes vendidos como souvenirs, aos viajantes ávidos por uma imagem dos trópicos, sustentada no exotismo e na constituição de uma tipologia social que tentava disfarçar a violência da colonização, da ocupação, da apropriação dos corpos apreendidos no gosto do colecionismo da época.

O relato de Flavio Varani, neto de Pastore, mostrou uma teia de sentidos e compreensões que aderem ao fotográfico. Segundo ele, o avô "criava quadros vivos, a madona negra, a madona africana. Ele traz para casa uma ex-escrava. Isso é uma projeção maravilhosa, histórica (...) é uma pessoa sofrida, que não tem cuidados, que merece atenção, que merece respeito. Essas coisas meu avô projetava". ${ }^{306}$ Mas não são as projeções sobre o fotógrafo que escolhia sua Pietà que propomos sondar neste momento.

Ao se rastrear possíveis circuitos de recepção, vê-se um repertório visual mantido vivo pelo fotógrafo. Talvez tais imagens tenham sido exibidas em seu mostruário lembrado pelo filho Dante, mas foram enviadas como presente ao rei da Itália. Imagens que, por um lado, denotam um apelo social e proteção, mas não estão destituídas dos elementos comuns a certo imaginário. Deste modo, é quase inevitável não lembrar de Christiano Jr., fotógrafo que ofereceu ao rei de Portugal, D. Fernando II, a série classificada como "Typos de negros", imagens realizadas na corte carioca entre 1864 a 1866. Buscando o mesmo prestígio, Pastore, já em novo século, presenteava o rei da Itália com a "foto de grupos de negros". É relevante pensar a mediação entre fotos e cartas, entre o súdito e o rei, mediações que desvelam redes de contatos mantidos vivos e atuantes por meio do material visual posto em circulação, retomando práticas mais antigas do métier.

\footnotetext{
${ }^{306}$ Relato de Flávio Varani no Curta metragem "Flávio Varani: Projeção", de dez minutos, dirigido por Paulo Cesar Toledo. Disponível na web em http://vimeo.com/69511937, com password: flavio1.
} 

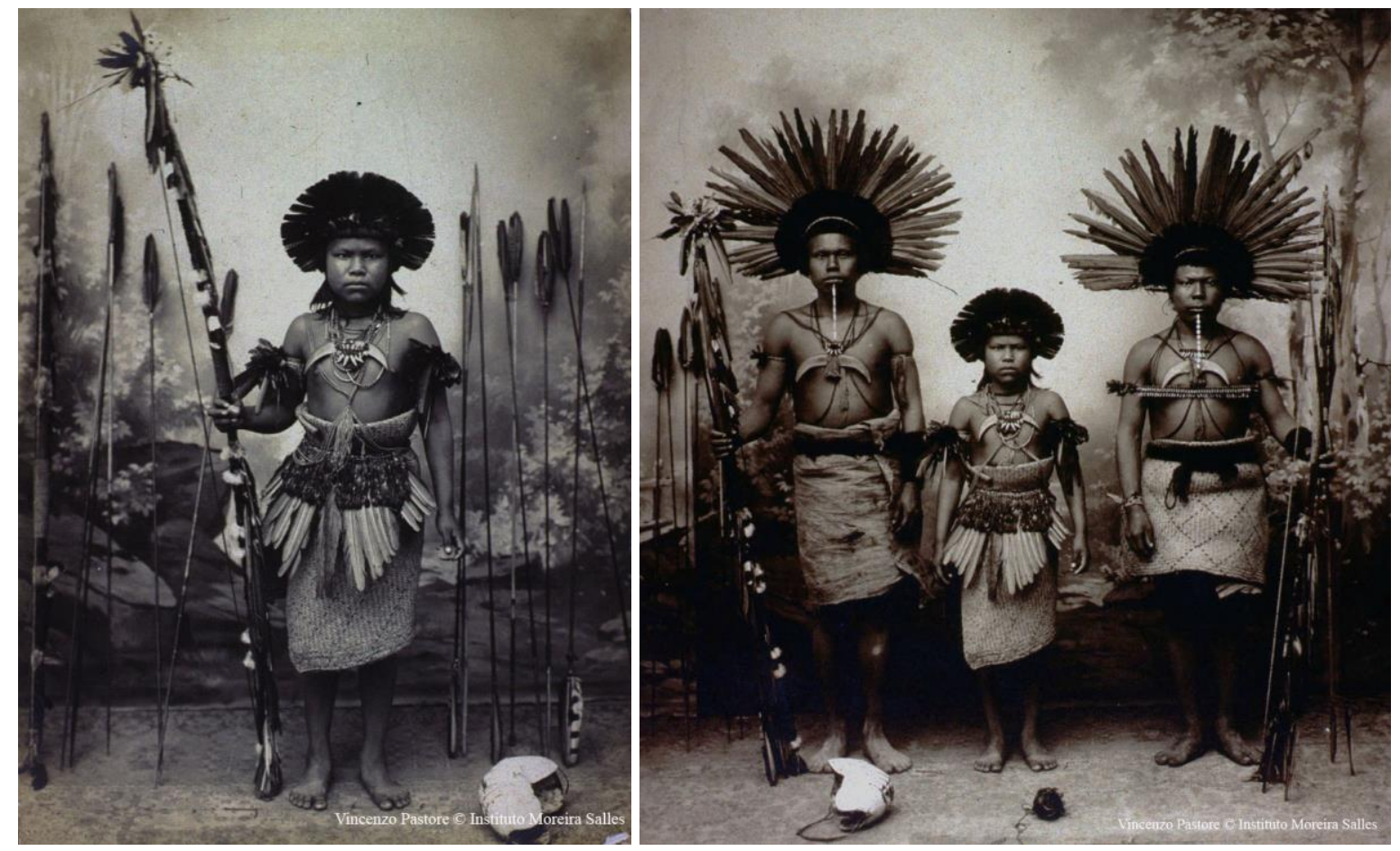

Figuras 252 e 253: à esquerda "Retrato de índio com arco e flechas"; à direita "Retrato de três índios com cocar e arco e flechas". Talvez tenhamos aqui reproduções de fotos enviadas ao papa e ao rei da Itália como presente. 1905 (C) Vincenzo Pastore / IMS

Em 1905 lá estava Pastore outra vez estreitando contatos. Mais uma vez o fotógrafo receberia "com a maior estima" outro agradecimento, dessa vez papal, pelas imagens de grupo indígena realizadas em seu estúdio. É o olhar do estrangeiro que se desdobra quando vemos tais imagens.

A carta enviada de Roma, no dia 10 de fevereiro de 1906, pelo "santo padre" agradecia

as fotografias enviadas de alguns indígenas bororos que vivem nas florestas da região do Brasil. Sua santidade sabe que não é tarde demais para neles penetrar a luz do Evangelho para levá-los a tornar-se parte da grande família católica. Enquanto isso dá de coração para ele e sua família a bênção apostólica esperada. ${ }^{307}$

Imagina-se o valor da carta recebida por este católico fervoroso. Nessa configuração visual feita por Pastore, vê-se, contudo, como o fotógrafo experimentava a dimensão da foto alegórica. Talvez diante da necessidade de sobreviver de seu ofício, dava continuidade a formas antigas de representação que conseguiam se atualizar, postuladas em estruturas visuais recorrendo, mais uma vez, à representação do índio, acomodando certos estereótipos.

${ }^{307}$ Coleção Dante Pastore. In: Caderno de Recortes. Cf. anexo, figura 286, p. 426. 
Motivava-se aqui todo um sistema de signos. ${ }^{308}$ A atenção a certos objetos, ao cenário, à pose, corriqueira nos retratos feitos em estúdio, reafirmavam a alteridade. Cascos de tatu foram deixados em evidencia. Indumentárias feitas de palha, penas de aves e outros atributos da cultura material indígena, como cocar, arco e flecha, somados a penas e adornos levados ao corpo, provocariam os efeitos de síntese criados na representação, reiterando o binômio do exótico e da natureza, intimamente ligados nas convenções visuais: "para corresponder ao ideal romântico do índio alegorizado não devia exibir nada que chocasse ou contestasse em excesso os padrões estéticos europeus", comentou Rezende (2011, p.56).

Os adornos labiais, os colabares bokori indicam que os retratados se tratavam de índios Bororo. Algo chama atenção, segundo o antropólogo Aramis Luis Silva. A ausência de "certa nudez", a presença de "certo pudor/recato", sugerem arranjos conceituais em torno do visual construído, reiterando as afirmações anteriores de Rezende, sobre as formas de se retratar o etnográfico. Não se tem, no entanto, alegorias que remetessem à vestimenta a moda clássica, comum na representação de índios em muitos rótulos comerciais impressos no século XIX. As fotos são o sucedâneo de reais "vestimentas" nativas, argumentou Silva:

Uma coisa que pode ser explorada é essa ideia do fotografado tornar-se
quase uma vitrine. Ele carrega uma quantidade enorme de peças/adornos,
que denota uma vontade do autor de colocar na imagem esse artesanal
etnográfico para mostrar a relação que essas peças teriam com o
homem/corpo, que aqui, estaria metaforizando "a cultura viva'. A ideia etno
é a chave. ${ }^{309}$

Silva (2011), em sua tese de doutorado, ao tratar do percurso realizado pela coleção de artefatos bororo, incluindo fotografias colocadas em trânsito pelos padres salesianos por mais de 80 anos em mostras e exibições missionárias, bem mostrou como, nos sistemas de significação, os signos são moventes, e significados aderem aos objetos, submetidos a certos agenciamentos. Quando observamos tais produções de Pastore, parece que de algum modo o fotógrafo estava em sintonia com os sentidos divulgados no projeto evangelizador eclesiástico, que não se rendia mais as idéias de exotismo e alteridade desqualificada:

\footnotetext{
${ }^{308}$ Falamos aqui da existência e recorrência de um sistema de signos postos em circulação por toda a segunda metade do século XIX. Rezende mostra como em rótulos comerciais, até mesmo de marcas de xarope, a imagem alegórica do índio estava presente nas representações oitocentistas, em medalhas, brasão imperial, quase nunca representado de forma fiel e autentica. Graças a litografia se difundiu a reprodução de imagens e textos numa mesma impressão. Cf. Rezende, 2011, p.33-40.

309 Informação pessoal. Depoimento do antropólogo Aramis Luis Silva.
} 
Mesmo que percebido como "selvagens", "bárbaro", "inculto", "atrasado", "infantilizado", "pobre”, "inferior", "decaído", "corrompido", "vitimizado", ou outro item qualquer da lista de qualificativos depreciativos utilizados na época das exposições para descrever os povos missionados, o mundo extraeuropeu marcava presença nas grandes exposições salesiana e vaticana, não só porque aquilo que era percebido como falta ou exotismo. Enquanto que as exposições leigas da Europa e Estados Unidos abriam sua programação para aquilo que foi chamado pelos historiadores franceses como zôo humano espécie de prenuncio dos realitys shows, nos quais representantes de grupos étnicos eram transportados de seus locais de origem para simularem em pequenos cercados ou jaulas, seus modos de vida, "selvagens e bárbaros", para entreterem as multidões, que faziam das exposições seus programas de lazer - nas mostras missionárias italianas, eles lá estavam também como provas públicas, da existência das múltiplas facetas do homo religiosus, ou seja, daquele que crê naturalmente. Um argumento teológico e científico de época com profundas implicações políticas. (Silva, 2011, p. 96).

Não conseguimos documentar o envolvimento de Pastore em nenhum projeto católico, empenhado em comprovar a universalidade da idéia de deus. Apesar de não se conseguir aferir se tais fotografias foram encomendadas nos arranjos de um mito religioso, Pastore foi parabenizado pelo santo padre por ter retratado aqueles que poderiam tomar lugar na "grande família católica", afirmava o papa em carta enviada ao fotógrafo, desvelando o cerne de ideias que promoveram, em 1888, uma grande exposição missionária em Turim, período em que Pastore ainda se encontrava na Itália. ${ }^{310}$

Nas consultas realizadas no Arquivo Salesiano de Roma, o pesquisador Aramis Luis Silva encontrou quatro circulares emitidas pautando as coleções que seriam expostas nas exposições italianas. A segunda circular interessa a essa pesquisa porque trazia orientações quanto às fotografias que desejavam receber: além dos missionários devidamente retratados em sua vida cotidiana, solicitavam fotos de paisagens geográficas, grupos pitorescos indígenas (termo que englobava índios e negros) e cenas características da vida local. Exigia-se a identificação precisa dos retratados, bem como o envio dos negativos e das imagens positivadas, ou seja, solicitavam tanto a foto reproduzida em papel, quanto a matriz fotográfica para futuras reproduções. ${ }^{311}$

\footnotetext{
${ }^{310}$ Segundo Aramis Luis Silva, que realizou parte de sua pesquisa no Arquivo Salesiano de Roma, os estudos de Chiara Evangelista, da Universidade de Gênova, indicam a existência de uma carta escrita funerária de Dom Giovanni Balzola, citando a exposição realizada em 1888.

311 PASTA A8260106. Arquivo Salesiano de Roma. Cf. Silva, Aramis L. Mapa de Viajem de uma coleção etnográfica - A aldeia bororo nos museus salesianos e o museu salesiano na aldeia bororo. 2011. Tese de doutorado em antropologia social. FFLCH-USP.
} 
Talvez o fotógrafo estivesse de algum modo afinado com o argumento teológico de algumas missões. Ao retratar o grupo de negros elegeu a cruz, elemento que parece saltar do pano de fundo para atender às preces da mulher negra que participava da encenação (fíg.251). Vemos Pastore num circuito que talvez, nem supunha existir de modo consciente, dialogando mais uma vez com a economia visual de seu tempo.

Sobreviver da fotografia era, como se vê, um desafio. Os fotógrafos, não se especializavam. Era vital estar pronto para comercializar produtos variados. Não se desfaziam de seus painéis de fundo com a mata, o verde, as águas, enfim, as florestas tropicais idílicas, amplamente representadas. O Brasil era ainda lembrado pela composição de retratos de pessoas negras e populações nativas, em meio a sua cultura material. Lembrança que sustentava muitos ateliês e fotógrafos criadores de vistas, panoramas, retratos e postais.

Imagens que o "sr. Pastore" levou para Itália, expostas na mostra permanente dentro de seu estúdio, como mostra o relato de um jornal local: "Todas as autoridades expressaram ao senhor Pastore sua admiração mais sincera pela beleza dos trabalhos expostos, da fotografia de pessoas de todas as raças, de tipos de todos os países, do negro ao japonês, ao brasileiro ao europeu". ${ }^{312}$ No piso térreo à esquerda, na entrada do estúdio barese, lá estava a "representação valiosa que descreve três índios em seus trajes nacionais". Esse comentário no artigo "L'esposizione di un nostro concittadino" confirma as suspeitas de Ricardo Mendes, sobre o desejo de Pastore de retratar tipos exóticos nacionais para exibi-los na Itália como lembrança do Brasil, perpetuando ícones nacionais construídos visualmente.

Quando já havia retornado ao Brasil, depois de ter investido tudo no estúdio aberto em Bari, Pastore recebeu a seguinte carta, em 1916, que ajuda a entrever aspectos de uma evidente mediação: "Sua Majestade Vittorio Emanuelle III pela graça de deus e vontade da nação o rei da Itália" nomeava "Vincenzo Pastore industrial de Bari" como "Cavalheiro da Ordem da Coroa da Itália". ${ }^{313}$ Fotos e cartas assinadas como documentos oficiais permeiam a experiência de imigração de Pastore, um viajante que não mediu esforços para retornar à terra de origem, levando consigo o desejo de expor aquilo que foi capaz de interpretar na terra de acolhida.

\footnotetext{
312 Coleção Dante Pastore. In: Recortes de jornais.

${ }^{313}$ Coleção Dante Pastore. Cf. anexo, figura 284, p. 424.
} 


\subsection{Fotografias que se desdobram em uma coleção doada e reinventada. As motivações para o capítulo seguinte}

Se existe aqui uma tradição das cenas de tipos e costumes, na qual a série de Pastore pode ter lugar; essa observação não deve, contudo, se consolidar de modo estanque, como uma categoria de análise fixa. Preferimos seguir as orientações de Menezes (1996, p.148) que apontou para o risco de se reificar as imagens devido a um "processo ilusório de naturalização", como se fossem apenas suportes resultantes de processos de transferências de sentidos e formas.

É preciso se afastar da explicação única da categoria fixa da tipificação dos sujeitos sociais retratados ou do peso da tradição. É pouco delinear os circuitos em que o fotógrafo teve tempo de investir, antes de sua morte tão prematura. Demos vazão até aqui às memórias de seus descendentes que ajudam na reconstituição das trajetórias de algumas fotos. Mas ainda assim temos de enfrentar o fato de tais imagens, tão reveladoras, de sociabilidades tão vibrantes, e historicamente obscurecidas, terem ficado guardadas numa caixa de papelão por quase um século.

Deste modo, é essencial voltarmo-nos para as práticas que delineiam como a coleção do IMS foi ativada em seus específicos desdobramentos de circulação: a recepção das imagens se deu, de modo contundente, fora de seu contexto de produção, assumindo um papel social em outra temporalidade. No início da pesquisa, suspeitava-se que a série teria sido produzida para ajudar a reforçar os discursos contra a imigração. Afinal, se evidenciavam as condições materiais precárias da vida e do trabalho enfrentadas pela população imigrante. Em 1902, o decreto Pinetti proibia a imigração para o Brasil. ${ }^{314}$ Abordagem esta que não somente impunha uma distância com a documentação, já que nada nesse sentido era encontrado, como se percebeu depois, o quanto se incorria num erro metodológico: ter uma idéia prévia do

\footnotetext{
${ }^{314}$ Em 1902, devido a precariedade da vida dos migrantes, se deu a aprovação do Decreto Prinetti, proibindo a imigração subsidiada de italianos para o Brasil, sob a justificativa da existência de "tratamento abusivo" nas áreas de cultivo. O maior grupo de imigrantes vindos para São Paulo, um pouco mais de 1.000 .000 de pessoas, somando $46 \%$ do total entre eles, "os primeiros a chegar à costa brasileira", precisaram de uma lei da terra de origem para sentirem-se um pouco mais protegidos porque além de alojados em senzalas, tinham seus salários atrasados, viviam sob o risco de espancamentos nada incomuns. Após o Decreto Prinetti foi criado em 1906 a Agência de Colonização como mecanismo de se garantir os direitos dos trabalhadores imigrantes. Cf. Love, 1982, p. 113.
} 
“objeto" pesquisado, e depois sair à caça de provas, sem contar é claro da natureza especulativa envolvida nesse procedimento.

Custou certo tempo para se reconhecer a maior especificidade dessa documentação visual: seu status de foto guardada. Caminhos menos nebulosos surgiram depois de se reconhecer que o importante era observar acima de tudo a própria historicidade das imagens, ou melhor, pensar a dimensão das práticas que envolvem o fotográfico. Aforismo generalizante, reduzido ao estereótipo alimentado pelo "tipo" ou apenas a consideração do referente ou do conteúdo visual historicamente relevante na reconstituição das experiências sociais retratadas, não problematizam suficientemente o ato fotográfico de Pastore. A análise para a recepção coloca-se como um problema criado pelo intérprete diante do material visual, que deve estar atento a vida social dos artefatos, aos seus contextos específicos de uso e circulação (Meneses, 2005). Deste modo, o procedimento se desdobra para a década de 1996, momento em que a série, até então em poder da família foi doada, ganhando vida pública, assumindo seus novos desdobramentos como coleção institucionalizada pelo Instituto Moreira Salles. Apenas na última década do século XX, a série ganhou um terreno de apreciação, liberando-se da instância familiar. Surgiram novas percepções sobre Pastore. Afirmava-se um novo lugar social para o fotógrafo como retratista da cidade.

No capítulo seguinte, tentamos compreender os arranjos históricos firmados a partir dessa trama visual levada ao público de forma inédita, revelando o potencial das imagens de se lançarem para o futuro, quando submetidas ao tempo de seus novos agenciamentos. Esse processo de migração das fotos pode ser tensionado porque, quando atualizadas, instituíram discursos representativos do passado, a partir de uma versão dada no presente, em suas novas apropriações que quase sempre levam a transcender a própria referência. 


\title{
Capítulo 5
}

\section{Memória do Ato Fotográfico}

\begin{abstract}
“Objetos são atores na história, não apenas o reflexo da ação, tendo eles próprios um papel em criar aquela mudança que chamamos o processo da história". (Pearce, 1993, p.211)
\end{abstract}

\subsection{Cadeia de historicidade das fotos}

As fotos de Vincenzo Pastore foram anunciadas como uma revelação. Invocava-se à força da memória da "Nossa Gente" quando a série fotográfica foi apresentada ao público, em 1997. Naquele momento, tornavam-se menos um fenômeno dos anos de 1910, data de sua produção. Sua circulação foi documentada, vinculando-se aos desdobramentos existentes ao final da década de 1990.

Iniciamos um caminho de interpretação histórica tentando compreender como as fotos de Pastore foram mobilizadas em seu momento de acomodação posterior, ao serem integradas ao Instituto Moreira Salles. Nesse processo de recontextualização das fotos, novos significados foram produzidos e agregados no tempo e nas práticas de armazenamento subsequientes. As diretrizes teóricas propostas por Meneses (1998, p.91) orientam a análise acerca das ações de ressemantização da coleção adquirida, contribuindo para uma reflexão que se propõe a desarticular as "ilusões de autonomia e naturalidade" aparentes, por vezes forjadas na trajetória de deslocamento das fotos. Trataremos assim da própria natureza conflitiva do documento fotográfico, como bem apontou Edward (1992, p.7): "A fotografia, por sua própria natureza, é do passado. Ainda assim, também é do presente. Preserva um fragmento do passado que é transportado em aparente totalidade ao presente — o 'lá-então' torna-se o 'aqui-agora'".

A problematização que segue por todo esse capítulo ganha corpo com a análise dos circuítos que caracterizam uma cadeia de apropriações: a aquisição, a exposição, a divulgação e a produção de livro e catálogo, bem como as interpretações históricas subsequentes à mostra realizada pelo IMS. É preciso perceber e destacar os sentidos criados e compartilhados em toda a rede que passava a guardar, divulgar, exibir e comercializar as fotos. Uma rede que envolveu diferentes agentes e passou a contar uma faceta de Pastore, conferindo-lhe um lugar social como retratista da cidade. O desafio deste capítulo é compreender como a série e o 
fotógrafo foram legitimados, valorizados e recriados num tempo deslocado do contexto de produção desse material visual posto em análise.

\subsection{A fotografia adentro dos arquivos e Museus}

A série produzida por Pastore é marcada pela mudança do estatuto da fotografia: abandonaram uma prática de colecionismo particular para ocuparem um novo lugar social no IMS, onde passaram a ser mobilizadas como documentos históricos, logo após a doação feita pelo neto do fotógrafo, Flavio Varani. Tratamos de um trânsito de imagens bastante comum ao processo de doação ou compra de coleções.

Os repetidos relatos informam como as fotos ficaram por décadas armazenadas numa caixa de papelão, supostamente de charutos. Susan Pearce rastreia esses caminhos trilhados pelas coleções, que chegam às instituições de guarda, muitas vezes, aos trancos e barrancos:

Coleções de museus incorporam uma parte importante da herança intelectual baseada na disciplina pela qual entendemos o mundo, e transmitem as aspirações dos colecionadores de uma geração para outra, mas têm uma terceira, igualmente significativa, característica que pode ser rotulada como sua natureza museológica. O material de museu não vem em uma forma préembalada, como engradados de feijão cozido que chegam a um supermercado. Muito pelo contrário: o material vem aos trancos e barrancos. Vem em todos os tipos de relações para o progresso da vida humana, inclusive como herança deixada depois da morte (...). (Pearce, 1993, p.120. Tradução Nossa)

A aquisição da coleção Pastore pelo IMS se coadunava com as práticas recentes do colecionismo fotográfico por parte de museus e acervos públicos e privados. As fotografias foram lançadas num circuito de migração de imagens que começava a se constituir de modo mais abrangente. Novas demandas acadêmicas, institucionais, pedagógicas ou motivadas pelo mercado editorial, como mostraram Vania Carvalho e Solange Lima (2000), fundaram um novo estatuto da fotografia. Em seus novos agenciamentos, reforçava-se a função documental do material visual, eleito por seus próprios atributos, para além de sua importância formal e estética. $^{315}$

\footnotetext{
${ }^{315}$ A década de 1980 foi "o marco inicial do reconhecimento da fotografia brasileira como documento". Ver Carvalho, Vânia Carneiro e Lima, Solange Ferraz. Fotografias como objeto de coleção e de conhecimento: por uma relação solidária entre pesquisa e sistema documental. 2000, p.22.
} 
No bojo da valorização da função documental da imagem na década de 1990, a cultura material, mediada também pela fotografia, encontrava novos espaços sociais de legitimação:

O colecionismo fotográfico acabou por caracterizar também uma forma bastante disseminada de sua incorporação aos acervos. Não são raros os exemplos - e entre eles destacam-se dois de suma importância, pela extensão e representatividade: a Coleção Tereza Cristina, depositada na Biblioteca Nacional do Rio de Janeiro e a Coleção Gilberto Ferrez, recentemente adquirida pelo Instituto Moreira Salles. Podemos citar ainda as coleções de retratos de Carlos Eugênio Marcondes de Moura, integrada em 1998 ao Museu Paulista da USP (São Paulo/SP) e a Coleção Francisco Rodrigues, da Fundação Joaquim Nabuco (Recife /PE). Trata-se de coleções particulares e, portanto, organizadas segundo as regras de seus proprietários, que se tornaram públicas ao ser incorporadas institucionalmente. (Carvalho e Lima, 2000, p.20-21)

A presença da fotografia no pensamento arquivístico abria um campo de ideias e métodos de tratamento desde meados de 1950. Aline Lacerda (2008) descreveu o antigo reconhecimento da fotografia como item de coleção e de arquivo, figurando nos oitocentos a entrada da fotografia nos arquivos e museus. Em alguns manuais que integram a bibliografia arquivística a imagem já aparecia como um tipo de documento passível de conceituação, fundada no valor historicamente adquirido como evidência e prova, dado aos apelos da ciência e das disciplinas que tentavam se afirmar também pela prática de observação e acumulação de registros.

Mas esse foi um trânsito circunscrito a um limite mais quantitativo, num âmbito institucional que se caracterizava ora como ação de guarda, ora como depósito legal de acervo. Lacerda pontuou detalhadamente esse processo de formação de núcleos de coleções de fotografias tomadas por diferentes instituições: da Biblioteca Nacional de Paris, à coleção Teresa Cristina da Biblioteca Nacional do Rio de Janeiro. A profusão de investimentos mais qualitativos, ou seja, uma maior preocupação com a entrada e tratamento do documento visual começou de fato a se inscrever no pensamento arquivístico, em meados do século XX. A produção de manuais e textos normativos ou teórico-metodológicos documenta essa preocupação.

Nos anos posteriores a fotografia passou a galgar o seu lugar na hierarquia do capital cultural eleito para simbolizar a vida social. A formação do capital cultural se dá por consenso. Canclini (2011) mostra como é no seio das instituições que se reúnem os bens herdados pela sociedade, bens adquiridos e remetidos a específicos usos sociais, submetidos a determinadas políticas atribuidoras de sentidos e articulações, ações sempre produtoras de 
valor, responsáveis pela transmissão de determinados saberes. Na visão de Canclini a cultura é essencialmente política, ideológica, forjada sob políticas institucionalizadas que definem o que deve ser conservado. ${ }^{316}$

A fotografia, de modo contundente, incluía-se socialmente como um saber e uma prática da cultura, como lugar privilegiado de memória. Ajudando a configurar essa nova virtude do artefato visual, subseqüentes políticas de aquisição e gestos espontâneos de doações rastreiam o crescente papel social da fotografia como documento de arquivo. A coleção de retratos de Militão Augusto de Azevedo é um bom exemplo dessas novas percepções sobre o fotográfico. Na Photographia Americana, estúdio onde Militão atuou por 20 anos, clientes ilustres e anônimos se revezavam em pose diante do fotógrafo. Os retratos do Imperador D. Pedro II, da Imperatriz Teresa Cristina, de Castro Alves, Joaquim Nabuco e de tantos outros renomados, funcionários públicos e políticos, assim como retratos de forros e escravizados, anônimos na maioria, ficaram sob a guarda da família do fotógrafo até 1996, sendo depois adquiridos pelo Museu Paulista da USP. ${ }^{317}$

A valorização de novas fontes e objetos submetidos à preservação museológica, deu luz a novos temas e abordagens, na esteira dos chamados estudos culturais. No campo da história cultural, as fronteiras rígidas entre o social, o político e cultural se diluíam, provocando "uma revalorização do indivíduo na história”, como bem mencionou Angela de Castro Gomes:

A história cultural que, grosso modo, vai sendo proposta a partir desse longo
esforço de reflexão e aprendizado, se quer distinta porque recusa
fundamentalmente a "expulsão" do indivíduo na história, abandonando
quaisquer modelos de corte estruturalista que não valorizem as vivências dos
próprios atores históricos, postulados como sujeitos de suas ações. Ao fazê-
lo, essa história cultural também rejeita as oposições entre coletivo e
individual e entre quantitativo e qualitativo, assumindo um enfoque que
trabalha com ambos os termos, mas que, em função da reação que
representa, inova ao postular a dignidade teórica do individual e a fecunda
metodologia do qualitativo (...) Os conceitos que povoam essa grande e
diversificada área de trabalho vêm de mais de uma disciplina e de vários e
diferentes autores: visão mundo; habitus e campo; estrutura da conjuntura;
circulação de idéias, apropriação cultural; tradição e sociabilidade
intelectuais; experiência, projeto e campo de possibilidade; geração;

316 Seguimos pressupostos de Nestor Canclini para compreender essa categorização. Há uma disputa na configuração hierárquica dessa capital cultural. Arte e artesanato, medicina científica e popular, cultura escrita e oral, são apropriados, se acumulam e se reestruturam com valorização diferenciada. A tomada da fotografia como um bem cultural mostra mais do que representações estáveis ou neutras. Ver Canclini. 2011, p. 195.

${ }^{317}$ Trata-se de mais de mais de 12 mil fotografias, sendo 400 delas identificadas pelo próprio fotógrafo. Cf. Carvalho e Lima, 2005, p. 57. 
trajetória e biografia, entre alguns que se pode destacar. (Gomes, 1997, p.122-123)

O interesse para o cotidiano e para as experiências dos sujeitos históricos atribui um novo lugar para os artefatos visuais. Arquivos particulares/familiares foram valorizados, dada a crescente política de aquisição de coleções por parte de muitas instituições. Segundo Carvalho e Lima, (2000, p.28), cartões postais passaram a ser "considerados como dignos de integrar coleções institucionais".

Essa nova postura historiográfica não pode deixar de ser associada diretamente a "própria materialização" de uma parcela considerável de fontes e dos novos procedimentos institucionalizados: "localizar o arquivo; seduzir o potencial doador; receber e tratar a documentação e salve! Trabalhar em primeiríssima mão com aquele mundo de documentos pessoais nunca antes navegado". ${ }^{318}$ Novos desafios surgem nesse cenário de mudanças que afeta, segundo Lacerda (2008, p.83), a própria natureza e usos dos documentos, dos sistemas de arquivos e de suas funções, bem como a definição de um campo teórico-metodológico contribuindo para a compreensão das novas incorporações.

Essa produção de uma memória social por meio da fotografia findava o antigo prestígio das grandes coleções, dando lugar àqueles sem notoriedade, sem vínculos com a história oficial, num esfacelamento do interesse centrado nas ações das elites antes enaltecidas. Muitos acervos passaram a abrigar coleções, guiados por critérios menos estanques, não mais submetidos a categorias mentais da história oficial, vinculados à história da nação e à valorização de grupos sociais mais destacados por conta do poder ou do dinheiro. Novas escolhas curatoriais, como pontuaram Carvalho e Lima, (2005, p.88), passaram a buscar “conjuntos que possam auxiliar na formação de séries maciças de documentos tipológicos, temáticos ou autorais (por exemplo, séries de retratos fotográficos, de paisagens da cidade de São Paulo, de representações sobre a história do Brasil, etc)".

Novos procedimentos foram guiados pela "convicção de que não existe história verdadeira a não ser a do coletivo", afirma Revel (2000). As novas reformulações da história, ou a inflexão historiográfica como o autor explicou colocou fim ao império do singular, à primazia das fontes oficiais. Novas exigências impuseram a "invenção de novas fontes",

\footnotetext{
${ }^{318}$ Gomes relata nesse artigo a sua experiência como pesquisadora do CPDOC na década de 1970. Cf. Gomes,
} 1997, p. 125. 
acarretando simultaneamente um inevitável ajuste das instituições de guarda frente à expansão da criação de novos objetos de pesquisa.

O processo de incorporação da coleção Pastore se deu no bojo dessas novas incursões do fotográfico e de todo o caminho inaugurado pelas pesquisas históricas, frente às novas possibilidades de se reconstituir o vivido por uma "história vista de baixo", como pronunciou Revel. As novas premissas orientaram a política de aquisição de instituições públicas, fortemente ligadas à produção do conhecimento, enquanto o IMS, uma instituição privada, esforçava-se em participar de tal conjuntura de valorização de fotografias como coleções asseguradas por sua qualidade estética e documental, coleções qualificadas pelo valor dado à autoria, na interface da imagem como registro documental, como mercadoria, como arte.

Nomeamos aqui práticas emergentes dentro de um contexto de crescente valorização da memória, bem como das instituições e espaços que passaram a organizar, divulgar e legitimar a memória social em construção. O estudo de Andreas Huyssen (2000, p.73) ajuda a caracterizar este período, permeado por uma "sensibilidade memorial e museica que arrebatava parcelas cada vez maiores da cultura e da experiência do cotidiano". A difusão de práticas memorialísticas se sustenta, segundo o autor (2000, p.15) desde a década de 1980, dado ao fortalecimento daquilo que o autor nomeia como uma intensa "cultura memorial", dando vistas de uma comercialização crescente e bem-sucedida da memória. ${ }^{319}$ A "cultura memorial", nessa perspectiva, permeia a circulação de fotos do passado, enaltecendo muitas vezes imagens de uma cidade já destruída.

A série de Pastore, após a doação, iniciou uma nova trajetória, promovida nesse contexto de "boom da memória". O fotógrafo, o material visual, a representação da cidade e os sujeitos históricos retratados, faziam-se para a história de modo inédito; suas fotos foram retomadas parcial ou totalmente inquiridas num campo produtor e articulador de discursos, ideias e práticas em torno da fotografia, reconstruída e recontextualizada em seus novos agenciamentos. Assumir uma proposição que tenta dar conta de tais desdobramentos, observando a própria dinâmica do material visual em movimento, parece a mais interessante problematização.

\footnotetext{
319 Huyssen trata da intensa "cultura memorial" promovida no contexto europeu e estadunidense, mas suas reflexões bem se colocam para analisarmos o contexto de apropriação e consumo das fotos de Pastore, ajudando-nos a compreender como as fotos foram mobilizadas.
} 
Compreender como esse material visual foi apropriado e promovido abre horizontes para a análise da recepção-circulação. Trabalhar historicamente com imagens, segundo Meneses (2002), "obriga a percorrer o ciclo completo de sua produção, circulação, consumo e ação", direcionando a análise para as práticas sociais mediadas por imagens, premissa que sustenta esta abordagem histórica.

\subsection{Biografia da doação}

A morte de Elvira Pastore marca a divisão, entre os descendentes, de toda a coleção por ela organizada e selecionada. Ao se documentar como se deu a doação das fotos ao IMS, vêse o rastro da partilha feita entre os filhos e netos de Vincenzo Pastore. A abordagem analítica aqui adotada dá a conhecer a vida social dos objetos, perspectiva cada vez mais importante a um campo interpretativo preocupado em biografar os objetos e suas trajetórias. A nova localização da coleção imprimi certas experiências da coleção, envolta por uma teia de relações entre os descendentes.

Costanza, a filha mais velha do fotógrafo, nascida em 1899, assim como Dante, seu irmão nascido em 1912, ficaram com muitas fotos produzidas em estúdio. O Mosteiro São Bento guarda a coleção deixada por Costanza como herança. Nesta encontram-se apenas registros fotográficos avulsos. Vestígios de cola no verso de algumas reproduções mostram que um dia tais fotos integraram álbuns fotográficos, possivelmente desfeitos no instante da partilha. Maria Lúcia, filha de Dante, zela pelo material guardado por seu pai: fotos de clientes realizadas em estúdio, fotos do estúdio barese, fotos em álbuns de família, o Caderno de Recortes, o diário de Elvira, o Álbum de Recordações com ínumeros documentos e cartas.

Mas foi a filha Leonor, nascida em 1908, quem ficou com as imagens de rua feitas por Pastore, seu pai. Após a morte de Leonor, algumas vezes chamada de Eleonora, como vimos em sua foto publicada na capa da revista $A$ Vida Moderna, um de seus filhos, Flávio Varani, guardou as fotos realizadas nas ruas da capital paulista. José Roberto Varani, irmão de Flávio, casou-se com a prima Maria Lúcia, filha de Dante. Ao lado da esposa zela pela coleção deixada pelo tio.

Flávio Varani, relatou que sua mãe recebeu 137 fotos que não eram "reconhecidas", fotos não comerciais, não realizadas para se "ganhar a vida". Fotos que, segundo Flávio Varani foram reveladas e reproduzidas por Elvira em restos de papel fotográfico, aqueles que 
"sobravam". A esposa de Pastore, mais uma vez desponta como figura central na trajetória do marido.

Esse material, segundo Flávio foi parar "nas minhas mãos", pontuou enfaticamente: “olha a visão que seu avô tinha (...) ele nota a vida das pessoas, quem são elas", dizia o pai de Flávio, marido de Leonor, uma das filhas mais novas de Pastore. Na troca de alguns email, no ano de 2012, Flávio, pianista clássico professor da Universidade de Yale, nos Estados Unidos, mencionou que sabia do valor das imagens que guardava, pontuando as razões da doação.

Os 'snapshots' não foram produzidos para ganhar dinheiro. Ampliados com retalhos de papel fotográfico, em tamanhos variados, por minha avó Elvira, foram vistos pela família como curiosidades artísticas - não sabiam o que significavam. Assim, ficaram com a filha caçula, minha mãe Eleonora, porque não tinham valor. Depois da morte de meus pais, recebi 137 imagens, sem os respectivos negativos. E veio à minha lembrança as falas de meu pai: 'seu avô foi um grande fotógrafo e a grandeza dele foi saber apreciar o povo'. Bem, guardei as imagens numa caixa de charutos, tamanho $30 \mathrm{x} 40$ $\mathrm{cm}$, um umidificador, pois os papéis fotográficos, já muito secos, estavam enrolando. Estava consciente do seu valor, confirmado pelo curador do Departamento de Fotografia da Yale University. Assim, doei-os ao Instituto Moreira Salles para que esta fundação brasileira pudesse melhor acondicioná-los. E, principalmente, ter a oportunidade de trazer o nome de meu avô à tona. ${ }^{320}$

Nessa trajetória da doação da coleção, Flávio Varani inscreve-se como o único doador. Antonio Fernando De Franceschi, na época diretor superintendente do instituto, afirmou ter sido evidente a satisfação com que Flávio fizera a doação. Uma rede de amizade motivada pelo apreço à música clássica e pela paixão pelo piano marcam a aproximação de De Franceschi com o neto de Pastore.

Conheci Flávio Varani através de uma amiga pianista, bastante próxima de Elza Moreira Salles Valim, que havia comentado comigo sobre o fato de FlávioVarani guardar fotos realizadas pelo avô retratando a São Paulo antiga. Em nosso primeiro encontro, Flávio trouxe as fotos em uma caixa de papelão, parecendo ser de sapatos, deixando já nesse momento todas as fotos comigo. O meu imediato interesse não foi menor comparado ao entusiasmo de Carlos Lemos diante das fotos que eu acabara de receber. Assim como Flavio Varani, sabíamos da importância do material que começávamos a adquirir. Gerenciar processos de aquisição de coleções não era tarefa fácil, é difícil conseguir fotos assim. O contato com Flávio foi uma sorte. ${ }^{321}$

\footnotetext{
320 Informação pessoal. Depoimento de Flávio Varani em troca de emails em 2012. O neto de Pastore, respondeu online, algumas questões feitas na nossa única conversa. Infelizmente, não pudemos encontrá-lo no Brasil.

${ }^{321}$ Informação pessoal. Depoimento de Antonio De Francheschi, diretor superintendente do IMS no período da doação da coleção VP.
} 
Em seu relato, De Franceschi reafirmou sua surpresa com a postura de Flávio Varani que, em nenhum momento, tentou negociar ou obter qualquer vantagem ou ganho futuro com a doação: "percebia o quanto era vital para Flávio fazer aquela doação. Era um homem só, que desejava preservar a memória do avô". Percebe-se o quanto o neto do fotógrafo criava o contexto que iria estabelecer e legitimar o vínculo familiar que talvez almejasse alcançar, porque Flávio, assim como Pastore, era também um imigrante, vivendo desde muito cedo, longe de seu país de origem, com pouca aproximação entre seus parentes residentes no Brasil.

Se por um lado, documenta-se o empenho de Flávio em doar e preservar as fotos que guardava, outras dimensões envolvem a narrativa visual criada por Pastore, por onde perpessa uma rede mais ampla. A carta escrita por José Roberto Varani, irmão de Flávio, também neto de Pastore, indicia memórias em disputa, nuançando o quanto a trajetória da série fotográfica se constitui por meio de relações que, segundo Meneses (1998, p.96), lhe dá suporte nesse trânsito de coleção particular para coleção institucionalizada, deixando patente o "caráter de interlocução, de ato em que está em jogo a subjetividade em diálogo".

Em fevereiro de 1997, na semana seguinte da inauguração da exposição "São Paulo de Vincenzo Pastore", organizada pelo IMS, a revista Veja São Paulo publicou na sessão "A Opinião do Leitor", a referida carta, trazendo o incomodo de seu autor. Segundo o neto do fotógrafo, a reportagem "Nossa Gente", não havia citado seu nome e seus esforços em também preservar a memória do avô, como havia feito seu irmão Flávio Varani, o doador da coleção. Para José Roberto a revista teria "involuntariamente" reduzido à zero seu trabalho, assim como dos demais familiares, que "amorosa e cuidadosamente" haviam igualmente guardado documentos que mantinham por décadas. ${ }^{322}$

A carta anunciava o desapontamento: “A magnânima e louvável contribuição de Flávio Varani ao doar as fotos não deve e não pode fazer crer que somente ele reconheceu e valorizou a arte de nosso avô". Nota-se como a retórica construída por meio do artefato em seu desdobramento não encobre a sua natureza simbiótica: apesar de se tornar pública a coleção seguia reivindicada pelos familiares, desvelando a complexa teia que a constitui.

Vê-se como a experiência na fabricação da imagem, e também de seus sentidos mobilizados, se estende num processo prolongado, envolvendo múltiplos sujeitos e

\footnotetext{
${ }^{322}$ Em sua carta José Roberto Varani ressalta o trabalho desenvolvido ao lado do pesquisador Ricardo Mendes, ao longo de dois anos, analisando fotos, traduzindo documentos e realizando entrevistas com diferentes descendentes de Pastore. Entrevistas que foram de grande valor para essa tese. Revista Veja São Paulo. Sessão Opinião do Leitor. Fevereiro/1997, p. 105.
} 
apropriações que marcam a materialidade. O material visual produzido por Pastore tem, na sua dimensão de foto guardada pela família, uma importância da qual seus descendentes não abrem mão em participar. Em Pastore nota-se como sentimentos e expectativas acompanham a trajetória das fotos atravessadas por uma apreciação individual, familiar, repleta de disputas dos diversos agentes envolvidos no seu processo de circulação.

\subsection{Organicidade da coleção doada}

Coleção quatro. Esse é o lugar das imagens feitas por Vincenzo Pastore no acervo iconográfico do Instituto Moreira Salles. No total são cento e trinta e sete imagens. Desconsiderando algumas repetições, soma-se um total de cento e dezessete; dentre essas, setenta e três compõem a série feita nas ruas da capital paulista.

A doação da coleção feita pelo neto do fotógrafo, impactou aqueles que trabalhavam no acervo de fotografia. A curadoria rapidamente formada via a coleção como um elo capaz de unir o século XIX ao XX. Foram esses os termos de sua invenção no novo ambiente de integração: para o instituto o mecanismo técnico da foto instantânea, um domínio do homem sobre o objeto e sobre o tempo remetiam às conquistas do século XX; por outro lado, o conteúdo visual, vinculava-se ao registro etnográfico, às fotografias de vistas, às fotos de tipos de rua, um repertório visual, ligado a um período que a antecedia. Foram esses os três elementos icônicos, ligados ao conteúdo das imagens que passaram a nortear a subdivisão temática do conjunto das fotos adquiridas, revelando o início de um viés interpretativo e de uma prática discursiva sobre o fotográfico, ${ }^{323}$ claramente tratado a partir de seu referente indicial.

Uma primeira noção conceitual de coleção na prática arquivística tem como significado uma "reunião artificial de documentos", sem arranjos prévios determinados. Apesar da inconsistência de tais arranjos, muitas vezes aleatórios, uma coleção, nessa perspectiva, depois de submetida a uma política institucional, torna-se parte de um acervo que reúne um conjunto de coleções. Obrigatoriamente ganham então uma organicidade, facilitando o seu

323 O fotográfico pode ser entendido como um conceito epistemológico para se compreender a fotografia como fato social, mediada pelo objeto que envolve todos sujeitos, práticas discursivas e processos na dinâmica de sua produção, tanto quanto nos espaços discursivos onde são posteriormente operacionalizados como documento histórico, como arte, como produto da cultura. Ver Krauss, Rosalind. O Fotográfico. Barcelona: Editora Gustavo Gili. 2013. 
entendimento. ${ }^{324} \mathrm{O}$ primeiro status de coleção das fotos de Pastore se deu em âmbito familiar. A preservação da memória de Pastore e o valor da ascendência, sempre presente no momento da doação, somaram-se ao reconhecimento artístico e histórico de todo o material visual guardado pela família. Reconhecimento que abriu caminho para a sua acomodação como coleção institucionalizada.

As observações de Susan Pearce ajudam a nortear o campo teórico escolhido:

A realização de uma coleção é uma maneira na qual organizamos nossa relação com o mundo físico externo, do qual coleções são uma parte. A formação das coleções é parte da relação entre o sujeito, concebido como cada ser humano individual, e o objeto, concebido como o mundo inteiro, material e que de outra maneira se encontra fora dele ou dela. Coleções são elementos significativos em nossa tentativa de construir o mundo e, portanto, o esforço para compreendê-las é uma forma de explorar nossa relação com o mundo. (Pearce, 1993, p.37. Tradução Nossa)

A natureza das coleções no IMS está associada à identidade pessoal dos artistas, noção enraizada na formação de todo acervo dessa instituição. As coleções estão diretamente associadas aos seus autores. A noção de autoria permeia toda a organização do acervo. Nesse espaço discursivo, produtor de ideias, Pastore surgia como o autor das fotografias inéditas da cidade paulistana, aspecto que dava legitimidade a aquisição. A intenção do IMS de se colocar como guardião da memória visual da cidade, forjava um lugar social para o fotógrafo/artista, bem como para o próprio instituto.

O início da constituição das coleções de fotografia de São Paulo do IMS se deu em 1995, atrelada a uma política incipiente de aquisição de imagens, denotando o quanto as coleções resultam de um processo de seleção. A interface entre o processo de escolha e rejeição se estende tanto na etapa de formação de uma coleção particular e individual, quanto em sua transformação formalmente privada para pública, como defende Pearce.

O IMS não tinha ainda um setor de fotografia definido. O Caderno de Literatura, produzido semestralmente, centralizava as atenções da instituição, fato que se modificou com a chegada da primeira coleção, Mestres Fotográficos do século XIX, adquirida de Pedro Correia do Lago, reunindo 2.500 importantes fontes visuais sobre o período. A ordem de chegada constituiu a hierarquia do material visual incorporado ao acervo. A segunda coleção englobava lotes, portfólios, pequenas coleções ou mesmo itens fotográficos individuais,

\footnotetext{
${ }^{324}$ Ver Almeida, Ana Maria de. e Bellotto, Heloísa Liberalli. Dicionário de terminologia arquivística. 1996, p. 5 17. Apud. Carvalho, Vania Carneiro e Lima, Solange Ferraz. Cultura Material e coleção em um museu de história: as formas espontâneas de transcendência do privado. Artigo, p. 89.
} 
conjunto constituído de forma continuada. Atualmente conta com 72 ítens, adquiridos entre 1995 e 2013. A coleção com os 44 negativos de registros de São Paulo feitos por Levi-Strauss foi a terceira aquisição. As 137 fotografias de Pastore passaram a compor a quarta coleção. ${ }^{325}$

Tais arranjos traçam o perfil da política de aquisição do acervo. A cidade se fazia como o principal viés semântico norteador da organicidade das coleções, dando unicidade e regendo o processo de aquisições de fotografias consideradas como documentais. ${ }^{326}$ Havia, desse modo, uma instância de valorização da cultura como meta do IMS, acabando por difundir ideais de progresso, de urbanização, extrapolando intenções sócio-estéticas comuns nas políticas de galerias de arte.

Inscrevem-se os dois diferentes espaços percorridos inicialmente pela série: primeiro no espaço físico do instituto em seu acervo de guarda e preservação mais especificamente, localizado na sede do Rio de Janeiro e, depois, exibida no Espaço Higienópolis, em São Paulo, onde o instituto promove mostras e exibições de suas coleções, espaço que pode ser entendido no circuito das galerias, já que promovem também a possibilidade de compra de fotos.

A cidade como tema central marcou o enfoque que criava os "vínculos arquivísticos" entre as coleções do acervo, estruturando um "valor utilitário-posterior", ou seja, conferia-se às imagens um valor documental, primeiro de modo mais abrangente, como mostra Lacerda (2011), ao se valorizar as informações registradas nos seus suportes, inicialmente portadores de um "valor utilitário-original". Depois, estiveram submetidas a ações e transações de ordem burocrática, social, cultural e econômica, rastreando uma polissemia de práticas amalgamadas na produção de sentidos forjados nos arranjos institucionalizados.

As aquisições do instituto foram realizadas na maioria por meio de compra. A coleção Pastore foi uma das poucas incorporadas ao acervo por doação, importante aquisição não somente devido ao ineditismo das imagens, mas por se tratar de um material visual perfeitamente adequado ao perfil idealizado: os diálogos estabelecidos entre as diferentes coleções voltadas para a memória urbana marcaram o sentido cultural deste acervo.

\footnotetext{
325 Tinham ainda, materiais avulsos recebidos tratando-se, algumas vezes, de uma única fotografia. De um conjunto inicial de 2.600 imagens, o acervo completou o ano de 2007 com o total de 450 mil registros fotográficos, somando hoje 550 mil aproximadamente. Somam no total 45 fotógrafos e coleções. ${ }^{326}$ Entrevista realizada em novembro de 2013, com Odette Vieira, Coordenadora Executiva de Apoio.
} 


\subsection{A coleção VP}

A coleção Pastore está dividida em dois diferentes lotes: o primeiro com identificação geral dada como lote e coleção 004, adquirida no dia 28 de agosto, de 1996, referindo-se à série de fotografias feitas nas ruas, doadas por Flávio Varani. Esse lote apresenta duas indicações: o número do lote foi articulado ao número da foto, portanto, a primeira fotografia é identificada como 004VP001. O segundo, lote 004a, foi doado por José Roberto Varani, irmão de Flávio, em 22 de março, em 2006, dez anos depois da primeira doação, referente a uma pequena produção de retratos e foto-montagens, incluindo auto-retratos, realizados no estúdio do fotógrafo, somando 11 imagens, diretamente associadas à primeira doação. O total da coleção Pastore, incluindo os dois lotes, passou a somar então 148 imagens.

É importante frisar como os diferentes lotes formaram um único conjunto, respeitandose a proveniência de cada doação. O respeito à "noção da origem" do material visual foi um dos atributos iniciais na identificação feita no momento de catalogação da coleção adquirida. ${ }^{327}$ Ao se pontuar os diferentes momentos de aquisição, não se romperam os vínculos com seus respectivos doadores. Flávio e José Roberto Varani, netos do fotógrafo, constituíram assim uma rede de guarda precedente.

No processo de arquivamento das imagens, Lacerda (1993, p.41-55) reafirmou a necessidade de se manter o sentido do conjunto documental, que está inevitavelmente relacionado aos responsáveis pela acumulação. Preservar aquilo que Lacerda chama de respeito à proveniência, é de fato historicizar o artefato. Carvalho e Lima (2005, p.88) também destacaram como esse processo assume um "significado social de que é investido o ato de doar". Conseguimos perceber como a doação do segundo lote intuía completar a biografia de Pastore. Um dos descendentes tentou demonstrar a qualidade do fotógrafo realizando retratos no estúdio. A doação de auto-retratos e fotomontagens reforçava diferentes circuitos de atuação de Pastore. Reverenciar a sua memória motivou os elos estabelecidos com o tempo e com o constante gesto de guardar: "a intenção de homenagear pode ser observada em inúmeras doações", afirmam as autoras.

No processo de identificação e descrição das imagens as formas de catalogação empregaram categorias de informações consideradas como modelo: criação de código do documento, autor, título ou legenda, local, indicação de provável datação e descrição das

\footnotetext{
${ }^{327}$ Sobre os métodos de catalogação e apropriação de fotos por parte dos acervos que devem respeitar origem do material visual Cf. Abreu, Regina 1994, p. 225.
} 
condições materiais de cada imagem. Verificamos a mesma preocupação em se obter informações relativas ao conteúdo visual, aos assuntos de cada registro. Articulava-se, desse modo, os termos de indexação que garantem a recuperação inicial dos documentos em um sistema de informação que viabiliza o acesso à pesquisa (Lacerda, 1993).

As imagens foram classificadas com o processo de gelatina prata, em fotos $\mathrm{P} \& \mathrm{~B}$. Apenas um dos registros feitos do rio Tamanduateí, antes das obras de retificação, foi identificado como goma bicromatada/pigmento. Os retratos realizados no estúdio eram produções em albumina, obtidos com a fermentação da clara de ovo, prática comum no século XIX, que perdurou até as décadas iniciais do século XX. Fotos que foram depois entregues ao instituto, avulsas e soltas, sem ordenação prévia.

O primeiro passo dado após o recebimento das fotografias foi observar se algo comprometia o material. Apesar da falta de ordenação ou numeração não organizada pelo próprio fotógrafo, é notório o fato de Pastore ter ampliado um número considerável de imagens, em dimensões pequenas, o que para os responsáveis pelo acervo, pode sugerir que se tratava de imagens contato, no jargão fotográfico, entendidas como simples provas para a escolha de futuras reproduções em maiores dimensões.

O IMS adquiriu apenas cópias positivas em papel, com total ausência de negativos, situação corriqueira quando se trata de arquivos pessoais, mesmo tratando-se de um fotógrafo profissional. Esses primeiros suportes de fixação das imagens nunca foram encontrados. Temse assim "os elementos de transposição" destituídos de sua matriz, o que não os inviabiliza de "serem considerados itens originais e autênticos num arquivo", defende Lacerda (1993). Hierarquizar a matriz desqualificando a cópia implicaria em comprometer a própria viabilização do trabalho arquivístico-histórico, que busca múltiplos indícios de observação da documentação. Nenhuma interferência nas cópias em papel como suporte em molduras ou em papel cartão, ou algum tipo de resíduo como aplicação de cola para fixar retratos em álbuns foi encontrada, o que poderia indicar possíveis usos e funções dessas imagens ao longo da sua história.

$\mathrm{Na}$ ficha catalográfica o primeiro campo foi designado como coleção VP, classificação dada seguindo a abreviatura do nome do autor, identificação para a entrada da coleção no acervo. Na sequência da apropriação, deu-se início à etapa de conservação preventiva do material visual, com ações específicas, sem grandes inferências diretas, tentando-se evitar ações de deteriorização dos objetos. Foi realizada, de acordo com Virgínia Albertini, 
coordenadora assistente do acervo fotográfico do IMS, no Rio de Janeiro, uma higienização superficial, com pincel soprador e pó de borracha no verso. Cópias fotográficas foram produzidas, indiciando o trabalho permanente ou contratado de fotógrafos à serviço das instituições de guarda, responsáveis pela criação de "matrizes de segurança" produzidas a partir das ampliações positivadas. Depois as fotos reproduzidas por Pastore foram acondicionadas em caixas de portfólios, em embalagens de guardas denominadas jaquetas que, trata-se de cartão suporte rígido envelopado com poliéster, material isolante que ajuda a retardar as ações do clima, além de garantir um futuro manuseamento e acessibilidade sem causar danos ao material. Esse acondicionamento de guarda adequada, tenta evitar fatores ambientais causadores de danos. Com as condições gerais estabilizadas, as imagens encontram-se atualmente em salas climatizadas. Tratar de tal procedimento ajuda a configurar o início de um processo de agenciamento sobre as imagens, inscrevendo a memória dessas ações de preservação, um dos motes que legitimavam tais incorporações.

A natureza da coleção VP permitia uma apropriação tida como "mais livre", segundo Albertini, por se tratar, para o instituto, de um conjunto mais sucinto. ${ }^{328}$ A série foi submetida a um ordenamento temático, não pré-existente: as cenas de ruas mais abrangentes foram apreendidas como vistas, sendo as primeiras numeradas; os recortes mais individualizados ou em planos médios foram tratados como retratos e, na sequência, o material produzido em estúdio. Esse método de catalogação tentava manter a lógica interna da coleção adquirida. Tal procedimento evidencia uma preocupação do instituto de não incorrer no erro de uma remontagem abstrata ou arbitrária, comprometendo o processo de recontextualização do objeto.

Há cada vez mais o enriquecimento de um campo teórico-metodológico que orienta e propõe diretrizes nesse processo de tomada e aquisição do material visual adquirido pelas diversas instituições:

Ao curador compete em primeiro lugar reconhecer legitimidade da coleção e o seu potencial para o conhecimento da sociedade, seu fim último. Em seu lugar, diferentemente do colecionador particular, que está preso ao objeto plástico, ao curador compete constituir a biografia do objeto da coleção, recuperando seu circuito e nele, os contextos perdidos. Em terceiro lugar, o curador precisa ter claro que os seus próprios critérios de seleção e montagem de coleções têm na sua base valores culturais. (Carvalho e Lima, 2000, p. 19)

\footnotetext{
${ }^{328}$ Entrevista realizada em novembro de 2013, com a Virginia Albertini, coordenadora assistente do Acervo Fotográfico do IMS.
} 
Nesse novo universo institucional não foi imposta à coleção Pastore uma coerência que não estivesse presente na própria dinâmica de todo o conjunto doado. $\mathrm{O}$ processo de classificação resultou numa sistematização da coleção, dando-lhe a princípio uma numeração justificada como ordenadora. Toda a catalogação da numeração e ordenação foi tarefa incumbida à Albertitni, responsável pela curadoria das coleções.

Temos um propósito inicial de formar um inventário visual reconhecendo a organicidade original da coleção recebida, relacionando todos os objetos, implementando um trabalho de identificação. Estabelecemos uma codificação provisória num processo não apenas de quantificação, mas de compreensão dos arranjos originais, as vezes por temas ou cronologias. Codificações preliminares tornam-se posteriormente definitivas. Outras etapas referem-se à higienização e à reprodução, inicialmente em baixa resolução para se poder trabalhar as imagens, depois digitalizadas em alta. Após a catalogação se cumpre o papel inicial do instituto: o da preservação. Depois vem a etapa de difusão, com a produção do catálogo e do site. ${ }^{329}$

Quando se vê a articulação da tomada da coleção com o propósito curatorial de se formar um inventário, fica claro que se trata de um investimento num tipo de instrumentalização que associa a coleção ao universo mais amplo de pesquisa. Inventários, guias e criação de catálogos, apresentados como critério institucional, viabilizam a possibilidade de produção de conhecimento. Inventariar e produzir matérias de divulgação são agenciamentos produtores de instrumentos de pesquisa, pré- requisitos, segundo Lima e Carvalho (2000, p.17), para a viabilização de acesso a documentos institucionais, promovendo-se o domínio público.

A preocupação com a preservação pontuada ao fim do relato acima, elucida o próprio papel social de muitos acervos e museus, bem como subscreve as funções que cumprem a coleção. Sobre essas ações e responsabilidades, "só recentemente as atividades de documentação e pesquisa, imprescindíveis no tratamento de coleções, ganharam relevância" Lima e Carvalho (2000, p.25). O papel social dos museus não é algo dado em si mesmo, é socialmente construído. As novas demandas de pesquisa e acesso passaram a exigir novas posturas no tratamento dos documentos recebidos pelas instituições de guarda que se adaptam à valorização da cultura material como importante campo de estudos. Novas práticas, problemas e fontes delimitam esse complexo campo de relações de profissionais e instituições, de pesquisas e conhecimento.

${ }^{329}$ Entrevista realizada em novembro de 2013 com Virgínia Albertini. 
Para participar da realização do inventário visual da coleção Pastore, Ricardo Mendes, na época responsável pelo acervo iconográfico do Centro Cultural Vergueiro, foi convidado a responder pela pesquisa como consultor responsável pela documentação contextual, colaborando com a descrição de cada imagem, devido à demanda do grau de pesquisa exigido. Vê-se uma prática de contratação de especialistas responsáveis pela curadoria histórica que se ateve, no processo de descrição das imagens, ao conteúdo informativo factual voltado para a identificação de todos os logradouros, por associação com outras referências visuais, afirma Mendes. ${ }^{330}$

Vale dizer que Mendes já havia realizado anteriormente algumas entrevistas com alguns descendentes de Pastore, interessado em documentar a atuação de fotógrafos retratistas na cidade. O Centro Cultural São Paulo, instituição onde Mendes atuava na época, mantinha um programa permanente de entrevista e coleta de depoimentos de descendentes e profissionais aposentados, ligados à prática fotográfica, independentemente de projetos. Após o convite para participar da contextualização da coleção no IMS, Mendes recorreu a outros descendentes, para complementar os relatos antes obtidos. Foram ouvidos o filho caçula do fotógrafo, Dante Pastore, a filha mais velha, Costanza, e o neto José Roberto Varani. ${ }^{331}$

A partir deste agenciamento institucional, a datação da produção das imagens ficou estabelecida entre os anos de 1908 e 1914. Trata-se de descrições de fundo genérico, não interessadas nos aspectos morfológicos das imagens criadas. A atenção ao aspecto descritivo constitui uma das vertentes do pensamento arquivístico que manifestava um enfoque essencialmente dirigido ao conteúdo visual, num procedimento, como informa Aline Lacerda (2011), muito enraizado pelas diretrizes adotadas no tratamento de fontes textuais, reproduzidas na criação dos documentos visuais de arquivo.

Instala-se nesse processo uma tensão significante. Tal procedimento reforça mais o caráter de documento fotográfico, e menos como documento de arquivo, que exigiria uma compreensão das razões de existência desse documento, assim como uma maior problematização das práticas e meios de produção, dos procedimentos que envolvem sua gênese, entendendo-se o contexto de origem e a própria natureza do material visual. Lacerda lançou luz à questão:

(...) hoje quase onipresentes nos conjuntos documentais de qualquer tipo, os registros fotográficos não têm suscitado muita especulação por parte dos

\footnotetext{
330 Entrevista realizada com Ricardo Mendes em abril de 2013 no Arquivo Municipal de São Paulo.

${ }^{331}$ As entrevistas com Costanza e Dante Pastore foram realizadas após o contato com o IMS.
} 
arquivistas, que na maior parte dos casos reproduzem técnicas de tratamento desses registros já consagradas por outra disciplina, a biblioteconomia, e que, sem os devidos questionamentos, acabam por perpetuar uma abordagem desses materiais na maior parte das vezes equivocadas. Com isso, tem perdido a oportunidade de desenvolver um pensamento próprio sobre a fotografia como documento, tema privilegiadamente de seu interesse. Essa abordagem equivocada, consubstanciada no tratamento isolado de cada fotografia tendo em vista extrair apenas seu valor informativo, ligado aos fatores visuais que representa, alimenta um círculo vicioso que culmina com a naturalização dessas fontes, por parte dos pesquisadores em geral, no sentido de as considerarem os melhores registros capazes de veicular de forma mais "fiel" uma realidade exterior a eles. Documentos descontextualizados, assim como fontes descontextualizadas, devem se constituir num problema de primeira ordem a arquivistas, historiadores e pesquisadores em geral no desenvolvimento de seu trabalho. (Lacerda, 2008, p. 78)

O esforço de Lacerda coloca como vital a reconstituição das formas e conteúdos, mas também da gênese e do percurso do documento fotográfico, que não é apenas um registro de uma realidade exterior, mas produto de relações sociais, da qual, não pode ser desvinculado quando submetido ao ambiente arquivístico. ${ }^{332}$ Ao IMS se pode atribuir uma compreensão mais expandida de museu, de arquivo, porque a instituição se coloca como um espaço de guarda de memória. Deste modo, lhe são estendidas também as mesmas instâncias conceituais aplicadas a este campo de interesse.

O modo de tratamento subdividindo a série por temáticas, numa abordagem quase puramente descritiva, definida pela especificidade da informação imediata, exclusivo ao conteúdo visual, pode ser explicado pelo ineditismo das imagens de Pastore, sem contar da ausência de fontes e pesquisas sobre o fotógrafo. O desejo confesso de levá-las ao público o quanto antes, ou melhor, a tempo das comemorações do aniversário da cidade, foi um fator relevante quando se observa a pouca contextualização alcançada. A contingência do uso nos faz retomar mais uma vez Lacerda:

Embora possam veicular conteúdos os mais diversos, os documentos imagéticos de arquivo são criados por uma vontade, para um objetivo, por meio da transmissão de uma mensagem, visando alcançar um público ou destinatário, assim como qualquer documento textual mais tradicional. (Lacerda, 2011, p.151)

\footnotetext{
${ }^{332} \mathrm{~A}$ autora recorre ao campo conceitual da Diplomática que oferece ferramentas teórico-metodológicas úteis ao tratamento dos documentos fotográficos, mesmo que tenham uma natureza distinta dos textos oficiais, jurídicos e administrativos os quais foram especificamente formulados. Para Lacerda a aplicabilidade de tais conceitos pode aprofundar a reflexão arquivística no tratamento dos registros visuais porque forçariam o estabelecimento com as conexões relativas ao contexto de produção dos artefatos. Cf. Lacerda, 2008.
} 
As ações de Mendes se inscrevem num escopo de uma "série de tarefas" que para Carvalho e Lima (2000, p.21) devem perseguir a constituição de uma coleção tais como “descrição, pesquisa contextual e bibliográfica, entrevistas, sempre de uma perspectiva remissiva que permita estabelecer ligações ou colocar em confronto diversos documentos". A tentativa de se formalizar o trabalho de identificação do conjunto fotográfico adquirido, ampliou o potencial das imagens de Pastore como fonte de pesquisa, mostrando como uma das práticas prioritárias na formulação de uma documentação adequadamente instrumentalizada é resultado de um conjunto de atividades solidárias, definidoras de toda prática curatorial envolvida neste processo de construção de significados das imagens, defendeu Lacerda (2011).

A coleção foi compreendida e articulada com a participação de Carlos A. C. Lemos, responsável pelo trabalho de curadoria geral, feito, como se vê, em parceria. A realização dos painéis, das ampliações e das reproduções fotográficas ficou sob encargo de Sergio Burgi, funcionário do instituto. Ao observarmos essa prática articulada entre profissionais de diferentes áreas de atuação, não se pode deixar de perceber como a prática curatorial, que envolve múltiplos articuladores, está dialeticamente entrelaçada com a produção de discursos, atrelada a outras disciplinas, ampliando as fronteiras entre os diferentes campos do conhecimento. Nessa perspectiva, não são apenas pessoas de diferentes áreas trabalhando em conjunto, mas sim, distintas práticas de mediação de determinados agentes que atravessam o espaço do instituto, arregimentados para elaborarem em conjunto questões que seriam, em seguida, ativadas para a compreensão e difusão da série.

Lemos mobilizava o interesse para a Coleção VP ao tratá-la como "verdadeiro tesouro", reforçando o seu eminente valor histórico. São esses aspectos que iriam acompanhar toda a etapa de divulgação da série. A tarefa de observar, articular e apresentar a coleção quatro, ou como ele chamava o "tesouro" adquirido, que é sempre aquilo que herdamos também como parte do nosso imaginário, não deixou de demonstrar a noção nuançada por Susan Pearce:

A gênese de nossa relação emocional com objetos de experiências infantis pode ser, mas como nossas vidas seguimos objetos, especialmente aqueles moldados pela arte, são capazes de carregar um simbolismo mais profundo. A ideia de tesouro corresponde aos antecessores de coleções modernas e a cultura museológicas. (Pearce, 1993, p. 47) 
QuickImage Records Page 1

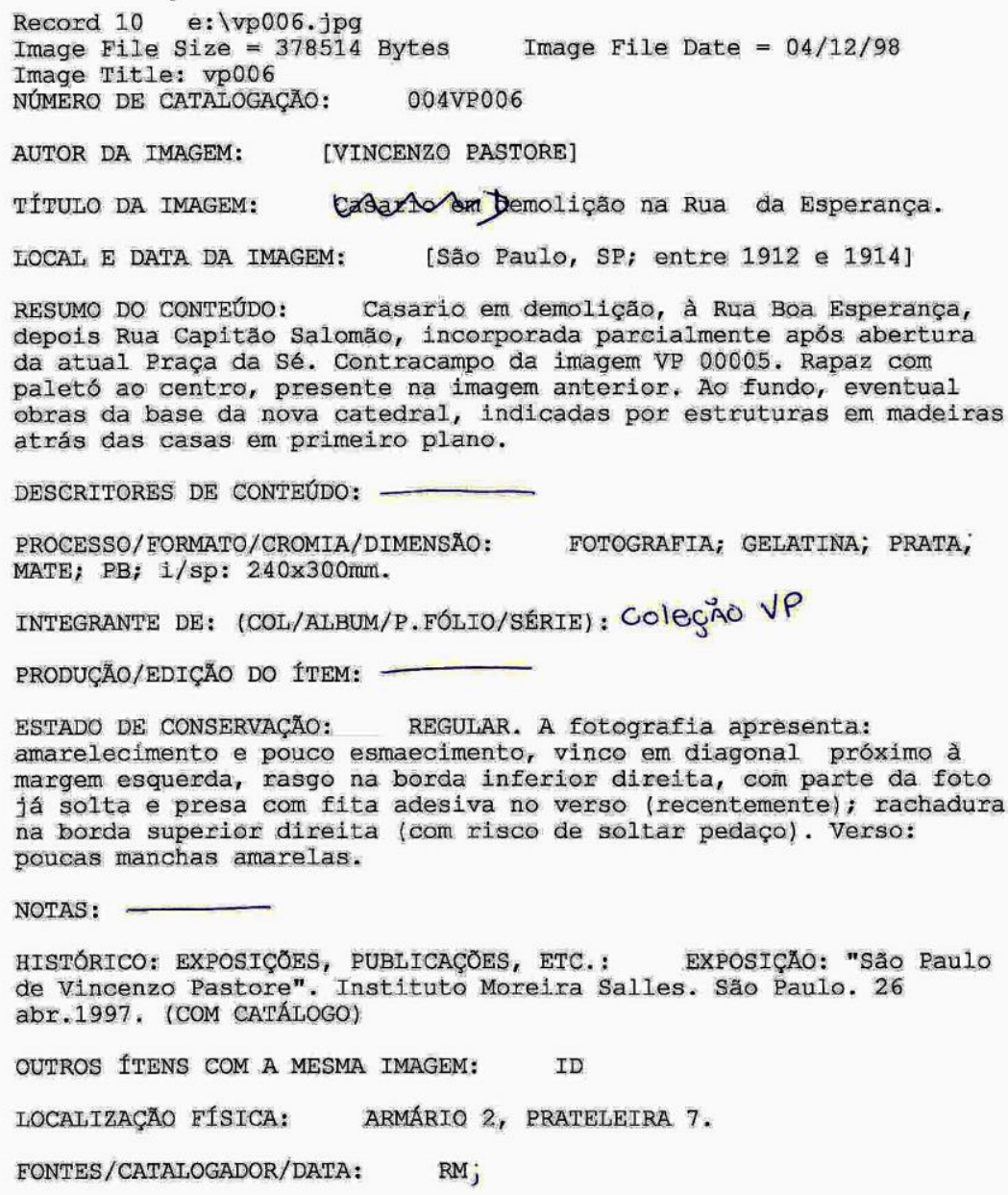

Figura 254: Reprodução de ficha técnica da imagem VP006. Página 01. IMS.

Observar a ficha de descrição/catalogação (fig.254) e de acompanhamento técnico (fig.255) nos auxilia na compreensão de outra etapa do processo de apropriação da coleção, reconstituindo-se dimensões da historicidade das fotos. Pontuamos uma das ações de conservação: o levantamento de diagnósticos. As fotos, quando incorporadas como acervo, foram observadas verificando-se as condições do material, avaliando-se possíveis perdas por deteriorações. De modo geral, o estado das fotografias foi assim descrito: referia-se à 
oxidação, amarelecimento, espelhamento, rachaduras, pequenas manchas, existência de bordas irregulares, as vezes esmaecidas, com vincos ou pequenos rasgos. Surpreende olhar as imagens no original e verificar o quanto mantêm a integridade do conteúdo retratado e do papel com seus tons preservados.

FICHA DE ACOMPANHAMENTO TÉCNICO

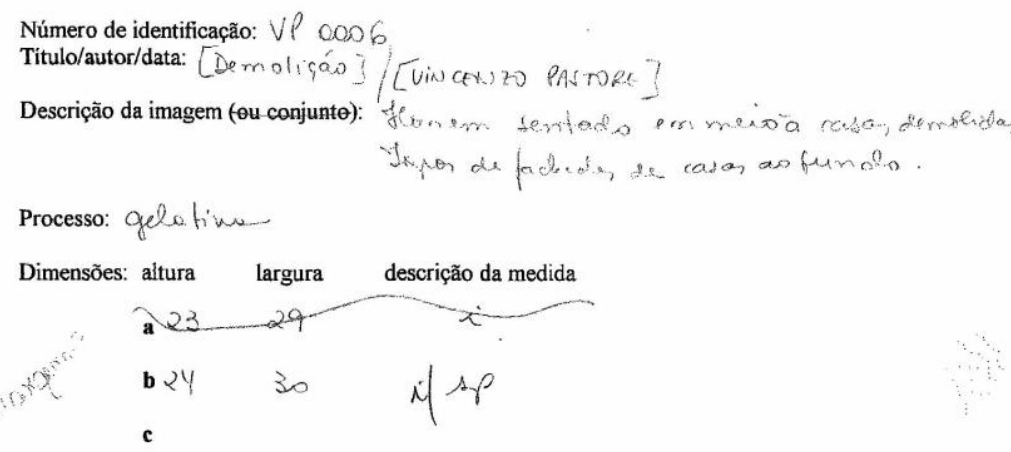

Descrição das características de deterioração:

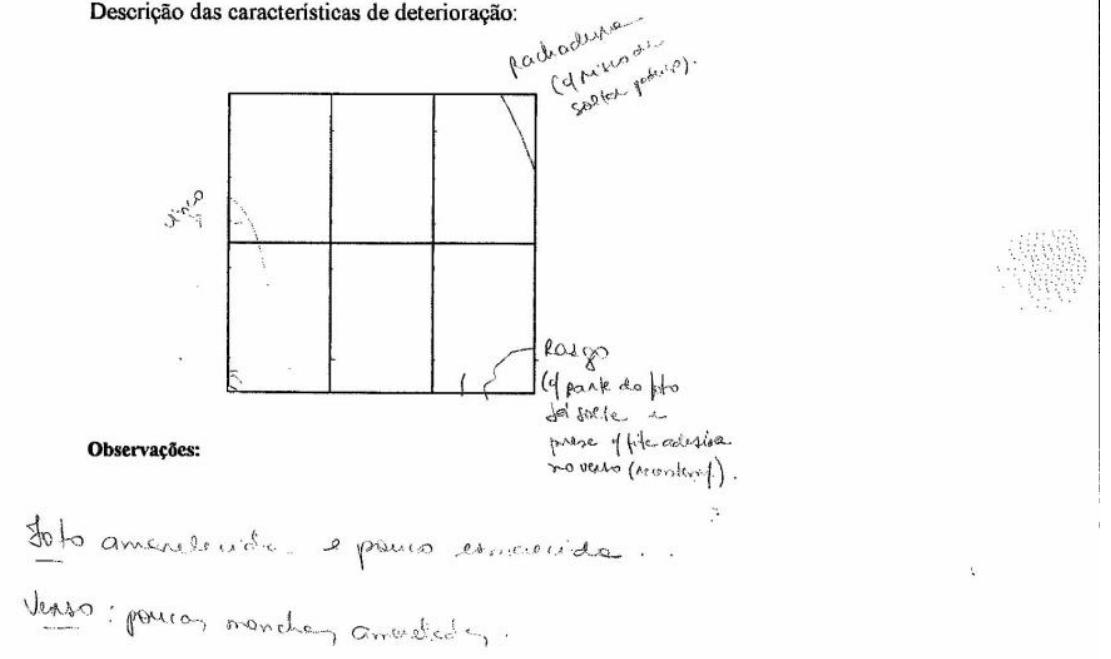

Figura 255: Reprodução de acompanhamento ficha técnica da imagem VP0006 com descrição e indicação das características de deteriorização . IMS.

As descrições de espelhamento e amarelecimento são sinais da existência de camadas de gelatina e prata, constituindo a materialidade que conseguiu sobreviver. A ficha técnica mostra como cada fotografia recebeu um título, uma numeração específica, uma descrição dos 
processos e dimensões fotográficas, um resumo de seu conteúdo visual e de seu estado de conservação. Observar a elaboração deste documento ajudou a aferir como, dentro das estruturas institucionais, a fotografia foi entendida mais na sua materialidade, não apenas como linguagem. A indicação das fichas de descrição das características de deteriorização, não assume aqui um procedimento metodológico para ressaltar os aspectos de conservação e preservação adotados. Ao contrário. Apresentar este procedimento técnico ajuda a historicizar a primeira etapa de apropriação, delimitando o tratamento dado a cada suporte material de modo individualizado. É a trajetória material do documento fotográfico posta em relevo.

Esse procedimento apontado deve ser visto como datado. Segundo Virgínia Albertini a ficha manuscrita, apresentada acima, retoma os tempos idos da aquisição da coleção, uma ficha "quase vintage". Hoje as fotografias de Pastore assumem a sua forma também imaterial, nas redes do mundo virtual, como vemos abaixo (fig.256).

Atualmente, trabalhamos com o banco de imagens Cumulus.

A ficha técnica - individual - usada atualmente contempla 51 campos (em anexo), com informações sobre: procedência e autoria, conteúdo da imagem, fontes da informação (fonte primária e/ou atribuições), descrição do objeto fotográfico, diagnóstico e tratamento do objeto fotográfico, informações sobre original/reprodução, histórico de uso da imagem, e informações sobre o catalogador.

As informações sobre estado de conservação, diagnóstico e tratamento são preenchidas pela restauradora do IMS, que em paralelo elabora o laudo técnico individual, de acordo com o tratamento previsto e executado.

Além da relação dos campos, segue também em anexo a reprodução de uma ficha técnica completa do Cumulus, disponibilizada apenas para pesquisadores presenciais (no site do IMS são disponibilizados apenas 14 campos).

Alguns campos foram incorporados à ficha posteriormente ao preenchimento dos dados da Coleção V.P, portanto ainda estão em branco ou preenchidos de forma diferente do que a atual (por exemplo: a pequena biografia do fotógrafo deveria estar no campo Sobre o Autor, e não mais no campo de Notas). ${ }^{333}$

Os novos aparatos tecnológicos utilizados documentam o desenvolvimento e a trajetória do próprio acervo que posteriormente, em seu processo de gestão das imagens, formou seu acervo digital. Esse novo instrumental deu origem ao banco de imagens institucional. O IMS criou um catálogo eletrônico tornando disponível, via site do instituto, parte da coleção VP. Ferramenta que dá visibilidade a todas as coleções adquiridas. Tais meios digitais oferecem a possibilidade de se comparar imagens, disponibilizando-as para um grande número de

333 Informação Pessoal. Depoimento de Virgínia Maria Albertini, Coordenadora-assistente do Acervo Fotográfico do IMS. 
pessoas, facilitando, por um lado, o acesso ao fotógrafo, tornando-se uma ferramenta de auxilio à pesquisa e, por outro, constituindo-se como uma ferramenta de divulgação do próprio instituto.

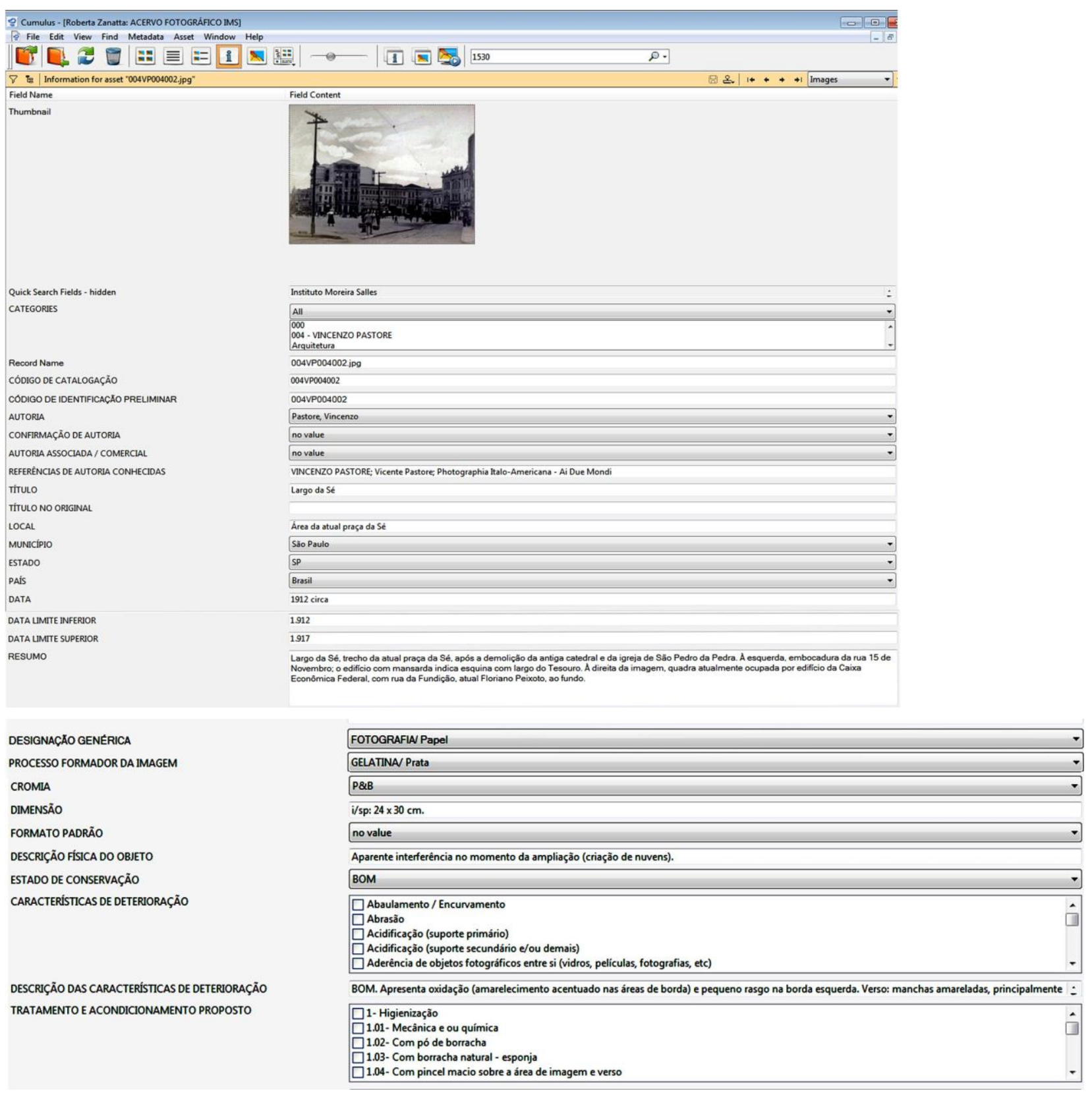

Figura 256: Reprodução da parte superior e inferior da ficha técnica informatizada com descrições, códigos de catalogação e com características de deteriorização. Instituto Moreira Salles.

Notamos, contudo, uma diferença do total do conjunto da coleção com aquele disponibilizado na web. No site estavam disponíveis apenas sessenta imagens da coleção VP. Número reduzido, lembrando que a coleção apresenta 146 no total. Segundo o IMS, as fotos online foram selecionadas seguindo o mesmo material visual publicado no catálogo e livro. $\mathrm{O}$ 
instituto considerou, após questionarmos as razões dessa diferença, que seria necessário rever essa postura, levando ao público o restante da coleção. A interface entre pesquisa e as instituições de guarda revela os meandros de um diálogo e de uma contribuição recíproca.

Trata-se de uma tecnologia de informação em permanente construção. A pesquisadora Cynthia Scott defende o quanto em tal relação, o conhecimento é sempre compartilhado por diferentes profissionais que contribuem no desenvolvimento de um campo cada vez mais expandido chamado de "computing age". As barreiras entre a produção do conhecimento e a preservação são rompidas: "linking knowledge creation and preservation, with knowledge sharing". Publicações, produtos e exibições não formam mais as únicas atividades da manipulação da informação sobre as coleções institucionais. As novas tecnologias formam novas esferas de atividade, segundo Scott, importantes ferramentas de informação que exigem "more creative collaboration between information managers, collections specialists, researchers, and educators" (Scott, 1999, p.75-78).

No acervo digitalizado cada fotografia segue acompanhada de suas descrições, identificando logradouros e oferecendo ao usuário alguns atributos formais do documento visual, tais como tamanho da ampliação e tipo de papel. No banco digital, vê-se categorias de informação tidas como modelo de descrição de imagens, oferecendo aos usuários o código do documento, autor, título, legenda, local, data e descrição física do documento.

Como as fotografias foram entregues avulsas, não existindo um suporte original, não tendo sido fixadas em álbuns, por exemplo, a apresentação ao público, nesse circuito digital, não havia como comprometer a compreensão da totalidade do conjunto, dada a inexistência de elementos antes agregadores ou norteadores de sentidos mais problematizadores do material visual. Contudo, algumas informações mais precisas indicadas na citação abaixo, não estão disponíveis no modelo descritor do site, apenas encontradas quando a pesquisa se realiza na rede de sistema interno do instituto, portanto, não disponível na web:

RESUMO: Cena de procissão na Rua Direita, realizada provavelmente a partir do edifício, onde se localizava o estúdio do fotógrafo, no número 24$\mathrm{A}$, em direção à rua São Bento. Notar, no primeiro plano à direita, detalhe do mostruário de fotos de Pastore, com seus "retratos mimosos", formato por ele criado para colar os retratos que produzia. Descrição das características de deterioração: Bom. Apresenta oxidação (amarelecimento).

Lacerda (1993) aponta que esse procedimento de se formar um texto legenda que acompanhe a unidade fotográfica é prática imprescindível para se considerar a imagem como fonte informacional ou documental. Existe uma ampla bibliografia que mostra como o 
procedimento puramente descritivo reforça a "busca da imagem única, ilustrativa, escolhida para complementar reflexões, produzidas à revelia daquilo que a própria imagem, como documento, pode nos oferecer". Tal perspectiva apontou a necessidade de se pensar a natureza visual "naquilo que ela tem de específico", aspecto que sublinha, para Carvalho e Lima (2005, p.98), o compromisso institucional com a investigação científica.

Para isso, seria preciso fugir de abordagens visuais generalizantes e tomar o documento como um artefato. Seus atributos formais tais como "morfologia, cor, textura, dimensões, arranjo, matérias-primas, etc., aos quais são atribuídos significados sociais" devem ser acompanhados na montagem do banco de dados, atrelados a problemas históricos definidos. A partir dessa perspectiva, o alargamento de tais funções contribui para um banco de imagens voltado para a pesquisa, marcando uma nova maneira de problematizar o documento visual, reconhecendo a sua dimensão polissêmica, em toda a sua complexidade.

Desvencilhar as imagens de seus conteúdos, colocando-as dentro de um campo reflexivo maior, que vá além de descrições do referente retratado, rompe com a concepção fortemente naturalizada da fotografia como janela para o mundo, para o real distante e perdido. Visão que escamoteia e negligencia a importância dos aspectos formais da imagem, e da sua dimensão social como "representação pictórica de longa duração", repleta de sistemas simbólicos, culturais, "relevantes para os estudos do imaginário social” (Idem). Define-se em tal crítica dirigida a abordagens unicamente preocupadas com os mecanismos descritores de indexação de imagens mais tradicionais, o papel das instituições e dos acervos digitais levados ao público.

Não consta ainda, na ferramenta digital que disponibiliza as imagens de Pastore, uma apresentação de informações sobre a expressão de cada uma delas, o que enriqueceria o sistema de informação do artefato:

\footnotetext{
Essa expressão seria a forma como uma imagem é mostrada, estando ligada a uma linguagem que lhe é própria e que envolve a técnica específica empregada, a angulação, o enquadramento, a luminosidade, o tempo de exposição, entre outros. Essas três dimensões do registro fotográfico conteúdo, expressão e forma - é que constroem, em última instância, a mensagem que informa. (Lacerda, 1993, p. 41-55)
}

Aspectos da composição de cada fotografia devem ser problematizados nos bancos de imagens. As características formais, apontadas no capítulo 3, que rastreiam a inclinação de Pastore para o pictorialismo, são alguns atributos pertinentes a essa questão. A constituição da "gramática visual" deve ser interpelada junto aos instrumentos descritivos e atributos formais 
identificados, formando indexadores de sentidos mais amplos, múltiplos. A exigência de novos padrões de visualidade incorporados às perspectivas históricas dos documentos, definem as bases de um campo voltado para o artefato, seus suportes e significados, entendose a produção de sentidos e as práticas sociais que constituem o material visual que deve ser problematizado, levando-se em conta seus aspectos formais e seu conteúdo, indissociáveis em sua compreensão.

A ausência de uma análise que vá alem do conteúdo evidente da imagem pode ser explicada, para Chen Hsin-Liangchen e Ediem Rasmussen (1996) pela "natureza subjetiva da interpretação", o que acaba provocando uma "falta de consistência" nos formatos indexadores mais tradicionais, disponibilizados de modo generalizado. As fotografias são facilmente incorporadas em sistemas de visualização, mas com reduzida profundidade de informações. Uma coleção verdadeiramente acessível deve oferecer aos usuários níveis mais profundos de significação, já que a imagem, entendida também como linguagem, é atravessada por sua historicidade. Temos aqui autores que defendem a interlocução entre os agenciadores das coleções e os usuários, pesquisadores que precisam expor as suas necessidades de informações. Os sistemas de recuperação e acesso devem se consolidar, a partir desses pressupostos, que visam um "ambiente de recuperação ideal”, por meio de uma prática de relações conjuntas, interdisciplinares, de colaboração mútua, empenhados na formação de sistemas com maiores níveis de complexidades de buscas.

Carvalho e Lima tensionam ainda mais a questão já que defendem ser preciso compreender as "qualidades formais que são mobilizadas para a produção de sentidos" (2005, p.104). Desenha-se o interesse pela imagem como prática social. Ferramentas instrumentais voltadas para a pesquisa, em instituições que se colocam diante desse compromisso, devem ser mobilizadas superando-se buscas automáticas, desconstruindo modos tradicionais de se conceber o documento visual: “é fundamental a constituição de tipologias gestuais e cenográficas para o estudo da pose no retrato de estúdio, ou de tipologias composicionais e temáticas no caso de imagens de cidade".

Visto sob este prisma, à Coleção VP, disponível no site do IMS, falta ainda um procedimento analítico que contemple a especificidade da imagem e de todo um repertório de sentidos que constituem a coleção, entendida desde o início de sua aquisição como um importante vetor na iconografia urbana. O campo teórico brevemente nuançado acena para o desenvolvimento de modelos analíticos ou cognitivos mais aperfeiçoados. 
Através desse suporte virtual de informação, cria-se um campo de circulação para as imagens que deve apresentar nesse ambiente informatizado, uma aproximação solidária articulando acervos e usos acadêmicos, pedagógicos e culturais, como definem Lima e Carvalho:

\begin{abstract}
A consulta eletrônica sobre uma determinada coleção, fotográfica poderia fornecer não só o histórico e dados específicos de cada uma de suas unidades, mas também referências sobre os usos que dela se fez após a sua integração ao acervo institucional. Indicações de pesquisas sobre temas e coleções correlatas, quadros contextuais, biográficos e técnicos seriam também imprescindíveis para a constituição de um sistema documental produtivo. (Carvalho e Lima, 2000 p.29).
\end{abstract}

De modo geral, nuançamos até aqui os primeiros desafios inerentes às práticas museológicas e arquivísticas quando agenciam os materiais que adquirem. São esses desdobramentos que seguem num contínuo, exigindo uma observação que considere como o material visual do passado somente será adequadamente interpretado quando considerada a sua recriação, formadora de um novo material visual, um novo documento, epistemologicamente complexo, polissêmico, dado as cadeias de apropriação que o tomam por completo.

Depois de cumprida a etapa da preservação e ordenação era preciso levar a coleção VP ao circuito das exposições, cumprindo-se o percurso comum da transferência de coleção do campo privado ao público. Iremos sondar a seguir como as fotos foram mobilizadas quando transferidas para a sua primeira etapa de difusão: a divulgação espontânea, realizada em jornais e revistas que noticiaram a exposição "São Paulo de Vincenzo Pastore".

\title{
5.6 Rastros de um acontecimento: a divulgação
}

A doação ao IMS marcou o início de um processo de migração das imagens. A coleção adquirida e submetida a uma política institucional, foi depois lançada em novos circuitos: a galeria Espaço Higienópolis. A análise neste momento volta-se para a divulgação da exposição, revelando uma nova vocação da série e do próprio fotógrafo, reinventado nesse cenário de difusão.

A intersecção entre galeria e meios de comunicação se coloca como um importante vetor de difusão a ser observado. Novos agenciamentos se inscrevem. Os discursos criados sobre Pastore, no âmbito institucionalizado foram diretamente transferidos para os textos jornalísticos que apresentavam Pastore ao público. Notamos o quanto os múltiplos agentes 
desse processo de difusão da série, dividiram os mesmos códigos em trânsito. O instituto enviou como press release à imprensa o mesmo texto publicado no catálogo da exposição. $\mathrm{O}$ texto, o qual a curadoria respondia, ressaltava o caráter de ineditismo da série fotográfica, bem como a capacidade da fotografia de Pastore de revelar o passado da cidade, aspectos que atravessam todos os textos divulgados na mídia impressa.

Em janeiro de 1997, a revista Veja São Paulo, apresentava Pastore recorrendo às citações e trechos redigidos por Mendes, ou seja, da curadoria do instituto: "Nenhum outro fotógrafo, pelo menos até os anos 30 havia voltado suas lentes para a gente comum da cidade". Às "cenas banais" eternizadas foram atribuídos os sentidos de revelar "os trajes e até os ritmos de vida dos paulistanos de então". O olhar inédito sobre a vida da metrópole foi acentuado com empolgação nas duas esferas de apropriação da série, tanto na proposta curatorial quanto na divulgação espontânea subseqüente.

Trataremos, nesse momento, de uma ordem de comunicação que atrelou fotos e texto jornalísticos, já que a série produzida teve em seus desdobramentos a interdependência entre estas diferentes linguagens justapostas. Observar as operações de produção, circulação e consumo de sentido nas diferentes etapas de tomadas das fotos possibilitou um aprofundamento na compreensão deste repertório visual remontado, rearticulado.

\subsubsection{Pastore recriado na Revista Veja São Paulo: memórias em disputa}

O texto de divulgação da exposição organizada pelo IMS na revista Veja São Paulo, reforçou o mito de uma cidade branca, imigrante, de descendência europeia, premissa também reiterada na escolha das fotos. Sentidos apontados antes pela curadoria:

Graças a uma delas, que registra pessoas navegando em pequenas canoas os historiadores sabem agora, por exemplo, que o Rio Tamanduateí foi uma via de transporte. "Nunca ninguém tinha escrito algo a respeito", garante Carlos Lemos, professor da Faculdade de Arquitetura e Urbanismo da USP. "São descobertas importantes de uma época em que a cidade passava por uma expansão sem precedentes, impulsionado principalmente pela imigração", afirma. (Revista Veja São Paulo. 29 de janeiro de 1997, p. 20-21)

A disposição da página dupla priorizou a apresentação das imagens impressas separadamente e não sobrepostas, aspecto visto em toda etapa de divulgação (fig.257). As sete fotos selecionadas nesta edição traziam cenas tidas como "flagrantes" do cotidiano: meninos engraxates próximos a zona de mercados da Rua 25 de Março, o carregador de malas da 
estação da luz lendo jornais, as mulheres vendeiras, o carregador de vassouras, crianças brincando no jardim da luz. No texto, a mais festejada entre elas foi a fotografia das canoas, ocupando, contudo, a página à esquerda, na parte inferior.

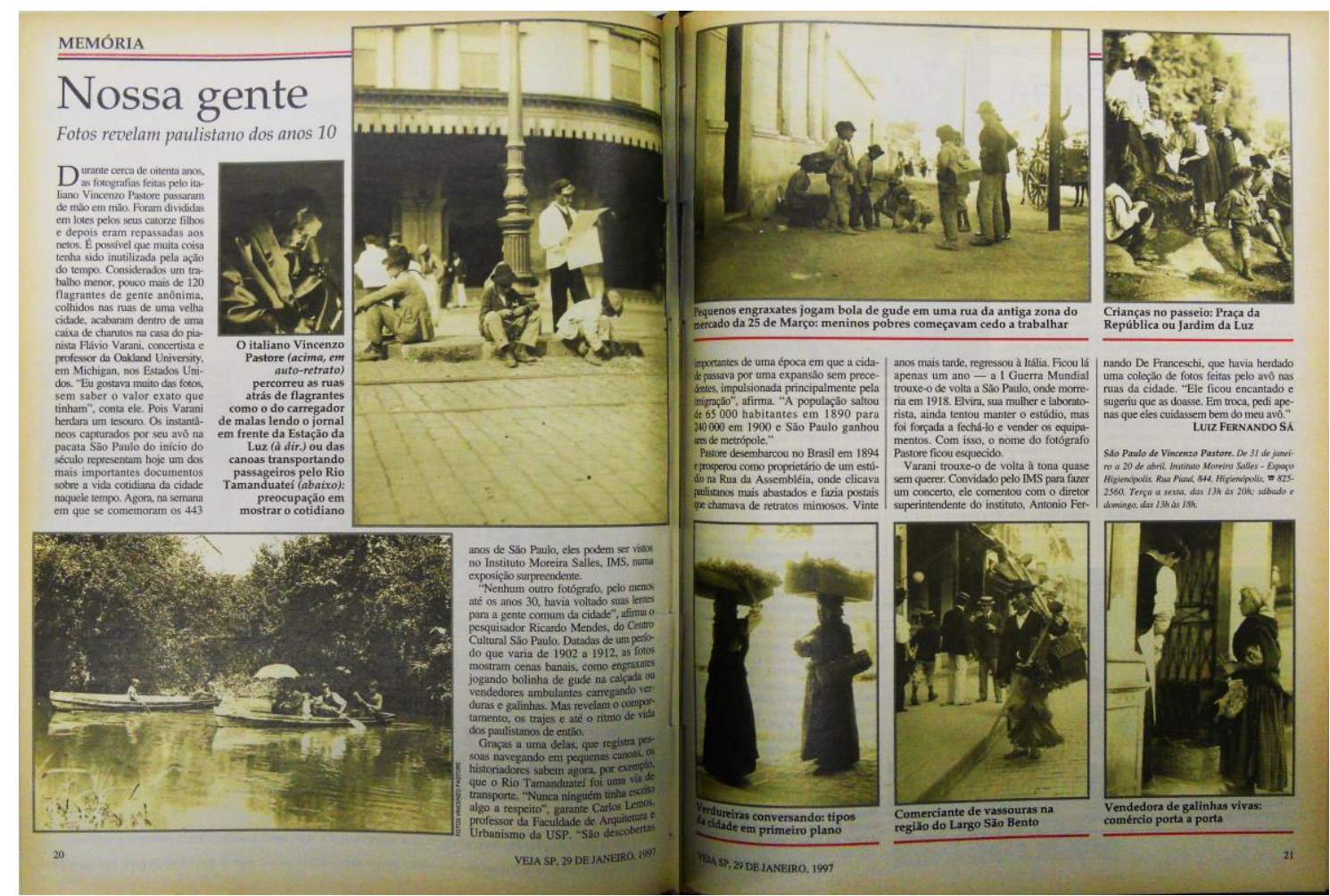

Figura 257: Reprodução de páginas da Revista Veja São Paulo. Janeiro/fevereiro de 1997. Biblioteca Mario de Andrade.

A revista ao criar uma dinâmica entre texto e imagens, organizados no espaço da página dupla, tentou sublinhar o ineditismo de uma das fotos, aquela que representava o rio Tamanduateí, usado como via fluvial. Evidencia-se uma expressão de clara valorização de um espaço de circulação de pessoas e mercadorias por meio da seguinte afirmação: "nunca ninguém tinha escrito algo a respeito (...) São descobertas importantes de uma época em que a cidade passava por uma expansão sem precedentes". Esse texto de divulgação recorreu ao depoimento do curador Carlos Lemos que afirmara a ideia de que Pastore trazia algo novo, desconhecido: o uso desse rio como via de transporte e circulação de pessoas, como se tal fato, não tivesse sido antes documentado em Atas da Câmara, apontado nas descrições de viajantes, documentado em jornais da época, ou ainda em relatos de muitos memorialistas.

Quando se observa a historiografia sobre a cidade de São Paulo, o ineditismo sugerido por Lemos e depois reiterado na revista, lentamente se dilui. Muitos estudos já haviam mostrado a importância dessas águas, onde se realizava, ao longo do século XIX, um intenso 
transporte de mercadorias. Antes das obras de retificação, no Beco das Barbas ao pé da Ladeira Porto Geral, canoas circulavam repletas de produtos de abastecimento e atracavam no pequeno porto que atendia a demanda de transporte de produtos vindos das roças dos ribeirinhos do Tamanduateí ou do Tietê. A foto de Pastore dava visibilidade a um uso bastante conhecido e sondado pela historiografia da cidade.

Leis municipais rastreiam sociabilidades que chamaram a atenção de Pastore. A partir de 1909 foi preciso criar políticas interligando a Vila Leopoldina à Vila dos Remédios. A lei municipal n. 1186 estabelecendo o uso da balsa no rio Tietê, verba que corria como "despesas imprevistas", indica as implicações necessárias na organização dessa circulação de mercadorias e da gente que ocupava cada vez mais os extremos da cidade..$^{334}$

Ao reforçarem o caráter de ineditismo das fotos, vê-se como a fotografia, em seus diferentes processos de apropriação, será sempre e inevitavelmente um "objeto deslocado", fruto de uma experiência compartilhada por todos. Vemos como a narrativa fotográfica é mediada pelo presente e pelas questões que, segundo Baxandall (1986), são colocadas posteriormente às obras. Passado e presente constituem as compreensões então produzidas.

A diagramação da página analisada deu prioridade ao visual, mantendo os efeitos formais associativos entre texto e imagem, que se relacionaram por complementação, interrelação delineada nas considerações propostas por Anne-Marie Christin (2011). Seu artigo integra a obra que reúne análises de diferentes autores, interessados pela inter-relação entre imagens e textos publicados em livros ilustrados, suportes socialmente já consolidados como uma importante forma de expressão por todo seu conjunto. Acreditamos ser possível estabelecer relações entre os conceitos apresentados pela autora e os procedimentos adotados pela revista Veja São Paulo, que tanto explorou a interdependência entre palavras e imagens em seu projeto de editoração. ${ }^{335}$

Os significados expressos textualmente na revista preenchiam lacunas; o texto ganhava um tom explicativo. A narrativa fotográfica de Pastore foi ali textualmente articulada com percepções sociais enaltecedoras da cidade, apresentando dados demográficos que indicavam

\footnotetext{
${ }^{334}$ Cf. CMSP. Conselho de Vereadores. Caixa 48. Fevereiro de 1909.

335 A autora questiona a categoria da interdependência entre palavra e imagem nos livros ilustrados, defendendo que cada livro assume um tipo diferenciado de relação. Ao tratar das funções das imagens, de delimitação, revelação e complementação, chama atenção para as interações formais produzidas a partir das mensagens linguísticas e visuais, nos empresta interessantes análises para pensarmos as relações entre as imagens de Pastore e os discursos estabelecidos na divulgação de sua série fotográfica. Cf. Christin. Texto $e$ Imagens. In: Van Der Linden, Sophie, 2011, p.91.
} 
sua expansão. A vocação para o trabalho vivificava o estereótipo: "meninos pobres começavam cedo a trabalhar", informava a legenda da foto dos pequenos engraxates; o contingente imigrante explicava o inchaço da cidade. Nota-se como nas "fotos que revelam os paulistanos dos anos 10", houve a intenção de esconder ou omitir imagens da população negra. Na constituição da "memória da nossa gente", título da reportagem, publicada no dia 29 de janeiro de 1997, percebe-se como a imagem do negro, importante na série, foi obliterada sem ressalvas.

Fica claro, no processo de tomada e divulgação das imagens de Pastore, o quanto o investimento sobre uma coleção é resultado de uma escolha. Reconstituir a memória de uma cidade imigrante, vocacionada para o trabalho expressam os significados celebrados. Nesse processo de recontextualização das fotos, vê-se um modo estanque de se entender a cidade. A descrição pontuou "flagrantes da gente anônima, colhidos nas ruas de uma velha cidade". Descortinam-se alguns sentidos mobilizados por meio das fotos: o passado foi celebrado porque havia sido superado pelo novo.

É nítido o esforço do texto em revelar a importância documental das representações do cotidiano da cidade, ou como diria Barthes (1980, p.148), reforçar a "força de evidencia" que possuem. Tratava-se, segundo a revista, de um tesouro herdado pelo neto do fotógrafo, assim como pontuava a curadoria. Quando se afirmou no corpo do texto que os "historiadores sabem agora", parece claro o sentido de verossimilhança atribuído à imagem, valorizada pelo sentido de testemunho conferido. O texto deliberadamente reforçava a idéia comum da fotografia como "analogon perfeito" do real, procedimento tido como reducionista para Barthes (1990, p.14). Vê-se aqui a sedução provocada pela aparente realidade. Elisabeth Edward alertou sobre tais riscos: "Fotografias são elas próprios históricas (...) a circunscrição cultural que capacitou uma imagem, e determinou e validou o momento fotográfico, expressa pelo menos uma parcialidade cultural, uma concepção do que é fotografável” (1992, p.6-7). A imagem na articulação da revista Veja São Paulo equivalia ao seu referente. A realidade foi dada como um dado imediato, inevitavelmente, aderida ao conteúdo da imagem.

Nessa etapa de divulgação da Coleção VP, vê-se o equívoco apontado por Ivan Gaskell (1992, p.241), contundente em sua crítica aos procedimentos mais antigos de interpretações acostumadas a deixar as imagens "trancadas em seu período", quando tomadas de maneira ilustrativa. $\mathrm{O}$ texto articulado na reportagem incorre numa significação que considerava a fotografia como "um meio transparente de transmissão de informação". O valor atribuído 
nesse texto de divulgação trata a fotografia como registro automático do mundo, desconsiderando aquilo que Gaskell soube pontuar:

Talvez só possamos sempre conhecer a arte do presente, parte da qual é o que sobrevive do passado, proporcionando o acesso mais tênue e incerto àquele passado. $\mathrm{O}$ significado do material visual se modifica; as interpretações diferem através dos limites cronológicos e culturais: aqueles que conhecemos só podem ser sempre aqueles que nós próprios geramos. (Gaskell, 1992, p. 264)

Ao se reforçar apenas o signo indicial, que tanto acompanha as noções sobre o fotográfico, perde-se o rastro da própria trajetória do material visual. Veremos a seguir como certas visões que tomam a imagem apenas como ilustrações, com noções pouco problematizadoras do fotográfico, acompanharam todo o processo de divulgação espontânea das fotos.

\subsubsection{Pastore recriado no jornal Folha de S.Paulo: Apego à signos conhecidos}

O jornal Folha de S.Paulo optou pela tradição do registro panorâmico, reforçando a literalidade do material visual para dar vistas da expansão vivenciada pela capital paulista. A foto panorâmica tornou-se historicamente suporte para a representação da cidade moderna, sentido rearticulado nessa mobilização que destacava a imagem na parte superior da página do jornal. No entanto, percebemos inicialmente uma contradição. O subtítulo ao centro da página destacava o inusitado "de uma época em que rebanhos de ovelhas pastavam no centro da cidade", aspecto também escolhido na abertura da matéria. A única imagem apresentada ao meio receptor, ou seja, ao público leitor, não foi, por sua vez, a baixada do Glicério, em seu aspecto pastoril na Várzea do Carmo. A fotografia escolhida voltava-se para a região central, priorizando claramente o registro da cidade como palco de inúmeras transformações urbanísticas (fig.258). Texto e foto aqui não se complementam.

Apesar da relação de contradição entre texto (ao assinalar a presença de ovelhas pastando nos arredores do centro) e imagem (panorama da cidade) percebe-se como não se ignoraram totalmente. A fotografia panorâmica, a única escolhida para apresentar a coleção VP ganhou relevo, como informa o texto, porque revelaria "o ritmo acelerado de mudanças que a cidade enfrentava nesse período". Foi esse o senso explicativo recorrente em todo o processo de apreciação e divulgação da série, direcionando a leitura do meio receptor. A foto panorâmica publicada reforçava uma escolha por signos conhecidos, que sempre têm como 
menciona Barthes, "uma força tranquilizadora: o homem ama os signos e os quer claros, evidentes" (1990, p.23).

A valorização da imagem de contextualização urbana ${ }^{336}$ sustenta-se na recusa da representação que remetia à permanência de aspectos rurais na paisagem urbana, já que não alimentava o imaginário do progresso que acompanha a iconografia da cidade, apresentandose, aos discursos forjados pela mídia impressa, como pouco útil aos comuns mecanismos de fetichização da cidade. O discurso curatorial e os textos de divulgação, na perspectiva crítica de Meneses (1999, p.15) confluíram para uma mesma tendência: a "memória, tanto como prática como representação está viva e atuante entre nós".

\section{São Paulo como a cidade era}

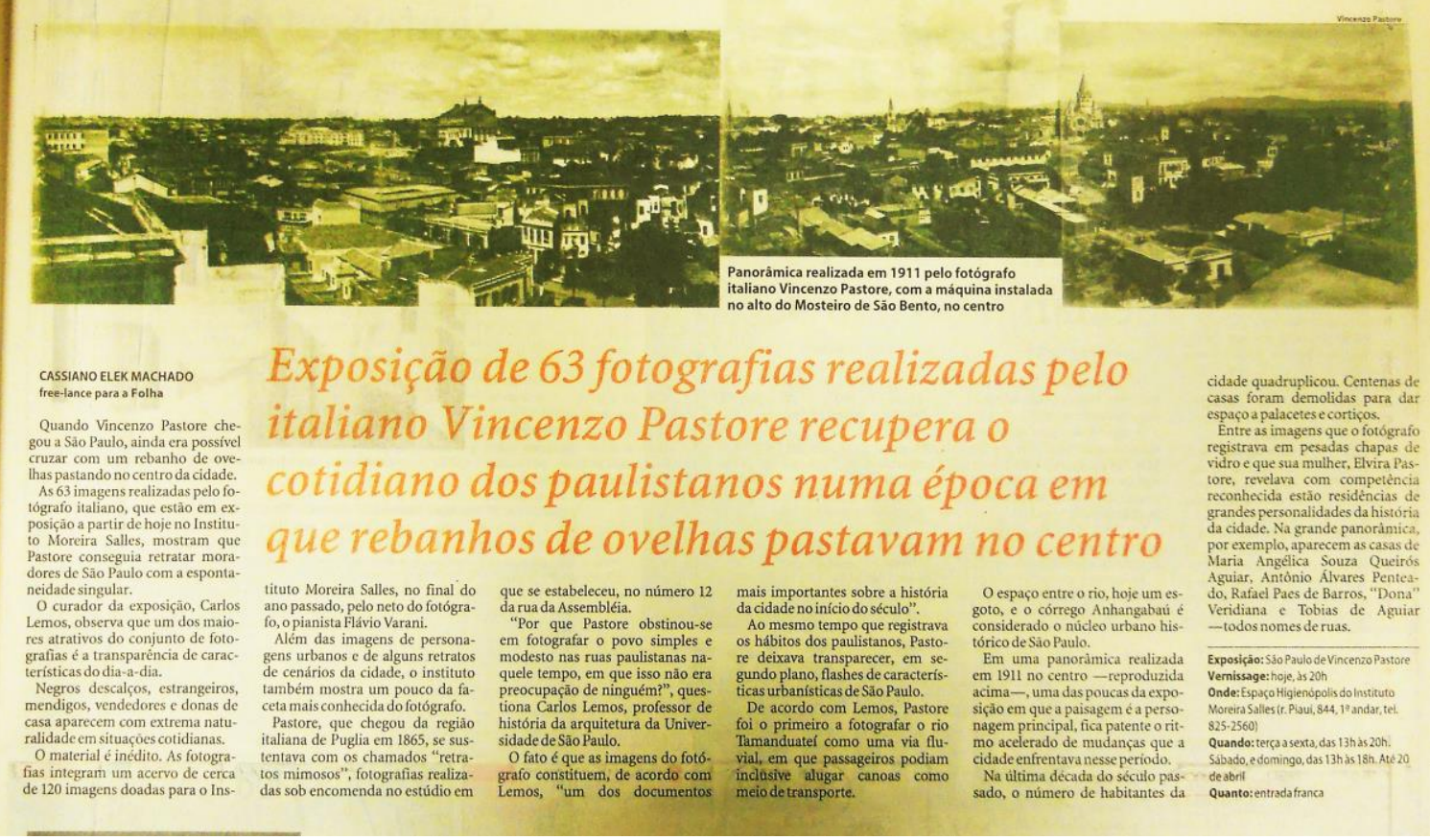

Figura 258: Reprodução Jornal Folha de S.Paulo, dia 29 de fevereiro de 1997. Caderno Acontece. Arquivo do Estado de São Paulo.

Atribuir à foto a capacidade de dar a ver a "São Paulo como a cidade era", como se vê na abordagem adotada por parte significativa da mídia, reforçou mais vez a falsa noção empiricista do registro como cópia do real, alusão perceptiva que dava crédito à objetividade da fotografia; noção empobrecedora, colocando-se como outro traço da etapa de divulgação da série. A percepção sobre o passado foi pouco problematizada nesse momento de circulação

336 Imagens de contextualização urbana se referem às fotos panorâmicas e também aéreas. Ver Lima e Carvalho (1997). 
das fotos no jornal citado, já que a relação passado-presente foi também dada de modo a ressaltar uma continuidade, premissas que, segundo Meneses (1999, p.14) se fundam "como se o passado fosse apenas um antes, com relação ao agora”. As fragilidades das noções de memória, expressam-se nessas abordagens que naturalizaram determinados processos, sedimentando concepções lineares da história, em conclusão, obscurecendo as tensões inerentes a tais processos.

Nesse texto de divulgação acerca das sessenta e três imagens que integraram a exposição, apontava-se como "maior atrativo" a capacidade das fotos de reportar ao passado como ele era, com a "a transparência de características do dia-a-dia". Nessa articulação construída pelo jornal pareciam inexistentes as distâncias que separam a representação, tanto ativada no presente, quanto inclina-se para o seu espaço e tempo original.

A fotografia quando entendida como uma janela para o passado, como fez o jornal, convidando o espectador-leitor a visitar a cidade como ela era, pode desembocar numa "tendência anti-histórica”. Em seus estudos, Meneses aponta para o risco de interpretações que enveredam para aquilo que o autor denomina como "realismo ingênuo". Verificamos como tais deslizes dominaram a cadeia de significados produzidos na etapa de divulgação da mostra. Menezes ajuda a aclarar a questão:

Supor que se possa visitar o passado, um passado fetichizado e congelado, oferecido a visão, confundida com o conhecimento - é postura confortavelmente anti-histórica e anti-pedagógica, pois nos aprisiona no presente e, incapaz de nos fazê-lo apreender o confronto crítico com o diverso, o outro, a alteridade, transformando-o no único termômetro capaz de tudo medir. (Meneses, 1999, p. 18)

É também interessante aferir para aquilo que Barthes (1970, p.67) chamou de estrutura original em que as fotografias publicadas se inserem nos canais de transmissão, o jornal propriamente dito. As fotos integraram-se numa estrutura que associa diversos elementos textuais, quer títulos, quer legendas. A totalidade da informação articulada entre texto e imagem está, desse modo, apoiada em duas estruturas de mensagens distintas e concorrentes, mas que se complementam. Não se quer tecer aqui uma análise do ponto de vista estrutural dessas duas linguagens, até porque Barthes, quando tratou dessa inter-relação, se referia às fotografias jornalísticas, marcadas por agenciamentos específicos, que não podem ser atribuídos às imagens de Pastore. Tentamos apenas apreender alguns sentidos nessa etapa de desdobramento da série, valendo-se de alguns conceitos que podem ser aproximados. 
A notícia construída para a foto panorâmica dava ênfase ao "ritmo acelerado de mudanças": afirmavam que "o número de habitantes da cidade quadruplicava", acrescentando-se que "centenas de casas foram demolidas" para erguer os palacetes "das grandes personalidades da história da cidade", sublinhava o jornal. Nenhuma referência foi feita aos casebres pobres de fundo de quintal onde as lavadeiras e donas de casa estendiam suas roupas, espalhando seus baldes e bacias em chão de terra batida. Nenhuma palavra foi dedicada às inúmeras carroças que atravessavam ruas e viadutos, conduzidas por agentes sociais que tiravam dali o sustento de muitas famílias. Cenas flagradas em toda a dimensão do panorama criado pelo fotógrafo. A paisagem destacada pelo jornal foi aquela que abrigava as residências das elites, tais como os sobrados habitados por Maria Angélica Souza Queirós Aguiar, Antonio Álvares Penteado, Rafael Paes de Barros, Dona Viridiana e Tobias de Aguiar, nomes citados no texto.

Uma cidade dividida entre cortiços e palacetes era rememorada por meio das fotos deixando à sombra os moradores menos abastados, de sobrenome sem tradição inventada. Tem-se nessa articulação entre texto e imagem a expressão de um tema persistente, aquilo que Barthes (1990) apontou como "conotação ideológica ou ética, aquela que introduz na leitura da imagem razões ou valores"? ?337 Vê-se aflorar aqui vestígios da luta pelo simbólico. E isso fica claro na escolha das hierarquias sociais apontadas como definidoras dos espaços territoriais da cidade, bem como das suas memórias em construção.

Quando se afirmou textualmente o interesse de Pastore pelo "povo simples e modesto", retratado com "espontaneidade singular", o conjunto de imagens exibido ganhava chance de uma maior problematização, logo obscurecida, quando o texto do jornal Folha de S.Paulo optou por reverenciar, mais uma vez, o aspecto paisagístico e de certo modo bucólico, posto em contraposição com a deteriorização subseqüente no processo de urbanização da capital:

Pastore foi o primeiro a fotografar o Rio Tamanduateí como uma via fluvial em que passageiros podiam inclusive alugar canoas como meio de transporte. $\mathrm{O}$ espaço entre o rio, hoje um esgoto, e o Córrego Anhangabaú, é considerado o núcleo urbano histórico de São Paulo. (Jornal Folha de S.Paulo. Caderno Acontece, dia 29 de fevereiro de 1997)

337 O jornal aproveitou como espaço para o texto-legenda o corte deixado na terceira imagem, na parte inferior, devido ao desequilíbrio da linha de fundo na montagem do panorama. Para não comprometer o resultado final o IMS propôs esse deslocamento, utilizado nesta proposta de diagramação. 
A vida social e toda a complexidade sugeridas nas fotografias de Pastore ou foram repetidamente deixadas de lado, não questionadas nos textos jornalísticos que apresentavam o fotógrafo ao público, ou apenas eram rapidamente citadas de modo pejorativo. Os sujeitos sociais retratados foram descritos como "negros descalços, estrangeiros, mendigos, vendedores". ${ }^{338}$ A função social que ocupavam como importantes mediadores nas redes de abastecimento da cidade foram escamoteadas. Noções mais preconceituosas detiveram-se nas restritas condições matérias sugeridas nas imagens, silenciando as experiências vivenciadas por pessoas negras, por brancos pobres, nacionais ou estrangeiros, sujeitos históricos que ocupavam um lugar social importante na economia popular da cidade. O referente imagético enaltecido foi a foto panorâmica para valorizar a crescente urbanização, onde tais experiências sociais se diluíam no agigantamento que projetava a cidade para um suposto futuro. A força do ícone promoveu as mobilizações aqui interrogadas.

\subsubsection{Pastore recriado no jornal $O$ Estado de S. Paulo: agenciamentos compartilhados}

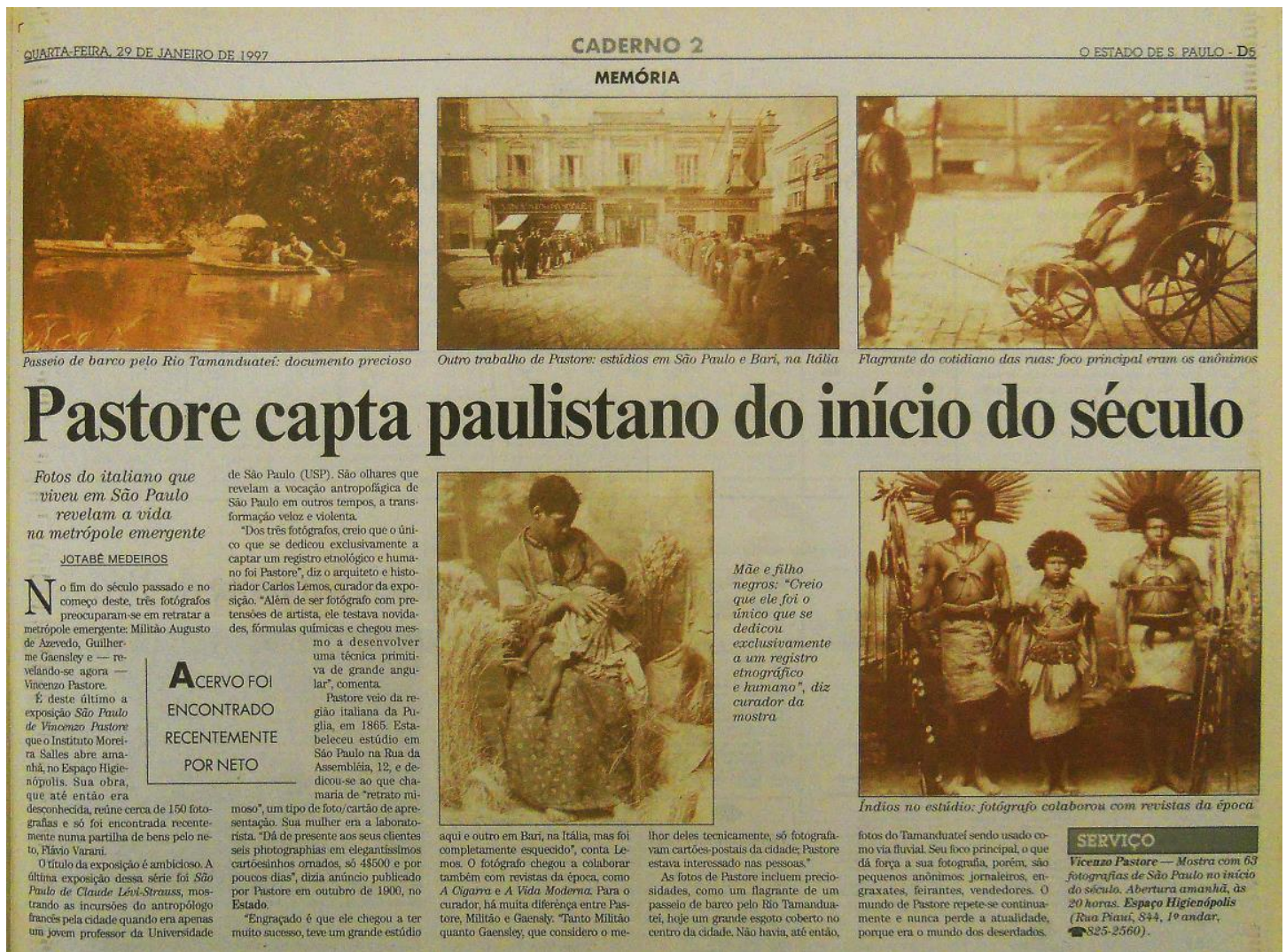

Figura 259: Reprodução Jornal O Estado de S.Paulo. 29 de janeiro de 1997. Caderno 2. Arquivo do Estado de São Paulo.

338 Jornal Folha de S.Paulo. Caderno Acontece, dia 29 de fevereiro de 1997. 
O preciosismo da imagem das canoas foi também um dos primeiros aspectos apontados por este jornal. Christin (2011) pontua a função definida como de ancoragem quando o texto conduz o leitor "por entre os significados da imagem". O texto apresentava a imagem, destacada acima à esquerda, como um "flagrante de um passeio de barco", ${ }^{339}$ um "documento precioso", ressaltando-se, mais uma vez, o ineditismo da cena do Tamanduateí usado com via fluvial.

No entanto, Pastore, nesse jornal impresso, foi "revelado" ao lado de nomes consagrados da fotografia: Militão Augusto de Azevedo e Guilherme Gaensly. O público, afirmava-se, poderia conferir no dia seguinte a exposição "São Paulo de Vincenzo Pastore". ${ }^{340}$ Título ambicioso segundo Jotabê Medeiros, jornalista que assinava a matéria, porque reavivava a "São Paulo de Claude Lévi-Strauss", exposição realizada um ano antes, na inauguração das instalações do Espaço Higienópolis, a galeria do instituto. Temos comparações que delineiam certos agenciamentos. Carvalho e Lima (2000, p.21) bem pontuaram essa inter-relação: "conjuntos documentais, a partir de sua incorporação institucional, passam a constituir uma nova trajetória, dialogando com outras coleções e fundos, ocupando um espaço físico e conceitual como patrimônio de acesso público".

A associação do trabalho de Pastore com as imagens da coleção de Levi-Strauss, também integrada ao mesmo acervo, não se deu por acaso. Reside aqui a intenção de agregar valor às coleções do instituto, reforçando-se o caráter de autoria das coleções. O próprio texto enviado como press release à imprensa pelo IMS, estabelecia os sentidos confluentes atribuídos às duas coleções, depois reafirmados nos diferentes textos de divulgação. Tratamos de ideias em trânsito, constantemente rearticuladas em diferentes etapas de apropriação das imagens. Quando operacionalizadas num espaço discursivo as imagens ganharam novos significados, o que lhes confere um status de representação determinado por um campo cultural específico:

Foi com a mostra São Paulo de Lévi-Strauss, reunindo fotografias do antropólogo francês pertencentes à sua coleção, que o IMS inaugurou, em janeiro de 1996, as instalações do Espaço Higienópolis, em São Paulo, comemorando o aniversário da cidade. Exato um ano depois, exibe-se no mesmo local a exposição São Paulo de Vincenzo Pastore, conjunto de fotos igualmente fundamentais para a memória iconográfica paulistana. Enquanto as imagens de Lévi-Strauss registravam os primórdios do processo de

\footnotetext{
339 Jornal O Estado de S. Paulo. 29 de janeiro de 1997. Caderno 2, p. D5.

${ }^{340}$ Exposição organizada pelo IMS, no Espaço Higienópolis, na Rua Piauí, sede da instituição em São Paulo, hoje com funções estabelecidas na Avenida Paulista. A mostra apresentou 63 fotografias apresentadas ao público a partir do dia 30 de janeiro. Ver O Estado de S. Paulo. 29 de janeiro de 1997. Caderno 2, p. D5.
} 
metropolização no final dos anos 30, a São Paulo de Pastore, no início do século, é ainda o burgo aprazível que começava a acolher os imigrantes europeus - como o próprio fotógrafo - e podia dar-se ao luxo de propiciar rios não poluídos para as navegações dominicais. ${ }^{341}$

Ficou evidente também a tentativa de se apresentar o fotógrafo como detentor de uma sensibilidade singular. A disposição da imagem escolhida para ocupar o centro da página do jornal $O$ Estado de S.Paulo foi a fotografia da mãe negra e seu filho pequeno nos braços (fig.259); foi esse o conteúdo semântico escolhido para introduzir o fotógrafo ao público, destacando a atenção do operador da câmera para o social: "Tanto Militão quanto Gaensly, que considero o melhor tecnicamente, só fotografaram cartões-postais da cidade; Pastore estava interessado nas pessoas", afirmava o curador, tendo seu depoimento também reproduzido no texto jornalístico. ${ }^{342}$ Press release e texto do jornal se aproximavam de modo evidente.

Estabelecer tal vínculo entre as coleções não somente nuança a política de acervo da instituição, como expõe o interesse de formar uma imagem da cidade, numa duração mais alargada, contrapondo fotógrafos e matérias visuais criados em momentos e contextos de produção divergentes, como na aproximação das fotos de Militão e Pastore, ou deste com aquelas produzidas por Levi-Strauss. Forjava-se, nessa perspectiva, uma imagem supostamente coesa da cidade, com sentidos falseados de acolhimento, claramente investida de noções lineares de seu processo de desenvolvimento, encobrindo de certo modo a especificidade de cada coleção, de cada "autor", amenizando-se as tensões de um processo modernizador que não alcançava a modernidade, no sentido social que lhe atribuímos hoje.$^{343}$

Nas invenções que ajudam a constituir os discursos sobre o urbano, a cidade enaltecida foi dada nesse texto de divulgação como acolhedora, de águas límpidas, um "burgo aprazível”, sem mais contestações. Tem-se aqui descrições enviesadas com práticas celebrativas: "Agora na semana em que se comemoram os 443 anos eles podem ser vistos no Instituo Moreira Salles, numa exposição surpreendente", noticiou a revista Veja São Paulo,

\footnotetext{
${ }^{341}$ Texto de press- release assinado por Antonio Fernando De Franceschi disponível no acervo do IMS, sede São Paulo e também publicado no catálogo "São Paulo de Vincenzo Pastore", 1997. IMS.

342 O Estado de S. Paulo. 29 de janeiro, de 1997. Caderno 2, p. D5

343 O conceito de modernização é entendido por muitos autores como uma etapa no processo de desenvolvimento socioeconômico; quando plenamente alcançado, abrangendo os diferentes grupos sociais, se concretiza a etapa do pleno desenvolvimento conceituado como modernidade, que pressupõe uma ruptura estrutural eliminando as contradições de processos de urbanização e modernização excludentes. Ver Marshall Berman. Tudo que é sólido desmancha no ar. 2007; Candido Malta Campos. Os Rumos da Cidade. Urbanismo e Modernização em São Paulo. 2002.
} 
no dia 29 de Janeiro de 1997. Lançar a exposição na semana comemorativa do aniversário da cidade foi uma atitude intencional do acervo, segundo Odette Vieira, coordenadora executiva da instituição. ${ }^{344}$ Vê-se como a exposição fazia parte da agenda de participação do IMS nas ditas comemorações.

O novo lugar de guarda da coleção propunha uma celebração. Era o espetáculo da origem da cidade posta em comemoração. Se pensarmos em Canclini (2011, p.162) teríamos aqui a fotografia como patrimônio: "A teatralização do patrimônio é o esforço para simular que há uma origem, uma substância fundadora, em relação a qual deveríamos atuar hoje (...) noções de coleção e ritual são fundamentais para desmontar vínculos entre cultura e poder ".

A divulgação da coleção VP, nessa específica semana de aniversário de São Paulo, não se desvencilhou do "peso todo da comemoração". Fato que muitas vezes explica a despolitização que acaba por marcar tais apreensões. Em tal conjuntura, para Meneses (1999, p.17-18), sempre "transparece uma relação problemática com o tempo e, sobretudo, com a história".

Por meio dessa mediação social entre instituto e agentes de divulgação, as fotos de Pastore, chegaram ao tempo presente com sentidos claramente investidos. As imagens ganharam um discurso, um agenciamento provocador de uma retórica produtora de enunciados, destinados a orientar a percepção do público, primeiro para o seu ineditismo; em seguida, para uma noção de cidade reforçando a função de memória do fotográfico, que se tornava o próprio significante, por vezes falseando alguns sentidos: A cidade não era tão pacata como se afirmou nesse texto de divulgação, tampouco homogênea como se apresentou. A interpretação das imagens foi marcada pela "postura presentista", deixando de lado reflexões contextuais que pudessem esclarecer e problematizar historicamente a série apresentada.

Os sentidos construídos estiveram marcados por esse contexto particular de cunho celebrativo, instituidor de memória, numa prática de agenciamento produtora de certas noções naturalizadas: a cidade como um vetor de transformação e as perspectivas teleológicas, fundadas nas ideias de progresso e evolução estavam imbricadas nos discursos que apresentavam o trabalho de Pastore ao público: "Fotos do italiano que viveu em São Paulo revelam a vida na metrópole emergente", sublinhava a chamada da matéria. ${ }^{345}$

\footnotetext{
${ }^{344}$ Entrevista realizada com Odette Viera no dia 9 de novembro de 2013.

345 O Estado de S. Paulo. 29 de janeiro de 1997. Caderno 2, p. D5.
} 
Diante desse contexto em que as imagens foram mobilizadas, sublinhamos a importância de se compreender a cidade a partir das três dimensões apresentadas na definição feita por Menezes (1996): “A cidade é artefato, é campo de forças e é imagem”, atribuições que evitam, como defende o autor, o erro de reificar as imagens e tomá-las por coisas que tem significados próprios:

A cidade é artefato, coisa complexa, fabricada, historicamente produzida. $\mathrm{O}$ artefato é um segmento da natureza socialmente apropriado, ao qual se impôs forma e/ou função e/ou sentido. Espaços, estruturas, objetos, equipamentos, arranjos gerais etc, todavia foram produzidos por forças econômicas, territoriais, especulativas, políticas, sociais, culturais, em tensão constante num jogo de variáveis que é preciso acompanhar (...) Mas, além de artefato, coisa material produzida pelas praticas sociais e por toda a atuação de um campo complexo de forças, a cidade é também representação. As práticas sociais (que produzem artefatos e também procuram neles reproduzir-se) não se fazem às cegas, mecanicamente oi por instinto. Esta intervenção concreta do homem no universo real é orientada pelas representações sociais, sempre presentes (...). A natureza política ou o uso político de muitas dessas imagens é essencial para apreender o que é, então, cidade. (Menezes, 1996, p.149).

De modo bastante repetitivo, os textos de divulgação sugeriam uma suposta capacidade do fotógrafo de apreender a realidade que via, materializando um duplo equivalente do real, como se a reprodução fotográfica não fosse também construção, submetida a escolhas subjetivadas. A relação entre texto e imagem faz lembrar Susan Sontag (2003, p.14) que afirmava "todas as fotos esperam sua vez de serem deturpadas por suas legendas".

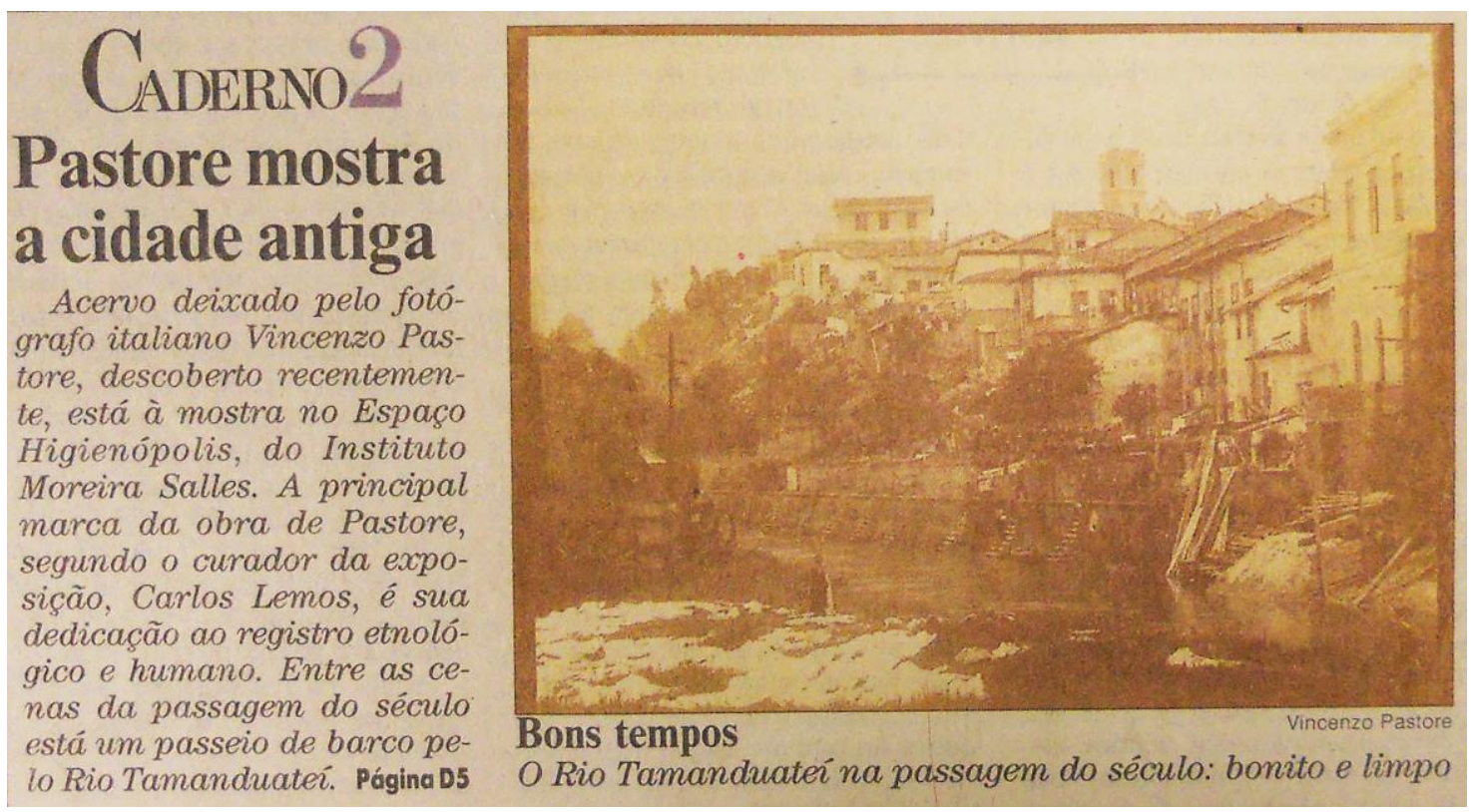

Figura 260: Reprodução Jornal O Estado de S.Paulo, dia 29 de fevereiro de 1997. Fragmento de capa do jornal. Arquivo o Estado de São Paulo. 
Estampada ao fim da primeira página (fig.260), a foto impressa no jornal $O$ Estado de S.Paulo, trazia como legenda os "bons tempos" que preservavam ainda o rio "bonito e limpo". Invoca-se, mais uma vez, a "cidade antiga" que o fotógrafo teria a capacidade de mostrar. Ressaltar os signos dos bons tempos vividos dava o mote para reintroduzir Pastore como fotógrafo da cidade, retórica que atravessava toda a apreensão e percepção do material visual.

Criava-se para Pastore, um enunciado de alguém que havia deixado sua "marca", dada a sua "dedicação" ao registro etnológico e humano: "Seu foco principal, o que dá força a sua fotografia, porém são pequenos anônimos: jornaleiros, engraxates, feirantes, vendedores. O mundo de Pastore repete-se continuamente e nunca perde a atualidade porque era o mundo dos deserdados". ${ }^{346}$ Talvez por isso, o jornal tenha escolhido como imagem representativa de toda a série a foto da mulher negra estendendo roupas às margens do Tamanduateí, para a capa da edição do dia 29 de janeiro de 1997. Mas lacunas e silêncios são insistentes nesse processo de recontextualização.

Contrapor indiretamente na legenda da foto o rio "bonito e limpo" às contingências atuais de poluição e degradação das águas da cidade, familiares aos leitores do jornal, promove apenas uma fruição nostálgica. Se por um lado o passado era rememorado, ativado no tempo presente, por meio da mostra e da sua divulgação, além de um inegável esforço de preservação, por outro, negavam-se maiores contextualizações, afinal, passados presentificados nem sempre contam toda a história escreve Huyssen (2000, p.13). Reiteravam-se discursos de rememoração pouco engajados, como se a cidade idealizada pudesse estar destituída das relações sociais e de sua dimensão humana que de fato a constituem.

Perdia-se, mais uma vez, a chance de melhor interpretar esse passado. A fotografia foi considerada como um registro de uma paisagem morta e nada mais. Os arranjos políticos e econômicos que expulsavam a população mais empobrecida para os arredores, como vimos no capítulo 3, sequer foram nuançados; tampouco foi problematizado o uso das águas citadas pelas mulheres moradoras das várzeas que lavavam roupa para fora, estendendo seus quintais pelas gramas crescidas às margens. Espaço que iria depois desaparecer como meio de sua sobrevivência. As águas foram controladas pelos projetos modernizadores. Uma realidade social vibrante foi pouco questionada no texto, apesar de pertinente na narrativa do fotógrafo. Se há um esvaziamento da função social da fotografia como documento histórico há também

${ }^{346}$ O Estado de S. Paulo. 29 de janeiro de 1997. Caderno 2, p. D5 
a definição de quem participava e quem ficava de fora da própria recontextualização do material visual operacionalizado na mídia.

Vê-se como as imagens, não se encerram em si mesmas, ou naquilo que o referente revela. Não está tampouco apenas submetida a um processo de codificação simbólica. Os seus agenciamentos criam sentidos e compreensões enviesadas, constituindo uma memória por vezes fabricada no campo discursivo. Huyssen esclarece: "a memória de uma sociedade é negociada no corpo social de crenças e valores, rituais e instituições" (2000, p.68). A abordagem e a interpretação do material visual encobriram inúmeras ações de resistência dos sujeitos históricos retratados, agências, a saber, como bem mostrou Johnson (2003), muitas vezes silenciosas e sutis, mas presentes em suas práticas de sobrevivência em contingências desfavoráveis.

A prática de trabalho realizado pela mulher que vivia de seus esforços à beira do Tamanduateí, sequer foi anunciada na legenda da foto. Por mais que esse texto não se trate de em texto de historiador preocupado com a história social e do trabalho, intrinsecamente associadas, a desatenção para tais sociabilidades chama atenção. Os textos de divulgação perderam a chance de pontuar ao menos superficialmente o que as pessoas, em seus esforços e suas ações, nem sempre organizadas ou claramente conduzidas "fazem por elas mesmas", dentro de certas experiências; inclusive quando não as modificam num enfrentamento direto, suas ações isoladas ecoam, provocam conseqüências, ao fim e ao cabo, encontram meios de levar adiante suas vivências não reduzidas frente às condições objetivas da vida (Johnson (2003). Apesar da presença da mulher tão diminuída quando vista em escala oposta aos casebres enfileirados, no último plano da imagem, ainda assim lembra aquilo que Revel (2000) já notou: “quantas coisas importantes podemos ver acontecer enquanto aparentemente nada acontece".

Se temos significados controlados nesta trajetória de deslocamento das fotos, o material visual se complexiza ainda mais ao adentrar no circuito da arte, sendo em seu conjunto, remontado para ser exibido e comercializado. Trataremos a seguir da historicidade das imagens como visualidade posta em exibição na galeria de arte do IMS, onde a série se difundia incorporada ao circuito das exibições, num espaço gerador de novos significantes ao passo que promoviam a inclusão social da obra colocada em exibição. Entender como se deu mais pontualmente a relação com esse passado, "num terreno fértil que é o da sociedade de consumo" como afirma Meneses (1999, p.7), exige o seguinte aprofundamento: reavaliar os 
processos de recriação, a sua apreciação pelo público, por outras mídias e pela História Social, um "caldo de cultura" que interpenetra as imagens que sobrevivem sempre em movimento.

\subsection{A exibição: "São Paulo de Vincenzo Pastore", fotos que finalmente se faziam para a}

\section{História}

No dia 30 de janeiro de 1997, às vinte horas foi inaugurada a mostra que se manteria com recorde de público entre as exposições realizadas pelo IMS até então. A "São Paulo de Vincenzo Pastore" era apresentada no Espaço Higienópolis, na capital paulista, numa noite de vernissage restrita à convidados.

No dia seguinte, a exposição foi aberta ao público em geral, que poderia visitá-la até o dia vinte de abril daquele ano. O papel institucional estruturado no binômio galeria coleção, ${ }^{347}$ cumpria uma das atividades curatoriais, intrínsecas às políticas de coleta de coleções por parte de muitas instituições. O espaço da exposição acomodava as fotografias em seu status de representação dado ao seu valor documental, sem contar da própria vocação das imagens em ocupar o circuito de exposição, onde foram vistas com entusiasmo.

O conjunto de imagens foi dividido em duas salas, apresentadas em painel, em paredes e em vitrines. Foram impressas em off-set, com variações de ampliações que iam de $21 \mathrm{~cm} x$ $30 \mathrm{~cm}$, até $49 \mathrm{~cm} \times 70 \mathrm{~cm}$; a medida dos passepartout foi de $80 \mathrm{~cm}$ x $90 \mathrm{~cm}$. No espaço destinado ao texto de abertura, tratava-se de imagens em plotagens atrás de painel, protegidas com vidro à frente.

Vitrines foram fixadas ao centro das salas promovendo a fruição do público com algumas reproduções originais (fig.262). Desejava-se apresentar as condições físicas do material visual adquirido, nuançando a historicidade do próprio artefato como aspecto relevante a ser exibido. Foi esse um recurso expositivo de um projeto curatorial que, segundo Sérgio Burgi, propunha uma leitura mais abrangente do fotógrafo, valorizando o conteúdo original. Nota-se, contudo, como sublinhar o aspecto de objetos únicos, sobreviventes do passado distanciado, assegurava a recriação do conjunto visual, fazendo Pastore surgir como autor, como personagem criador de fotos que encontraram espaço para acontecerem no tempo.

347 Foi também realizada uma exposição em Poços de Caldas: Cartaz: "São Paulo de Vincenzo Pastore. Fotografia. De 31 de Janeiro a 20 de abril". 


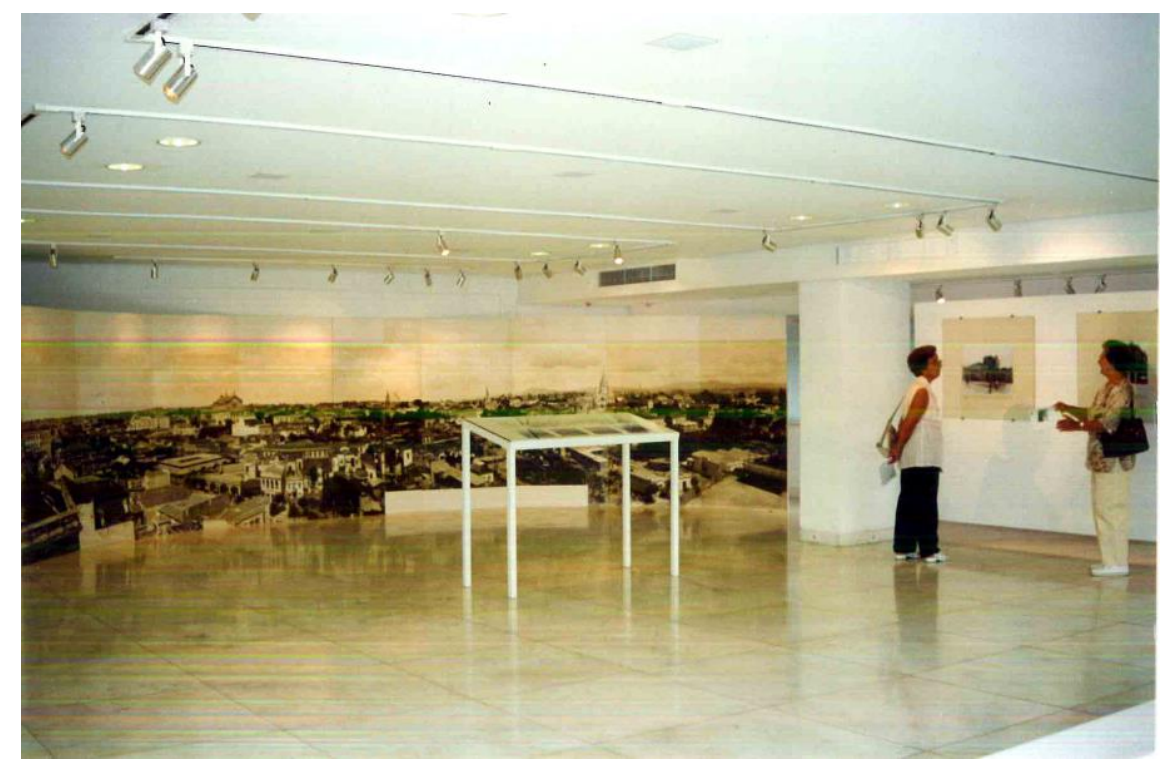

Figura 261: Fotos da exposição realizada em janeiro de 1997 concedidas pelo IMS.

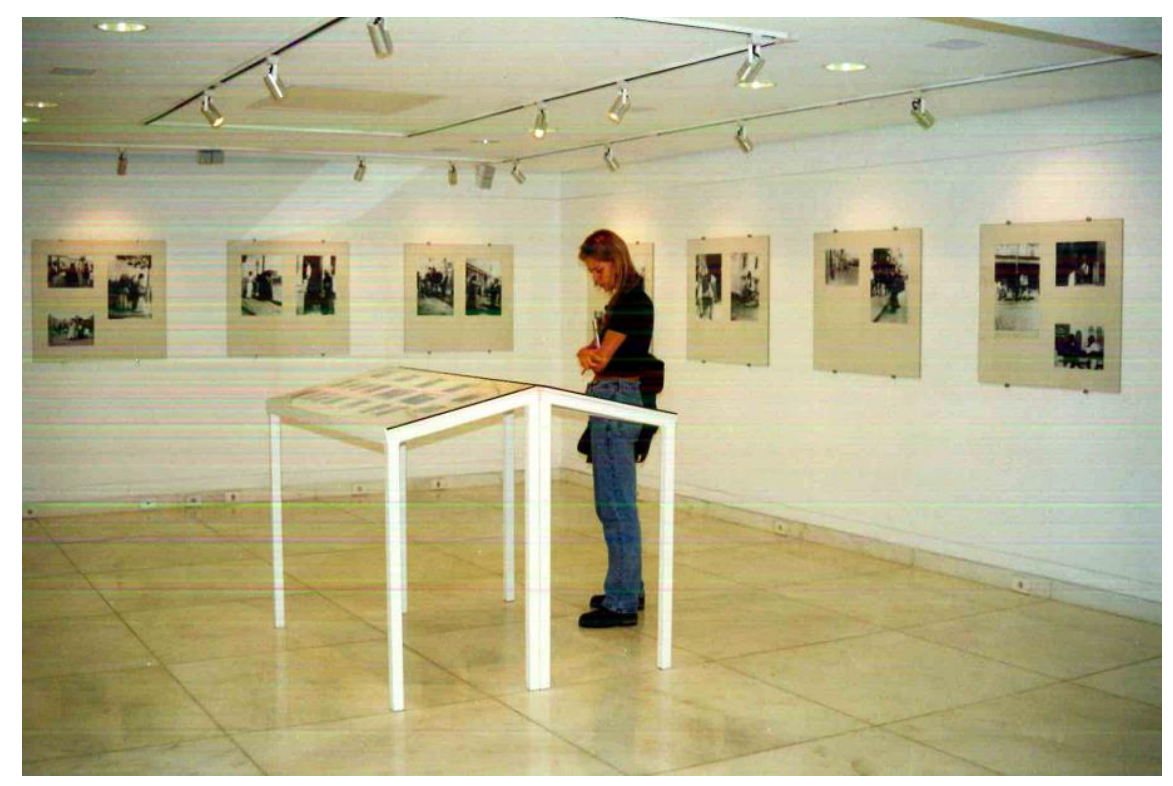

Figura 262: Fotos da exposição realizada em janeiro de 1997 concedidas pelo IMS. Visitante observa imagens originais em uma das vitrines da mostra.

A noção de autoria sustenta-se como um valor conferido à série, para além da questão histórica e documental envolvida. As vitrines apresentavam ao público o conjunto de uma obra criada, reunida, selecionada pelo fotógrafo. Cada fragmento era valorizado como um objeto individual, legitimando a posição do autor e da instituição, mantenedora desses suportes herdados. Suportes que ultrapassavam suas dimensões pequenas, originais, únicas e se faziam agigantados nas paredes.

Tratamos de diferentes situações documentais criadas no processo de produção de documentos incorporados aos acervos e arquivos. O IMS, além de lugar de guarda promovia outras configurações documentais a partir das fotos adquiridas. Nessa etapa de apropriação, as 
fotos foram entendidas como documentos originais, assumindo situações múltiplas e diversificadas, ampliadas nas paredes conformando aquilo que Lacerda (2008) apresenta como novos documentos, autônomos e inseridos em situações e configurações específicas: catálogo e livro, imagens digitalizadas e disponibilizadas em meio eletrônico, ampliadas na parede, em apreensões que superavam e transcendiam a referência inicial centralizadas nas vitrines.

Vê-se aqui explicitada a dupla função assumida pelo IMS: ora assumindo o papel de arquivo histórico, privilegiando o aspecto narrativo, material e o conteúdo registrado, ora vincula-se ao papel conferido a um espaço de arte, preocupado em organizar mostras e construir relações de obra e autoria. A existência da coleção VP, firmou-se sob tais relações firmadas, sendo essas as formas investidas para chegar ao mundo.

Mas outros atores foram também participantes das significações construídas, acolhendo as propostas curatoriais. Ao se observar o caderno de assinaturas dos visitantes da exposição, percebemos como tais imagens foram interpretadas pelo público, ora como resgate da história, ora como formadora de memória. Quase sempre se impunha a força da verossimilhança do fotográfico, sob um estatuto tido como incontestável. Ao mesmo tempo, nuançava-se uma genuína experiência diante das imagens, como metáfora da perda ou daquilo que Barthes (1980, p.24) chama de "regresso do morto": a foto que trazia o aspecto do passado perdido era revivida no presente, revelando as diferentes temporalidades do material visual distanciado do instante do registro:

Adorei poder ter a oportunidade de ver como foi São Paulo naquela época", (Luisa Vanossi); "gostei de conhecer a década de 1910 e o trabalho desse fotógrafo"; "imagens evocativas de história"; "resgata a memória de nossa querida cidade", (Fernando Romano/Editor); "Bela exposição, belíssimo espaço", (Paulo Gars); "Bonita exposição. Parabéns pelo espaço", (Patrícia Gouvêa); "orgulho da minha terra, viva Pastore por ter proporcionado tão belo visual", (Wal); "obrigada pelo privilégio"; "parabéns pela curiosidade histórica, assim é que se faz memória de um povo"; "Para não nos perdermos no meio de um avanço tão rápido... reconstruir através de pequenos fragmentos pessoais. $\mathrm{O}$ que somos hoje é resultado do que fomos ontem", (Angela Janoni/Radialista) "O IMS, trouxe o que o paulistano precisava, Memórias", (Felicia de Lima); "Revivi algo de meu passado nesta maravilhosa exposição!", (Lucy de Salles Penteado); "a presença de pessoas de diferentes classes sociais torna as imagens mais humanas de uma São Paulo que acolhe a todos. (Regina Garrido). ${ }^{348}$

\footnotetext{
${ }^{348}$ Cadernos de assinaturas da exposição São Paulo de Vincenzo Pastore. 1997. IMS, sede São Paulo.
} 
Em caprichosa letra, uma das espectadoras da mostra, ao ver as 63 fotos de Pastore, fez questão de registrar a sensação vivida diante das imagens ampliadas para a exibição. Este relato descortinou uma percepção que acolhia as imagens de modo atento, não menos comovente: "Que bom ver a São Paulo antiga, não sob a ótica da cidade "quatrocentona", mas enxergando o povo que, de verdade, fez e faz a terra. Estou cheia de orgulho". ${ }^{349}$

As imagens foram apreendidas como capazes de reconstruir a história da terra da qual se orgulhavam, evocativas de um passado perdido, mas que, por meio das fotos, poderia ser revisitado: As imagens aconteceram como uma possibilidade de descoberta, de se reviver e conhecer, numa experiência de quase contemplação; aconteceram então como uma aventura, como disse Barthes, para quem a fotografia somente acontece diante do espectador que a olha, a perscruta e a toma como uma "emanação do real passado: uma magia não uma arte". 350

Esse "ato de magia social", a qual Bourdieu (1998) também se referiu, está fundado na premissa "transforma-te no que és". No depoimento da espectadora Angela Janoni, vê-se como a sociedade se apropria da sua história por meio de imagens. Ao afirmar "O que somos hoje é resultado do que fomos ontem", a visitante da exposição expressou uma percepção nuançada nas reflexões de Canclini (2011, p.193): em sua abordagem crítica, esse autor pontua as estratégias de instituições e agentes modernos frente ao agenciamento do patrimônio histórico: "você que recebeu a cultura como um dom e a toma como algo natural, incorporado ao seu ser, comporte-se como você já é: um herdeiro.” O culto das imagens do passado expressa a crença de que tais herdeiros, o público/audiência da exposição, conseguiram preservar, ao menos por meio das fotos, traços relevantes de espaços, na verdade, já destruídos do cenário urbano.

Outros comentários se mostraram com menor inclinação enaltecedora, chegando a fazer até mesmo sugestões que denotam o valor nostálgico da ascendência; outros apontam percepções mais críticas sobre a vida social:

O autor das fotos tem um olhar preciso que revela a desigualdade social tão antiga na cidade. (Neise, Neide e Ricardo).

Por essas provas antropológicas conseguimos ter uma noção da tamanha capacidade de destruição da nossa própria tradição. (D.J).

Muito importante esta exposição visto que temos as imagens de São Paulo do ponto de vista elitizado, com suas grandes edificações. Esta, ao contrário, privilegia as figuras do cotidiano. (Anna).

\footnotetext{
${ }^{349}$ Cadernos de assinaturas da exposição São Paulo de Vincenzo Pastore. 1997. IMS, sede São Paulo. Assinatura de Selma Solera. 8/03/1997.

${ }^{350}$ Barthes, Roland. A Câmara Clara. Lisboa, Portugal: Edições 70. 1980, p. 125.
} 
Faltou tão só o neto fazendo um belo fundo musical, em um belo piano da época. (Eliana e Marcelo). ${ }^{351}$

No depoimento de Anna, que contrapõe fotografias do ponto de vista elitizado às imagens de Pastore, onde prevalece o olhar para o cotidiano, vemos como no envolvimento da sociedade com a imagem é que se determina o caráter de emblema sempre construído socialmente, no âmbito da circulação e recepção das imagens. Ao observarmos a historicidade das fotos de Pastore se verifica como, após a exibição no espaço da galeria, um espaço de legitimação, a série passou a ganhar um discurso estético, histórico, articulando-se com a própria história da fotografia, como aponta o relato do espectador visitante Hans Gunter Flieg, importante fotógrafo de origem alemã, que assim como Pastore, viveu e retratou São Paulo. No caderno de assinaturas da exposição, Flieg afirmou a sua participação na mostra:

Parece-me que, depois da descoberta isolada da fotografia por Hercules Florence, antes de Daguerre, o trabalho de Vincenzo Pastore veio a segunda contribuição revolucionária do Brasil à História Mundial da Fotografia. Sugiro um livro em formato grande como os impressos com os Cadernos de Literatura. Creio ser este o primeiro registro fotográfico espontâneo e humano nas ruas de São Paulo. Parabéns e obrigado pela iniciativa de divulgar este acervo. (Hans Gunter Flieg). ${ }^{352}$

A grande sensação da exibição foi a foto-panorâmica montada a partir de quatro diferentes registros, colocando o fotógrafo dentro de um circuito visual dominante: a representação de vistas, a tomada abrangente do registro, onde a sensação de imersão parece nunca esgotar o tempo e o prazer da observação.

Excelente trabalho, boa explicação. É muito bom poder visualizar o local onde moramos, a muito tempo atrás! (Marcela Carano).

Agradável imaginar (ver!!) a praça da Sé naqueles tempos. Uma pequena Consolação para quem a freqüenta atualmente. (Helena O. freire).

Parabéns! Emocionante ver minha cidade de outrora. Localizar a casa dos meus avós. Foi um presente ter visto esta exposição. (Sandra Salgado).

O gosto pelas fotos panorâmicas, como definiu Dubois (2005, p.215), nascia do prazer de identificar. Visualizar a cidade de tempos antigos, estranhar a "pequena Consolação", localizar a casa dos avôs, imaginar e "ver", compõem um quadro de emoções provocadas pela experiência diante de um gênero fotográfico que torna intrínseca essa varredura perceptiva

351 Cadernos de assinaturas da exposição São Paulo de Vincenzo Pastore. 1997. IMS, sede São Paulo.

${ }^{352}$ Cadernos de assinaturas da exposição São Paulo de Vincenzo Pastore. 1997. IMS, sede São Paulo. 
por um campo visual que faz o espectador refém do agigantamento criado, invocando os sentidos do reviver.

A sensação experimentada pelo fotógrafo, o seu ponto de vista sobre o território, chegava ao tempo presente revelando o desejo que tomou completamente àqueles que paravam diante da vista realizada entre 1911 e 1912, instalada primeiro na sala 1 da galeria do Espaço Higienópolis, depois transferida para a estação do metrô Luz (fig.263). A montagem media nove metros de largura, indo do chão ao teto. As quatro fotografias feitas separadamente foram justapostas. Trata-se de fotos em processo fotográfico, com camadas de gelatina e prata, reproduzidas em papel no formato $24 \mathrm{~cm}$ x $30 \mathrm{~cm}$. No projeto curatorial formaram um único registro panorâmico do Vale do Anhangabaú, ${ }^{353}$ de 9 m x 1.80 m. Ajustar a terceira foto do panorama, fazendo-lhe um corte, foi necessário para dar uma mesma sequiência à linha do horizonte. Arranjo feito para completar a vista, em sua nova reconfiguração, imaginada antes pelo próprio fotógrafo, quem sabe desiludido ao notar a diferença no terceiro registro avulso.

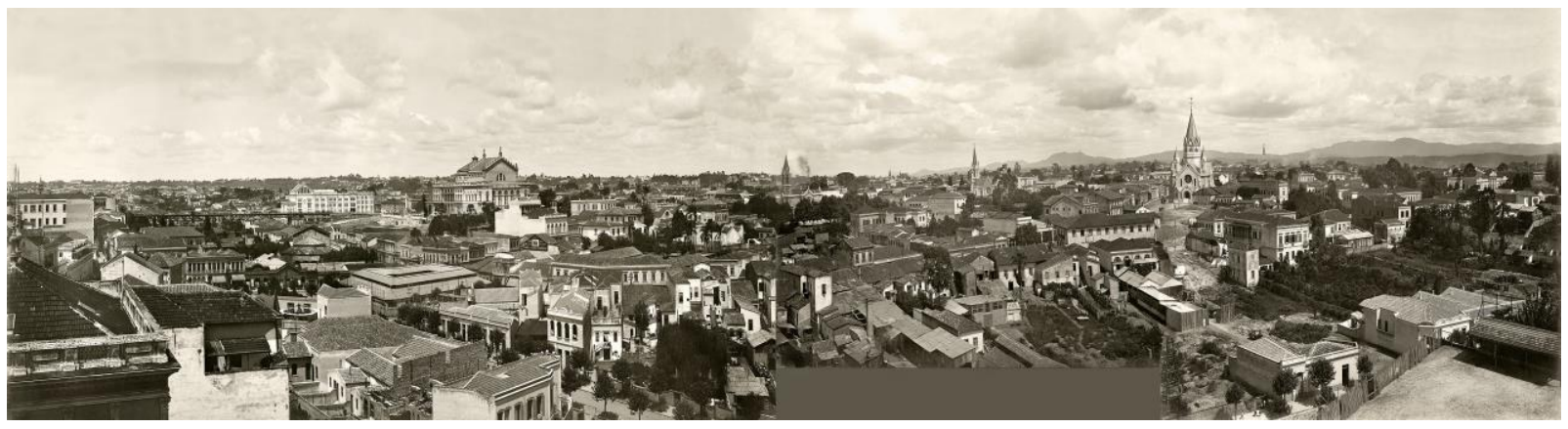

Figura 263: Fotografias em papel. Foto panorâmica com vista do Vale do Anhangabaú, realizada em quatro diferentes tomadas. (Viaduto do Chá). 1910 @ C Vincenzo Pastore/Instituto Moreira Salles.

Do torreão existente no antigo prédio do mosteiro São Bento, Pastore retratou a área central da capital paulista, demonstrando a força da cidade como um gênero pictórico. Sua composição passava pelo Viaduto Santa Ifigênia, pelo Liceu do Sagrado Coração de Jesus,

\footnotetext{
353 Essa fotografia panorâmica foi enviada à Exposição Nacional no Rio de Janeiro, em comemoração aos 100 anos da chegada da corte ao Brasil. Foi uma fotografia tomada do Colégio São Bento. No primeiro plano vê-se Anhangabaú, o edifício da Companhia Paulista de vias Férreas, Rua Libero Badaró; ao centro, viaduto do Chá inaugurado em 1892, tendo ao fim o Teatro São José, ao fundo do convento São Francisco, no largo que recebe este nome; no segundo, Rua Formosa ao fundo do Mercado da Rua São João, construído em 1890 na cidade nova; último plano se vê os fundos do Teatro Municipal. Ao fundo, á esquerda, Igreja de Santa Ifigênia e obras da construção do viaduto que recebeu este mesmo nome, construído entre 1909 e 1913 . No horizonte Serra da Cantareira e Torre do Liceu Sagrado Coração de Jesus. Toda a descrição foi feita por Ricardo Mendes para o Acervo do IMS. Essa fotografia panorâmica está hoje instalada no metrô próximo a Estação da Luz, local onde Pastore realizou as quatro fotografias. O IMS fez uma troca, colocando vidro de proteção, tamanho o interesse das pessoas em localizar e reconhecer os espaços antes retratados.
} 
pelo Largo Paissandu, até chegar ao Teatro Municipal. A Serra da Cantareira serviu de painel de fundo à vista urbana projetada pelo fotógrafo, também interessado pela estrutura narrativa visual que contempla trajetórias e transformações do espaço urbano.

A tomada das imagens em perspectiva e o equilíbrio das linhas de fundo indiciam a intenção de Pastore, que assumiu seu lugar na convenção visual do registro panorâmico, ligando-se a uma tradição de um domínio técnico-temático pertinente a fotografia:

A limitação do ângulo de visão foi superada pelo desenvolvimento da fotografia panorâmica. A técnica aqui foi combinar várias chapas em um conjunto maior para produzir uma vista arrebatadora - de uma cidade ou selva - que era destinada a evocar a experiência de realmente estar em uma paisagem. (Orvell, 1989, p. 79. Tradução Nossa)

É preciso romper com mais este silencioso sobre a atuação de Pastore e colocá-lo na tradição da fotografia panorâmica, um gênero fotográfico formador de uma singularidade estética, da qual esse fotógrafo não escapou e, sequer a curadoria neste processo de escolhas, seleção e produção de significados, deixou de investir. Esse gênero fotográfico, disseminado na fotografia desde 1860, proveniente dos diálogos da fotografia com a produção de gravuras, facilitado pela invenção das placas de colódio úmido, ${ }^{354}$ marca o interesse da fotografia pelas vistas, por territórios, grandes cidades e monumentos. O desejo de ver amplamente, de romper os limites do enquadramento clássico, de abrir, esticar e estender o quadro é assim delineado por Dubois:

Parece-me que se podem distinguir, esquematicamente dois grandes tipos de panoramas fotográficos (e vários subtipos): de um lado, os panoramas no sentido estrito, isto é, oferecendo uma vista panorâmica numa única imagem, realizada numa só tomada; de outro lado, os panoramas no sentido amplo, se assim se pode falar, isto é, obtidos por meio de montagem de várias vistas, cada uma destas mais ou menos convencional, de modo a poder reconstituir a continuidade espacial de um campo estendido. (Dubois, 2005, p. 215)

Assim fez Pastore. Construiu quadros com intenção claramente englobante, interessado na ambiguidade desse gênero visual que parte de uma técnica de recorte e fragmento, mas ambiciona o movimento, a perspectiva, a integração do todo. O olhar central do espectador, em determinado ponto de vista, tinha disponível a imensidão, mas era curioso pelo detalhe,

\footnotetext{
354 Colódio úmido ou seco eram as novas emulsões fotográficas que, a partir de 1850, promoveram na fotografia maior riqueza de detalhes, maior sensibilidade e facilidade de manipulação, utilizadas em negativos de vidro, ambrótipos, ferrótipos e positivos diretos; as placas, emulsionadas com o colódio, inauguram, com essa nova técnica, a redução do tempo de exposição.
} 
ávido pelas pequenas coisas. Como fez Sandra Salgado ao visitar a mostra: procurou a casa da infância que trazia a vivência com os avôs. Pequenas coisas empoderadas pelos diálogos estabelecidos no tempo.

Dubois sugeriu o diálogo da foto panorâmica com a pintura como prenúncio do cinema, sem perder a sua estreita relação com as fotografias de vistas anunciadas em grandes formatos, desde fins da década de 1860. Dubois (2005) dialoga assim com Crary (2013, p.36): Em meados do século XIX, afirmou este autor, tinha-se a "imposição de tipos específicos de sínteses perceptivas", associada com a "difusão em massa do estereoscópio no início da década de 1850 até as primeiras formas de cinema, na década de 1890”. Reter a atenção do espectador numa nova tendência de envolvimento individual com a imagem, por meio da atração provocada pelos novos aparelhos mecânicos de reprodução, era prática que se popularizava e se consagrava primeiro pelas pinturas de panorama, depois por vistas "abrangentes e em varreduras, obtidas pela sucessão de muitas vistas menores" (Idem, 2013, p.148).

$\mathrm{Na}$ visão de mundo do século XIX predominava um regime escópico da vista, com uma cultura visual seduzida pela criação de espaços ilusórios que pudessem levar o espectador para uma experiência de imersão na fotografia. Nesta visualidade estava introjetado um modo de ver, construído socialmente pelas vistas panorâmicas, alimentadas pelo legado das imagens estereoscópicas, encontrado forma de se reativar no presente.

Pastore tomava lugar numa tradição. Marc Ferrez, em 1869, anunciava: "Fotografia Brasileira, especialidade em vistas do Rio e arredores de todas as dimensões. Imagens tiradas de chácaras, navios, monumentos, de todos os tamanhos, por-sic-- preços razoáveis etc." 355 O Largo do Jardim Botânico, a praia de Paquetá, a Cascata da Tijuca e a vista da Avenida Central feita em 1910 colocam Ferrez como o maior especialista de vista no Brasil, considerado como "um mestre no emprego de chapas de grande formato para vistas panorâmicas". ${ }^{356}$ Esse fotógrafo, também pesquisador de novas técnicas fotográficas, produziu imagens para estereoscópios, cartões-álbuns, trabalhando como retratista "das 8 às 4 da

\footnotetext{
355 Jornal do Commercio, 6 de junho de 1869, p. 3. Apud. Kossoy. 2002, p. 134. Tradução Nossa.

${ }^{356}$ Almanak Laemmert, 1872, p. 746. In: Kossoy. 2002, p. 137. Ferrez foi contratado pela Comissão Geográfica e Geológica do Império, tendo trabalhado também para a Marinha Imperial. Ferrez produziu também álbuns destinados à turistas, tendo assim registros de índios, reproduzindo a lógica da iconografia do exótico, vendidas como souvenirs.
} 
tarde". ${ }^{357}$ Realizou panoramas pequenos, mostrando que o desejo de ver mais de perto e ver tudo, como indicou Dubois, tinha tradição na visualidade produzida no Brasil.

O nome de Marc Ferrez estava acompanhado de Leuzinger, fotógrafo proprietário da importante Casa Leuzinger, que também incorporou panoramas de paisagens no seu ofício. Ao compor a cena urbana, Leuzinger chegou a usar cinco negativos para compor uma vista do Rio de Janeiro com ângulos que iam de 110 a $360^{\circ}$; Ferrez recorria a um único negativo de médio ou grande formato numa câmera, segundo Balady (2012, p.107) com capacidade de registro em $180^{\circ}$, com correção automática de perspectiva, tendo construído um aparelho fotográfico para a execução de grandes tomadas panorâmicas. Todo um mercado passava a oferecer diferentes câmeras fotográficas desenvolvidas para atender este específico mercado de intensa demanda de vistas. Alguns aparelhos giravam completamente; em outros, somente a lente se movimentava, captando registros de vistas que dariam notoriedade aos fotógrafos.

Valério Vieira fez seu nome pelas tomadas de vistas muitas vezes encomendadas. Em 1905 realizou o primeiro Panorama da Capital de S. Paulo, medindo 11m x 1,43m, utilizando cinco chapas de $18 \times 24 \mathrm{~cm}$. A composição final atingia $180^{\circ}$. Foram necessários para a realização dessa imagem, apresentada na Exposição Nacional do Rio de Janeiro, em 1908, e na Exposição do Salão Progredior, de 1905, dezessete meses de estudos preliminares. O desafio era tornar imperceptível, as emendas das chapas, bem como se avaliar o melhor lugar para a realização do registro, momento não isento de tensão ou riscos, como mostra Balady (2012, p.114): "uma das vezes que subiu a torre do Santuário do Sagrado Coração de Jesus com o intuito de observar a cidade e estudar a incidência da luz, teve uma vertigem e foi amparado por seu assistente, incidente este que poderia ter-lhe sido fatal". Segundo a autora, o trabalho prolongado por meses, deu à Valério o prêmio Grand Prix, em 1908, considerado, na antiga capital do Império, o recorde mundial de tamanho de fotografia num só papel; para apresentá-la foi preciso criar espaço nomeado Anexo Paulista, um galpão sem janelas, com cobertura de duas águas, em estilo chalé.

A foto panorâmica como convenção para se representar a cidade desde os oitocentos foi intensamente reforçada pela circulação de álbuns comparativos. ${ }^{358}$ Dava-se fôlego às

\footnotetext{
357 Jornal do Commercio, 6 de dezembro de 1868, p. 3. In: Kossoy. 2002, p. 134.

358 O Álbum comparativo da Cidade de São Paulo, 1862-1887, levado a cabo pelos esforços do fotógrafo Militão, inspirado segundo Carvalho e Lima (2009, p. 397) "em publicações semelhantes lançadas em Paris" foi depois apropriado na nova ressemantização comparativa da cidade feita através dos álbuns produzidos na gestão de Washington Luis, sob encargo do fotógrafo Aurélio Becherini, contratado principalmente pela Secretaria de Estado da Viação. Sua tarefa era documentar o intenso processo de implementação de obras na cidade Os álbuns
} 
dualidades que reiteravam os sentidos falseados de atraso e progresso, civilizado e não civilizado, cidades próximas ou distanciadas do modelo e padrões europeus. Os discursos sobre a cidade estiveram sempre permeados por um caráter teleológico; o fim é o progresso, tensionando a relação passado - presente. Representações se estruturavam numa narrativa que iria ajudar a estabelecer e legitimar as noções de antigo e moderno, justapondo "o antes e o agora", binômios ativados na cultura visual, como defendem Carvalho e Lima (2009, p.397).

Noções evolucionistas naturalizavam as transformações, despolitizavam tais processos, afinal, a cidade era entendida como "resultado de uma sucessão temporal de mudanças", esvaziada de "experiência coletiva e corporal". Formar uma rede material que sustentasse visualmente esse vigor apolítico, essas "visões da história" foi o grande esforço de uma empreitada permeada de sentidos nacionalistas, mas que valorizava "a referência ao processo de mudança", como o próprio "ciclo natural da vida". A construção do visual, ou melhor, da "cidade-souvenir", como afirmam as autoras (Idem. 2009) não está isenta da instrumentalização de um campo de ideias que aderem às imagens.

O progresso eleito e enaltecido não estava apenas na codificação do referente, mas na própria profusão de imagens, explica Rezende (2011, p.44): "No modelo de sociedade capitalista, a noção de progresso e civilidade, estava intimamente associada à de abundância material. Quem tem mais e exibe mais, de acordo com os padrões que regem a sociedade de consumo é mais bem sucedido". A imagem da cidade em transformação encontrou um ambiente de forte acolhida desse repertório, até meados da década de 1950, sendo também rearticulada na mostra em 1997.

A partir da compreensão dessa rede de imagens, se reconstitui a "historicidade das vivências profissionais de uma geração, as permanências de temáticas e os contextos plurais que as sustentam e as difundem", desvelando, como afirmou Heliana Angotti Salgueiro (2007, p.307), as "estruturas perceptivas" em um tempo e espaço, "os processos de

foram editados com encadernação em capa de couro apresentando 2 volumes cada um deles, com mais de 50 fotografias, feitas a partir de emulsão de gelatina em chapas de vidro coladas em papel no tamanho $18 \times 24 \mathrm{~cm}$. Documentação disponibilizada na Biblioteca Mario de Andrade, inclusive no recurso digital. Na década de 1890, Gaensly anunciava seu interesse pelo "cenário da belle époque": "photographias de todos os systemas, copias e augmentos de todos os tamanhos; grande collecção de vistas de São Paulo". ${ }^{358}$ Repertório intensificado à luz de outros processos de visualização: pinturas, foto-gravuras, litografias, um campo iconológico que a fotografia também tomou parte, mais convivendo a opondo-se, defende Bann (2001). A capacidade de reprodutibilidade da fotografia com menores custos foi decisiva para se difundir ainda mais os sentidos e significados estruturados em outras produções de vistas urbanas; a fotografia assumia, contudo, suas específicas funções cognitivas, demonstrando o quanto a percepção visual é também um aprendizado, herdado de outras técnicas, suportes, artes e ofícios. 
apropriação e os olhares comuns", socialmente compartilhados. Vimos na mostra organizada pelo Instituto Moreira Salles como a fotografia está sempre imbricada com seus tempos múltiplos, afinal, o IMS afirmava o diálogo com essas convenções.

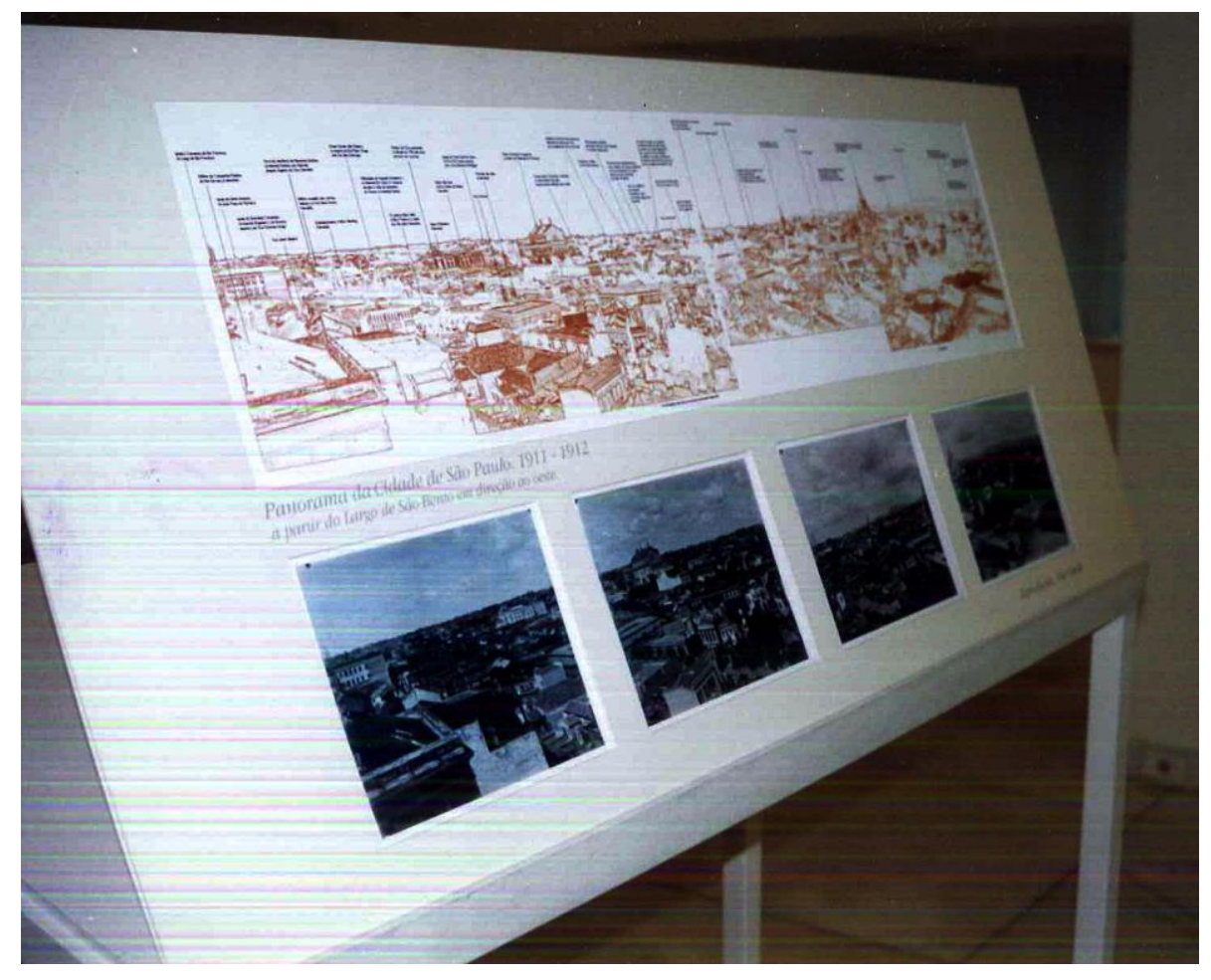

Figura 264: Desenho de Hélio de Almeida e Fotografias de Vincenzo Pastore em painel apresentado na exposição realizada em janeiro de 1997. Espaço da Galeria Higienópolis. Foto concedida pelo IMS.

A contextualização da foto-panorâmica levou ao público aspectos sobre o meio de produção do panorama, informando ao espectador como a imagem final foi reconstruída a partir de quatro fragmentos. Foi criado um desenho chamado pelo IMS de "silhueta panorama", em duas folhas justapostas, reproduzindo as imagens das quatro chapas fotográficas individualizadas (fig.264). Na parte superior da folha impressa foram inscritos textos-legendas identificando logradouros. Vê-se nessa mobilização, a partir dos quatro registros tomados por Pastore, uma articulação que indicia os meandros de uma hibridização na escolha curatorial, que remontava uma aproximação da fotografia, do desenho e das artes gráficas.

A prática da curadoria não envolve apenas sujeitos que se encontram "behind-thescenes”, mas antes articuladores e produtores de uma cultura visível, exercendo papel central tanto na organização de uma exposição, quanto na constituição dos modos perceptivos da arte, e de toda a produção de discurso subsequente, problematiza O’Neill (2012). A curadoria, ao acomodar a foto de Pastore na Estação da Luz, após o fim da exposição na galeria, recolocou 
a própria cultura da foto panorâmica em outro contexto, oferecida primeiro aos visitantes da mostra e, depois, aos usuários do metrô. Promovia-se uma circulação da imagem que se movimentava rompendo fronteiras: da galeria para o espaço físico de onde surgiu. Pastore a realizou quase um século antes, em suas caminhadas pelo bairro da Luz que agora abriga a montagem. Ao recolocarem a foto no centro da cidade, cumpria-se uma trajetória definida para a foto panorâmica: a sua exibição ampla, afinal, fotos de vistas foram sempre criadas com o intuito de serem exibidas ao público. Valério Vieira, como já mencionamos, chegou a ter nas grandes exposições espaços como galpões específicos para a apresentação de suas fotos panorâmicas. Pastore ao adentrar no IMS, passou a participar desses processos de iconização das imagens da cidade.

A organização de exibições, segundo O'Neill (2012, p.27), deve conceber a arte como ideia, como um campo mediado; entendê-lo, exigi informar sobre as ações, torná-las claras. A curadoria, nessa perspectiva, deve ser desmistificada para de fato se entender as condições de produção das exibições: "desmistificação, como uma forma de tornar visíveis essas mediações, parece ser a função necessária de tais movimentos, animações e práticas".

A imagem feita por Pastore neste mesmo local passou a ser constantemente apreciada, tornando-se parte da cidade como um patrimônio herdado e socialmente compartilhado, nuançando as formas de reorganização do mundo das imagens e a força de permanência de certos códigos visuais. Se em Pastore, como Frehse sugeriu (2011, p.480), não se via uma obstinação de cenas da cidade em transformação, no processo de acomodação posterior de sua série, vimos o instituto obstinado por tal configuração.

Inscreve-se assim a própria biografia das fotos: da caixa de papelão passaram pelo arquivo, submetida a uma política que a levou para a galeria, recriada em catálogo, para ser permanentemente abrigada no museu sem paredes da travessia da passagem subterrânea do Metrô Luz que hoje promove novas interações. As fotos, através do tempo, se inscrevem em seus novos espaços de abrigo. Neste sentido, a interpretação atenda a trajetória das imagens retoma a premissa defendida por Appadurai $(2008$, p.17) que pontua a importância de um campo teórico atento a biografia das coisas, aos seus percursos mediados socialmente, afinal, "seus significados estão inscritos em suas formas, seus usos, suas trajetórias". São as coisas em movimento, defende o autor "que elucidam seu contexto humano e social".

Deste modo, parece pertinente sondar onde reside a força dessa fotografia em chegar ao tempo presente? Onde está a sua potencialidade em se atualizar e migrar para circuitos 
múltiplos? Infelizmente não há registros escritos para sondarmos as sensações dos usuários do metrô que ali transitam, estando em contato diário com tal imagem, diferentemente do que ocorreu no espaço da mostra, na galeria do instituto.

O depoimento da espectadora da mostra realizada no espaço Higienópolis, Sandra Salgado, pode indiciar sentidos que elucidam o "boom da memória", a "obsessão cultural" por imagens da cidade, como vimos no estudo de Huyssen. A emoção de ver a "cidade de outrora" ou a chance de identificar e rever a casa dos avôs nuança traços de uma rememoração capaz de diminuir a sensação de uma perda. Mas há ainda outras camadas de entendimento:

A questão, no entanto, não é perda de alguma idade de ouro de estabilidade ou permanência. Trata-se mais da tentativa, na medida em que encaramos o próprio processo real de compreensão do espaço-tempo, de garantir alguma continuidade dentro do tempo, para propiciar alguma extensão do espaço vivido dentro do qual possamos respirar e nos mover. (Huyssen, 2000, p. 30).

A valorização da fotografia da São Paulo antiga é uma reação às transformações do próprio tempo presente. Da galeria para o metrô, promovia-se uma fruição nostálgico frente a angústia que cada caminhante/visitante traz em si. Uma experiência menos efêmera com o tempo e o contato com a matéria é oferecido ao espectador frente àquele documentomonumento. O passado presentificado responde a questões colocadas no presente, expressando o fato de que a sociedade "precisa de ancoragem temporal", reitera Huyssen (2000, p.36).

Os usuários do metrô e todo o público interessado pela fotografia ao observá-la, entravam em contato com a obra exposta, tocando, marcando e até comprometendo a imagem, tamanho o prazer em identificar. Segundo o IMS, a fotografia fixada na estação da Luz, precisou ser trocada e protegida das mãos que apontam curiosas cada espaço retratado, querendo reconhecer ruas e avenidas como um espaço conhecido, percorrido, vivenciado em outras temporalidades.

O interesse que submerge essa reativação da foto panorâmica, paisagem agora inserida em outra temporalidade, ao tempo da obra em seus diferentes desdobramentos sociais, foi também indagado por Rosalind Krauss (2002, p.11): "por que a fotografia é tão importante hoje para nós?". Pertinente questão já que tratamos de um passado preservado apenas por meio de fotos. A sedução "por uma forma de arte diretamente conectada ao real, uma arte 
fundamentalmente realista, no sentido estrito da palavra, por sua própria natureza, sua função de índice", ajuda, como menciona a autora, a explicar "a complexidade do relacionamento que a modernidade nunca deixou de cultivar com a realidade".

É ainda mais pertinente a observação de Menezes (1996, p.150) ao tratar das criações de imagens panoramas, das vistas produzidas ao longo do século XIX: o sentido de compensação motivaria tais agenciamentos. A noção de nostalgia perderia sua força explicativa nessa perspectiva. Premissa que ajuda melhor compreender as novas apropriações das fotos de Pastore, mobilizadas fora de seu contexto de produção, podendo de algum modo, manter viva a idéia de uma possível compensação, indo além de exercerem a função de síntese da cidade. As vistas agigantadas estiveram para Menezes no centro da difusão desta visualidade, dando ao homem comum, a sensação de certo domínio:

\begin{abstract}
As cenas urbanas tiveram grande impacto, sobretudo por permitirem um ângulo de aproximação capaz de compensar a perda gradual de domínio da cidade como um todo, pelo habitante comum, num momento em que a transformação e o crescimento das grandes capitais já se vinham manifestando de forma sensível. (Meneses, 1996, p.150)
\end{abstract}

Essa perspectiva analítica aponta como além de se configurar um "padrão de leitura da categoria cidade", formando um "observador da cidade" adestrado, familiarizado com os ícones recorrentes de tais representações típicas das cidades modernas, há ainda este sentido de suposto controle sobre a paisagem urbana incessantemente modificada. O relato de Angela Janoni, espectadora da mostra reforça está precisa percepção frente à montagem das fotos de Pastore, indiciando como as imagens da cidade não têm de fato, significados próprios: "Para não nos perdermos no meio de um avanço tão rápido... reconstruir através de pequenos fragmentos pessoais. O que somos hoje é resultado do que fomos ontem". A ideia de compensação e continuidade expressam-se fortemente nesse relato.

A força desta permanência vai ao encontro com aquilo que faz cada usuário do metro dedicar algum tempo diante do panorama montado. Força que envolve múltiplos agentes. O’Neill destacou "uma multiplicidade de práticas, disciplinas e posições", configurando o que o autor definiu como uma "rede triangular" onde confluem artista-curador-público, ${ }^{359}$ formadores de uma audiência inter-relacionada, em um "field of activities".

\footnotetext{
${ }^{359}$ A prática de curadoria deve ser entendida como um campo recentemente constituído, diferenciados-se das práticas mais antigas de curadoria, defendo ser hoje entendida como a produção de um discurso especifico do campo da arte contemporânea. Cf. O”Neill. 2012.
} 
Propomos agora expandir a noção de "audience" de O”Neill já que além da mostra foram criados outros suportes de circulação. O público é também aquele que compra o catálogo, o leva para casa, dá de presente, podendo ainda revisitar a obra em outro material impresso pelo IMS, o pequeno livro denominado como portfólio. Público que deseja possuir os novos documentos criados, agenciados institucionalmente, num complexo trânsito de imagens.

\subsection{Pastore em catálogo e Portfolio: vestígios de uma circulação em novos suportes de memória do ato fotográfico}

A coleção Pastore se desdobrou como parte de um projeto institucionalizado que claramente combina preservação, exposição e publicação, uma tríade de difusão interligada como vertentes de uma política de acervo que encontrava meios de se auto-divulgar. A acessibilidade das fotos, destinada a um público ainda maior, foi alcançada com a produção de materiais impressos por meio de práticas que remetem a uma mercadorização, caracterizando um novo circuito de circulação e consumo das imagens. ${ }^{360}$

A montagem da exposição potencializou um "canal de comunicação entre o museu e a sociedade" delineando uma teia de interesses em volta do material visual adquirido:

Apesar de pautadas por critérios de natureza científica, as práticas curatoriais estão longe de ser neutras, nem se dissociam de seus curadores, sujeitos às contingências de ordem políticas, econômicas e culturais, bem como àquelas ditadas pela subjetividade. (Carvalho e Lima, 2005, p.99)

Observar a produção de tais artefatos, bem como o viés interpretativo conferido às imagens em tais produtos comercializados, é um importante caminho metodológico para compreender com mais profundidade os desdobramentos de circulação da série de Pastore.

O catálogo da exposição realizada em 1997 foi logo esgotado. Apresenta um formato de $22 \mathrm{~cm} \times 21,5 \mathrm{~cm}$, trazendo na capa a fotografia de meninos jogando bolinha de gude, engraxates que levavam às costas os caixotes de madeira, artefato de seus ofícios. A escolha dessa foto revela a sutileza da "São Paulo de Vincenzo Pastore", título do catálogo, onde

\footnotetext{
360 Segundo a coordenadora executiva do instituto, a venda dos produtos vinculados à coleção Pastore, bem como de toda a documentação visual do acervo são revertidas para o próprio acervo, algumas vezes não cobrindo os investidos realizados. Além de cobrir os custos com organização de exposições e produção de matérias impressos, os ganhos valem-se ainda para a compra de novas coleções e preservação daquelas já adquiridas. Uma atividade definida como voltada para a produção do conhecimento, tratando-se de um "instituto ímpar que não visa fins lucrativos", sendo auto-financiado, não dependente de aportes financeiros. Entrevista realizada com Odette Vieira, coordenadora executiva do IMS, em novembro de 2013.
} 
desfilam a "graça e o lirismo das cenas da infância", afirma De Franceschi (1997), o qual assinou o texto de apresentação do catálogo da exposição. Mas outros sentidos aderem ao fotográfico. A infância foi tratada no texto como sendo também a da própria cidade, "porque foi a infância de São Paulo que Pastore retratou". Infância "que logo iria sucumbir ao processo de transformação destrutivo da cidade, quase sem deixar vestígios além das poucas e belas fotos que restaram". Essa quase metáfora da infantilização do espaço urbano sob mantos de destruição lembra o último ato de Fausto, assim interpretado por Barmann:

O imenso canteiro de obras, ampliando-se em todas as direções, em constante mudança e forçando os próprios figurantes a mudar também tornou-se o cenário da história mundial em nosso tempo. Fausto, O Fomentador, ainda apenas um marginal no mundo de Goethe, sentir-se-ia completamente em casa no nosso mundo. (Berman, 2007, p. 94)
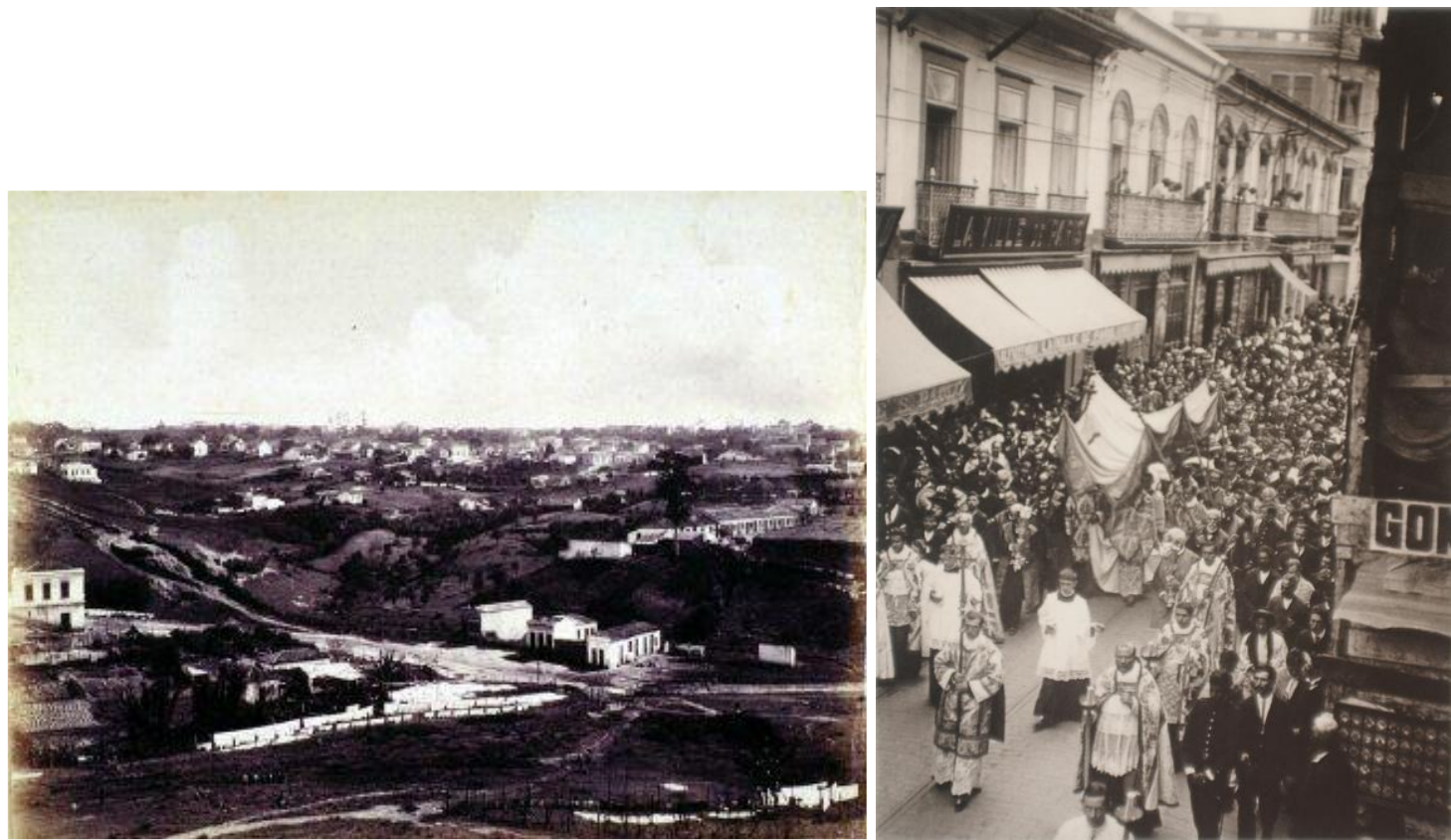

Figura 265 e 266: À esquerda Vista do "Vale do Saracura". Aproximadamente 1900. Ao centro, trecho posteriormente ocupado pela Praça 14 Bis (provavelmente). Ao fundo, casario na altura da rua Frei Caneca com Herculano de Freitas. Segundo o professor Carlos Lemos, essa região corresponde à Bacia do Itororó, e a foto foi tomada de um ponto próximo à rua do Sol (atual Samuel Neves). À direita "Procissão na rua Direita" segundo descrição do instituto a foto foi realizada provavelmente a partir do edifício onde se localizava o estúdio do fotógrafo, no número 24-A, em direção à rua São Bento. As procissões depois se apagariam do cotidiano da capital paulista. Ao lado direito, mostruário de fotos fixado na parede externa do atelier de Pastore.1910. Ambas @ Vincenzo Pastore/Instituto Moreira Salles.

Duas fotografias acompanham o breve tex to de abertura do catálogo, o mesmo enviado à imprensa como press release de divulgação e também utilizado na exposição como textoparede. A foto da procissão na Rua Direita (fig.266) e a do Vale do Anhangabaú (fig.265), onde hoje passa a Avenida Nove de julho, formam as duas cenas da cidade, tida como ainda 
criança. O fotógrafo começava a ser apresentado atribuindo-se valor documental às suas fotos. Pastore da sacada do sobrado onde residia e trabalhava acompanhou a procissão, registrando elos da cidade, em suas muitas sociabilidades. A Rua Direita surgia em Pastore reinventada pelos grupos que dela se apropriaram naquele momento de celebração religiosa.

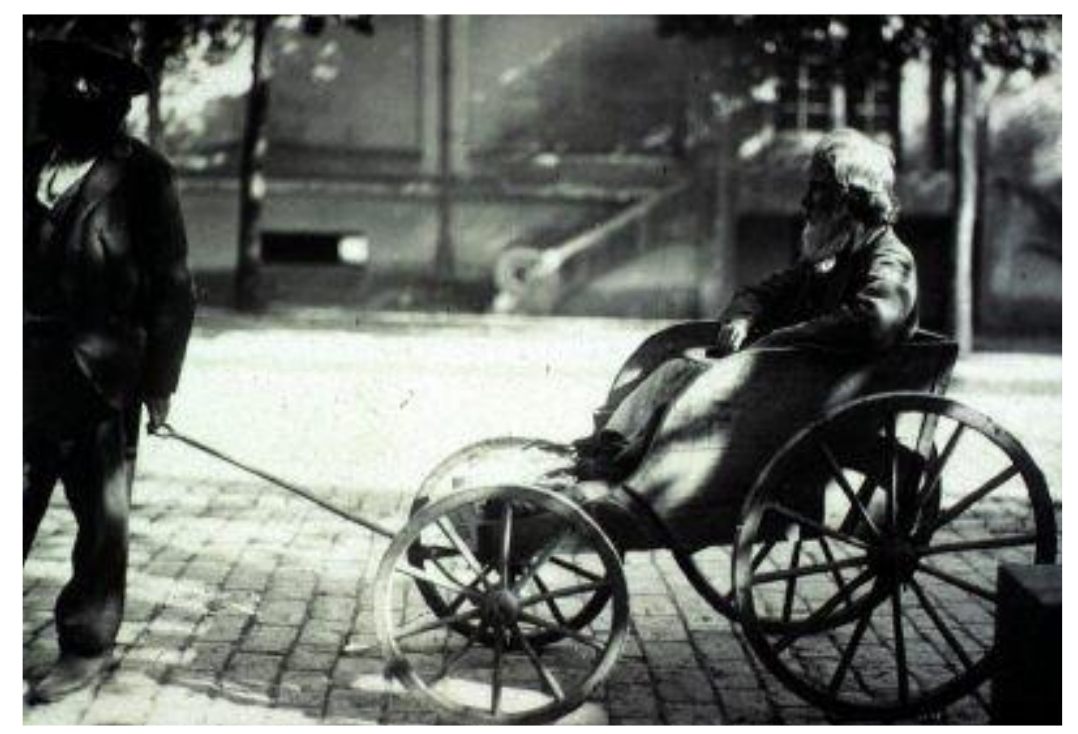

Figura 267: Fotografia em papel.

"Homem idoso em pequena carruagem”. 1910 () Vincenzo Pastore/Instituto Moreira Salles.

Se, por um lado, definiam um lugar social para Pastore como fotógrafo da cidade, por outro, definia-se no press release o papel social do IMS como uma "entidade cultural de atuação diversificada" que colocava a fotografia "ao lado do cinema, literatura e artes plásticas, como eixos predominantes de intervenção”. Biografias se mostram em construção.

O texto principal do catálogo foi assinado pelo curador Carlos Lemos (1997) e traz além do auto-retrato do fotógrafo, a foto de um homem puxando carruagem (fig.267). No verso dessa imagem há uma indicação, observada quando vimos a reprodução no original na sede do instituto no Rio de Janeiro: trata-se de uma das únicas com inscrição à lápis indicando "número 8", sugerindo uma possível intenção de Pastore em criar uma organização ou sequência sistematizada para sua série; infelizmente, não encontramos elementos suficientes para melhor aferir está hipótese.

Depois de descrever as sensações da subida da serra íngreme e os desafios enfrentados por muitos imigrantes, assim como fez Plínio Salgado (1936, p.15) ao relatar a experiência de se chegar na "terra livre da América, como um condenado", Lemos, concentrou-se longamente em mostrar "a São Paulo, que ficara cosmopolita de uma hora para outra", passando por uma experiência tida como rara: aumento populacional expressivo "para o qual não estava preparada", formação das novas elites ligadas ao café, classes médias ascendentes, 
não deixando de citar a agiotagem crescente em torno dos cortiços, das moradias populares como "as milhares casas de aluguel” que se avolumavam pela cidade, repleta de crises de abastecimento de água, epidemias, dificuldades de comunicação e vias de transporte insuficiente. $\mathrm{O}$ fotógrafo para a curadoria testemunhava esse processo de transformações.

Os novos entroncamentos das linhas férreas romperam com o isolamento do velho centro, o "célebre triângulo", no topo do núcleo urbano. Graças aos viadutos ali inaugurados, primeiro o Viaduto do Chá, depois o de Santa Ifigênia, surgiram planos de grandes avenidas e a construção de "edifícios suntuosos", redesenhando os novos caminhos na urbe. Vislumbrava-se aproximar São Paulo das cidades civilizadas, defende Lemos. O texto, que já caminharia para o fim, encontrou o momento de finalmente introduzir Pastore como um retratista das vistas urbanas. O fotógrafo começava a tomar o seu lugar numa longa tradição iconográfica:

Vincenzo Pastore não ficou indiferente a essas intervenções na cidade que
escolhera para morar. Fez, de modo meio descuidado, uma panorâmica com
sua câmera instalada no Mosteiro de São Bento e registra ali, as primeiras
demolições que permitiriam a construção do Viaduto de Santa Ifigênia.
Impressionou-se com a derrubada de casas dos quarteirões da Sé velha de
que resultou grande espaço, proporcionando inesperada paisagem. (Lemos.
1997)

A foto panorâmica realizada a partir do Largo do São Bento em direção ao oeste do centro da cidade passava a ganhar destaque absoluto no catálogo. Assim como na exposição, onde surgiu como a primeira foto que o visitante da mostra era levado a observar. As transformações urbanas e as constantes demolições marcam quase toda a retórica textual de Lemos sobre a imagem.

Os projetos gráficos das duas publicações (catálogo e no livro/portfólio "Na Rua Vincenzo Pastore”) apresentam algumas semelhantes: projetos simples, aparentemente de baixo custo, não utilização de capas-duras com imagens pequenas e centralizadas. As legendas em letras sempre reduzidas promovem uma maior fruição na leitura das imagens. No entanto, diferenças entre os materiais impressos devem ser pontuadas.

A fotografia panorâmica no catálogo foi impressa em página dupla com dobras, quando abertas ultrapassam quase duas vezes a largura do material (fig.268). Chamamos atenção para a legenda. Evidentemente foi criada uma interessante proposta para facilitar uma melhor apreciação do panorama; a legenda de cada página dupla fica no verso da outra dobra, 
ocupando o mesmo campo de visualização da imagem respectiva. Foi essa uma escolha gráfica pensando em facilitar a identificação de logradouros por parte dos leitores.

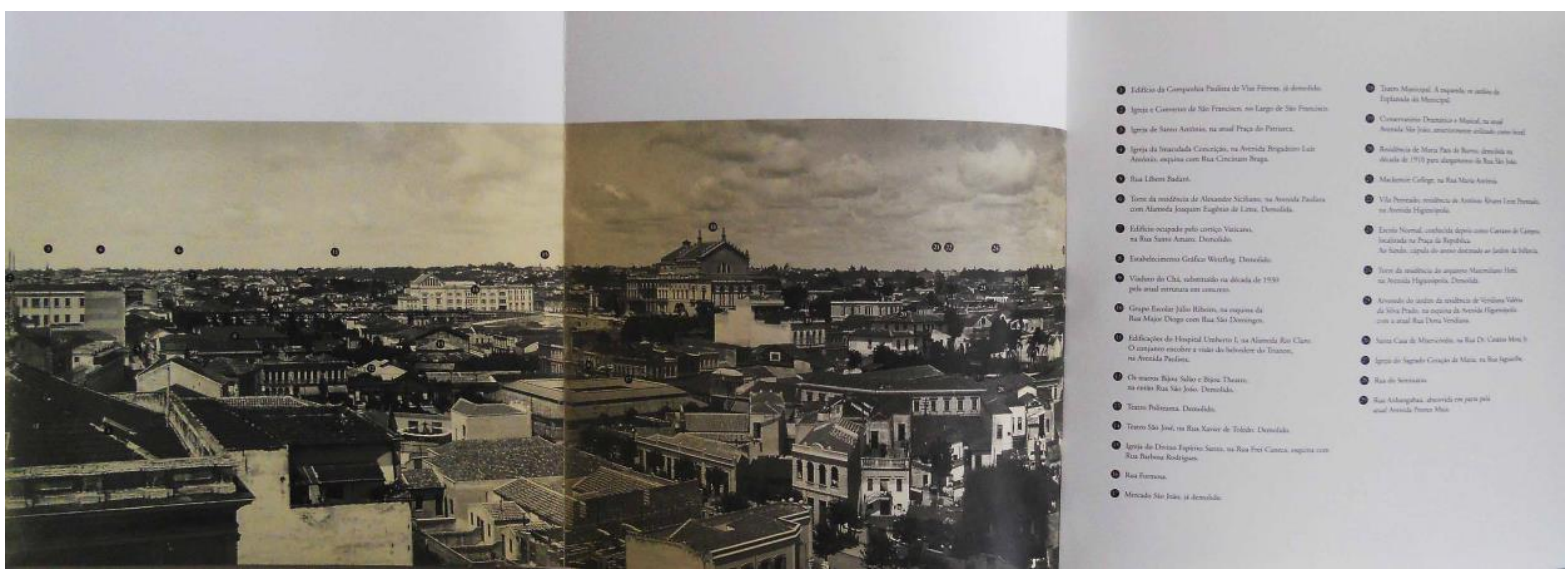

Figura 268: Reprodução fotografia de fólios do catálogo da exposição de Vincenzo Pastore no Espaço Higienópolis. 1997. Foto Panorâmica tirada a partir do Largo São Bento.

As legendas indicam nomes de ruas, de igrejas, teatros, mercados, seminários, edifícios comerciais, escolas, hospitais, dando nome aos residentes ilustres, moradores dos palacetes rodeados de arvoredos. Os novos traçados urbanos foram identificados, um a um, mostrando como a curadoria articulava uma percepção sobre a cidade. Dada essa condução o fotógrafo surgia como um profissional interessado pelas constantes transformações vivenciadas. Fotógrafo e cidade eram aqui duas imagens em construção. Sobre as noções de cidade Abreu (1994, p.223) matiza algumas percepções: "alterava-se o panorama da natureza, domesticando-a por meio das grandes obras que as invenções científicas tornaram factíveis, unir com os trilhos e fios o imenso território ainda por dominar, enfim, construir a nação". Valendo-se da convenção do registro panorâmico, Pastore era colocado em sintonia com tais transformações, expressão de um avanço também nacional.

Ao se observar as reproduções originais, notamos mais uma vez o desejo do fotógrafo pelo panorama. As duas tomadas do Largo da Sé, formariam uma vista de 180 graus. No processo de classificação das imagens indexadas no acervo, ambas as imagens foram diretamente associadas, o que não ocorreu em seus desdobramentos de circulação. Na edição do livro "Na Rua" a escolha foi mostrar apenas aquela em que se vê o homem seguindo a passos lentos com seus panelões (fig.138); na edição do catálogo, ambas estiveram ausentes. No espaço da mostra levada ao público as duas imagens foram apresentadas, mas não colocadas lado à lado, o que não promoveu uma associação da vista, fato que indicia escolhas 
aproximadas entre o material visual exibido ao público na exposição e o impresso na produção de catálogos e livros.
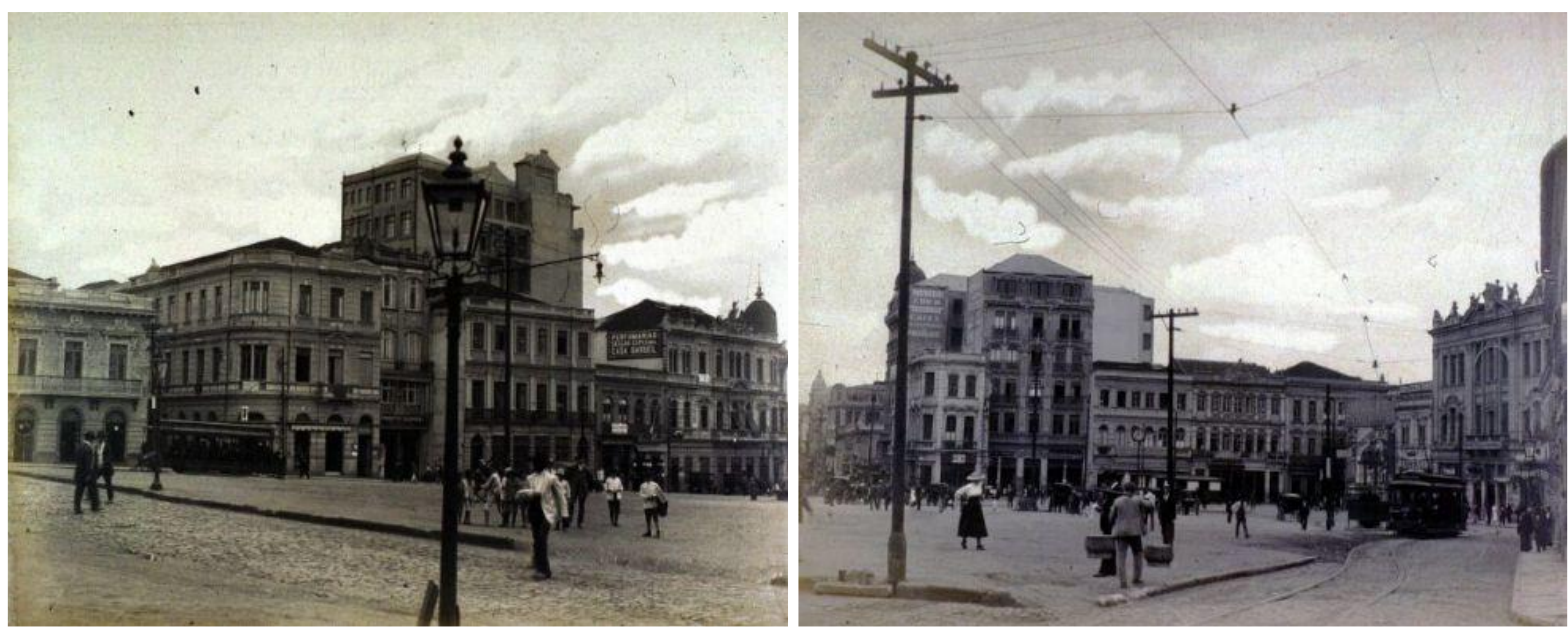

Figuras 269 e 138: "Largo da Sé". Foto à esquerda segundo a descrição de Ricardo Mendes foi tirada na altura da rua Santa Tereza, em direção ao cruzamento das ruas Direita com 15 de Novembro. À esquerda, rua da Caixa d'Água, atual Barão de Paranapiacaba. Na esquina da rua Direita, cúpula de edifício ocupado pela famosa Casa Baruel. Nenhuma das construções persiste, exceto o edifício ao lado da Casa Baruel e o prédio alto ao fundo, com entrada pela rua Direita $\mathrm{n}^{\circ}$ 7, conhecido como Casa Guinle (posteriormente, o térreo seria ocupado pela loja Lutz Ferrando).1910 @ Vincenzo Pastore/Instituto Moreira Salles

A escolha curatorial em publicar a imagem exclusivamente da direita foi reproduzida em outros contextos. No estudo de Frehse (2011), a autora apenas citou no corpo do texto a existência da segunda vista (fig.269) que completaria, segundo o IMS, a imagem à direita (fig.138). Talvez a existência de certos atributos formais, vocacional a repetida reprodução dessa única foto, que melhor retoma as cenas típicas dos cartões postais de ruas e largos centrais que priorizavam a estrutura urbana moderna. Vê-se nessa imagem de maior circulação, um maior equilíbrio de composição e perspectiva, com maior ênfase aos edifícios ao fundo, com suas fachadas ecléticas e em art nouveau, contrapostas aos elementos distribuídos nos outros planos. Destaca-se ainda a instalação da rede elétrica e dos trilhos, com a presença do bonde em movimento, além de vestígios de uma maior circulação de pessoas pelas calçadas que ladeavam as construções modernas por todo largo central, registrado em maior amplitude quando comparada à imagem à esquerda.

Nesse sentido, a produção do catálogo soube com perspicácia explorar essa dimensão em Pastore, mas abrindo mão da incompleta vista da Sé. Talvez tenhamos aqui uma vista inacabada. É possível também que tal conteúdo material tenha se perdido nos descaminhos enfrentados pela família, a guardiã da coleção. 
As vinte e oito imagens seguintes, impressas no catálogo, são apresentadas individualmente em cada página, com legendas, quando inseridas, separadas por um fio. Imagens que para Lemos (1997) guardam "para sempre aquelas cenas envolvendo trabalhadores informais engajados nos serviços terciários, agora estabelecidos na cidade grande pós-abolição e, nesse momento, as construções eram pano de fundo”.

O texto de Ricardo Mendes "Fazendo a América" encerra o catálogo, apresentando um retrato de estúdio de Pastore com Elvira, que trazia no broche levado ao peito a imagem do marido. Constam também um retrato-mimoso, a foto de uma mulher não identificada, uma foto-montagem da filha Eleonora Pastore e mais duas fotografias do estúdio Itálo-americano - Ai due Mondi, em Bari, realizada em 1914. Imagens que se articularam com a construção textual, preocupada em informar acerca da trajetória do fotógrafo, voltando-se, sobretudo, para atuação de Pastore no estúdio. Mendes, responsável pela Nota Biográfica do catálogo, nuançou em poucas páginas "a visão ampla da produção do estúdio" e o quanto o fotógrafo mantinha laços com sua terra.

É preciso dizer que aquilo que mais se destaca no catálogo foi a acertada escolha de imprimir as fotografias respeitando o tamanho original das ampliações doadas, deixando evidentes todo corte original do negativo de vidro. As bordas em preto, muitas vezes com rasgos e pequenas rachaduras ou dobraduras, com pontas desiguais, trazem aspectos do vivido pelo artefato. A sua materialidade original exibida desvela o documento em sua fragilidade, que apesar de tudo conseguiu sobreviver.

Além do catálogo foi produzido o livro "Na Rua, Vincenzo Pastore”, publicado em 2009, denominado pelo IMS como Portfólio (fig.270). Nessa posterior publicação imperava o tratamento mais formal das imagens. As bordas foram recortadas talvez percebidas como imperfeições. No total foram publicadas 43 fotografias, todas em páginas duplas. Cada fotografia foi disposta na página ímpar, considerada como página principal. A respectiva legenda e o fólio, que equivale ao número da página, aparecem apenas na página de número par, com legendas deslocadas para a parte superior. Há também, um efeito provocado no movimento de se virar cada página: a possibilidade do branco no folio par, intensificado por uma gramatura mais espessa, apaga e limpa a presença da foto anterior, promovendo-se não apenas uma maior fruição, mas também uma maior valorização de cada imagem. O campo de visão dá ênfase à fotografia como um objeto único. 


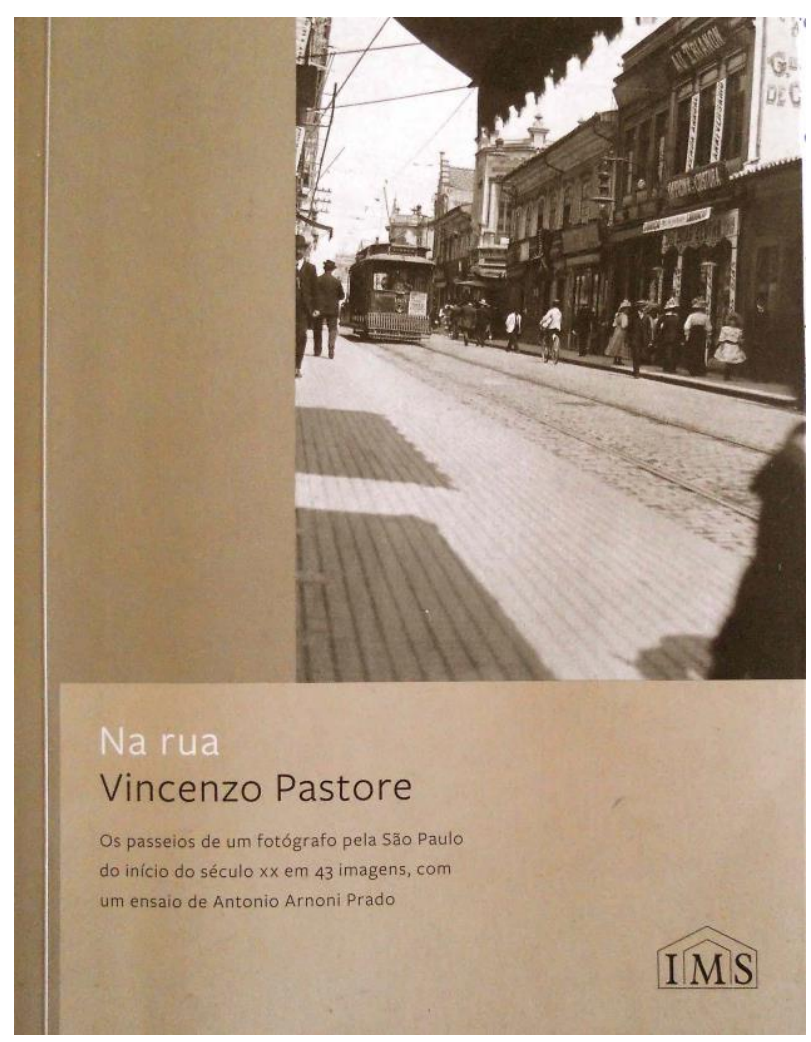

Figura 270: reprodução da capa do livro portfólio editado pelo IMS.

Antonio Arnoni Prado assina o ensaio de abertura do livro/portfólio. Foi pontuado logo na primeira página que "não foram pontos modernos, como os da Rua do Rosário, onde se concentrava a gente grã-fina da cidade, que atraíram o olhar forasteiro de Vincenzo Pastore". Entretanto, a fotografia escolhida para a capa do portfólio foi a prestigiada Rua do Triângulo: A Rua Direita, com seu calçamento já modernizado, com toda extensão de paralelepípedo arrastando o olhar do espectador do primeiro plano até a presença do bonde ao fundo.

A foto panorâmica nessa outra publicação recebeu mais uma vez bastante destaque. Trata-se de um folheto separado, com quatro dobras. De um lado se apresenta apenas a foto panorâmica montada, impressa sem nada que pudesse interferir na leitura e fruição do leitor. As legendas foram deslocadas para o verso das quatro dobras; em cada uma delas, vê-se a tomada avulsa de cada quadro que forma o panorama. Portanto, o verso traz fotos repetidas diretamente vinculadas à legenda, formando uma imagem-legenda para cada foto feita em separado pelo fotógrafo. Pontua-se novamente o valor dado à identificação de logradouros.

Se vale o relato do pesquisador, não foi vivenciado sem emoção o momento em que foram vistas as reproduções, guardados no acervo do IMS na sede do Rio de Janeiro. Ter obtido total acesso aos originais doados ao acervo foi de extrema importância para se poder constatar algo pouco evidenciado na edição do catálogo, do livro/portfólio, ou na web. 
As reproduções são reveladoras ao indicarem pontos de vistas múltiplos de uma mesma cena, dada algumas vezes em sequência, reforçando o aspecto serial de todo o material visual criado por Pastore. A narrativa inscreve a atitude do fotógrafo em acompanhar o trajeto de um deslocamento nas águas do Tamanduateí. O registro sequenciado dessa prática de transporte não foi priorizado nas edições publicadas, mas estava presente nos recortes construídos por Pastore, como vemos abaixo; negligenciar esta informação obscurece um traço do fotógrafo: algumas vezes insistiu em acomodar em sua narrativa modos articulados de compor aspectos da cidade.
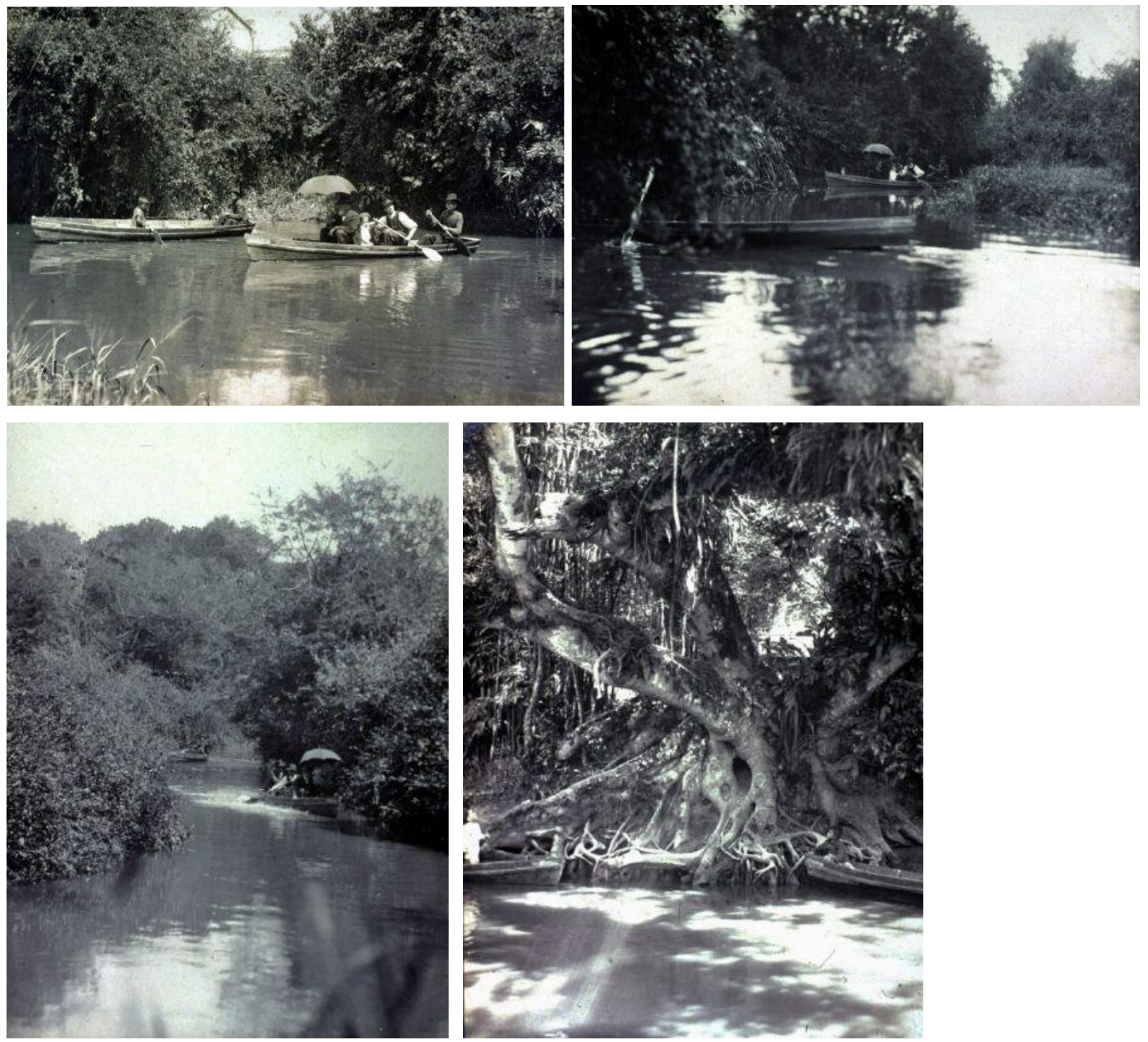

Figuras 207, 271, 272 e 273: "Barcos no rio Tamanduateí" e "Figueira junto ao rio Tamanduateí". Fotos feitas possivelmente próximas a região do Brás. Segundo descrição do instituto provavelmente trata-se de um dos braços do rio paralelo à rua Santa Cruz da Figueira, conforme a "Planta Geral da Capital de São Paulo", de 1897, organizado sob direção de Gomes Cardim. 1910 (C) Vincenzo Pastore/Instituto Moreira Salles. 
O fotógrafo documentou a circulação de canoas conduzidas por barqueiros. Ele reproduziu três fotografias, em maiores formatos, entre $12 \mathrm{~cm}$ x $18 \mathrm{~cm}$. Vê-se como Pastore acompanhou uma mesma canoa, com os mesmos passageiros, para depois indicar o ponto de parada próximo à figueira de raízes expostas (fig.273), dando sinais do ir e vir constante pelas águas do Tamanduateí. Segundo as descrições do IMS, trata-se provavelmente de um dos braços do rio paralelo à Rua Santa Cruz da Figueira. Em cada lado da imagem, pode-se ver um barco a remo, com crianças observando e tocando a árvore, importante referência para a localidade.
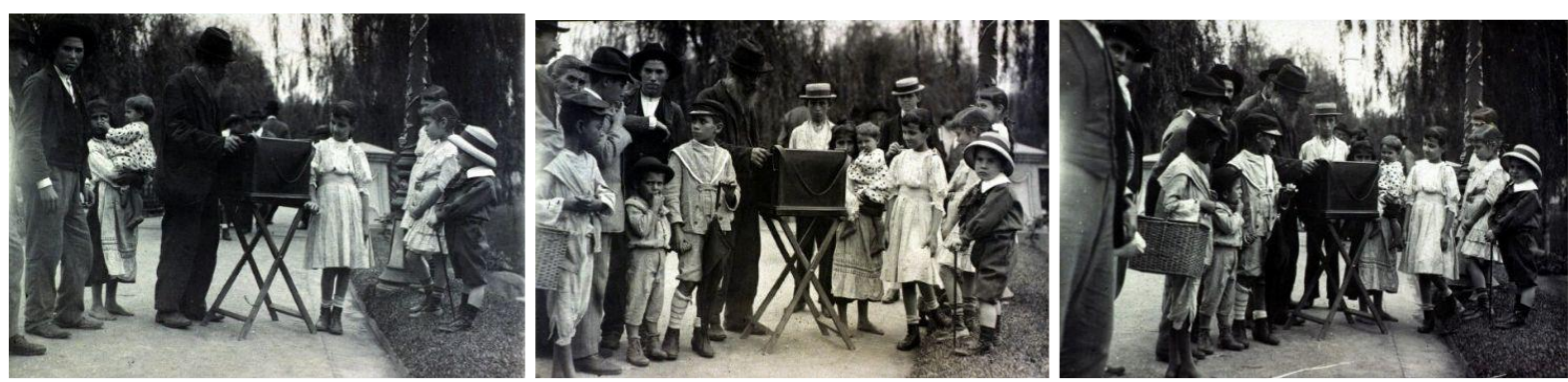

Figuras 274, 136 e 275: "Grupo de pessoas ao redor de realejo, na Praça da República". 1910 (C) Vincenzo Pastore/Instituto Moreira Salles.
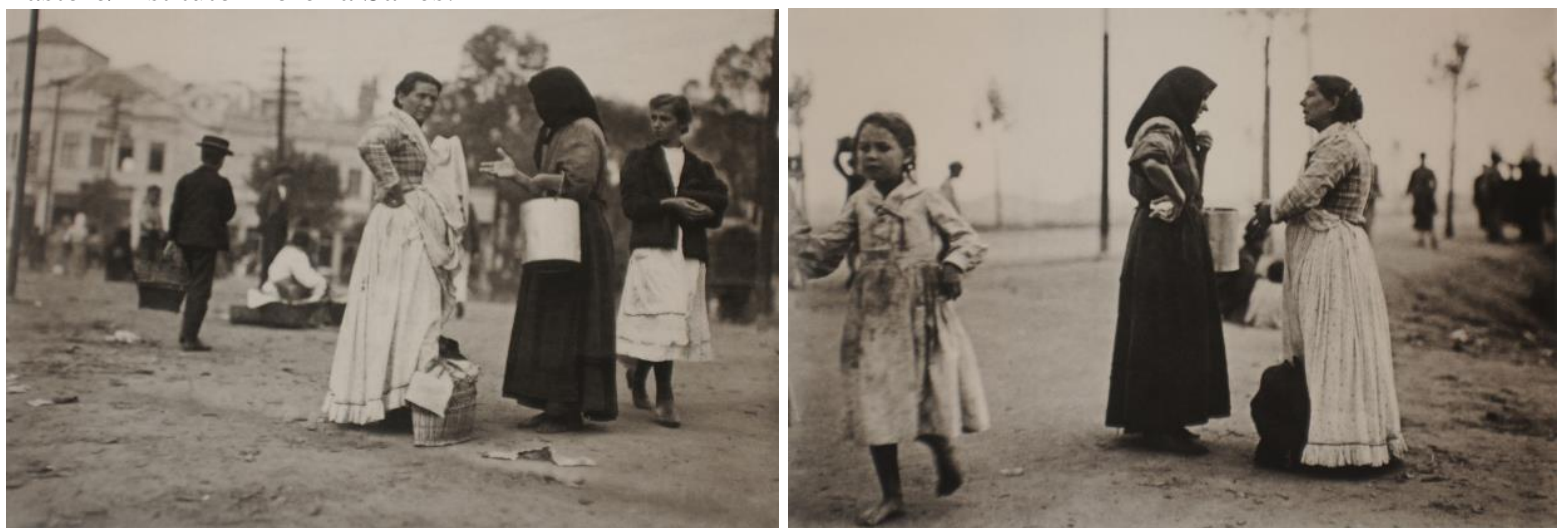

Figura 276 e 277: à esquerda "Encontro de mulheres, próximo ao mercado dos caipiras"; à direita "Mulheres conversando em área descampada". 1910 () Vincenzo Pastore/Instituto Moreira Salles.

Em outro momento sequencial (fig. 274, 136 e 275) Pastore deu foco ao tocador de realejo cercado de ouvintes e curiosos, outra composição que reforça a serialização das imagens, vista também nas cenas que retratam mulheres que buscavam sempre os melhores preços dos gêneros alimentícios oferecidos nos mercados livres, onde arrastavam suas saias de poucas folhas, vestimentas daquelas com menores recursos (fig.276 e 277).

Trata-se de uma sequência de duas imagens em composições que buscam menos detalhes e mais pontos de oposição, contextualizando a presença de mulheres nos arredores da Rua Vinte e Cinco de Março. O registro mostra a intenção do fotógrafo em evidenciar a 
circulação de pessoas, colocando em perspectiva, à esquerda, a presença de vendedores e compradores nas redes de abastecimento local.

Os recursos formais alcançados não mostram, contudo, uma imagem bem resolvida da cidade, sem nenhuma intenção de um campo visual coeso. $\mathrm{O}$ corte da avenida deixava ainda uma cicatriz mal definida. A linha de corte do horizonte não deu equilíbrio ao enquadramento, apresentando uma leve rotação de eixo do fundo. O fotógrafo aqui realizou mais de um registro de uma mesma cena, associação não impressa no catálogo, sequer apresentada na exposição.

Os aspectos cumulativos das tomadas, tradicionalmente ficavam de fora do momento de apresentação das imagens, ausentes, portanto, do discurso estético em torno da fotografia. As exposições, ou os produtos a ela relacionados, quase sempre escolhem clichês isolados: o modelo da Pintura, da imagem excepcional, da busca incessante pela obra-prima pontual, continua a predominar, explica Lugon (2007).

$\mathrm{Na}$ descrição feita pelo IMS para a imagem intitulada "Demolição" foi sugerido um aspecto peculiar da atuação de Pastore, percebido pelos curadores. Ao definir o recorte e a composição é possível que o fotógrafo, preocupado com essa vivência em transformação, tenha solicitado ao transeunte que passava na calçada do casario de portas de comércio fechadas (fig.278), que participasse da composição que iria mostrar casas demolidas em outra tomada (fig.279). Talvez Pastore tenha pedido ao rapaz para se sentar à frente dos escombros. Para o IMS, trata-se do mesmo rapaz em ambas as fotos. A imagem à esquerda foi considerada como um possível contra-campo da imagem à direita. No entanto, essa suposição não é apresentada no catálogo da coleção, nem no livro $N a$ Rua, tampouco na exposição no Espaço Higienópolis. A imagem "Demolição", assim identificada pelo IMS, não apareceu em nenhum desses circuitos sociais de desdobramento. Uma dimensão da cidade foi deixada de fora da visualidade selecionada. O antigo-colonial era signo eleito como representação da cidade escamoteando os escombros de um processo transformador que bania esse passado, demolindo tudo que pudesse relembrá-lo. 

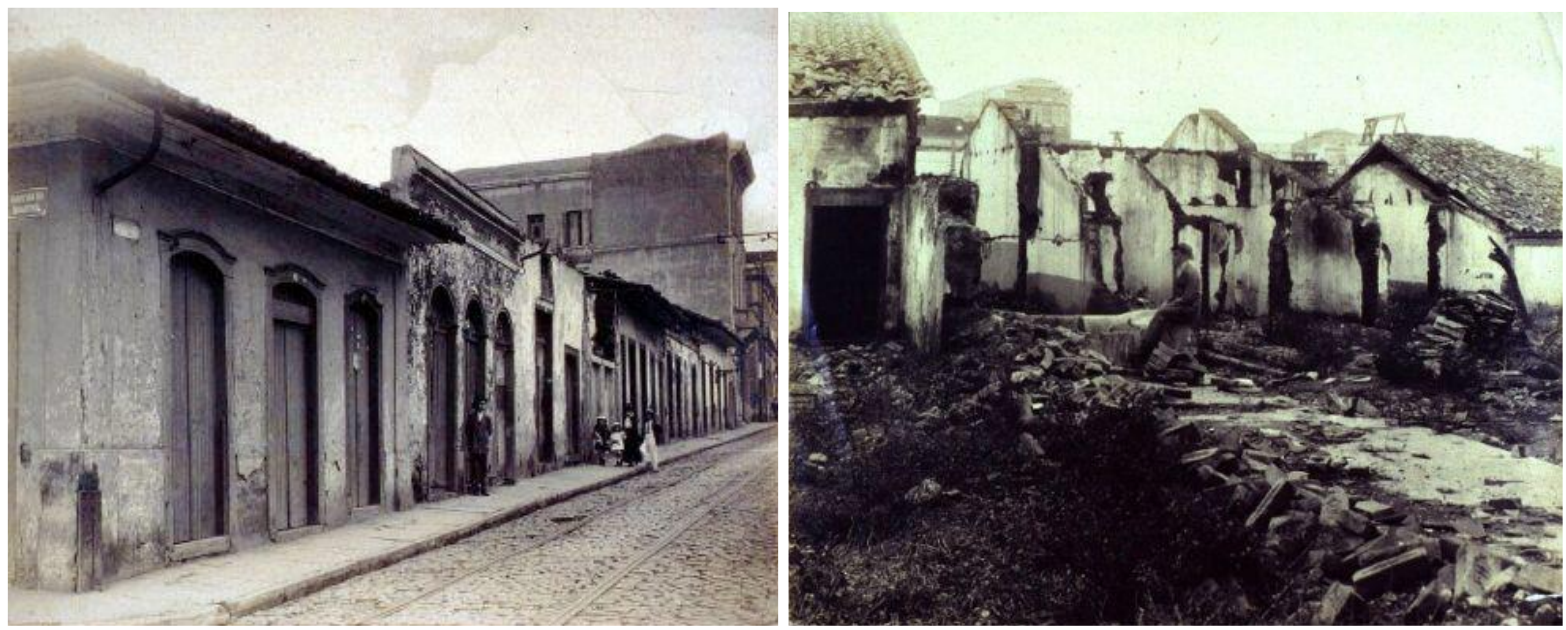

Figuras 278 e 279: À esquerda "Casario da Rua da Esperança", depois chamada de capitão Salomão. Esquina com a Travessa do Quartel. 1912. À direita, "Casario em demolição na Rua da Esperança", ao fundo, eventual obras da base da nova catedral, indicadas por estruturas em madeiras atrás das casas do primeiro plano. 1912 () Vincenzo Pastore/Instituto Moreira Salles.
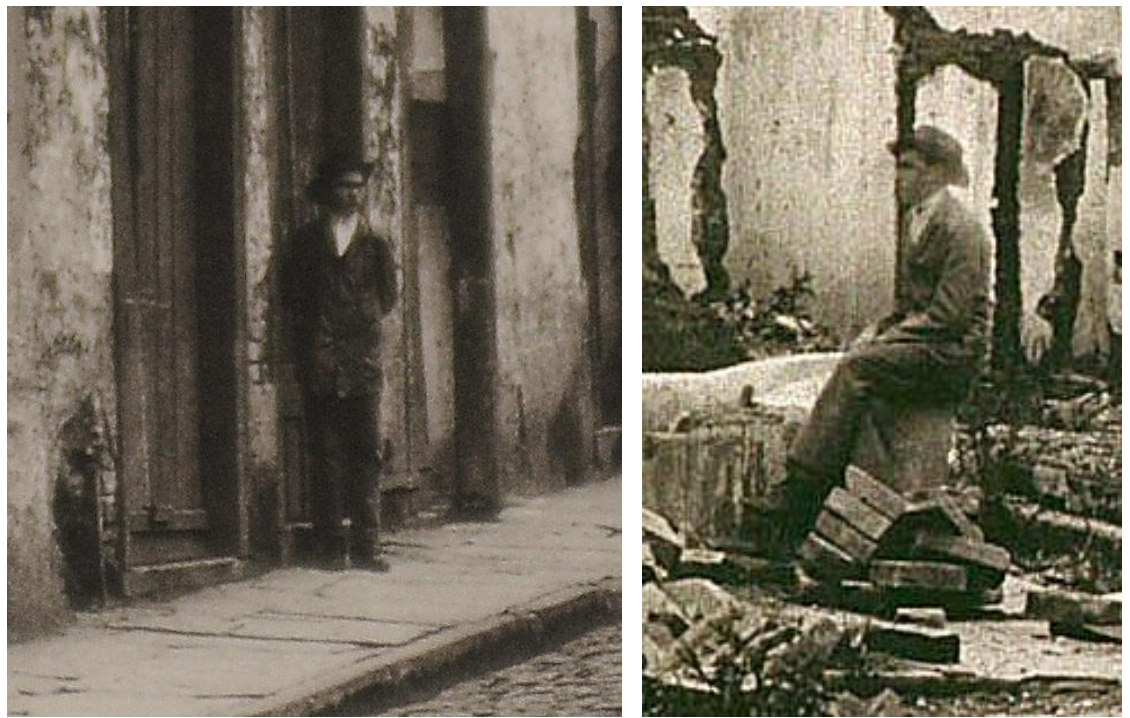

Figuras 280 e 281: Detalhes das imagens 284 e 285 respectivamente.

Os recortes foram sugeridos para melhorar a visualização do leitor e o próprio exercício interpretativo agora proposto (fig.280 e 281); a aproximação de detalhes indicia um hábito e todos os esforços que não mais abandonariam a prática dos fotógrafos que organizavam e dirigiam a cena em busca da melhor composição, contando com a colaboração dos retratados que se deslocavam de um lugar a outro, como personagens essenciais da cena urbana imaginada.

Quando Pastore retratou o casario em demolição na Rua da Boa Esperança, depois Rua Capitão Salomão, incorporada na atual Praça da Sé, imprimia os primeiros sinais daquilo que mais tarde definira os fotógrafos modernos, adeptos, segundo Salgueiro (2007, p. 134), do 
estilo documentário, às voltas com certos conteúdos visuais: "Imagens do caos, de ruínas, de esculturas quebradas, de objetos amassados, fragmentados, fragmentados ou marcas de desgaste e abandono (...) seja como sinais do tempo que passa e das coisas que se transformam (...)".

A rusticidade do espaço motivava as inúmeras desapropriações, aprovadas como medidas de utilidade pública. O conflito entre proprietários e poder municipal ganhava as páginas dos jornais. ${ }^{361}$ À reurbanização interessava apagar os vestígios coloniais da cidade banindo das travessas, becos e ruas estreitas da Sé, as casas de um pavimento com portas indicando usos comerciais, com paredes de taipa ainda resistente às chuvas. Destruía-se assim, um modo de viver tido como caipira, atrasado, banindo também a gente pobre que habitava e vivia do ganho, da venda, do abastecimento popular na região ao sul da Sé.

O referente foi aqui o objeto da transição. O fotógrafo retratou ora casas demolidas, ora sob esse risco, mostrando o seu interesse em documentar pontualmente as transformações urbanas, sem abrir mão da presença humana. O cotidiano da cidade não surgia para o fotógrafo apenas na foto panorâmica. Pastore acompanhava as minúcias deste cotidiano primeiro lendo jornais, depois saindo às ruas.

É interessante refazer o percurso do fotógrafo imaginando Pastore diante dos jornais diários, preocupado em anotar o nome das ruas onde as casas seriam demolidas. Sua filha Costanza, relembrou esse momento onde o pai, acompanhava as notícias sobre as obras de melhoramentos para depois documentar o que estava prestes a desaparecer: "Antes de demolir ele ia fotografar. Fotografias de lugares tombados. De lugares que seriam demolidos. Tudo isso se perdeu", ${ }^{362}$ lamentou Costanza, em entrevista concedida a Ricardo Mendes. Muitas fotos da cidade foram dadas de presente para amigos da família ao longo de muitas décadas.

\footnotetext{
361 Em edital publicado no dia 01 de junho de 1909, determinava-se o valor da indenização paga para a desapropriação da casa de número 8, de propriedade de Antonio Rego Veiras, no valor de 3:092\$000, valor idêntico, ao determinado no período para a casa de n.6. No dia 21 de julho de 1910, na lei n. 1336, finalizavase o processo da casa de n. 6. As desapropriações que envolviam os prédios de n.6 e 8 da Travessa da Esperança foram promulgadas lei n. 1209, em 24 de abril de 1909. A casa de n.6 foi indicada como de caráter judicial. A prefeitura finalmente autorizou o pagamento a Genésio Braulio Rodrigues, como cabeça do seu casal, a d. Antonia Benedicta de Toledo Santos e d. Adelina Amelung de Toledo. A quantia, consideravelmente diminuída, passou para um conto trezentos e setenta e três mil réis (1:373\$000).

362 Divisão de Pesquisa Centro Cultural São Paulo. Entrevista com Costanza Pastore realizada pelo pesquisador Ricardo Mendes. 1994. Costanza nasceu em São Paulo, em 1899, ano em que Pastore retornou pela segunda vez ao Brasil. No período de realização das imagens, por volta de 1910, a filha mais velha do fotógrafo já tinha possivelmente mais de onze anos de idade.
} 


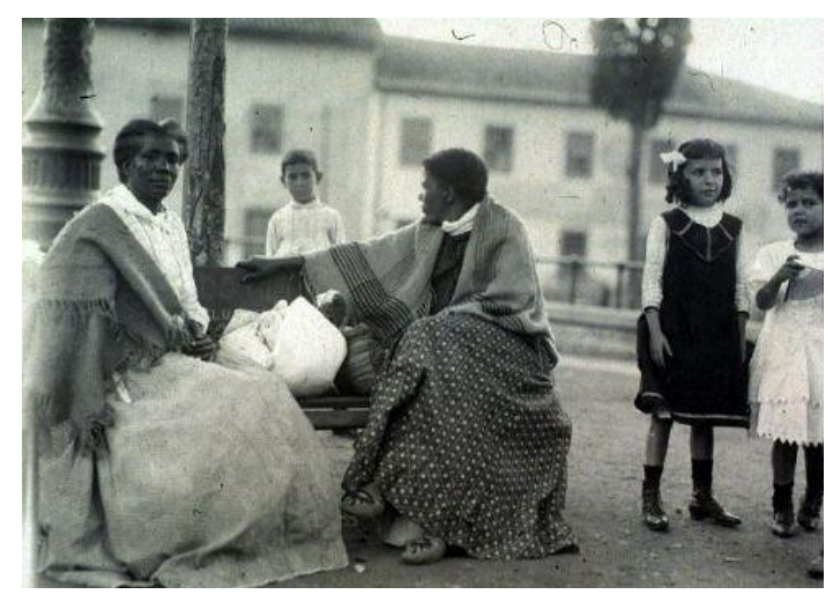

Figura 241: Mulheres conversando em banco de praça. 1910 (C) Vincenzo Pastore/Instituto Moreira Salles.

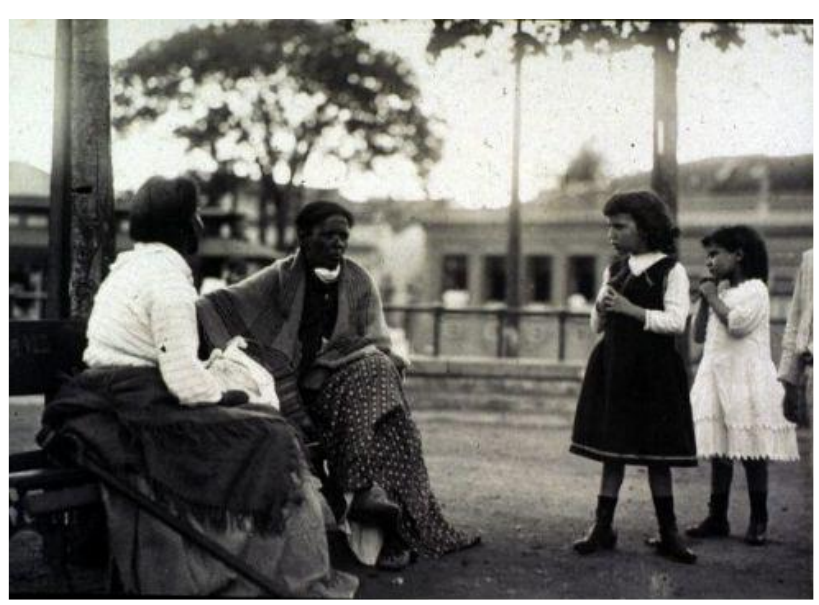

Figura 242: Mulheres conversando em banco de praça. 1910 (C) Vincenzo Pastore/Instituto Moreira Salles.

Não há como documentar com precisão se a produção de Pastore se trata, de fato, de uma produção sistemática, aspecto que acompanhava a postura do "imperativo documental" desde o século XIX. O fato de ter sobrevivido na maioria reproduções únicas não significa, como se viu, um contentamento com instantes isolados.

As imagens das mulheres sentadas em banco de praça (fig.241 e 242), não foram apresentadas em conjunto na mostra levada ao público ou nas duas publicações, no entanto, são pertinentes em mostrar como Pastore selecionava mais de um aspecto para registrar. Parece que o fotógrafo buscava a desatenção de uma delas, talvez querendo reforçar o aspecto de foto-flagrante, que permeia todo o conjunto doado ao IMS; ou teria ele, quem sabe, retratado apenas gestos sem pretensão, misturando certa informalidade com a poesia do peculiar e do corriqueiro?

Pastore reafirmava a presença dos populares, dos gestos cotidianos que afloravam pelas ruas revelando estilos de vida, contatos e interações; na atenção à população negra, 
representada nos espaços públicos da cidade, mulheres estavam firmes em sua representação, apreciadas pelo fotógrafo.

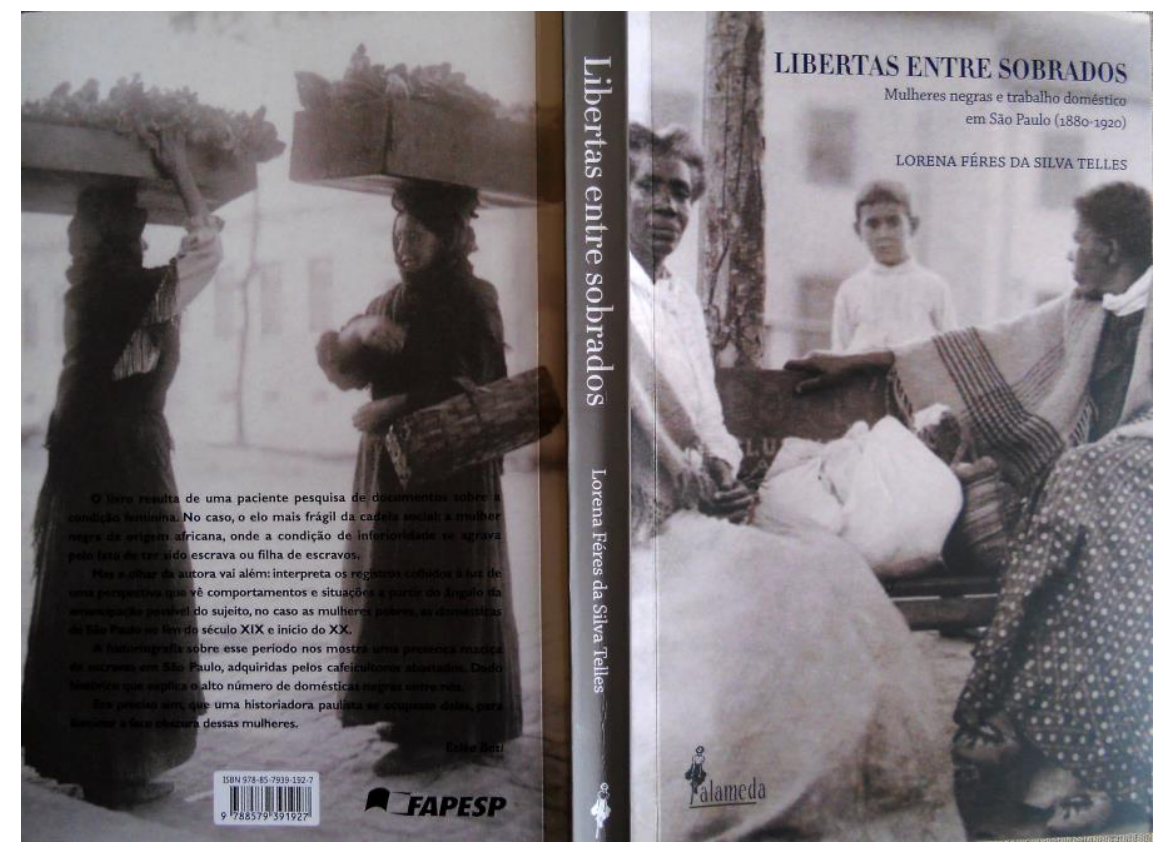

Figura 282: Reprodução capa e contra-capa do livro Telles. Libertas entre Sobrados. Mulheres negras e trabalho doméstico em São Paulo (1880-1920). São Paulo: ed. Alameda. 2013.

Essa ausência de associação direta entre as duas imagens, que cabia ao instituto promover, inviabilizou a construção de uma percepção do aspecto serial visto em Pastore, reduzindo as chances de apropriações mais amplas do material fotográfico produzido. A escolha da capa e da contra-capa do livro de Telles oferece outra instância de circularidade das fotos, reproduzidas em contexto editorial (fig. 282).

A apropriação parcial de imagens que possuem afinidade com determinado tema, resultam em escolhas dadas pelo conteúdo da imagem. A escolha da contra-capa (fotos de possíveis imigrantes), nesse caso perde a intenção serial vista em Pastore, deixando de revelar os diferentes instantes fotográficos de uma mesma cena, o que poderia oferecer ao leitor as múltiplas faces de mulheres libertas, bem como as muitas experiências que envolveram as mulheres negras em trabalho doméstico sondadas por Telles em sua pesquisa. É claro, que o autor e a editora podem sempre escolher apenas uma única imagem, mas deve ser oferecido ao público e ao pesquisador, que fazem uso de tais imagens, essa dimensão visual em Pastore, para então garantir apropriações mais afinadas com a coleção. Observar de modo mais pontual como as fotos, depois de produzidas como fontes, se fizeram no campo da história 
social, usadas muitas vezes para ilustrar períodos precedentes e carentes de representação, é o desafio que desponta como análise final agora proposta.

\subsection{A série fotográfica: entre diálogos com a história social e perspectivas familiares em busca de Pastore}

Se, partindo do pressuposto que ao fotográfico aderem diferentes sentidos, isso não deixou de ocorrer nas interpretações históricas subseqüentes à doação da coleção; sentidos foram ativados primeiro na contextualização das fotos em seu espaço institucionalizado, depois quando lançadas ao campo historiográfico.

Modelos de interpretação enraizados marcaram a abordagem das fotos tanto no texto do catálogo quanto no ensaio de abertura do livro/portfólio. Distanciando-se de tais abordagens e compreensões, pesquisadores do campo da história social assumiram uma perspectiva analítica que recusava a premissa da subalternidade, atentos, portanto, às agências e resistência das sociabilidades das camadas populares. Temos então o desafio de conduzir o leitor para esses dois caminhos que apresentaram diferentes percepções sobre o material visual criado pelo fotógrafo. Trataremos das diferentes interpretações produzidas entre 1997, momento de divulgação da série fotográfica de Pastore até 2009, ano da última publicação das fotos pelo IMS através do livro/portfólio "Na Rua. Vincenzo Pastore".

Diferentes olhares para uma mesma configuração visual delineiam as tensões que envolvem a coleção, em suas múltiplas abordagens, produtoras de diferentes Pastores! O intuito da análise trilhada nesse momento é demonstrar como "na dimensão visual, opera-se a sedimentação de determinadas visões da história" (Carvalho e Lima, 2009, p. 403)

No ensaio do catálogo da exposição, Lemos (1997) ao tratar da cidade que "ficará cosmopolita de uma hora para outra" especulou como na passagem do século, Pastore "e sua câmera viam perplexos aquela mistura incrível de nacionalidades". Se a heterogeneidade da formação populacional e os traços da mentalidade preconceituosas das elites e dos grupos emergentes foram indicados, reforçando-se o tema mítico da mistura e da cidade que crescia como estrangeira, ambigüidades de cunho evolucionista foram nuançadas na seguinte afirmação "numa seleção natural, poucos ascenderam ao cume da sociedade preconceituosa".

Se o traço dessa perspectiva histórica foi apenas sugerido nessa passagem do texto do catálogo, talvez desatento da premissa teórica que retomava, o ensaio do livro/portfólio 
assumia como diretriz teórica de modo bastante evidente, considerações que se alinharam com a historiografia que defendia a incapacidade da população negra para a vida emancipada.

Tratamos de textos que merecem maior atenção. Se o viés interpretativo do catálogo de modo indireto retomou as ideias evolucionistas da história, o texto do livro/portfólio diretamente se associava às abordagens propostas pelos estudos da Escola Paulista de Sociologia ${ }^{363}$ que produziu inegáveis considerações no reconhecimento da violência do sistema escravista, recusando as abordagens evolucionistas e a falsa idéia de democracia racial no Brasil, mas que acabaram colando o escravo sob o estatuto de vítima, destruindo o seu legado cultural e generalizando a ideia do déficit do escravo para às exigências do capitalismo moderno, abordagens que resultaram posteriormente nas teorias da "coisificação/ reificação" do escravo. ${ }^{364}$

É preciso destacar que nessa etapa de produção do conhecimento no campo da sociologia, tais análises partiram do paradigma da ausência, não contando com a vasta historiografia que se tem atualmente atravessada por uma vastidão de fontes que rastreiam os esforços e empenhos dos despossuídos, escravizados ou não.

Notamos como os paradigmas desses estudos ecoaram nas observações de Arnoni Prado (2009), autor que assina o texto do livro/portfólio. Os sujeitos sociais retratados por Pastore, segundo Prado, expressariam a "própria alma da gente sofrida da terra, inconsciente, quase à inocência, da extensão verdadeiramente desumana de seu abandono". Há uma construção de subordinação clara nessa interpretação dada às fotos. $\mathrm{O}$ fotógrafo aqui foi tido como o retratista dos sem ação, daqueles inconscientes das condições materiais e do lugar social que ocupavam.

O texto publicado em 2009 estruturou-se na dualidade da cidade dividida entre o velho repetidamente contraposto ao novo, em descrições pejorativas: as fotos foram apresentadas como um "desfile de pobreza raramente interrompido". Preso ao conteúdo restrito da imagem, o enfoque ficou comprometido pela ambiguidade.

Poucos anos antes, sob as recordações de José Bonifácio e reforçada pelo furor poético de Luis da Gama, vivia-se a explosão libertária da abolição, que culminaria em 1887: a imprensa radical avançada, os conservadores

\footnotetext{
${ }^{363}$ Este termo ou denominação que identifica o grupo de pesquisadores ligados à Florestan Fernandez e ao campo de pesquisas que tenta demonstrar os impasses da integração do negro na sociedade brasileira foi usado pela primeira vez em artigo de Vilmar Faria.

364 Cf. Fernandes, Florestan. A Integração do negro na sociedade de classes. Ensaio de Interpretação Sociológica. São Paulo: Ed. Globo, 2008. Ver também estudos de Fernando Henrique Cardoso. Capitalismo e escravidão no Brasil Meridional. 1962.
} 
recuando, os capitães do mato e os fazendeiros vaiados, os escravos fugindo das fazendas a caminho de Santos, onde caíra o cativeiro... Tudo ao contrário das fotografias de Pastore. Nelas, a vida permanece inalterada. Continuam sendo raras as imagens em que os dois campos opostos no passado se aproximam. O panorama que prevalece é o de uma São Paulo estagnada no fim do século XIX, embora já estivesse no início do século XX. Uma cidade na qual pobres, imigrantes, e ex-escravos figuram como bizarro apêndice urbano, a exibir o abandono de seu desalinho e o estranhamento da penúria que os iguala. (Prado, 2009, p.8-9)

Ao tratar dos imigrantes ou pessoas negras egressas da escravidão, o ensaio negava contatos e sociabilidades. Primeiro se afirmava: "nas poucas vezes em que se aproximavam, não se misturavam"; em seguida, hesitava-se:

É do anonimato das ruas que saem as personagens mais significativas de Pastore, uma sucessão de protagonistas em cujos rostos ele vai esculpindo a própria expressão dos movimentos da urbe: imigrantes chegando-se para juntar-se aos mulatos e caipiras, aos brancos pobres e às negras de ganho com seus tabuleiros, cruzando o caminho dos senhores de pouca posse e das mulheres humildes, garantindo fora de casa o sustento diário da família. (Prado, 2009, p. 10)

O conjunto visual de "crueza implacável" retrataria na interpretação de Prado (2009) "corpos enxovalhados"; o corpo como sinal de pano velho, roto, sem viço ou vida, iria depois associar-se não a trabalhadores imersos nas estruturas sociais de sobrevivência, mas sim a "homens famintos e enchapelados". A calçada "imunda" abrigaria, segundo o texto, "o homem cercado de farrapos que consertava a própria botina, com o pé esquerdo descalço"; homem associado a "um pária". Com pouco cuidado, segue a descrição: "seu aspecto só não é mais triste que o da peixeira labreada, olhando atenta, as mãos na cesta de vime, para o tipo sujo que aponta indeciso, cuja cara é tosca e barbada, sob as abas rebaixadas do chapéu".

Descrição dos sujeitos tidos como sujos, indecisos, estagnados, desalinhados, tidos como figuras bizarras ao contexto urbano, retomaram ideias e compreensões que consideravam a população antes escravizada como "figuras deslocadas e aberrantes", alienados e inconscientes, incapazes de seguir em "direção do futuro", desiludidos e autocondenados a uma existência “ambígua e marginal", como afirmou Fernandes (2008).

A trama textual que tratava das fotos de Pastore ao pontuar a "penúria local" como aspecto principal do conteúdo visual produzido, não conseguiu se desvencilhar desses pressupostos teóricos que explicavam o processo de marginalização no período pós-abolição, desconsiderando as agências dos sujeitos históricos, que encontravam apesar das 
contingências adversas, modos de inserção autônomos, aprendidas nas tramas de improvisação herdadas dos tempos de escravidão.

$\mathrm{Se}$ as dificuldades matérias enfrentadas foram percebidas e sublinhadas no ensaio de Prado (2009) a interpretação acabou comprometida pela ambigüidade, apesar de querer afirmar as dissonâncias e abismos sociais da cidade que "embicava para a metrópole". Afirmava-se que "negros descalços" foram tratados como "desocupados nas ruas (...) à espera de nada"; incompreensões seguiam num contínuo: "tipos toscos da rua empurram carroças encalhadas no barro; meninos sujos brincam nas praças, fumam cigarros ou engraxam os sapatos dos homens ocupados, que lêem jornais"; ou ainda: "mulheres emporcalhadas, cobertas de saias longas e grossas, xales escuros e panos na cabeça (...)".Tais afirmações diminuíam a importância dos papéis sociais ocupados por meninos que trabalhavam, por negros que viviam de pequenos bicos; mesmo tendo pontuado o fato das tais mulheres "emporcalhadas", de xales escuros, com seus cestos e tabuleiros, ganharem o sustento batendo de porta em porta, a interpretação perdeu o tom e a medida certa de apresentá-las na dignidade que possuíam.

Atílio José Avancini foi o pesquisador que escreveu o único estudo que tomava a produção fotográfica de Pastore como objeto de sua investigação. A dissertação de mestrado de Atílio José Avancini, ${ }^{365}$ defendida em 1999, foi produzida apenas dois anos após a série ter sido levada à público. O pesquisador não se valeu de conceitos evolucionistas que aprisionam os mais pobres na condição dos mais fracos, pensando o fotógrafo em seu repertório atento aos problemas da vida social. Nessa interpretação Pastore se contrapunha às ideologias dominantes do progresso, "sem esconder a nossa mestiçagem”, compondo "um quadro humano mais ampliado". Algumas dimensões sociais, entretanto, se perdem na subdivisão feita para a série: Meninos na rua de pés descalços, Negros e Trabalhadores de Rua.

Separar o universo dos meninos retratados da dimensão do trabalho exercido pelas crianças significa perder o papel relevante que assumiam no sustenta familiar. Dimensão explorada pelo próprio fotógrafo que afirmava com insistência, em sua narrativa visual, como

\footnotetext{
${ }^{365}$ A tentativa de Avancini (1999) foi a de confrontar dois pontos de vistas divergentes sobre a cidade: $O$ olhar de Pastore, retratando os populares, contraposto às imagens flagrantes das elites andando pelas ruas ou em eventos sociais. Apesar de se constituírem em diferentes percepções, Avancini, as tratou como fotografias "articuladas por um mesmo gênero, fotografia de rua".
} 
vimos no capítulo três, aspectos da vivencia dos pequenos engraxates, que podiam também já ter experimentado a função de vendedores de jornais. ${ }^{366}$

Havia muitos meninos também vendedores de jornais, saltando de um bonde a outro, atravessando bairros, até chegarem onde moravam, onde tentavam vender os últimos exemplares, dividindo os mesmos estribos com os pequenos engraxates. Crianças que recorriam aos jornais quando algo atrapalhava o ganho pão de todo dia.

Vieram a nossa redação os pequenos vendedores de jornaes - em numero superior a quinze- pedir-nos fazermos uma reclamação ao poder competente, á vista de uma violência que estão sofrendo no uso da sua profissão. (...) a policia exige que eles compareçam a aula de um padre justamente na hora que devem ganhar o pão para a boca vendendo os jornaes. (Jornal A Capital. 25 de julho de 1913)

O estudo de Avancini de 1999, lentamente passava a enfocar o conformismo e a suposta anomia da população negra retratada. Ao afirmar que "a cultura negra há vinte e poucos anos de sua recém liberdade, se adapta à cultura dominante (...) Caracteriza-se mais pelo conformismo do que pela resistência", Avancini inclina-se para as conclusões distantes das contribuições que o campo historiográfico já apresentava no período para melhor se recuperar os papéis sociais dos sujeitos retratados por Pastore.

Quando Avancini afirmou que os trabalhadores retratados por Pastore "não progridem nem retrocedem" num contexto que "revela-se pálido, solitário, indefinido", ou ainda numa "atitude corporal dos indivíduos de desânimo" visto como sujeitos que "esperam o trem da história passar" negou o campo de forças em que atores sociais retratados atuavam. Os estudos de Thompson (1998), em sua abordagem crítica às concepções que defendem a noção de uma hegemonia capaz de "impor uma dominação abrangente aos governados", já bem demonstraram a força das atuações dos grupos que recusam as categorias da subordinação. $\mathrm{O}$ campo de conhecimento se enriquece quando recusa concepções deterministas da história,

\footnotetext{
${ }^{366}$ A profissão de vendedor de jornais foi regulamentada pela lei 1428 de 26 de maio de 1911, proibindo o exercício da profissão sem a devida licença concedida pela prefeitura. As determinações restringiam o ofício aos menores de 13 de idade, a todos que não tivessem o consentimento de seus representantes legais, quando menores de idade, devendo sempre carregar a carteira de identidade expedida pela polícia, levando do lado esquerdo do casaco uma chapa de metal com o número da matrícula e a inscrição "jornaes", prova da regularização d atividade. Estavam proibidos por lei de subir nos estribos dos bondes. Quando maiores de 20 anos pagariam além da taxa de matrícula de $2 \$ 000$ obrigatória a todos, mais um imposto anual de $10 \$ 000$. Ver Ementa da legislação Municipal: Resoluções, Atos e decretos-Leis do Município de São Paulo. 1892-1947.
} 
afinal, como defendeu Thompson a "hegemonia só pode ser sustentada pelos governantes pelo exercício constante da habilidade, do teatro e da concessão". ${ }^{367}$

A construção do conhecimento histórico se faz por meio desses diálogos, dessas verdades parciais acumuladas, deste constante revisitar de análises, que contam com um campo historiográfico em constante construção, fundamental para alargarmos as percepções históricas, em suas novas perspectivas, afirma Le Goff (2003). Um campo onde as ideias também envelhecem como Revel (2000) já declarou. De tempos em tempos elas se mostram limitadas, incertas, por vezes ambiciosas demais. Talvez nos textos e ensaios apresentados, seus autores não haviam se dado conta dos novos caminhos já propostos pela história social que se contrapunha aos modelos de interpretação mais antigos.

Novas abordagens históricas já se destacavam ao fim da década de 1990, tentando compreender a cotidianidade a partir de outros procedimentos e pressupostos, dentro do campo de trabalho da história social. Maria Odila Leite da Silva Dias, em Quotidiano e Poder, por exemplo, já lançava luz desde 1995, para as ações dos grupos tidos como subalternos, mas que provocavam desde meados dos oitocentos a remodelação do espaço urbano de sobrevivência através de uma rede de comércio de abastecimento que dominavam.

Não se pode esquecer que a mesma capacidade de improvisação e recusa à subordinação vistas no período escravista, foi levada como herança indissociável da experiência no pós-abolição. Não se pode deixar de documentar nessa nova contingência, apesar de poucas rupturas, a astúcia de uma população que sabia negociar o melhor preço para enfrentar a concorrência, como bem demonstrou Dias; ao se compreender os laços de vizinhança e solidariedade, vê-se como não estavam nunca sozinhos, mas antes envolvidos numa troca a troca de informações nas ruas, nas irmandades organizadas historicamente onde mantinham seus espaços culturais de resistência, ou nas associações de ajuda mútuas promovidas pelos imigrantes; perde-se muito ao negar o horizonte de futuro e um presente de resistência de sujeitos que eram impelidos a improvisar, em vivências sinuosas, obrigados a sair às ruas e se dedicar ao comércio e atividades socialmente desqualificadas para sobreviver.

\footnotetext{
367 Thompson se opunha "a visão, popular em alguns círculos estruturalistas e marxistas na Europa Ocidental". Ele definiu o conceito de hegemonia como necessário e valioso, mas recusa premissas deterministas ou automáticas na constituição da vida e das experiências sociais dos sujeitos históricos. Os grupos destituídos de poder encontram meios também simbólicos de ameaça, de insubordinação, num ambiente de resistência, nem sempre direta e evidente, mas presente em meio a uma cultura que não pode ser entendida como um conceito homogêneo ou ultraconsensual. Cf.Thompson, 1998, p.22-79.
} 
Outros pesquisadores ficaram comovidos com a série fotográfica produzida por Pastore porque tais imagens eram capazes de revelar a feição histórica que investigavam por meio de fontes escritas. No estudo de Cristina Wissenbach (1997, p.146) "Ritos de Magias e Sobrevivência. Sociabilidades e práticas mágico-religiosas no Brasil (1890-1940)”, as fotos de Pastore foram tomadas como fontes complementares porque, segundo a autora, permitiam "materializar um pouco mais as dimensões de tempo e de espaço às quais se refere à documentação" que pesquisava. As fotografias, dada a sua vocação documental, propuseram assim um encontro entre o desejo de maior visualização e aproximação de um passado que os pesquisadores conseguiam, até então, entrever em documentos apenas escritos, lidos à contrapelo.

O caráter indicial da fotografia, entendida como vestígio, como fragmento descolado do passado, garantia a sua apreciação. A tomada das fotos de Pastore como documento sustentase naquilo que Derrida (2012, p. 293) chama de "efeito de rastro" dado a "origem do cultual e do testamentário" inerente ao fotográfico, assegurando, de acordo com o autor "a possibilidade dos deslocamentos da obra, da sua circulação". Sentidos esses que estariam na base, no "debaixo da obra", ordenando toda a sua estruturação.

Os horizontes de crenças e práticas religiosas populares que Wissenbach sondava se materializariam nas vivências visualmente registradas por Pastore. Essa capacidade da fotografia de "marcar uma data", como defende Derrida (2012, p.308), revela o aspecto "irredutivelmente próprio ao fotográfico". Dessa "suposta" existência do referente, nasce uma confusão que tem origem "no desejo que avança na direção do outro, o outro inegável, mas apenas prometido através de seu duplo, através do véu, do filme, da película do simulacro".

O desejo de ver movimentou a tomada das fotos da coleção VP. Temos, em Wissenbach, uma compreensão sobre o fotográfico, mas também a expressão de um desejo em ver o outro, num posicionamento dentro de um campo historiográfico que valoriza os espaços de sobrevivências de sujeitos sociais que conquistavam relativa autonomia ao ocuparem papéis sociais informais, que exigiam vocação para o improviso diante de conjunturas adversas, instáveis, precárias, como descortinou Dias (1995). Posturas historiográficas que tanto ajudaram nesta abordagem da materialidade criada por Pastore, norteando a presente pesquisa:

No registro dos diferentes tipos sociais das ruas, o olhar do fotógrafo sensibiliza-se mais ainda, ao colocar lado a lado homens, mulheres e crianças, uns trajados com vestes e sapatos próprios a momentos diletantes, e outros improvisando o diletantismo no curso de seus afazeres: negros e 
negras, caipiras e imigrantes, vendedores e vendedoras ambulantes, alguns de pé no chão, carregando e ofertando diferentes produtos, sem se esquecerem de seus patuás protetores, sem esquivarem de longas conversas, possivelmente nestas, todas as informações corriam soltas. (Wissenbach. 1997, p. 146)

Entre as fotografias escolhidas como fonte no estudo de Wissenbach, lá estavam as duas mulheres negras em banco de praça, "indiciando que ainda sobrava tempo para as conversas". Nas legendas das fotografias do vendedor de cestos e vassouras e das vendeiras de aves, Wissenbach ressaltava que tais sujeitos históricos "não deixavam de se fazer acompanhar de seus amuletos". Deste modo, a autora encontrava nessas fotografias os vestígios das sociabilidades que se esforçava em documentar, desvelando a importância da produção de Pastore para o campo dos estudos do cotidiano:

A luta pela sobrevivência, questão que se colocou em última instância atrás das práticas mágicas, implicava também em vencer o outro, projetando-se individualmente através, quem sabe, das fórmulas de sucesso que eram oferecidas pelos homens das práticas mágico-religiosas. ${ }^{368}$

O desejo de ver e se aproximar do outro pela fotografia, o outro, neste caso, visto parcialmente nas representações escritas, quase sempre enviesadas pelo relato oficial, delineia a apropriação de tais imagens por historiadores interessados pelo "passado irrecusável", como mencionou Derrida (2012, p.310). Wissenbach firma uma postura metodológica tratando as imagens como representações emblemáticas de uma sociabilidade, afirmando o quanto ficou comovida ao ver as imagens de Pastore exibidas na mostra. De modo preponderante, a autora, ao incorporar a fotografia de Pastore como um importante vetor de sua interpretação, mostra como no processo de iconização das imagens, o fotógrafo tornava-se referência para os estudos do pós-abolição. Uma interpretação que não o encerrava como um fotógrafo/autor, superando assim percepções vagas e abrangentes apontadas pela curadoria. As representações realizadas por Pastore, para a pesquisadora, mostram uma cidade com características próprias onde convivam os aspectos modernizantes e coloniais, urbanos e rurais. A "excepcionalidade"

\footnotetext{
368 Wissenbach. Julho/1997, p. 161. No ano seguinte, Wissenbach publicou também artigo "Da escravidão a liberdade: dimensões de uma privacidade possível", onde também incorpora algumas fotografias de Pastore em sua análise. Há neste artigo a indicação de que muitos dos amuletos usados como seriam possivelmente confeccionados de dentes de porco-do- mato. Cf. História da Vida Privada. República: da Belle Époque à Era do Rádio. V.3.1998, pp. 50-130.
} 
de Pastore reside em sua atenção para as tramas de uma cidade marcada por rupturas e permanências flagradas em seus registros. ${ }^{369}$

Nota-se também como a coleção Pastore atendia a essa demanda frente à invisibilidade de uma época, respondendo a esse interesse dos pesquisadores pelo cotidiano. Maria Luiza Ferreira de Oliveira, em sua tese de doutorado, defendida em 2003, depois publicada em livro em 2005, escolheu seis fotografias de Vincenzo Pastore: a fotografia da procissão da Rua Direita, carroceiros recolhendo lixo, a fotografia da lavadeira estendendo roupas às margens do Tamanduateí, dois senhores conversando de pé em calçada, a imagem do vale do Anhangabaú e, mais uma vez, o vendedor de cestos, espanadores e vassouras, com seu amuleto levado ao peito.

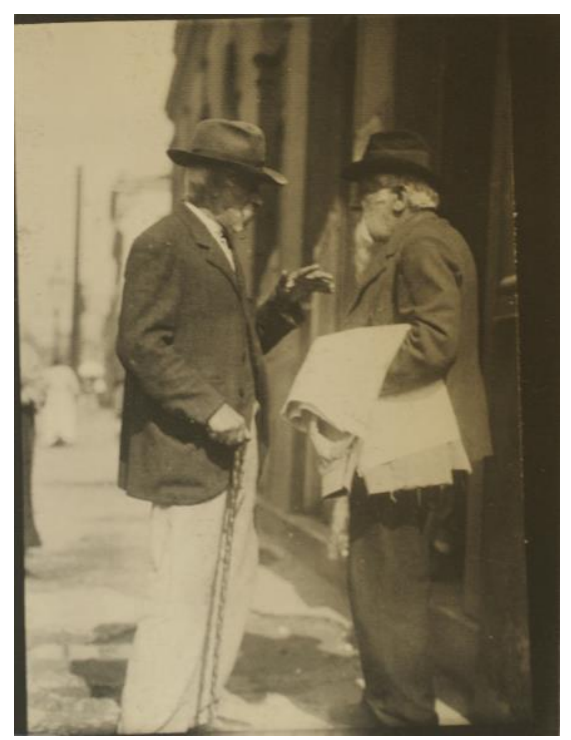

Figura 283: "Dois homens conversando na calçada". Um deles leva ao braço roupa embrulhada em jornal. Seria ele um alfaiate fazendo sua entrega? No verso dessa fotografia foi escrito a lápis o número 20 o que pode indiciar uma tentativa de organização da série realizada. 1910 ( ) Vincenzo Pastore/Instituto Moreira Salles

Oliveira, ao documentar a importante relação de crédito e a difusão de empréstimos que envolviam comerciantes, homens e mulheres pobres e livres, e até mesmo escravizados, não resistiu aos efeitos associativos possíveis entre suas fontes escritas, majoritariamente inventários, e a fotografia de dois supostos imigrantes (fig.283). A capacidade de imaginação que ronda o ofício do historiador, como destacou Marc Bloch (2001), acompanha a legenda feita por Oliveira (2005, p.134) que, por outro lado, desconsidera o contexto de produção da série: "dois senhores numa rua de São Paulo se encontram e combinam um negócio: não teria um dinheiro para deixar comigo? Por três meses, se vencer pago $1 \%$...”. O tratamento dado à

369 Informação pessoal. A pesquisadora Wissenbach foi uma das professoras que integrou a minha banca de qualificação e também de defesa da tese em 18 de junho de 2015. Em ambos os momentos declarou o quanto ficou comovida quando se deparou com as fotos de Pastore exibidas na galeira do Espaço Higienópoles do IMS. 
foto reitera o uso da imagem como ilustração de tempos e diálogos precedentes ao da feitura do retrato.

Ao sondar tais "espaços de improvisação na luta pela sobrevivência", Oliveira tecia a sensibilidade do historiador - intérprete, também valendo-se da imagem do vendedor de vassouras para explicar como a cidade crescia incapaz de abrigar imigrantes ou nacionais em empregos fixos. As ocupações retratadas para Oliveira mostravam os "diversos expedientes encontrados para contornar a fome e a pobreza". Nota-se a recorrência dessa fotografia, escolhida por Wissenbach e Oliveira. Mesmo que escape a intenção do fotógrafo, a imagem do vendeiro cercado de seus pertences postos à venda redimensionava a modernização que tentava se constituir, indiciando que práticas antigas de sobrevivência, e de fé, não haviam sido eliminadas. A coexistência de costumes e condutas herdadas era o que se tinha de peculiar na modernização em curso, não sustentada em falsas oposições. Isso talvez explique a atração provocada pelo conteúdo visual guardado por Pastore, que tanto comoveu os historiadores.

Nesse sentido, as autoras ofereceram interpretações menos pejorativas, atentas às minúcias do trabalho e às fímbrias de uma urbanização que se consolidaria na década de 1930, ao peso de um enorme custo social. Em ambas as abordagens, o trabalho de Pastore veio dar feição aos rostos anônimos que os pesquisadores entreviam nas fontes escritas, nos processos-crimes ou inventários, ou ao menos, de modo secundário, nas imagens que destacavam o urbano em construção. Temos assim o encontro da série fotográfica com a demanda de um campo da história social que não subestimava o ardil cotidiano de improvisação, comprometido em documentar mais profundamente, e de modo menos preconceituoso, as vivências documentadas.

No tratamento das imagens dado por Oliveira, ressalta-se, por sua vez, o caráter da foto tida como ilustração, cometendo-se alguns equívocos. O uso das fotografias também se deu sob o desejo de oferecer uma imagem do passado histórico investigado, entretanto, as imagens produzidas por volta da década de 1910 foram articuladas com relatos e documentos escritos referentes a períodos anteriores. A fotografia dos carroceiros recolhendo lixo ilustrou a passagem do texto em que a autora tratava das condições de trabalho de cocheiros em São Paulo décadas antes. A fotografia de Pastore realizada entre 1908 a 1914, daria, para Oliveira, a dimensão do cotidiano de trabalho de Marcelino Alves da Cruz, em 1874, e do carroceiro alemão Francisco Buchmann, falecido em 1878. 
$\mathrm{Na}$ ânsia de dar maior visibilidade às sociabilidades investigadas, alguns procedimentos provocam efeitos na tomada do material visual. As fotografias migram para outros contextos, nem sempre relacionados às especificidades do corpus documental tratado. A despeito de possíveis equívocos, sabe-se da raridade de representações do cotidiano na visualidade da cidade de São Paulo. Pouco se documentou visualmente as contingências da população mais empobrecida, envolvida com trabalhos desqualificados, provocando uma carência de tais registros. Queremos apenas destacar como as fotografias realizadas por Pastore davam visibilidade a sociabilidades que interessavam e atravessavam as pesquisas dos historiadores sociais, sendo mobilizadas como imagens de informação, também do século XIX, inclusive de seus primórdios.

Esse procedimento que confunde noções de tempo e espaço específicos do processo de produção das imagens, forjando pontos de convergência em nome de uma fruição visual associada ao texto, ocorreu também na produção do documentário sobre o cronista da "São Paulo de Juó Bananeri”, dirigido por João Cláudio de Sena. Ao tratarem da população “instável e misturada", de início de século, remanescente da escravidão e das levas imigrantistas, num contexto social de usos ainda caipiras, pensando a cidade e o próprio Juó Bananeri como "produto desses cruzamentos de uma massa desenraizada", ${ }^{370}$ as fotos de Pastore foram tomadas quando a voz do narrador do documentário se referia aos traços provincianos vindos do início do século XIX; as imagens da coleção foram ora articuladas como referente visual da pobreza da cidade, desde o tempo de sua fundação, ora intercaladas com imagens realizadas por Militão Augusto de Azevedo, na década de 1860. O distanciamento de contexto é surpreendente em tais agenciamentos.

Enquanto o depoimento do historiador Nicolau Sevcenko tratava no documentário do contingente humano da cidade que se constituía, sobretudo, de mulheres e crianças, já que os "homens construíram suas experiências fora da cidade", as fotografias de Pastore foram mobilizadas na edição de imagens do documentário para ilustrar o relato do historiador que se referia a uma cidade de meados do século XIX. O tratamento das fotos conferido pelo editor João Claúdio de Sena, tentou ilustrar a contingência da formação da cidade, tida historicamente como um burgo desprezível. As imagens das vendedoras ambulantes com seus tabuleiros, e muitas quituteiras, dos meninos jogando bolinhas de gude ou das duas mulheres conversando em uma calçada da cidade, cercado de cestos de verduras e frutas, se misturavam

\footnotetext{
370 Relato do historiador Elias Tomé Saliba, um dos pesquisadores entrevistados no documentário de trinta minutos, "São Paulo de Juó Bananeri", dirigido por João Cláudio de Sena em 1998. Disponível na web.
} 
nessa apropriação, à narrativa da cidade antes da expansão cafeeira, que viria a alterar esse quadro de ocupação.

Abrigavam-se nas imagens sentidos de convergência de diferentes temporalidades, como se pudessem formar uma imagem única de um passado visto como decaído. Um sentido, portanto, fora da imagem, usada como atestação e figura metonímica de um período pouco promissor que antecedia ao momento da produção das imagens, como se Pastore tivesse criado um material visual para ilustrar todo o período oitocentista, do começo ao fim. Sob o status de ser inédita, a série fotográfica foi abraçada denotando o seu valor histórico e uma vocação inventada quando tomada e retomada por diferentes agentes.

O curta metragem "Flávio Varani: Projeção", com direção de Paulo Cesar Toledo, traz uma reconstrução sensível sobre o fotógrafo. Pastore foi visto pelos olhos do neto, responsável pela doação feita ao IMS. Flávio Varani, doador da coleção VP, em seu depoimento, dava lentamente significado às imagens, ao passo que desvela aspectos da trajetória do avô, da mãe, da própria trajetória familiar marcada por sonhos, ressentimentos e idealizações construídas em torno de um Pastore projetado, construído por memórias também afetivas. A força do relato, que explica a trajetória de Flávio Varani como músico de sucesso foi associada, em quase todo o transcorrer do documentário, à serie de fotografias realizadas por Pastore, merecendo ser transcrita na íntegra. Palavras que nuançam muitas lembranças e mostram agora sentidos mais íntimos que aderiram às imagens criadas por Pastore:

A minha vida de artista eu devo a existência do meu avô. Meu avô era uma pessoa que eu nunca encontrei. Ele morreu muito cedo na vida e ele tinha sido um fotógrafo muito inventivo. Ele inventou um tipo de fotografia que se chamava fotografia mimosa. A fotografia mimosa era um cartão de visita com a fotografia do sujeito. Com isso ele ganhou muito dinheiro. Ele usou. Ele gostava de viajar. Punha a família inteira num navio, e passavam semanas para chegar na Itália. Ele viajava com todos os filhos, com a esposa e duas irmãs dela, um homem que ajudava, uma mulher que ajudava, um periquito e um macaco. Ele teve um problema físico, uma hérnia e teve que ser operado. Não descobriram que ele tinha alergia ao cloroforme. Em dezessete dias ele faleceu envenenado. A minha mãe que era uma das mais jovens, ela não teve ginasial, tinha que olhar para os irmãos e dizer que 'eles tiveram uma vida melhor do que eu. Eu não conheci meu pai, não fui pra Europa, não tive educação'. É ai que eu sinto que a força vem. Da família. Mamãe precisava reestabelecer o nível do pai dela que ela nunca conheceu. Então ela projetou isso nos filhos. Ela achou que a vida de artista é uma vida de glamour, uma vida que traz felicidade financeira e importância social. Essa fascinação que eu tenho pela arte eu estou em busca do meu avô, que não conheci. E isso me foi passado pela minha mãe que estava em busca do pai dela. (...) a gente tem lembranças: fotos, comentários da família; neste caso nos temos obras de arte que não eram reconhecidas. Minha mãe recebeu 130 snapshots. Meu avô às cinco horas da tarde gostava de perambular por 
São Paulo. E tudo que lhe interessava ele tirava uma foto (...) de pessoas fazendo a vida de todo dia. (...) não eram fotos comerciais, para ganhar a vida, e ficaram. Minha avó tinha revelado em papéis, que sobravam. E isso veio parar nas minhas mãos. Minha mãe dizia: 'olhem para o seu avô e vejam a visão que ele tinha'. Ele tem um lado cientifico, de pesquisador. Ele nota a vida das pessoas, quem são eles. Ele é o único da época dele que faz isso. Pode ser que eu estou criando um desejo. Mas se você fica olhando as fotos do meu avô que são aquilo que eu chamo de pesquisa de luminosidade, ele estava a procura da projeção, (...) ele pega um lado da pessoa e traz pra fora. Ele criava quadros vivos, a madona negra, a madona africana. Ele traz para casa uma ex-escrava. Isso é uma projeção maravilhosa, histórica (...) é uma pessoa sofrida, que não tem cuidados, que merece atenção, que merece respeito. Essas coisas meu avô projeta. Graças a deus é isso o que eu procuro fazer na minha própria arte. ${ }^{371}$

A direção de fotografia e edição de imagens de Abigail Spindel foi articulada para mostrar a transcendência de duas práticas artísticas inter-relacionadas: a música do neto e a fotografia do avô, demonstrando a força da ascendência na constituição do sujeito que descende. A trajetória de Pastore foi descrita como um inevitável condão na construção identitária do neto, mas também na da filha pequena que perdeu o pai, e projetou a imagem que fazia dele no destino de seu próprio filho, o pianista Flávio Varani.

A impressão indelével de pertencimento de grupo, de vocação para a arte, de ajuste de contas com as traições do destino saltam no relato, onde se inscrevem sucessivas negativas da vida: "não conheci meu pai, não fui para Europa, não tive educação", teria afirmado Eleonora, mãe de Flávio, num relato que guardava quase o desalento. Oliveira bem documentou o desfecho traiçoeiro de muitos descendentes de famílias remediadas, como a de Pastore, donas de um pequeno negócio, empurradas para a experiência de intimidade ora com a condição de pobreza, ora com as limitações que não conseguiam superar após a morte da figura paterna.

Mas há mais nesse relato. Pode-se ver as múltiplas camadas de memória sobre Pastore. Se, para o neto do fotógrafo, as lembranças de uma vida de sucesso e glamour foram mimetizadas, memória essa construída por Eleonora, mãe de Flávio, entra em cena veladamente outra figura, já que sua mãe era ainda muito pequena quando seu pai, Vincenzo Pastore, veio a falecer. Sua memória, portanto, foi forjada no seio da família onde encontramos, além dos filhos mais velhos, a presença de Elvira, agente ativa na imagem construída sobre o marido. Eleonora deve ter ouvido de sua mãe e irmãos mais velhos a narrativa de uma vida de viagens e oportunidades. A viúva Elvira, no entanto, deixou em seu

${ }^{371}$ Relato de Flávio Varani no Curta metragem "Flávio Varani: Projeção", de dez minutos, dirigido por Paulo Cesar Toledo. Disponível na web em http://vimeo.com/69511937, com password: flavio1. 
diário, indícios de uma vida marcada por fases de pouco trabalho, motivo das muitas queixas feitas à Pastore. A inconstância e a incerteza de se viver da fotografia, entretanto, não permeia a memória dos descendentes.

Diante da dor de perder seu marido, Elvira precisou escrever e expressar o sofrimento que não poupou "os dez filhos menores de idade que adoravam o pai, nem uma esposa que ama e é amada!". Outra faceta de Pastore foi por ela tecida: "Pobre e caro Vincenzo" lamentou Elvira, que o descrevia como um homem jovem, saudável, não entregue a nenhum vício que pudesse prejudicar sua saúde, e principalmente, um homem devoto, que em seu leito de morte beijou e abençoou os filhos sem desesperar-se porque os deixava sozinhos, sem apoio e sem recursos, escreveu Elvira. Em quase todas as linhas de seu diário articulou-se a construção da memória de um homem de fé, descrevendo detalhadamente o momento em que Pastore, diante da morte, encorajou os filhos "a perseverar no caminho do bem a qual estávamos encaminhados para encontrá-lo no paraíso”. Nas palavras de despedida Pastore teria dito:

Deixo todos vocês no coração de Jesus e com a Virgem do Carmo. (...) sejam bons, obedeçam à mamãe, lembrem-se de mim que quis tão bem à vocês, vivi só para vocês, trabalhei só para vocês, para deixar-vos um nome honrado e estimado, e procurem não manchá-lo nunca, nunca, em homenagem à minha memória. No paraíso nos reuniremos todos outra vez, se vocês assim o quiserem. ${ }^{372}$

Segundo a viúva, o marido "morreu como santo, morreu como viveu, como homem justo e honesto, morreu no senhor!". ${ }^{373}$ A pátria do fotógrafo imigrante italiano que se despedia lembrando a vida de constante trabalho, era acima de tudo, aquela que alcançaria a dimensão de uma alma devota, vista de modo fragmentário na construção desses diálogos que intuíam restituir aspectos que definem Pastore, e atravessam toda sua trajetória e subjetividade, reconstruídas também nas lembranças guardadas entre os seus familiares, onde ocupou o lugar do respeito e da admiração: "foi um grande fotógrafo e a grandeza dele foi saber apreciar o povo". ${ }^{374}$

\footnotetext{
372 Coleção Dante Pastore. Diário de Elvira. 1918. Tradução do diário feita por Thais Cavalcanti.

${ }^{373}$ Coleção Dante Pastore. Diário de Elvira. 1918. Tradução Thais Cavalcanti.

374 Depoimento de seu neto Flávio, filho de Eleonora. In: AVANCINI. Em Flagrante. Leitura de Fotografias de Rua do Cotidiano da Cidade de São Paulo Nas Duas Primeiras Décadas do Século XX. 1999.
} 


\section{Considerações finais}

Este trabalho não nasceu pensando em Vincenzo Pastore. Foi o interesse inicial em estudar as imagens de mulheres negras, no pós-abolição, que lentamente conduziu o projeto de pesquisa para a coleção do fotógrafo, sob a guarda do Instituto Moreira Salles. As sociabilidades retratadas nas redes de abastecimento da capital paulista revelavam sujeitos históricos que ocupavam as ruas da cidade, trabalhando de forma autônoma nas primeiras décadas após a escravidão. Das cenas retratadas, às vezes, sob sol a pino, era certo que indagações sobre o próprio fotógrafo surgissem. Se Pastore explicitava realidades sociais antes pouco mencionadas, de visibilidade rarefeita, a sua própria vivência despontava como algo inédito. Era preciso trazer à tona a sua própria trajetória, que pouco consegue se desvincular de suas fotos.

A tarefa não era fácil. Não contávamos com nenhuma pesquisa de fôlego maior. A investigação impunha a tarefa de melhor investigar a sua atuação como fotógrafo retratista, afinal, foi o estúdio, que começara na Rua da Assembleia, depois, localizando-se na Rua Direita, o local onde Pastore ganhou dinheiro e sustentou sua extensa família. Aprender nova língua, estudar o campo teórico e metodológico sobre coleções fotográficas, driblar a dificuldade de acesso às fontes sob o domínio familiar, dar conta de uma trajetória de uma personagem com tantas idas e vindas entre Brasil e Itália, foram desafios a ser superados para melhor documentar a experiência social desse fotógrafo, deixada de lado em sua própria terra natal. Nos estudos históricos sobre a fotografia da região da Puglia e da Basilicata, constatamos o quanto Pastore, pouco aparece.

Documentamos como Vincenzo Pastore viveu do retrato mais comercial, fazendo dinheiro com os Retratos Mimosos, a saber, as carte-de-visite, registros populares e mais baratos, prensados numa simples moldura em papel cartão. No entanto, demonstramos como em sua prática, não foram escamoteadas as qualidades fundamentais da fotografia, anteriormente submetida às noções de fidedignidade, típicas do século XIX. Ao criar a imagem do ferreiro e tantos retratos feitos em estúdio, retratando inclusive seus filhos, Pastore estabeleceu um diálogo com o movimento pictorialista, dada à atitude interpretativa vista em muitas de suas imagens. Era preciso se apresentar a sua clientela como um profissional afinado com as questões fotográficas de seu tempo. Participou das discussões enveredadas pelo movimento, também escrevendo, num relato que sugeriu a sua recusa em estreitar sua produção a um 
único modelo. Desvelamos uma prática que conciliava o retrato comercial com expressões de sentidos estéticos na fotografia, quer nas produções em foto-pinturas ou nas aprimoradas fotos à carvão- print, quer recorrendo a goma-bicromatada, tão bem-quista entre os fotógrafos pictorialistas. O gosto de Pastore pela arte o levou inclusive a exigir dos filhos mais velhos uma formação artística permanente. ${ }^{375}$

Verificamos como práticas diversas constituíam esse fotógrafo que não abriu mão de reivindicar o papel de fotógrafo-intérprete, pois sua câmera não era usada apenas para comunicar o real, Pastore lançou-se em experimentos, em composições que interrogavam o próprio aparato técnico-mecânico, ou seja, a própria especificidade da técnica fotográfica, apresentando-se como um fotógrafo atento as discussões fotográficas de seu metier. Pastore propôs novos enquadramentos, perspectivas e efeitos de luz, em tomadas de cenas de cunho mais realista, voltado para o cotidiano. Foram muitos os vestígios a demonstrar como nosso fotógrafo experimentou e tensionou os aparatos oferecidos pela câmera. Pouca nitidez dos planos de fundo, recorrente desfocamento, contra-luz, intensificação de áreas claras e escuras, indicam atitudes questionadoras de Pastore que pouco hesitou em participar de todo um debate que desnuda o quanto a fotografia não se submete a uma visão fixa e determinada. Ao tratarmos das fotos produzidas em estúdio, mas também daquelas realizadas nas ruas da cidade, acreditamos melhor documentar o quanto Pastore conhecia os pressupostos idealizados por uma das vertentes do movimento pictorialista, porque foi este um fotógrafo híbrido, com total domínio da técnica para confrontá-la, recusando a fotografia como representação automática do mundo. Inferências que nos levaram a interrogar a economia visual também italiana, bem como e as tensões da fotografia de virada de século.

A não especialização de Pastore ajuda a caracterizar o próprio metier do retrato, que apresentava uma instabilidade constante, iniciada antes mesmo do fotógrafo, ter imigrado para o Brasil. Diferenciar-se pelo domínio de técnicas aprimoradas, oferecendo ainda serviços à uma clientela que buscava as formas do retrato mais comercial, caracteriza um aprendizado necessário quando atuou em Potenza, depois importante na experiência de imigração vivenciada no Brasil. Por meio de muitos anúncios, publicados no Brasil e na Itália, encontramos Pastore sendo reverenciado como um artista-fotógrafo. Para os italianos, Pastore

\footnotetext{
${ }^{375}$ Entrevista com o neto de Vincenzo Pastore, Flávio Varani.
} 
era o "distinto fotógrafo" da "cosmopolita São Paulo"; para os paulistanos, era um "habilíssimo artista" dono da "última palavra na fotografia tida como arte". ${ }^{376}$

Há em sua série fotográfica emblemática, produzida em São Paulo, uma especificidade notada à primeira vista: este material visual ilumina o quanto é de fato limitado pensar a cidade a partir de referências abstratas e generalizantes, que partem de certos procedimentos para fetichizar a cidade a partir da oposição rural-urbano. Na perspectiva de Ulpiano Bezerra de Meneses (1996), abordagens menos "deformantes" dependem de compreensões mais abrangentes: a cidade, segundo o autor, deve ser entendida como um complexo de fenômenos diversificados e de articulações multiformes, aspectos articulados em toda série.

A repetição de ações e gestos semelhantes dá ao material visual o seu aspecto de narrativa, a partir de fragmentos tirados do cotidiano de trabalho urbano, mostrando o empenho do fotógrafo em preservar uma coerência espacial, reforçando efeitos de real flagrado. Foi a performance do trabalho de quituteiras, do vendedor de vassouras e de tantas vendeiras de aves, flagrados próximos aos mercados de abastecimento ou acima da colina, nas ruas do Triângulo Central, que Pastore documentou: uma cidade múltipla, heterogênea e em plena expansão surgiu nesse entrecruzar de experiências então vivenciadas.

O encontro e a mobilidade na sinuosa morfologia da capital auriverde foi o conteúdo nodal da narrativa de Pastore. Foi, por certo, um olhar crítico sobre o processo de metropolização da cidade, não obscurecendo as experiências de sujeitos históricos que tentavam recuperar permanentemente a centralidade dos espaços perdidos. Pastore, com sua câmera portátil se aproximou de modo comovente de todos eles. Seus registros, quando comparados à visualidade da época, ou melhor, àquilo que se produzia como imagem da cidade paulistana, resultaram numa representação não fetichizada pelo viés modernizador, abstrato e generalizante, denotando uma cidade como um complexo de fenômenos diversificados. Em Pastore temos o rompimento de noções da cidade como uma "categoria estável e universal", premissa frágil e esvaziada de historicidade, como defende Menezes (1996).

Se, em Pastore foi possível demonstrar traços das convenções da fotografia de rua italiana, a qual ele evidentemente assimilou, há ainda algo que cabe destacar. Seus registros desvelam como a população paulistana não se fazia apenas de estrangeiros, ou como estes não estavam apartados de um convívio intenso com a população nacional. Emociona ver a foto do

${ }^{376}$ Cf. Coleção Dante Pastore. 
homem negro trabalhando ao lado do imigrante branco, ambos dedicados à venda de tecidos, batendo de porta em porta, como vimos no capítulo três. O sustento para muitos deles veio do trabalho ambulante nas ruas. Ambos os grupos somaram a aprendizagem acumulada: os imigrantes relembravam as diferentes regiões da baixa Itália como o lugar da existência de uma "miséria danada"; 377 os negros guardavam a experiência do cativeiro. Da instabilidade que marcava tais vivências, ambos os grupos, em convivência, conseguiram formar experiências novas, compartilhadas na experiência do urbano. Dividindo espaços, não sem tensões, sobreviviam de seu trabalho, de seus esforços. Encará-los como uma população pobre ou como grupos despossuídos tão somente, seria como apagar suas vivências, perdê-los da trama da história. Deixar morrer é esquecer a complexidade da vida.

É certo que Pastore foi um caminhante, saindo das ruas do Triângulo Central até chegar às bandas do Brás, às várzeas e, ainda, ao Ipiranga. Retratou casebres envolvidos por vegetação rasteira. Retratou crianças ao fundo de quintal. Das margens dos rios, deu a ver as lavadeiras que trabalhavam para sustentar seus filhos. Guardou o instante revelador do casal lidando na roça. A exibição da coleção comoveu historiadores sociais e o público em geral, que compunham a audiência na mostra organizada pelo IMS, em 1997. Na trajetória das fotos de Pastore foi possível documentar um trânsito de imagens: da caixa de papelão, para a exposição em múltiplos suportes; de uma guarda que envolvia toda a família, para uma doação a um instituto privado. Acompanhar esse deslocamento segue o pressuposto metodológico de recompor a "biografia das imagens".

Compreender as práticas sócias exige seguir as coisas em si mesmas, em suas específicas trajetórias, como bem defendeu Arjun Appadurai (2008). O capítulo cinco foi todo construído a partir deste referencial porque era vital compreender o circuíto que caracterizou toda a cadeia de apropriação da coleção VP: a aquisição, a exposição, a divulgação e a produção de livro e catálogo, bem como as interpretações históricas subsequentes à mostra realizada pelo IMS.

Tentamos indicar o uso ilustrativo de suas fotografias. Usos que recorreram às imagens para dar visibilidade às sociabilidades de décadas precedentes ao contexto de sua produção, o que, por um lado, denota o valor histórico e certos agenciamentos das fotos apropriadas para preencher lacunas visuais de períodos carentes de representação da capital paulista. Por outro,

\footnotetext{
${ }^{377}$ Nas lembranças das primeiras gerações de imigrantes calabreses e sicilianos chegados ao Brasil a baixa Itália era lembrada pela miséria. Ver Moreno, Júlio. Memórias de Armandinho do Bixiga. São Paulo: Ed. Senac. 1996, p.24.
} 
mostra como ainda estamos presos ao conteúdo da imagem de forma pouco problematizadora do ato fotográfico.

Pastore não se encerra em um lugar fixo. Tentamos demonstrar como sua prática fotográfica se deu de modo evidente no estúdio. Mas o seu lugar social foi primeiro apresentado como um fotógrafo da cidade. Tentamos compreender a trajetória de Pastore observando essas duas dimensões. Privilegiar uma, sem considerar a outra, seria um risco, sem contar dos ganhos em observar como as fotos são agenciadas socialmente.

Foi no Instituto Moreira Salles que as fotos de Pastore foram mobilizadas. De tais agenciamentos, Pastore se tornou um fotógrafo da cidade. Foi este um viés interpretativo criado na esteira de um processo de fabricação do próprio arquivo, que criava para si mesmo um papel social, colocando-se como uma instituição/acervo de fotografias da cidade, documentando seu processo de urbanização. Foi esse o espaço social que transformou as fotografias em documento, valendo-se da categoriza de autor e obra, fotos lançadas em seu novo status como foto-monumento, manipulada pelo acervo, submetidas a um discurso da curadoria; fotos depois destituídas de sua materialidade porque transpostas do espaço expositivo da galeria de arte do instituto, o Espaço Higienópolis, para o circuito virtual, disponibilizadas ao público pela web. Na trajetória das fotos, uma delas se mantém viva na estação do metrô Luz. Outras sobrevivem no suporte catálogo, e no singelo livreto, chamado timidamente de portfólio. Pastore merecia mais.

A fotografia guarda, como se vê, essa riqueza infindável, se movimentando nas memórias interditas entre o passado, o presente e o futuro. Tratamos aqui de fotografias que se desdobraram no tempo, em memórias presentificadas, reconstruídas, revividas, agenciadas quando institucionalizadas como coleção, terreno fértil, pulsante à observação histórica, à crítica do intérprete munido de suas ferramentas e metodologias para desvelar os limites e as fendas da memória.

A carta escrita por José Roberto Varani, neto de Pastore indicia memórias em disputa. A revista Veja São Paulo, em fevereiro de 1997, ao menos publicou na sessão “A Opinião do Leitor", o desapontamento deste descendente em não ver seu nome citado e seu gesto reconhecido, porque ele e sua esposa Maria Lúcia, também zelaram "amorosa e cuidadosamente" pela coleção guardada entre os descendentes por quase um século. ${ }^{378}$

${ }^{378}$ Cf. Revista Veja São Paulo. Sessão Opinião do Leitor. Fevereiro/1997, p. 105. 
É preciso terminar a tese, esperando deixar aqui uma pequena contribuição para melhor entrever nosso Vincenzo Pastore, em toda sua complexidade, em todo seu incessante ato de recomeçar ora em Potenza, ora em São Paulo, ora tentando retornar à Bari, sua província natal. Frente aos seus esforços de viver do retrato, Pastore contou sempre com a parceria firmada com Elvira, a quem ficamos ainda devendo um olhar mais apurado. A "Viúva Pastore" ainda tentou manter o estúdio aberto após a morte do marido, afinal, era preciso tentar garantir a sobrevivência dos filhos. Não restou herança suficiente para tal fim. Os investimentos no estúdio aberto em Bari, no ano de 1914, talvez tenham consumido um montante significativo das reservas da família.

Conseguimos nos aproximar melhor de Pastore, pelas palavras de Elvira, inscritas num diário pessoal. Elvira fez questão de descrevê-lo como um homem religioso. Ser católico foi um traço marcante em Vincenzo Pastore. Foi devoto de Nossa Senhora. Quando hospitalizado, minutos antes de ser anestesiado para retirada de uma hérnia, beijou primeiro a pequena medalha com a imagem da santa e, depois, o crucifixo de Cristo; os levou à boca, para em caso de óbito, ser reconhecido no céu como um homem de fé. Seus atos de devoção não o livraram, contudo, das febres posteriores acima dos quarenta e um graus, da sede e dos repetidos gemidos, sinais do processo de intoxicação por ter recebido clorofórmio em seu organismo, desencadeando um processo alérgico que o levaria a morte em 1918, com apenas 53 anos de idade. 


\section{ANEXOS}

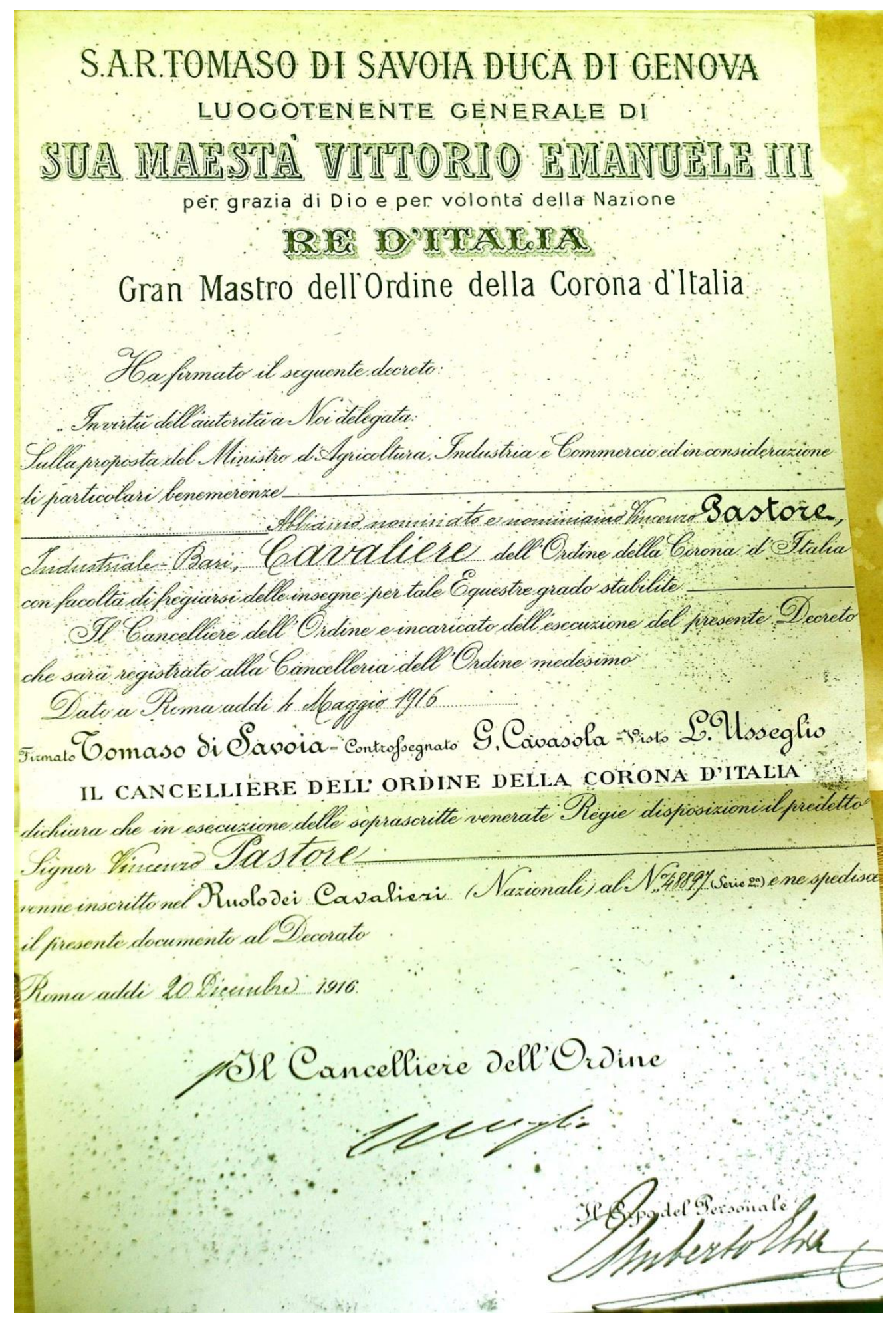

Figura 284: Reprodução do documento de nomeação de Vincenzo Pastore como Cavalheiro da Ordem da Coroa da Itália. Cadernos de Recortes. Coleção Dante Pastore, p. 3. 


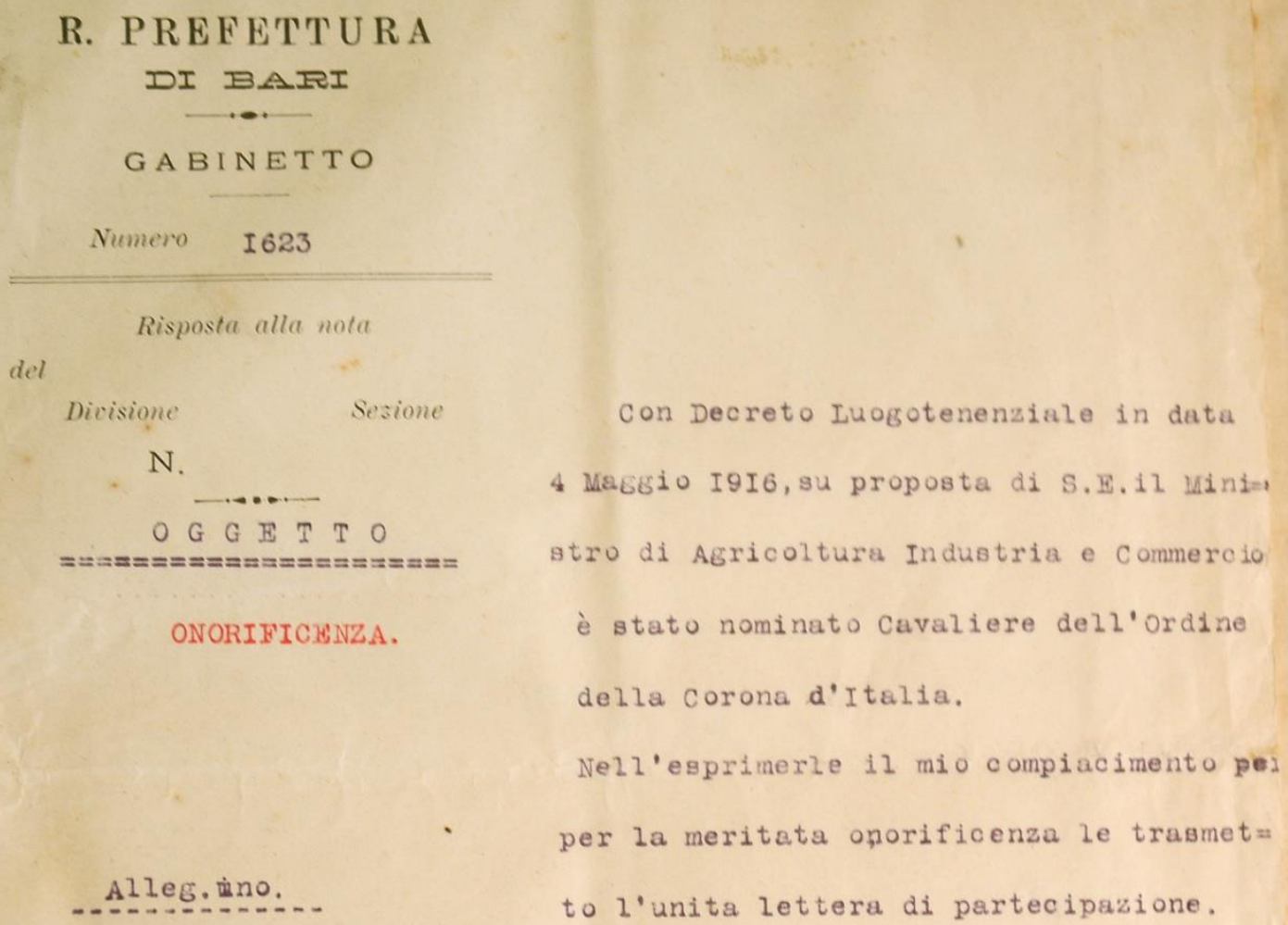

Sig. Cav, Vincenzo Pasture Botografo.

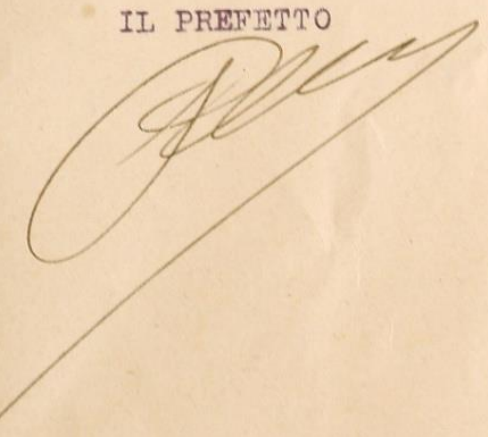

B A R I

\&\&\&ar\&\&\&\&\&\&\&\&\&\&\&\&

Figura 285: Reprodução do documento assinado pelo prefeito de Bari. Maio de 1916. Caderno de Recortes. Coleção Dante Pastore, p. 86. 


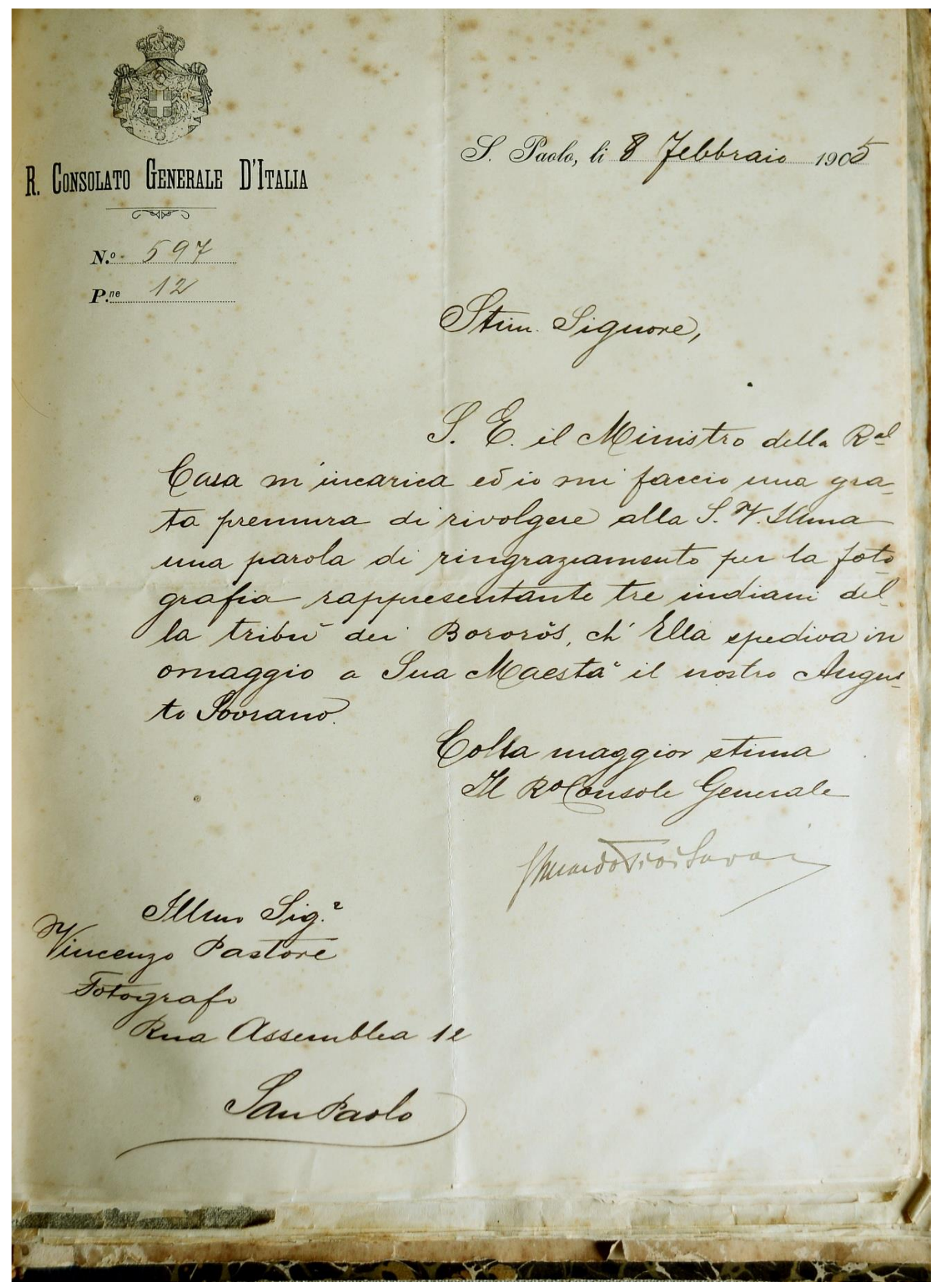

Figura 286: Reprodução de carta com agradecimento real, pelo envio de fotos realizadas por Vincenzo Pastore retratando índios Bororos no Brasil. Reprodução Caderno de Recortes. Coleção Dante Pastore, p. 8. 
R. CONSOLATO GENERALE D'ITALIA

menen-
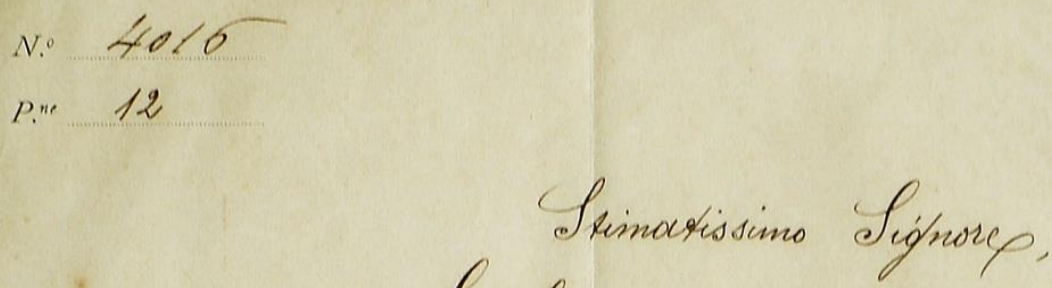

Sua becellenso il dinistro della Real Casor m'viforma che la S. Y. Yelmos ha civiato in omad.

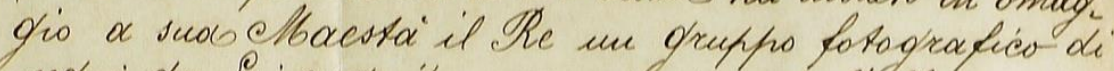
neo'ri da Sei exquito, accompragnando l'offerta con éespressione di scutimenti devoti e m'invitos dol espric merLe una focrola di'ring rariaments nel Real Clome. piocere.

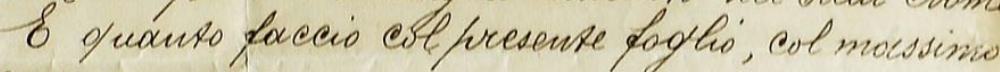
Grow

della mido distintos stimas.
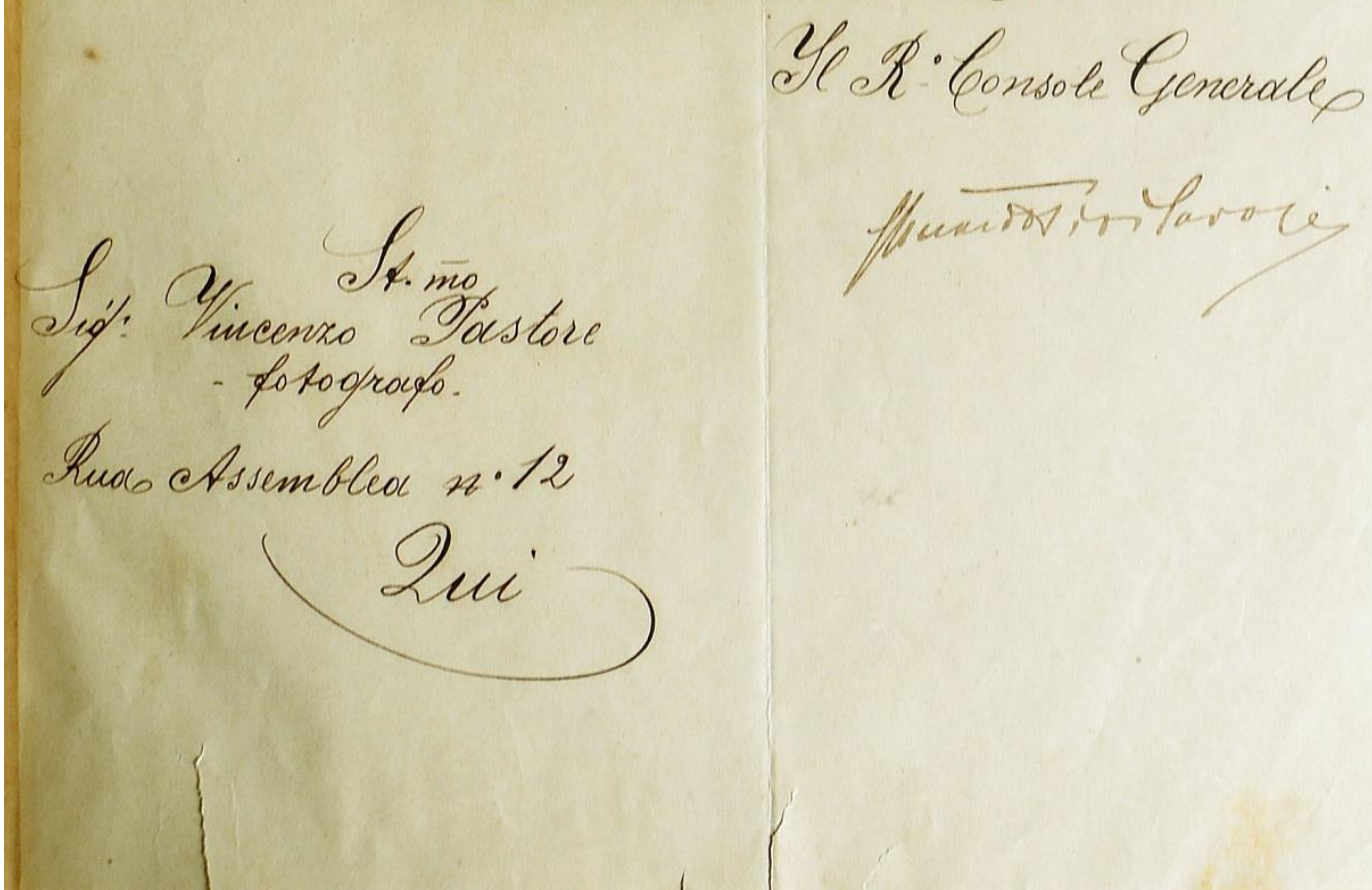

Figura 287: Reprodução de carta real agradecendo o envio de fotos de "grupos de negros" retratados por Vincenzo Pastore no Brasil. Caderno de Recortes. Coleção Dante Pastore, p. 7. 


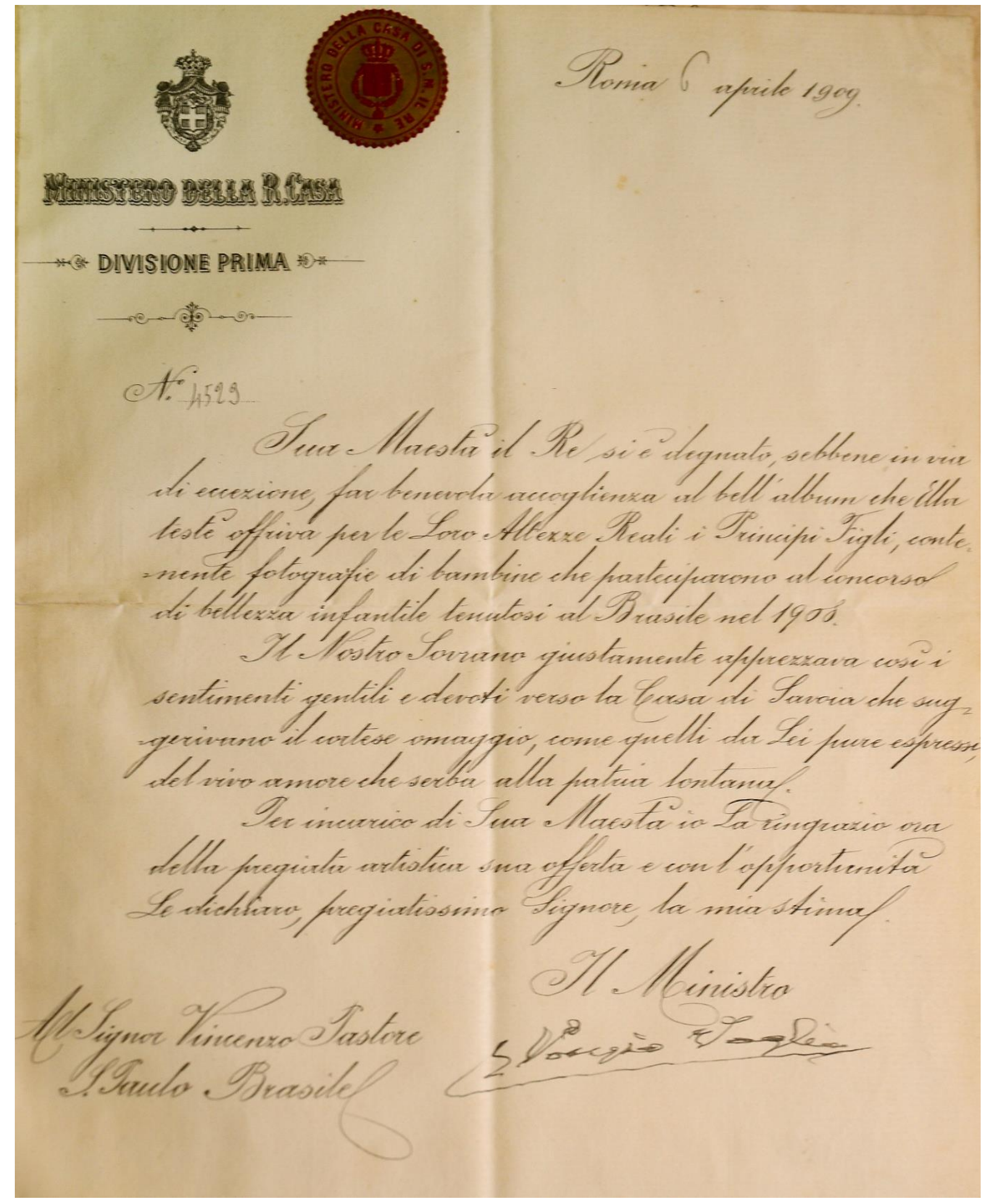

Figura 288: Reprodução de carta real parabenizando o fotógrafo Vincenzo Pastore pela realização de concurso de beleza em Bari, região da Puglia. Caderno de recortes Coleção Dante Pastore, p. 85. 


\section{ARQUIVOS CONSULTADOS}

Arquivo Público do Estado de São Paulo

1. Periódicos

2. Documentos em manuscritos:

- Maços de Processos de Órfãos. Número 10726. 31 de julho de 1911.

3. Papéis avulsos:

- Caixas de 1909, 1910 e 1911.

Arquivo Histórico Municipal de São Paulo

1. Documentos oficiais impressos:

- Atos/Leis Municipais de 1908 à 1914.

- Relatório anual de 1909 enviado pelo prefeito Antonio Prado à Câmara Municipal.

- Relatório anual de 1910 enviado pelo prefeito Antonio Prado à Câmara Municipal.

2. Acervo manuscrito:

- Papéis Avulsos. 1908. Localização: 2046, 2047, 2056

- Seção de Polícia e Higiene. 1909. Caixa 53.

- Conselho de Vereadores. Fundo CMSP: Caixa 48. Janeiro, Março de 1909.

Museu Paulista

1. Acervo Iconográfico

2. Biblioteca

Instituto Moreira Salles

1. Acervo Iconográfico

Arquivio Storico Capitolino - Roma

1. Acervo iconográfico

Biblioteca Nacional de Roma

1. Sessão de manuscritos

2. Sessão de obras raras

3. Periódicos

Biblioteca Università la Sapienza di Roma

1. Livros, dissertações e teses 
Biblioteca Provinciale di Potenza

1. Manuscritos

2. Periódicos

3. Acervo Iconografico

Biblioteca dell' Archivio di Stato di Potenza

1. Periódicos

Biblioteca Nazionale di Potenza

1. Periódicos

2. Livros e manuscritos

Biblioteca da Università Degli Studi della Basilicata

1. Livros, dissertações e Teses

Pinacoteca Provinciale de Bari

1. Periódicos

2. Livros

Biblioteca Della Provincia Delle Puglia, Bari.

1. Acervo iconográfico

Centro di Ricerca Audiovisuale Università di Napoli Federico II.

1. Acervo Iconográfico 


\section{BIBLIOGRAFIA}

ABREU, Regina. História de uma coleção: Miguel Calmon e o Museu Histórico Nacional. Anais do Museu Paulista. São Paulo. N. Ser. V. 2, p. 199-233. Jan./dez.1994.

ALLEN, William. Teaching Composition Digitally. Come of a Age of the digital Image. In: Visual Resources. An International Journal of Documentation. V. XV. Number 1. 1999, pp. $65-78$.

ALPERS, Svetlana. A arte de descrever. São Paulo: EDUSP. 1999.

ALVES, Cauê. A Curadoria como historicidade viva. In: Ramos, Alexandre Dias (org.). Sobre o ofício do curador. Porto Alegre, RS: Zouk, 2010.

ALVIM, Zuleika M. F. Brava Gente. Os italianos em São Paulo. 1870-1920. São Paulo: Brasiliense. 1986.

AMERICANO, Jorge. São Paulo Naquele tempo 1895-1915. São Paulo: Carrenho Editorial/Narrativa Um/ Carbono 14, 2004.

ANDREWS, George Reid. Negros e brancos em São Paulo (1888-1988). Bauru, SP: EDUSC, 1998.

APPADURAI, Arjun. A vida social das coisas: as mercadorias sobre uma perspectiva cultural. Niterói: Editora da Universidade Federal Fluminense. 2008.

ARANTES NETO, Antônio Augusto. Paisagens paulistanas: transformações do espaço público. Campinas / SP: Editora da UNICAMP, 2000.

AREND, Silvia Fávero. Trabalho, Escola e Lazer. In: Nova História das Mulheres no Brasil. São Paulo: Contexto, 2012.

ARTIÈRES, Philippe. Arquivar a Própria Vida. Escrita de Si/ Escrita da História. Fundação Getúlio Vargas - CPDOC. 1998.

AVANCINI. Em Flagrante. Leitura de Fotografias de Rua do Cotidiano da Cidade de São Paulo Nas Duas Primeiras Décadas do Século XX. Dissertação de Mestrado em Ciências da Comunicação na área de Jornalismo apresentada à Escola de Comunicação e Artes da Universidade de São Paulo, ECA- USP. 1999.

AZEVEDO, Célia Maria Marinho. “Abolicionismo. Estados Unidos e Brasil uma história comparada (século XIX). São Paulo: Annablume, 2003. 
AZEVEDO, Elciene. A metrópole às avessas. Cocheiros e carroceiros no processo de invenção da "raça paulista". In: Trabalhadores na Cidade. Campinas, SP: Editora Unicamp, 2009.

BALADY, Sonia Umburanas. Valério Vieira: um dos pioneiros da experimentação fotográfica no Brasil. Dissertação de mestrado do Programa de Pós-graduação Interunidades em Estética e História da Arte - USP. 2012.

BALDI, Alberto. Storia della fotografia familiare e sociale lucana. Linee di ricerca Ed esiti. In: Mirizzi, Ferdinando. Da vicino e da lontano. Fotografi e fotografia in Lucania. Milano, Italy: Imagines FrancoAngeli. 2010.

Vite di Giocattoli. Uma ricerca sull'universo lúdico lucano. Napoli: Electa Napoli. 1999.

Scatti per sognare: Avigliano nelle Fotografie dell'archivio Pinto. Napoli:Electa Napoli. 2004.

Foto familiare e ricerca antropológica: un tentativo di analisi. In: Lusini, Sauro. Fototeche e Archivi Fotografici. Prospettive di sviluppo e indagine delle raccolte. Toscana: Archivio Fotografico Toscano, 1996.

BANN, Stephen. Photographie et reproduction gravée: l'economie visuelle au XIXeme siècle.In: Études Photographiques, n.09, maio/2011.

In The Age of Reproduction. Paralllel Lines. Printmakers, Painters and Photographers in Nineteenth-Century France. New Halen \& London: Yale Universitiy Press, 2001.

BARVARÒ, Michele Falzone. Gli ateliers. In: Segni Di Luce. La Fotografia dall'età Dell collodio al pittorialismo. Ed. Longo/Ravenna. V.2. 1993.

BARRETO, Lima. Numa e a Ninfa. Rio de Janeiro: Garnier. 1915.

BARTHES, Roland. A Câmara Clara. Edições 70. 1980.

o Óbvio e o Obtuso. Ensaios sobre a fotografia, cinema, pintura, teatro e música.

Rio de Janeiro: Nova Fronteira. 1990.

Crítica e Verdade. São Paulo: Perspectiva. 1970

Mitologias. Rio de Janeiro: Difel. 2007

BAXANDALL, Michael. Padrões de Intenção. A explicação histórica dos quadros. São Paulo: Companhia das Letras, 2006. 
BELTRAMIM, Fabiana. Sujeitos Iluminados. A reconstituição das experiências vividas no estúdio de Christiano Jr. São Paulo: Alameda. 2013.

BENJAMIN, Walter. Obras escolhidas Magia e Técnica, Arte e política. São Paulo: Ed. Brasiliense. V.1 e 2. 1994.

BERMAN, Marshall. Tudo que é sólido desmancha no ar. São Paulo: Companhia das Letras, 2007.

BERNARDO, Teresinha. Memória em Branco e Negro. Olhares sobre São Paulo. São Paulo: Educ. Ed. Unesp, 1998.

BESSE, Susan. Modernizando a desigualdade: reestruturação da ideologia de gênero no Brasil. 1914 / 1940. São Paulo: EDUSP, 1999.

Crimes passionais: a campanha contra os assassinos de mulheres no Brasil: 1910 / 1940”. In: REVISTA BRASILEIRA DE HISTÓRIA / ANPUH No 18: A mulher e o espaço público. São Paulo: Marco Zero, 1989, pp. 181 / 197.

BESSER, Howard. Visual acess to visual images: The UC Berkeley Image Database Project. Library Trends, v.38, No. 4, Spring 1990, pp. 787-98.

BEZERRA DE MENESES, Ulpiano. As “trajetórias” das Imagens. Comentário III. Anais do Museu Paulista. Nova Série, $n^{\circ}$ 1, Universidade de São Paulo. 1993.

BLOCH, Marc. Apologia da História ou o Oficio de Historiador. Rio de Janeiro: Jorge Zahar Ed. 2001.

BLOM, Philipp. Ter e Manter. Uma História Íntima de Colecionadores e Coleções. Rio de Janeiro: Record. 2003.

BOURDIEU, Pierre. A Ilusão Biográfica. In: Ferreira, Marieta e Amado, Janaina. Usos e abusos da história oral. 1998.

BOSI, Ecléa. Memória e Sociabilidade. Lembranças de Velhos. São Paulo: Companhia das Letras. 1994.

BRAUDEL, Fernand. História e Ciências Sociais. Lisboa: Editorial Presença. 1990.

BRETAS, M.L. Ordem na Cidade. Rio de Janeiro: Rocco, 1997.

BRONZINI, Giovanni Battista. Lares, Trimestrale di studi demoetno antropologici. Ano LX, n.4. Firenze: Leo S. Olschki. Outubro-dezembro de 1994.

BRUNO, Ernani Silva. Historia e tradições da cidade de São Paulo. Rio de Janeiro: Livraria José Olympio Editora. 1954. V 2 e V3.

BRUSCHINI, Cristina. Uma questão de gênero. São Paulo: Fundação Carlos Chagas, 1992. 
BUCCARO, Alfredo. Le città nella storia d'Italia. Potenza. Ed. Laterza, 1997.

BURK, Peter. Testemunha Ocular: História e Imagem. São Paulo: Bauru, SP: EDUSC, 2004.

CALABRESE, Luigi; Piro, Antonio D’Andria e Restaino, Lucia. Potenza, Capoluogo (18062006). Napoli: Universidade da Basilicata. v.1 e 2. 2008.

CAMPOS, Candido Malta. Os Rumos da Cidade. Urbanismo e Modernização em São Paulo. São Paulo: Editora Senac, 2002.

CANCLINI, Néstor Gárcia. Culturas híbridas: estratégias para entrar e sair da modernidade. São Paulo: Edusp, 2011.

CANO, Jefferson. A Cidade dos Cortiços. Os trabalhadores e o poder público em São Paulo no final do século XIX. In: Trabalhadores na Cidade. Campinas, SP: Unicamp, 2009.

CARDOSO, Rafael. Os impressos efêmeros como fonte para o estudo da História Cultural Brasileira. In: HEYNEMANN, Cláudia. Marcas do Progresso: consumo e design no Brasil do século XIX. Rio de Janeiro: Mauad X/Arquivo Nacional, 2009.

CARVAlHO, Vania. Gênero e Artefato. O Sistema Doméstico na Perspectiva da Cultura Material - São Paulo, 1870-1920. São Paulo: Editora da Universidade de São Paulo. 2008.

As representações da natureza na pintura e na fotografia brasileiras do século XIX. In: Fotografia. Usos e funções no século XIX. São Paulo Edusp, 2008.

CARVALHO, Vania C. e LIMA, Solange Ferraz. Fotografia no museu: o projeto de curadoria da coleção Militão Augusto de Azevedo. Anais do Museu Paulista. História e Cultura Material. V. 5. jan/dez. 1997.

Fotografia e cidade: da razão urbana à lógica do consumo. Campinas / São Paulo. Mercado de Letras/Fapesp, 1997.

Banco de imagens: Do consumo ao aprendizado. In: Antunes, Benedito (org.) Memória, literatura e tecnologia. São Paulo: Cultura Acadêmica. 2005.

Fotografias como objeto de coleção e de conhecimento: por uma relação solidária entre pesquisa e sistema documental, 2000.

Cultura Visual e curadoria em museus de História. In: Estudos Ibero-americanos. Revista do departamento de História. 2005.

Cultura Material e coleção em um museu de história: as formas espontâneas de transcendência do privado. In: Betânia Gonçalves Figueiredo; Diana Gonçalves Vidal (org.) Museus: dos gabinetes de curiosidades à museologia moderna. $1^{\mathrm{a}}$ ed. Belo Horizonte: Argumentum/CNPq, 2005, p.85-110. 
Vistas Urbanas, doces lembranças. O “antigo" e o "moderno" nos álbuns fotográficos comparativos. In: Pires, Francisco Murari (org.). Antigos e Modernos. Diálogos sobre a escrita da história. São Paulo: Alameda, 2009.

Indivíduo, Género Y Ornamento em los retratos fotográficos, 1870-1920. In: Fernando Aguayo e Lourdes Roca (org.), Imágenes e Investigación Social. México, Instituto Mora, 2005 .

CASSIDY, B. Iconography in the theory and practice. In: Visual Resources, v. 11. 1996, pp.323-48.

CASTro, Ana Claudia Veiga. A São Paulo de Menotti Del Picchia. Arquitetura, arte e cidade nas crônicas de um modernista. São Paulo: Alameda,2008.

CAULFIELD, Martha Abreu Suean. 50 anos de virgindade no Rio de Janeiro - As políticas de sexualidade no discurso jurídico e popular 1890 a 1940.

CAVELL, Stanley. The World Viewed. New York, Viking Press, 1971, p. 24. In: Krauss. KRAUSS, Rosalind. O Fotográfico: Barcelona: editora Gili. 2002.

CERTEAU, Michel de. A beleza do Morto: o conceito de cultura popular. In:Revel,George,org. A invenção da sociedade,Lisboa,Difel,1989.

CHALHOUB, Sidney. Visões de Liberdade. Uma história das ultimas décadas da escravidão na corte. São Paulo: Companhia das Letras. 1990.

Cidade Febril: Cortiços e epidemias na Corte imperial. São Paulo. Companhia das Letras. 1996.

CHARTIER, Roger. A História da Cultura: Entre práticas e representações. Lisboa: Difel. 1990.

CHRISTIN, Anne-Marie. Textos e Imagens. In: Van Der Linden, Sophie. Para ler o livro ilustrado. São Paulo: Cosac \& Naify, 2011.

COURTINE e HAROCHE. História do Rosto. Lisboa: Editorial Teorema. 1995.

COSTA, Helouise. A Voz de um fotógrafo. Prefácio. In: Rocha, Regina Maurício da. A Poética de Fotográfica de Paul Strand. São Paulo: Edusp. 2012.

Pictorialismo e Imprensa: O caso da Revista o cruzeiro (1928-1932). In: Fabris (org.) Fotografia, Usos e Funções no Século XIX. 2008.

Costa, Helouise e Silva, Renato Rodrigues. A Fotografia Moderna no Brasil. São Paulo: Cosac Naify. 2004. 
CRARY, Jonathan. Suspensão da Percepção. Atenção, Espetáculo e Cultura Moderna. São Paulo: Cosac Naify, 2013.

Techniques of the observer: on vision and modernity in the nineteenth century. Cambridge:Mit Press, 1992.

CUNHA, Olívia Maria Gomes da. e GOMES, Flávio dos Santos. Quase-Cidadão - histórias e antropologias da pós-emancipação no Brasil. RJ: Editora FGV. 2007.

CUCHE, Denis, A noção de Cultura nas ciências sociais. Bauru: Edusc, 1999.

DARBÓN, Sebastien. O etnólogo e suas imagens. In: Saiman, Etienne (org.) O Fotográfico. São Paulo: Senac- Hicitec. 2005.

D’AUTILIA, Gabriele. Storia della fotografia dal 1839 a oggi. Editora Piccola Biblioteca Einaudi. 2012.

DEAECTO, Marisa Midori. Comércio e vida urbana na cidade de São Paulo (1889-1930). São Paulo: editora Senac. 2002.

DEAN, Warren. The Industrialization of São Paulo. 1880-1945. Austin, Tex. 1969.

DE BEAUVOIR, Simone. O Segundo Sexo. V.1 e 2. Lisboa: Quetzal Editores, 2008

DEBES, Celio. Washington Luis: 1869-1924. São Paulo, Imprensa Oficial do Estado, 1994.

DEBRAY, Régis. Vida e Morte da Imagem. Rio de Janeiro: Paz e Terra, 1993.

DE FRANCESCHI, Antonio Fernando. Texto do catálogo da exposição "São Paulo de Vincenzo Pastore”. IMS, 1997.

DEL BARBARÒ, Michele Falzone e TEMPESTA, Claudia. Marius Pictor Fotografo. L’album fotografico di Mario De Maria. 1882-1887. 1979.

DERRIDA, Jacques. Pensar em não ver. Escritos sobre as artes do visível (1979-2004). Florianópolis: Ed. Da UFSC. 2012.

DIAS, Maria Odila Leite da Silva. Hermenêutica do Quotidiano na Historiografia Contemporânea. In: Trabalhos da Memória. Projeto História: revista do Programa de PósGraduação em História e do departamento de História da PUC-SP. São Paulo: EDUC. 1981. Teoria e Método dos Estudos feministas: Perspectiva Histórica E hermenêutica do Cotidiano. In: Uma questão de gênero. Costa, Albertina e Bruschini, Cristina. Rio de Janeiro: Rosa dos Tempos; São Paulo: Fundação Carlos Chagas, 1992.

Quotidiano e Poder em São Paulo no século XIX. São Paulo: Brasiliense, 1995.

Nas fímbrias da escravidão urbana: negras de tabuleiro e ganho. Estudos econômicos 15, Número Especial. 1985. 
Novas Subjetividades na Pesquisa História Feminista: Uma Hermenêutica das diferenças. Trabalho apresentado no colóquio internacional Formação, Pesquisa e Edição Feminista na Universidade: Brasil, França e Quebec, Rio de Janeiro, 1994.

Resistir e Sobreviver. In: Nova História das Mulheres no Brasil. São Paulo: Contexto. 2012.

Forros e brancos pobres na sociedade colonial do Brasil: 1675- 1835. In: História Geral da America Latina, Unesco, v.3, cap. 14. 2001.

Sociabilidades Sem História: Votantes Pobres No Império, 1824-1881. In: Historiografia Brasileira em Perspectiva. São Paulo: Contexto, 2003.

DONZELOT, Jacques. A polícia das famílias. Rio de Janeiro: GRAAL, 1986.

Darbón, Sebastien. O etnólogo e suas imagens. In: Saiman, Etienne (org.) O Fotográfico. São Paulo: Senac- Hicitec. 2005.

DUARTE, Adriano e PAOLI, Maria Celia. São Paulo no Plural: espaço público e redes de sociabilidade. In: História da Cidade de São Paulo. São Paulo: Paz e Terra. 2004.

DUBOIS, Philippe, O ato fotográfico e outros ensaios. Campinas, SP: Papirus. 1994.

A fotografia panorâmica ou quando a imagem fixa faz sua encenação. In: Samain, EDWARD, Elisabeth. Anthropology \& Photography 1860 - 1920. 1992.

ENGELS, Magali Gouveia. Meretrizes e Doutores. Saber Médico e Prostituição no Rio de Janeiro, 1881-1903. São Paulo: Brasiliense. 1989.

ETIENNE, Saiman. (org.) O Fotográfico. São Paulo: Senac- Hicitec. 2005.

FABRIS, Identidades Virtuais. Belo Horizonte: Editora UFMG. 2004.

Fotografia Usos e Funções no século XIX. São Paulo: Udusp. 2008.

O desafio do olhar: fotografia e artes visuais no período das vanguardas históricas. São Paulo: Editora WMF Martins Fontes, 2011.

Nas pegadas de D. Marina da Glória. Prefácio de GOULART, Paulo Cezar Alves e FALZONE DEL BARBARÒ , Michele. Gli Ateliers. In. Segni Di Luce. La fotografia dall' eta dell collodio al pittorialismo. V. 2. 1993.

FANELLI, Giovanni. L'Italia virata all'oro attraverso le fotografie di Giorgio Sommer. Ed. Pagliai Polistampa. 2007.

FAUSTO, Boris. Controle Social e criminalidade em São Paulo: um apanhado geral (18401924). In: PINHEIRO, Paulo Sérgio. Crime, Violência e Poder. São Paulo: Brasiliense, 1983. 
FERNADES, Florestan. A integração do negro na sociedade de classes. São Paulo: Ed. Globo. 2008.

FERRARI, Oreste. In: Del Balbarò, Michele Falzone e Tempesta, Claudia. Marius Pictor Fotografo. L'album fotografico di Mario De Maria. 1882-1887. Editora IFotolibri/Longanesi\&C. 1979.

FIELDS, Barbara J. Ideology and race in American History. In: KOUSSER, J.Morgan e McPHERSON, James M. Region, race and Reconstruction. Oxford university Press. 1982. FREHSE, Fraya. Ô da Rua. O transeunte e o advento da modernidade em São Paulo. 2011. FRIZOT, Michel (org.). Nouvelle histoire de la photographie. Paris: Adan Biro; Larousse, 2001.

The New History of Photography. Köln: Könemann, 1998.

FOCAULT, Michel. Vigiar e Punir. História da Violência nas Prisões. Petrópolis: Vozes. $2^{\circ}$ ed. 1987.

FONER, ERIC. Nada além da liberdade. A emancipação e seu legado. Rio de Janeiro: Paz e Terra. 1988.

FONTCUBERTA, Joan. Estética fotográfica. Barcelona: Ed. Gustavo Gili, 2003.

FRANZINA. A Grande Imigração: o êxodo dos italianos do Vêneto para o Brasil. Campinas: São Paulo, 2006.

GABARA, Esther. Facing Brazil: The problem of portraite and a modernist sublime. The New Centennial Review, v. 4, number 2, Fall 2004.

GARCIA, Angela Célia. São Paulo em prata: A capital paulista nas fotografias de Aurélio Becherini (anos 1910-1920). Dissertação de mestrado defendida na FAU-USP. 2008.

GASKELL, Ivan. História das Imagens. In: Burke, Peter. A Escrita da História. Novas perspectivas. São Paulo:Ed. UNESP. 1992.

GEERTZ, Clifford. A interpretação das culturas. Rio de Janeiro: Guanabara. 1989.

GELL, Alfred. Art and Agency. Na Anthropological Theory. Clarendon Press. Oxford. 1998.

G. BERTUZZI, M. Di Stefano. Fotografi a Piacenza (1857-1900). Piacenza: TEP. 1982.

GILARDI , Aldo. Il Ritratto nella fotografia delle origini in Italia. In: Segni di Luce. V. 1993.

GOULART, Paulo Cezar Alves e MENDES, Ricardo. Noticiário Geral da Photographia Paulistana. Centro Cultural São Paulo: Imprensa Oficial do Estado de São Paulo. 2007.

GRAHAM, Sandra. Caetana diz não. História de Mulheres da sociedade escravista brasileira. São Paulo: Companhia das Letras, 2005. 
GRANGEIRO, Cândido Domingues. As Artes de um Negócio: A Febre Photographica. São Paulo:1862-1886.Campinas, SP: Mercado deLetras; São Paulo: Fapesp, 2000.

GOMES, Angela de Castro. Na Malhas do Feitiço: o Historiador e os Encantos dos Arquivos Privados. Artigo para o Seminário Internacional sobre Arquivos Pessoais Rio/São Paulo, CPDOC-FGV/IEB-USP, novembro de 1997.

GORENDER, Jacob. A escravidão reabilitada. São Paulo: Editora Ática.1991.

HARDING, Sandra. A instabilidade das categorias analíticas na teoria feminista. Revista Estudos Feministas. Vol.1. nº.1. Rio de Janeiro. UFRJ. 1993. p.7-32.

HIRSZMAN, Maria Lafayette Aureliano. Entre o typo e o sujeito: os retratos de escravos de Christiano Jr. Dissertação de Mestrado. ECA-USP. 2011.

HSIN-LIANGCHEN AND EDIEM, Rasmussen. Intellectual Access to Images. Artigo disponível na web: https://www.ideals.illinois.edu. Ver também Cassidy, B. Iconography in the theory and practice. In: Visual Resources, v. 11. 1996.

HODES, Martha. The Mercurial Nature and Abiding Power of Race: A transnational Family Story. In: The American Historical Review. Vol. 108,n 1. 2003.

Sex, Love, Race. Crossing boundaries in North American History.

HOLANDA, Sergio Buarque. Raízes do Brasil. São Paulo: Companhia das Letras, 1995.

HOOKS, Bell. Feminist Theory From Margin To Center.

HUYSSEN, Andreas. Seduzidos pela Memória: arquitetura, monumentos, mídia. Rio de janeiro: Aeroplano. 2000.

JOHNSON, Walter. On Agency. Journal of social history. 2003.

JUNIOR, Caio Prado. Formação do Brasil Contemporâneo. São Paulo: brasiliense. 2008

JUNIOR, Rubens Fernandes. A cidade multiplicada. In: Guilherme Gaensly. 1843-1928. São

Paulo: Cosac Naify, 2011.

Lições de demolições do olhar. In: Aurélio Becherini. São Paulo: Cosac Naify. 2009

KOSSOY, Boris. Origens e Expansão da Fotografia no Brasil - Século XIX. Rio de Janeiro: Edição Funarte. 1980.

Fotografia \& História. São Paulo: Ateliê editorial. 2001.

Dicionário Histórico-Fotográfico Brasileiro. Fotógrafos e Ofício da Fotografia no Brasil (1833-1910). São Paulo: Instituto Moreira Salles, 2002.

A São Paulo Fotogênica de Guilherme Gaensly. In: Guilherme Gaensly. São Paulo: Cosac Naify. 2011. 
KOUTSOUKOS, Sandra Sofia Machado. Negros no estúdio do fotógrafo. Campinas, SP: Editora da Unicamp, 2010.

KOUSSER, J.Morgan e McPHERSON, James M. Region, race and Reconstruction. Oxford university Press. 1982.

KOWARICK, Lúcio. Trabalho e Vadiagem. A origem do trabalho livre no Brasil. Rio de janeiro: Paz e Terra, 1994.

KRAUSS, Rosalind. O fotográfico. Barcelona: Editorial Gustavo Gili. 2002.

LACERDA, Aline. Arquivos e Coleções: a fotografia em diferentes contextos. In: Magalhães, Aline Montenegro e Bezerra, Rafael Zamorano. Coleções e colecionadores: a polissemia das práticas. Rio de Janeiro: Museu Histórico Nacional, 2011.

A Fotografia nos Arquivos. A produção de documentos fotográficos da Fundação Rockefeller durante o combate à febre amarela no Brasil. Tese Doutorado. Programa de PósGrasduação em História Social da FFLCH-USP. 2008.

Os Sentidos da Imagem. Fotografias em arquivos pessoais. In: Revista do Arquivo Nacional. V.6, n.01-02. Jan/Dez. 1993.

LANNA, Ana Lúcia Duarte. Aquém e além-mar. Imigrantes e Cidades. Belo Horizonte: VARIA HISTORIA. vol.28, no 48, p.871-887: jul/dez 2012.

LANDI, Bruno. Prefacio do livro Roma e il Lazio Negli Archivi Alinari. Firenze: Fratelli Alinari. 1989.

LAPA, José Roberto do Amaral. Os excluídos. Contribuição à História da Pobreza no Brasil (1850-1930). Campinas, SP: Editora Unicamp/EDUSP. 2008.

LATOUR, Bruno. A esperança de Pandora. Bauru, SP: EDUSC, 2001.

LE GOFF, Jacques. História e Memória. Campinas, SP: Editora da Unicamp, 2003.

LEITE, Miriam Moreira. Retratos de Família. São Paulo: Edusp. 1993.

LE MEN, Ségolène. Le XIX siècle de L'image. In: Gerverau, Laurent. Peut-on Apprendere À Voir? Paris. Ensba, 1996.

LEMOS, Carlos. "São Paulo de Vincenzo Pastore". Texto do catálogo da exposição IMS, 1997.

LEONARDI, Sérgio. La Fotografia Dell'Ottocento a Bari. Bari: Mario Adda Editore. 1997.

LEONE, Nicole. La scoperta da fotografia nella stampa napoletana. 1839. In: Segni Di Luce.

V. 1. 1993. 
LÉRIAS, Reinéro Antonio. O Encilhamento e a cidade de São Paulo, 1890-1891. Dissertação de Mestrado. FFLCH-USP. 1988.

LIMA, Solange Ferraz. São Paulo na virada do século: As imagens da razão urbana. 1995. Dissertação de mestrado - USP-FFLCH.

Fotografia e Cidade. Campinas, SP: Mercado de Letras, São Paulo: Fapesp. 1997.

O circuito social da fotografia: Estudo de caso - II. In: Fotografia. Usos e Funções no Século XIX. Fabris (org.). 2008.

LIMA,Valeria Alves Esteves. A Viajem Pitoresca e Histórica de Debret: por uma nova leitura. Tese de doutorado em História. IFCH. Unicamp. 2003.

LINDEN, Sophie Van Der. Para ler o livro ilustrado. São Paulo: Cosac Naify. 2011.

LISINI, Sauro. Fototeche e Archivi Fotografici. Prospettive di sviluppo e indagine delle raccolte. Toscana: Archivio Fotografico Toscano, 1996.

LOVE, Joseph. A Locomotiva. São Paulo na Federação Brasileira 1889-1937. Rio de Janeiro: Paz e Terra. 1982.

LOWE, Donald. Historia de La Percepcíon Burguesa, 1982. Cidade do México: Fondo del Cultura Económica, 1986.

LUGON, Oliver. Séries, Sequências e pranchas-contato. In. Salgueiro. O Olho Fotográfico Marcel Gautherot e seu tempo. São Paulo: FAAP, 2007.

LUCCIONI, Luigi. Saluti da Potenza. Ed: La Buona Stampa. 1983.

MACHADO, Maria Helena Pereira Toledo. Corpo, Gênero e Identidade no Limiar da Abolição:Benedita Maria da Ilha, mulher livre/Ovídia, escrava narra sua vida (Brasil, sudeste, 1880). Revista Afro-Ásia, n 42, 2010.

Rastros e Raças de Louis Agassiz: Fotografia, Corpo e Ciência, Ontem e Hoje. São Paulo: Capacete \&29 São Paulo Biennial. 2010.

MAGALHÃES, Angela e PEREGRINO, Nadja Fonseca. Fotografia no Brasil. Um olhar das origens ao contemporâneo. Rio de Janeiro: Funarte. 2004.

MALUF, Mariana e Mott, Maria Lúcia. Recônditos do mundo feminino. In: História da Vida Privada no Brasil. 1998.

MARCENARO, Giuseppe. La fotografia ligure dell ottocento de Giuseppe Marcenaro. Edidizione Esagragh. 1984.

MARANO, Francesco. 1994, In: Bronzini, Giovanni Battista. Lares, Trimestrale di studi demoetno antropologici. Ano LX, n.4. Firenze: Leo S. Olschki. Outubro-dezembro de 1994. 
MARINS, Paulo César Garcez. Habitações e Vizinhança: Limites da Privacidade no Surgimento das Metrópoles Brasileiras. In: História da Vida Privada no Brasil. São Paulo: Companhia das Letras. V1. 3. 1998.

Através da Rótula. Sociedade e Arquitetura no Brasil. Séculos XVII a XX. São Paulo: Humanitas/FFLCH/USP, 2011.

MASDEA, Maria Cristina. Le Vestiture del Regno di Napoli: Origini e fortune di um genere nuovo. 1991.

MAUAD, Ana Maria. Fotografia e História - Possibilidades de Análise. In: Ciavatta, Maria e Alves, Nilda (org.). A leitura de imagens na pesquisa social. História, Comunicação e educação. São Paulo: Cortez. 2004.

MAZZACANE, Lello. Percorsi della fotografia lucana tra Ottocento e Novecento. In:

MELLO, Maria Teresa Villela Bandeira de. Arte e Fotografia: o movimento pictorialista no Brasil. Rio de Janeiro: Funarte. 1998.

MENDES, Ricardo. São Paulo e suas Imagens. In: Cadernos de Fotografia Brasileira. São Paulo 450 Anos. São Paulo: Instituto Moreira Salles. 2004.

Noticiário Geral da Photographia Paulistana. Centro Cultural São Paulo: Imprensa Oficial do Estado de São Paulo. 2007.

Descobrindo a fotografia nos manuais: América (1840-1880). In: Fotografia usos e funções no século XIX. Fabris. (org.) 2008.

Pequeno Livro das Vinhetas. Fotografia no Brasil. 1860-1920. 2010.

São Paulo de Vincenzo Pastore. Catálogo do instituto Moreira Salles. 1998.

MENESES, Ulpiano Bezerra de. História e Imagem: iconografia/iconologia e alem. In: Ciro F. S. Cardoso, Ronaldo Vainfaz (org.) Novos Domínios da História. Rio de Janeiro: Elsevier, 2012.

Rumo a uma história visual. In: Eckert, Cornelia \& Caiuby< Silvia (org.). O Imaginário e o poético nas Ciências Sociais. Bauru: EDUSC, 2005.

_ Fontes Visuais, cultura visual, história visual. Balanço Provisório, propostas cautelares. In: Revista Brasileira de História. São Paulo, v. 23, n45, pp.11-36. 2003.

A fotografia como documento - Robert Capa e o miliciano abatido na Espanha: Sugestões para um estudo histórico. Tempo, Rio de Janeiro,n ${ }^{\circ}$ 14, 2002.

A crise da memória, história e documento: reflexões para um tempo de transformações. In: Silva. Z. L. da (org). Arquivos, patrimônio e memória. São Paulo:Unesp, 1999. 
A crise da memória, história e documento: reflexões para um tempo de transformações. In: Silva. Z. L. da (org). Arquivos, patrimônio e memória. São Paulo:Unesp, 1999.

Memória e cultura material: documentos pessoais no espaço público, In: Revista Estudos Históricos, Rio de Janeiro: CPDOC/FGV, vol. 11, n. 21, 1998.

Morfologia das Cidades Brasileiras. Introdução ao Estudo Histórico da Iconografia urbana. Revista USP, São Paulo. n.30. Junho/Agosto. 1996.

MERLEAU-PONTY, Maurice. Fenomenologia da Percepção. São Paulo: Martins Fontes, 2006.

MILLER, D. Street Cryers and Itinerant Tradsmen in European prints, Standford Art Gallery, 1970.

MIRAGLIA, Marina. Francesco Paolo Michetti Fotografo. Torino: Ed. Einaudi Letteratura 43. 1975.

Bari inizio secolo nelle fotografie degli Antonelli. 1883-1915. Roma: Edizione Quasar. 1985.

"Genere" e "tableau vivant": appunti veloci su due opposte tendenze delle età dell collodio e della gelatina bromuro d'argento. In: Zannier, Itàlo. Segni Di Luce fotografia italiana dall'età dell collodio al pittorialismo. 1993.

Spechio che l'occulto rivela. Ideologie e schemi rappresentativi della fotografia fra Ottocento e Novecento. Milão, Itália: Ed. Imagines Franco Angeli. 2011.

MIRIZZI, Ferdinando. Da vicino e da lontano. Fotografi e fotografia in Lucania. Milano, Italy: Imagines FrancoAngeli. 2010.

MIRZOEFF, Nicholas. An introduction to Visual Culture. Edition Routledge. 2009.

MONTELEONE, Joana. Sabores Urbanos: Alimentação, sociabilidade e consumo. São Paulo 1828-1910. Dissertação de Mestrado. História econômica- FFLCH- USP. 2008.

MORSE, Richard. O espelho de Próspero: Cultura e Idéias nas Américas. São Paulo: Companhia das Letras. 1988.

Formação Histórica de São Paulo. De comunidade à metrópole. São Paulo: Difusão Européia do Livro. 1970.

MOUTINHO, Laura. Razão, cor e desejo - Uma análise comparativa sobre relacionamentos afetivo-sexuais inter-raciais no Brasil e na África do Sul. Editora Unesp, 2003.

MOMBEIG, Pierre. Pioneiros e fazendeiros de São Paulo. São Paulo: Hucitec. 1984.

MORENO, Júlio. Memórias de Armandinho do Bixiga. São Paulo: Ed. Senac. 1996. 
MUAZE, Mariana. As memórias da Viscondessa. Família e Poder no Brasil Império. Rio de Janeiro: Jorge Zahar. 2008.

NADER, Maria Beatriz. A mulher e as transformações sociais do século XX. Revista de História do Departamento de História da Universidade Federal do Espírito Santo, $\mathrm{n}^{\circ} 7$, Vitória, 1998.

Mudanças e relações conjugais: novos paradigmas da relação mulher e casamento: 1970-2000. Tese de Doutorado apresentada no Programa de Pós-Graduação em História Econômica da Universidade de São Paulo. São Paulo, 2003.

NARANJO, Juan. Fotografía, Antropología y Colonialismo (1845-2006). Barcelona: Editorial Gustavo Gili, 2006.

NAXARA, Márcia Regina Capelari. Estrangeiro em sua própria terra. Representações do brasileiro, 1870-1920. São Paulo: Annablume. 1998.

Occhiuzzi, Donatella. Sguardo antropológico e senso della perdida nella Roma Pittoresca di Ettore Roesler Franz. In: Itinerari nella Roma pittoresca di Ettore Roesler Franz. Palombi Editori, 2012.

OLIVEIRA, Maria Luiza Ferreira. Entre a Casa e o Armazém. Relações sociais e experiências da urbanização. São Paulo, 1850-1900. São Paulo: Alameda, 2005.

$O$ registro dos limites da cidade: imagens da várzea do Carmo no século XIX. Anais do Museu Paulista - USP, v. 6/7. 1998-1999. Editado em 2003.

O'NEILL, Paul. The Culture of Curating and The Curating of Culture (s). The MIT Press. Cambridge, Massachusetts, London, England. 2012.

ORVELL, Miles. The Real Thing. Imitation and authenticity in american culture. 1880- 1940. London. Chapel Hill, 1989.

PAGNOTTA, Linda. Volti e Figure. Il Ritratto Nella Storia della Fotografia. Editora Apax Libri, AIÓN. 2009.

PAVAN, Margot. Fotomontagem e Pintura Pré-Rafaelista. In: Fabris, Annateresa. Fotografia Usos e Funções no século XIX. São Paulo: Udusp. 2008.

PEARCE, Susan M. Museums, Objects and Collections. A Cultural Study. 1993.

Penteado, Jacob. Belenzinho, 1910: Retrato de uma época. São Paulo: Carrenho Editorial/Narrativa. 2003. 
PEREIRA, Adriana Maria Pinheiro Martins. A Cultura Amadora na virada do século XIX: a fotografia de Alberto Sampaio (Petrópolis/ Rio de janeiro, 1888-1914). Doutorado. FFLCHUSP. 2010.

PEREIRA, Robson Mendonça. Washington Luis na administração de São Paulo (19141919). São Paulo: Ed. UNESP. 2010.

PERES, Elena Pajáro. Exuberância e Invisibilidade. Populações moventes e cultura em São Paulo, 1942 ao início dos anos 70. Tese Doutorado. FFLCH. 2006.

PERRETTI, Vincenzo. Potenza così com'era. Brani di storia e di cronaca cittadina illustrati da immagini del secolo scorso. Anzi/Potenza. 2008.

PERROT, Michelle. Os Excluídos da História. Operários, Mulheres e Prisioneiros. Rio de Janeiro: Paz e Terra, 1988.

PINHEIRO, Paulo Sérgio. Transição Política e Não Estado de Direito na República. In: Brasil Um século de transformações. São Paulo: Companhia das Letras, 2001.

PINHEIRO, Paulo Sérgio. Crime Violência e Poder. São Paulo: Brasiliense. 1983.

PRADO, Antonio Arnoni. Últimas Imagens do Império. Ensaio de abertura In: Na Rua Vincenzo Pastore. São Paulo: IMS, 2009.

PREVIATI, Chiara Troccoli. Il Ritrato. In: MIRAGLIA, Marina. Bari Inizio Secolo Nelle Fotografie Degli Antonelli. 1883-1915. Edizioni Quasar. 1985.

POIVERT, Michel; GUNTHER, Andre. L'art de la photographie. Paris: Constellation, 2007.

QUINTAVALLE, Arturo Carlo. Gli Alinari. Fotografi a Firenze. 1852-1920. Edizoni Alinari. 1977.

RAGO, Margareth. As Mulheres na Historiografia Brasileira. In: Silva, Zélia Lopes. Cultura Histórica em Debate. São Paulo: Editora da Universidade Estadual Paulista, 1995.

REVEL, Jacques. A história ao rés-do-chão. Prefácio: In: Levi, Giovanni. A herança Imaterial. Trajetória de um exorcista no Piemonte do século XVII. Rio de Janeiro: Civilização Brasileira, 2000.

REZENDE, Lívia Lazzaro. A circulação de imagens no Brasil oitocentista: uma história com marca registrada. In: Cardoso, Rafaler (org.) O Design Brasileiro antes do Design. Aspectos da história gráfica, 1870-1960. São Paulo: CosacNaiify. 2011.

RIBEIRO, Vanessa Costa. Várzea do Carmo a Parque Dom Pedro II: de atributo natural a artefato. Décadas de 1890 a 1950. Dissertação de Mestrado. Universidade de São Paulo. FFLCH, 2012. 
RICOEUR , Paul. The Conflict of Interpretations. Evanston: Northwestern University Press, 1974, p. 66. In: Crary, Jonathan. Suspensão da Percepção. Atenção, Espetáculo e Cultura Moderna. São Paulo: Cosac Naify, 2013.

ROCHA, Regina Maurício da. A Poética de Paul Strand. São Paulo: Edusp. 2012.

RODRIGUES, Jaime. Alimentação Popular em São Paulo (1920a 1950) - políticas públicas, discursos técnicos e práticas profissionais. In: Anais do Museu Paulista. História e Cultura Material. Nova Série, v. 15, n² 2, Jul-Dez. 2007.

ROLNIK, Raquel. A Cidade e a Lei. Legislação, Política urbana e Territórios na Cidade de São Paulo. São Paulo: Studio Nobel: FAPESP, 2003.

ROLNIK, Suely. "Machos \& fêmeas". In: A dominação masculina revisitada. Campinas: Papirus, 1998, pp. 69 / 71.

ROUILLÉ, André. A fotografia entre documento e arte contemporânea. São Paulo: Senac. 2009. La photographie em France. Textes \& controverses: une anthologie, 1816-1871. Paris, Editions Macula, 1989.

SAMAIN, Étienne. O Fotográfico. São Paulo: Senac. 2005

Quando a Fotografia já fazia os antropólogos sonharem: O Jornal La Lumière (18511860). Unicamp, 2001.

SALGADO, Plínio. O extrangeiro, 1936.

SALGUEIRO, Heliana Angotti. O Olho fotográfico. Marcel Gautherot e seu tempo. São Paulo: FAAP, 2007.

SALIBA, Elias Tome. Histórias, memórias, tramas e dramas da identidade paulista. In:

História da Cidade de São Paulo. São Paulo: Paz e Terra, v. 3, 2004.

SALINARDI, Ernesto. La fotografia: storia e protagonisti a Potenza. In: Potenza, Capoluogo (1806-2006). V.2. 2008.

SANTOS, Carlo José Ferreira dos. Nem tudo era italiano: São Paulo e Pobreza (1890-1915).

São Paulo: Annablume/Fapesp, 1998.

SANTOS, Gislene Aparecida. A invenção do ser negro. Um percurso das ideias que naturalizaram a inferioridade dos negros. São Paulo: Educ/FAPESP. 2002.

SAMARA, Eni de Mesquita. "Mistérios da "fragilidade humana": o adultério feminino no Brasil, séculos XVIII e XIX”. In: Representações. Revista Brasileira de História / ANPUH n ${ }^{\circ}$ 29. São Paulo: Contexto, 1995, pp. 57 / 71. 
As mulheres, o poder e a família: São Paulo, século XIX. São Paulo: Marco Zero, 1989.

SANT’ANNA, Denise Bernuzzi de. Cidade das águas. Usos de Rio, Corregos, Bicas e Chafarizes em São Paulo (1822-1901). São Paulo: Editora Senac São Paulo. 2007.

SANTOS, Carlos. J. Ferreira dos. Nem tudo era Italiano: São Paulo e Pobreza. 1890 a 1915. São Paulo: Annablume/FAPESP. 1998.

SANTOS, João Marcelo Pereira dos. Os trabalhadores da Light São Paulo, 1900-1935. Tese Doutorado. Unicamp. 2009.

SAYAD, Abdelmalek. A Imigração. São Paulo: EDUSP. 1998.

SEGALA, Lygia. Arquivo e Coleção Fotográfica. In: O Olho Fotográfico: Marcel Gautherot e seu tempo. São Paulo: FAAP, 2007.

SCHWARCZ, Lilia Moritz. Biografia como gênero e problema. 2013.

SCOTT, Cynthia. Museums, Libraries, and Archives: A Summer Institute for Knowledge Sharing. In: Visual Resources. An International Journal of Documentation. V. XV. Number 1. 1999, pp. 75-78.

SETTIMELLI, Wladimiro. Roma e il Lazio Negli Archivi Alinari. Firenze: Fratelli Alinari. 1989.

SEVCENKO, Nicolau. De mameluca, mulata e gótica a moderna, cosmopolita e caótica: as metamorfoses de Piratininga. In: Cadernos de fotografia brasileira - São Paulo 450 anos: Instituto Moreira Salles. 2004.

História da Vida Privada no Brasil. V. 2 e 3. São Paulo: Companhia das Letras. 1998. Orfeu Extático na Metrópole. São Paulo sociedade e cultura nos frementes anos 20. São Paulo: Companhia das Letras. 1992.

Peregrinations, Visions and the City. In: Schelling, Vivian (org.). Through the Kaleidoscope. The Experience of Modernity in Latin America. London: Verso, 2000.

SHAPOCHNIK, Nelson. Cartões-Postais Álbuns de Família e Ícones da Intimidade. In: História da Vida Privada No Brasil. V.3. São Paulo: Companhia das Letras. 1998.

SILVA, Aramis Luis. Mapa de viagem de uma coleção etnográfica - A aldeia bororo nos museus salesianos e o museu salesiano na aldeia bororo. Tese de doutorado. Faculdade de Filosofia, Letras e Ciências Humanas - USP. São Paulo, 2011.

SILVA, João Luiz Maximo. Transformações no espaço domestico - o fogão a gás e a cozinha paulistana, 1870-1930. In: Anais do Museu Paulista/USP. História e Cultura Material. Nova Série, v. 15. n², jul-dez. 2007. 
SIMIONI, Ana Paula Cavalcanti. Regina Gomide Graz: modernismo, arte têxtil e relações de gênero no Brasil. Revista do IEB, n. 45. Setembro, 2007, pp. 87-106.

SOIHET, Rachel. Condição feminina, e formas de violência. Mulheres Pobres e Ordem de urbana. 1890-1920. Rio de Janeiro: Forense Universitária, 1989.

História das Mulheres e História de Gênero: Um depoimento. Cadernos de Pagu, pp. 77-87, 1998.

"Mulheres ousadas e apaixonadas em processos criminais cariocas (1890 / 1930)". In: REVISTA BRASILEIRA DE HISTÓRIA / ANPUH No 18: A mulher e o espaço público. São Paulo: Marco Zero, 1989, pp. 199216.

SONTAG, Susan. Sobre Fotografia. São Paulo: Companhia das Letras. 2004.

Diante da dor dos outros. São Paulo: Companhia das Letras. 2003

SORBO, Luca e Scateni, Luciano. Italia inédita di un secolo fa. Napoli, Venezia, Palermo, i borghi di Caiazzo e di Cerreto Sannita nelle lastre ritrovate di Eugenio Buono. Napoli: Edizioni Intra Moenia. 2008.

SOULAGES, François. Estética da Fotografia Perda e Permanência. São Paulo: Editora Senac. 2012.

SOUZA, Márcia Maria Cabreira Monteiro de. O povo da caixa e a 25 de março: memórias da imigração síria e libanesa em São Paulo. Tese doutorado. FFLCH-USP, 2002.

STEPAN, Nancy Leys. A hora da eugenia. Raça, gênero e nação na América Latina. Rio de Janeiro: Editora FioCruz, 2005.

TELES, Maria Amélia de Almeida. Breve história do feminismo no Brasil. São Paulo: Ed. Brasiliense. 1993.

TELLES, Lorena Féres da Silva. Libertas Entre Sobrados: Mulheres Negras E Trabalho Doméstico Em São Paulo. (1880-1920). São Paulo: Alameda Editorial. 2013.

THOVEZ, Enrico. Poesia fotográfica. In: L”arte all'esposizione del 1898. Número 9.

TOLEDO, Benedito Lima. Prestes Maia e as Origens do urbanismo Moderno em São Paulo. São Paulo: Empresa das Artes. 1996. São Paulo: “Belle Époque”. São Paulo: Ed. Nacional. 2010. Anhangabaú. São Paulo: Federação das Indústrias do estado de São Paulo. 1989 TOMASSINI, Luigi. La Lucania nell'editoria fotográfica della prima metà del XX secolo. 2010 . 
TRINDADE, Liana Salvia. O negro em São Paulo no período pós-abolicionista. In: História da Cidade de São Paulo. São Paulo: Paz e Terra, 2004.

TURAZZI, Maria Inez. Uma Cultura Fotográfica. In:Revista do Patrimônio Histórico e Artístico Nacional, s. 1 ,n. 27, 1998.

O Bulício das ruas na litografia Briggs. In: Tipos e Cenas do Brasil Imperial. A Litografia Briggs na Coleção Geyer. Petrópolis/Rio de Janeiro: Museu Imperial. 2002.

VAN DER LINDEN, Sophie. Para ler o livro ilustrado. São Paulo: Cosac \& Naify, 2011.

VELLOSO, Verônica Pimenta. Cartões-postais: imagens do progresso (1900-1910).História,

Ciências, Saúde. FioCruz. Nov. 2000/fev.2001. In: Mendes, Ricardo. São Paulo e Suas Imagens. n. 108, 2010.

VERRASTRO, Angela. Invarianti strutturali e tensioni al cambiamento Nei genere della foto di famiglia lucana. In: Mirizzi, Ferdinando. Da vicino e da lontano. Fotografi e fotografia in Lucania. Milano, Italy: Imagines FrancoAngeli. 2010.

Il genere fotografico tra tradizione e innovazione nell'operato di dieci studio del potentino. Tese de doutorado Faculdade de Sociologia da Università degli Studi di Napoli Federico II. 2005.

ZALUAR, Alba. A máquina e a revolta: as organizações populares e o significado de pobreza. São Paulo: Brasiliense, 1985.

ZANNIER, Italo. Alle origini della fotografia in Italia. In: Segni di Luce. V. 1993.

Leggere La Fotografia Le Riviste Specializzate in Italia. (1863-1990). Editora NIS. La Nuova Italia Scientifica. 1993.

Cultura fotografica in Italia. Antologia di testi sulla fotografia 1839-1949. Milão: Ed. Franco Angeli Libri. 1985.

ZANINI, Giulia. La rivista "La Fotografia Artistica" e il pittorialismo in Italia. Tese de doutorado em Economia e Gestão de Artes e de Atividades Culturais da Università Ca'Foscare Venezia. Ano Acadêmico 2013/2014.

ZAVATtini, Cesare e Monti, Paolo. Foto D’Archivio. Italia Tra' 800 E 900. Milão: Ed. Touring Club Italiano. 1979.

ZEVI, Fillipo. Le Altre Città e Il Paesaggio Italiano. 1977. In: QUINTAVALLE, Arturo Carlo. Gli Alinari. Fotografi a Firenze. 1852-1920. Edizoni Alinari. 1977.

WILLIAMS, Raymond. Cultura. Rio de Janeiro: Paz e Terra, 1992. 
WILLUMSON, Glenn. Making meaning. Displaced materiality in the library and art museum. In: EDWARDS, Elisabeth. Photographs Objects Histories. London and New York, 2004.

WISSENBACH, Maria Cristina Cortez. Da Escravidão À Liberdade: Dimensões de Uma Privacidade Possível. In: História da Vida Privada no Brasil. São Paulo: Companhia das Letras, 1997.

Ritos de Magias e Sobrevivência. Sociabilidades e práticas mágico-religiosas no Brasil (1890-1940. Tese de doutorado defendida na Faculdade de Filosofia, Letras e Ciências Humanas da Universidade de São Paulo, sob a orientação da professora Maria Odila Leite da Silva Dias. Julho/1997. 